Universidade de São Paulo

Faculdade de Arquitetura e Urbanismo

iara Pierro de Camargo

\title{
O LIVRO \\ DE LITERATURA: \\ ENTRE O DESIGN \\ VISÍVEL E O \\ INVISÍVEL
}

São Paulo

2016 
O LIVRO

DE LITERATURA: ENTRE O DESIGN VISÍVEL $E$ INVISÍVEL 


\section{O LIVRO DE LITERATURA: ENTRE O DESIGN VISÍVEL E O INVISÍVEL}

Tese apresentada à Faculdade de Arquitetura e Urbanismo da Universidade de São Paulo para obtenção do título de Doutor em Arquitetura e Urbanismo Área de concentração: Design e Arquitetura Orientador: Prof. Dr. Carlos Zibel Costa

São Paulo 
AUTORIZO A REPRODUÇÃO E DIVULGAÇÃO TOTAL OU PARCIAL DESTE TRABALHO, POR QUALQUER MEIO CONVENCIONAL OU ELETRÔNICO, PARA FINS DE ESTUDO E PESQUISA, DESDE QUE CITADA A FONTE.

E-MAIL DA AUTORA: iaritcha@hotmail.com$$
\text { Camargo, Iara Pierro de }
$$

O livro de literatura: entre o design visível e o invisível / Iara Pierro de Camargo. -- São Paulo, 2016.

348 p. : il.

Tese (Doutorado - Área de Concentração: Design e Arquitetura) FAUUSP.

Orientador: Carlos Zibel Costa

1.Livros (Design ; História) 2.História do livro 3.Tipografia 4.Literatura I.Título

CDU 7.05

\section{CAMARGO, Iara Pierro de}

o livro de literatura: entre o design visível e o invisível

Tese apresentada à Faculdade Arquitetura e Urbanismo da Universidade

de São Paulo para obtenção do título de Doutor em Arquitetura e Urbanismo

Área de concentração: Design e Arquitetura

Aprovada em:

Banca Examinadora

Prof. Dr(a)

Instituição:

Julgamento:

Assinatura:

Prof. Dr(a)

Instituição:

Julgamento:

Assinatura:

Prof. Dr(a)

Instituição:

Julgamento:

Assinatura:

Prof. Dr(a)

Instituição:

Julgamento:

Assinatura:

Prof. Dr(a).

Instituição:

Julgamento:

Assinatura: 
Dedico

este trabalho à minha tia Ligia Maria Hellmeister Gonçalves e Bernardo (in memorian) por todo apoio e incentivo durante minha jornada acadêmica (nunca me esquecerei do seu "sermão" sobre a importância dos fichamentos desde meu primeiro dia como estudante universitária). Sem suas sugestões e "empurrões", provavelmente não conseguiria terminar este trabalho. Muito obrigada por tudo, mesmo. Saudades imensas.

\section{Agradeço, especialmente,}

Ao meu orientador Carlos Zibel Costa, por toda contribuição a este trabalho e também pelo apoio em minha trajetória acadêmica nesta instituição

À professora Priscila Lena Farias e ao professor Fernando Paixão, cujas considerações, críticas e sugestões, em minha qualificação, foram de grande importância para o aprimoramento e desenvolvimento deste trabalho; e aos professores do departamento Vicente Gil Filho e Feres Lourenço Khoury, que me apoiaram e me deram dicas para ao trabalho em suas disciplinas. Aos professores Marcos da Costa Braga, Cibele Haddad Taralli, Clice de Toledo Sanjar Mazzilli e Cristiane Aun Bertoldi, Daniela Kutschat Hanns, Sara Goldchmit e Gil Barros pelos pertinentes comentários ao longo dos encontros de pesquisa do departamento;

Aos meus pais e ao meu marido, Gabriel, pelo incentivo, apoio incondicional, carinho, parceria, paciência e revisão deste trabalho;

À minha tia Ligia Maria Hellmeister Gonçalves e Bernardo (in memorian) por todos os comentários e pelo incentivo, ao meu tio Humberto Wagner Bernardo, por conseguir a cópia do original de Beatrice Warde, às minhas primas Marília (pelas caronas à biblioteca) e Elisa por todo apoio, carinho e hospedagem durante minhas temporadas de pesquisa nos Estados Unidos. Agradeço também ao amigo Erik Flora pela revisão do abstract.

Aos designers: Elaine Ramos (Cosac Naify), Alceu Nunes e Fabiana Roncoroni (Companhia das Letras), Pedro Inoue (Editora Aleph), Anna Gerber (Visual Editions), Wilber H. "Chip" Schilling (indulgence Press), Warren Lehrer, Barbara de Wilde, David Drumond, Martin Venesky, Michael Carrabeta, Cheryl Towler Weese, Geoff Kaplan, Susan Viguers e Robert Tauber pelas entrevistas e sugestões;
Aos bibliotecários da Cleveland Public Library, em especial a Bill Chase e a Evone Jeffries;

A toda equipe de bibliotecários da New York Public Library, em especial a Jessica Pigza;

A toda equipe de bibliotecários da Morgan Library, em especial a John T. McQuillen;

A bibliotecária Meghan Constantinou, do Grolier Club;

A Henrique Nardi, Antônio Carlos Castro, Kollontai Diniz e Catherine Dixon por seus comentários e preciosas sugestões relativas à minha apresentação sobre a pesquisa na Conferência da Atypi em 2015, em São Paulo, que certamente foram úteis para repensar alguns tópicos deste trabalho;

A Katherine McCoy, pela revisão em Inglês do artigo sobre a pesquisa publicado no congresso ICDHS 2014 em Aveiro, Portugal;

Ao Geoff Kaplan e a Pam, pela estadia e apoio em São Francisco

A Vanessa Espínola, por sua grande amizade e ajuda na digitação das incontáveis páginas de fichamentos;

Aos irmãos, André e Melina, à vovó Lou, ao tio Manoel Carlos, aos meus sogros, cunhadas, cunhado e às "irmãs de coração" Lívia e Letícia, que nunca deixaram de me apoiar;

Ao amigo Umberto Ribeiro pela leitura crítica;

Aos colegas professores das Faculdades Integradas Rio Branco, pelas constantes conversas e desabafos sobre o processo: Paulo Durão, Alexandre Alves, Fabrício Marangon, Márcio Rinaldi, Noemia Davidovich Fryszman, Marcos José Pereira, Dario Luis Borelli e, é claro, a todos meus alunos e (ex-alunos) com os quais aprendo mais a cada dia e me incentivam a melhorar sempre;

A todos os voluntários que se dispuseram a comprar, ler e responder o questionário sobre Bartleby, o escrivão;

Aos colegas da Fau: Leilane Rigatto, Elisabeth Romani, Eunice Liu, Leandro Velloso, Kollontai Diniz, José Roberto Delboux, Ana Paula Campos, Camila Assis e Isabela Aragão, pelos debates e pelo apoio acadêmico. 


\section{RESUMO}

Os livros destinados à leitura contínua, como romances, apresentam, em sua maioria, leiautes simples. São livros funcionais, destinados basicamente à leitura e que raramente chamam atenção para seu design. Obras simples como essas poderiam, em uma primeira análise, ser concebidas como "invisíveis", de acordo com os conceitos apresentados no ensaio The Crystal Goblet or Printing Should be Invisible, de Beatrice Warde, de 1930. O ideal da invisibilidade se refere ao design transparente, que não oculta o conteúdo (texto) e é baseado em etiquetas de composição que asseguram sua qualidade. Em oposição a essa abordagem "invisível", observa-se, tanto hoje como desde o início da produção de livros impressos, livros de literatura com uma abordagem "visível", isto é, que apresentam vinhetas, capitulares, ornamentações, ilustrações e até experimentos tipográficos.

Esta tese, a partir de exemplos encontrados em bibliotecas especializadas em edições raras, contempla estas duas abordagens em cinco séculos do livro impresso. A pesquisa privilegia o estudo de dois momentos históricos em que essas duas abordagens são evidentes: as primeiras décadas do século $\mathrm{XX}$, em que ao mesmo tempo em que se defendia o livro "invisível" eram produzidos diversos livros especiais e ilustrados na Europa e nos Estados Unidos, e o segundo momento, o atual, em que se observa que a maioria das obras são simples e produzidas a partir de templates e em que, como alternativa "visível", temos o surgimento de editoras como Cosac Naify (Brasil), Visual Editions (Inglaterra), Almadía (México) e Libros del Zorro Rojo (Argentina e Espanha), que trazem elementos visuais para seus livros.

A presente pesquisa busca investigar a "invisibilidade" e a "visibilidade" no design do livro impresso de literatura (prosa), de forma a promover o debate sobre estas duas categorias e testar a hipótese de que a visibilidade dos livros contemporâneos é resultado de uma integração entre projeto gráfico e texto literário, cujo resultado são livros que apresentam tanto uma função estética quanto semântica, além da funcional, que é a da leitura.

Palavras-chave: Design de Livros, História do Livro, História do Design de Livros, Tipografia, Literatura

\section{ABSTRACT}

Books intended for continuous reading as novels present mainly simple layouts. They are functional but aimed basically to reading and rarely drawing attention to its design. Simple projects like these, in a first analysis could be conceived as "invisible", accordingly to the concepts presented in Beatrice Warde's essay "The Crystal Goblet" or "Printing Should Be Invisible" from 1930. The idea of invisibility refers to the transparent design that doesn't hide the content (text) and it is based in composition labels that ensure quality. In opposition to this "invisible" approach, we see, nowadays and also in the beginning of the production of print books, literature books with a "visible" approach, that is, that present vignettes, capitulars, ornamentations, illustrations and also typographic experiments.

This thesis, starting from examples found in specialized libraries, discuss these two approaches in five centuries of print books. The research privileges the study of two historical moments, in which these approaches are evident: The first decades of the 20th century, in which at the same time the "invisible" book was defended and there was also a production of many special and illustrated books in Europe and United States. The second moment, nowadays, in which we see most part of the works produced starting from templates and in which, as a "visible" alternative, we see the appearance of publishing houses like Cosac Naify (Brazil), Visual Editions (England), Almadía (Mexico) and Libros del Zorro Rojo (Argentina and Spain), which bring visual elements to their books.

This research focuses on how to investigate the "invisibility" and the "visibility" at the design of press book literature (prose) as a way to promote the debate of these two categories and test the hypothesis that visibility in contemporary books is the result of an integration between graphic project and the literary text, what results in books that present an aesthetics function and also a semantical one, beyond the functional reading.

Keywords: Book Design, Book History, Book History Design, Typography, Literature 


\section{SUMÁRIO}

Introdução e problemática

Hipótese

Justificativa

Materiais e métodos

Pesquisa bibliográfica

Pesquisa de campo

Pesquisa qualitativa

Estrutura da tese

Capítulo 10 livro invisíve

Abordagens "invisíveis" do século XV ao XIX

A revolução industrial e o combate ao livro "mal feito"

Reforma da Impressão: resgate histórico e adaptação

de tipos para uso em máquinas de composiç̃a

O ideal do livro "invisível"

Jan Tschichold, a Penguin e o bom livro de bolso

Função

A "retomada" da invisibilidade

Invisibilidade: um paradigma ultrapassado?

Capítulo 2 Abordagens visíveis

Edições de Decameron

Edições de Dom Quixote

A visibilidade no final do século XIX e início do século XX

A visibilidade no movimento da Imprensa Particular

Eragny Press

Golden Cockerel Press

Nonesuch Press

Livros ilustrados na França

A fina impressão nos Estados Unidos

Bruce Rogers

William Addison Dwiggins

The Limited Editions Club

Alusão, interpretação e saturação

Capítulo 3 A tipografia dá o tom

Retórica tipográfica

Materialidade

Estudo de caso: 4 propostas para a AIGA
Capítulo 4 Abordagens contemporâneas "visiveis"

visibilidade do livro a partir da

interpretação tipográfica

Kapow!

A visibilidade do livro a partir da produção gráfica

Tree of Codes

Primeiro Amor

A fera na selva

Abordagens do livro ilustrado

La peste escarlata

Fausto

El príncipe feliz y otros cuentos

Tráeme tu amor y otros relatos

Una ocasión para una pequeña desesperación

A metamorfose

Los culpables

Frankenstein

Decameron

Capítulo 5 Perspectivas teóricas para a análise de projetos

gráficos de livros de literatura

Capítulo 6 Bartleby, o escrivão: entre a

invisibilidade e a visibilidade

O conto "Bartleby, o escrivão"

Análises de quatro edições de "Bartleby, o escrivão"

Edição de Bartleby, da Editora Assírio e Alvim (1988)

Edição de Bartleby, o escriturário, da Editora Rocco (1986)

Edição de Bartleby the Escriviner, pela editora Indulgenge Press (1995)

Edição de Bartleby, o escrivão: uma história de Wall Street,

da Editora Cosac Naify (2005)

Capítulo 7 Ser visível ou invisível, eis a questão

A invisibilidade sob suspeita

A invisibilidade como descaso

Padronização

A visibilidade como tendência e a "ameaça digital"

Considerações finais

Bibliografia consultada

Pesquisa realizada com leitores de Bartleby
200

207

210

214

216

220

226

237

264

266

267 


\section{INTRODUÇÃO E PROBLEMÁTICA}

O livro impresso é um objeto composto de capa e miolo. Mesmo unidas e compondo um único objeto, o design dessas partes pode ser completamente diferente, como se pode verificar hoje em inúmeros volumes, em especial de ficção. Aparentemente, a capa tem em geral função de proteger e "vender" e o miolo, a de ser um "suporte" ou "portador" do texto.

É possível verificar essa abordagem do livro com uma capa graficamente trabalhada e miolo simples em outros gêneros, mas aparentemente no livro de ficção essa fórmula é comumente aceita e seguida pela indústria editorial.

Apesar de se verificar hoje a predominância do livro de literatura graficamente simples, ao longo da história do livro impresso já foram produzidos livros ricamente decorados, como incunábulos de contos medievais, além de livros ilustrados.

A composição tipográfica do livro de páginas "simples" provavelmente nasceu em Veneza, pelos ideais do editor e impressor Aldo Manuzio, entre o final do século XV e início do XVI. Além de criar um modelo de livro portátil in-oitavo, Manuzio também produziu a partir do volume De Aetna (1495-96), de Pietro Bembo, um modelo de livro sóbrio, bem impresso, modesto, com margens funcionais, espaço interlinear satisfatório e sem ornamentos, que parece ter influenciado profundamente a aparência dos livros e muito se assemelha com nossas obras literárias atuais.

No entanto, na época, provavelmente não havia uma "norma" específica na composição das páginas dos livros de literatura, já que é possível observar diferentes abordagens de impressores e designers ao longo da história do livro impresso no Ocidente. Alguns livros, especialmente de clássicos da literatura como Boccaccio, Shakespeare e Cervantes, impressos nos séculos XV, XVI, XVII e XVIII, têm ornamentos, além de ilustrações. Desde o final do século XIX até a primeira metade do século XX, verifica-se uma boa quantidade de livros impressos 
nos Estados Unidos e na Europa ilustrados, ou seja, não são "simples" como a maioria dos livros que vemos hoje à venda nas livrarias ${ }^{1}$.

Esses exemplos mencionados acima foram produzidos em condições muito diferentes das que temos hoje, eram impressos em tipos móveis ou em composição a quente ${ }^{2}$, um trabalho mais lento e que resultava em tiragens menores do que a capacidade de produção em fotocomposição dominante nas décadas de 1950 a 1990 até a composição digital, o processo pelo qual os livros são projetados hoje em dia.

Antes da Revolução Industrial, o livro era um objeto produzido de forma quase artesanal, se comparado à produção de hoje. Muitos deles apresentavam esmero na impressão, composição, qualidade do papel e encadernação. Pelo cuidado na produção, são objetos que não perecem, sobrevivem em excelente estado de conservação, mesmo tendo mais de quinhentos anos. Logo após a Revolução Industrial, foram produzidas grandes tiragens de livros de péssima qualidade de leiaute e materiais que em poucas décadas já se desintegravam. Em vez de duradouros como os demais, tornaram-se perecíveis.

Em oposição ao livro industrializado e mal feito surgiram, entre o fim do século XIX e início do século XX, iniciativas que promoveram o livro bem feito a partir de técnicas manuais, como no chamado Movimento das Prensas Particulares. Muitos desses livros eram edições de textos literários que procuravam chamar a atenção para o seu design, por meio da qualidade dos materiais, da impressão e da ornamentação.

Em 1930, Beatrice Warde, então editora do periódico Monotype Recorder, utilizou pela primeira vez o termo "tipografia invisível ou transparente" para se referir ao projeto tipográfico para livros, especialmente de prosa, isto é, o leiaute de suas páginas, simples, claro e que não deveria chamar a atenção, para não comprometer a leitura. Muitos designers e tipógrafos - tanto da época em que Beatrice Warde usou o termo pela primeira vez como Stanley Morison e Eric Gill,

1 Foram realizadas visitas a livrarias na Europa, nos Estados Unidos, no Brasil, na Argentina e no México e verificou-se que a maioria dos livros de literatura mantém quase empre o mesmo leiaute padrão. Além de livrarias, foram visitadas três feiras de livro 列 Bienal Internacional do Livro.

2 A partir de máquinas de composição como Monotipo ou Linotipo quanto designers e autores contemporâneos como Jury, Lee, Hendel e Middendorp - defendem essa abordagem e usam esse termo, além de outros como transparência e clareza como forma de defender um livro simples, que não chame a atenção para seu design, porém esses ideais parecem refletir um ideal estético. Não se trata apenas de se defender o livro simples, pretende-se defender um livro bem feito.

O conceito de invisibilidade já foi bastante debatido no campo do design editorial, como se pode verificar na coletânea de breves textos sobre essa temática organizada por Plínio Martins Filho (2003). O termo "invisível" relativo ao design, porém em contexto diferente ao de design de livros, foi utilizado também por Ana Cláudia Gruszynsky (2008) em Design gráfico: do invisivel ao ilegivel, em que trata da invisibilidade em relação ao design modernista, especialmente sobre os ideais do Estilo Tipográfico Internacional ou Estilo Suíço das décadas de 1950 e 1960 e sua posterior crítica pós-moderna "ilegível".

Sobre a visibilidade, Benton (2000: 113) usa o termo em contexto relativo a livros ilustrados, finos e de edições limitadas. A visibilidade é discutida e verificada em muitos exemplos ao longo da história do livro impresso e especialmente hoje, nas primeiras duas décadas do século XXI em que a visibilidade nos livros de literatura parece ganhar cada vez mais força, de acordo com exemplos coletados ao longo desta pesquisa de doutorado.

Em razão do amplo uso desse termo no campo da tipografia e do design editorial para expressar o design do livro simples, adotaremos o termo "livro invisível" para denominar a abordagem de designers que optam por trabalhar leiautes de páginas mais simples. Pretende-se nesta tese de doutorado também investigar com profundidade os usos e implicações desse termo. Como contraponto ao conceito "invisível" mencionado acima, e como outra modalidade, ou estratégia, de design utilizaremos o termo "visível" para tratar de livros em que há algum experimento visual, seja pelo uso de algum ornamento, vinheta, ilustração, tipografia ou mesmo pelo uso de materiais ou produção gráfica, que, em oposição à invisibilidade, chame atenção para o design.

Dessa maneira, propõe-se nesta tese duas categorias de design de livros de literatura: visível e invisível. A partir da proposição destas duas categorias propõe-se aqui um panorama, um levantamento e 
uma investigação de forma também de validar para o campo do design editorial o estudo de ambas.

Livros podem ser invisíveis por serem simples ou visíveis por apresentarem algum elemento gráfico que chame atenção. Embora existam livros que evidententente possam pertencer a uma ou a outra categoria propostas nesta tese de doutorado, há níveis tanto de visibilidade quanto de invisibilidade.

Outra questão que se levanta nesta pesquisa, especialmente em relação aos livros cuja abordagem é visível, é relativa à natureza das mesmas. Qual é a função da visibilidade, porque os livros de literatura são decorados, ou ilustrados, os ideais por trás dos livros ilustrados no século XVIII são os mesmos do ideal dos livros ilustrados no século XXI? Há alguma relação entre a recente "retomada" da visibilidade e a emergência do livro digital?

Editoras como a brasileira Cosac Naify, a britânica Visual Editions, a argentina Libros del Zorro Rojo e a mexicana Almadía, por exemplo, tratam alguns de seus livros de literatura como objetos integrados, cuja capa e o miolo apresentam relações formais, as páginas de texto de diversos livros possuem tratamento particular e não padronizado, como o da maioria das editoras contemporâneas. Além dessa unidade, por sua "visibilidade" o projeto gráfico pode ter funções tanto estéticas quando semânticas se o o projeto gráfico do volume apresenta relações formais/conceituais com seu conteúdo textual.

Exemplos como os das editoras Cosac Naify, Visual Editions, Libros del Zorro Rojo e Almadía parecem ampliar a função atual do design do livro de literatura, o de se criar um objeto para ser lido, para um objeto para ser visto, manipulado e que muitas vezes apresenta camadas de significação de linguagem gráfica que podem complementar o texto verbal. Essa abordagem material e visível do livro não é recente e está frequentemente presente em volumes de fora do campo da literatura, como arte, arquitetura e livros infantis.

Segundo Fawcett-Tang (2007: 9):

Tornou-se rigueur que os editores de livros de arte, design e arquitetura explorem técnicas de produção diferenciadas para atrair seu público-alvo ansioso por novidades - seja no formato, na encadernação, no material da capa ou na embalagem.
A partir de Fawcett-Tang, observa-se que essa abordagem "visível" é comum em outros tipos de livros, como os de arte e arquitetura, e podem ser encontrados inúmeros exemplos de designers e editores que trabalham a materialidade do livro nesses segmentos, como a designer holandesa Irma Boom, a editora alemã Gestalten, a editora suíça do designer Lars Müller, a própria Cosac Naify, que também publicava livros de arte, e de pequenos estúdios de design que desenvolvem projetos para editoras desses segmentos, como Appetite Engineers, de Martin Venezky, em San Francisco, e Studio Blue, em Chicago, entre outros.

Quanto a projetos gráficos de livros de literatura, experimentos gráficos, hoje, são mais raros e talvez mais problemáticos, uma vez que o público de livros literários é extensamente maior e pode estar mais acostumado a projetos tradicionais do que um público, comparativamente menor, interessado por livros de arte.

Sabe-se também que um projeto gráfico que sai do "padrão" é geralmente mais dispendioso, o que torna o produto final mais caro para o leitor. Um livro de arte, provavelmente, apresenta uma função mais estética do que utilitária, o que poderia justificar a qualidade do projeto e dos materiais. Já o livro de literatura é geralmente feito para ser "lido" em vez de "visto" como os livros de arte e, por esse motivo, talvez, que a maioria dos volumes são mais simples. Assim, ao se comparar um livro de arte com literatura, pode-se inferir que o leitor de literatura se relacione com o livro de forma diferente do leitor de um livro de arte.

\section{Hipótese}

Propomos que o campo do design de livros pode ser estudado por meio de duas categorias ou abordagens: visível e invisível.

Nossa hipótese baseia-se no pressuposto de que abordagens de design invisíveis e visíveis do livro de literatura coexistem durante a história do livro impresso, uma vez que foram, ao longo desse período, produzidas tanto edições simples quanto ornamentadas. Nossa hipótese é que a abordagem visível nos livros contemporâneos vai além da simples ornamentação comum nos livros ao longo da história da impressão e apresenta uma função semântica, pois cria interações com o texto literário. Dessa maneira, o livro com design visível, por apresen- 
tar outras funções - semântica, estética e funcional -, complementa o texto e a experiência para além da essencialmente utilitária da leitura e assim valoriza o objeto.

\section{JUSTIFICATIVA}

Como apresentado acima, nossa hipótese é a de buscar comprovar que a natureza da visibilidade nos livros contemporâneos é diferente da visibilidade dos livros antigos, por exemplo. Se a hipótese gira em torno dos livros chamados visíveis, qual seria a necessidade de se pesquisar os livros chamados invisíveis? Justamente porque é necessário também ao campo e especialmente em relação ao livro de literatura mostrar que existem essas duas abordagens, essas duas possibilidades, que uma não exclui a outra e que ambas possuem virtudes e características diferentes.

Dessa maneira, nesta pesquisa procurou-se estudar livros impressos que apresentassem uma ou outra das abordagens mencionadas acima. Foram privilegiados exemplos produzidos na Europa e na América, por serem mais acessíveis do que livros produzidos em outros continentes. Os livros analisados ao longo desta tese refletem a escolha de exemplos gráficos que parecem relevantes para a discussão do tema. Dessa maneira, foram privilegiados dois momentos históricos do design do livro ocidental:

O primeiro é relativo ao surgimento das Prensas Particulares, do Movimento da Fina Impressão e da Reforma Tipográfica, que se situa entre o final do século XIX até os anos 1930

O segundo momento histórico é o atual, contemporâneo, que contempla especialmente as primeiras duas décadas do século XXI, em que parece haver novamente uma tendência de busca da visibilidade e da materialidade do objeto livro, talvez como crítica ao livro padronizado ou mesmo como alternativa às ameaças dos livros eletrônicos. Deste período foram apresentados exemplos de editoras britânicas, argentinas, espanholas, mexicanas e brasileiras.

Uma investigação sobre a visibilidade ou a invisibilidade do projeto gráfico do livro de literatura se justifica especialmente em um contexto marcado pela concorrência de outros suportes de leitura, como os eletrônicos, uma vez que, se o projeto gráfico do livro for pensado ape- nas do ponto de vista utilitário, se sua função é a de apenas criar um suporte de leitura, a importância do design do livro poderá diminuir progressivamente em comparação, por exemplo, com o livro eletrônico, que pode tornar a função do design praticamente inexistente, já que cada leitor, nessa plataforma, tem o poder de customizar e recriar o leiaute das "páginas do livro".

Outra questão que pode ser levantada é a própria definição do termo design. Segundo Villas-Boas (2007: 54), o design de livros se enquadra dentro de uma subcategoria do design gráfico chamada design editorial. Esta profissão ou área de atuação para o autor é fruto pós -revolução industrial. Assim como Villas-Boas, outros autores, como Souza (2001), discutem se é possível trabalhar o termo design gráfico antes que o mesmo tenha sido criado. Autores como Eskilson (2007) e Hollis (2000) traçam uma história do design a partir do século XIX, uma vez que não apresentam peças ou produtos gráficos produzidos antes desse período, e dessa maneira, infere-se sua posição ideológica quanto ao início da profissão, ou a delimitação do campo. No entanto, livros, mesmo que produzidos de forma artesanal e copiados a mão, datam de milênios antes da criação do termo design gráfico ou mesmo do termo design de livros, elaborado anteriormente, ou mesmo do termo design, cujo emprego data do século XVII ${ }^{3}$. O design, por outro lado, pode ser entendido, segundo Eskilson (2007: 24), como a divisão do trabalho, quando o profissional responsável pelo projeto não era o mesmo responsável pela impressão, ou seja, "a profissão do design gráfico foi estabelecida quando a dimensão estética dos meios de comunicação foi separada de seus meios de produção". Benton (2000:7) a respeito do design de livros, explica que a divisão do trabalho entre designer, tipógrafo e impressor se solidificou nos anos 1920, mas que antes havia muita confusão em termos dessa divisão.

Autores como Meggs (2013), Drucker (2009) e Cardoso (2008) têm uma visão mais ampla do design e tratam como design os precursores, ainda que a profissão ou a terminologia tenha surgido depois. Sabe-se que as convenções de leitura e especialmente as convenções e origens do livro pouco mudaram se compararmos os primeiros impressos.

3 Segundo Cardoso (2008: 21-22) "o primeiro emprego da palavra design registrado pelo Oxford English Dictionary data do século 17". 
Dessa maneira, mesmo que possa parecer problemático assumir livros impressos no século XVI como produtos de design não se pode negar sua importância nem deixar de usá-los como exemplo, mesmo porque grande parte dos maiores designers de livros do século XX, como Bruce Rogers ou Daniel Berkeley Updike (como se pode observar ao longo desta tese), buscaram inspiração em modelos renascentistas, o que mostra que a tradição, quando se fala especialmente em design de livros, é mais presente do que uma ideologia ou metodologia criada a partir da revolução industrial ou mesmo no século XX.

\section{MATERIAIS E MÉTODOS}

A presente pesquisa envolveu tanto pesquisa bibliográfica quanto de campo.

\section{Pesquisa bibliográfica}

Revisão da literatura de autores dos campos: Design Gráfico, Design de Livros, Tipografia, História do Livro, História do Design do Livro, Análise e Retórica da Imagem, Teoria Literária, Linguística e Semiótica.

\section{Pesquisa de campo}

Foram realizadas entrevistas com designers e visitas técnicas a bibliotecas, livrarias e feiras de livros para coleta de exemplos que apresentassem as abordagens mencionadas na hipótese. A lista com todas as entrevistas e visitas encontra-se abaixo:

Brasil: Entrevistas com os designers Elaine Ramos (Cosac Naify), Alceu Nunes e Fabiana Roncoroni (Cia das Letras) e Pedro Inoue (Aleph);

Entrevistas por e-mail ou Skype: Barbara De Wilde, David Drumond e Anna Gerber (Visual Editions);

Viagem técnica aos Estados Unidos - San Francisco (pesquisa de campo para o doutorado) 08 a 18 de fevereiro de 2013, Visita à Codex 2013, importante feira de livros artesanais/experimentais e de artista; entrevistas com os designers/;artistas Martin Venesky, Wilber Chip Schilling, Didier Mutel, Jeremy Mende e Geoff Kaplan. Visita à editora Chronicle Books e entrevista com designers e com o diretor criativo Michael Carabeta. Visita à editora McSweeneys e conversa com o de- signer Brian McMullen. Visita ao SF for the book http://sfcb.org/;

Viagem técnica aos Estados Unidos entre 27 de junho a 31 de julho de 2013: visita à University of Arts na Philadelphia - Departamento de Artes do livro - Entrevista com Susan Viguers. Entrevista com o designer Warren Lehrer, em Nova York, Pesquisa na Arts Library Special Collections da Universidade de Yale e na New York Public Library. Visita à fundação organizadora da http://nyartbookfair.com/ Printed Matter em NYC. Entrevista com a designer de livros Cheryl Towler Weese, do Studio Blue em Chicago. Visita à University Libraries Center for Book Arts \& Logan Elm Press da Ohio State University e entrevista com Robert Tauber;

Visita técnica à Feira Internacional do Livro de Guadalajara (Dezembro de 2013);

Visita técnica à Feira Internacional do Livro de Buenos Aires (Maio de 2014);

Visita técnica à Biblioteca Pública de Cleveland em janeiro de 2015; Visita técnica às bibliotecas: Biblioteca Pública de Nova Iorque, Morgan Library, Grolier Club e Biblioteca Pública de Cleveland, entre junho e julho de 2015.

\section{Pesquisa qualitativa}

Pesquisa qualitativa com 22 leitores voluntários ${ }^{4}$ que compraram o livro Bartleby, o escrivão, de Herman Melville (2005), da editora Cosac Naify, e responderam a um questionário sobre sua experiência de leitura.

\section{ESTRUTURA DA TESE}

Buscou-se neste trabalho, além de abordar as categorias ou abordagens de design do livro propostas (visível e invisível), apresentar um panorama amplo sobre o assunto para que depois fosse possível problematizar ambas as abordagens e comprovar a hipótese apresentada acima.

Os leitores que se mostraram interessados em participar da pesquisa a partir de convites por e-mail e por redes sociais se prontificaram a comprar o exemplar de Bartleby publicado pela Cosac Naify e responderam ao questionário. Não houve uma seleção específica por profissão, faixa etária ou escolaridade, embora a grande maioria do grupo se encontre na faix dos 30 anos e tenha curso superior completo, como se pode observar no anexo. 
O primeiro capítulo é dedicado a mostrar exemplos de livros com abordagens simples desde o início da impressão e introduzir e explicar o conceito de invisibilidade (ou transparência) a partir de autores como Beatrice Warde, Stanley Morison, Eric Gill e Jan Tschichold, entre as décadas de 1920 a 1940. Em seguida, no mesmo capítulo, o conceito da invisibilidade é trabalhado sob a perspectiva de autores contemporâneos como Lee, Hendel, Jury e Lupton.

No segundo capítulo, num primeiro momento é apresentado um breve panorama do livro "visível" a partir de edições diferentes de dois clássicos da literatura ocidental: Decameron e Dom Quixote. Num segundo momento são apresentadas as abordagens visíveis do design de livro em um contexto bastante importante para esta pesquisa, pois é justamente contemporânea à época em que o conceito de invisibilidade ganhou força, que vai do movimento das prensas particulares no final do século XIX até o início do século XX, e sobre o fenômeno da fina impressão, especialmente nos Estados Unidos na década de 1930

O terceiro capítulo faz uma revisão bibliográfica técnica e trata da tipografia como elemento que pode sugerir ou conotar significados em livros de literatura.

No quarto capítulo são apresentados exemplos de livros "visíveis" contemporâneos.

Em seguida, no quinto capítulo foi apresentado referencial teórico e técnico para a análise de projetos gráficos de livros e, no sexto capítulo, a partir do estudo de caso do livro Bartleby, publicado em 2005 pela editora Cosac Naify, investiga-se a "visibilidade" como evidência da relação entre design e texto literário.

Já no sétimo capítulo as abordagens visíveis e invisíveis são problematizadas, é apresentado um questionamento sobre a qualidade ou a falta de qualidade do design de livros e a ameaça do livro digital é abordada.

\section{O LIVRO INVISÍVEL}

A maioria dos livros destinados à leitura contínua, como romances, apresentam leiautes de páginas simples: mancha de texto de uma coluna composta em tipos serifados, sem ornamentos e ilustrações. São livros funcionais, destinados à leitura, tradicionais e, nesse sentido, hoje são o padrão. São também familiares, uma vez que o público leitor está acostumado com seu design e ele raramente chama atenção. Livros simples como esses poderiam, em primeira análise, ser concebidos como "invisíveis" conforme ideais apresentados no famoso ensaio de Beatrice Warde intitulado Crystal Goblet, or why Printing should be Invisible, de 1930¹. O ideal da invisibilidade se refere ao design transparente, que revela e não oculta o conteúdo (texto) e é baseado em protocolos de composição que asseguram sua qualidade 2 . Apesar de o termo se tornar bastante conhecido no campo do design de livros e tipografia e de seus ideais serem seguidos e debatidos por muitos autores e designers, a abordagem do livro "simples", ou seja, sem ornamentos, não foi criada naquela época.

O presente capítulo busca apresentar e debater a ideia da invisibilidade $^{3}$ em diferentes contextos, além do que foi primeiramente utilizado (década de 1930), como um dos conceitos-chave que permeiam o design de livros, em especial o de literatura.

\section{ABordagens “INVISÍveIs" DO SÉculo XV AO XIX}

Os primeiros livros impressos ocidentais, conhecidos como incunábulos, eram ricamente decorados, mantendo uma configuração parecida com a dos livros manuscritos produzidos antes do advento da prensa com tipos móveis. Mesmo sendo impressos, ganhavam acabamentos manuais, como capitulares e ilustrações.

1 Palestra apresentada no encontro da British Typographers' Guild no St. Bride Institute, em Londres, em 7 de outubro 1930, com o título Printing Should be Invisible. O texto foi impresso em forma de panfleto posteriormente em 1932, em coletânea de ensaios da própria autora e posteriormente em coletâneas.

2 A simplicidade, no contexto de Warde, relaciona-se à qualidade e não à ausência de design, que é possivel identificar em muitos livros de bolso existentes no mercado, que apresentam corpo de texto pequeno, com entrelinhas e margens insatisfatórias.

3 Nesse contexto, o ideal de invisibilidade é relativo apenas às páginas de texto e não às capas. 
Figura 1. Páginas de De Aetna, de Pietro Bembo (1470 - 1547), impress em 1496 na oficina de Aldus Manuzio. Livro do acervo da Morgan Library. Fotos da autora.
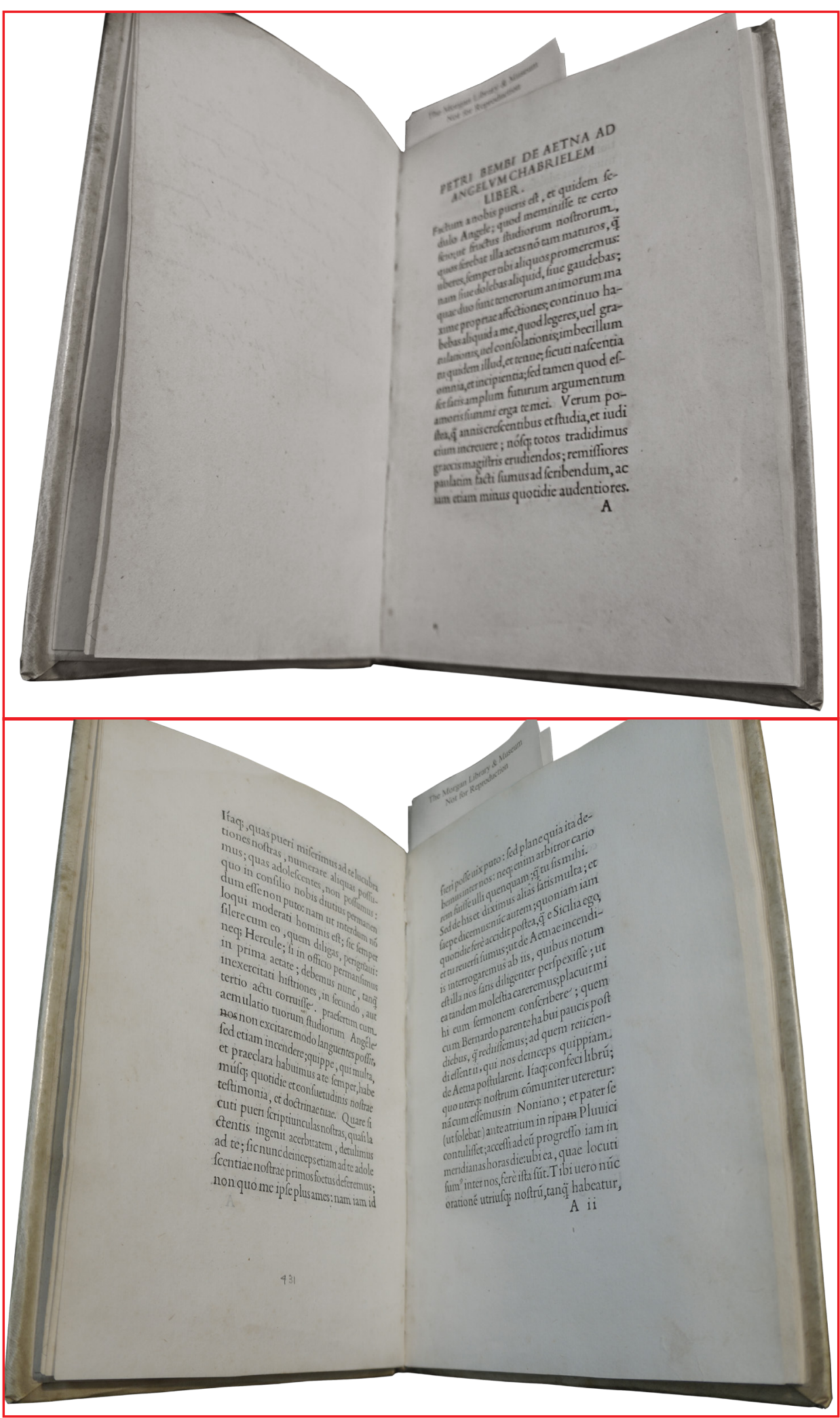

Apesar de o que é ou não visível possa ser relativo, de acordo com determinada época, se pensarmos no termo como "padrão", por exemplo, talvez um livro ornamentado do século XV por ser comum na época fosse menos "estranho" ao leitor do que um livro simples a que ele não estava acostumado devido à tradição manuscrita.

Se tomarmos como ponto de partida a abordagem visível que se apresenta em livros de literatura com ornamentos e não apenas o texto, é possível encontrar exemplos ao longo da história do livro4 ${ }^{4}$ Se levarmos em conta o "invisível” como abordagem simples esta também é presente ao longo da história do livro impresso e não pode ser considerada uma abordagem recente.

Como exemplo de incunábulo "invisível", ou seja, mais simples se comparado com as edições mencionadas acima, temos De Aetna ${ }^{5}$, de Pietro Bembo, impresso por Aldo Manuzio em 1496, em Veneza.

De Aetna (fig. 1), de formato $14,5 \times 20^{6} \mathrm{~cm}$, é composto em um tipo claro e legível, com provável uso de espaço interlinear, margens generosas e sem nenhum ornamento em nenhuma página. O papel é robusto ${ }^{7}$ e sua cor, mesmo após mais de 500 anos, continua alcalina, devido à qualidade do papel que, na época, era produzido a partir de fibras naturais de tecidos.

A tipografia utilizada nesse volume, criada por Francesco Griffo para Aldo Manuzio, chamou a atenção do tipógrafo Stanley Morison, que produziu uma adaptação desses desenhos para a Monotype Corporation em 1929: "O tipo é realmente notável. É claro, aberto, mas não muito arredondado, e vigoroso embora não muito escuro". (Morison, 1960: 24).

Em relação ao tipo usado em De Aetna, Daniel Berkeley Updike (1980: 76) não parece concordar inteiramente com Morison sobre a qualidade da face tipográfica desse volume em especial:

4 Alguns exemplos foram encontrados em pesquisa nas bibliotecas mencionadas na introdução e serão apresentados ao longo desta tese.

5 Um dos primeiros livros impressos simples e sem ornamentos.

6 Formato aproximado medido no local. Os formatos podem variar da época em que foram produzidos, por serem muitas vezes reencadernados. Este volume pertence à Morgan Library.

7 Aproximadamente $100,120 \mathrm{~g} / \mathrm{m}^{2}$ 
Cinco ou seis fontes romanas foram cortadas para o grande impressor e editor Aldus Manutius. Sua primeira romana, que foi usada em $D e$ Aetna, de Bembo, não foi particularmente bem-sucedida, mas a terceira fonte romana, desenhada pelo célebre Francesco da Bologna (Griffi), que depois cortou o caracter itálico Aldino, era excelente. Essa face romana foi usada no famoso livro Hypnerotomachia Poliphili, ou "The Strife of Love in a Dream", impresso por Aldus no último ano do século. (UPDIKE, 1980: 76)

Como se pode observar, Updike prefere o tipo usado em Hypnerotomachia Poliphili ao usado em De Aetna, porém Hypnerotomachia é um livro muito mais visual (visível) do que De Aetna: apresenta ilustrações e capitulares impressas decoradas.

O estilo aldino, como se sabe, inspirou muitos impressores em toda Europa e, de acordo com Alan Bartram, essas características tipográficas se tornaram "o arquétipo de nossos tipos romanos até o início do século XVIII” (BARTRAN, 2001: 15).

Jan Middendorp (2012:22) acredita que "um livro como De Aetna do cardeal Pietro Bembo, impresso na oficina de Aldus em 1495-96, não é significativamente diferente das brochuras que são produzidas hoje". Essa questão abordada por Middendorp é pertinente, no sentido de que o livro simples não é novidade e pouco mudou desde De Aetna.

Um livro simples, claro e funcional como esse pode ser justificado pelo modelo de negócio de Manuzio, que procurou publicar livros menores e mais simples para ampliar a oferta e aumentar suas vendas. Uma explicação sobre esse modelo pode ser encontrada em Kate Clair (2009: 61):

No início dos anos 1490, na época das viagens de Cristovão Colombo para a América, o estudioso e professor italiano Aldus Manutius visualizou livros impressos de baixo custo como meio de tornar disponíveis a estudantes antigos manuscritos, bem como um meio de fazer dinheiro. Aos 40 anos de idade, Aldus juntou-se a um patrocinador financeiro e um impressor, começando a imprimir livros de referência. Seu empreendimento comercial mudou a conceituação dos livros. O livro pesado e grande não estava mais limitado ao púlpito no qual os mestres liam em voz alta para os discípulos. Ele imprimiu livros menores, facilmente portáteis para que as pessoas pudessem ler individualmente para si mesmas.
O projeto de Aldo é importante também pela quantidade de volumes que imprimiu. Segundo Manguel (1996: 160-161):

Em 1494, Aldus começou um ambicioso programa de publicações que produziria alguns dos volumes mais belos da história da imprensa: primeiro em grego - Sófocies, Aristóteles, Platão, Tućdides -e depois en tion autores deveriam ser lidos "sem intermediários" - na língua original e quase sem anotações e glosas - , e para possibilitar aos leitores "conversar livremente com os mortos gloriosos", publicou livros de gramática e dicionários junto com os textos clássicos. Não somente buscou os serviços dos especialistas locais, como também convidou humanistas eminentes de toda a Europa - inclusive luminares como Erasmo de Roterdã - para ficar com ele em Veneza.

Esse espírito empreendedor de Aldo, como apresentado por Clair e Manguel, é percebido especialmente pela criação dos primeiros livros portáteis e impressos em tipo itálico que, por ser mais estreito, resultava na impressão de mais palavras por página. Segundo Febvre e Martin (1992:126), Aldo Manuzio “manda gravar por Francesco Griffo caracteres inspirados na cancellaresche romana (1501) e lança assim a moda do itálico, escrita inclinada, mais fechada, que permite imprimir em páginas de formato reduzido um texto relativamente longo".

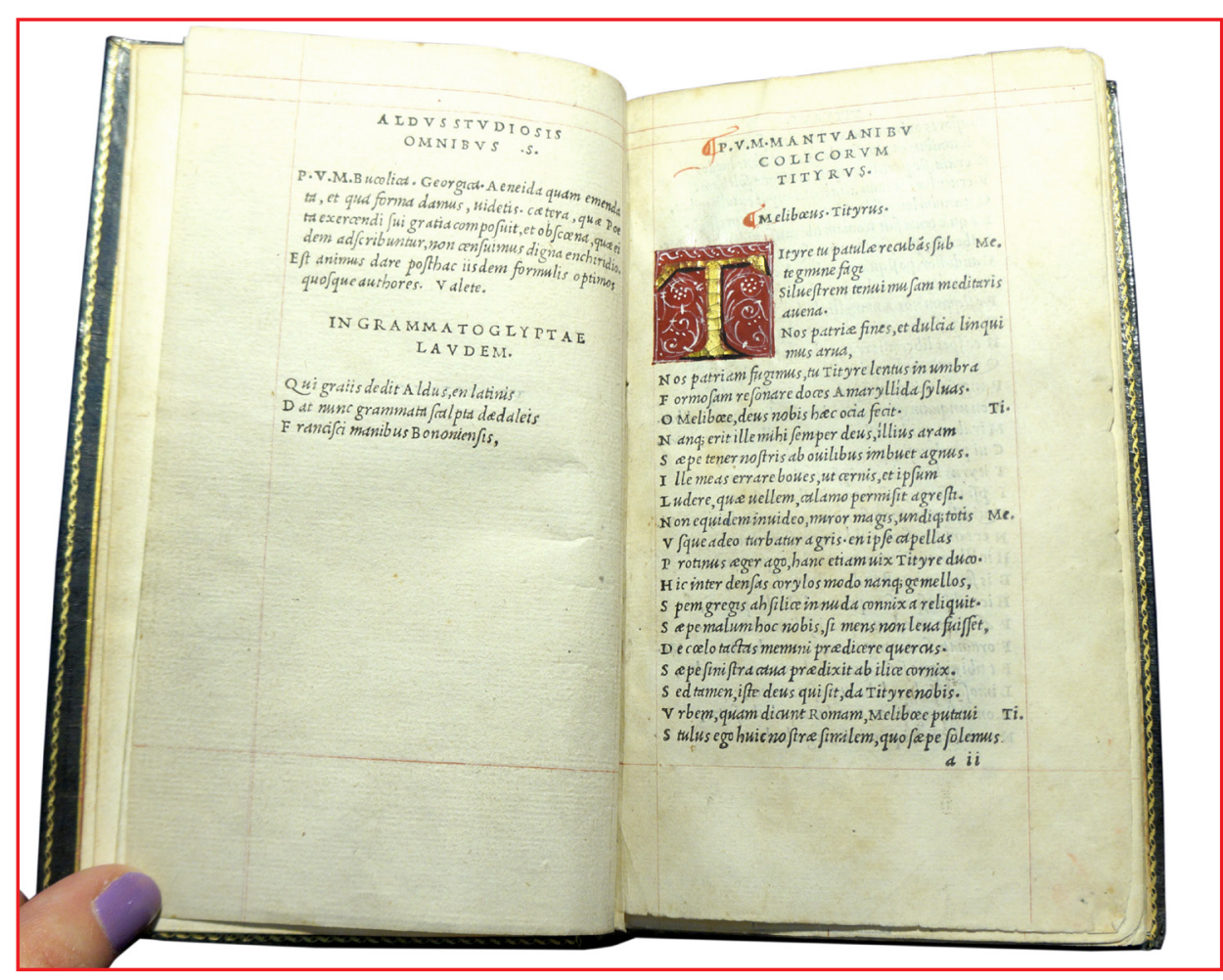

Figura 2. Virgílio (70 a.C.-19 a.C.) publicado na Oficina de Aldo Manuzio em 1501. Livro do acervo da New York Public

Library. Foto da autora. 
Um exemplo de livro conforme o modelo apresentado por Febvre e Martin é este volume de Virgílio (fig. 2), impresso em 1501, de dimensões $10 \times 18 \mathrm{~cm}$. As margens são relativamente menores se comparadas às de De Aetna. O corpo do texto e entrelinha são de aproximadamente 9/11 pontos e o papel é de baixa gramatura, também se comparado ao de De Aetna. Tem-se aqui provavelmente o modelo, especialmente de produção, muito próximo ao de edições de bolso: fonte mais condensada, tamanho do corpo do texto pequeno e papel de baixa gramatura.

Febvre e Martin (1992: 173-181) também apresentam uma série de exemplos sobre custos de materiais e de impressão e concluem que o papel é o elemento mais caro para a produção do livro entre os séculos XV e XVIII. A partir desse levantamento, não é de se estranhar o empenho de impressores como Aldo em produzir livros mais simples e portáteis.

Sabe-se que os livros de Aldus inspiraram muitos impressores de diversas partes da Europa, mas não é possível constatar nem a partir da literatura consultada nem em relação aos exemplos de livros encontrados e analisados nesta tese se a abordagem extremamente simples de De Aetna influenciou outros impressores a trabalhar sem nenhuma ornamentação. Ao que parece, a ornamentação continou a ser utilizada até o século XVII.

No entanto, a partir do século XVIII, o leiaute da página simples parece novamente ganhar terreno. Segundo Frans A. Jansen (in LOMMEN, 2012: 174-175):

No leiaute de livros das últimas décadas do século XVIII, encontramos um uso extravagante de espaços em branco: nas margens, no espaço interlinear, no espaço entre palavras e no espaço ao redor de sinais de pontuação. Páginas de rosto foram tours de force tipográficos, criadas a partir de letras maiúsculas centralizadas e bem espacejadadas: o ornamento fo reduzido a uma ocasional linha simples impressa.

Morison também aborda a ausência de ornamentação em livros do final do século XVIII e início do XIX, em ensaio sobre a importância da ornamentação:

A repulsa do século XVIII contra o ornamento ganhou terreno por cinquenta anos, de 1790 a 1840, que viu o desuso de todas as formas de decoração tipográficas, a não ser o de uma linha simples. (MORISON, decoraçăa 3 )
O impressor e tipógrafo inglês John Baskerville (1706-1775) apresenta uma abordagem minimalista (sem ornamentação) e muito arejada. Segundo Adrian Wilson (1993: 20): "Sua dependência na tipografia em vez de ilustração e ornamento foi uma revelação no design de livros".

Para Bartram (2004: 16), desde os primeiros impressores italianos, Baskerville foi o primeiro a praticamente dispensar a decoração em seus livros e Bodoni "completou essa revolução trazendo lógica ao arranjo dos títulos correntes".

Muitos de seus livros apresentam margens e entrelinhas generosas e o uso de um tipo claro e racional ${ }^{9}$ impresso em papel liso, o que consagrou seu estilo e que, segundo Morison (1963: 46-47), tornou a impressão inglesa influente e inspirou impressores e tipógrafos como P.S. Fournier e Giambattista Bodoni.

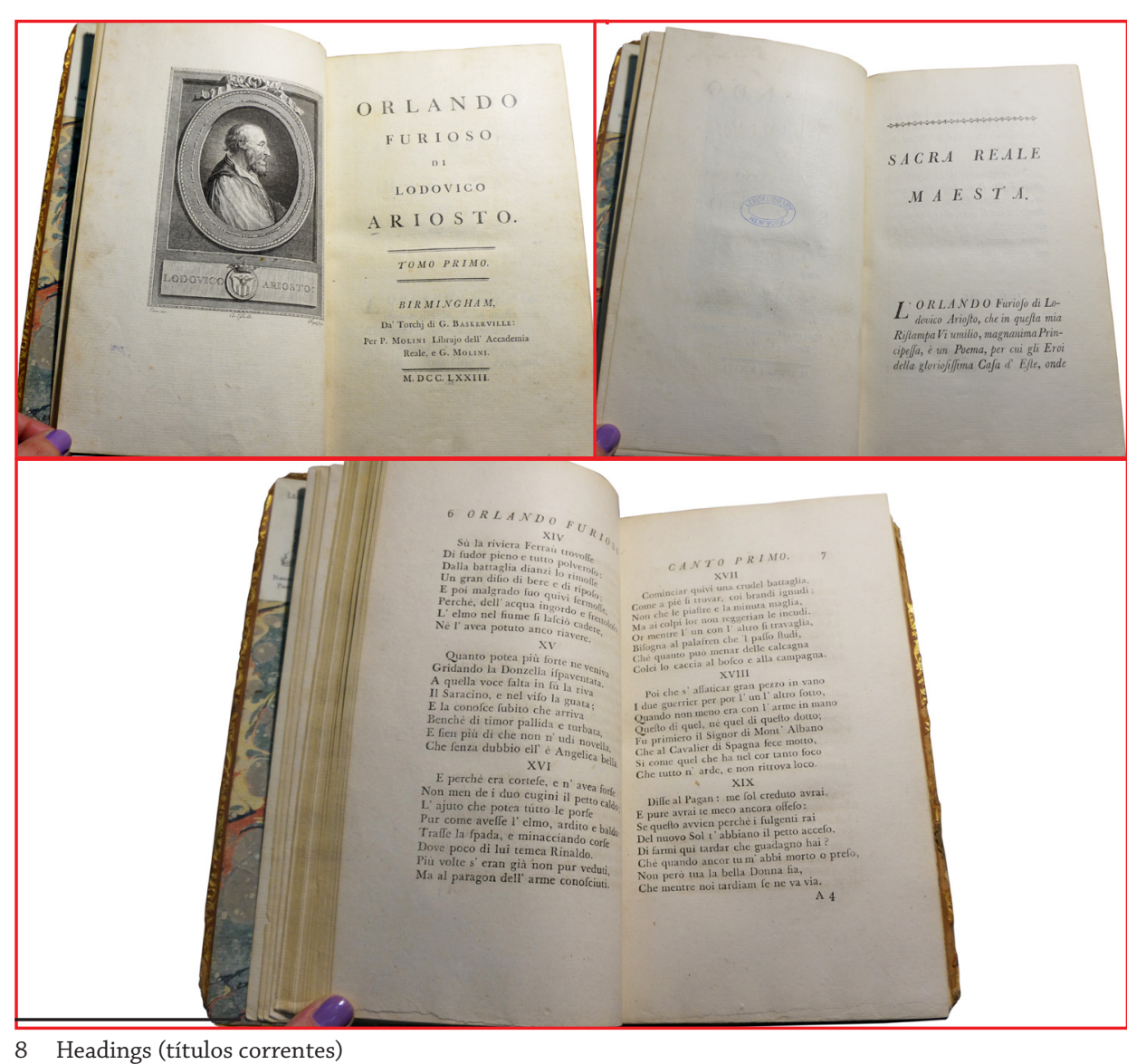

Figura 3. Orlando Furioso (1516), de Ludovico Ariosto (1474-1533). Impresso em 1773 por John Baskerville. Livro do acervo da New York Public Library. Fotos da autora.

O tipo que Baskerville desenvolveu é racional, pois é concebido a partir de formas mais geométricas e eixo de contraste vertical. Segundo Jury (2004:10), "Baskerville, ciente dos acontecimentos na França, sob os auspicios da Academia de Ciências, deu passos significativos rumo a uma abordagem mais racional do design de sua tipografia, marcando um período de transição aos passos decisivos que foram tomados para o total abandono de referências de formas caligráficas por Didot na França, logo depois na Itália por Bodoni? 


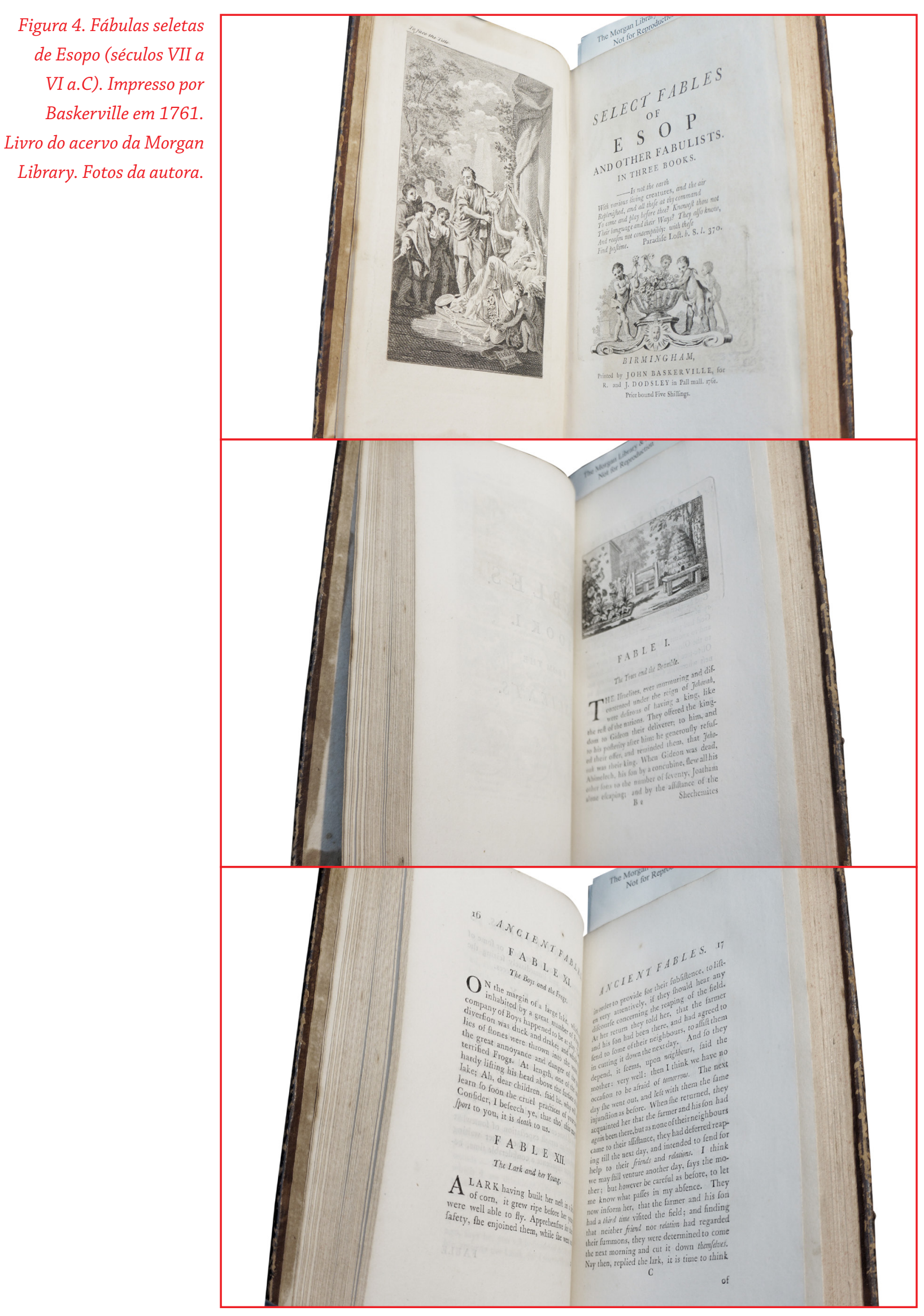

A edição de Orlando Furioso (figura 3), de Ludovico Ariosto, impressa em 1773 por Baskerville, foi, segundo Morison (1963: 47), uma grande influência para o impressor italiano Giambattista Bodoni, que mais tarde passaria a seguir seu exemplo de uma composição mais simples e mais arejada (amplas margens e espacejamento).

As páginas do volume de 14,5 × $25 \mathrm{~cm}$ são desprovidas de ornamentos, os títulos correntes foram compostos em maíusculas itálicas espacejadas. O texto é recuado e apresenta margens generosas e foi composto em corpo de 12 pontos com entrelinha de 14 pontos.

Já este outro exemplo, Fábulas de Esopo (Figura 4), apresenta ilustrações e capitulares, demonstrando uma abordagem um pouco diferente da de Orlando Furioso. Porém, o volume de 11 x 17,5 cm não apresenta ornamentos e as capitulares são simples ${ }^{10}$. O estilo da fonte ${ }^{11}$ usada nesta edição é muito parecida com a de Orlando Furioso, porém, o tamanho do tipo é menor devido ao tamanho do volume: corpo e entrelinhas de aproximadamente $9 / 11$ pontos.

Outros exemplos de abordagens mais simples do design da página impressa podem ser encontrados na Itália no final do século XVIII e início do século XIX, produzidos por Giambattista Bodoni (17401813), que, como apresentado acima, a partir de Morison (1963), foi particularmente influenciado pelo trabalho de Baskerville.

Lommen (2012: 174) mostra que Bodoni, além de se inspirar em Baskerville, também admirava o trabalho do impressor espanhol Joaquín Ibarra (1725-1785), que igualmente trabalhava a página de forma mais limpa, como se pode observar pelo exemplo da edição de 1780 de Dom Quixote, por encomenda da Real Academia Espanhola.

A edição impressa de $31 \times 21 \mathrm{~cm}$, em quatro volumes, tem as dimensões de um livro de mesa. Por mais que apresente página de rosto e abertura de capítulo decoradas, as páginas de texto deste exemplo são limpas, claras, com margens generosas e compostas em um tipo claro de serifas apoiadas, com terminais lacrimais e eixo de contraste vertical. 


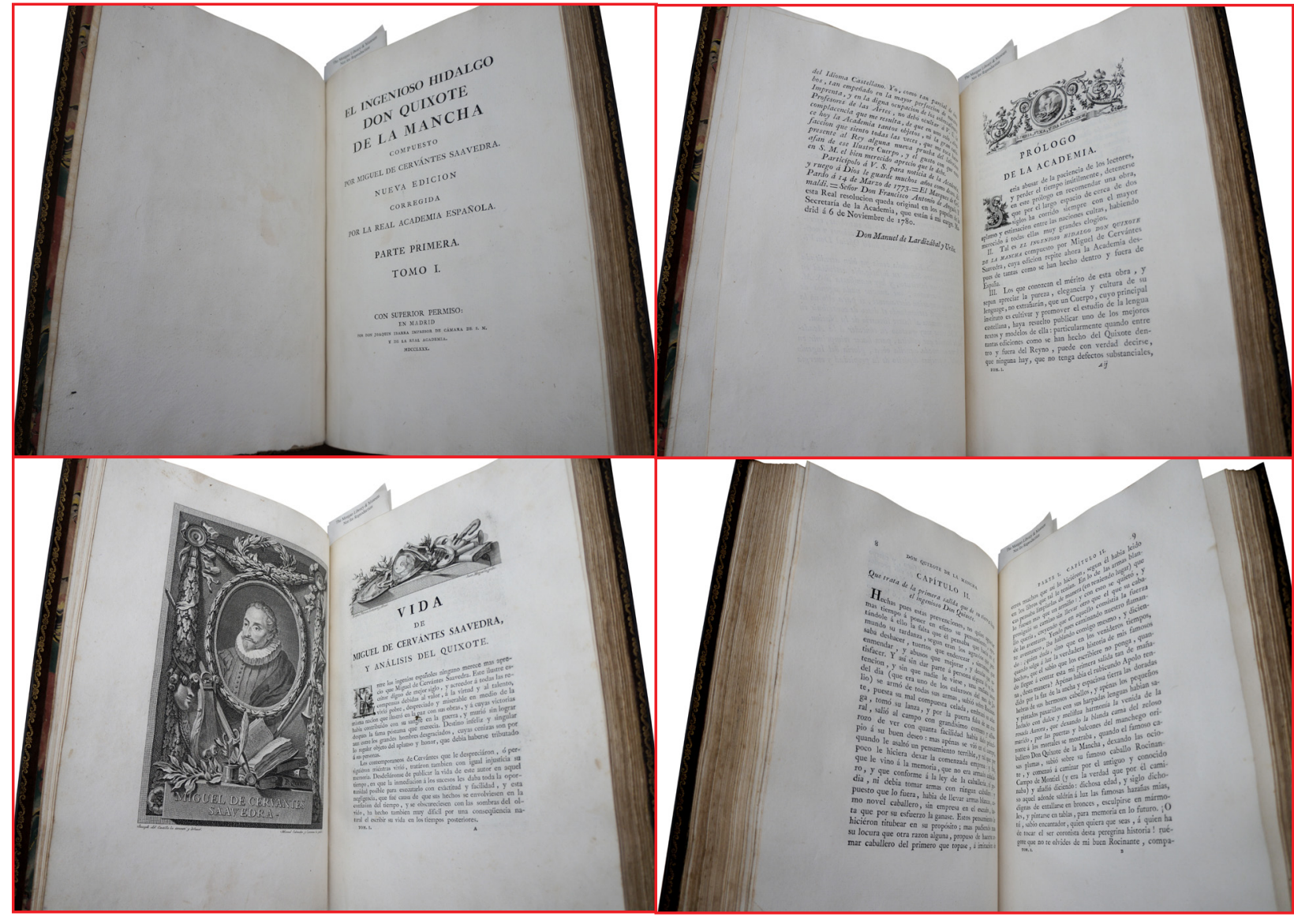

Figura 5. Dom Quixote Como se pode ver nos exemplos apresentados abaixo, Bodoni, assim (1605-1615), de Miguel de como seus precursores como Baskerville, trabalhou o leiaute da págiCervantes (1547-1616). na sem ornamentos e com margens e espaços entrelinha generosos e Impresso por Joaquin impressos com um tipo de eixo racional ${ }^{12}$. Embora as abordagens pare1780. Livro do acervo çam ser semelhantes, a tipografia é bem diferente. Os tipos de Bodoni, da Morgan Library. assim como os de Didot, na França, introduzem um novo tipo de seriFotos da autora. fas, de tipo filete. Além dessa diferença nas serifas, outra importante característica é o alto contraste entre traços e finos e grossos. Tipos com essas características vieram a ser chamados posteriormente de modernos. Segundo Sutton e Bartram (1999: 13), os tipos modernos:

Foram desenhados para impressionar os olhos. As finas serifas e o abrupto e exagerado contraste entre traços finos e grossos demandam uma manipulação cuidadosa, uma técnica de impressão sofisticada e um papel mais suave (liso) e de ótima qualidade (...).

2 Eixo de contraste reto. O tipo apresenta poucos detalhes caligráficos como eram os tipo de classe humanistas ou garaldes. No terceiro capítulo as classes e as diferenças entre os desenhos das letras serão abordadas com mais detalh

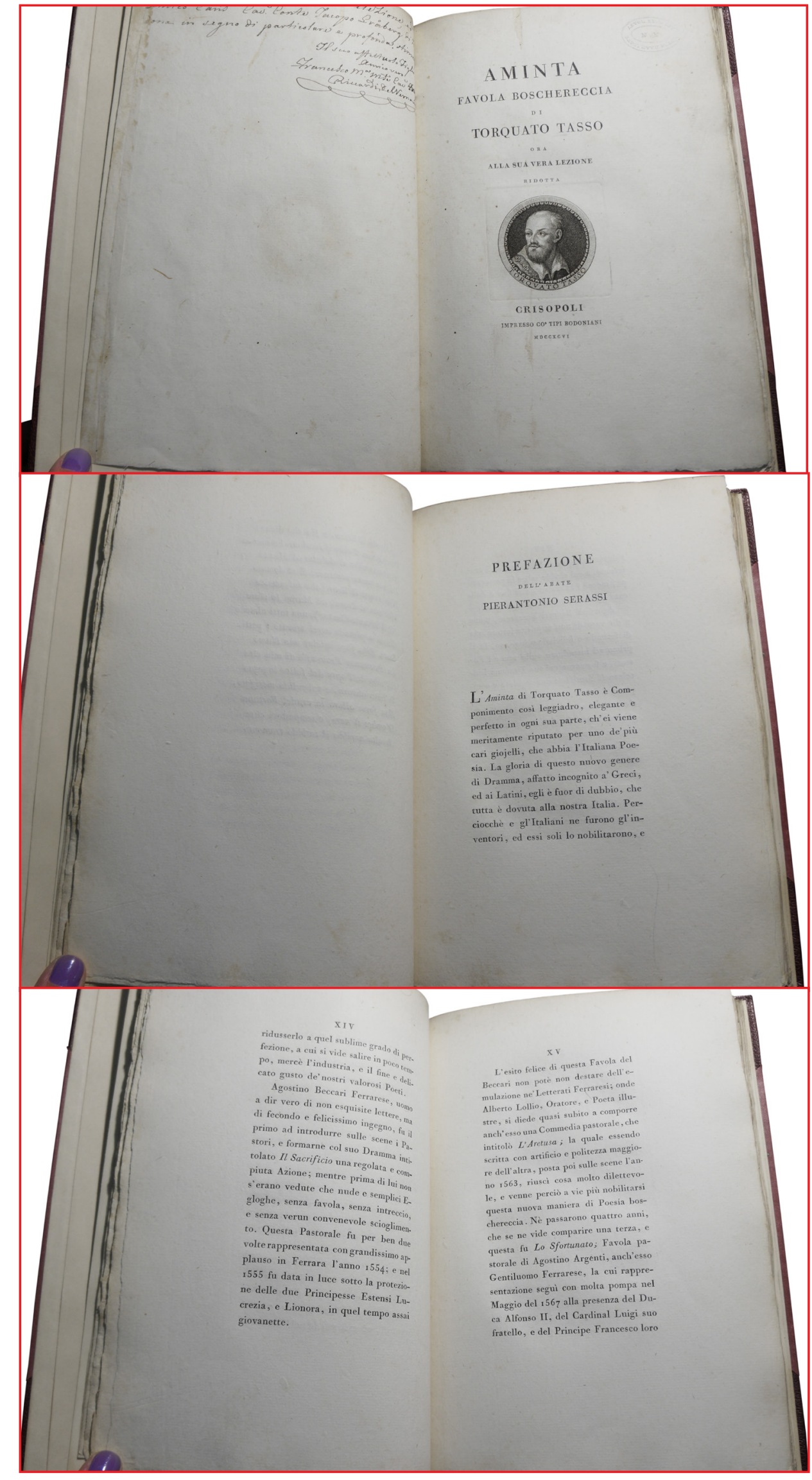

Figura 6. Aminta, de Torquato Tasso (15441595). impressa em 1796 por Giambattista Bodon (1740-1813). Livro do acervo da New York Publi Library. Fotos da autora. 
A afirmação de Sutton e Bartram sugere que os tipos modernos, como os de Bodoni, não são neutros e chamam a atenção. Jury (2004 10) explica que esses tipos rompem com certas regras da leiturabilida$\mathrm{de}^{13}$ (readability) por seu acentuado contraste, mas que "Didot e Bodon conscientemente tentaram (e conseguiram) produzir alguns dos mais magníficos livros já impressos, projetados para serem vistos e admirados assim como para serem lidos". Ou seja, por mais que, aparentemente, os livros tenham design simples e sem ornamentos não são necessariamente "invisíveis". A partir de Jury, infere-se que estes livros apresentam, além da função utilitária da leitura, uma função estética.

A peça teatral Aminta (Figura 6), de Torquato Tasso (1544-1595), impressa em 1796 em Parma, por Bodoni, de dimensões 17 x 24,5 cm, apresenta amplas margens e foi composta pelo tipo de sua autoria, que como vimos anteriormente é chamado de moderno. Bodoni trabalha com um espaço interlinear bem maior que Baskerville ou Ibarra. Neste exemplo específico, foi usado corpo 12 e entrelinha de 18 pontos, ou seja, a entrelinha é $50 \%$ maior que o corpo ${ }^{14}$, o que hoje talvez seja considerado exagerado. É possível que esse amplo espaço interlinear seja utilizado para dar mais leveza ${ }^{15}$, já que o tipo é pesado, contrastado e condensado. Curioso observar também um espacecajemento entre palavras um pouco maior que o habitual, especialmente pelo texto ter sido composto alinhado à esquerda.

Esta edição de Sonho de Polifilo (Figura 7), de Francesco Colonna, impressa por Bodoni em 1811, apresenta páginas simples com título corrente composto em maiúsculas romanas que são mais discretos do que a forma como Baskerville os utilizava, já que não são tão espacejados e,

13 Segundo Gruszynsky (2008: 33) "O vocabulário técnico mantém - em língua inglesa uma distinção entre readability e legibility. A primeira refere-se à facilidade de ler textos extensos; associa-se, portanto, ao arranjo dos tipos. A segunda diz respeito ao seu rápido reconhecimento, sendo relacionado a textos curtos e, assim, ao design dos tipos."

14 A porcentagem do espaço interlinear comumente usada em textos é de

aproximadamente 20\%, como se pode observar em Bringhurst (2005: 45): “A maior parte dos textos requer uma entrelinha positiva. Especificaçoes como 9/11, 10/12, 11/13 e 12/15

15 A questão sobre uso de espaço interlinear maior em composições com tipos modernos se comparados a tipos oldstyle como a Bembo tamberm é apresentada por Bringhurst (2005: 45): "Fontes como a Bauer Bodoni, com cor forte e eixo vertical rigido, precisam de muito mais entrelinha do que fontes como a Bembo, em que a cor é clara e o eixo se baseia na scrita manual"

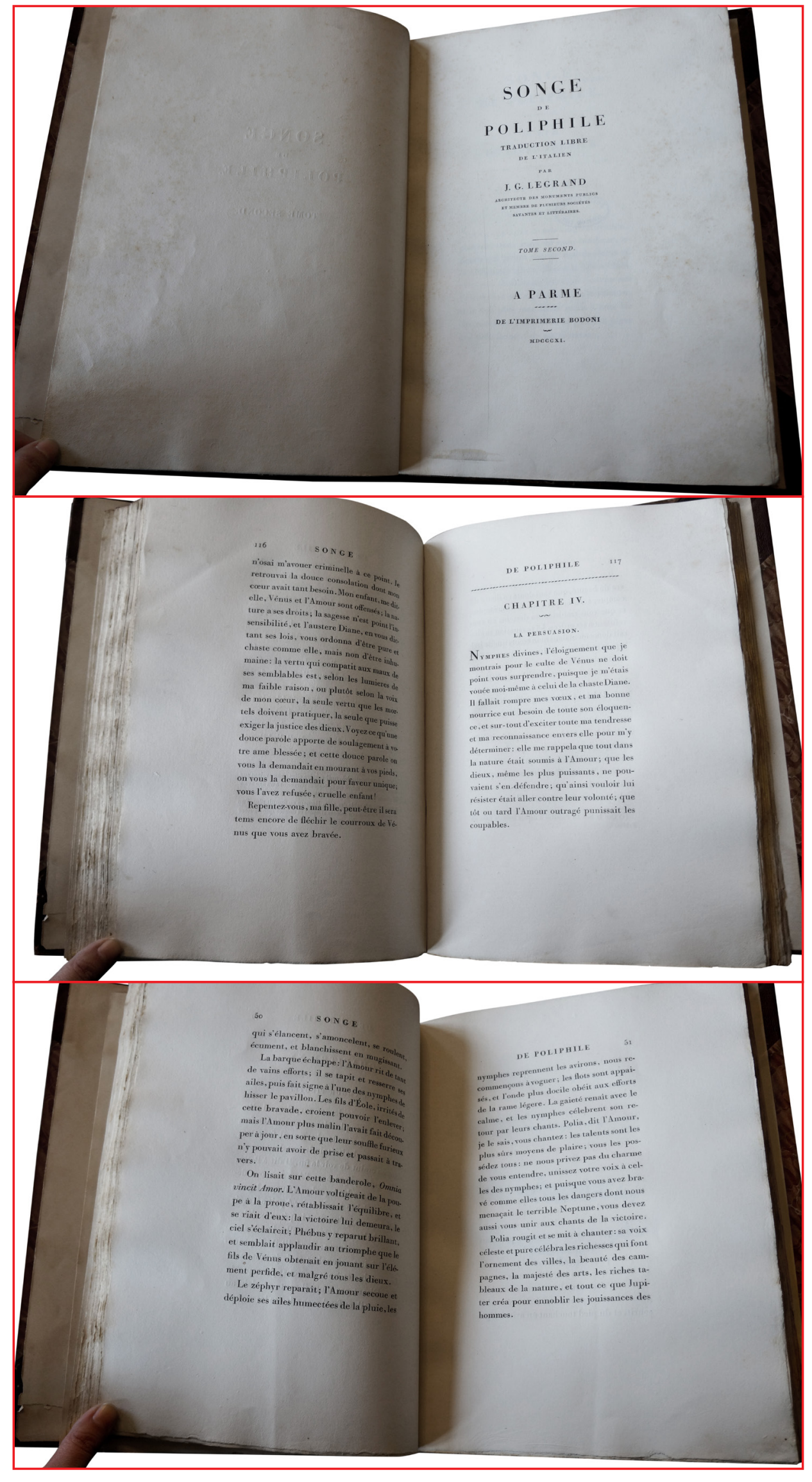

Figura 7. Sonho de Polifilo, de Francesco Colonna (1433/1434-1527). Impresso por Giambattista Bodoni (1740-1813) em

1811. Livro do acervo da

Cleveland Public Library

Fotos da autora 
em vez de itálico, Bodoni utiliza os romanos cujo desenho é o mesmo que o utilizado no corpo do texto. O tipo usado neste volume, de corpo 16 e entrelinha de 24 pontos, é aparentemente mais pesado e mais contrastado do que o empregado em Aminta. Essa diferença talvez seja um ajuste de corpo: fontes de metal em corpo menor são em geral menos contrastadas do que fontes em corpo maior. O papel utilizado é de gramatura maior (150 mg aproximadamente). Todos esses atributos sugerem que este exemplar é mais luxuoso e imponente que o anterior, porém, a partir de comparação, a leitura de Aminta aparenta ser mais agradável.

Os livros impressos por Bodoni, além das características descritas acima, são muito bem feitos: os espaços entre palavras são regulares, a impressão é uniforme e aparentemente há uma preocupação com a proporção dos elementos: tamanho do tipo versus tamanho da página, tamanho da mancha (coluna) versus margens, etc. Esse cuidado talvez não tenha sido tomado em livros produzidos por outros impressores que seguiram o estilo de Bodoni, como esta edição de Decameron, de 1812-1814, impressa na Stamparia Blanchon (Figura 8) em Parma, que, apesar de arejado como Sonho de Polifilo, tem a mancha muito estreita se comparada às margens. O formato $12 \times 21 \mathrm{~cm}$ é bastante estreito, o que, pelo uso exagerado das margens, resulta em uma mancha de texto justificada de apenas 40 caracteres por linh ${ }^{16}$, criou espaços entre palavras irregulares e apresenta muitas sequências de hífens ${ }^{17}$. Sonho de Polifilo tem uma média de 45 caracteres por linha, o que não representa uma grande diferença, porém a textura do bloco de texto é mais uniforme. Nota-se aqui também o estranho espaço (para nossos olhos) utilizado antes e depois de sinais de pontuação.

Os tipos criados por Bodoni na Itália e por Didot na França tiveram muito impacto durante todo século XIX. McLean (1972: 12) aponta o uso extensivo desses tipos na Inglaterra no início do século XIX, dessa forma, não é de se estranhar que no final deste século e início do século XX tipos modernos foram perdendo sua popularidade a partir do resgate de tipos oldstyle promovido especialmente nas primeiras décadas do século XX.

\section{Média aproximada.}

17 De acordo com as normas tipográficas apresentadas por Bringhurst (2005) em Elementos do estilo tipográico, este design, na etiqueta atual, apresenta muitos problemas técnicos: mancha de texto justificada com menos caracteres do que o minimo desejável, que é de 45, sendo o ideal 66; muitas sequências de hifens, espaços entre palavras irregulares e espaços antes e depois de sinais de pontuação.

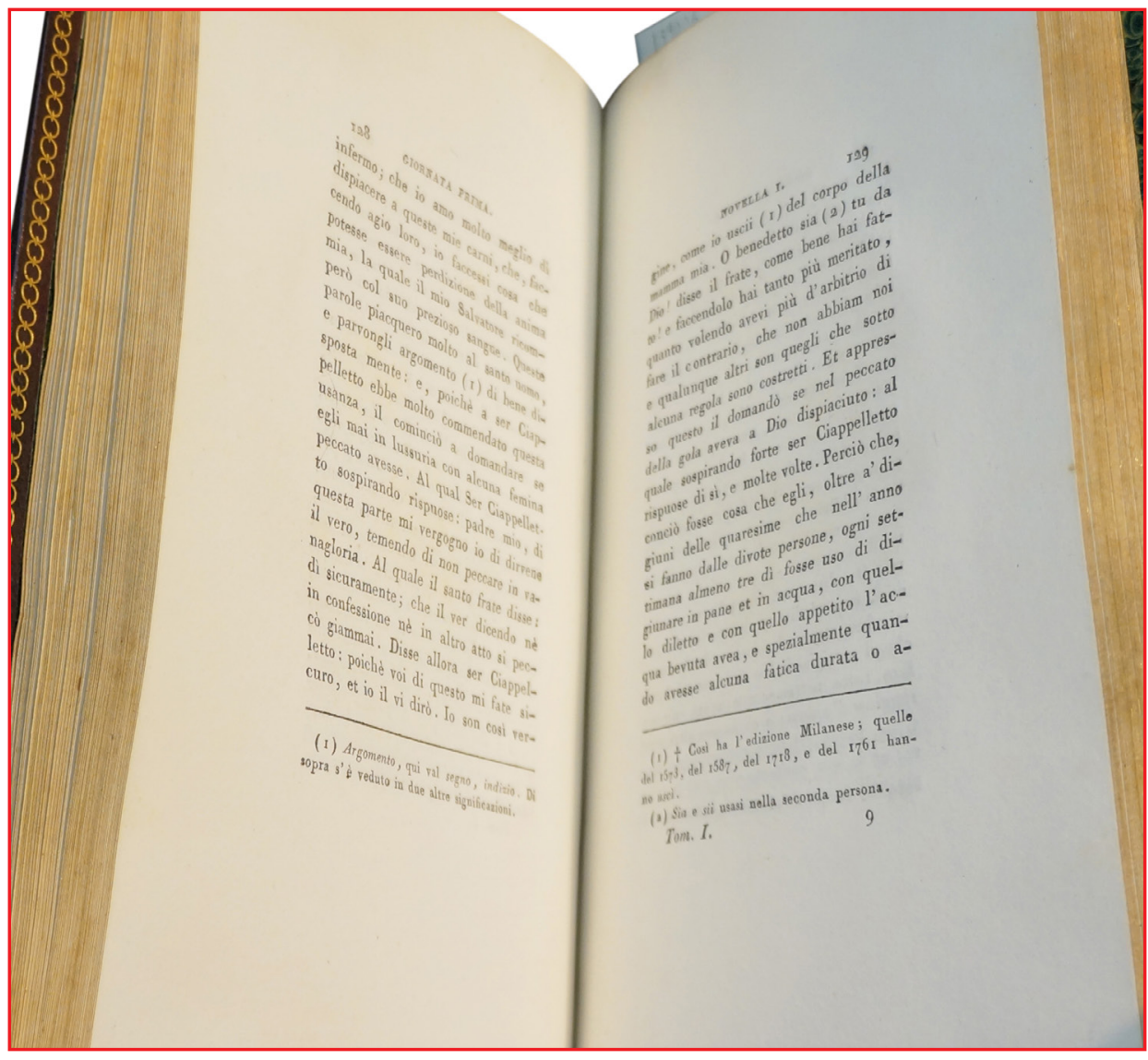

Figura 8. Decameron (1353), de Giovanni Boccaccio (1313-1375). Impresso em 1814 pela Stamperia Blanchon. Livro do acervo da Morgan Library. Foto da autora.

\section{A REVOLUÇ̃̃o INDUSTRIAL E O COMBATE AO LIVRO “MAL FEITO"}

No decorrer do século XIX, a partir da Revolução Industrial e de novas tecnologias de produção de papel (de qualidade inferior, se comparados aos papéis artesanais produzidos anteriormente), de máquinas de impressão rotativas, da facilidade de produção de tipografia de estilos variados e com o surgimento de máquinas de composição tipográficas mecânicas, a demanda por livros aumentou, porém sua qualidade caiu, como assinala Ruari McLean (1958: 4-5):

A qualidade do design do livro, como de muitos outros ofícios artesanais, deteriorou-se gradualmente como os efeitos da Revolução Industrial. Durante o século XIX, a indústria de impressão foi mecanizada em cada departamento.

A baixa qualidade de alguns livros ao longo do século XIX pode ser observada a partir desta edição de Orgulho e preconceito (Figura 9), publicada em 1833 por Richard Bentley. Esta é uma edição simples ${ }^{18}$, em comparação com as demais edições que apresentamos ao longo 


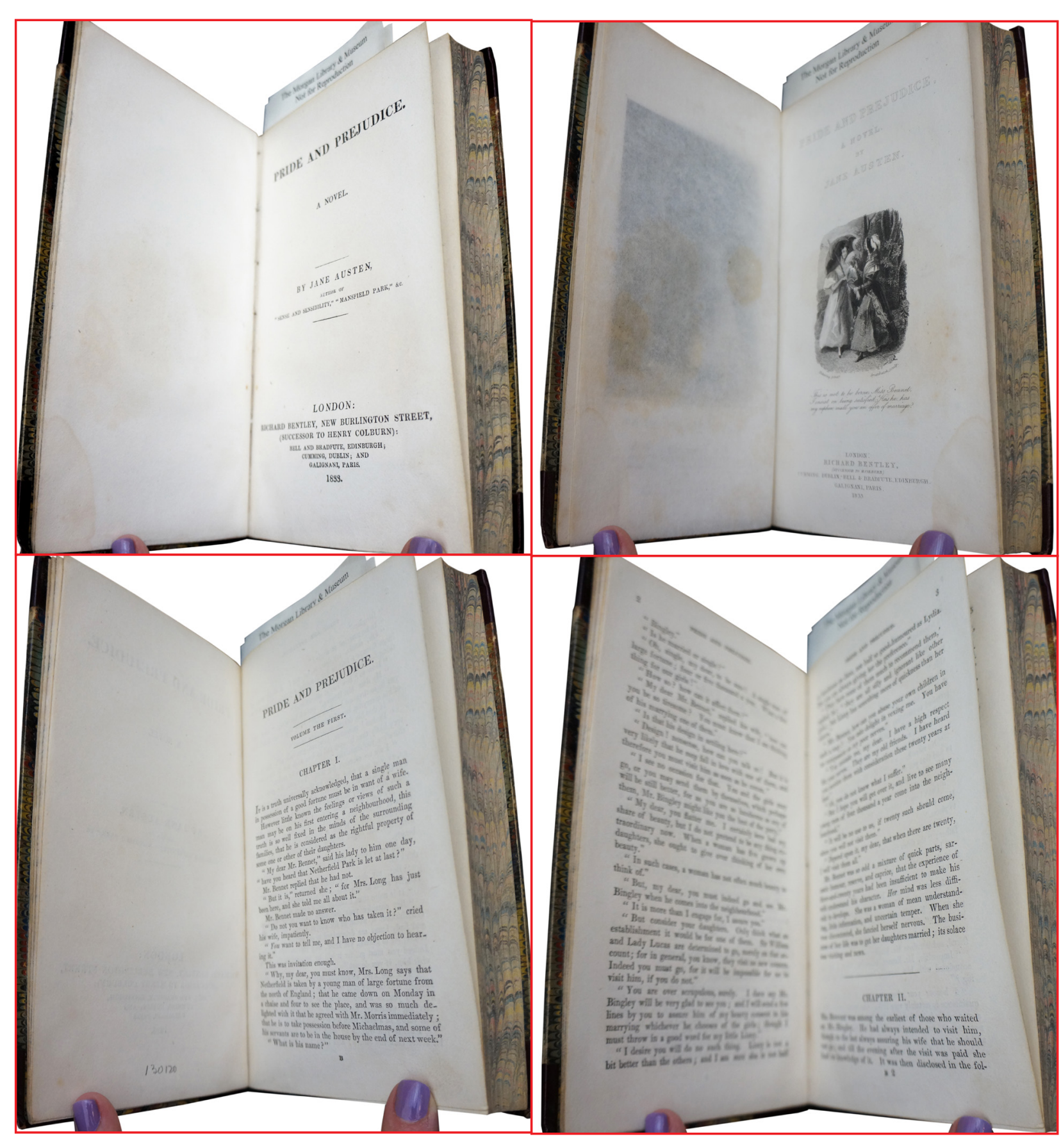

Figura 9. Orgulho e desse capítulo, no entanto sua simplicidade, ao contrário de Bodoni e preconceito (1813), de Baskerville que tinham na limpeza seu estilo, o design deste exemplar Jane Austen (1775-1817). indica que seja uma edição mais popular, que apresenta margens re-

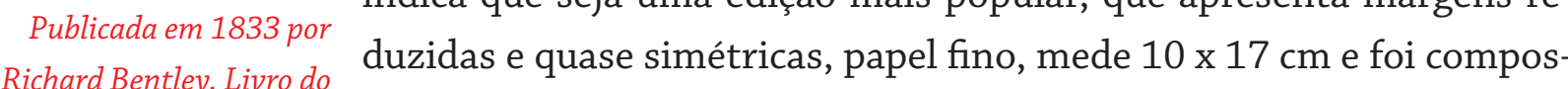
Richard Bentley. Livro do to com um tipo de eixo racional e bem contrastado (moderno) porém Fotos da autora. com corpo e entrelinha muito pequenos. Os capítulos foram separados apenas por linhas simples e não por ornamentos. Este volume integra uma coleção de livros ${ }^{19}$ no qual o romance Emma, da mesma autora, também foi publicado com o mesmo projeto gráfico. Esta edição "barata", com margens e tamanho do corpo do texto insatisfatórios para uma leitura agradável, pode servir como exemplo que retrata a massificação da produção dos livros no século XIX.

Steinberg (1979: 277) explica que:

A impressão depois de 1800, assim como outros negócios, teve uma lenta transformaç̃o até se tornar uma indústria. Aprimoradas técnicas de Engenharia auxiliaram esse processo de ruptura do sistema de guildas.

Dessas transformações apontadas por Steinberg, nota-se a produção do papel industrialzado a partir do processo elaborado em 1798 por Nicolas-Louis Robert. Segundo o autor (ibid, 1979: 278), com o aumento da produção, o papel teve seu custo reduzido.

Outro processo importante foi o de estereotipia ${ }^{20}$, criado por Earl Stanhope (1753-1816), que, de acordo com Steinberg (1979: 278-279), é um "método de preservar páginas tipográficas para futuras reimpressões evitando, assim, que o texto tenha que ser recomposto". Nesse processo, cria-se um molde a partir dos tipos compostos, que geram uma lâmina com a página tipográfica inteira em relevo. Além do processo de estereotipia, Stanhope também criou uma prensa feita de metal, diferente das anteriores, que eram de madeira. Outro recurso criado que tornou possível a mecanização da impressão foi a prensa rotativa ${ }^{21}$ a vapor criada pelo alemão Friedrick König em 1811 que, conforme aponta Emanuel Araújo (2000: 333), “(...) punha a funcionar em Londres uma prensa mecânica que permitia imprimir oitocentas folhas por hora: introduzia-se a velocidade como fator precípuo na indústria gráfica".

19 Segundo descrição da Morgan Library, faz parte da coleção “Bentley’s standard novels ; no. $30^{\prime \prime}$

20 Em inglês: Stereotyping. Em verbete encontrado no Dicionário do livro (FARIA e PERICÃO: 2008, 313), as autoras defininem o processo, mas os criadores da técnica não são os mesmos citados pelos autores acima: "Estereotipia: arte de fundir páginas para impressão das obras de que vão se fazer várias edicỗes e cujo molde da matriz foi tirado impressão das obras de que vão se fazer várias ediçōes e cujo molde da matriz foi tirado em 1753 e consideravelmente aperfeiçoada por Hofmann em 1783. A estereotipia reduz sempre a composição ou gravura na razão 1/60, isto é, em 60 pontos reduz 1 - clichagem clicheria - local onde se estereotipa."

21 Segundo definição de Faria e Pericão (2008: 593): "prensa rotativa: máquina com que se faz a tiragem em que quer a matriz quer o rolo compressor tem a forma cilindrica." 
Outra mudança observada nesse período refere-se a encadernação, uma vez que, processos manuais ${ }^{22}$ e materiais finos como couro, que comumente revestia as capas, foram substituídos por tecido ${ }^{23}$.

Manguel (1997: 166) refere-se ao editor inglês William Pickering como um dos primeiros a utilizar tecido em suas obras:

$\mathrm{O}$ pano de encadernação substituiu o oneroso couro (o editor inglês $\mathrm{Pi}$ ckering foi o primeiro a usá-lo, em seus Diamond Classics de 1822), e, uma vez que era possível imprimir sobre tecido, ele logo foi utilizado para propaganda. $\mathrm{O}$ objeto que o leitor tinha agora em mãos - um romance popular ou um manual de ciências num confortável in-octavo encadernado em pano azul, protegido às vezes com invólucros de papel nos quais também se podiam imprimir anúncios - era muito diferente dos volumes encadernados em marroquim do século anterior.

Além dessa substancial mudança nos materiais e processos de encadernação, surgem também no século XIX, segundo Steinberg (1979: 282), sobrecapas (dust-cover ou jacket) em 1833 e que mais tarde, depois de 1890, tornaram-se muito comuns por suas possibilidades "publicitárias".

Outro ponto importante nesse processo de industrialização do livro é o desenvolvimento de máquinas de composição nos Estados Unidos no final do século XIX, como a Linotype (1886) e a Monotype (1887), que fundiam os tipos e os compunham na sequência correta, que por fim substituiriam, mesmo que não completamente, a composição manual feita com tipos móveis de metal. Steinberg (1979: 288) explica que o surgimento dessas máquinas só foi possível a partir da criação de outra máquina feita por Linn Boyd Benton em 1885, que cortava as punções de tipos ${ }^{24}$ : "Esta máquina de gravação tornou possível a pro-

22 A partir de Febvre e Martin (1992:166), verifica-se que as encadernações até o século XIX eram muito caras e "os livros eram encadernados aos poucos e não impressos de uma vez como hoje (...) eram encadernados à medida que fossem vendidos." Outro dado importante era que muitas vezes a encadernação não era feita pelo impressor/editor, muitas vezes os livros eram vendidos em cadernos (folhas dobradas) sem encadernar.

23 Steinberg (1979: 281-282) explica que, por volta de 1820, o couro passou a ser substituído pelo tecido (cloth), material bem mais barato. $\mathrm{O}$ autor também cita o exemplo da coleção 'Diamond Classics', criada por William Pickering, como uma das primeiras empreitadas em larga escala usando tecido em lugar de couro.

24 Punção, segundo definição de Faria e Pericão (2008: 609), é uma "pequena haste de aço temperado, em cuja extremidade está gravado um sinal ou o olho da letra e que se bate sobre um bloco de cobre ou outro material para obter uma matriz. Este foi o processo que serviu para a reprodução em número ilimitado de caracteres em metal fundido e que esteve na base da invenção tipográfica." dução em massa de punções que seria indispensável pré-requisito para a composição mecânica".

A máquina linotipo fundia os tipos em uma linha sólida em relevo (lingote) e a Monotype fundia os tipos individualmente, mas na sequência de uso.

Segundo McLean (1958: 46), o uso da monotipo era preferível no design de livros:

Pelo fato de a Monotype ser a única máquina do mundo que poderia fundir tipos móveis, e assim que esses tipos, uma vez fundidos, são intercambiáveis com qualquer outros tipos do impressor e também por apresentar uma variedade de tipos muito bons, a Lanston Monotype Corporarion alcançou uma importância única e influência em todos negócios do livro em escala mundial.

O uso mais extensivo da Monotype na composição de livros, como apontado acima por McLean, se comparada à Linotipo, pode estar relacionado às dificuldades de correção de linhas já fundidas, entre outros problemas abaixo enumerados por Araújo sobre esta máquina (2000: 357):

A grande vantagem dos processos baseados na composição de linhas ou lingotes fundidos é a economia, i.e., apenas um operador compõe e corrige o texto, sobretudo no processo da Linotype. Há, entretanto, nesse sistema, quatro grandes inconvenientes:

- apresenta pouca flexibilidade na variação de caracteres;

- adapta-se mal a diagramações mais complexas;

- torna as entrelinhas rígidas: uma vez que as linhas e entrelinhas se compõem em peça única, é possível aumentar o entrelinhamento intercalando-se tiras de metal (como na composição manual, essas tiras, de um a seis pontos, são chamadas de 'entrelinhas', daí em diante de 'lingotes'), nunca a reduzi-lo;

- dificulta as correções, pois a supressão ou o acréscimo de uma simples vírgula implica nova composição de toda a linha, o que aumenta a possibilidade de erros, visto que ao corrigir a vírgula o operador ainda pode cometer um erro inexistente na linha original;

Assim, recomenda-se o processo do linotipo para textos de justificação e entrelinhas fixas, em que as variações se limitem, no máximo, à inclinação e à força dos tipos.

A partir do exposto acima, verifica-se um grande esforço de invenções para mecanizar e popularizar a produção de livros. São grandes os benefícios de uma produção em massa, mas as virtudes dos livros 
cuidadosamente compostos antes desse desenvolvimento não foram, inicialmente, seguidas pela indústria.

McLean (1958: 6) observa que, no final do século XIX, muitos livros eram produzidos por impressores amadores e mesmo com os avanços tecnológicos lhes faltava "gosto" e "treino", o que resultava em livros compostos com tipos inadequados, largo espacejamento entre letras e palavras e margens não planejadas cujo resultado final, para ele, era terrível: "Eles não são feios, são piores, por isso eles são negativos".

Mesmo que nessa época tenham sido produzidos livros de péssima qualidade, encontram-se no século XIX bons impressores, como William Bulmer e William Pickering. Este último, segundo Morison (1923: xi), foi um dos primeiros que iniciou o revival da bela impressão ${ }^{25}$ usando tipos oldstyle, como Caslon, como alternativa aos tipos mais modernos como os de Bodoni ou transicionais de Baskerville. Esse passo parece ter sido importante pelo fato de que muitos dos principais tipógrafos do final do XIX e início do XX passaram a apresentar uma maior predileção pelos tipos oldstyle, em detrimento dos tipos rígidos e ultracontrastados baseados nos modelos de Bodoni.

Em contrapartida e como uma crítica ao livro "industrializado", surgem no final do século XIX oficinas tipográficas como a Kelmscott Press de William Morris, na Inglaterra, empenhadas em produzir livros de qualidade, resgatando o bom costume dos livros produzidos artesanalmente.

A Kelmscott Press foi criada em um momento de grande crítica não apenas ao livro "industrializado", mas de outros itens industrializados. Morris já havia produzido livros anteriormente, mas parece ter sido influenciado por Emery Walker, graças a uma palestra proferida em 1888 para a Sociedade de Artes Unidas, na qual defendia que o design do livro deveria ter unidade, ou seja, que todos seus elementos estejam integrados.

Em sua palestra de 15 de novembro, Walker apresentou dispositivos de manuscritos medievais e desenhos de tipos incunabulares. Defendendo a unidade do design, Walker disse à plateia: "O ornamento, seja qual for figura ou padronagem, deve fazer parte da página, deve estar integrado ao plano global do livro". Walker considerava o design do livro semelhante a arquitetura, uma vez que somente o cuidadoso planejamento de cada as-

25 English revival of fine printing. pecto - papel, tinta, tipo, espaçamento, margens, ilustração e ornamento - poderia resultar numa unidade de projeto. (MEGGS, 2013: 222)

Meggs (2013: 222-223) explica que, após a palestra, "Morris decidiu aprofundar-se no projeto e na impressão de tipos" e que em sua Kelmscott Press buscou resgatar "a beleza dos livros incunabulares, meticulosa impressão manual, papel artesanal, xilogravuras feitas à mão, capitulares e filetes".

Há, porém, nessa "retomada" dos valores antigos e artesanais uma preocupação "funcional", que pode, de forma indireta, ter afetado a impressão comercial (indústria), como assinala Meggs (2013: 226):

A influência de William Morris e da Kelmscott Press no design gráfico, particularmente no design de livro, evidenciou-se não só na imitação estilística direta dos filetes, capitulares e estilos de tipos; o conceito de Morris do livro bem feito, seus belos projetos tipográficos baseados em modelos anteriores e seu senso de unidade do design, com os detalhe mais ínfimos relacionados ao conceito total, inspiraram uma nova geraão inteira de designers de livros. Por ironia, esse paladino da habilidade manual tornou-se a inspiração para uma restauração do refinado design de livros que adentrou o século XX e pouco a pouco se infiltrou na impressão comercial.

Esse "senso de unidade" mencionado por Meggs e que está presente no trabalho de Morris pode ser verificado na coerência formal apresentada em seus livros, ornamentos que combinam com os tipos utilizados, etc. Essa ideia de "unidade formal" nem sempre era levada em consideração anteriormente. Alguns livros do final do século XIX apresentavam mesclas de estilos e os ornamentos nem sempre complementavam o leiaute. Essa questão de unidade poderia novamente ser discutida nos dias de hoje, nos quais a maioria dos livros de literatura a capa e o miolo não "conversam", parecem partes distintas e não integrantes de um mesmo objeto.

De acordo com McLean (1958: 25), as ideias da Kelmscott Press foram "rapidamente imitadas por um grande número de prensas particulares na Europa e nos Estados Unidos". O autor explica também que algumas dessas prensas particulares foram fundadas porque "seus proprietários realmente queriam imprimir livros que agradassem a eles próprios, e essas são as genuínas imprensas particulares". Nesse sentido, entende-se que as prensas particulares estavam mais interes- 
sadas em seus próprios interesses, de produzir trabalhos de qualidade porém distanciavam-se consideravelmente do mercado editorial.

Essa nova corrente, presente na Europa e nos Estados Unidos, da criação de pequenas oficinas dedicadas à produção de livros de qualidade, denomina-se Movimento da Imprensa Particular (Private Presses Movement).

Mesmo sendo amplamente divulgados e tendo inspirado outros impressores e designers, os livros da Kelmscott Press, com seu estilo ricamente decorado, não foram levados adiante e outras prensas do período trabalhavam com leiautes mais simples, a exemplo da inglesa Doves Press de T.J. Coben-Sanderson e Emery Walker, que, segundo Ruari McLean (1958: 26), trouxe um caminho um pouco diverso do de Morris, cujo trabalho era bastante ornamental e complexo ${ }^{26}$, e "parece ter apontado o caminho certo". O trabalho da Doves Press apresenta páginas simples, sem ornamentos além de capitulares, amplas margens, que demonstravam preocupação com a boa composição e impressão em papel de boa qualidade.

Não apenas o trabalho da Doves Press é diferente da Kelmscott, como a posição ideológica de seus proprietários é bastante diversa. Cobden-Sanderson (in MCLEAN, 1995: 12) escreveu em 2 de outubro de 1902:

Eu não acredito na doutrina de William Morris. Não acredito que o prazer no trabalho de alguém produz ornamento. Tampouco acredito que o ornamento tem qualquer privilégio na produção de felicidade. Ornamento nasce da aptidão, e pode ou não ser precedido, acompanhado ou seguido pela felicidade.

Cobden Sanderson (In MCLEAN, 1995: 11-12), em The ideal book or book beautiful, publicado pela Doves Press em 1900, em seção intitulada The Whole Duty of Typography, escreve que o impressor e o tipográfo devem ser comprometidos com a clareza e com as palavras do autor. "O dever integral da tipografia, assim como da caligrafia, é comunicar à imaginação, sem perdas pelo caminho do pensamento ou imagem pretendida a ser comunicada pelo autor". Dessa maneira, conclui que há uma razão para "almejar" a clareza e a beleza do texto como um partir de um ideal de unidade. todo. Essa questão de qua a tipografia está a serviço do autor é retomada como veremos adiante por outros designers e tipógrafos, especialmente entre as décadas de 1920 e 1930.

Essa diferença de abordagens entre Morris e Cobden-Sanderson pode ser verificada nos exemplos abaixo. Note que Morris ${ }^{27}$ usa uma abordagem mais visível, enquanto a de Cobden-Sanderson é mais "invisível".

O exemplar de The Story of the Glittering Plain (Figura 10), escrito e projetado ${ }^{28}$ por William Morris em 1891, apresenta capitulares decoradas em todo o livro. Seu estilo lembra o do impressor alemão Erhard Ratdolt (1442-1528), o tipo e as capitulares ilustradas são pesados e parecem criar uma unidade. Tanto os tipos do texto quanto as capitulares são visualmente ricos e a ideia de resgatar estilos antigos da Idade Média e do Renascimento parece ter marcado a história do livro impresso do final do século XIX ao XX. Morris trabalha com amplas margens e o tipo utilizado é robusto e remete ao estilo do impressor francês Nicolas Jenson ${ }^{29}$ (1404-1480). Neste livro, Morris não usa recuos para marcar parágrafos, usa símbolos de parágrafo como na época dos incunábulos. O texto foi composto com tipos de aproximadamente 12 pontos de corpo por 13 pontos de entrelinha, o que dá mais peso à página, uma vez que o bloco de texto fica mais pesado pela pequena entrelinha. No entanto, por conta do pequeno espaço interlinear, as hastes ascendentes e descendentes das letras quase colidem. Este não é um dos livros mais ornamentados de Morris e o tipo escolhido é muito mais leve do que outros que ele já utilizou.

A edição de Hamlet (Figura 11), impressa pela Doves Press em 1909, não apresenta capitulares ornamentadas nem molduras, como no exemplo de Morris. Cobden-Sanderson usa uma capitular caligráfica, mas simples, no início do texto. O uso da cor vermelha para diferenciar os personagens de seus diálogos parece ser uma estratégia funcional (de separar e destacar os elementos do texto) e foi também utilizada nas rubricas que indicam as ações dos personagens. Mesmo que a página

27 Outros exemplos de Morris serão abordados no próximo capítulo.

28 Foi utilizada para análise uma cópia fac-símile impressa em 1891 por Roberts Brothers em Boston.

29 Tanto Nicolas Jenson quanto Ratdolt trabalharam como impressores em Veneza. 


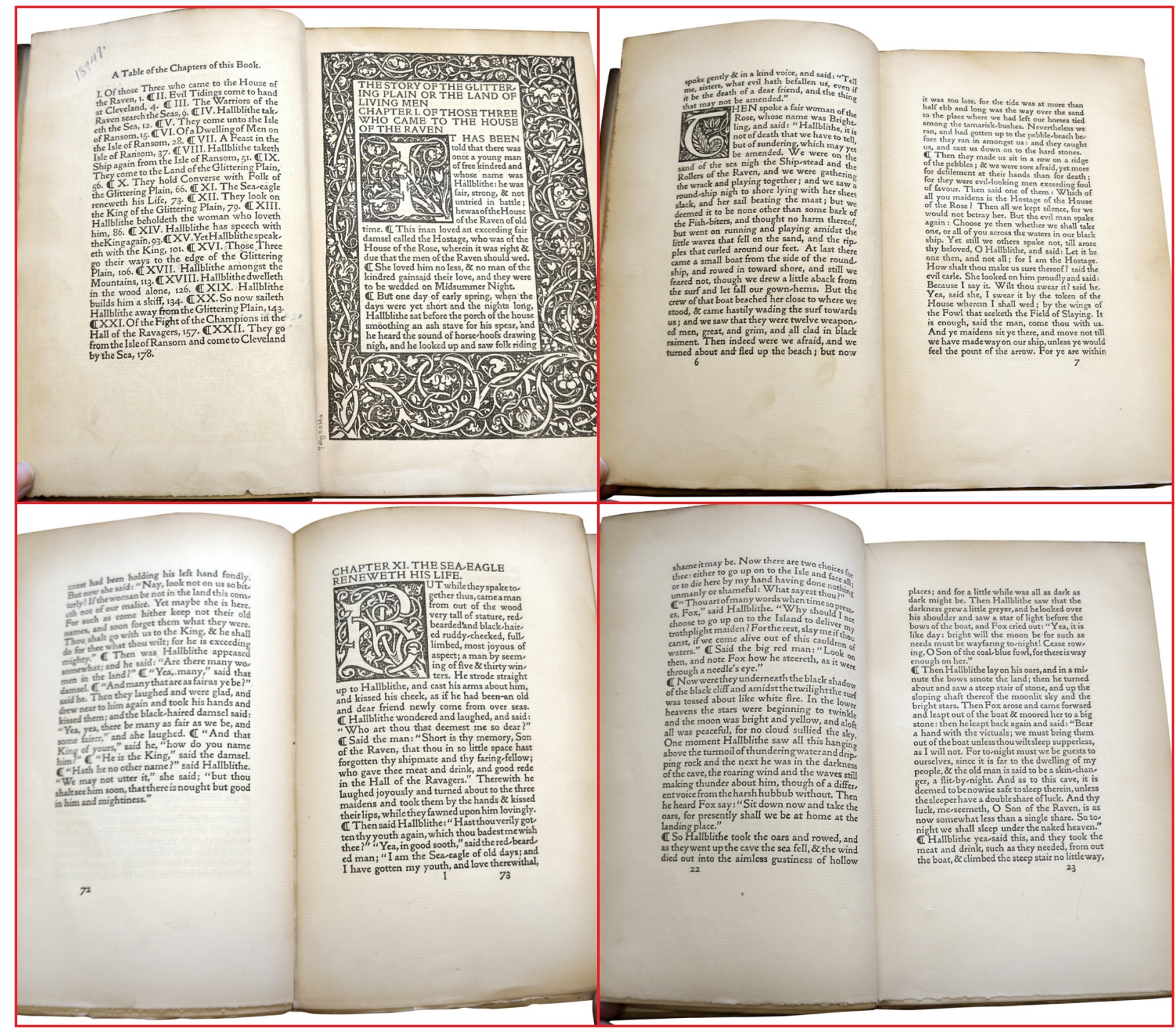

Figura 10. The Story of the não apresente ornamentos, o uso de uma cor extra já torna a página Glittering Plain (1891), mais "visível". Cobden-Sanderson usa papel artesanal e o material da de William Morris (1834 capa é pergaminho e teve o título impresso na lombada em dourado. -1896), impresso em 1891 As margens, como se pode observar, são generosas e mantêm certa esna Kelmscott Press. Cópia As margens, como se pode observar, são generosas e mantêm certa es-
fac-simile. Acervo da cala e proporça com a mancha de texto, composta em um tipo humafac-símile. Acervo da Fotos da autora. que os tipos utilizados por Morris. $\mathrm{O}$ uso de maior espaço interlinear, além do desenho do tipo que é, como observado acima, mais leve, tornam a página mais arejada. Comparando esses dois designers, um é evidentemente mais favorável à "invisibilidade" do que o outro.

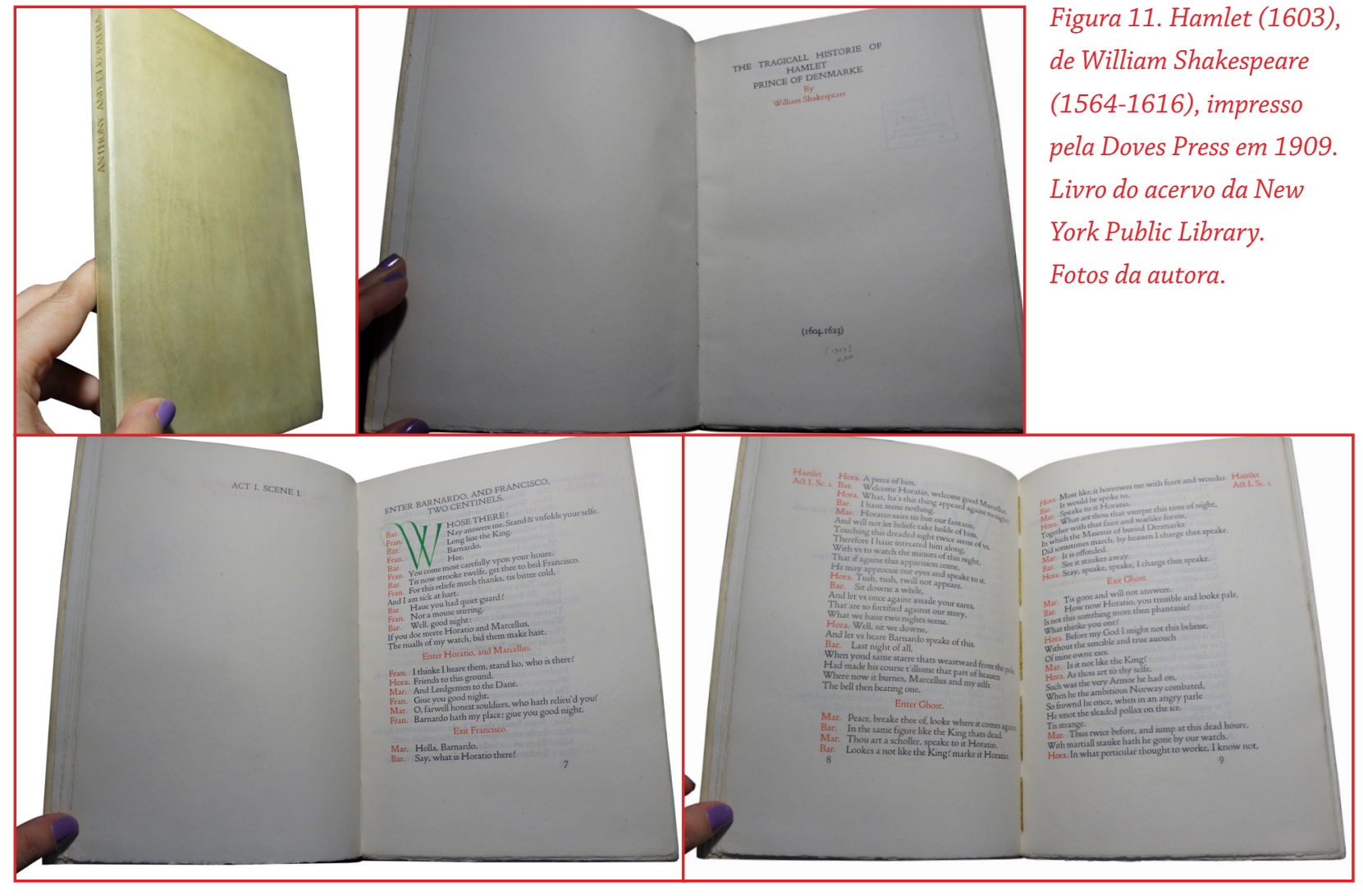

A Tragédia de Antônio e Cleópatra (Figura 12), impressa pela Doves Press em 1912, apresenta o mesmo estilo e leiaute similar ao de Hamlet. A única coisa que muda é a cor da capitular.

Apesar de apresentarem ideologias diferentes quando ao design das páginas dos livros, tanto Morris quanto Sanderson buscavam produzir livros bem feitos e artesanalmente, como alternativa aos livros produzidos em massa que muitas vezes eram de má qualidade. Morris e Sanderson buscaram "resgatar" estilos antigos, o que veio a inspirar muito impressores e designers do final do século XIX e início do século XX, tanto pelo uso de tipografias da renascença (ou no caso de Morris, também medievais) quanto pelo modo de produção em que todos os livros eram compostos com tipos móveis manualmente, em vez de mecanicamente por máquinas como a Monotipo ou Linotipo, pelo uso exclusivo de papéis artesanais e outros materiais nobres como pergaminho, velino e couro e encadernados à mão. Livros feitos dessa maneira são muito mais duráveis do que os livros produzidos em escala industrial e com papel industrializado produzido a partir de polpa de madeira, o que era comum na época. Talvez um dos objetivos de ambos 


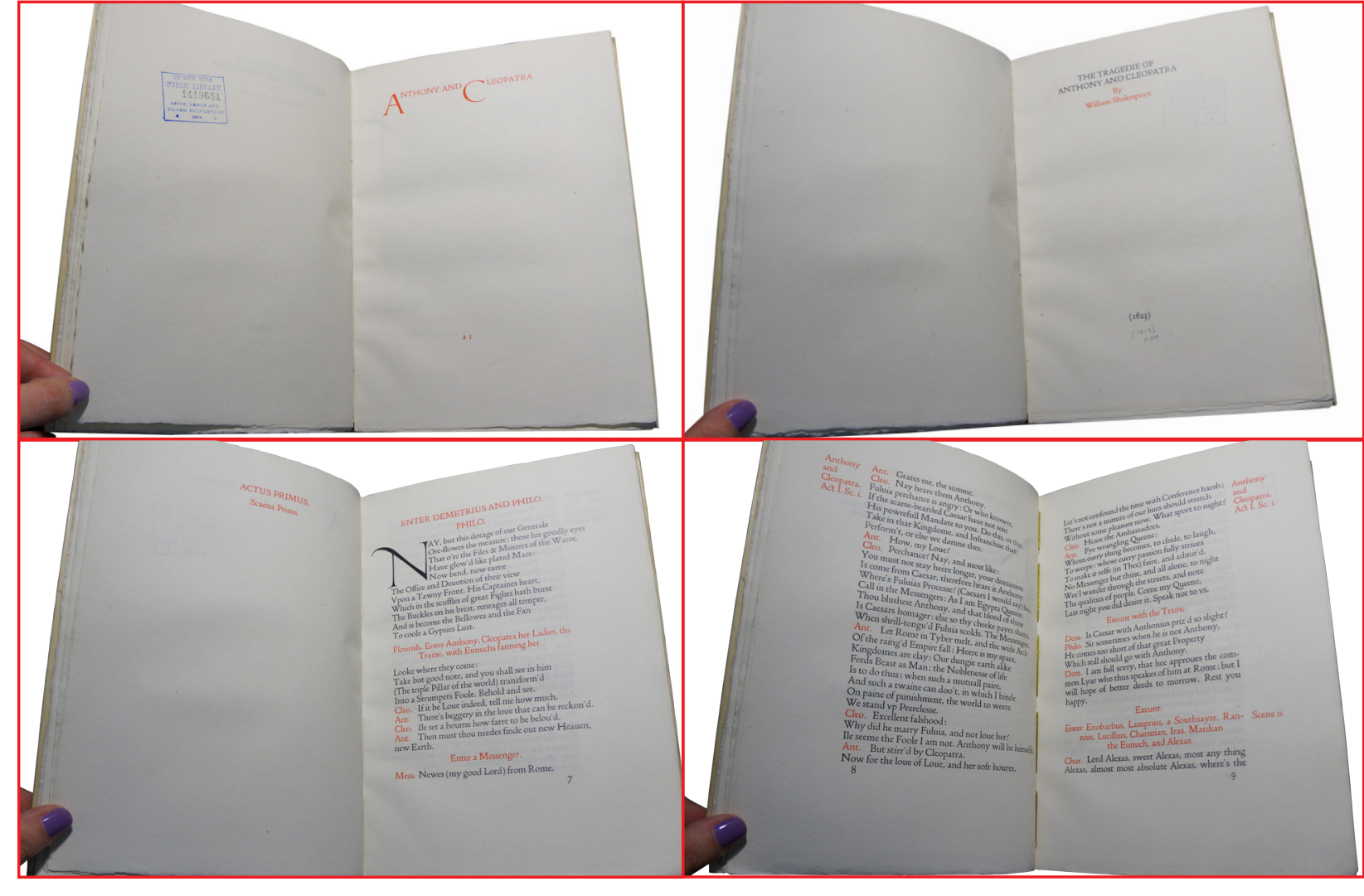

Figura 12. Tragédia de designers possa ser também o de provar a permanência do livro artesaAntônio e Cleópatra nal versus a impermanência, ou perecibilidadedo livro industrializado. (1607) de William O uso desses materiais e o cuidado com a impressão e o design geShakespeare (1564-1616)
impresso pela Doves ram livros não apenas de qualidade, mas "visivelmente belos". Essas impresso pela Doves acervo da New York Public produzidos industrialmente:

Library. Fotos da autora.

William Morris, Cobden-Sanderson e a maioria dos outros impressores particulares tentavam fazer os livros mais belos possíveis para eles, com as próprias mãos e as de seus funcionários. Tal objetivo não poderia, naquela época, ser alcançado por métodos de produção em massa. Seus livros foram geralmente impressos de forma manual, adornados um por um a mão e encadernados individualmente, de modo que cada cópia fosse quase única. Isso pode parecer contradizer a natureza mesma da impressão, que é a reprodução de cópias idênticas, mas foi o primeiro passo lógico tomado naquele momento. Os primeiros alvos das críticas deles foram ao trabalho artesanal inferior e às condições de trabalho miseráveis. Todos estes livros tiveram e continuarão a ter uma contribuição duradoura para a arte e o negócio da impressão. Eles são protótipos, a partir dos quais o editor e o aprendiz ainda podem obter inspiração e informação. William Morris, Emery Walker, Cobden-Sanderson e os outros não estavam apenas colocando o relógio para andar para trás (como foram acusados de fazer), mas deram corda nele novamente, quando o relógio havia parado de funcionar. (MCLEAN, 1958: 30)

No trecho acima McLean explica que a retomada de processos manuais não estavam "colocando o relógio para trás" no sentido de perpetuarem uma técnica que viria a se tornar obsoleta, mas o que realmente se tornou importante em relação a esses dois designers e impressores foi seu posicionamento crítico e necessário em um período com tantas mudanças no modo de produzir e na forma de pensar essa produção.

A imprensa particular como movimento, como se viu acima, surgiu no final do século XIX e início do século XX, mas algumas das ideias apresentadas pelo movimento se perpetuaram e podem ser observadas até hoje, quando pequenas casas impressoras ainda funcionam com o objetivo de produzir livros finos e de boa qualidade. ${ }^{30}$

A maior influência que o movimento pode ter tido foi, no entanto, nas primeiras décadas do século XX. Logo após a Primeira Guerra Mundial, especialmente na Inglaterra, originou-se o movimento "Reforma da Impressão" ou "Novo Tradicionalismo" (Kinross), além de um movimento mais genérico e mais extenso denominado por Meggs (2013) como "Renascimento do Livro", que cobre Europa e Estados Unidos.

Esse período pós-Primeira Guerra é marcado por um aumento expressivo do número de designers, impressores e tipógrafos dedicados a produzir livros de qualidade e aprimorar a produção de fontes tipográficas. Esses profissionais engajaram-se em promover boas práticas de design a partir de textos publicados, tanto em periódicos como em livros, além de reuniões e encontros em clubes e associações como Double Crown Club (Inglaterra) e Grolier Club (Estados Unidos).

A emergência desses textos e desses profissionais deu-se provavelmente em uma época em que muitos livros ainda eram produzidos com descaso, o que justifica essa enorme energia crítica, didática e técnica de aprimoramento por parte de diversos tipógrafos e designers, tanto na Europa quanto nos Estados Unidos.

30 Verificou-se a existência de pequenas casas publicadoras que produzem livros ce forma artesanal desde os primórdios da impressão até os dias de hoje. Há uma feira internacional chamada Codex, visitada durante o desenvolvimento dessa pesquisa, na qual diversos designers e impressores comercializam seus livros impressos com tipografia em papel artesanal. 
Um exemplo dessa crítica se personifica em Extracts from an Investigation into the Physical Properties of Books as They Are at Present Published, publicado em 1919 pelo americano William Adison Dwiggins. Trata-se de um texto ficcional e irônico que emula diálogos com editores e livreiros para mostrar os problemas referentes aos negócios editoriais e causados pela baixa qualidade de muitos volumes publicados na época.

$\mathrm{Na}$ introdução, Dwiggins afirma que:

O Comitê começou o trabalho pela análise de todos os livros produzidos na América do Norte desde o ano 1910. Essa análise levou os pesquisadores a concluir que "todos os livros dos dias atuais são mal feitos". ${ }^{31}$

O texto da introdução acompanha um diagrama em que se apresenta a curva descendente da qualidade dos livros desde 1910. Na "ilustração", a curva do diagrama "cai" tão abruptamente que o "destrói”. Temos, claramente, uma representação irônica, crítica e exagerada sobre a indústria editorial (Figura 12)

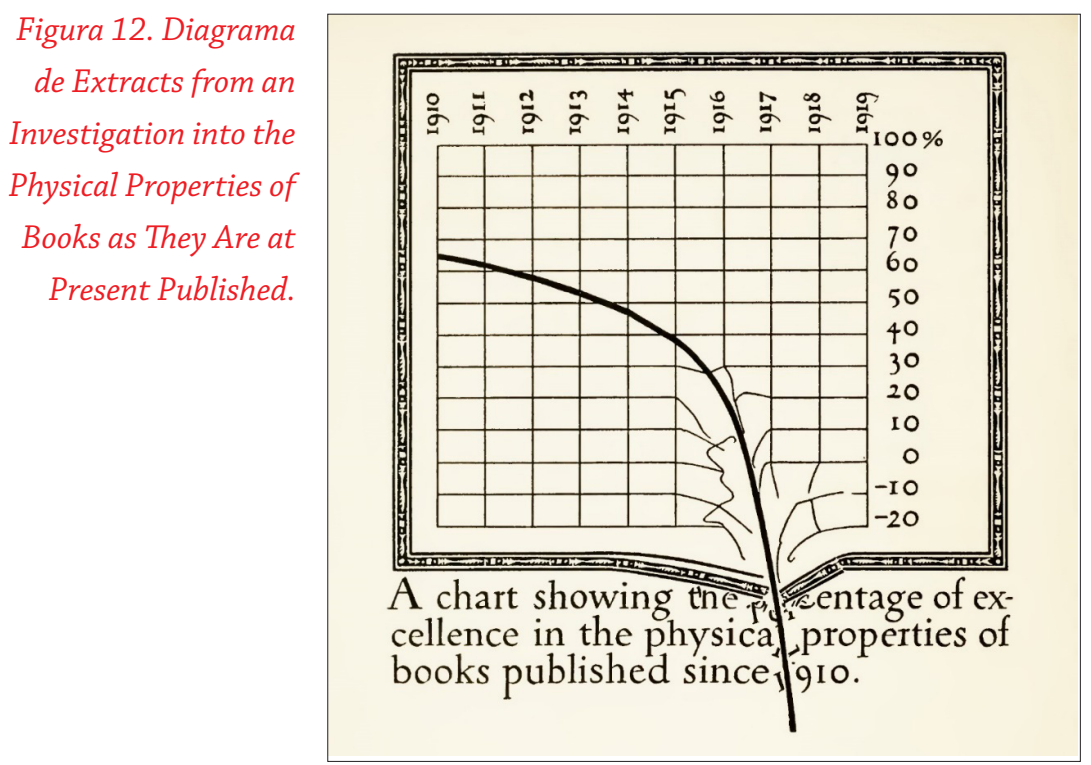

No primeiro diálogo, um "editor" é entrevistado e em suas respostas percebe-se o óbvio descaso em relação à qualidade dos livros e uma grande preocupação com o lucro. A produção de livros para o fictício editor é comparada à produção de sabão ${ }^{32}$ :

31 Disponivel em: https://archive.org/stream/extractsfrominve00socirich\#page/2/ mode/2up acesso em setembro de 2015.

32 Disponivel em: https://archive.org/stream/extractsfrominve00socirich\#page/2/
- Você compararia a produção de sabão com a produção de livros? - Não vejo por que não.

Bruce Kennet (2012) ${ }^{33}$ explica que essa série de diálogos fictícios publicada por Dwiggins "expõe, de forma prazeirosa, a qualidade inferior da maioria dos livros comerciais e das atitudes de quem os produzem". Ainda de acordo com Kennett:

Dwiggins recordou mais tarde que um editor realmente o contactou preocupado que algum de seus funcionários houvesse concedido uma entrevista! Este modesto folheto causou uma grande agitação no mundo do livro naquele período, e certamente contribuiu para a reputação de Dwiggins como designer de livros.

Esses diálogos, apesar de terem sido escritos há quase cem anos, continuam de certa forma atuais, uma vez que se pode observar ainda hoje o descaso de muitos grupos editoriais pela qualidade gráfica de seus livros e a luta de alguns designers, como o próprio Dwiggins, por tentar restabelecer esses padrões.

Além de Dwiggins, Morison (1927: 5) também apresenta o problema do editor versus o designer devido ao fato de que era comum que editores dessem instruções de como devia ser o design, dando assim pouca liberdade ao impressor. As atitudes tanto de Dwiggins quanto de Morison parecem ser as de defender o livro e de promover boas condutas de forma a valorizar o ofício.

Logo, temos em comum, nas primeiras décadas do século XX, uma crescente preocupação com a qualidade do livro, que parece ter se dividido em abordagens um pouco distintas. Uma é aquela do livro bem feito, porém simples e funcional, composto mecanicamente por meio de máquinas como a monotipo e a linotipo, e outra de livros extremamente ilustrados e visíveis sendo produzidos manualmente conforme as antigas tradições.

Discutiremos a seguir a abordagem do livro simples e no próximo capítulo trataremos da segunda abordagem. Para entender as ideias e os princípios funcionais que regem o ideal do livro invisível, é preciso antes apresentar o contexto da reforma da impressão.

mode/2up; acesso em setembro de 2015

33 Disponível em: http://www.fpba.com/parenthesis/select-articles/p21_private_press activities_of_dwiggins.html; acesso em maio de 2015 


\section{REFORMA DA IMPRESS ÃO: RESGATE HISTÓRICO E ADAPTAÇÃO}

\section{DE TIPOS PARA USO EM MÁQUINAS DE COMPOSIÇÃO}

Robin Kinross (2004: 64) explica que o "Movimento de Reforma da Impressão", que começou a se formar na Inglaterra logo após a Primeira Guerra Mundial, relaciona-se com a Kelmscott Press, de Morris, por esta ter sido uma das primeiras fases de um resgate histórico da tipografia, e pela busca de padrões mais elevados de design e impressão. No entanto, segundo o autor, os reformadores diferiam de Morris quanto ao uso e à aceitação da mecanização, de prensas mecânicas e de máquinas de composição como a Monotipo e a Linotipo

Kinross acredita também que a reforma da impressão é relacionada com o surgimento de diversos consultores de tipografia que levavam aos impressores "elementos do design", como se pode perceber pela passagem abaixo:

A reforma no pós-guerra é amplamente relacionada ao surgimento de tais 'consultores', trazendo aos negócios da impressão elementos de design. 'Design', nesse caso é tanto no sentido de uma consciência estética quanto no sentido de uma coordenação racional de produção. (...) O design teria sido incorporado na emergente figura do tipógrafo. Esse profissional já não era mais o mestre impressor, mas na Inglaterra era o educado, (ou autodidata) amador com senso estético e paixão pela história dos livros e a impressão. (Kinross, 2004: 68)

Esse movimento de reforma é apresentado por Kinross como um "novo tradicionalismo" ${ }^{34}$, relacionado tanto ao desenvolvimento da boa tipografia adequada à mecanização quanto ao resgate histórico e um comprometimento com a estética tradicional.

A Reforma da Impressão parece ter demonstrado pelo menos dois interesses: o de produzir faces tipográficas adequadas a este novo maquinário e a de promover diretrizes para a boa composição, "idealizando" um livro mais simples e menos decorado ${ }^{35}$, sendo essa posição um pouco diferente quando comparada à estética dos belos e adornados exemplos produzidos por algumas das Imprensas Particulares.

\section{New traditionalism}

35 Ao menos pelas ideias de Beatrice Warde, Stanley Morison, Eric Gill Daniel Berkeley Updike.
Kinross (2004:64) explica que uma das ideologias da reforma da impressão, quando se tratava do design de livros, era a de procurar aperfeiçoar a qualidade dos impressos utilizando máquinas de composição (como a da Monotype Corporation). Os tipos para composição mecânica nas primeiras décadas do século XX, ao que parece, não atendiam aos padrões de qualidade dos reformadores e precisavam ser repensados.

A reforma também se associa ao surgimento de diversos periódicos destinados a divulgar boas práticas e a ampliar a literatura teórica e técnica sobre tipografia e design de livros, como o inglês The Imprint, de 1913. Seguindo-se a este, na década de 1920, surgiram outros periódicos ingleses como The Fleuron e The Monotype Recorder ${ }^{36}$, os quais também se dedicavam a discutir e aprimorar o ofício e estabelecer novos padrões. A tipografia usada no The Imprint, que havia sido criada especialmente para este periódico e fundida em tipos móveis, foi adaptada à composição mecânica pela Monotype. Essa empreitada foi tão bem-sucedida que estimulou a criação e adaptação de novos tipos para essa máquina. Segundo Kinross (2004: 70), a relação dos reformadores com a indústria se deu pela necessidade do desenvolvimento de tipos (fontes) que se adequassem à mecanização e explica que empresas líderes na produção de máquinas de composição nos Estados Unidos e na Inglaterra, além de fundidores de tipos para composição manual, tenham passado a produzir tipos baseados em modelos históricos, além de "designs" de tipos originais.

O resgate histórico parece também, segundo Kinross, ter sido estimulado pela publicação de vários textos sobre a história da impressão como, por exemplo, a do reconhecido Printing Types: Their History. For$m s$ and Use, de 1922, escrito pelo americano Daniel Berkeley Updike, um dos grandes defensores do livro "simples" e bem feito.

36 Apesar de no texto acima apresentarmos apenas três periódicos ingleses, publicações de outras partes da Europa e dos EUA também eram influentes e dedicavam-se à indústria da impressão. Joseph Blumenthal (1982: 45-46) apresenta outros periódicos influentes, como Alphabet and Image, Signature and Typography, da Inglaterra, Arts et Métiers Graphiques, da França; Gebrauchsgraphik, da Alemanha; Philobiblon, da Áustria. Dos americanos, Blumenthal cita The Colophon, The Dolphin (1933-1941) editado por George Macy e Ars Typographica, editado por Frederic Goudy. 
Kinross destaca a importância da pesquisa histórica de D.B. Updike:

Esse esforço de revitalização foi possibilitado pelo surgimento de Printing Types, de 1922, de D. B. Updike. A partir desse texto, foi dado um esboço claro e factual à história do que havia de disponível antes para os emergentes. Para aqueles que trabalham sobre a história da tipografia, as contribuições poderiam agora ser razoavelmente descritas como "antes" e "depois" de Updike. (Kinross, 2004: 70)

Essa contribuição histórica, especialmente de Updike, parece ter sido muito importante pois fez com que muitos profissionais passassem a pesquisar e estudar a história da impressão e do livro.

Nesse contexto, o tipógrafo e designer inglês Stanley Morison teve um importante papel como consultor na empresa Monotype, como assinala Araújo (2000: 336):

A Monotype, aliás, programou em 1920 a recuperação de vários repertórios clássicos, projeto que ficou a cargo de uma das maiores figuras da tipografia, o inglês Stanley Morison (1889-1967); graças a ele redesenharam-se, com marcado virtuosismo, por exemplo, os antigos baskerville, bell, bembo, fournier, garamond, plantin e walbaum. Por sua vez, a Mergenthaler Linotype lançaria os seus granjon, baskerville, janson e outros, além do famoso caledônia (1938), desenvolvido por William A. Dwiggins (1880-1956) do antigo scotch roman, talhado por William Martin na década de 1790 para William Bulmer.

Megan L. Benton (2000: 91) também apresenta a importância do resgate desses tipos históricos na época e acrescenta que até hoje costumam ser muito utilizados no design editorial:

Para atender a essa demanda e ajudar a promover o esforço de reforma, ao longo da década de 1920 percebe-se a emergência de uma leva de novos tipos com base em modelos históricos. Não é pequena ironia o fato de que eles vieram principalmente das empresas Monotype e Linotype, emque eles vieram principalmente das empresas Monotype e Linotype, em-
bora fundições tradicionais, tais como American Type Founders (ATF) ${ }^{37}$, tenham lançado novos tipos baseados em modelos dos séculos XV ao XVIII. Os nomes desses tipos revelavam sua gênese histórica, imortalizando o designer original, o impressor que primeiramente ou mais frequentemente o usou, ou o título ou autor de livro que serviu de modelo. A maioria desses tipos, agora digitalizados, permanecem sendo utilizados para a composição do livro hoje, assim como na década de 1920, até o usuário mais casual de tipografia está familiarizado com os nomes das grandes figuras da tipografia ocidental, ainda que involuntariamente. Entre os mais duradouros estão Bembo e Centaur (e seu companheiro itáli-

37 Fundição Americana de tipos de metal para composição manual fundada em 1892. co Arrighi), com base nas primeiras letras romanas do século XV; várias versões de tipos cortados no século XVI pelo francês Claude Garamond tipos ingleses de William Caslon e John Baskerville do século XVIII; os tipos neoclássicos do francês Pierre-Simon Fournier e do impressor italiano Giambattista Bodoni. E difícil imaginar o curso da tipografia do século XX sem esses tipos ressuscitados; designers do pós-guerra dependiam enormemente desses tipos historicamente derivados.

Talvez esse resgate histórico não apenas tenha proporcionado o desenvolvimento de bons tipos para texto para serem usados em máquinas compositoras, mas também pode ter estimulado uma abordagem mais simples da tipografia, a partir de exemplos de composição de Aldo, Baskerville e Bodoni, que, como apresentado acima, trabalhavam com páginas sem ornamentação. Sabe-se que especialmente os livros renascentistas italianos como o de Aldo Manuzio são frequentemente elogiados por tipógrafos e autores do período.

Daniel Berkeley Updike teve um importante papel na revitalização da tipografia pelo seu livro Printing Types, já citado, mas também foi um dos defensores do livro "simples":

No ensaio "Style in the Use of Type", de 1902, Updike apresenta as virtudes do livro "simples", mas bem executado, do estilo veneziano, do final do século XV e início do XVI, no qual são utilizados tipos belos e legíveis, papel de qualidade e mancha gráfica e margens proporcionais. Para o autor, os livros mais belos são aqueles sem elementos decorativos:

Outra qualidade que cria um estilo é a simplicidade; e aqui novamente os livros italianos têm muito a nos ensinar. Eles eram estritamente simples, dependendo apenas de belos tipos, de bom papel e uma página proporcionalmente composta, que produzia um resultado elegante. Qualquer um pode colocar uma capitular decorada vermelha em cima de uma página para deslumbrar o leitor momentaneamente. Mas para produzir uma página agradável e bela apenas a partir de margens proporcionais, tipografia, etc. requer muito estudo, experiência e gosto. Parece, portanto, que alguns dos mais belos livros são aqueles sem decoração, estilo não depende de decoração, depende muito mais da proporção e da simplicidade. (Updike in PETERSON, 2002: 24)

Como se percebe, Updike usa o termo "simplicidade", que, após algumas décadas, ressurgirá pelo conceito de "invisibilidade", de Beatrice Warde. 


\section{O IDEAL DO LIVRO “INVISÍVEL"}

O resgate de tipos históricos teve um importante papel de ampliar e aprimorar os tipos para impressão. Isso naturalmente pode ter influenciado a redação de diversos textos para promover princípios da boa composição, ou seja de um bom design, e de como fazer bom uso de todos esses novos recursos disponíveis, especialmente em periódicos como The Imprint, The Fleuron e The Monotype Recorder ${ }^{38}$, no qual grandes figuras da tipografia da época colaboraram ou escreveram, como Oliver Simon, Francis Meynel, Beatrice Warde, Joseph Thorp, Stanley Morison, entre outros.

Segundo Moran (1917: 24), o movimento por uma tipografia mais simples foi iniciado pelo americano Theodore Low De Vinne (18281914). De Vinne publicou um extenso manual em quatro volumes chamado Practical Typography, em que trata de modos e formas de compor, unidades tipográficas, composição, escolha dos tipos, ornamentação etc., ou seja, de todos os itens pertinentes para o design e impressão de livros.

Nesse texto, De Vinne já defendia o livro simples, o que pode ser verificado na passagem abaixo:

No livro comum, evite decoração e tipos esquisitos que não tornam o conteúdo claro, que não fazem o objeto mais claro. As grandes obras -primas da impressão são as mais simples. Tipos simples corretamente -primas da impressão são as mais simples. Tipos simples corretamente
compostos e espaçados e com grande atenção aos pequenos detalhes, claramente impressos em tinta preta sobre papel liso e com margens apropriadas, têm um charme que é reconhecido por um inexperiente. Ele pode não saber por quê, mas esse livro é mais agradável e atraente do que o livro profusamente decorado, mas ele vai perceber que livros assim destacam-se como obras superiores. (DE VINNE, 1904: 168)

Mesmo defendendo o livro simples, talvez como um objeto funcional, para ser lido, De Vinne observa que nem todo livro tem o objetivo de proporcionar uma leitura séria e concentrada, e estes sim podem ser decorados:

38 Stanley Morison contribuiu em The Imprint e foi editor de Monotype Recorder e The Fleuron. Beatrice Warde escreveu tanto para The Fleuron como Monotype Recorder, às vezes sob o pseudônimo de Paul Beaujon, além de depois se tornar editora deste último.
No entanto, são necessários livros com decoração. Aqueles que são classificados sob o nome de "leitura leve $e^{39 "}$, não destinados ao estudo, ma para diversão ou informação, podem receber ornamento de muitas maneiras, desde linhas ocasionais em tinta vermelha ou bordas de bronze elaboradamente gravadas, vinhetas iniciais e finais ${ }^{40}$, bordas floridas ou fos, ilustaç̃os explicativas, tintas decores variahas bu um tipo de texto de design excêntrico ou peculiar. Esses são alguns dos muitos método de tornar um livro atraente, mas a maioria deles demanda certa quantidade de habilidade, paciência e custo que parecem fora de proporção ante o resultado atingido. (DE VINNE, 1904: 168).

No final desse trecho, De Vinne parece demonstrar que muitas vezes a ornamentação não vale a pena, pelo esforço e pelo valor, em relação a seu resultado. De qualquer forma, aqui se expõe não apenas a sua contribuição na defesa de um livro mais simples e funcional, que de acordo com Moran (1917: 24) o conjunto destes quatro volumes de princípios parecem ter inspirado Morison em seu famoso ensaio First Principles of Typography, que será abordado posteriormente.

O termo invisível, como será explorado adiante, foi utilizado pela primeira vez relacionado à tipografia de livros por Beatrice Warde. Não há evidências de que outros autores tenham utilizado esse termo antes dela, apesar de existirem outros termos para designar ideias semelhantes, como "simplicidade" e "clareza", por exemplo.

Muitas das ideias de diversos autores, tipógrafos e impressores do perído parecem convergir, e assim há aparentemente um claro intercâmbio dessas ideias, especialmente entre tipógrafos americanos e ingleses, sobretudo durante as décadas de 1920 e 1930.

No início dos anos 1920, a americana Beatrice Warde começou sua carreira como bibliotecária da American Type Founders ${ }^{41}$ (ATF) e era casada com o eminente tipógrafo e designer de livros Frederic Warde que, em 1924, foi chamado para trabalhar na Inglaterra para a Monotype Corporation a convite de Stanley Morison. É possível que a experiência anterior de Beatrice Warde em uma biblioteca cujo acervo era especializado em tipografia tenha lhe dado repertório suficiente para escrever um artigo para o periódico "The Monotype Recorder", que tinha Morison como editor.

\section{9 "Light reading"}

$40 \mathrm{O}$ termo usado era tailpiece, que pode ser entendido como um elemento decorativo usado no final de uma página, de um capítulo ou de um livro.

41 Importante distribuidora e produtora de tipos de metal fundidos. 
Segundo Gruendler (2011):

Warde publicou um artigo sobre caligrafia no Monotype Recorder, o periódico institucional da Monotype Corporation. No ano seguinte, sob o pseudônimo Paul Beaujon, ela escreveu um extenso artigo sobre Fournier e tipografia francesa do século XVIII.

A partir de Gruendler (2011) ${ }^{42}$, que escreveu a biografia de Beatrice Warde ${ }^{43}$, logo depois da chegada dela à Inglaterra com seu marido, Frederic Warde, ela se separou dele e, para conseguir se sustentar, "pediu a Morison algum trabalho de escrita ou edição freelancer, o que resultou em ser chamada para ser sua assistente no The Monotype Recorder". Gruendler (2011) completa que seu desempenho notório a fez tornar-se a editora oficial do periódico em 1927 ou 1928. Em 1929, Warde foi promovida a relações públicas da empresa. Para Gruendler, "Warde percebeu seu papel em perpetuar as ideias de Morison, lidando e educando amadores".

Beatrice Warde, sob o pseudônimo de Paul Beaujon, escreveu no “The Fleuron" n. 6, de 1928, sobre a ornamentação de livros nos Estados Unidos. Nesse artigo, Warde utiliza a ideia de transparência, depois retomada em famoso discurso de 1930.

Warde acredita que os tipos romanos, pelo menos os da época em que escreveu o texto, não combinavam com ornamentos. Infere-se a partir do texto de que há uma pequena justificativa ao uso do ornamento, porém há livros mais sérios, em que não há lugar para o ornamento: "Se os livros forem apenas recipientes transparentes para o argumento não há lugar algum para decoração". (BEAUJON in "The Fleuron", 1928: 69-70)

Mas Warde (BEAUJON in "The Fleuron", 1928: 69-70) acredita que há motivos para algum ornamento dependendo do caso, pois os livros apresentam um "sistema de conotações" e, assim, argumenta que os iluminadores medievais "fizeram bem em ilustrar videiras douradas ao redor das páginas da Bíblia”. Ela explica a seguir que a decoração, nesse sentido, "mantém o subconsciente em paz enquanto o intelecto está ocupado". (BEAUJON in "The Fleuron", 1928: 69-70)

42 Disponível em: http://elarcadearciniegas.blogspot.com.br/2011/10/beatrice-warde-byshelley-gruendler.html; acesso em Agosto de 2015.

43 Gruendler escreveu a biografia de Beatrice Warde em sua pesquisa de doutorado pela Universidade de Reading na Inglaterra
Nesse ensaio, Warde (BEAUJON in The Fleuron, 1928: 70) observa as qualidades e experimentos frutíferos em designers americanos que tratam a ornamentação do livro com "seriedade e discrição" como Frederic Warde, T. M. Cleland e W.A. Dwiggins, mas critica grande parte das decorações de estilos antigos.

Segundo Shelley Gruendler (2011):

Em 7 de outubro de 1930, Beatrice Warde fez uma palestra intiulada "Printing should be invisible" ${ }^{\text {"44 }}$ para a Guilda dos Tipógrafos Britânicos ${ }^{45}$ no St. Bride Institute, em Londres. Seis dias após sua apresentação, o texto da palestra foi impresso no British \& Colonial Printer \& Stationer, um boletim semanal sobre os negócios da impressão.

A partir de Gruendler, verifica-se que a palestra foi extremamente influente e bem-sucedida, pois logo depois de proferida passou a ser divulgada em veículos impressos.

Nessa palestra, Warde (1956: 11-12) faz uma analogia entre a tipografia de livros (página impressa) e uma taça de cristal, estabelecendo um paralelo entre a taça e sua função de recipiente transparente para que se veja seu conteúdo. Segundo Warde (1956:11), a taça possui uma haste cuja função é a de ser segurada, para que se evite que impressões digitais sejam marcadas na copa, onde o vinho é colocado. Ou seja, para evitar a criação de ruídos (interferências) no recipiente que alterem a visão do líquido. Essa haste é comparada às margens do livro, cuja função é evitar que os dedos do leitor se apoiem sobre o texto. Para a autora, taças de vinho e a composição tipográfica devem ser ambas transparentes.

A partir desse trecho, fica claro que a intenção da autora não é de tratar de tipografia e composição para outros usos, mas especialmente para o design de livros.

Warde continua a comparação entre a taça e a página impressa, agora tratando de outros dispositivos compositivos como o uso essencia da entrelinha que evita a duplicação ${ }^{46}$. Talvez também esteja implícita a relação com o tamanho do tipo e a largura da coluna:

44 A impressão deve ser invisível.

45 British Typographer's Guild.

46 Do original em inglês "doubling". No sentido de que durante a leitura linhas não sejam "puladas" ou lidas repetidamente. 
Há um milhar de maneirismos tipográficos que são tão insolentes e arbitrários quanto servir um vinho do Porto em copos de vidro verde ou vermelho! Quando a taça tem uma base que parece pequena e insegura demais, não faz diferença com que engenhosidade é equilibrada; você sempre fica nervoso com a possibilidade de que ela tombe. E há maneiras de compor linhas que, embora de aparência bem razoável, deixam o leitor subconscientemente preocupado, temendo duplicar as linhas, ou ler três palavras como se fossem uma, e assim por diante. (WARDE in ARMSTRONG, 2015: 48-49)

Warde pensa a tipografia de forma essencialmente utilitária, como forma de transmitir ideias e pensamentos. Dessa maneira, uma composição "mal feita" é comparada a discursos com ruídos. Nesse sentido, "os tipos bem empregados são invisíveis enquanto tipos, assim como a voz ideal é o veículo despercebido para a difusão de palavras e ideias". (WARDE in ARMSTRONG, 2015: 50). Fica claro aqui também que ela trata da composição dos tipos e não do desenho dos tipos em si, ou seja, parece tratar de uma abordadem de design funcionalista e "invisível", que aparentemente também é defendida por outros tipógrafos, como ela sugere na passagem abaixo:

(...) essa ideia do impresso como meio de transmissão é, pelo menos na opinião de todos os grandes tipógrafos com que tive o privilégio de conversar, o único indício que nos serve de orientação através do labirinto. Sem essa humildade essencial de espírito, já vi designers fervorosos equivocarem-se de maneira irremediável, cometerem os erros mais absurdos por causa do entusiamo excessivo, muito mais do que eu teria considerado possível. (WARDE in ARMSTRONG, 2015: 50-51)

Para reforçar sua posição sobre a transparência da página impressa ela afirma que "quanto aos livros, a tarefa do tipógrafo é colocar uma janela entre o leitor dentro de um aposento e a paisagem, que são as palavras do autor" (WARDE in ARMSTRONG. 2015: 53) e, então, compara abordagens de design com três tipos de janela:

Vitral

mas que não funcione como janela; ou seja, pode lançar mão de tipos complexos e requintados, como uma fonte gótica, que é algo para ser visto, mas não para se ver através dele." (WARDE in Armstrong. 2015: 53)

Inferimos nesse caso que livros impressos com fontes tipográficas muito elaboradas podem atrapalhar a leitura, pois chamam muita atenção para sua forma e estilo, embora possam ser belas. A autora usa como exemplo o tipo gótico, cujo desenho é mais complexo e "visível" e dessa maneira poderia "ofuscar" o conteúdo, o que se explica pela metáfora: se vê a janela, mas é difícil ver a paisagem através dela.

Janela transparente

Ele [o tipógrafo] pode instalar um vitral de maravilhosa beleza ou pode trabalhar com o que chamo de tipografia "transparente" ou "invisível". Em casa tenho um livro do qual não tenho a menor lembrança no que se refere à aparência dos tipos; quando penso nele, tudo que vejo são os três mosqueteiros e seus companheiros pavoneando-se para cima e para baixo nas ruas de Paris. (WARDE in ARMSTRONG, 2015: 52)

Entende-se aqui que a tipografia é veículo do texto e não há detalhes que o desviem dele, como uma janela limpa e transparente. Nota-se também aqui que o exemplo que Warde traz é de um livro de literatura (Os três mosqueteiros, de Alexandre Dumas), e a partir dessa passagem infere-se que o ideal da transparência é voltado especialmente para livros de ficção (prosa), em que cabe ao texto literário incentivar a imaginação do leitor.

\section{Janela com o vidro fragmentado}

O terceiro tipo de janela é aquele na qual o vidro está fragmentado em placas relativamente pequenas separadas por chumbo, e isso corresponde ao que hoje se denomina "impressão fina", no sentido de que você fica pelo menos consciente de que há uma janela ali, e de que alguém apreciou construí-la. Isso não é reprovável, devido a um fato muito importante que tem a ver com a psicologia da mente subconsciente. (WARDE in ARMSTRONG, 2015: 52-53)

A partir dessa passagem, fica difícil concluir se há uma crítica especial à "impressão fina" ("fine printing"), que é abordagem de edições limitadas, ilustradas e bem feitas da década de 1920 e 1930, mas que, de acordo com a proposta da janela transparente, seria um desvio da clareza, ou se ela apenas a menciona como uma abordagem menos clara, porém não desprezível enquanto abordagem de design.

Warde conclui essa passagem sobre as janelas explicando que qualquer desvio ou ruído pode ser problemático:

O tipo que, por qualquer distorção arbitrária do design ou excesso de "cor", obstrui o quadro mental a ser transmitido é um tipo ruim. O nosso 
subconsciente sempre teme os erros (nos quais podermos incorrer levados pela composição ilógica, pelo espacejamento apertado e pelas linhas longas demais e com pouco entrelinhamento), os aborrecimentos e as intromissões. O título corrente que insiste em atrair a nossa atenção, a linha que mais parece uma única e longa palavra, as maiúsculas espremidas e sem qualquer espaço fino - tudo isso significa desatenções subconscientes e perda de foco mental. (WARDE in ARMSTRONG, 2015: 53)

Warde finaliza o ensaio defendendo, é claro, a invisibilidade da composição tipográfica. Dessa maneira, apresenta também a função do designer de livros de sempre trabalhar a favor da leitura e da limpeza da página:

A tipografia requer humildade de espírito e, devido à falta desta, muitas das belas-artes estão agora mesmo naufragando com experimentos autorreferentes e piegas. Não há nada simples ou enfadonho na produção de uma página translúcida. A ostentação vulgar é duas vezes mais fácil enquanto disciplina. Quando nos dermos conta de que a tipografia feia jamais desaparece, então seremos capazes de alcançar a beleza, tal como os sábios alcançam a felicidade ao visar outro objetivo." (WARDE in ARMSTRONG, 2015: 53-54)

Segundo Robin Kinross (2004: 80), este texto de Warde "recapitula a doutrina morisoniana de abnegação e obediência em termos de um discurso de um jantar", ou seja, talvez critica o discurso como superficial e acredita que este texto demonstra influências das ideias de Stanley Morison, com quem Warde trabalhou e sempre conviveu.

Nesse contexto, é difícil defender de quem é a ideia original, já que tanto Warde quanto Morison foram influenciados por muitas outras fontes e conviviam com outros tipógrafos que defendiam ideias semelhantes. Sabe-se, por exemplo, a partir de McLean (1995: 17), que Warde foi extremamente inspirada pelo livro de Joseph Thorp Printing for Business, de 1919, que valoriza a página simples e condena o excesso de decoração.

A respeito de tipos e composição de tipos, o primeiro desiderato é a legibilidade. A decoração é puramente subsidiária e decoração que põe em risco a legibilidade é resultado de trabalho mal feito. Isso nos leva a pensar não apenas na escolha certa do tipo, mas no entendimento correto de alguns princípios relativos à sua disposição. (...) a simplicidade, a dignidade e um senso de estilo são suficientes para se ler uma mensagem mais rapidamente e trazem mais prazer do que um trabalho espalhafatoso e excessivamente ornamentado. (THORP, 1919: 49)
Warde parecia empenhada em promover um livro "invisível" e de qualidade, o que se reflete na redação de diversos outros artigos. É importante também entender que, talvez por seu papel como relações públicas da Monotype, Warde tinha que apresentar propostas e soluções de design, o que, de certa forma, também deveria valorizar a companhia aos olhos do público, manisfestar um compromentimento com a qualidade e também de promover didaticamente a impressão e produção de livros de qualidade através do periódico The Monotype Recorder, entre outras ações.

Segundo McVarish (2010) ${ }^{47}$, o texto de Beatrice Warde é entendido muitas vezes como uma espécie de "declaração de princípios". Para McVarish, esse texto é constantemente citado e difundido entre alunos de design e tipografia e "pode ser entendido com um clichê entre tipógrafos" e "continua a formar as primeiras ideias sobre tipografia ao ser evocado como um guia de boa prática".

McVarish (2010) analisa o texto de Warde com cautela, especialmente por conter diversas generalizações "formais e morais" somadas à ideia de que "a tipografia deveria desaparecer em virtude da 'entrega textual”".

As analogias de Warde pertencem a uma estratégia de alinhamento que implica deduções, expansões, e julgamentos. "Se você concorda com isso", ela escreve em um ponto, "então você vai concordar com a minha uma ideia principal". Suas construções silogísticas têm o poder de cancelar a oposição e reivindicar território categórico para sua posição.

McVarish destaca a força argumentativa de Warde na passagem abaixo:

Warde conclui seu sermão tipográfico com uma chamada para dedicacão aos desafios de projetar uma página transparente. (...) "Quando você percebe que a tipografia feia não se apaga, você será capaz de capturar a beleza como os sábios capturam a felicidade almejando outra coisa" . A frase "tipografia feia não se apaga" traz, além de repreensão, um aviso: tipografia que chama a atenção para si é feia, e nunca passará desapercebida. Este duplo ponto exemplifica o ímpeto embalado pelo ensaio de Warde e contém um segredo de seu sucesso retórico: seus artifícios tendem a operar em mais de um nível. (MCVARISH, 2010)

47 Disponível em: http://www.designstudiesforum.org/journal-articles/reconsidering$\% \mathrm{E} 2 \% 80 \% 9$ Cthe-crystal-goblet\%E2\%80\%9D-the-underpinnings-of-typographic convention/; acesso em 25.08.2014. 
Essa questão abordada por McVarish de dois níveis de significado textual pode levar também a entender não apenas que a tipografia que chama a atenção é feia, mas é justamente feia porque chama a atenção. Ou seja, um livro mal projetado é tão visível como um livro que tem um projeto gráfico bonito, atraente, criativo.

Dessa maneira, os ideais sobre a "invisibilidade" e a necessidade do design do livro bem feito são também tratados em outros textos de Beatrice Warde, que serão apresentados e discutidos a seguir.

Apesar de promover a invisibilidade, Warde não faz críticas nem elogios a livros específicos e, por isso, é difícil inferir em que medida a página é invisivel ou não. Fica claro que a página de um livro não pode desviar o leitor de um texto, mas podem existir desvios sutis

No artigo On the choice of type faces, escrito por Beatrice Warde, sob o pseudônimo Paul Beaujon, para o periódico The Monotype Recorder, ela afirma que:

A legibilidade de uma face tipográfica apresenta um paralelo com a audibilidade de uma voz humana. Um palestrante deve tornar cada palavra audível e distinta; ainda dentro dos limites de audibilidade situa-se toda a gama de tons, desde um sotaque monótono aos infinitamente flexíveis e persuasivos tons de um bom orador.

Nessa passagem, Warde trata especificamente do desenho do tipo e que este pode expressar o tom do discurso, desde um tom monótono a um tom persuasivo, ou seja, diferenças nos desenhos dos caracteres de uma fonte podem influenciar a leitura. Warde explica que não apenas o tipo, mas sua composição é o que torna um texto "leiturável ${ }^{48 "}$ ou não:

O tipo, a voz da página impressa, pode ser legível e enfadonho, ou legível e fascinante de acordo com seu design e sua composição. Em outras palavras, o que o amante dos livros chama de leiturabilidade ${ }^{49}$ não é sinônimo do que os oculistas chamam de legibilidade ${ }^{50}$. (BEAUJON, 1933: 5)

Warde (BEAUJON, 1933: 6) explica que há propostas distintas de impressos e cada uma deve ter sua composição e escolha de tipos adequada, como um romance ou um livro didático que tem não apenas públicos diferentes, mas funções diferentes.

\section{Readable. \\ 49 Readability. \\ 50 Legibility.}

Após apresentar a importante questão da legibilidade e leiturabilidade, Warde explica que tipos distintos dão tons diversos ao texto, da mesma forma que há diferença quando mais de uma pessoa (vozes) pronuncia um mesmo discurso:

Componha uma página em Fournier comparando a outra em Caslon e uma outra em Plantin, é como se você tivesse ouvido três pessoas diferentes proferindo o mesmo discurso - cada uma com pronúncia impecável e clareza, mas por meio de uma personalidade diferente. Talvez 0 leigo não seja capaz de diferenciar uma composição "old style" a parti de outras duas do mesmo grupo, no entanto, ele não poderia ler as três páginas sem ao menos inconscientemente discerni-las. A menor variação da construção de uma serifa é enorme e pode ser comparada a uma vibração de um disco de metal, num receptor de telefone que vibra e reproduz sons apresentados por uma ou por outra voz, e mesmo assim é fácil deduzir por essas vibrações que um velho amigo está nos perguntando: “Adivinha quem é?" (BEAUJON, 1933: 6)

A partir do exposto acima, qualquer variação do design de tipos pode dar ao texto "uma voz", certa "personalidade", e o ideal da invisibilidade proposto no texto já debatido torna-se um pouco escorregadio. Warde, claro, apresenta fontes com Fournier, Caslon e Plantin, que, por seu amplo uso, podem ser considerados como tipos bem feitos e adequados para a leitura de textos, porém todos têm distintas personalidades.

Há, então, certa contradição sobre o ideal da "invisibilidade" nos discursos de Warde, uma vez que ela considera que variações tipográficas dão um "tom" diverso ao texto impresso, já que mesmo pequenas di ferenças entre tipos de mesma classe podem, ainda que inconscientemente, causar impressões diversas para o leigo.

Ainda no mesmo texto, de forma um pouco mais didática do que no artigo The Crystal Goblet, or Printing Should Be Invisible, ela adverte sobre as diferenças das proporções das letras, ainda que sejam de mesmo corpo. Outra questão apresentada é a de que certos tamanhos (corpos) $)^{51}$ de certos tipos funcionam (têm um melhor design) do que outros. Além desses critérios, ela apresenta a importância da adequação da tipografia ao tipo de papel com o exemplo de que tipos old style impressos em papel revestido apresentam um aspecto fraco. (BEAUJON, 1933: 8-9) 
Em ensaio escrito no início da década de 1950, "The Design of Books"52, publicado na coletânea Crystal Goblet: sixteen essays on tipography (1956), Beatrice Warde apresenta conceitos para a produção do livro ideal, está preocupada com o livro do "futuro". Ela apresenta também críticas ao livro "modernista", ao livro de bolso e ao público leitor recém-acostumado com linguagens de fácil assimilação, como o cinema e o rádio.

Nesse texto, assim como em outros da autora, há uma série de figuras de linguagem como, por exemplo, quando ela compara o entusiasta pelo design moderno a um comediante que derruba uma bandeja cheia de pratos, ou seja, predisposto a cometer uma tolice.

Warde (1956: 32-33) condena o descaso modernista com a história, uma vez que, para ela, os clássicos são exemplos dos mais belos livros já produzidos. O livro, para ela, tem que ter uma aparência familiar, própria do design de livros e não de qualquer outro material impresso, que se pode entender nesse contexto como tradicional e convencional.

Preocupada com o futuro do livro, Warde explica os problemas do design modernista, ou vanguardista, quanto ao uso de tipos sem serifa. Ela argumenta que há uma função por trás das serifas que reside na diferenciação de certos caracteres e também critica tipos "egípcios", oriundos da era vitoriana, não recomendados para a leitura por não possuírem contraste (variação entre traços grossos e finos) nas letras minúsculas.

(...) Eu ainda não encontrei livros de vanguarda que ofereçam qualquer ameaça séria às convenções de estilo de livro (...) Um livro pode pode ser impresso em tipos sem serifa porque seu designer é um daqueles estéticos nudistas que acreditam que nada é aparentemente melhor, ou pelo menos mais 'moderno', por serem 'limpos'. Mas serifas não são de nenhuma maneira ornamentos dispensáveis: elas permitem-nos distinguir a letra maíscula $\mathrm{I}(\mathrm{i}) \mathrm{da} \mathrm{I}(\mathrm{I})$ minúscula e 0 numeral aŕbico $1(\mathrm{um})^{53}$, le elas fortalecem os traços principais dos descendentes através da forma-
ção de contraste à luminosidade do papel branco e discretamente criam uma linha na qual os caracteres minúsculos são acomodados, e elas são essenciais para impedir que palavras como "Illicit" pareçam visualmente "tolas". As sem serifas, para além disso, assim como suas companheiras

52 Publicado na coletânea The Crystal Goblet. Texto de 1951 "Paper for the Weekend Conference of the Library Association, 1951"

53 Tradução adaptada "they enable us to distinguish cap. I from lowercase I and Arabic numeral 1". vitorianas "egípcias" são ineficientes para uso em livros pois seus caracteres não têm contraste ou variações de traçado. (WARDE, 1956: 35)

Em seguida, Warde (1956: 36) apresenta outras questões sobre o design de página de livros, como a importância das margens, e o uso, para ela problemático, de alguns elementos decorativos que podem comprometer o design do livro. Nesse caso, para ela, o profissional que se vale de muitos recursos pode estar comprometendo o design, a função do objeto, para poder enfatizar sua expressão pessoal. Nesse ponto, o design, como servo da leitura, deve ser impelido de qualquer manifestação de autoexpressão, ideia que já havia sido abordada no ensaio Printing Should be Invisible.

$\mathrm{Na}$ esfera da expressão e da crítica ao livro "mal feito", em especial os de bolso, Warde considera problemáticos os projetos em que há uma maior preocupação com o design de capa do que com o miolo, uma questão até hoje atual (WARDE, 1956: 37):

Então nos voltamos agora para algo mais característico do "espírito de nosso tempo": o novo respeito com que grandes designers tipográficos estão olhando para o livro de bolso brochura barato. Anteriormente suas capas eram decoradas, mas seus textos foram evidentemente entregues ao impressor sem muita instrução, além de procurar encaixar toda a matéria textual em um determinado e máximo número de páginas, que implica em pensar no leitor como tão pobre a ponto de forçado a abrir suas capas de papel e nunca reclamar de sua tipografia maçante e barata.

Porém Warde (1956: 37-38) traz como alternativa o bom exemplo dos livros de bolso da Penguin ${ }^{54}$ "que proporcionava aos leitores boa literatura em uma roupagem civilizada" 55 . Na passagem a seguir, considera muito próxima a abordagem da coleção Penguin Shakeaspere desenvolvida por Jan Tschichold ao de um bom exemplar clássico produzido na era de Aldo Manuzio (Imprensa Aldina):

O que há de novo sobre o belo design desses livros baratos é sua determinação em tratar o homem literato comum com o devido respeito - com base no pressuposto de que aquele homen tem algum instinto que aprecia o bom design - que a geração de Aldus sentiu até mesmo pelo mais pobre estudioso viajante que "devorava" clássicos recém-resgatados.

54 Editora inglesa de livros de bolso criada por Allan Lane em 1935 que ficou muito conhecida ao produzir livros de boa qualidade a preço justo. A editora contou com a colaboração de grandes designers, como Jan Tschichold no final da década de 1940 e seu sucessor Hans Schmoller.

55 infere-se que o termo roupagem civilizada é usado no sentido de design. 
Não parece claro se Warde era especialmente contra os "livros finos", que eram muitas vezes ilustrados, impressos especialmente nos anos 1920 e 1930 nos Estados Unidos e na Europa, mas para ela o livro do futuro não seria ilustrado, as ilustrações deveriam ser destinadas apenas a livros para crianças.

Os proeminentes designers de livros do futuro, creio eu, trabalharão sem a desanimadora escassez mundial de materiais ${ }^{56}$ (..) Eles terão pouca chance em trabahar com luxuosas e chance en trabs limitadas; mas em livros infantis continuarão a encontrar uma real justificativa para usar imagens e decorações. (WARDE, 1956: 45)

Ao tratar do design do futuro, nesse contexto, infere-se que Warde, de certa forma, critica as famosas edições limitadas, o que parece um tanto estranho uma vez que ela era amiga de grandes designers que desenvolviam livros ricamente decorados ilustrados e limitados, como os americanos Bruce Rogers e T.M. Cleland e até mesmo seu próprio ex-marido Frederic Warde. Porém na época em que ela escreveu este artigo, no pós-Segunda Guerra, as gloriosas edições limitadas de qualidade, a partir de Benton (2000), já haviam perdido sua força.

Mesmo algumas décadas depois da escrita de Printing Should be Invisible, em entrevista realizada na Austrália em 1959 e transcrita por Sara De Bondt (2012) ${ }^{57}$, Warde ainda promove esse ideal:

Eu acho que o verdadeiro propósito da boa impressão deve ser o de transmitir o que o autor está dizendo ao leitor com o mínimo de impedimento. A grande ideia sobre a impressão é que deve ser invisível. Você deve saber o que o autor ou o escritor está dizendo, e não ser prejudicados por qualquer exibicionismo, feiúra ou aparência desleixada sobre o meio através do qual suas palavras estão sendo transmitidas. Assim como eu estou tentando distintamente falar agora, porque acho que há melhores maneiras de fazer isso do que um 'umwouah-huoah weuh ${ }^{\text {558 }}$, da mesma forma a impressão ravés de um bom design tipográfico e de um bom maquinário - isso quer dizer de um bom trabalho impresso pelo qual a aplicação da tinta sobre o papel é uma grande arte - porque por são através de suas boas condutas que as pessoas vão ler.

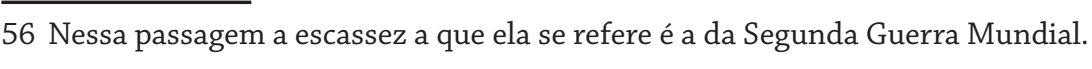

57 Disponivel em: http://www.eyemagazine.com/feature/article/beatrice-warde-mannersand-type; acesso em setembro de 2015.

58 No sentido de um discurso ininteligivel.
Apesar de Warde ter proposto o termo invisibilidade, especialmente relacionado a obras em prosa (textos para leitura contínua, como romances), não se pode deixar de discutir e avaliar os ideais de tipógrafos de seu convívio na época, que também apresentavam pensamentos semelhantes.

Stanley Morison, que, como se sabe, trabalhou diretamente com Warde, também defende a "invisibilidade", embora sem utilizar esse termo, no ensaio First Principles of Typography publicado originalmente em 1930 na sétima e última edição do periódico The Fleuron e posteriormente publicado na forma de livro em 1936. Morison propõe um conjunto de diretrizes de composição que devem ser utilizadas quanto à construção da mancha de texto, das margens, dos espaçamentos, da escolha de tipos etc. Os preceitos por ele discutidos no texto podem ser inferidos a partir do próprio projeto gráfico do livro em que o ensaio foi publicado (Figura 14).

Morison (1936: 1) adverte que a tipografia é um meio essencialmente utilitário e apenas acidentalmente estético e que

(...)qualquer disposição de material impresso, independente de sua intenção, se tiver o efeito de interferência entre o autor e o leitor está errado (...) livros impressos são feitos para serem lidos e aqui resta pouco espaço para uma tipografia "brilhante", ou seja, expressiva ou "inspirada.

Ele defende que a monotonia ou a banalidade são menos viciosas para o leitor do que a "excentricidade tipográfica" e que a tipografia para livros "além da restrita categoria das edições limitadas ${ }^{59}$ requer obediência à convenção que é quase absoluta e racional”. (MORISON, 1936: 2)

Na passagem acima, o autor explica que a tipografia para livros deve obedecer as convenções, porém faz uma exceção à regra que é a de edições limitadas, seja de livros produzidos por prensas particulares, seja por livros publicados por editores especializados em edições limitadas para colecionadores que, como veremos no próximo capítulo, tratamse de livros "visíveis" que apresentam uma função estética que vai além da utilitária. Aqui então ele traz duas classes de livros, dos comerciais, que nesse sentido devem ser funcionais e obedecer às tradições, e livros especiais que, provavelmente, a partir do exposto, podem ter outras funções além daquela da leitura. 
Figura 14. Páginas duplas de First Principles of Typography (1930) de Stanley Morison (1889-1967), impresso em Nova York pela The Macmillan Company em 1936. Acervo da autora. Foto da autora.

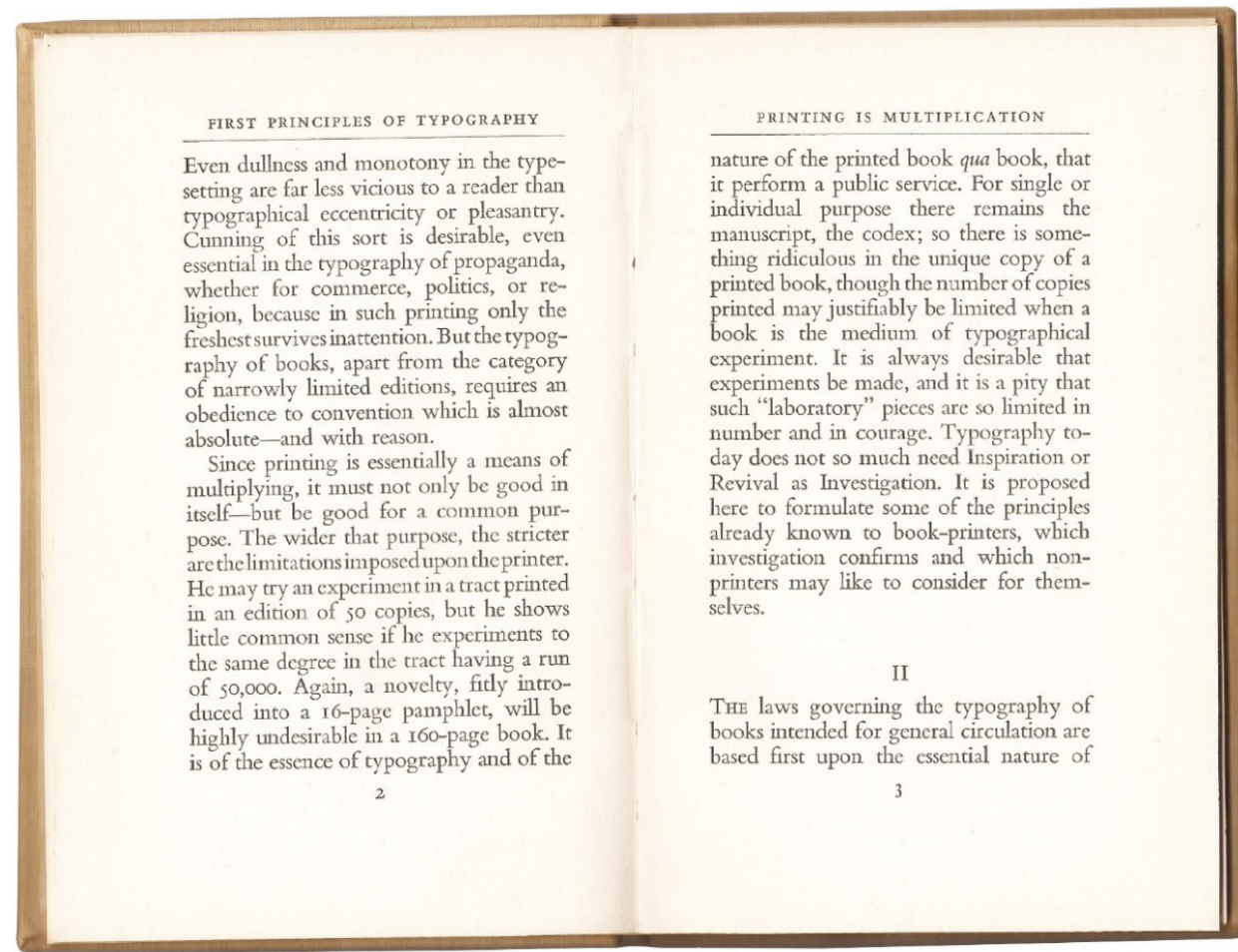

A fluência da leitura é uma das maiores preocupações de Morison, que explica que mesmo o olhar de um leitor experiente tem dificuldade para ler textos com uma quantidade acima da ideal de palavras por linha. (MORISON, 1936: 9)

O autor apresenta detalhadamente os princípios da boa tipografia para livros, mas que podem ser resumidos no seguinte parágrafo:

De acordo com a nossa doutrina, um livro bem construído é feito a partir de páginas verticais oblongas com a disposição de parágrafos que tenham uma média de 10 a 12 parágrafos por linha e consistentemente espaçados, compostos com uma fonte tipográfica de tamanho confortável e aparência familiar; as linhas devem ser suficientemente separadas para prevenir duplicação $0^{60 . " ~(M O R I S O N, ~ 1936: ~ 16) ~}$

Morison afirma que é possível ser mais "criativo" em outras áreas do design, mas livros devem ser "protegidos" de vícios e inventos criativos. O livro deve ter uma aparência familiar, e a familiaridade pode ser entendida como a obediência a certas convenções.

60 Nesse contexto, a duplicação (“doubling") é um efeito no qual o leitor perde a linha que estava lendo devido a espaços interlineares reduzidos. Essa duplicação deve ser sempre evitada com o estabelecimento de um espaço interlinear adequado.
Livros também devem ser "regidos" de acordo com o segmento (es pecialmente em relação ao formato), como, por exemplo, livros de literatura, livros científicos. (MORISON, 1936: 26)

Morison era favorável à produção padronizada de livros, como se pode observar a partir de Nicolas Barker (1972), em ocasião em que Morison procurou convencer o responsável pela produção dos livros da Doubleday, nos Estados Unidos, Daniel Longwell, a padronizar o design:

Morison convenceu Longwell sobre a conveniência da padronização na produção de livros, particularmente no que respeita ao lettering, encadernações e leiaute das páginas de rosto. De acordo com Morison, padronização desses dois itens tornaria possível a atribuição do trabaTho a um profissional mais jovem e menos experiente. Logo depois que Morison ajudou Longwell a elaborar um "template" padrão para a série "Crime Club", a economia nos custos de produção deixou maior margem para os gastos em publicidade. (Barker, 1972 : 219)

Outra referência que aponta sua preferência pela padronização é encontrada em McLean (1975: 97), que explica que Morison padronizou a tipografia (Baskerville) e o leiaute para os romances publicados pelo editor inglês Victor Gollancz nos anos 1930.

O tipógrafo inglês Eric Gill, que era amigo próximo de Morison e Warde, em An Essay on Typography escrito em 1931, apresenta ideais próximos aos deles:

o livro é um objeto para ser lido - todos nós devemos começar a partir disso - e vamos supor que o leitor é uma pessoa sensível e sensata. Agora, a primeira coisa que deve ser notada é que é o ato de ler e as circunstâncias desse ato é que devem determinar o tamanho do livro e o tipo da tipografia a ser usada (...) Um bom tipo é apropriado para todo e qualquer livro, e o tamanho de um livro é regulado não pelo que ele contém mas pelo modo pelo qual ele será lido, se o livro será lido segurado pelas mãos (por exemplo, um romance), ou lido apoiado em uma mesa (por exemplo, livros de história ou referência com mapas ou outros necessariamente com grandes ilustrações), ou em uma mesa ou estante (por exemplo, um missal ou um livro de coro), ou mantidos no bolso (por exemplo, um livro de oração ou um dicionário). (GILL, 1988: 105)

O design do livro para Gill (1998: 108) "deve ser governado pelas mãos e pelos olhos". A mão deve orientar o formato do livro, uma vez que volumes de grandes proporções são difíceis de segurar, e os olhos devem orientar a superfície impressa. Ele observa que linhas de texto compostas com mais de 10 a 12 palavras são difíceis de ler. Linhas longas aumentam a atividade 
muscular dos olhos e, às vezes, da cabeça, por isso necessitam de entrelinhas maiores (leading). Algumas das ideias apresentadas por Gill podem ser exemplificadas pelo design de seu próprio livro An Essay on Typography (Figura 15), em que ele mesmo imprimiu e utilizou seu tipo Joanna. O texto foi composto em corpo 12 e com entrelinha de 16 pt, que dão uma mancha leve e legível, e foram utilizadas margens generosas. Em vez de recuos, Gill utilizou símbolos como marcação de parágrafo e em vez de justificar o bloco de texto, o designer optou pelo alinhamento à esquerda.

Nesse contexto, a invisibilidade pode ser entendida como um preceito funcional, na medida em que "livros são impressos para serem lidos" É importante notar, no entanto, que o ideal da "invisibilidade" não se refere apenas à "simplicidade" da página, mas a um conjunto de regras de composição e estilo que podem ser encontradas em textos como os de Morison e Gill. Warde (1956: 13) apresenta as diferenças entre readability (fluência de leitura) e legibility (legibilidade): mesmo uma página sendo legível, não é necessariamente readable. A fluência de leitura está relacionada à facilidade de se ler um texto. Infere-se que a "fluência da leitura" relaciona-se aos princípios da invisibilidade: livros bem compostos, com uma quantidade ideal de palavras por linha e espaços interlineares satisfatórios e margens que "auxiliem o manuseio do volume".

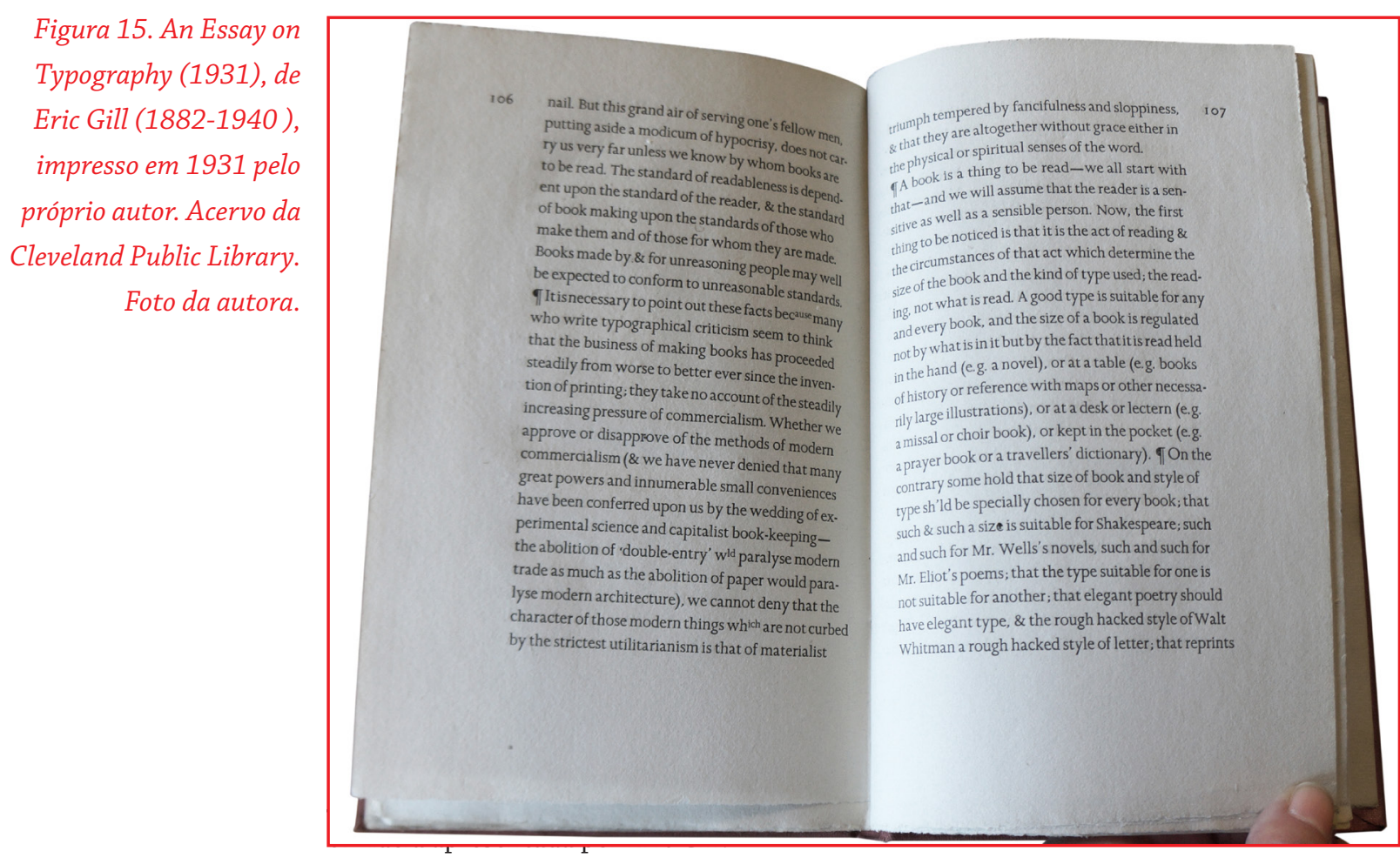

\section{Jan Tschichold, a Penguin e o bom livro de bolso}

Algumas décadas após a defesa do livro "invisível" pelos "reformadores" como Warde e Morison, o tipógrafo alemão Jan Tschichold ${ }^{62}$ (19021974) que, no início de sua carreira, defendia uma abordagem um tanto radical, passa também a privilegiar um livro simples e tradicional.

No final da década de 1940, Tschichold assume o cargo de designer na editora britânica Penguin Books e, além de projetar e supervisionar o design dos livros, escreve um guia de regras de composição que, segundo Chappell e Bringhurst (1999: 257), inspirou designers e editores em diversos países.

Em "A forma do livro", texto iniciado em 1967 e publicado em 1975 (um ano após sua morte), Tschichold defende que:

(...) Um designer de livro deve ser um servidor leal e fiel da palavra impressa. É sua tarefa criar um modelo de apresentação cuja forma não ofusque o conteúdo e nem seja indulgente com ele. (TSCHICHOLD, 2007: 31).

O autor acredita que a real função do designer é a de servir ao texto. Com isso, ele serve ao leitor, tornando a leitura agradável, e serve novamente ao texto ao não tirar o foco nem a atenção dele.

Tschichold compartilha de certa forma algumas das ideias de Eric Gill apresentadas acima de que o livro bem feito deve ser produzido de acordo com a mão e com o olho do leitor:

Duas constantes dominam as proporções de um livro bem feito: a mão e o olho. Um olho sadio está sempre a mais ou menos dois palmos da página do livro, e todas as pessoas seguram um livro do mesmo jeito. (...) Além dessas constantes que se relacionam ao manuseio e à leitura do livro, o autor apresenta duas categorias principais de livros: "os que pomos em cima de uma mesa para estudo sério e os que lemos reclinados

62 Jan Tschichold, importante designer e tipógrafo do século XX, é conhecido especialmente por seu trabalho vanguardista da "Nova Tipografia" cujo "manifesto" foi publicado em 1928. Tschichold teve formação em tipografia clássica, segundo Paulo Heitingler: "Dedicava inúmeras horas ao estudo dos livros da Biblioteca da Federação de Impressores de Leipzig, onde aprofundou o seu saber sobre tipografia clássica, especialmente Fournier, e começou a colecionar livros antigos" e posteriormente dedicou-se à tipografia de vanguarda trabalhando com grades e composiç̧ão assimétricas, tipos sem serifa e cores primárias. Tschichold, posteriormente, abandonou os ideais modernos propostos na "Nova Tipografia" e passou a valorizar padrões clássicos. Disponível em: http://www. tipografos.net/designers/tschichold.html; acesso em janeiro de 2015 . 
numa cadeira, numa poltrona ou enquanto viajamos de trem". (TSCHICHOLD, 2007: 61)

A retomada de Tschichold por valores clássicos de projeto de livro e tipografia não aparenta ser uma busca apenas estilística, pois o foco do designer era bastante funcional. Em A forma do livro, Tschichold dedica-se a identificar características de livros clássicos (em especial do Renascimento) como bons exemplos de design editorial.

Tschichold explica que o formato do livro deve se basear em sua finalidade, ou seja, relaciona-se com o formato das mãos de um adulto. Do mesmo modo, "os livros infantis não devem ser produzidos em tamanho in-fólio, porque esse formato não é cômodo para uma criança”. Nesse contexto, explica também que livros pesados não são adequados, assim como livros muito grandes. Nesse caso o autor parece tratar de livros portáteis, os que se carrega ou se lê na cabeceira (2007: 61).

Pode-se inferir que seus novos ideais sobre o design de livro possam ser encontrados em muitos dos livros que projetou a partir da década de 1940, especialmente no trabalho que fez para a editora Penguin, ao reformular o projeto gráfico para as edições de bolso, como mostra Doubleday (in JONG, 2013: 266):

Na época em que Tschichold chegou à Penguin, em março de 1947, as brochuras haviam se tornado uma forma popular de meio de comunicação em massa e a Penguin Books, em particular, supria o público em geral de uma grande variedade de literatura de baixo custo. Em virtude do declínio na quantidade e na qualidade do papel durante os anos de guerra, porém, o design dos livros da Penguin não correspondia à sua reputação literária. Agora, a editora seria capaz de retornar ao seu padrão de design e produção de livros de antes da guerra. Antes de sua chegada à Penguin, Tschichold solicitou exemplares dos livros da editora e logo percebeu que não havia normas e padrões de composição, uma vez que o departamento de produção dependia de diferentes modelos de página e de um conjunto de normas fornecidos pelos vários impressores da Penguin. Além disso, Old Style No. 2, Gill Sans e Times New Roman eram as únicas famílias tipográficas utilizadas em todos os livros. A estratégia encontrada por Tschichold para ajudar a ensinar os funcionários não familiarizados com o processo de design do livro foi preparar notas explicativas e pareceres críticos e fazê-los circular entre o pessoal dos departamentos editorial e de produção. (DOUBLEDAY in JONG, 2013: 269)

McLean (1975: 88) reitera que Tschichold "pediu uma cópia de cada papel impresso, assim como dos livros” e anotou suas críticas. Esses documentos circularam pelo editorial antes de sua chegada e isso já podia ser considerado "uma educação tipográfica em si mesma".

Na passagem abaixo, verificamos, a partir de Doubleday, o projeto do sistema de design para as publicações da editora Penguin:

Tschichold decidiu estabelecer para a Penguin um visual "prático", que se adequasse a um grande número de livros, alcançando equilíbrio, consistência e legibilidade. Em sua opinião, a fidelidade aos princípios da tipografia clássica - legibilidade, equilíbrio dos estilos tipográficos, margens largas, contraste, simplicidade e fios e ornamentos integrados - era essencial à função do livro. Por exemplo, ele preferia as famílias tipográficas clássicas para páginas com muito texto, observando que "a boa tipografia deve ser perfeitamente legivel e, desse modo, resultado de um planejamento inteligente. As famílias tipográficas clássicas como Garamond, Janson, Baskerville e Bell são, sem dúvida, as mais legíveis. DOUBLEDAY in JONG, 2013: 269-270)

Para McLean, o guia de design criado por Tschichold, intitulado Penguin Composition Rules, não teve apenas importância para a própria editora, mas num contexto mais abrangente:

Sua importância para os negócios do livro britânico como um todo não pode ser subestimada. Hoje, um quarto de século depois, ele ainda é certamente válido e ainda tem que ser lembrado: ignorância e descuido dos detalhes tipográficos ainda são lamentavelmente comuns na imprensa britânica. As regras de Tschichold merecem ser lidas atentamente: palavra por palavra e até o fim. Perceber-se-á enfim que seu objetivo não é o de promover os caprichos estéticos de um designer, mas para alcançar uma comunicação agradável entre autor e leitor - que é, afinal, tudo o que o design tipográfico deve ser". (MCLEAN, 1975: 90-91)

Rafaeli (2005: 9) explica que, antes da chegada de Tschichold, não havia um estilo tipográfico consistente e observa que as regras de composição da Penguin criadas por Tschichold "foram adotadas por muitos impressores de livros britânicos e sua influência continua até os dias atuais".

O manual de regras de Tschichold para a Penguin (disponibilizado de forma integral em MCLEAN, 1975: 94-95) apresenta diretrizes para a composição e design de livros como uso de indentações, espaços entre palavras e letras, uso de estilos de fontes, adequações de projeto para livros de poesia, teatro etc.

McLean nota, no entanto, que as regras de composição não representam de forma alguma um tipo de padronização, apenas diretrizes de 
conduta para educar os funcionários e aprimorar a qualidade da produção. Nesse sentido, compara a estratégia de Tschichold com a de Stanley Morison que era, de certa forma, favorável a uma padronização:

É interessante observar que, embora Tschichold tenha estabelecido normas para cada detalhe do projeto para a Penguin, ele nunca padronizou nem a tipografia nem o leiaute das páginas de rosto - como Morison tinha feito com sucesso quando escolheu Baskerville e um leiaute padronizado para os romances de Gollancz ${ }^{63}$ nos anos 1930. A lista da Penguin incluía livros de muitos tipos e características diferentes, muitos com atributos especiais, como poemas ou citações ou ilustrações nas páginas de título, e grandes diferenças no comprimento e nas formas de organizacão do canitulo e assim por diante, que Tschichold decidiu tratar como um problema de design separado. Ele, portanto, deu a si mesmo a liberdade de escolher os tipos mais adequados (quase sempre da magnífica gama da Monotype planejados por Morison) daqueles disponíveis pelo impressor específico contratado para imprimir o livro; e o tratamento adequado às necessidades de cada página de rosto. Fo uma tarefa formidável, mas foi uma decisão alinhada com a insistência de Allen Lane sobre a mais alta qualidade dos livros que eles escolhiam para publicar. Esse tratamento, de encarar os livros de literatura como individuais, era mais respeitoso com o próprio objeto livro - em vez de tratá-los como produtos produzidos por uma máquina de salsicha. (MCLEAN, 1975: 97)

A partir do exposto acima, verificamos que Tschichold, embora também acreditasse que o livro devesse ser simples e destinado à função da leitura, não defendia a padronização do design que hoje é um procedimento comum na maioria das editoras. No entanto, a partir das ideias de Morison, pode-se inferir que a simplicidade, a "invisibilidade" pode ter aberto o caminho para a padronização, pois se os livros são simples e não chamam a atenção para seu design, podem muito bem ser padronizados, o que torna sua produção mais rápida e barata.

\section{FUNÇÃO}

Os pressupostos apresentados acima apresentam uma abordagem do design do livro voltada especialmente para a função da leitura. O livro simples, que não chama atenção por não ter elementos decorativos, pode distanciar o leitor de talvez perceber uma função estética claramente explorada nos livros de literatura do movimento das Imprensas Particulares e dos livros de edição limitada ricamente ilustrados, produzidos especialmente nas décadas de 1920 e 1940, que serão abordados no próximo capítulo.

No livro organizado por Thomas J. Wilson intitulado Graphic Forms, publicado em 1949, quatro importantes designers de livros (György Kepes, P. J. Conkwright, W. A. Dwiggins e Carl Purrington Rollins) foram convidados para escrever artigos sobre a função do design do livro e de sua "fitness for purpose" 64 . Esses textos apresentam o posicionamento crítico sobre a função do livro no momento seguinte à Segunda Guerra que também é logo posterior ao fervor dos anos 1930 da defesa do design invisível e do fenômeno das edições limitadas.

György Kepes (in WILSON, 1949: 7) explica que, enquanto outros objetos produzidos pelos homens mudaram de forma e tiveram suas funções utilitárias reavaliadas pelo uso de novos materiais e técnicas, "a forma do livro foi praticamente intocada pelos recentes progressos tecnológicos e científicos". No entanto, ele explica que a produção do livro deve ser tão eficiente em todos os sentidos e também naqueles que "agoram afetam o design de todos os produtos fabricados", ou seja, trata o livro como objeto industrializado.

A primeira tarefa é, então, repensar os meios em termos de invenções mecânicas e reajustar o trabalho para os avançados métodos de reprodução e técnicas de impressão. Se o design do livro for feito com um espírito inventivo, alimentado por meio do conhecimento avançado de técnicas de impressão e métodos de produção inevitavelmente será marcado por sua honestidade e clareza, que são os primeiros requisitos do design funcional. (KEPES in WILSON, 1949: 7-8)

64 Termo empregado por alguns dos autores apresentados nessa seção que é semelhante ao pressuposto de "a forma segue a função", ou seja, que a forma do objeto deve cumprir um bjetivo, ser útil, ser funcional. 
Por outro lado, Kepes adverte que não se deve pensar o design do livro funcional apenas em relação com seus modos de produção, mas especialmente à sua performance:

O designer deve repensar as funções do livro em seus aspectos físicos, ópticos e psicológicos. Um livro tem peso, tamanho, espessura e qualidades tácteis, qualidades que são manipuladas pelas mãos que o utilizam. $\mathrm{O}$ livro pode ser concebido a partir de suas necessidades de manuseio. (KEPES in WILSON, 1949: 8)

Além da adequação do design à função do manuseio, ou seja, um design feito para as diferentes necessidades das mãos, o livro deve atender especialmente às necessidades dos olhos do leitor:

A forma visual de um livro deve satisfazer as necessidades do olho. Os fatores que influenciam a visibilidade e legibilidade são correlacionados ao funcionamento da unidade visual, ao tamanho da página, ao tamanhos dos tipos, à distribuição dos tipos e de seu peso e proporção, à luminosidade e ao contraste entre a cor do papel e a tinta. (KEPES in WILSON, 1949: 9)

No entanto, Kepes observa que não é o olho sozinho que lê, é o olho através da mente que lê e dessa maneira "a organização da página impressa deve ser guiada a partir de um completo e avançado conhecimento de descobertas da psicologia". (KEPES in WILSON, 1949: 9)

Kepes (in WILSON, 1949: 9) explica que "uma clara estrutura visual individual das páginas não é suficiente para tornar um livro integrado". Já que o livro comanda o movimento da leitura, todas suas partes como sobrecapa, capa, encadernação, folhas de guarda, página de rosto, aberturas de capítulos e todas as páginas "devem ser integradas por uma orquestração de sequências visuais". O autor afirma, também, que diferentemente da música, que possui apenas uma direção, o livro não deve forçar o leitor a seguir determinado movimento: "a organização do fluxo visual deve ser flexível o suficiente para escapar de uma restrição".

O autor ainda adverte que poucos livros produzidos na época em que escreveu seu artigo têm uma forma "que corresponde à viva pulsação do olho leitor." (KEPES in WILSON, 1949: 9). Em seguida, Kepes apresenta a questão da personalidade que o livro deve ter, ou seja, que além da função da leitura e de modos de produção funcionais, pode-se inferir a partir desse texto que o o livro pode apresentar uma função estética e expressiva, relacionada com o conteúdo textual que esse objeto contém. O projeto gráfico tem a função aqui de interpretar e complementar o conteúdo textual:

Para dar ao livro unidade, a forma gráfica da comunicação deve corresponder ao tipo de ideia de que é veículo. Um livro pode ter uma personalidade integrada - a sua forma exterior pode corresponder a seu conteúdo interior. Hoje a individualidade do livro é apenas a assinatura visua de seu designer. Uma forma genuína, que é uma verdadeira unidade de espírito, só pode ser alcançada pela tradução de conteúdo verbal em seus termos visuais apropriados. (KEPES in WILSON, 1949: 10)

Kepes finaliza sua argumentação sugerindo não apenas uma integração entre as partes do livro mas de todos os profissionais envolvidos em sua realização: o autor, o designer, o impressor, o ilustrador ${ }^{65}$. Ele explica que uma equipe colaborativa "desenvolve um espírito integrado":

Apenas tal colaboração pode estimular o leitor a considerar o livro em seus termos verdadeiros. Pode ajudá-lo a pensar e escrever em consideração aos ritmos visuais par midichen dos os níveis de experiências sensoriais. (KEPES in WILSON, 1949: 14)

Kepes trabalha a questão da funcionalidade do livro pensando-a em sua totalidade, em sua complexidade que não se restringe apenas à forma, à leitura e aos processos produtivos, mas da interação do leitor com o objeto e de suas funções estéticas e simbólicas com seu conteúdo intelectual. Nesta última passagem, sugere a importância de um maior envolvimento do autor de modo a desenvolver novas formas literárias que estimulem e criem novas relações sensoriais com o leitor.

Conkwright, ao escrever sobre a função em livros de editoras universitárias, especialmente sobre livros científicos, explica que, quanto mais o designer conhecer o assunto, mais perto ele está de fazer um "livro útil". (CONKWRIGHT in WILSON, 1949: 16-17). A essa ideia da importância de o designer conhecer com profundidade o assunto científico, acredita que para os livros de arte e história esse conhecimento prévio do assunto também se torna necessário.

, que significa gravador. Neste caso, podese técnica de ilustração, no caso a gravura, é utilizada para se referir a ilustração de modo geral. 
Para o autor, livros publicados por editoras universitárias são geralmente tratados como obras de maior valor do que outras, talvez por sua permanência em relação a obras de outros gêneros. "Livros acadêmicos desse tipo, frequentemente referenciais, precisam ser mais robustos e necessitam de certos tratamentos em comparação a que romances ou livros de interesse temporário". (CONKWRIGHT in WILSON, 1949: 17)

Nesse sentido, o autor trata esse tipo de livro como mais importantes do que obras de ficção e, ao afirmar que livros de mais valor merecem ser lidos e estudados, aponta de certa forma para um fenômeno que é visto hoje na maior parte das editoras: muitos livros de literatura não são necessariamente lidos antes de serem projetados, o que reflete na padronização, se não há necessidade de se conhecer com profundidade um texto, um designer pode usar qualquer modelo pré-determinado e não criar um projeto especial para aquela obra.

Conkwright (in WILSON, 1949: 18) acredita, no entanto, assim como Kepes, que o design deve refletir o conteúdo e explica que algumas tipografias podem "sugerir ou estar em melhor harmonia com o espírito do texto do que outras. Alguns tipos expressam visualmente poesia e outras, de fato, prosa".

William Addisson Dwiggins, reconhecido por seu papel como designer de livros, em especial para a editora de Alfred A. Knopf, escreve em artigo sobre a função do design do livro em edições comerciais que existem pelo menos duas e não excludentes funções: a da leitura e a da venda. Dwiggins (In WILSON, 1949: 23) explica que muitas vezes é difícil combinar as duas, pois ambas muitas vezes, aparentemente, estão em conflito. Para Dwiggins, cabe ao designer, então, tentar reconciliar essas duas partes, embora nem sempre a combinação dessas duas funções resulte em um produto coerente. A função de venda é, para o mercado de livros, muito importante: "um livro tem que sair de sua casa publicadora. Se não vende, ele 'morre' e não interessa o quanto bom e útil" ele é.

Sobre a função da venda, Dwiggins (in WILSON, 1949: 24) explica que "demanda que toda página seja admirável e nova e convencionalmente bela a todo custo. $\mathrm{O}$ departamento de vendas não vê o livro como algo para ser lido, o vê como algo para ser vendido".
Para amenizar essa tensão entre venda e uso com a qual o designer tem de lidar, o autor (DWIGGINS in WILSON, 1949: 25-26) explica que há apenas uma parte em todo o livro em que a função de "uso" pode ser deixada de lado para que a de venda se sobressaia, e esta é a sobrecapa ${ }^{66}$ (ou capa):

Quanto mais bela, surpreendente e nova for a capa, melhor será sua venda. A mais bonita que você pode fazer a jaqueta e o romance mais surpreendente e melhor será para as vendas. Este é o lugar para fascinar e usar todas as qualidades 'de uma caixa de doces' que o departamento de vendas almeja. (DWIGGINS in WILSON, 1949: 25-26)

A partir de Dwiggins, pode-se refletir que seja justamente por essa explícita função de venda da capa que muitas vezes as editoras se preocupem muito mais com seu design do que com o design do livro como um todo, especialmente em relação ao miolo.

Dwiggins explica também que os livros comerciais não têm relação ou talvez não tenham uma função de perenidade, ou seja, de durar, de ser eternos como os livros antigos que mesmo após centenas de anos permanecem intactos ${ }^{67}$ :

Os livros que os nossos antepassados colocavam em suas prateleiras como tesouros, os livros que foram feitos para durar para sempre - papel, encadernação, que já têm mais de quinhentos anos - esse tipo de questão não cabe em relação à função de uma edição de livro comercia. Você está fazendo algo mais permanente do que um jornal, porém não muito mais duradouro do que uma revista. E eu acho que é justamente essa vida curta do livro que deve ser considerada como parte essencial de seu sistema de design. Isto provavelmente desagradará alguns de vocês como uma certa traição aos padrões da arte do livro (...) mas não posso deixar de vê-la como uma inevitável consequência da funcionalidade do design - de descobrir o que uma coisa é, como é que vai ser usada, qual é seu objetivo e, em seguida, desenvolvê-la para esse fim. (DWIGGINS in WILSON, 1949: 27)

Dwiggins explica que entende que alguns livros comerciais são efêmeros e como tal, não são feitos para durar, e assim que esse livro deve

66 Dust jacket. Nos Estados Unidos é mais comum que a sobrecapa seja mais gráfica do que a capa. No Brasil, é mais comum livros terem apenas capas.

67 Durante essa pesquisa de doutorado foram analisados exemplos de livros dos primórdios da impressão e a maioria deles não se deteriorou ao longo de algumas centenas de anos, o que indica que esses materiais e os processos em que eram impresso e encardenados realmente terão uma vida mais duradoura do que livros comerciais produzidos na época de Dwiggins e mesmo hoje em que muitas vezes a encadernação é colada e a capa e miolo podem se desmembrar. 
ser planejado, quanto ao uso de seus materiais e de sua simplicidade em design, porém "mesmo sendo efêmeros não precisam ser tediosos e enfadonhos - eles podem brilhar durante sua curta vida" (DWIGGINS in WILSON, 1949: 27). Ou seja, para o autor, mesmo sabendo que livros comerciais tenham "vida curta", eles devem ser bem feitos.

Em seguida, Dwiggins critica a influência modernista no design e observa que ela deve ser evitada em projetos de livros:

A página do livro é uma questão altamente conservadora. A manipulação de seus componentes tem sido uma prática estabelecida há muito tempo, logo, não se pode repentinamente ignorar sua familiaridade sem confundir o ler. Voceño pode, por exemplo, virar as píginas de labo com a esperança tor. Voce nao pode, por exenplo, virar as páginas de lado com a de o leitor seguir as suas ginásticas; você não pode colocar todos os detalhes de uma página e deixar um grande espaço vazio sem sentido na outra, que torna todo o trabalho muito confuso. (...) Geralmente, o designer que trabalha dessa forma não está, de nenhuma maneira, pensando em pegar o livro para ler. Ele tem seus próprios objetivos e teorias sobre a função de um texto impresso (...) ele está pensando, talvez, sobre a criação de um tom emocional sobre as palavras que irão conduzir o seu tema profundamente em seu subconsciente, pela surpreendente manipulação de espaço e por seu padrão dramático. (DWIGGINS in WILSON, 1949: 27).

A partir do exposto nessa passagem, Dwiggins conclui que a necessidade dos modernistas por um modelo novo e dramático não "joga limpo com a função do livro - ou com o leitor" (in WILSON, 1949: 27), ou seja, ele defende ainda o design tradicional por sua "familiaridade".

Dessa maneira, a partir do texto de Dwiggins, entende-se que o livro apresenta tanto a função de uso quanto de venda. $\mathrm{Na}$ função de venda, especialmente da capa, há possibilidades novas e expressivas, mas quanto à de uso, ou seja, em relação do miolo do livro, deve-se manter minimamente a tradição e elaborar o leiaute do livro de forma familiar, com aquele tipo de design ao qual o leitor está acostumado e evitar "manobras" modernas.

Já Carl Purington Rollins (in WILSON, 1949: 29) acredita que a função do livro é a de "fornecer informação e entretenimento de uma forma tão concisa e simples, em relação à sua aparência física, que uma pessoa de inteligência mediana possa facilmente lê-lo". O autor complementa essa passagem dizendo que qualquer objeto é belo quando "adaptado à sua função" e é assim também que deve ser o livro: "razão e beleza devem ser combinadas para um todo harmonioso".
Rollins explica que a forma de ler continua a mesma desde o início da produção dos livros, e que a função principal que o design do livro deve desempenhar é a de facilitar a leitura, porém há questões contextuais e de época que devem ser considerados como: o tipo de leitor, a luminosidade etc.:

Enquanto as funções de um livro, nos primeiros dias de impressão, são as mesmas de hoje, as condições que circundam o processo de impressão e da leitura dos livros são diferentes. As diferenças entre o público leitor, a imprensa, o tipo, e o armazenamento de livros dos séculos XV ao XX não precisam ser elaborados aqui. A abordagem do estudo será a do cumprimento satisfatório dos requisitos funcionais. Será que os primeiros livros mpressos atendiam as exigências de seus leitores e, se não o fizessem, de que maneira falhavam? Podemos concluir que um saltério de 1457 foi impresso em tipo muito grande porque as igrejas não eram adequadament iluminadas e os sacerdotes eram míopes. (...) Plínio, de Jenson ${ }^{68}$, é fácil de ler ainda hoje, enquanto é ainda formidável aos olhos modernos e também deve ter sido fácil de ler para um estudioso do século XV, assim como Encicloṕdia Columbia é para nós. Ou podese comparar os livios da mprensa Plantin com os de John Day, ou com os Estiennes; ou ainda os livros ingleses do século XVII com aqueles que estavam sendo impressos na América do Norte, ao mesmo tempo. Ou, ainda mais instrutiva, podese comparar os primeiros livros espanhóis com seus contemporâneos em outros países europeus. (ROLLINS in WILSON, 1949: 30-31)

De qualquer maneira, é importante notar a partir do que foi abordado acima que a leitura de um livro pode não ser tão simples quanto parece e que diferentes circunstâncias podem sugerir que não há apenas um tipo de leitura, mas várias: a leitura do míope, a leitura em ambientes mal iluminados, entre outras. Infere-se, a partir daí, que cabe ao designer perceber e não ignorar essas diferenças enquanto está desenvolvendo um projeto gráfico de um livro.

Por ocasião de uma das edições do concurso dos 50 melhores livros da AIGA $^{69}$, T. M. Cleland questiona e critica uma suposta abordagem funcionalista e moderna no design de livros. Nesse texto ele faz analogias com a arquitetura e com outras artes. Cleland (in HART, 1941: 44) observa que muitos arquitetos e designers "adotaram o funcionalismo com um entusiasmo fanático" e que este "oferece um novo evangelho para a regeneração do nosso mundo estético, restringindo todo o projeto para a função de seu objeto ou de seus materiais".

68 História natural, de Plínio, o velho, publicada em Veneza, em 1476, por Nicolas Jenson. 69 American Institute of Graphic Arts. 
Ao fazer analogia com a arquitetura, Cleland (in HART, 1941: 44) observa que mesmo edifícios como uma catedral gótica são "como uma perfeita obra de engenharia perfeitamente adaptada aos seus propósitos", ou seja, que mesmo objetos decorados ou com uma forma diferente da proposta pelo modernismo também cumprem suas funções. Diante disso, o princípio do funcionalismo, tal como proposto pelos modernistas, para o autor, é um tanto estreito.

Ouvimos muito santo falar "da simplicidade" nestes dias, e a ideia da simplicidade expressa por uma ausência total de tudo que não é essencial para uma função mecânica tem sido elevada à categoria de fetiche. cial para uma função mecanica tem sido elevada à categoria de fetiche.
Temos divorciado a simplicidade de seu velho amigo, o charme (...) Mas nesta reverente renúncia de todo adorno que não seja estritamente funcional e, neste sentido, limitado, temos que parar para nos perguntar se estamos de fato seguindo um instinto humano básico, ou apenas tentando tornar virtuosa uma invenção fraca? Não há nenhuma evidência de que o homem é imbúdo de um amor instintivo pela simplicidade nos objetos que o cercan e que consdera uteis. (CLLLANDi cidade nos objetos que cercam e que considera úteis. (CLELAND in HART, 1941: 46)

Cleland observa em seguida que a "ornamentação é profundamente enraizada no instinto humano" (CLELAND in HART, 1941: 47), ou seja, questiona essa ideologia funcionalista de uma simplicidade extrema.

Após apresentar essas ideias, Cleland discute a funcionalidade na tipografia:

(...) Essa embaraçosa inércia dos esforços atuais rumo a uma "nova tipografia" é mais angustiante do que são ainda mais angustiantes deformações semelhantes em outros campos. Tipografia, repito, é uma serva - uma servidora do pensamento e da linguagem a qual torna sua existência visível. Quando houver novas formas de pensamento e uma nova linguagem, haverá tempo suficiente para uma nova tipografia. Quando todos nós alterarmos todos os nossos hábitos e costumes sociais, só en tão será hora de alterar radicalmente as convenções bem fundamentadas dessa arte menor. (...) (CLELAND in HART, 1941: 54)

Cleland (in HART, 1941: 54) considera a Nova Tipografia como algo "neurótico" e "esquizofrênico": "é como se um homen entrasse em uma sala de jantar com suas mãos em vez de seus pés e, em vez de comer sua sopa, a colocasse no colo de seu anfitrião".

Sua crítica (in HART, 1941: 55) à Nova Tipografia se relaciona com sua recusa em seguir as convenções, como exemplificado pela alteração na si- metria das páginas e margens. Outra posição dessa corrente que Cleland abomina é a do uso de fontes sem serifas como formas simplificadas:

Eles simplificam as formas tradicionais da tipografia como você poderia simplificar um homem cortando as mãos e os pés fora. Eles não podem dispensar as características essenciais do alfabeto romano escritas ou impressas, assim como não se pode dispensar os sotaques e entonações da fala humana. Esta é uma simplificação para simplórios. (CLELAND in HART, 1941: 58)

Cleland opõe-se então a essa "limpeza" radical, acreditando que certas características formais não podem ser facilmente descartadas. Para ele, essa ideologia do design modernista em livros "desencoraja o leitor a ler". (CLELAND in HART, 1941: 56-57)

Outra questão que talvez pudesse ser levantada a respeito da "invisibilidade" é que talvez esses textos que a "defendiam" fossem direcionados à indústria livreira, mas com o objetivo de melhorar a qualidade geral dos livros impressos, uma vez que Warde e Morison trabalhavam para uma das maiores empresas de distribuição e produção de máquinas para composição de livros em larga escala (Monotype). Tschichold também direcionava seus escritos teóricos à indústria livreira, sendo que ele próprio criou um manual de boas práticas destinado a uma grande editora.

Esses ideais poderiam ter sido desvirtuados por outros editores, menos preocupados com princípios de boa composição e mais interessados em leiautes simples, apenas por "aparentemente" serem mais econômicos e práticos. Entende-se aqui que o livro "invisível" é "aparentemente" mais econômico, pois, embora pareça simples, seus ideais de composição de texto e construção de margem não são necessariamente "dispendiosos", pois há um tamanho ideal de corpo de texto, de entrelinha e margens. Logo, livros podem ser simples e legíveis como também podem ser simples e ilegíveis.

As ideias apresentadas acima sobre a construção de livro "bem feito" ou "invisível" e mesmo sobre as funções que o design do livro desempenham parecem continuar a ser difundidas para que, talvez, se possa procurar manter algum padrão de qualidade. 


\section{A "RETOMADA" DA INVISIBILIDADE}

Nas últimas décadas do século XX e nas duas primeiras do século XXI posições ideológicas como as de Tschichold e dos autores da Reforma da Impressão ainda sobrevivem, a partir de discussões de autores como Hendel, Jury e Lee, que se justificam por uma preocupação com a produção de livros a partir de novas tecnologias (editoração eletrônica e tipografia digital) e processos editoriais.

Em O design do livro, Richard Hendel (2006) apresenta a invisibilidade não apenas como uma "função" ou "boa prática" do design (como em Warde), mas como fenômeno que se observa a partir da relação do público leitor com o projeto gráfico de livros: "Quando aceitamos a ideia de que o importante no livro é o significado das palavras e não o modo como se apresentam, isso se deve à própria invisibilidade do design". (HENDEL, 2006: 1)

O autor explica que o design é invisível à medida que não foge do padrão, ou seja, quando é convencional e não "chama a atenção" (HENDEL, 2006: 9).

David Jury (2007: 31) também se posiciona a respeito da invisibilidade, acreditando que, em livros, "o melhor design era o invisível, o que certamente se aplicava também à tipografia”.

Jury (2007: 31) explica também que:

Hoje em dia a atitude é diferente, provavelmente devido à influência e à variedade de meios disponíveis para deles se extrair informação. Capas de livro infláveis, recipientes de poliestireno, encadernações criativas e tecnologia do papel são todos usados para testar até que ponto o conceito de livro pode ser expandido antes de este deixar de ser um livro. Mas, embora esses projetos atraiam os meios especializados (e é com demasiada frequência que são destinados a fazer isso mesmo), há muito mais tipografia com muito mais valor a agir discreta e eficazmente para enriquecer as nossas vidas cotidianas normais. (JURY, 2007: 31)

Jury (2007: 17) acredita que essas investigações criativas, que testam limites físicos dos livros, nem sempre são "nobres" como uma boa tipografia discreta. $\mathrm{O}$ autor acrescenta também que, apesar da flexibilidade de hoje, muitas regras e convenções permanecem e muitas delas devem ser consideradas.

Marshal Lee (2004: 109) explica que, em tipografia, é necessário re- conciliar as demandas estéticas e práticas de seu tempo. O autor exemplifica que com a tipografia em metal era possível, para o compositor, produzir quase tudo que o designer especificava, mesmo que isso fosse extremamente impraticável e caro. Dessa maneira, o designer acabava, por questões econômicas, evitando projetar livros muito complexos. O resultado é que esses limites práticos, de certa forma, impuseram um rigor estético.

Hoje, para Lee (2004), essas limitações práticas e econômicas não existem na composição digital. Além disso, não há, hoje como naquela época, um rigor que direcionava uma linha estética, ou, em suas palavras, "restrições estéticas".

Lee (2004: 109) assinala ainda que:

Anteriormente, tipógrafos eram guiados pelos melhores exemplos de trabalho feito por seus antecessores e pelas tradições do ofício. Apesar de esse processo ter resultado em repetições sem criatividade, forneceu um quadro no qual os designers de todos os níveis de competência produziam um excelente trabalho.

No trecho acima, o autor recomenda que sejam observados bons exemplos de livros já publicados, da mesma forma que Morison e Updike, por exemplo, estudaram, analisaram e foram inspirados pelos livros Italianos dos séculos XV e XVI. Bons exemplos, mesmo simples, são na maioria das vezes "bem feitos" por seguirem algumas regras. Jury acredita que regras restringem os erros, e Lee (2004: 109) acredita que hoje, com a composição tipográfica digital, muitas tradições tipográficas podem ter perdido sua influência.

Hendel (2006: 9) também reitera a importância do conhecimento sobre convenções e tradições do livro para os designers:

A tipografia de livros apoia-se (alguns poderiam dizer: mergulha) na tradição e nas convenções. Os designers devem entender a história as convenções da tipografia de livros, porque há boas razões para a sua existência. Mais de meio século atrás, Stanley Morison e Oliver Simon reiteraram o que devemos considerar os princípios da boa tipografia. Essas supostas regras para um bom design de livros não são absolutas, mas fornecem pontos de partida úteis - o que Robert Bringhurst chama "etiqueta tipográfica".

Bringhurst (2005) como aponta Hendel, parece também ter um importante papel na divulgação de boas práticas em tipografia e design 
de livros ao apresentá-las no seu Elementos do estilo tipográfico, hoje adotado como referência bibliográfica por muitos designers, já que é distribuído em diversos países e traduzidos em várias línguas. ${ }^{70}$

É preciso observar também as condições atuais em que os livros são publicados, com grandes grupos editoriais talvez mais interessados no lucro do que na qualidade do design. Dessa maneira, ideais do livro "bem feito" precisam ser retomados.

Chappel e Bringhurst (1999: 295) apontam que hoje, com a engenharia de softwares, a composição tipográfica está à disposição de qualquer um e "a liberdade de publicar é quase absoluta". No entanto, os autores advertem que há grandes empresas que monopolizam o mercado e muitas vezes não são necessariamente editoras, mas empresas que visam o lucro, mais do que a divulgação de textos impressos. Apresentam, assim, as diferenças entre um editor e um gestor (que hoje é quem administra, em geral, grandes editoras):

Os objetivos de um editor são, via de regra, contribuir para a cultura através da publicação de bons livros e desfrutar os prazeres de uma vida literária e, consequentemente, fazer um pouco de dinheiro no processo. Os objetivos do gestor, via de regra, são a máxima penetração no mercado, cota máxima de mercado, e lucro máximo. (CHAPPEL e BRINGHURST, 1999: 295)

É importante ressaltar que o modo de produção do livro se alterou substancialmente após o lançamento, em 1984, do computador pessoal da Apple que permitiu aos designers manipular tanto o processo quanto o projeto (sabe-se que em especial antes a divisão de trabalho do designer do livro e do tipógrafo se intensificaram e nem sempre era o próprio designer que executava o processo). Ao manipular processo e projeto, o designer podia também "manipular" a tipografia (trabalho antes restrito ao impressor-compositor). Além disso, a tipografia em metal era "inflexível". Se antes o trabalho tipográfico apresentava diversas restrições técnicas e métricas, sendo, conforme Jury (2007: 14-15), inflexíveis, o computador torna a tipografia flexível (pode-se alterar, mesmo não sendo recomendável, as formas dos tipos por softwares de editoração).

70 Foram encontradas no decorrer desssa pesquisa edições em português, espanhol, além do original em inglês.
Sobre a flexibilidade (dos meios atuais) versus a inflexibilidade da composição tipográfica tradicional (tipos de metal, composição a quente etc.), sabe-se que antes o designer, na hora de projetar ou especificar a tipografia, o formato e as margens de um livro precisava trabalhar com precisão com as unidades de medidas convencionais: pontos (pts), paicas, pontos didot, pontos cíceros etc. Além disso, principalmente com a tipografia em metal, inflexível, era impossível deformar ou transformar o desenho da letra. Hoje os softwares de editoração eletrônica oferecem muita maleabilidade e flexibilidade ao design. Isso possibilita composições menos metricamente rígidas, porém pode também ser um recurso perigoso aos que, intencionalmente ou não, distorcem a forma dos tipos ou usam margens mínimas. ${ }^{71}$

Jury (2007: 16) assinala que:

Atualmente, muitos tipógrafos, que estudaram em escolas de arte e de design, foram incentivados a ser mais flexíveis na linguagem que empregam, bem como a reconhecer que as reações emotivas têm uma função que os textos podem ser concebidos com paixão. A tecnologia desempenhou um papel importante nesta transformação, tornando o processo tipográfico mais insular, proporcionando independência e a oportunidade de experimentar

O autor acrescenta também que, apesar da flexibilidade de hoje, muitas regras e convenções permanecem e devem ser consideradas. (JURY, 2007: 17)

Para Hendel (2006), deve-se repensar certas regras e tradições tipográficas e adaptá-las, uma vez que modas e gostos mudam. Dessa maneira, pondera que muitas regras não são obsoletas, porém não podem ser consideradas absolutas. "Hoje os escritores escrevem de maneira diferente daqueles que escreviam no século XVII. Atualmente, vemos constantemente o tipo ser usado de uma maneira inovadora" (HENDEL, 2006: 24). Da mesma forma que os estilos de escrita mudaram e se adequam ao tempo, Hendel diz que o mesmo deve ocorrer com as regras tipográficas. Destacamos de sua tese sua "analogia" de como se comportaria um designer do começo do século, como Bruce Rogers, ao

71 Em composiçãao com tipos móveis as margens tinham que ser maiores por conta da imposição das páginas, hoje é possível utilizar margens muito pequenas, o que pode ser problemático, uma vez que as margens, como já tratou Beatrice Warde, têm a função de que o livro seja segurado sem que os dedos fiquem sobre o texto. 
projetar livros de autores contemporâneos como Jaques Derrida ou John Cage.

O autor questiona, assim, a especificidade do design para cada obra, já que o que se percebe no mercado editorial é que muitos livros, apesar de apresentarem diferenças substanciais em suas capas, podem ter o miolo semelhante, especialmente se pertencerem a alguma coleção.

Pode haver pressupostos sobre a aparência que deve ter um livro convencional, mas é preciso que o design de livros parta das palavras do autor, e não de uma teoria abstrata. $O$ design de dois livros não pode ser exatamente igual, assim como dois livros não podem ser escritos com as mesmas palavras. $\mathrm{E}$ embora se possa usar um design como modelo para apresentarão cheias de defeitos. (HENDEL, 2006: 24)

Hendel apresenta o fato de que hoje muitos livros são parecidos uns com os outros, por conta de sistemas de padronização instaurados em algumas editoras, mas acredita na importância da produção de projetos específicos para cada tipo de texto. Além dessa questão, o autor apresenta a falta de qualidade de projeto gráfico em livros:

Como podemos saber algum dia qual é o impacto que tem um design sobre a edição? Peguem os best-sellers nas livrarias e examinem seus designs. E tão raro você achar um bom que chega a desanimar. Os livros que mais vendem são, na maioria das vezes, aqueles cujas páginas são destituídas de margens e carregadas de uma tipografia repulsiva. (Hendel, 2006: 25)

\section{INVISIBILIDADE: UM PARADIGMA ULTRAPASSADO?}

Com base neste breve panorama é possível perceber que o ideal do livro "invisível" não se restringe a uma preocupação do início do século $\mathrm{XX}$. Antes de parecer um design simples, o ideal do livro invisível é um valor estético embasado em princípios de produção.

É importante ressaltar que os textos aqui discutidos, apesar de defenderem o design de um livro simples, não defendem o "simplório", representam um conjunto de boas práticas que devem ser seguidas para projetar um livro "bem feito". Mesmo que os ideais de Morison e Warde pareçam alinhados à indústria editorial (de um livro simples), a "invisibilidade" e a ausência de ornamentos promovidas por eles não correspondem apenas a um livro de texto corrido comum, mas basea- do em princípios funcionais. Infere-se que esta ideologia busca favorecer o leitor e não apenas o lucro do editor.

Os ideiais da maioria dos autores apresentados neste capítulo, nem sempre são seguidos, muitos livros apresentam às vezes margens estreitas, o corpo do texto e a entrelinha são reduzidos por fatores econômicos.

É possível perceber que as atitudes de Bringhurst, Hendel, Jury e Lee resgatam, de certa forma, os princípios da invisibilidade de outrora para refletir sobre os problemas editoriais atuais e, dessa maneira, com o resgate de algumas regras (não mencionadas aqui, mas apresentadas em seus textos), alertam para a importância da produção de livros de qualidade, já que em muitos livros impressos, até recentemente, alguns princípios e convenções são neglicenciados.

Warde e Tschichold parecem querer combater qualquer manifestação expressiva na tipografia em livros e é possível verificar no design de muitos deles, em especial nos de literatura (leitura contínua), a presença de ideais como o apresentado por Lupton (2006:63) de que: "Embora muitos livros vinculem o propósito da tipografia à melhoria da legibilidade da palavra escrita, uma das funções mais refinadas do design é de fato ajudar os leitores a não precisar ler. ${ }^{72 "}$ (LUPTON, 2006: 63), ou seja, o design deve ter o o papel de facilitador da leitura.

A afirmação corrobora a ideia de Warde da invisibilidade da tipografia, com a busca de um trabalho neutro e comum a ponto de não chamar a atenção para a forma e tornando a leitura agradável.

É difícil discordar inteiramente de tais acepções uma vez que o livro, em especial o de literatura, por ser de leitura contínua (ou prosa - Swann, 1991), não deve atrapalhar o leitor, pois este deve conseguir ter contato com o conteúdo sem interrupções.

Por mais que autores como Warde (na década de 1930) e mesmo Lupton (início dos anos 2000) defendam certa transparência do texto, autores como Bringhurst (2008: 11) afirmam que nenhuma página impressa ou mesmo um copo de vidro é invisível, embora possam aparentemente desaparecer em virtude do conteúdo. Bringhurst, no entanto, acredita que o design de livros tem significado porque torna visível a realidade do texto. Nesse sentido, o designer de livros é um "intérprete que desenha a superfície em que a forma será revelada”. (idem, 2008: 11)

72 Itálico do original 


\section{ABORDAGENS VISÍVEIS}

Como se viu no capítulo anterior, a "invisibilidade" como abordagem simples do livro de literatura foi defendida especialmente nas décadas de 1920 e 1930, mas essa abordagem, embora não seja designada por esse termo antes da palestra de Beatrice Warde em 1930, não é exclusiva daquela época, como se pode observar a partir dos livros "simples", ou seja, sem ornamentos, impressos, entre outros, por Aldo Manuzio, Baskerville e Bodoni.

Essas duas abordagens, no entanto, parecem coexistir durante a história do livro impresso. A partir da literatura encontrada, não se pode precisar se uma ou outra abordagem era mais comum antes do século XX. O que se pode encontrar são indícios de que em determinados países alguns livros eram mais decorados do que outros, como se pode observar a partir de Blumenthal (1973: 23), que observa que livros publicados no século XVIII, que na França eram luxuosos, na Itália e Espanha eram produzidos para a elite (provavelmente decorados) e que na Inglaterra preferiam-se edições mais simples e sem ornamentos supérfluos:

Durante os anos da extravagância francesa em Versalhes, os impressores profissionais em Paris, auxiliados pelos melhores artistas e gravadores franceses, naturalmente impulsionaram o espírito do livre de luxe. Eles transformaram charmosos octavos ilustrando temas de amor em jardins encantados e vestiários para senhores [boudoirs], tomos luxuosos celebrando pompas reais e os clássicos em fólios suntuosos ricamente encadernados para adornar mesas rococós em salas de estar. Na Itália na Espanha, produziram volumes espetaculares para os ricos, que provavelmente nunca eram lidos. Na Grã-Bretanha, por outro lado, apareceram alguns impressores que produziram excelentes edições literárias dos textos mais valorosos, dependentes de um design de tipos sólido de ótimas proporções de páginas, livres da ornamentação e da ostentação supérfluas. Essa foi uma evolução lógica, num momento em que, segundo G. M. Trevelyan, "os pesquisadores britânicos se tornaram mais que nunca isolados de seus irmãos do continente [europeu], a reflexão e o aprendizado tornaram-se mais nacionais, mais populares e mais estreitamente ligados à literatura. (BLUMENTHAL, 1973: 23) 
Outro dado sobre essa questão pode ser encontrado em texto de Bartram (2004: 16), que explica que os livros italianos do século XVI eram desprovidos de ornamento, enquanto os franceses os utilizavam com mais frequência:

Os primeiros impressores italianos dispensaram muitas vezes qualquer forma de decoração. Mas a partir da primeira metade do século XVI até meados do século XVIII, impressores franceses (que assumiram rança, superando os italianos), enquanto ainda trabalhavam com o conceito clássico de simetria formal, geralmente constritora, eram regidos por uma tradição diferente. Eles produziam livros que eram primariamente decorativos, mais que um meio de comunicação. Muitos de seus ornamentos ou adornos, e mesmo ilustrações, eram usados para livros muito diferentes, de qualquer maneira, sem uma tentativa de criar um novo design pertinente para um novo texto. Qualquer faixa ornamental velha ou inicial decorativa servia: economias na produção eram importantes mesmo nisso.

A partir de levantamento realizado na Morgan Library, na New York Public Library e na Cleveland Public Library, porém, foram encontrados muitos exemplos de livros de textos literários cujas páginas são mais visíveis, seja por meio de vinhetas, ornamentos, capitulares ou ilustrações. Muitos dos livros encontrados entre os séculos XV e XIX apresentam uma função estética, quando comparados aos livros simples de literatura.

$\mathrm{O}$ uso de elementos decorativos muda de acordo com o estilo de cada impressor, de cada período e de cada local. A visibilidade, assim, parece ser condicionada por esses fatores. Outro ponto que é preciso ponderar é de que a "visibilidade" é relativa. Se tomarmos como ponto de partida a maioria das edições de livros comerciais produzidas hoje, todas as edições apresentadas nesse capítulo são "visíveis", mas talvez não fossem na época em que foram produzidas, pois o leitor poderia estar acostumado a elas, como por exemplo os incunábulos, decorados pelo fato de que os manuscritos eram antes decorados, ou seja, o nível de "visibilidade" pode ser determinado pelo gosto da época.

Neste capítulo, abordaremos a visibilidade em distintas fases da história do livro, especialmente no final do século XIX e no XX, quando surge o movimento da Imprensa Particular, em que abordagens visíveis de livros literários parecem ganhar mais espaço.
Antes, porém, vamos apresentar um breve panorama do livro "visível" ao longo da história da impressão. Para evitarmos a dispersão por um universo tão amplo, vamos focalizar apenas edições de dois clássicos da literatura ocidental: Decameron, de Giovanni Boccaccio, e Dom Quixote, de Miguel de Cervantes. Escolhemos uma obra escrita antes da invenção da imprensa e da qual há publicações impressas em diversas línguas, estilos e também inclusive bem no início da impressão. A segunda obra, Dom Quixote, foi escrita quase 150 anos depois da Bíblia de Gutenberg, mas se mantém como uma das mais lidas da história. Segundo Zilberman (2001:20), Dom Quixote teve 12 mil exemplares vendidos na época da publicação e marca o início do romance moderno. Ademais, de acordo com Lyons (2011: 89):

Após 1660, o livro começou a conquistar um público mais popular. Edicões espanholas baratas se multiplicaram, usando gravuras de edições estrangeiras, que muitas vezes tinham pouca relação com a realidade espanhola. Até meados do século XVIII, Dom Quixote geralmente era propanhola. Até meados do século XVIII, Dom Quixote ge
duzido em dois volumes in-quarto em papel medíocre.

Lyons (2011: 89) complementa que Dom Quixote, durante o iluminismo, "foi lido tanto por leitores de classe baixa como pela elite social." De acordo com a essa passagem, percebe-se que o livro teve grande popularidade, o que justifica sua publicação por diversos impressores em grande parte do Ocidente.

Nossa proposta aqui é explorar uma pequena amostragem com base no acervo disponível nas bibliotecas visitadas, para comprovar a "visibilidade" pela presença de ornamentos e ilustrações em obras de literatura, o que pode, hoje, parecer estranho ao nosso olhar contemporâneo acostumado com páginas simples, pois há décadas o design dos livros de textos literários é "simples".

\section{EDIÇõES DE DECAMERON}

Este volume de Decameron (Figura 16) foi impresso em 1492, por Johannes e Gregorius de Gregoriis, em Veneza, no que seria depois a Itália unificada. O livro apresenta ilustrações xilográficas e a ornamentação se encontra principalmente na abertura dos capítulos. O 
tipo utilizado lembra o romano de Nicolas Jenson ${ }^{1}$. Como se sabe, os impressores sempre deixavam espaços em branco para depois serem iluminados, coloridos a mão. Nesse volume, há espaço para iniciais se(1353), de Giovanni rem iluminadas em momento posterior à impressão do texto, porém Boccaccio (1313-1375). este exemplar não teve esse tratamento. O texto é apresentado em Impresso em 1492 por Johannes e Gregorius de Gregoris. Livro do acervo

da Morgan Library.

Fotos da autora. duas colunas, como na tradição manuscrita. Há recuos como marcação de parágrafo em algumas páginas, mas não se pode afirmar se estes eram espaços que depois receberiam símbolos do iluminador ou se o impressor já usava essa estratégia.

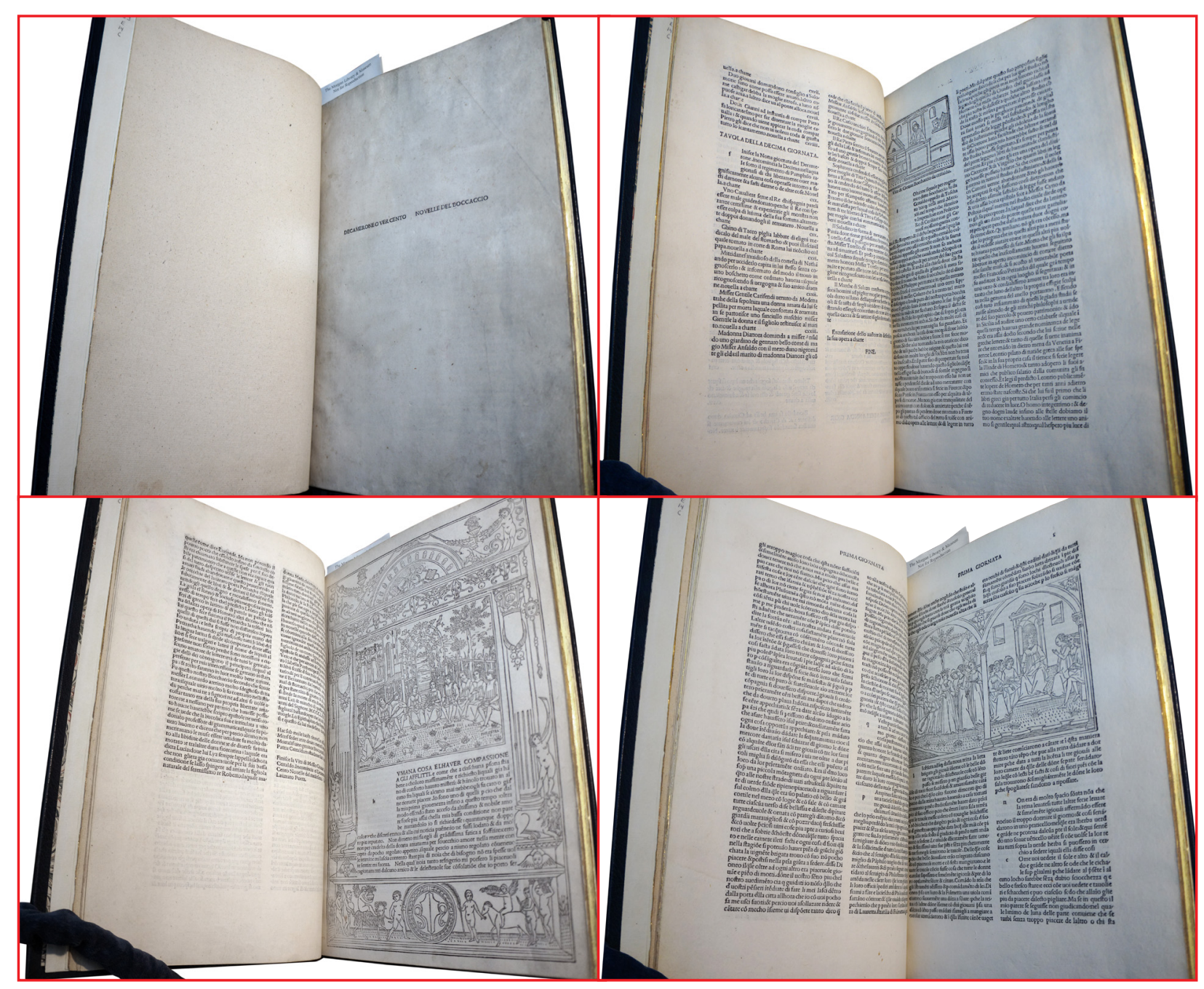

1 Nicolas Jenson (1420-1480), tipógrafo francês, que trabalhou em Veneza de 1470 até sua morte.
Já esta edição de 1473 (ou 1476), impressa por Johannes Zainer, em Ulm (Figura 17), no que seria posteriormente a Alemanha, de dimensões aproximadas $22,5 \times 32 \mathrm{~cm}$, não apresenta folha de rosto nem ilustrações, mas traz belas capitulares decoradas e pequenos símbolos, como marcação de parágrafo e composição em duas colunas. A fonte é mais pesada, não é um tipo leve como os romanos baseados em Jenson, porém a página ganha leveza por suas amplas margens. Zainer, segundo Blumenthal (1973: 6), produziu livros populares e alguns também ilustrados.

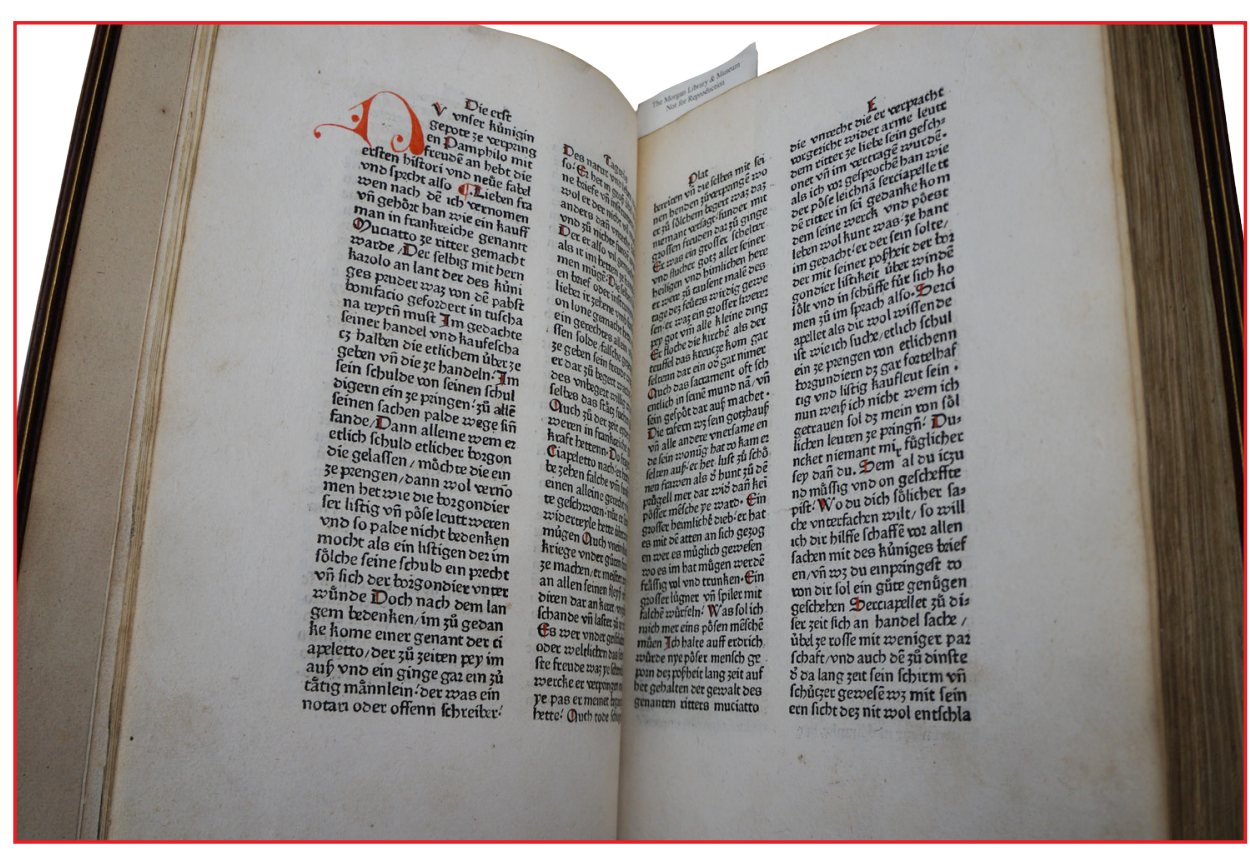

Figura 17. Decameron (1353), de Giovanni Boccaccio. Impresso em 1473 por Johannes Zainer Livro do acervo da Morgan Library. Fotos da autora.

Esta edição foi impressa pelo inglês Isaac Iaggard, em 1620, que foi o impressor dos primeiros fólios de Shakespeare (Figura 18). O formato da obra é de $17 \times 28 \mathrm{~cm}$ e o papel utilizado é de baixa gramatura. O texto foi impresso em duas colunas em um tipo itálico e só os textos introdutórios foram compostos em tipos romanos em uma coluna. $O$ volume apresenta problemas de distribuição dos espaços e alguns borrões no meio do texto, talvez pelo fato de o olho da fonte ser muito fechado ou por descuido do impressor que não se preocupou com a uniformidade da superfície impressa, ou talvez também não tivesse a habilidade para resolver esses problemas. No leiaute das páginas, foram impressas linhas entre os títulos correntes para separá-los da 


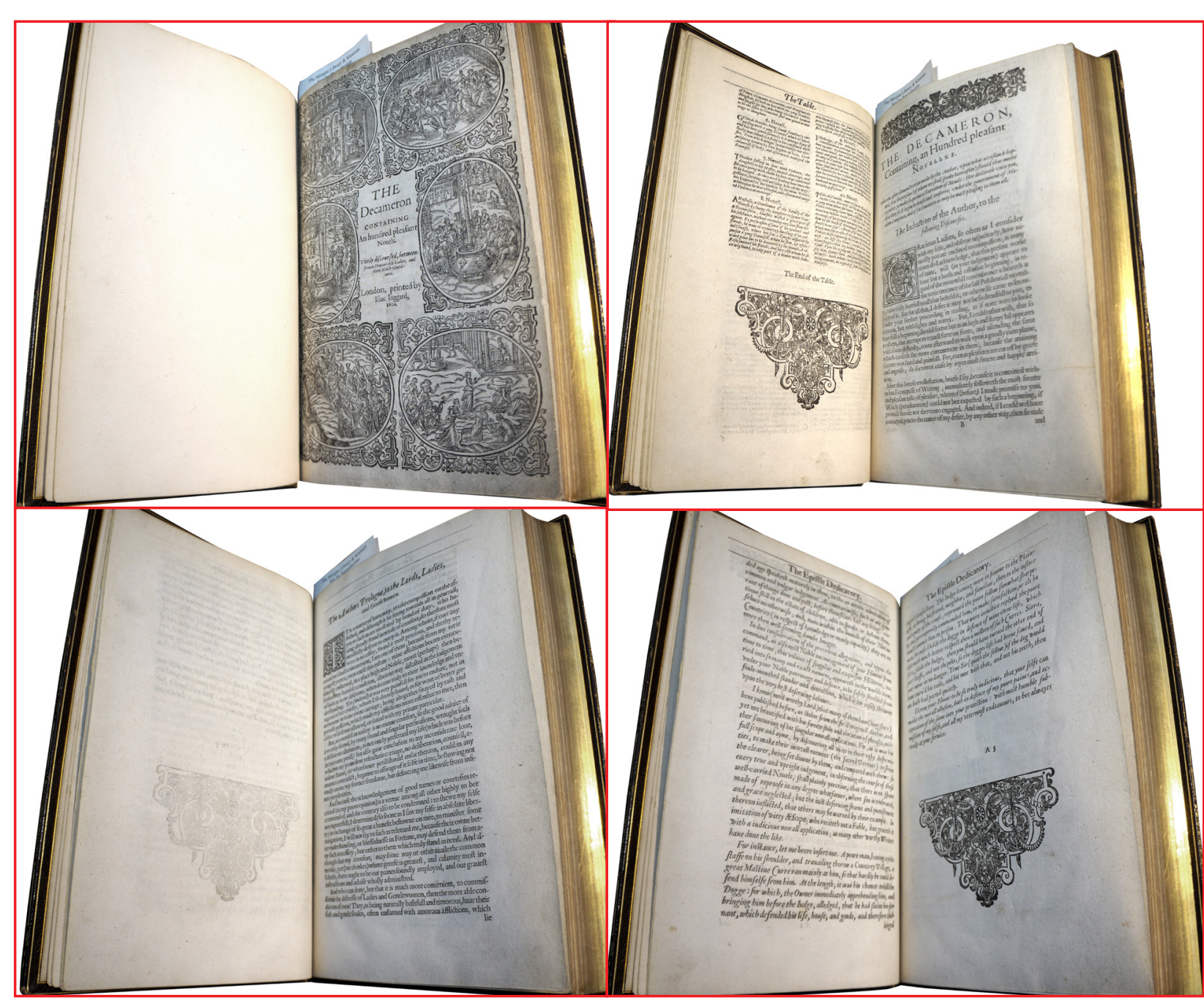

Figura 18. Decameron mancha, há vinhetas e capitulares no volume, porém em apenas algu(1353), de Giovanni mas páginas.

Boccaccio. Impresso em Esta edição, impressa em 1665 pela Casa Elzevir, em Amsterdã, de Livro do acervo da Morgan Daniel Elzevir (Figura 19), é compacta, formato duodécimo de 7,5 x Livro do acervo da Morga Library. Fotos da autora. $14 \mathrm{~cm}$ e tem 744 páginas. Mesmo sendo uma obra compacta, apresenta vinhetas e capitulares ornamentais, além de capitulares simples. O texto introdutório foi impresso em itálico e o texto principal, em romano. O volume é bem impresso, mas muito pequeno e com margens mínimas. O corpo do texto é pequeno, de aparentemente 7 ou 8 pontos, com pouco espaço interlinear.

Segundo Araújo (2000: 326-327), a casa Elzevir tornou-se conhecida por imprimir livros de formato reduzido, como já haviam feito Manuzio e Plantin. O autor explica que, durante sua existência, a casa Elzevir lançou cerca de dois mil títulos. Esses dados sugerem o sucesso desses pequenos livros, menos dispendiosos que os demais. No entanto, após verificar o original, o volume não é tão legível devido ao tamanho do corpo e entrelinha. É interessante notar que, mesmo um livro compacto, que tem como princípio ser mais popular, é ainda assim ornamentado, o que indica uma predileção pela ornamentação mesmo em livros cujo objetivo era o de ser mais compacto e popular

Lyons (2011: 79-80) assinala que:

Essas edições de bolso dos clássicos eram produtos de qualidade: eruditas, confiáveis e de preço razoável. A edição de 1636 das obras completas de Virgílio teve tanto sucesso que foi reimpressa quinze vezes. Clássico em tamanho de bolso logo se tornaram conhecidos como 'edições elzevir', fossem ou não publicadas por essa casa editorial.

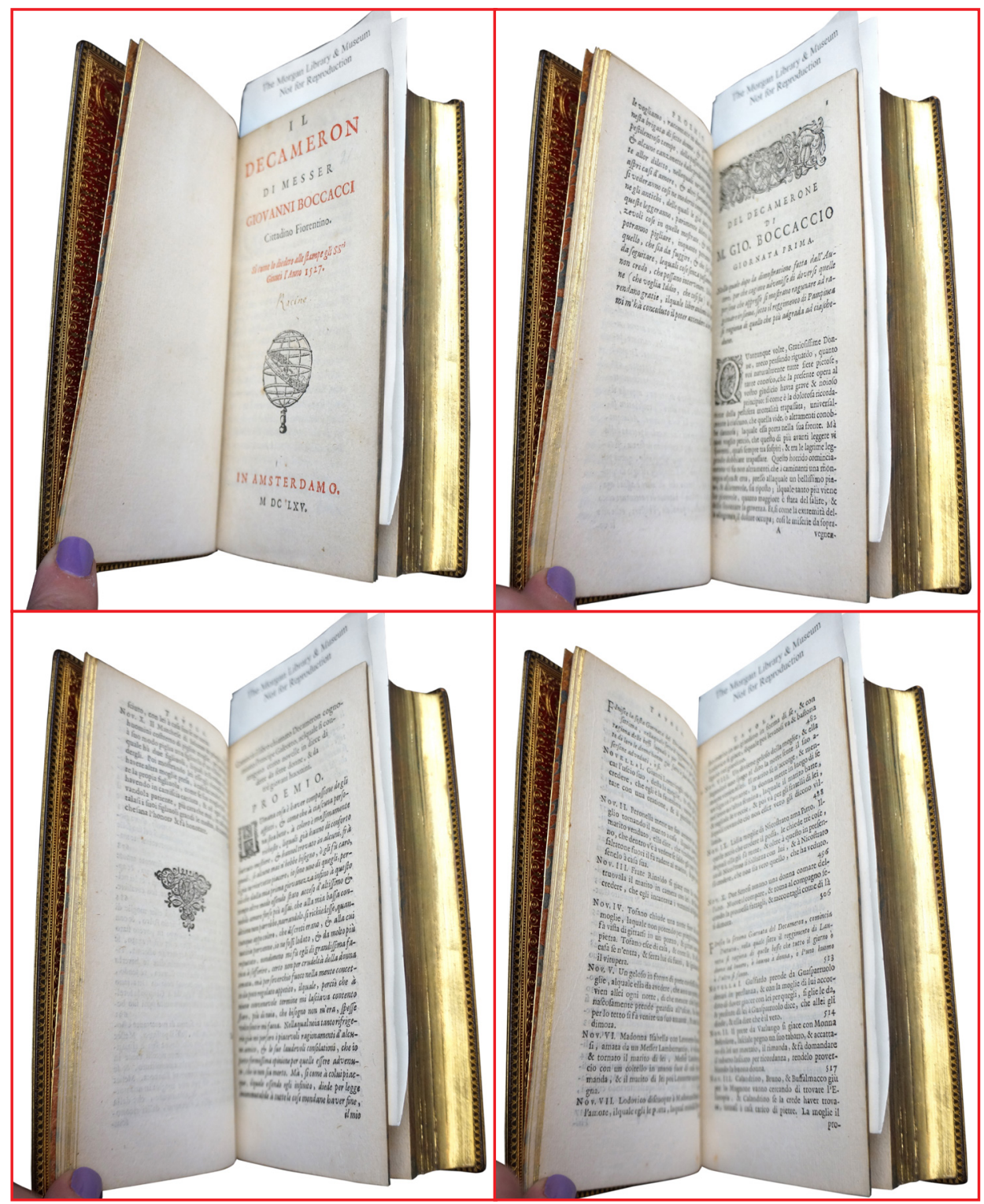

Figura 19. Decameron (1353), de Giovanni Boccaccio. Impresso em 1665 por Daniel Elzevir. Livro do acervo da

Morgan Library.

Fotos da autora. 
Esta edição em italiano, publicada em Londres por William Pickering, em 1825 (Figura 20), apresenta páginas simples, embora seja ilustrado. Nesse exemplar não há uso de capitulares nem de vinhetas. Apesar de Pickering ter se tornado famoso por resgatar o tipo oldstyle de William Caslon, o presente volume foi composto com um tipo de classe moderna, de eixo vertical rígido e alto contraste. O corpo dos tipos é pequeno, de aproximadamente 9 pontos. Pickering utilizou mais espaço interlinear e margens generosas para compensar o peso do tipo; abordagem semelhante, como se pode observar no capítulo anterior, à de Bodoni. Neste exemplar foi utilizado um papel mais fino, de gramatura aproximada de $70 \mathrm{mg}$. O livro é compacto e mede $11,5 \mathrm{~cm}$ x $19 \mathrm{~cm}$.

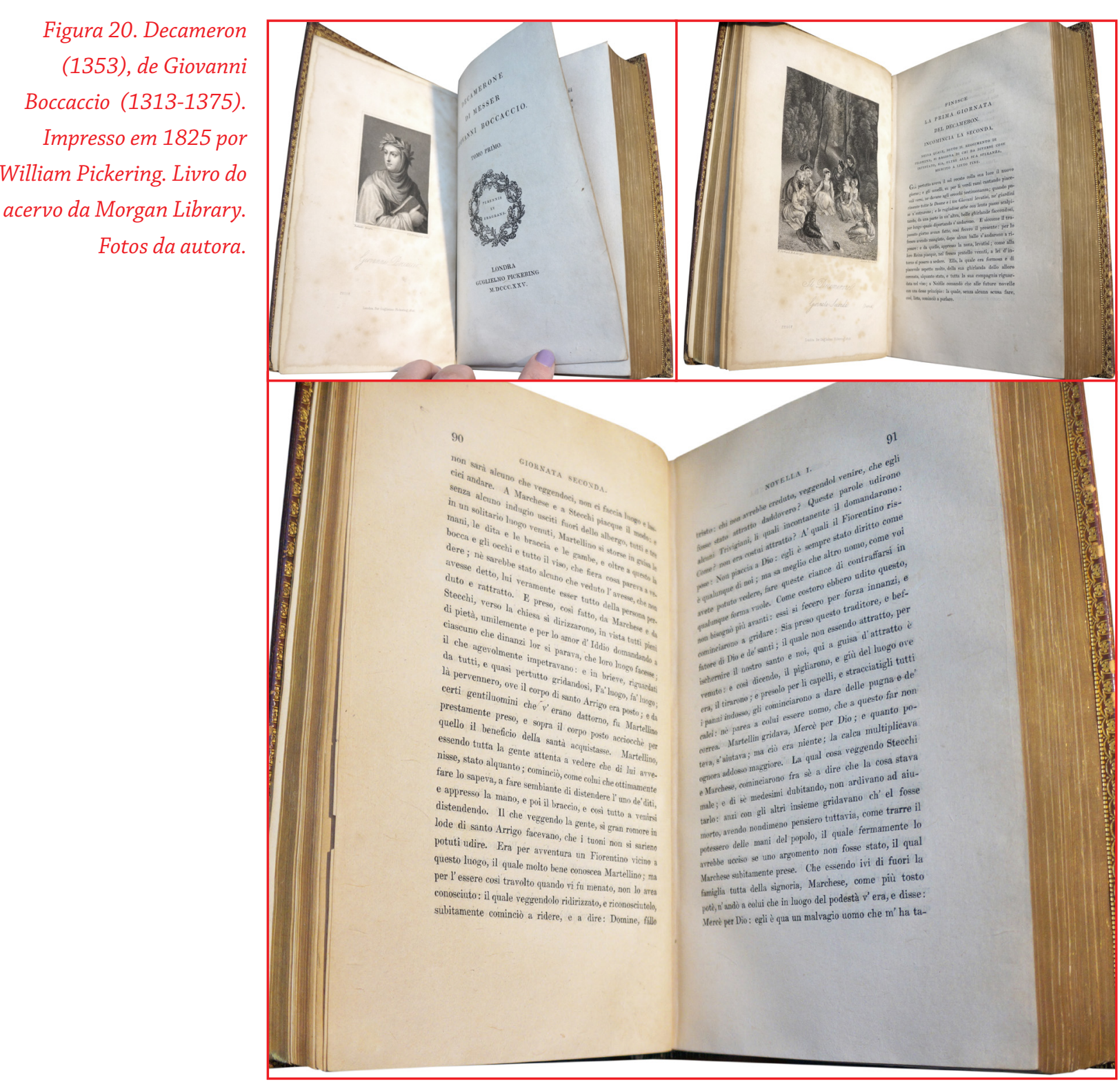

Segundo Blumenthal (1973: 33), Pickering foi um dos poucos editores ingleses que não sucumbiu à moda vitoriana e se inspirou nos séculos XV e XVI para produzir seus livros. O autor acrescenta ainda que, no trabalho de Pickering, encontra-se um dos primeiros exemplos da separação de tarefas entre impressor e editor, já que Pickering não imprimia, mas editava e projetava.

\section{EDIÇõES DE DOM QUIXOTE}

Este exemplar é fiel à edição original de 1605 (Figura 21) e apresenta vinhetas, capitulares decoradas e margens generosas. O tipo utilizado na mancha de texto é da classe garalde, com espaço entre as letras maior que o comum e nem todas as páginas apresentam ornamentos.

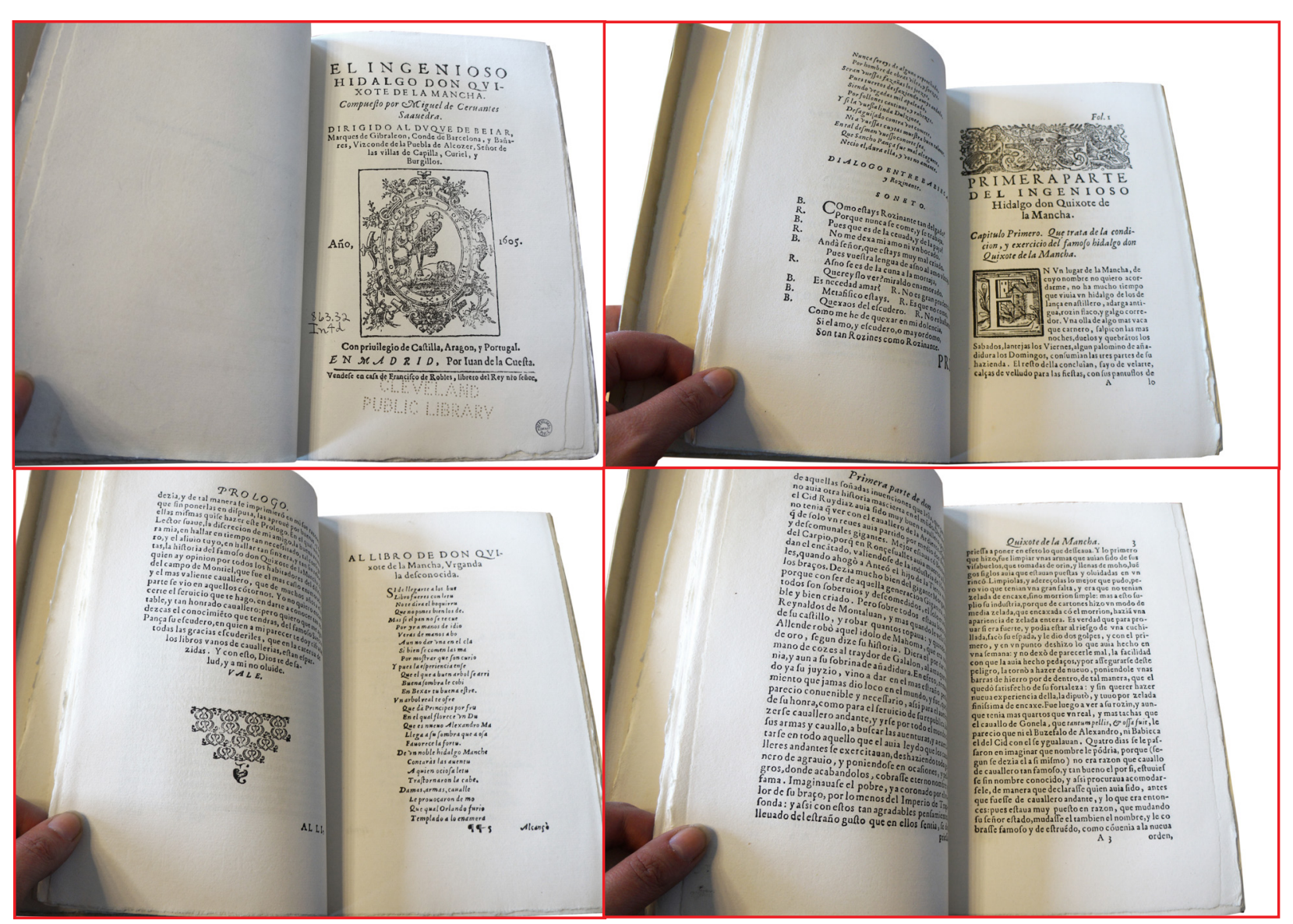

Figura 21. Dom Quixote (1605-1615), de Miguel de Cervantes (1547-1616). Fac-símile do original de 1605, impresso no início do século XX pela Hispanic Society of America. Livro do acervo da Cleveland Public Library. Fotos da autora. 
Esta edição em francês, "Les principales aventures de l'admirable Don Quichotte" (Figura 22), publicada em 1746, é uma edição ilustrada de 22 x $28 \mathrm{~cm}$, impressa por Pierre de Hondt, na Holanda. O livro apresenta recuos de parágrafo proporcionais ao tamanho do corpo e da entrelinha. As margens são generosas, mas a mancha de texto é muito larga. O tipo usado é leve e apresenta eixo vertical, mas não é pesado como os modernos - talvez se trate de um tipo de transição. Algumas páginas, além das ilustrações, apresentam ainda vinhetas e capitulares decoradas.

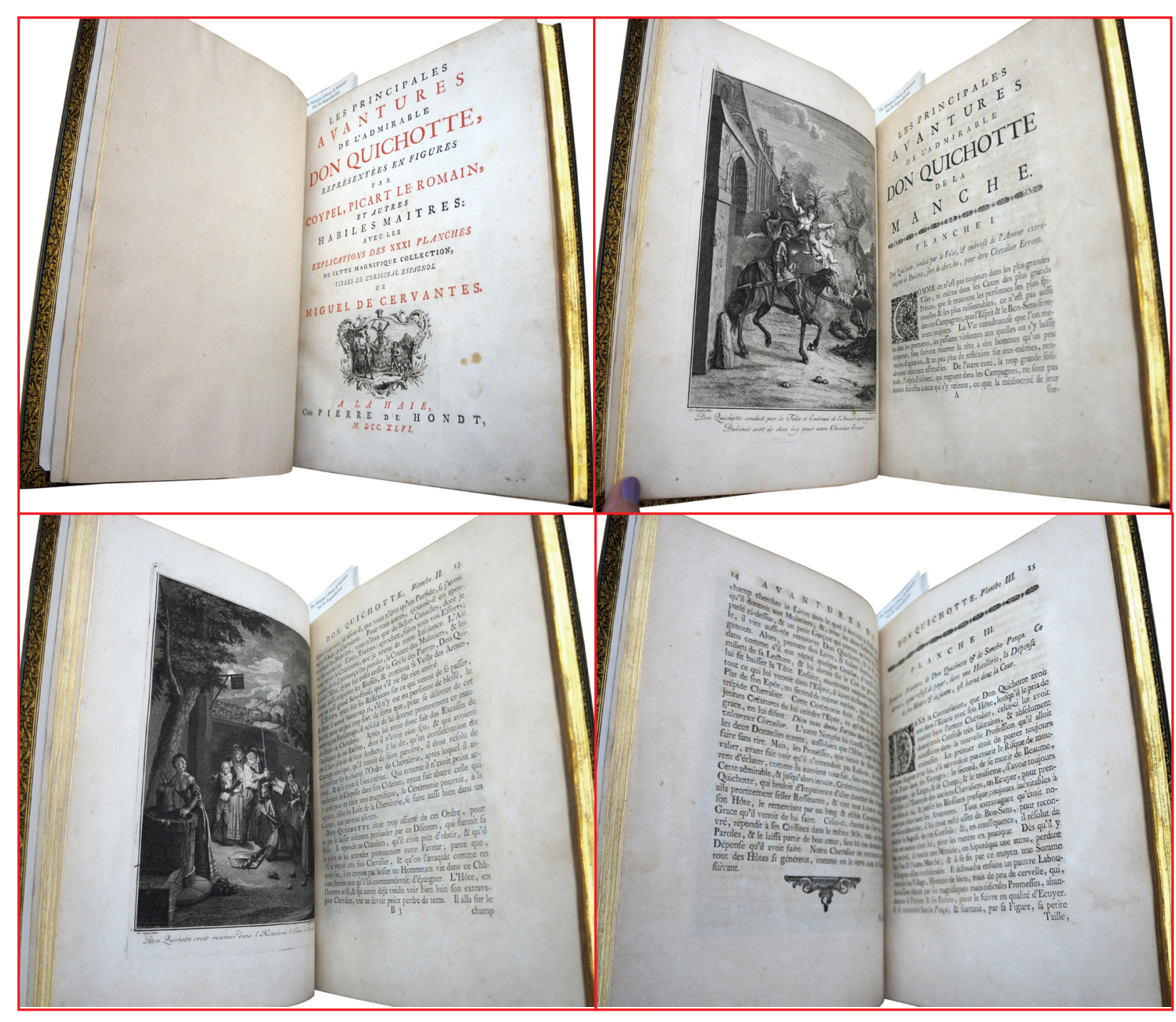

Figura 22. Dom Quixote (1605-1615), de Miguel de Cervantes (1547-1616). Impresso em 1746 por Pierre de Hondt. Livro do acervo da Morgan Library. Fotos da autora.

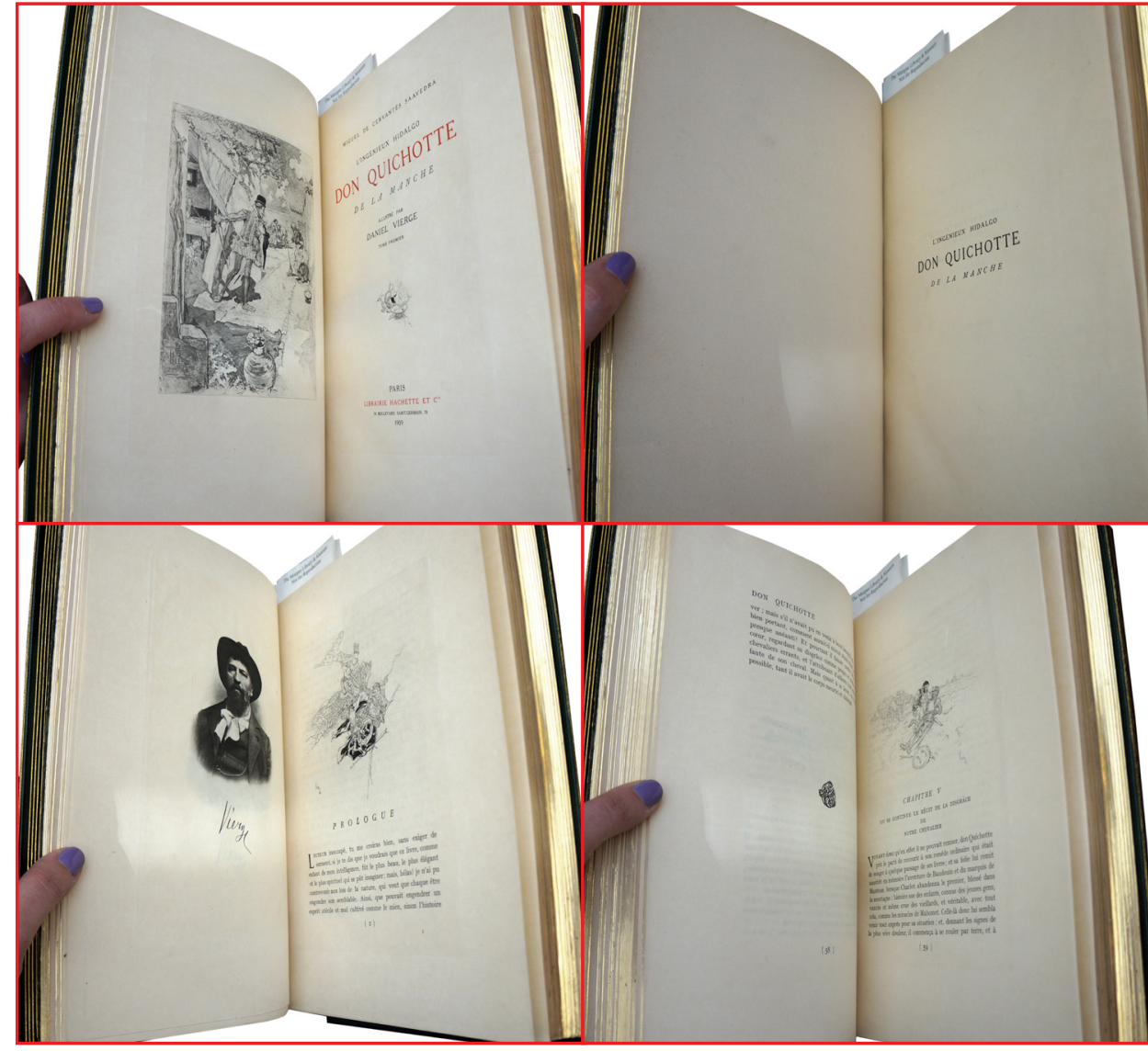

Figura 23. Dom Quixote (1605-1615), de Miguel de Cervantes (1547-1616). Impressa em 1909 pela Editora Hachette. Livro do acervo da Morgan Library. Fotos da autora.

Esta edição francesa, publicada pela editora Hachette (figura 23), em 1909, é muito mais limpa em ornamentos do que a anterior. As ilustrações são mais leves, talvez pelo processo de fotogravura. A obra, de 20 x $29 \mathrm{~cm}$, foi ilustrada por Daniel Vierge e é uma edição limitada de 350 cópias. Embora as ilustrações sejam leves e apresentem harmonia com os demais elementos do volume, a composição do texto em tipo de eixo racional apresenta problemas pois os espaços entre palavras são muito grandes, logo formam-se muitos buracos no meio do texto ${ }^{2}$ o que não resulta em uma mancha uniforme.

Já o exemplar, sem data, publicado em Madri pela editora Sáenz de Jubera (Figura 24), provavelmente entre o final do XIX e início do século XX, foi impresso em papel feito com fibra de madeira, bem fino, que amarela rapidamente e se torna quebradiço com o passar do tem-

O termo em inglês é "rivers of white". Em português, na tradução de Bringhurst (2005:34), o termo utilizado para denominar esses espaços irregulares indesejáveis no meio do texto é "espinha branca" ou "porcos-espinhos . Na tradução de Hochuli (2013:49), o termo usado é "caminhos de rato". 
po. $\mathrm{O}$ uso desse tipo de material pode ser considerado um exemplo da massificação pela industrialização do livro. É um livro ilustrado, "visível”, que chama a atenção como objeto, porém é mal feito. Os materiais utilizados são de péssima qualidade, falta coerência visual entre as ilustrações e os demais elementos gráficos do livro, a mancha de texto é extremamente larga e difícil de ler, especialmente por ter sido composta com um tipo pesado, de classe moderna, com pouco espaço interlinear. Este é apenas um exemplo de como os livros na época poderiam ser mal feitos. A partir desse caso, percebe-se que há uma predileção pela ornamentação e ilustração, porém os materiais e o design são ruins. Exemplos como esse justificam as críticas à industrialização, pois de nada adianta ter um objeto que não cumpre sua função: prejudica a leitura por ser mal projetado e se decompõe rapidamente devido à qualidade de seus materiais, especialmente o papel. ${ }^{3}$

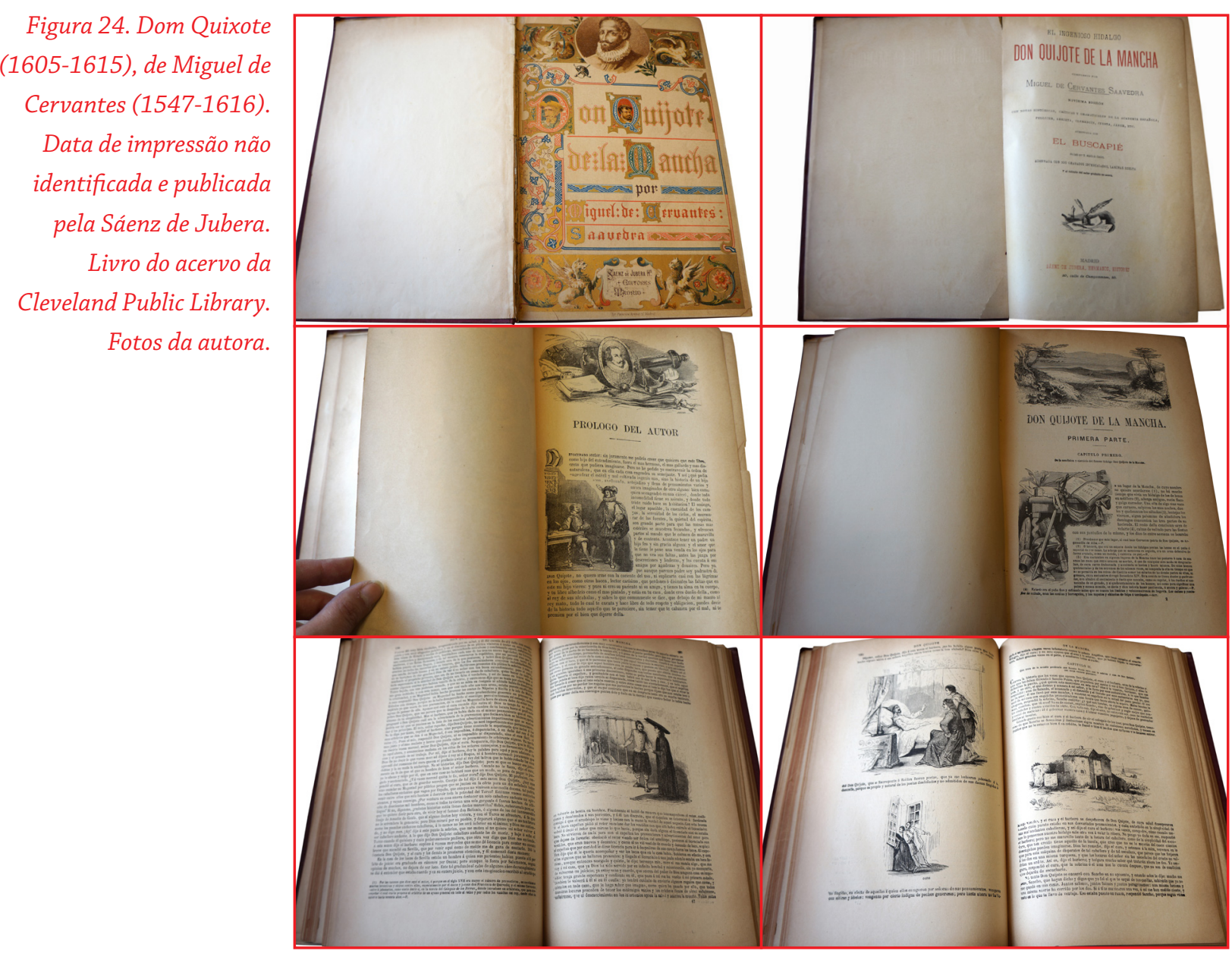

3 Ao manusear o volume em pesquisa de campo na Biblioteca de Cleveland, mesmo com cautela, as páginas se despedaçavam.
A partir desses exemplares de Decameron e Dom Quixote, nota-se que todos apresentam algum nível de "visibilidade", seja pelas ilustrações ou pelos elementos decorativos. Alguns são mais visíveis do que outros, claro, mas nesses casos os livros não são apenas suporte do texto, como são, em sua maioria, nossos livros de literatura hoje.

Como observado no capítulo anterior, o século XIX foi marcado por profundas transformações tecnológicas, que "massificaram" a produção de livros, tornando-os menos duradouros e bem feitos. Sem essa "massificação", porém, a leitura hoje não seria tão acessível. Este último exemplo de Dom Quixote reflete os pontos negativos da produção industrial, pela baixa qualidade de seus materiais e de seu design.

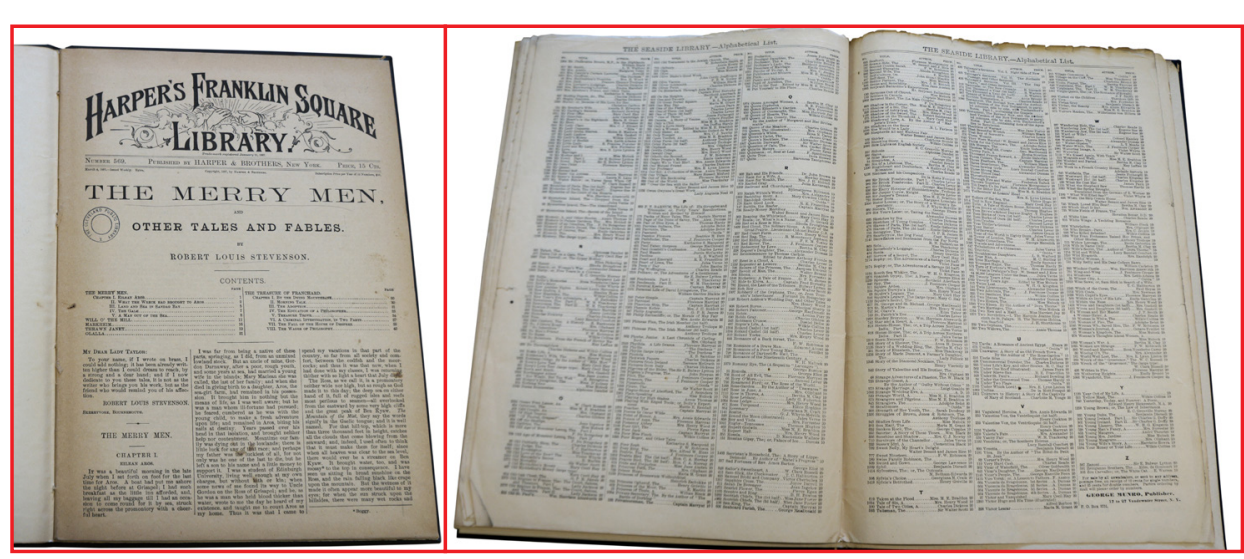

Figura 25. Folhetim Harper's Franklin Square resso em 1887. Acervo da Cleveland Public Library. Fotos da autora.

\section{A VISIBILIDADE NO FINAL DO SÉCULO XIX E INício do SÉculo XX}

Textos literários podiam também, no final do século XIX, ser publicados e lidos em folhetins, como este exemplo acima The Merry Man and other Tales and Fables (Figura 25), de Robert Louis Stevenson, de 1887. Esses textos eram mal compostos, com letras pequenas a ponto de ser difícil imaginar que o leitor que tivesse esses volumes em suas mãos tivesse prazer real em lê-los.

No entanto, generalizações são perigosas, McLean (1972), em Victorian Book Design and Colour Printing, apresenta uma série de designers e impressores produzindo livros de qualidade ao longo do século XIX, ao mesmo tempo foram criadas novas técnicas "baratas", como o uso de tecido para revestir as capas e a encadernação colada, em vez de costurada. 
E assim como também se tratou brevemente no capítulo anterior, a partir da proliferação de livros produzidos em massa e de baixa qualidade, William Morris e outros passaram a criticar os novos processos de produção industrial e resgatar a forma artesanal como alternativa para produzir livros de qualidade e duradouros. No capítulo anterior, entretanto, como o conteúdo era dedicado a tratar do livro simples, pouco foi apresentado sobre o resultado gráfico e os livros ricamente decorados de William Morris e de alguns outros integrantes do movimento da Imprensa Particular.

Nas próximas seções deste capítulo abordaremos a visibilidade no livro de literatura, desde o Movimento da Imprensa Particular até meados da década de 1930, em que a chamada "fina impressão"4 ganha espaço na Europa e, especialmente, nos Estados Unidos. Este é um período que parece bastante intelectualizado e elitizado, no qual diversos designers, além de produzir livros de qualidade com materiais nobres, escrevem sobre as boas práticas em diversos periódicos, como já se mencionou no capítulo anterior. Sobre a importância desses movimentos, John Kane (2012: 40) assinala:

O movimento para resgatar antigos modelos de tipos, liderado por T. J. Cobden Sanderson, Stanley Morison e Beatrice Warde, no Reino Unido, e por Daniel Berkeley Updike, Frederic W. Gougy, W. A. Dwiggins e Bruce Rogers, nos Estados Unidos, floresceu no inicio do século XX. O trabalho intelectual que fizeram apresentou a tipografia, pela primeira vez como um assunto que valia a pena ser estudado e procurou demonstrar o valor dos mais antigos.

A visibilidade, ou seja, livros ornamentados ou ilustrados, não eram apenas produzidos pelos profissionais, dos quais trataremos neste capítulo, mas também por editoras comerciais, porém usando materiais de qualidade inferior e com projetos gráficos mal feitos, como no exemplo da editora espanhola mostrado anteriormente. Procurou-se nesta tese dar maior ênfase aos livros da "fina impressão", muitas vezes edições limitadas, especialmente por serem mais fáceis de encontrar em

4 O termo utilizado em inglês é "fine printing". Optou-se por traduzir por "fina impressão". O termo era conhecido naquele contexto, não se refere apenas à boa impressão, mas à impressão feita em materiais e processos especiais e com design elaborado, dessa maneira outros termos como boa impressão não parecem dar conta da complexidade que envolve tanto a produção quanto a ideologia dessa abordagem. acervos de bibliotecas, pois como são obras raras e importantes foram bem conservadas. $\mathrm{O}$ acesso a edições populares antigas é difícil, pois talvez muitas delas podem ter se deteriorado. Não foi possível, por exemplo, encontrar edições de bolso da editora Penguin das décadas de 1930 e 1940, pois estas podem ter se desemembrado ou mesmo sido substituídas por edições mais recentes.

Muitos desses livros eram compostos à mão, impressos em papéis artesanais e acabamentos luxuosos. Entre o final do século XIX e as primeiras décadas do século $\mathrm{XX}$, além dos livros impressos à mão, sur giu uma vertente, muitas vezes ilustrada, em edições limitadas do "livro fino" de literatura, porém produzido mecanicamente, como idealizado pelo inglês Francis Meynell na década de 1920, cujo processo foi nitidamente criticado pelo impressor e tipógrafo Edwin Grabhorn (in HART, 1941: 74). Grabhorn (in HART, 1941: 65-78) explica que a fina impressão devia ser feita pelos processos manuais, pois são eles que tornavam os livros duradouros como a encadernação manual, o ajuste manual da pressão da tinta sobre o papel etc. Em ambos os casos, sendo produzidos pela máquina ou à mão, esses livros eram produzidos com esmero e design refinado.

Muitos dos livros de literatura apresentados possuem ilustrações em suas edições. Segundo Christopher Sandford (in: The Dolphin, n. 2, 1935: 83), muitos livros requerem ilustrações, enquanto outros, não. Em relação aos livros de literatura, ele acredita que podem ou não ser ilustrados e que isso depende dos "objetivos da publicação". No entanto, Sandford adverte que não são apenas as ilustrações que tornam os livros belos, mas que todos os elementos devem ser integrados, estar em harmonia.

Para Robert Josephy (in: The Dolphin, n. 2, 1935: 95), a ilustração do livro deve apresentar o tom e as ideias do livro e o trabalho do ilustrador deve ter um espírito e "feeling" em sintonia com o do autor.

Os exemplos que serão apresentados a seguir foram selecionados por sua importância histórica e/ou por seu vínculo ou sua coerência entre ilustração e outros elementos gráficos. 


\section{A Visibilidade No MOVimento da IMprensa Particular}

No capítulo anterior, introduzimos a importância do Movimento da Imprensa Particular para o desenvolvimento do livro impresso de qualidade na época, já que teve um papel crucial na crítica ao livro industrializado. Nesta seção buscaremos apresentar as abordagens e exemplos "visíveis" de algumas dessas prensas. Não se trata aqui de uma abordagem cronológica, mas de uma amostra de princípios e ideias sobre a visibilidade, a ornamentação e a ilustração no livro de literatura.

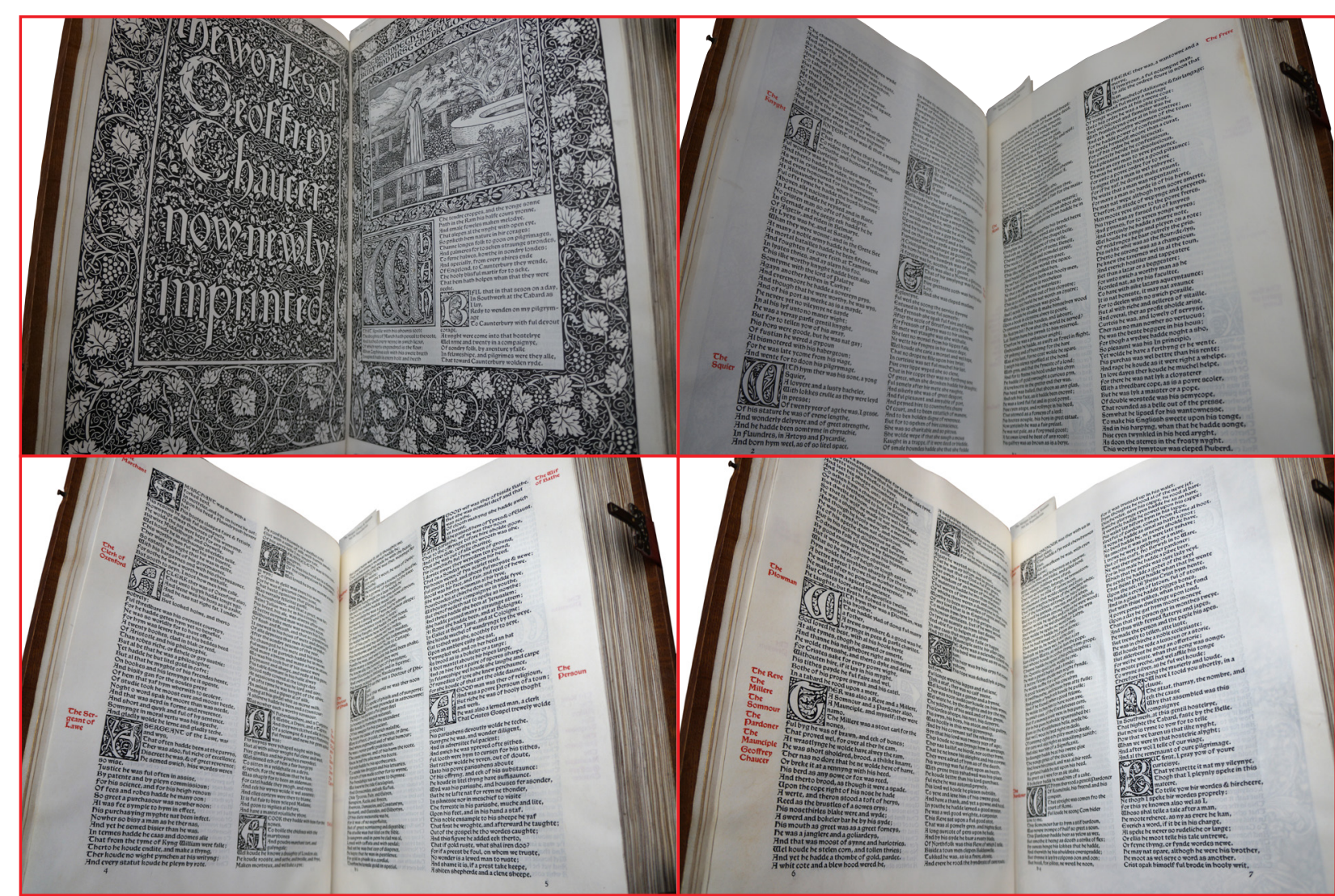

Figura 26. The Works of Esta obra de Chaucer (Figura 26) produzida por William Morris na Geoffrey Chaucer now Kelmscott Press em 1896 foi ilustrada por Edward Burne-Jones e teve newly imprinted. Impresso em 1896 por Williar

Morris. Acervo da Morgan

Library. Fotos da autora. 425 cópias produzidas em papel e 13 em velino; o exemplar acima é em velino. Pela reprodução não é possível apreciar a beleza do exemplar e o brilho da tinta impressa no liso, brilhante e alcalino velino. A edição em fólio mede $44 \mathrm{~cm}$ de altura e o tipo composto é de inspiração medieval, criado por William Morris, chamado Chaucer ${ }^{5}$. É um livro difícil de ler, pela densidade da mancha de texto composta nessa tipografia gótica, além de ser um volume muito grande para o manuseio de suas páginas que requer uma leitura sobre uma mesa. Trata-se de uma obra para ser mais contemplada (como arte) do que lida (como obra literária), o que contradiz os objetivos de Morris ao fundar a Kelmscott Press, em $1891^{6}$. Nas suas palavras:

Eu comecei a imprimir livros com o objetivo de produzir alguns deles que pudessem ser realmente qualificados como belos, enquanto ao mesmo tempo fossem fáceis de ler e não deveriam ofuscar a vista ou atrapafui um fui um grande admirador da caligrafia da Idade Média e da impressão anterior que tomou seu lugar. (MORRIS in MCLEAN, 1995: 3)

É possivel que Morris estivesse observando os exemplos medievais do ponto de vista daquele tempo, em que os leitores estavam acostumados a determinado tipo de letra, portanto a facilidade da leitura também deve ser pensava em relação ao seu tempo. Mas os tipos como os que ele usou em Chaucer são incontestavelmente mais difíceis de ler do que tipos romanos.

No mesmo texto, Morris apresenta um resumo de seus ideais de composição, que, com exceção do uso da entrelinha (ele defende que ela seja evitada), não parece muito distante da apresentada por muitos outros autores, como Morison ou mesmo Tschichold, como se pode observar abaixo.

Morris explica que a face da letra deve ser bem próxima ao corpo do tipo, para evitar espaços em branco entre palavras ${ }^{7}$, além de advertir para que os espaços entre palavras também não sejam maiores do que o necessário para "dividir as palavras". Segundo ele, esses espaços devem, sempre que possível, ser sempre iguais. Morris afirma ainda que "Impressores modernos, mesmo os melhores, prestam pouca atenção a esses dois elementos essenciais". Ele critica os famosos e feios "rivers

5 Morris produziu outro tipo com inspiração medieval chamado Troy e outro inspirado no modelo veneziano de Nicolas Jenson chamado Golden

6 No texto Aims in Founding the Kelmscott Press.

7 A parte em relevo da letra (face) deveria ser rente ao tipo de metal para que não ocorressem espaços extras. 
of white" (caminhos de rato), que incorrem em composições mal feitas. Outro ponto observado por Morris em sua doutrina de composição é que deve se evitar o uso de muita entrelinha ${ }^{8}$. A última das diretrizes que apresenta relaciona-se às margens, em que a margem interna deve ser a menor, a do topo em sequência maior, a externa maior ainda e a inferior, a maior de todas. Ele conclui que "os impressores modernos sistematicamente as transgridem, dessa forma contradizendo o fato de que a unidade do livro não é uma página, mas um par de páginas." (MORRIS in MCLEAN, 1995: 5)

Seus ideais sobre o espacejamento correto entre letras e entre palavras e do livro como um objeto que deve ter unidade parecem realmente ter influenciado uma grande geração de designers e, para muitos, esses princípios ainda são válidos.

No mesmo texto, Morris justificou que pretendia criar livros belos e legíveis e defendeu sua predileção pela ornamentação de seus livros:

Era natural que eu, um decorador de profissão, devesse tentar ornamentar meus livros adequadamente; sobre essa questão só vou dizer que sempre tentei manter em mente a necessidade de fazer a minha decoração uma parte da página impressa. Posso acrescentar que, no projeto das magníficas e inimitáveis xilogravuras que decoram vários dos meus livros e, acima de tudo, adornam o Chaucer que agora se aproxima da conclusão, meu amigo Sir Edward Burne-Jones nunca perdeu de vista esse ponto importante, de modo que esse trabalho não só nos apresenta uma série das mais belas e imaginativas ilustrações, mas cria mais harmoniosa in MCLEAN, 1995: 5-6)

Nessa passagem, Morris adverte que pretende tornar a decoração parte da página, ou seja, em harmonia com os demais elementos e do objeto como um todo.

8 Morris buscava blocos de texto mais pesados e densos, mas, como já foi abordado no capítulo anterior, entrelinhas são necessárias para se evitar uma "duplicação" de linhas durante a leitura.

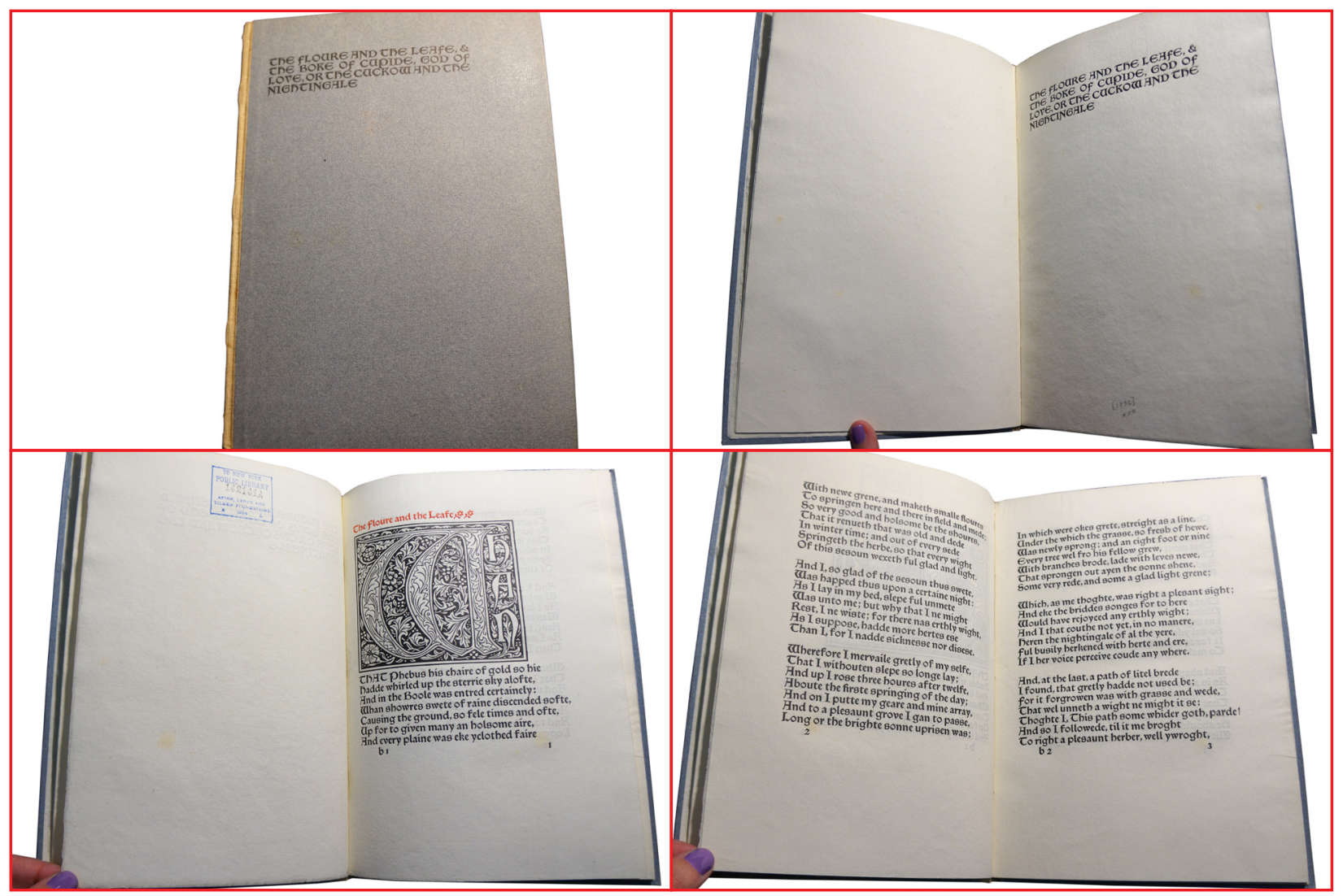

Nem todos os livros de Morris apresentam-se de forma tão decorada Figura 27. Capa e páginas como o Chaucer, citado acima. Há exemplos como The Floure and the de The Floure and the Leafe Leafe \& The Boke of Cupide, God of Love, or the Cuckow and the Nightin- \& The Boke of Cupide, God gale, impresso em 1896, of Love; Or, The Cuckow páginas de abertura dos dois poemas: The Floure and the Leafe e The Geoffrey Chaucer (1343Boke of Cupide, God of Love, or the Cuckow and the Nightingale. Além das 1400). Impresso em 1896. capitulares nas aberturas, as páginas não apresentam ornamento, são Acervo da New York Public páginas de texto simples, compostas com o tipo Troy, também neome- Library. Fotos da autora. dieval, e alinhadas à esquerda. O volume é mais compacto, medindo aproximadamente $16 \times 23 \mathrm{~cm}$.

Após mostrar as abordagens visíveis de Morris, vamos tratar de outras prensas particulares.

\section{Eragny Press}

Segundo Lommen (2012: 282), o casal Lucien e Esther Pissarro foi dos primeiros seguidores de Morris e fundaram a Eragny Press em 1894. Os livros da Eragny Press apresentam influência Art Nouveau e, segundo Lommen (2012: 282), Pissaro se tornou grande amigo do ar- 
Figura 28. Histoire de Peau d'Ane (1694), de Charles Perrault (16281703). Impressa em 1902. Acervo da New York Public Library. Fotos
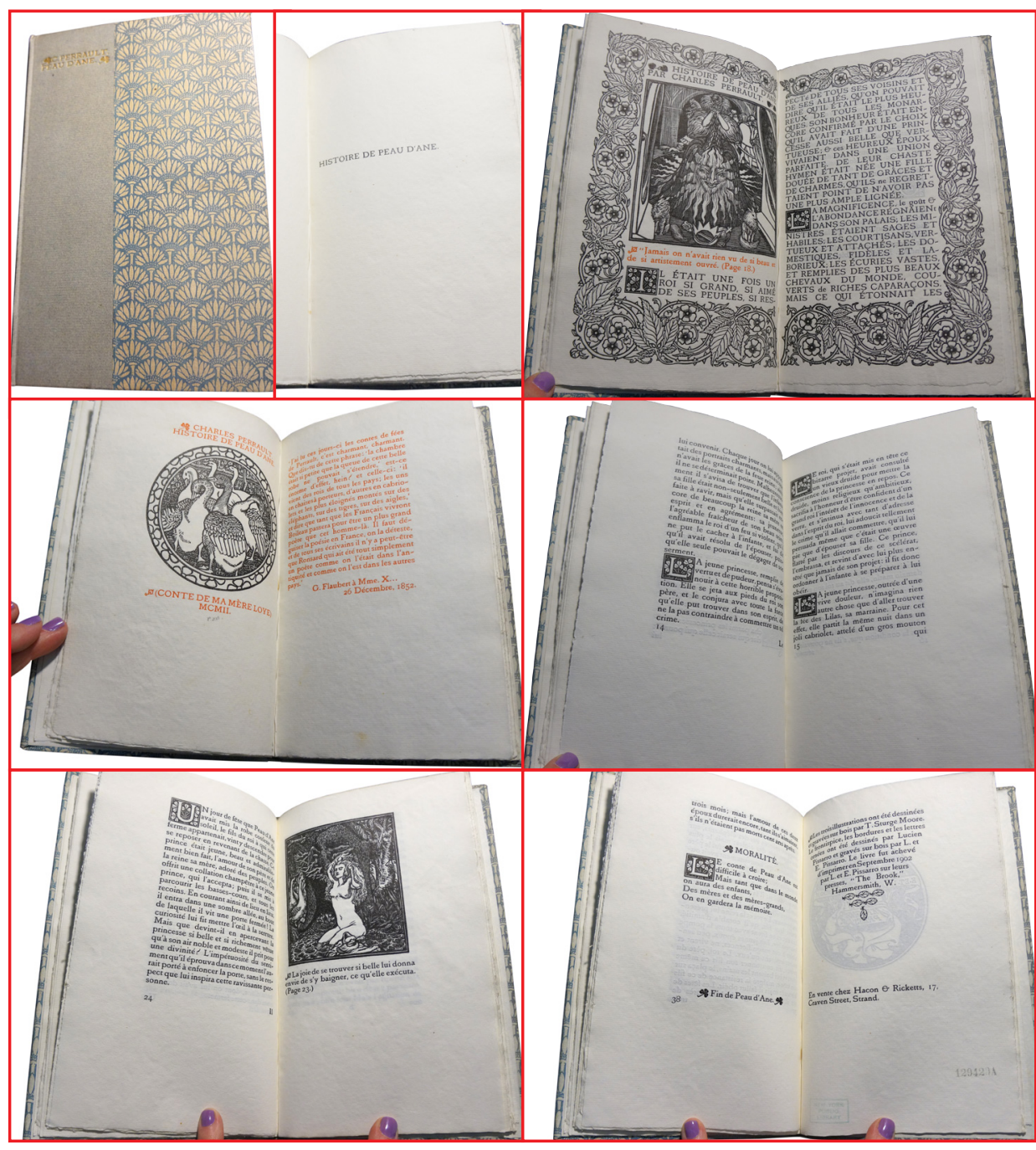

tista Charles Ricketts, que trabalhava nesse estilo e que logo depois também fundou sua própria casa publicadora, chamada Vale Press.

Histoire de Peau d'Ane (figura 28), de Charles Perrault, foi impressa em Londres pela Eragny Press em 1902 e ilustrada por Lucien Pissarro. O livro de dimensões $13 \times 20,5 \mathrm{~cm}$, impresso em papel artesanal, possui amplas margens e o texto é composto em corpo 14, com entrelinha aproximada de 16 pontos. Apresenta capitulares e símbolos como marcadores de parágrafo em vez de recuos, mas a página mais pesada e ornamentada é a de abertura. Os tipos são largos e arredondados e não ovais e parecem combinar com os demais elementos pictóricos do volume, pois seus desenhos têm uma clara influência Art Nouveau. A tiragem da obra foi de 230 cópias. ${ }^{9}$

Disponivel em: https://www.vialibri.net/552display_i/year_1902_0_347953.htm acesso em janeiro de 2016
Un cour simple (figura 29), de Gustave Flaubert, impresso em 1901 é um pouco mais compacto que os anteriores $(10 \times 14,5 \mathrm{~cm})$, também apresenta margens generosas e o tipo do texto parece o mesmo utilizado nos demais volumes impressos por Pissarro. As páginas internas são também mais limpas que a dos demais volumes, com uma ou outra capitular, mas em geral a mancha é simples só com texto e numeração de página (fólio).

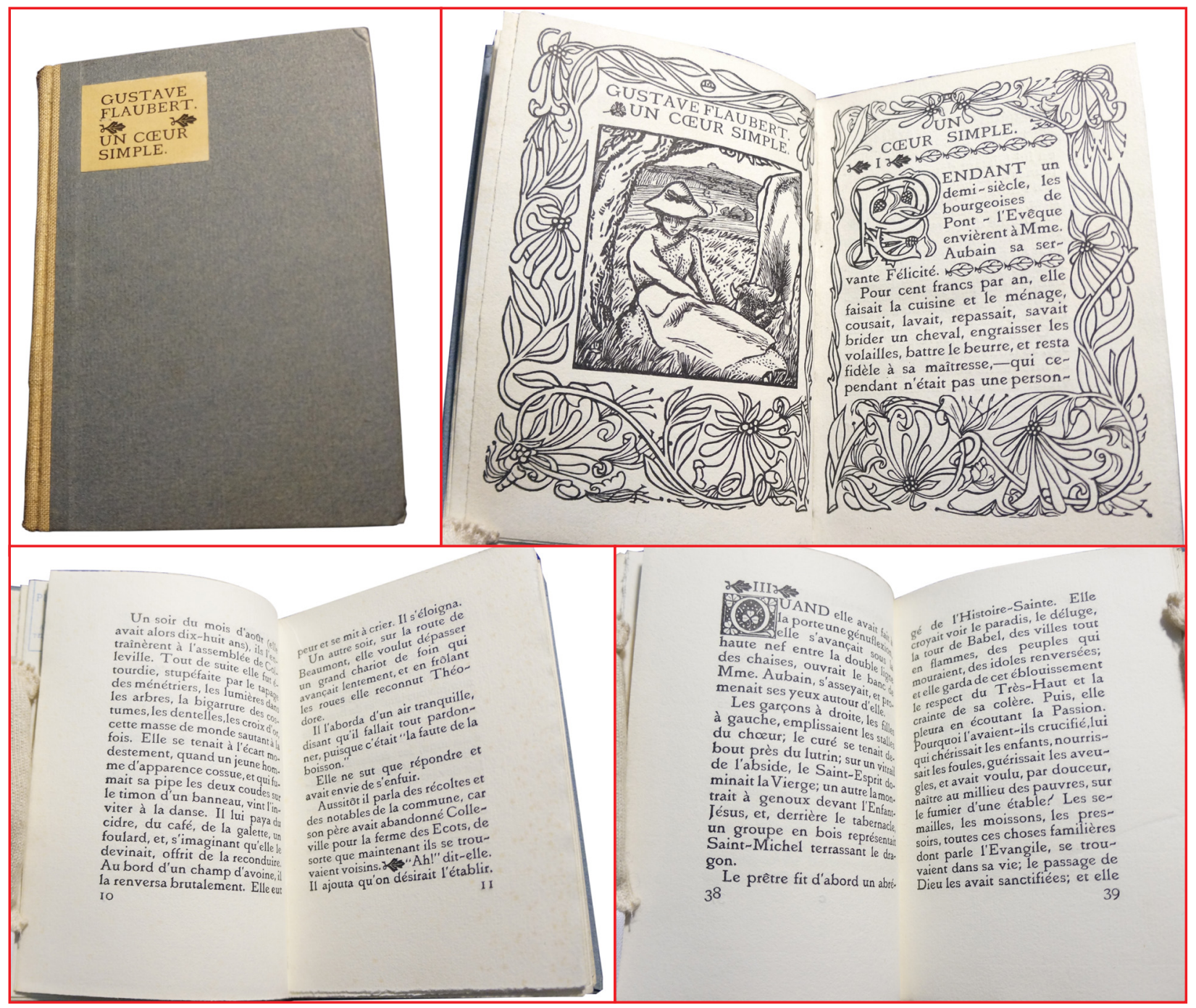

Figura 29. Capa e páginas de Un coeur simple (1877), de Gustave

Flaubert (1821-1880). Impresso em 1901 pela Eragny Press. Acervo da New York Public Library. Fotos da autora. 


\section{Golden Cockerel Press}

Salambo (figura 30), de Gustave Flaubert (1821-1880), foi publicado pela The Golden Cockerel Press em 1931. Foram produzidas 500 cópias e o volume foi impresso por Robert e Moira Gibbings, com texto composto por F. Young e A. H. Gibbs. O tipo usado é da classe garalde. O volume apresenta ilustrações em preto nas aberturas de capítulo, fólio centralizado próximo à mancha sem marcação de parágrafo (recuo), lombada redonda com um material que parece couro. Segundo Blumenthal (1975: 11), a Golden Cockerel Press, sob a direção de Robert Gibbings, "imprimiu um grande número de lindos livros". Blumenthal acrescenta ainda as diversas parcerias que essa casa impressora teve com o eminente tipógrafo Eric Gill (1882-1940).

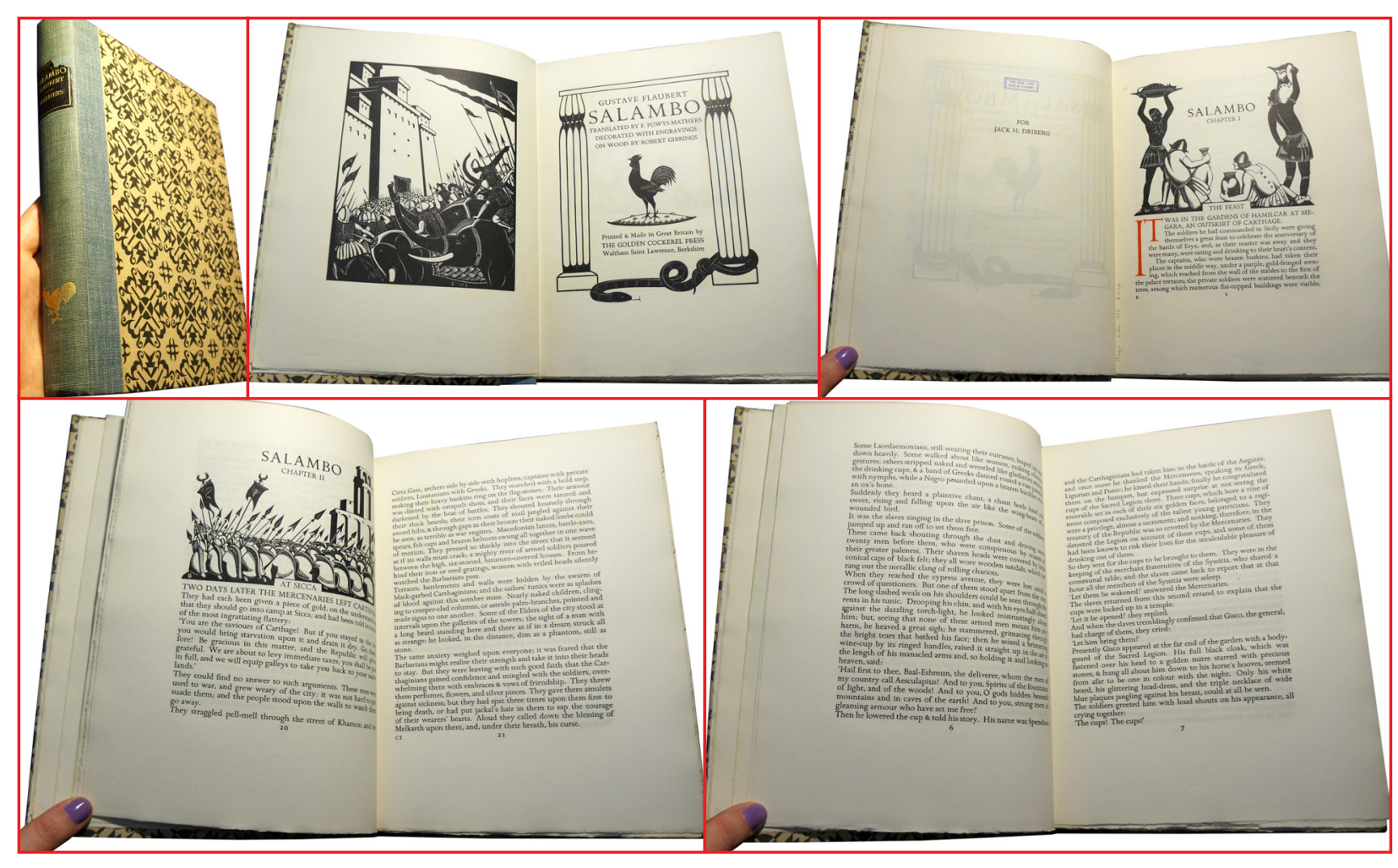

Figura 30. Capa e páginas de Salambo (1862), de Gustave Flaubert (1821-1880). Impresso em 1931 pela The Golden Cockerel Press.

Acervo da New York Public Library. Fotos da autora.

\section{Nonesuch Pres}

O inglês Francis Meynell criou em 1923 a Nonesuch Press e produziu belos livros ilustrados, na mesma tendência de outros impressores e designers dedicados à fina impressão, mas utilizando as novas tecnologias da época.

Segundo McLean (1958: 49), Meynell tinha o objetivo de publicar livros finos, porém produzidos por métodos modernos. McLean afirma ainda que a política de Meynell não era a de se restringir a usar seu próprio equipamento, mas de produzir seus livros nas oficinas que tivessem disponíveis os melhores materiais para seus objetivos. "Os resultados deram à Grã-Bretanha uma ideia completamente nova do papel que o design do livro pode ter no prazer da literatura".

Blumenthal (1982: 11) explica que Meynell era de uma família de editores e literatos. Meynell, ainda de acordo com Blumenthal, projetava os livros e os imprimia "sob sua próxima supervisão" em diversas oficinas, especialmente a partir do uso de máquinas de composição Segundo Blumenthal, Meynell imprimiu também nas prensas das Universidades de Oxford e Cambridge.

Steinberg (1979: 320) salienta a importância e o sucesso da Nonesuch Press em utilizar processos mecânicos para produzir seus livros:

Fundada em 1923, a Nonesuch Press, de Francis Meynell, mostrou a compatibilidade do cuidado que as prensas particulares concediam à edição e à produção com o sucesso comercial do qual as empresas comerciais dependiam. Foi a primeira editora a utilizar máquinas para a impressão dos chamados livros finos, e, assim, superou o preconceito sem instrução da escola dos amantes dos livros "feitos à mão".

Meynell, em artigo publicado no periódico The Monotype Recorder intitulado A Printer Considers a Book, explica que, em sua visão de editor, os livros devem ter três características: legibility (legibilidade), readability (leiturabilidade) e aesthetics (estética). (MEYNELL, 1933: 9)

Sobre as qualidades estéticas do livro, Meynel trata sobretudo das ilustrações e dos ornamentos, que não podem ser meros enfeites vazios:

Acredito que o decorador de um livro, seja ele impressor ou ilustrador-artista, tem de tratar seu trabalho como se fosse um anotador - um editor. nificado do autor: ele não deve, como um editor pretensioso, escrever notas tão longas que o texto 
fique obscurecido por suas intervenções; ele não deve, como um tradutor ineficaz, deformar os valores do autor. Mas, se ele pode ver o ponto de vista do autor, e até mesmo ir um pouco além dele; se ele pode, por sua seleção e distribuição do tipo, lançar luz e ainda ocultar sua lâmpada; se ele pode suspender seu pano de boca e agrupar os atores - suas letras - como o invisível produtor-chefe de uma peça, de modo que o significado dramático seja mais claro graças a seus efeitos: se ele pode ser magnífico e humilde, evocativo e silencioso ao mesmo tempo, então ele está produzindo o belo ao mesmo tempo em que está transmitindo-o. (MEYNELL, 1933: 11)

Meynell (1933: 11) critica a vertente funcionalista, pois segundo ele há aspectos essenciais que vão além da máxima "fitness for purpose", que corresponde "a forma segue a função", já que existem outros aspectos relativos ao design do livro, como os estéticos, que podem ser prazerosos ao leitor.

O designer também apresenta sua justificativa sobre o uso de técnicas modernas para a produção de seus livros. Ele considera que as ideias de que livros, para serem belos e importantes, devem ser apenas produzidos à mão não fazem sentido, porque desde o início da impressão já havia tentativas de produzir livros de forma mais industrial.

Alguns ainda insistem em pensar o trabalho manual como algo fundamentalmente "diferente". É essencialmente a mesma coisa. E um grande livro - grande do ponto de vista do impressor - pode ser produzido de forma mais fácil e barata pelos elaborados mecanismos dos nossos dias

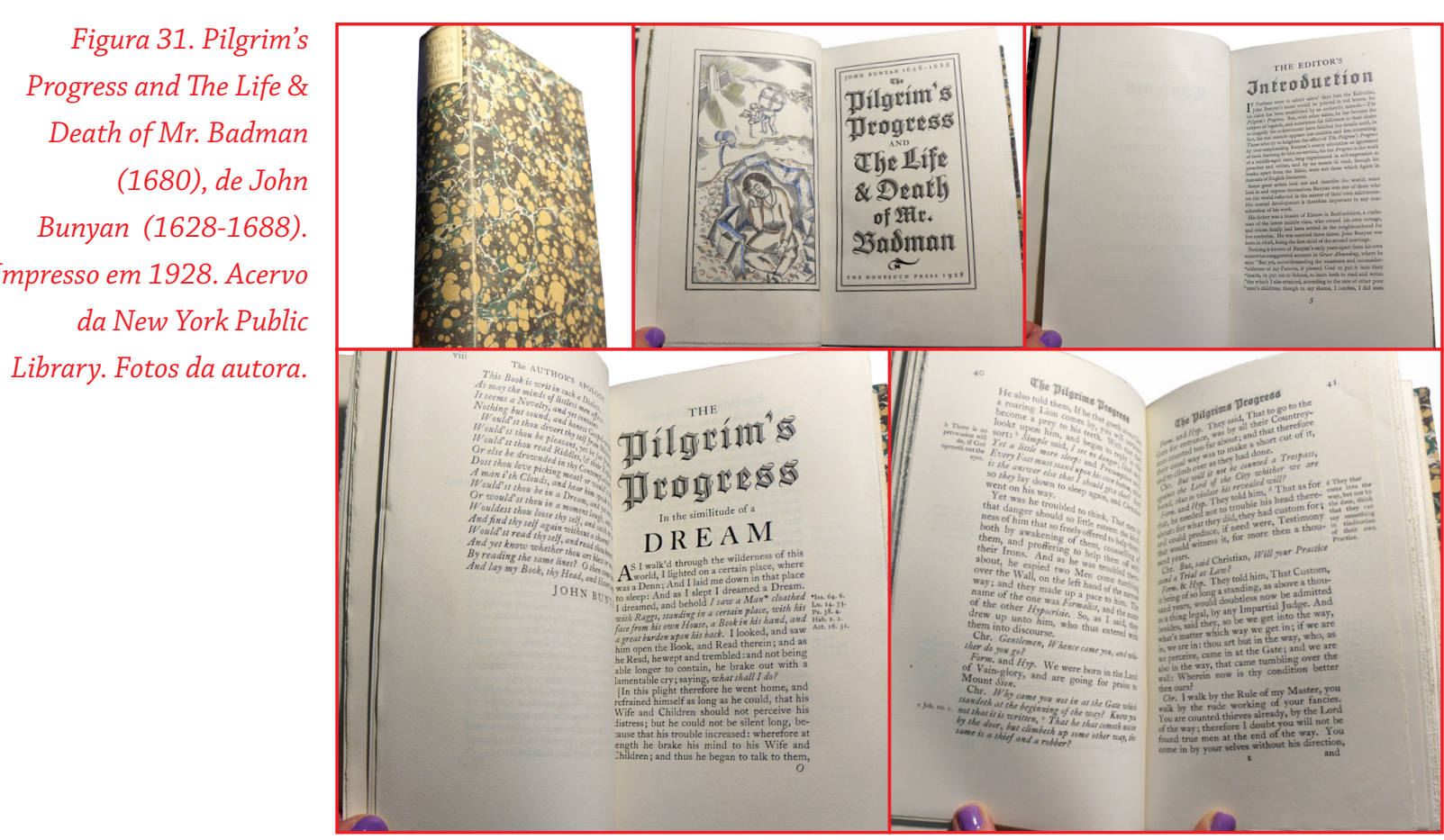

do que pelos mecanismos de ontem, menos eficientes. Nenhum impres sor do passado tinha materiais tão ricos para trabalhar como agora. (...) Quantos tipos Aldus teve? Nem meia dúzia. E Morris? Três. Nossos papéis, nossas tintas, nosso trabalho de impressão são todos mais ricos n mesma proporção. E o mesmo é válido para nossa tradição, nossa experiência. "Toda História", disse um sábio, "é história contemporânea". Nós organizamos o passado - e que passado rico! A impressão "nasceu perfeita" porque começou como a laboriosa falsificação de algo muito bonito e tradicional, o livro manuscrito: seu presente era todo o passado do calígrafo. (MEYNELL, 1933: 12-13)

The Pilgrim's Progress and The Life \& Death of Mr. Badman ${ }^{10}$ (figura 31), de John Bunyan, projetado por Francis Meynell, produzido pela Nonesuch Press e impresso pela Kynoch Press em 1928, teve tiragem de 1600 cópias, com 600 delas destinadas à venda nos Estados Unidos. O volume tem $21 \mathrm{~cm}$ de altura e foi composto com tipo Caslon em corpo 10, entrelinha 12 e em papel Arches. A tipografia gótica usada na página de rosto chama Deutsche Zierschrift. As ilustrações são xilogravuras colorizadas pela técnica de estêncil pela Curwen Press ${ }^{11}$.

Don Quixote de La Mancha (figura 32), publicado em Londres por Francis Meynell pela Nonesuch Press apresenta dimensões de 14,5 x $23 \mathrm{~cm}$ e foi impresso no papel artesanal Casinensis. Esta edição é composta por dois volumes com 21 litografias do proeminente ilustrador E. McNight Kauffer. Foram produzidos 1475 exemplares, 574 dos quais destinados para a venda nos Estados Unidos pela Random

10 Segundo Lyons (2011: 118), “O progresso do peregrino, um romance alegórico de John Bunyan (1628-1688) foi o texto mais conhecido de todas as religiões protestantes. Para s protestantes não conformistas só perdia em importância para a Bíblia. Publicado pela século XVII No déculo XIX, em 1678 e 1684, pertencia à tradição dissidente radical do e africano. Ele conquistou o mundo antes de "retornar" ̀̀ Inglaterra no fim do século XIX e ser tardiamente incorporado ao cânone literário inglês. $O$ progresso do peregrino conta a história das tribulações de seu herói, Cristão, que luta contra a tentação, a desesperança e outros perigos. Ele se livra do pesado fardo do pecado e, finalmente, chega à cidade celestial, onde se une a Deus. A teologia da alegoria era compreensivel e facilmente ilustrada. O livro funcionava como uma espécie de substituto da Bília e era uma útil ferramenta pedagógica cristã, particularmente no encorajamento à conversão; os missionários muitas vezes o encadernavam com partes da Bíblia. Alguns africanos, portanto, consideravam o livro como um fetiche do homem branco, dotado de poderes mágicos: nos anos 1830, por exemplo, os madagascarenses queriam ter uma cópia, mesmo sendo incapazes de lê-lo."

11 Outra importante Imprensa Particular em que trabalhou o proeminente tipógrafo Oliver Simon (um dos fundadores e editores do periódico The Fleuron) 
House. A mancha de texto foi composta em corpo 10 com entrelinha 12 de pontos, porém o tipo é mais contrastado e denso do que o usado em The Pilgrim's Progress. Os volumes foram impressos por Walter Lewis na prensa da Universidade de Cambridge.

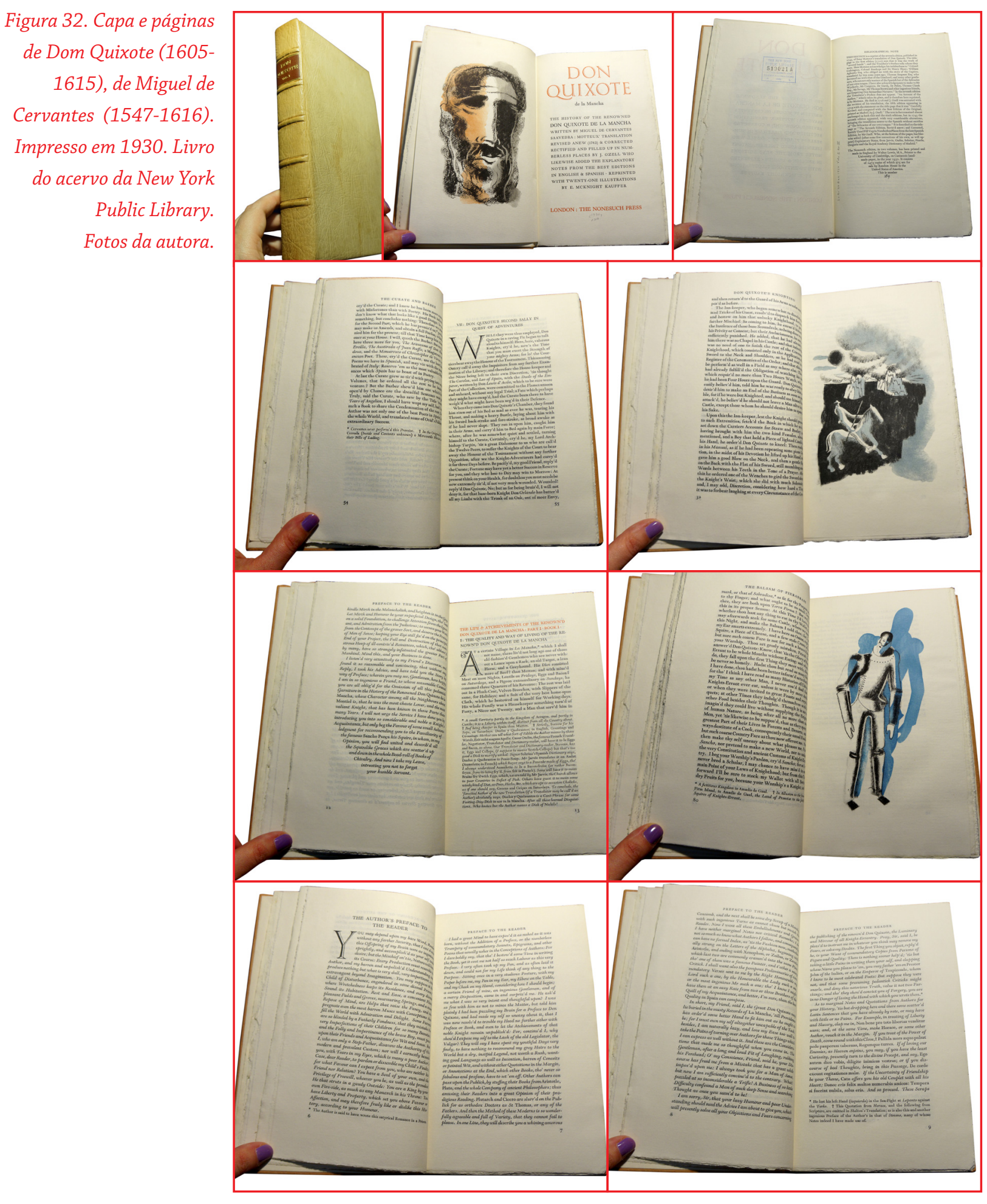

Benito Cereno (figura 33), de Herman Melville, lançado em 1926 pela Nonesuch Press, também foi ilustrado por E. McKnight Kauffer e colorido por processo de estêncil pela Curwen Press. O volume, de 32 $\mathrm{cm}$ de altura, foi impresso em papel artesanal Van Gelder e composto com Walbaum, um tipo moderno e contrastado, porém já que o tipo é mais pesado se utilizou uma entrelinha maior. Foram produzidos 1650 exemplares para venda na Inglaterra e nos Estados Unidos.

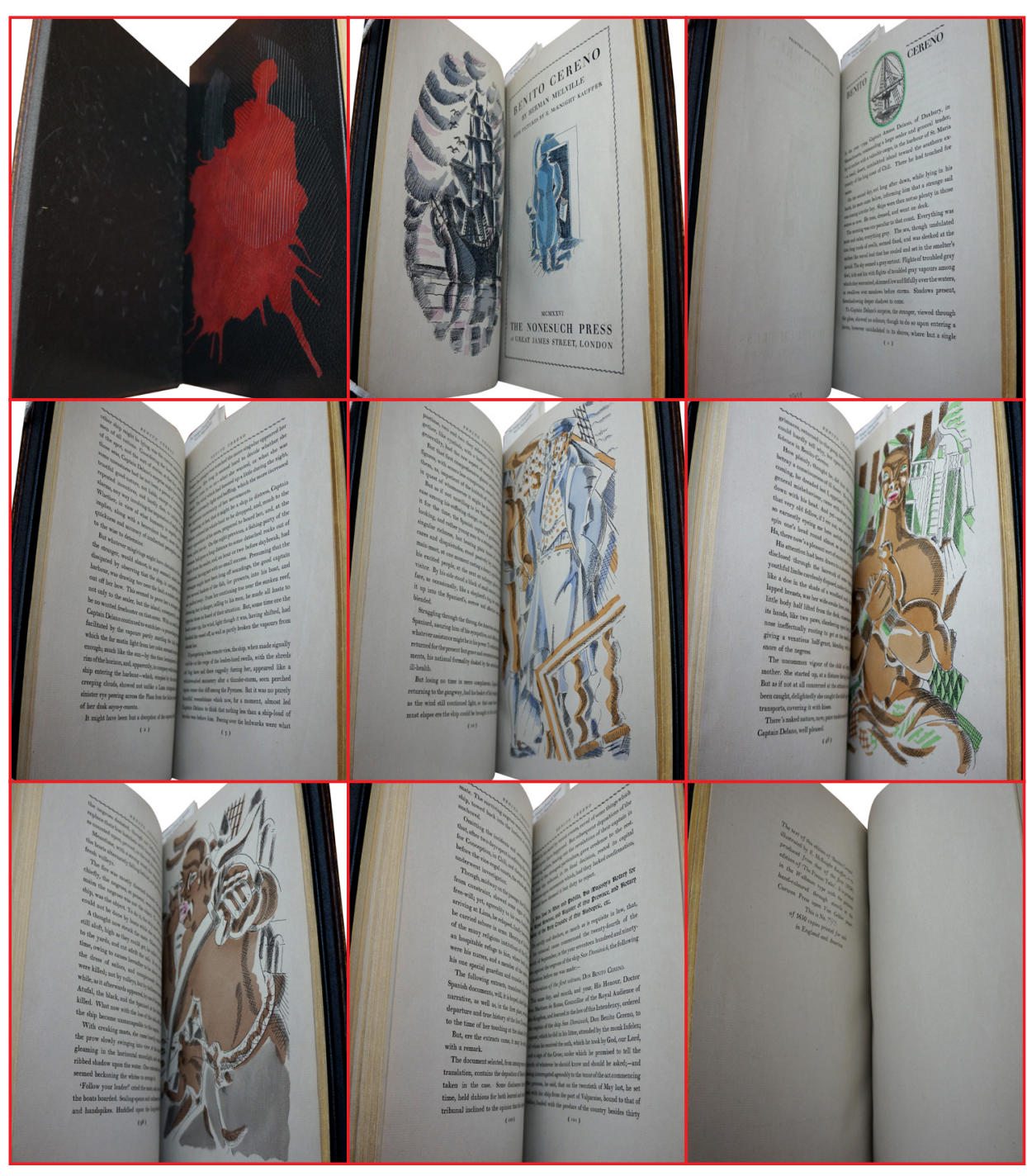

Figura 33. Benito Cereno (1855), de Herman Melville (1819 -1891) publicado em 1926 pela Nonesuch Press. Livro do acervo da Morgan Library. Fotos da autora. 


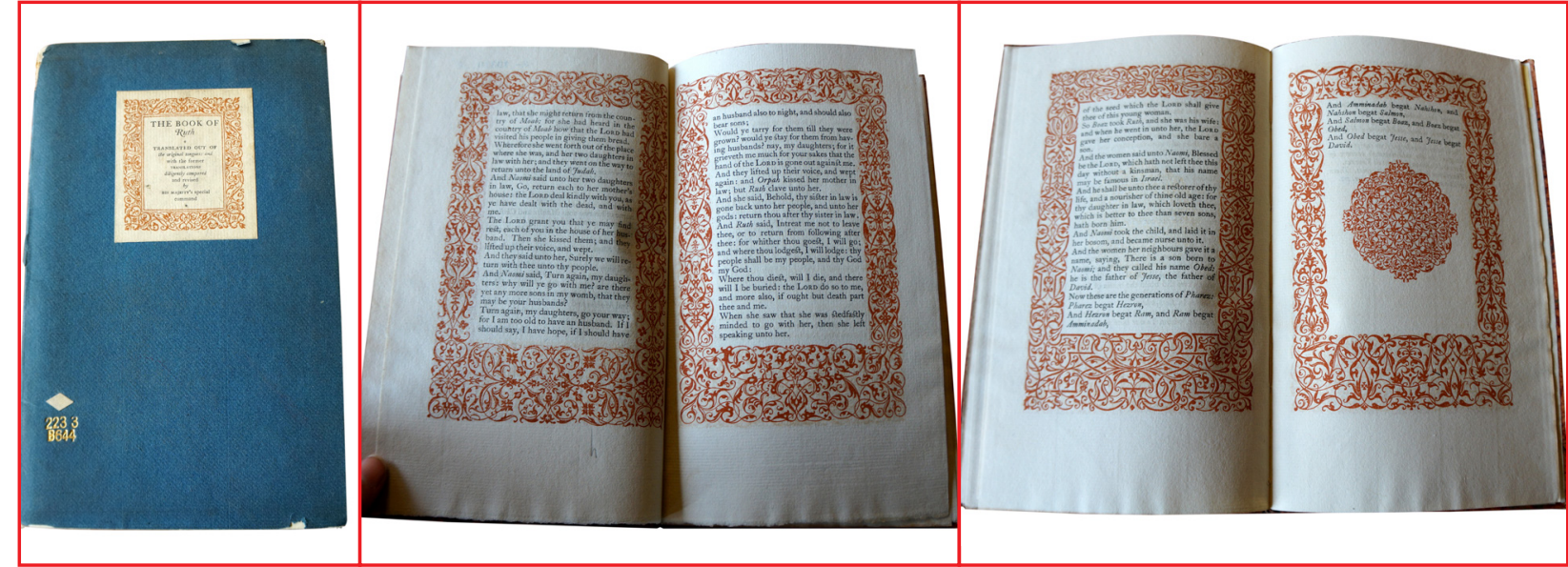

Figura 34. The Book of Ruth, impresso em 1923 pela Nonesuch Press. Livr

Este exemplo (figura 34), embora não seja de uma obra literária, é uma edição com costura simples, sem capa dura e impresso em 1923 pela Nonesuch Press com tiragem de 250 exemplares $^{12}$, composta com Public Library. um tipo modificado a partir do desenho de Caslon. Esta edição de The Fotos da autora. Book of Ruth foi citada por Beatrice Warde (in BEAUJON, 1932) em seu artigo Epitaph upon "period" printing como um exemplo de design datado. Nesse artigo, Warde, sob pseudônimo de Paul Beaujon, critica o design 'alusivo', sob o termo de "period" printing, ou seja, a "imitação" ou alusão de estilos históricos.

\section{Livros ilustrados na França}

Segundo Morison e Day (1963: 64), a França influenciou a "fina impressão" em outros países por seus belíssimos livros ilustrados. São citados como referência o trabalho dos impressores Edouard Pelletan, Leon Pichon e Ambroise Vollard.

Como exemplo da modalidade da impressão "fina" na França, apresentaremos uma obra de Pelletan.

Lewis (1967: 37) explica que Pelletan se preocupava tanto com a ilustração quanto com a tipografia, o que diferia das Édition de Luxe, nas quais a maior preocupação era com a ilustração. Ainda de acordo com Lewis, Pelletan "exigiu um alto padrão de seus impressores, era um tipógrafo exigente e fez bom uso das fontes de Jannon e Grandjean ${ }^{13}$.

12 Disponível em: http://www.abebooks.co.uk/BOOK-RUTH-Nonesuch-PressLondon/15289471199/bd; acesso em outub

13 Tipógrafos franceses dos séculos XVII e XVIII respectivamente.
Este exemplar de O misantropo (figura 35), publicado em 1907 por Édouard Pelletan possui 29 x 18,5 cm e é ilustrado. O texto do diálogo é composto em itálico e o nome dos personagens aparece em tipos romanos maiúsculos, impressos em cor. Nesta edição, as ilustrações e demais elementos gráficos parecem integrados, ou seja, há uma coerência formal entre ilustrações e leiaute.

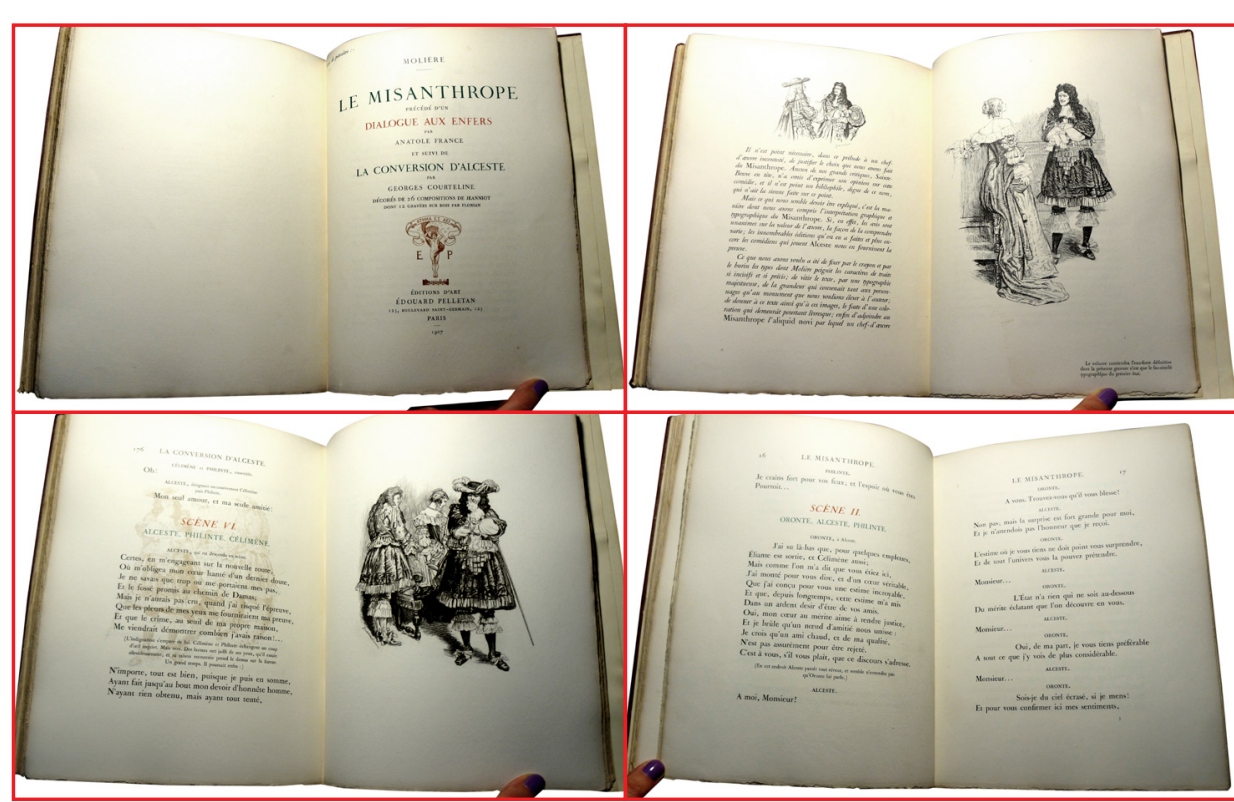

Figura 35. Le misanthrope (1666), de Molière (1622 1673), publicado em 1907 por Édouard Pelletan. Acervo da New York Public Library. Fotos da autora.

\section{A FINA IMPRESSÃO NOS ESTADOS UNIDOS}

O movimento da prensa particular teve um grande impacto nos Estados Unidos, muitos impressores e tipógrafos passaram a questionar os meios de produção dos livros em massa e a propor alternativas. Especialmente após a Primeira Guerra, sobretudo na década de 1920, havia diversas casas especializadas na produção de livros "finos", especiais e limitados, muitos produzidos a partir da tradição dos livros artesanais. Essa abordagem é conhecida por 'fine printing' (fina impressão). Alguns dos designers conhecidos por propagar e trabalhar com essa abordagem nos Estados Unidos são Daniel Berkeley Updike, Bruce Rogers, William Addison Dwiggins, Rudolph Ruzicka, Frederic Goudy, John Henry Nash, Edwin e Robert Grabhorn, T. M Cleland, Frederic Warde, Carl Purrington Rollins e Elmer Adler. 
No livro The Beauty and the Book, Megan L. Benton (2000: 33-34) escreve sobre esses livros "especiais" e suas implicações no país. Segundo a autora, a "fina impressão" surgiu como uma espécie de "sacerdócio", que renovaria a produção de livros seguindo os mais altos padrões de design e impressão.

Nesse período, foram produzidos diversos livros de literatura "visíveis", desenvolvidos por importantes designers. Nesta seção apresentaremos alguns desses livros e seus designers.

\section{Bruce Rogers}

Um dos mais importantes tipógrafos/designers do período foi Bruce Rogers, que desenvolveu centenas de projetos para diversos impressores e editores. Rogers começou trabalhando na Riverside Press e depois tornou-se freelancer (BLUMENTHAL, 1989: 66). Rogers passou algumas temporadas na Inglaterra, trabalhando com Emery Walker e na Oxford University Press. Para Blumenthal (1989: 63), "A genialidade de Bruce Rogers foi duplamente percebida em sua clara habilidade de cruzar a fronteira dos métodos artesanais para os industriais. A grandeza dele reside em suas brilhantes manipulações de tipos e ornamentos". Rogers foi também, segundo Wilson (1993: 22), um dos primeiros designers americanos a criar leiautes (esboços) dos projetos de seus livros. Dessa forma, infere-se que a prática do planejamento esquemático do desenho prévio da página não era tão comum até o trabalho deste profissional. Em nossa pesquisa de campo, no acervo da biblioteca do Grolier Club foram encontrados alguns leiautes originais de Rogers (figura 36).

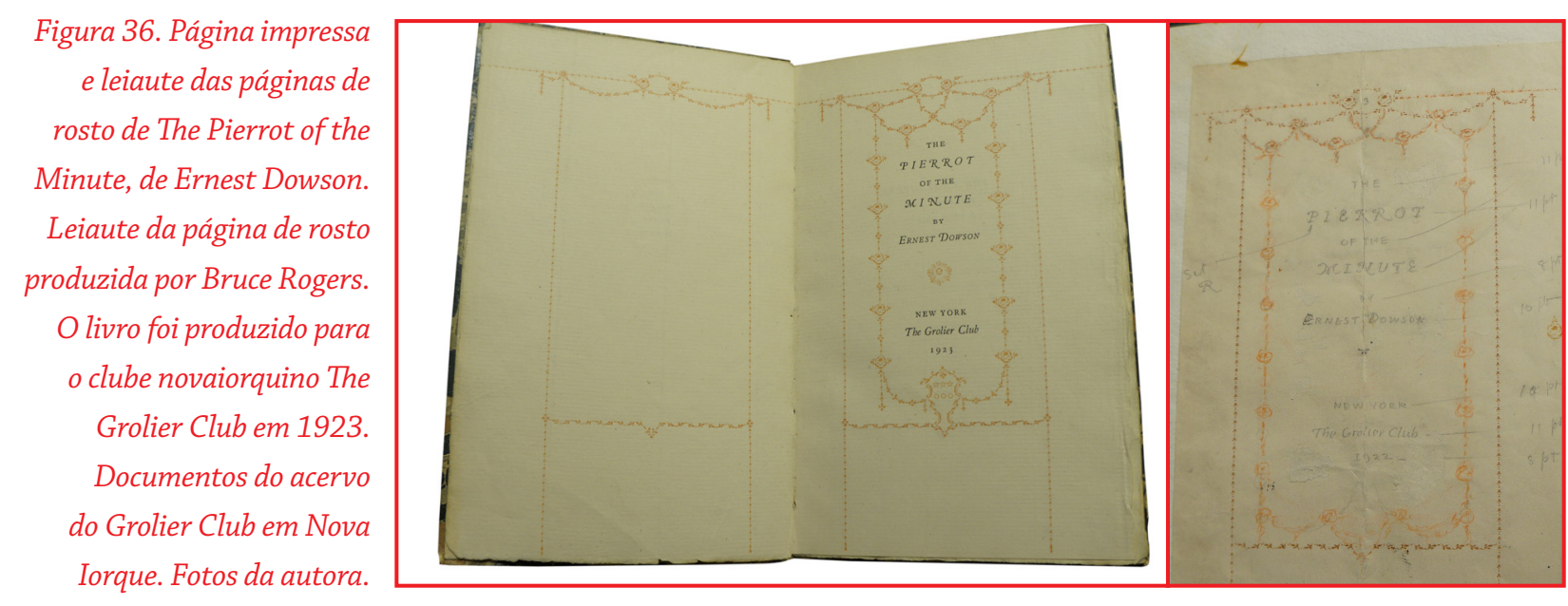

Em 1943, Bruce Rogers (1979) publica a primeira edição de Paragraphs on Printing, em que escreve sobre suas ideias de como produzir livros de qualidade e explica o processo de alguns dos livros que ele próprio projetou. Na introdução, Rogers (1979: 2) adverte que, em sua época, a profissão de designer era relativamente nova, o que nos faz entender o anseio de diversos tipógrafos e designers de divulgar princípios para bons projetos.

Para Rogers, os livros vão além de sua forma material. O texto que o livro comporta é importante, deve ser apresentado de forma clara, "sem distrações de composições ousadas, tipos estranhos ou decoração sem sentido". (ROGERS, 1979: 6)

Rogers apresenta, na afirmação acima, um ideal parecido com o de Warde e Morison, porém seus livros eram ricamente decorados. No entanto, ele acredita que esses atributos não devem atrapalhar a leitura. O designer entende que, desde o início da impressão,

Os livros eram feitos primeiramente para serem lidos e, nos séculos subsequentes, o mesmo propósito era aplicado a quase todos eles. No entanto, existiam em todos os períodos da impressão livros produzidos de forma deliberadamente bizarra. (ROGERS, 1979: 6)

Rogers (1979: 10) adverte que o problema com os designers jovens e aspirantes é que "muitos deles acabam se entusiasmando muito pelos seus próprios trabalhos", o que indica que ele se preocupava que os designers tornassem-se autorais demais, que é o que acontece quando o profissional claramente impõe seu estilo ao design de um livro. No entanto, Rogers, segundo Benton (2000: 107-109), era um designer autoral.

Os livros de Rogers eram quase sempre decorados e, para ele, "clássicos de literatura, belas letras, etc., são os que mais combinam com embelezamentos tipográficos, mas eles também são frequentemente melhores quando simples". (ROGERS, 1979: 10-14) 


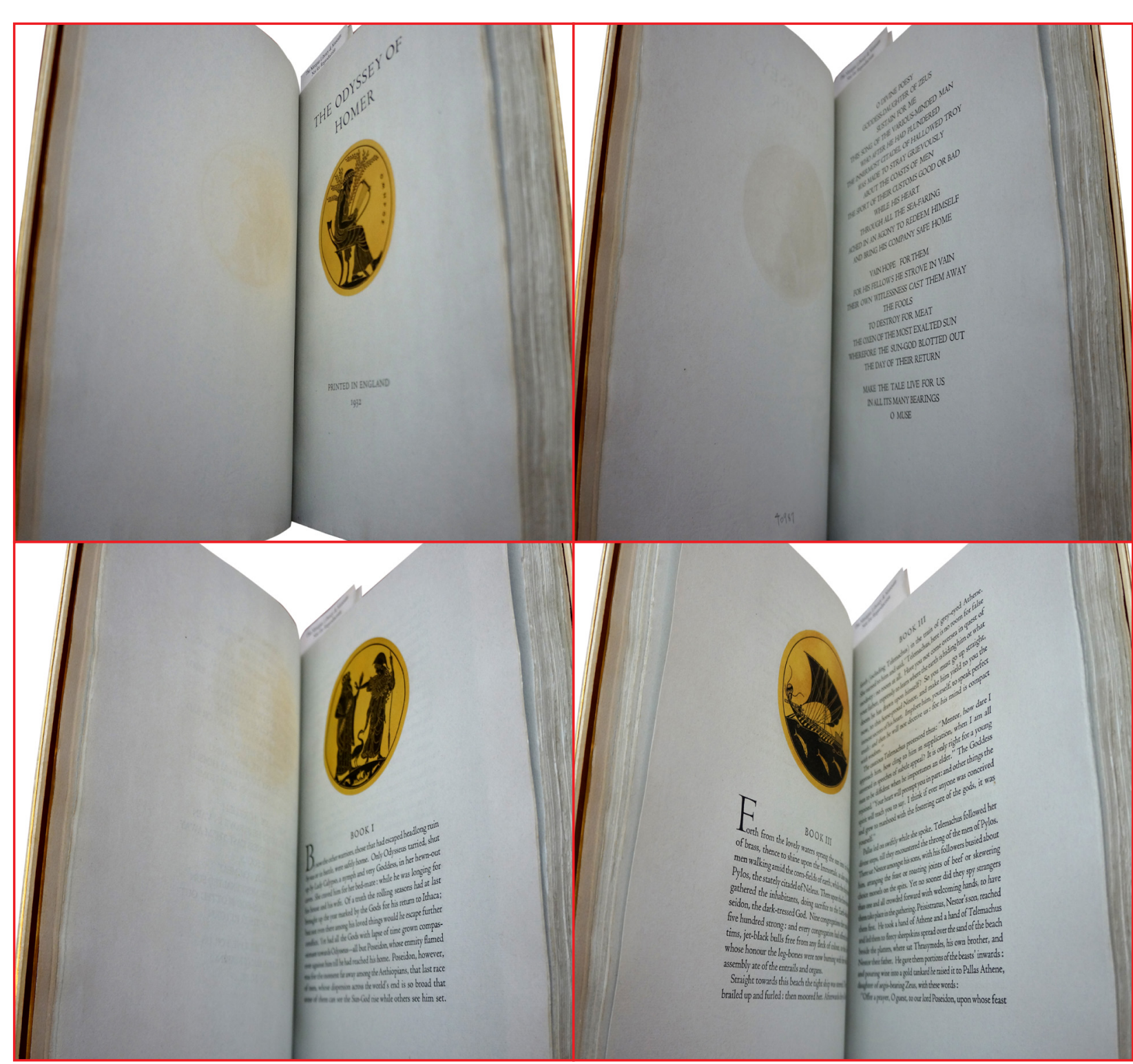

Figura 37. Odisseia, de Homero (928 a.C-898 a.C), impressa na Oxford University, 1932. Liwro do acervo da Morgan Library.

Fotos da autora.

Esta é uma edição limitada e luxuosa de apenas 530 exemplares de A Odisseia, com design de Bruce Rogers e impressa por Emery Walker e Wilfred Merton e possui ilustrações impressas em preto dispostas dentro de círculos impressos em dourado. As páginas de texto são simples, impressas com tipo com eixo humanista com margens e entrelinhas generosas, o que torna a mancha leve e bem legível. O pape utilizado é fino e flexível.
William Addison Dwiggins

Outro designer de extrema importância do período é William Addisson Dwiggins que, segundo Blumenthal (1987: 90),

era uma pessoa altamente literata e respeitava a dinâmica da linguagem. Sua manipulação do texto era, portanto, clara e conservadora. Mas ele acreditava que os livros pudessem ser decorados. Sua ornamentação geralmente consistia em abstrações de padrões florais, construídas a partir de moldes ${ }^{14}$ de celulóide cortados. (BLUMENTHAL, 1987: 90)

Além de designer de livros, Dwiggins teve um importante papel como designer de tipos e criou alguns dos mais utilizados para composição de livros, como Electra, Caledônia e Eldorado, além de outros tipos bastante utilizados, como Metro ${ }^{15}$. Todas essas fontes foram projetadas para a empresa Linotype.

McLean (1958: 81-82) observa que Dwiggins trabalhou bastante com design de livros comerciais, especialmente para o editor Alfred A. Knopf, para o qual projetou livros individuais e séries, inclusive, a partir de 1929, trabalhou com a coleção de bolso Borzoi. Dwiggins era, portanto, um designer versátil, que tanto trabalhou desenvolvendo projetos especiais quanto comerciais e destinados a um público amplo.

A edição limitada (Figura 38) de Strange Case of Dr. Jekyll and Mr. Hide (romance mais conhecido no Brasil como $O$ médico e o monstro), foi publicada pela Random House, com ilustrações e design de William Addison Dwiggins e impressa pela Pynson Printers. O volume de $14 \mathrm{x}$ $20,5 \mathrm{~cm}$ apresenta mancha de texto composta com tipo de classe garalde com pouco contraste, corpo 12 e entrelinha de 14 pontos e margens generosas. O papel utilizado é texturizado tipo vergê, de gramatura aproximada de $90 \mathrm{~g} / \mathrm{m}^{2}$. As ilustrações foram impressas com tinta preta sobre papel colorido. A capa dura apresenta o título abreviado em baixo relevo (sem tinta) e na lombada é aplicado hot stamping dourado com as informações textuais. Por se tratar de uma edição limitada, todos os volumes foram assinados pelo designer.

O livro de contos de Edgar Allan Poe (figura 39), ilustrado por Dwiggins e impresso por William A. Kittredge na Lakeside Press, em Chicago, possui $18,5 \times 12,5 \mathrm{~cm}$. Foram produzidos apenas mil exemplares.

14 Stencil: Molde vazado.

15 Um tipo sem serifa. 


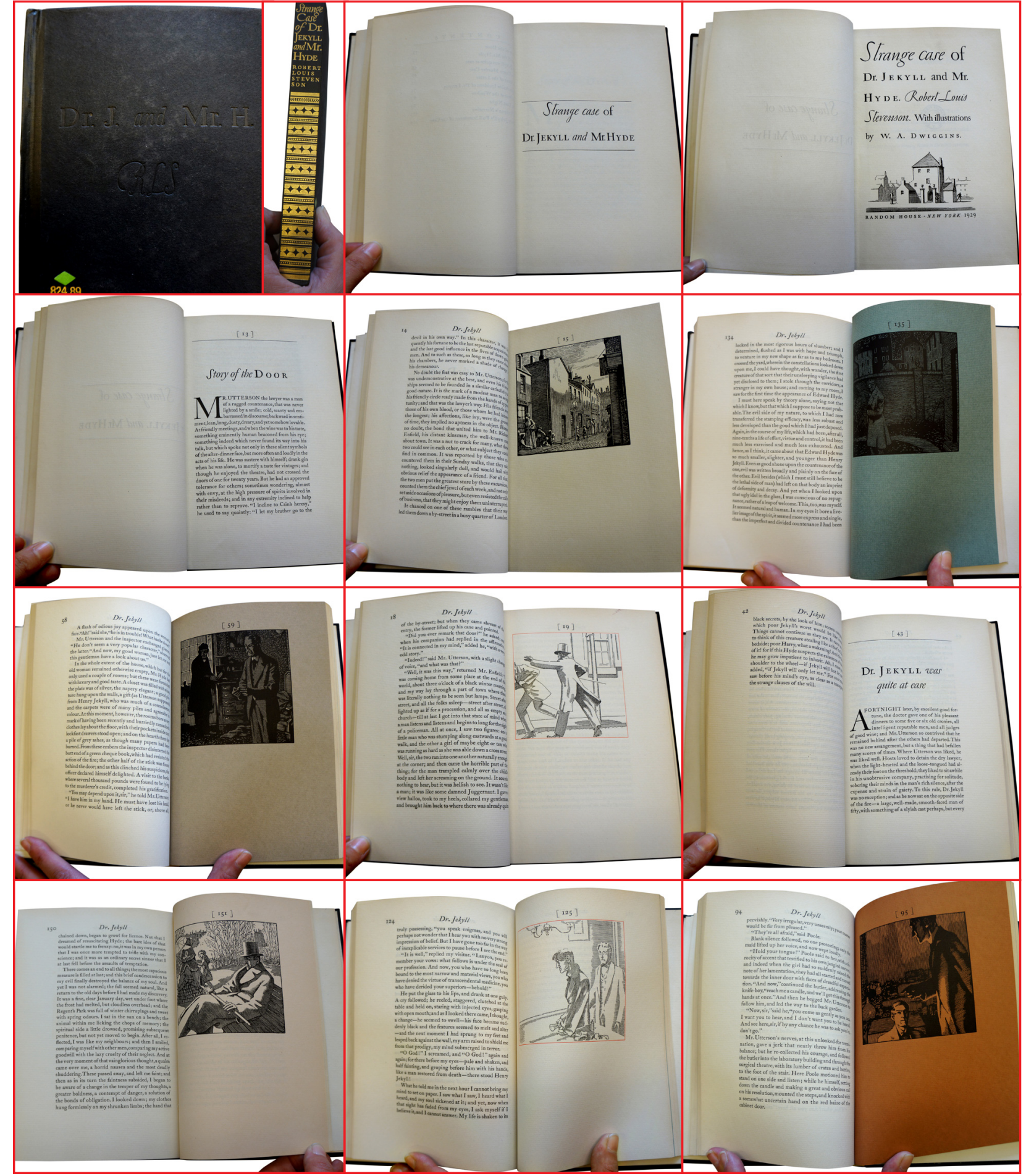

Figura 38. Capa e páginas de Strange Case of Dr. Jekyll and Mr. Hide (1886), de Robert Louis Stevenson (1850-1894) publicada em 1929 pela Random House. Acervo da Cleveland Public Library. Fotos da autora.
Dwiggins trabalhou com dois estilos de ilustração, para as aberturas de capítulo e para as ilustrações internas. As ilustrações das aberturas de capítulo remetem aos experimentos decorativos de Dwiggins baseados em formas geométricas. O texto é composto com um tipo de eixo Figura 39. Contos, de racional, legível. As margens são satisfatórias, mas não tão generosas, $\begin{aligned} & \text { Edgar Allan Poe (1809- } \\ & 1849) \text {. Publicado pela }\end{aligned}$

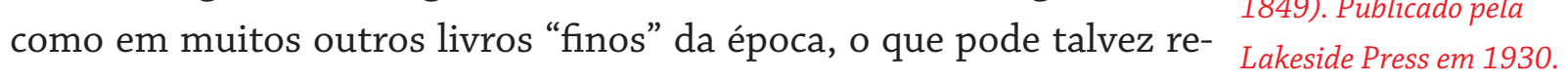
fletir o interesse funcional de Dwiggins e de seu repertório como de- Acervo da Cleveland Public signer também de livros comerciais.

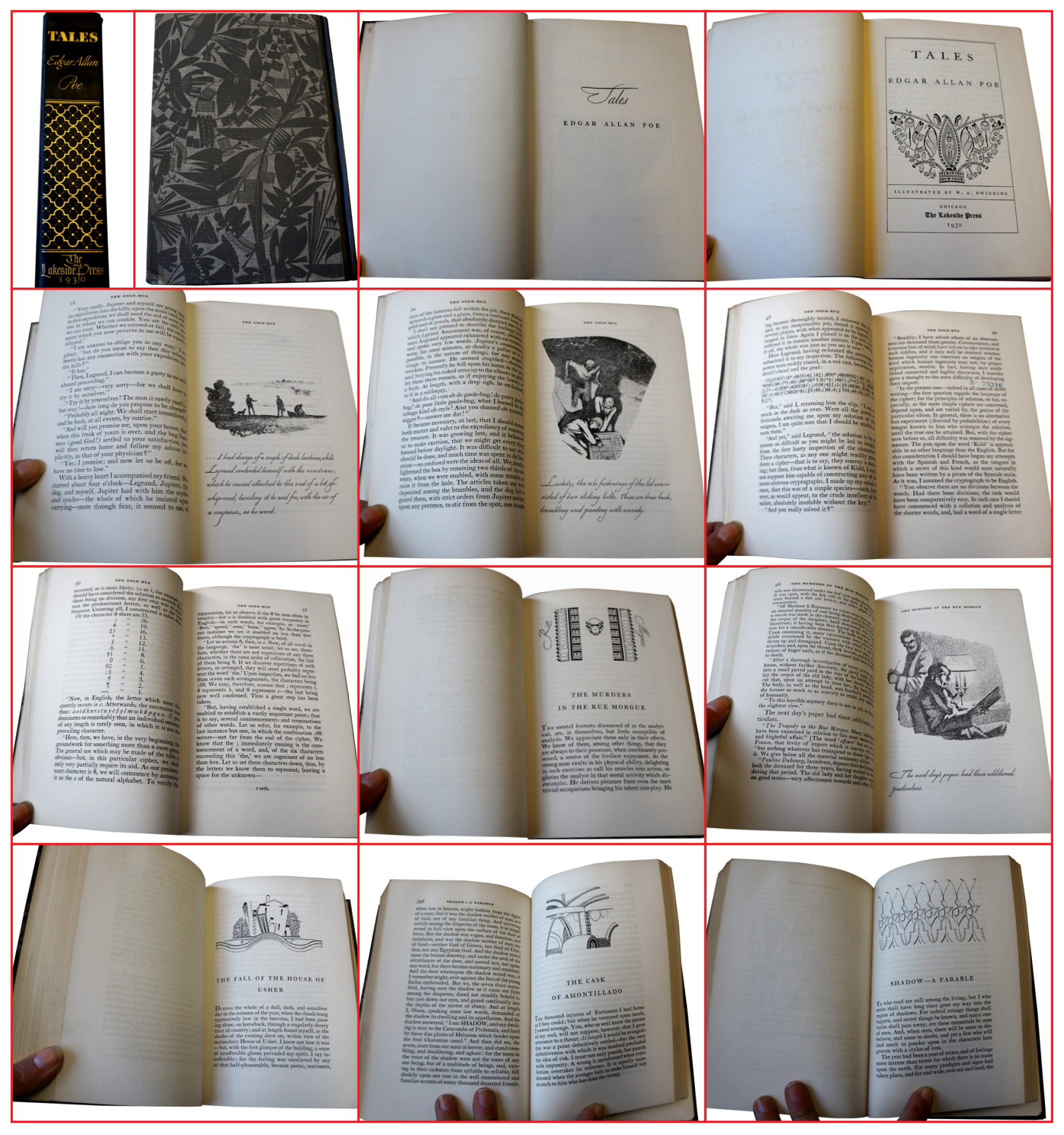




\section{The Limited Editions ChuB}

Um dos mais importantes difusores e produtores da fina impressão foi o americano George Macy que, em 1929, lançou The Limited Editions Club (Clube de Edições Limitadas) um clube de livros para assinantes, em que eram impressos, produzidos e ilustrados pelos mais importantes profissionais do período clássicos da literatura mundial. Macy lançava mensalmente um livro, a um custo anual de 120 dólares para cada assinante, ou 10 dólares por volume.

Ao criar o Clube de Edições Limitadas, Macy procurou seduzir os futuros associados argumentando que os textos seriam compostos à mão ("printed from type only"), impressos em papéis artesanais importados e que as ilustrações seriam gravuras originais ${ }^{16}$, seja xilogravura, gravura em metal ou litografia. (BENTON, 2000: 63-64)

Benton (2000: 126) acrescenta ainda que o projeto editorial de George Macy era lançar apenas obras clássicas e consagradas, de autores como Chaucer, Shakespeare, Edgar Allan Poe e Robert Louis Stevenson, não obras inéditas.

Segundo Chappel and Bringhurst (1999: 251), a empreitada de George Macy conseguiu florescer, mesmo com a Depressão, por ter um calendário definido de quantos livros produziria: 12 títulos ao ano com tiragem de 1.500 exemplares cada um.

Joseph Blumenthal (1989: 135) reitera a qualidade dos livros de Macy, que editava clássicos "ilustrados por famosos artistas, como Picasso e Matisse, projetados pelos mais talentosos tipógrafos e produzidos pelos melhores impressores da Europa e da América". Blumenthal também apresenta outra empreitada de Macy, a Heritage Press, que produzia quase sempre os mesmos livros, porém sem tiragens limitadas, com materiais menos nobres e preços mais acessíveis.

Os livros produzidos para The Limited Editions Club apresentam grande variedade de abordagens, já que cada obra era desenvolvida por equipes diferentes, porém todos os exemplos encontrados nesta pesquisa de doutorado demonstram grande comprometimento do livro como objeto, como algo para ser lido, mas também visto e colecionado.

\footnotetext{
16 Gravuras cujo bloco (matriz) era impresso junto ao texto, ou seja, não eram reproduções de gravuras já impressas.
}

A edição de The Life and Strange Surprising Adventures of Robinson Crusoe, of York, Mariner (figura 40), de Daniel Defoe, publicada pela The Limited Editions Club em 1930, foi projetada pela californiana Grabhorn Press. O volume de 27 x 17,5 cm foi ilustrado por Edward A. Wilson e composto em um tipo humanista. A página de rosto e aberturas de capítulo apresentam vinhetas, texto em tipo gótico (blackletter) e algumas capitulares manuscritas. As margens são genero- Figura 40. Robinson Crusoe sas e o texto foi composto em corpo e entrelinha de 12/18 pontos, o (1719), de Daniel Defoe que tornou a página bastante arejada. Há alguns destaques no meio $\begin{aligned} & \text { (1660-1731). Publicada } \\ & \text { pelo The Limited Editions }\end{aligned}$ do texto com palavras impressas em tipos góticos. É curiosa a posi- Club em 1930. Acervo da ção do fólio composto também em tipos góticos junto às margens Cleveland Public Library. internas. Além dos fólios, foram utilizados tipos góticos nos subtí- Fotos da autora.

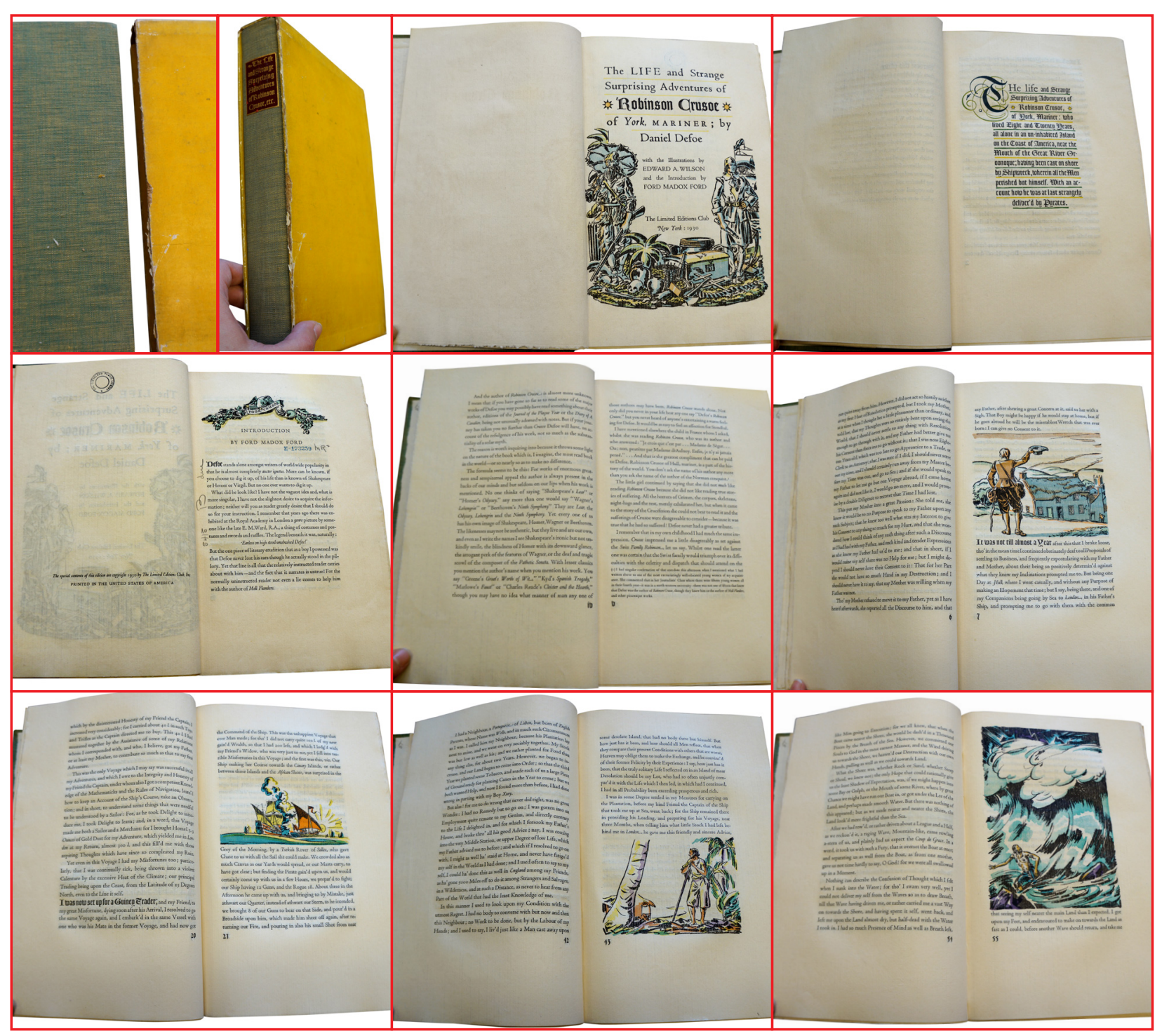


tulos. O volume foi impresso em papel texturizado, provavelmente artesanal, de gramatura aproximada de $90 \mathrm{~g} / \mathrm{m}^{2}$.

Decameron (figura 41), de 1930, foi publicado em dois volumes e projetado e decorado pelo importante designer T. M. Cleland. O volume de $30 \mathrm{~cm}$ de altura apresenta o texto de classe oldstyle composto em duas colunas, de forma similar a como eram compostos os manuscritos, porém esta é uma versão muito mais leve do que os densos livros medievais. O designer faz alusão ao período e ao mesmo tempo traba-

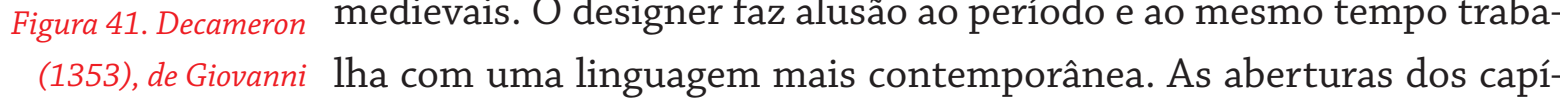
Boccaccio (1313-1375). tulos são vinhetas na parte superior e o texto destas páginas apresenta Publicada em 1930 pela capitulares simples. Foram criadas vinhetas para os subtítulos com o

The Limited Editions texto dentro. O papel utilizado é texturizado tipo vergê, de gramatura Cleveland Public Library. aproximada de $120 \mathrm{~g} / \mathrm{m}^{2}$. Para cada capítulo foi utilizada uma cor dife-

$$
\text { Fotos da autora. rente, tanto nas ilustrações de abertura como nas vinhetas. }
$$

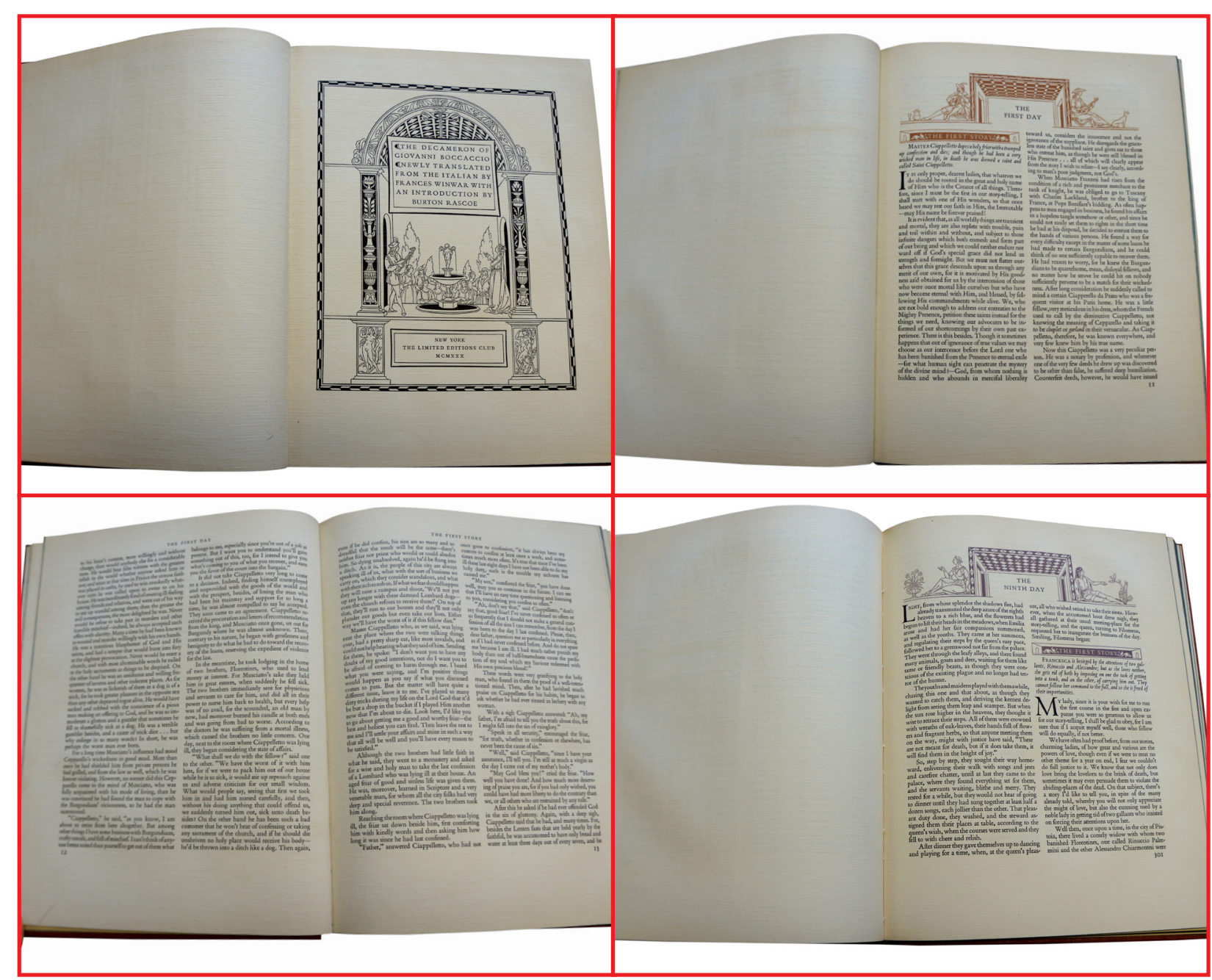

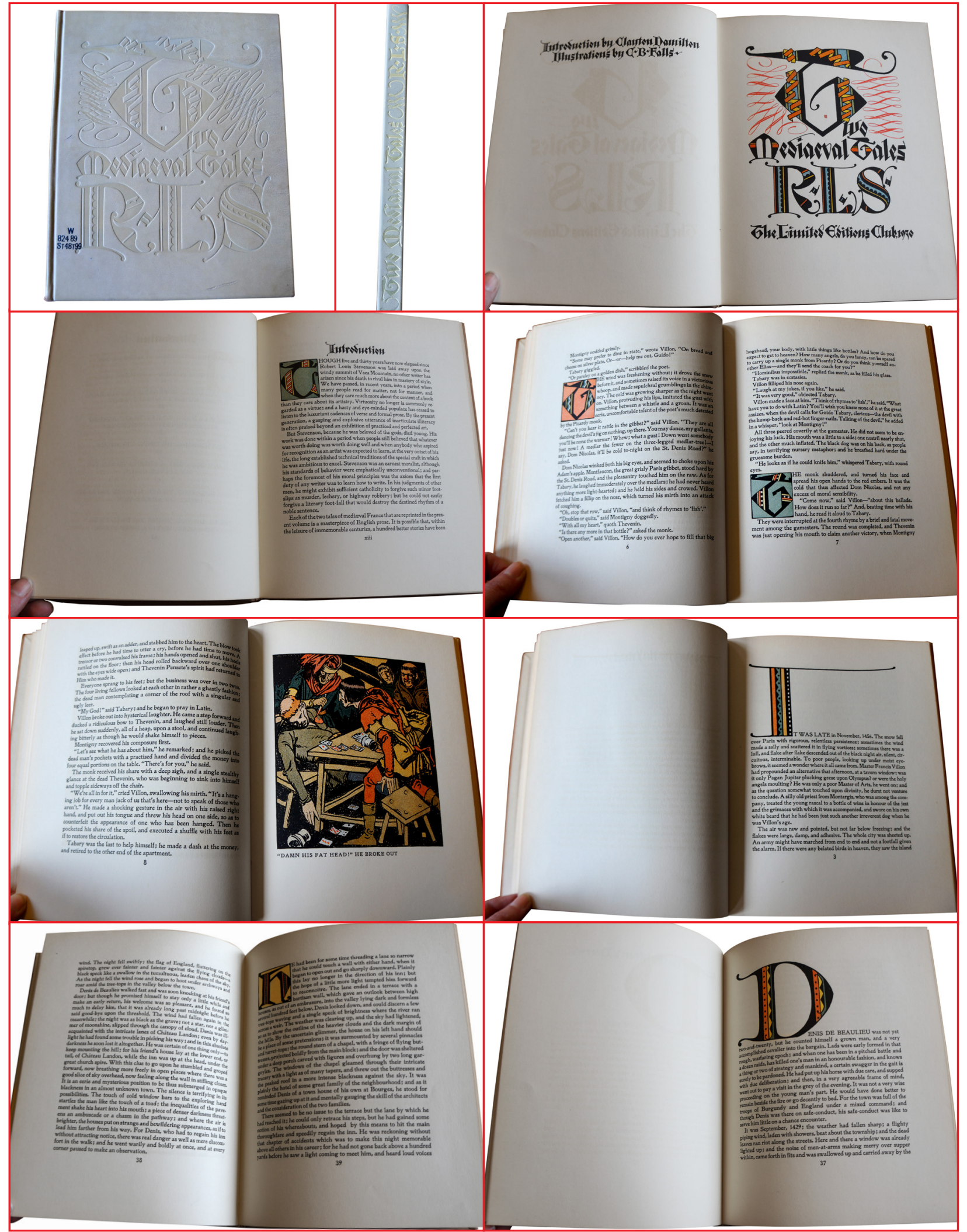

Figura 42. Two Mediaeval Tales, de Robert Louis Stevenson (1850-1894). Publicado em 1930 pela The Limited Editions Club. Acervo da Cleveland Public Library. Fotos da autora. 
Two Mediaeval Tales (figura 42), de Robert Louis Stevenson, publicado em 1930, tem o formato de $18,5 \mathrm{~cm} \times 22,8 \mathrm{~cm}$ e foi ilustrado por C. B. Falls e impresso pela Marchbanks Press. A edição apresenta capa dura em relevo e há capitulares que remetem a letras góticas, porém são mais leves e modernas e apresentam motivos geométricos e cores vivas. Neste projeto, pode-se entender que o desenho dessas iniciais são uma interpretação gráfica contemporânea de suas ancestrais góticas. O texto é composto em uma coluna com um tipo pouco contrastado com traçado humanista de corpo e entrelinha de aproximadamente 12/14 pontos. As margens são generosas e dão leveza à página, já que a mancha é um pouco mais pesada.

The Tragedy of Hamlet, Prince of Denmark (figura 43), de William Shakespeare, foi lançado em 1933 e impresso e projetado por Hague and Gill, em 1933. Eric Gill criou os letterings (letreiramento)17 para a página de rosto e o tipo utilizado no corpo do texto é o Joanna (de sua autoria), composto em corpo e entrelinha de 11/13 pontos. Há capitulares manuscritas e ilustrações no início das cenas. As ilustrações em xilografia são pesadas e bem contrastadas.

Figura 43. Hamlet (1601), de William Shakespeare (1564-1616), publicad pela The Limited Edition Club em 1933. Livro do Acervo da Cleveland Public Library. Fotos da autora

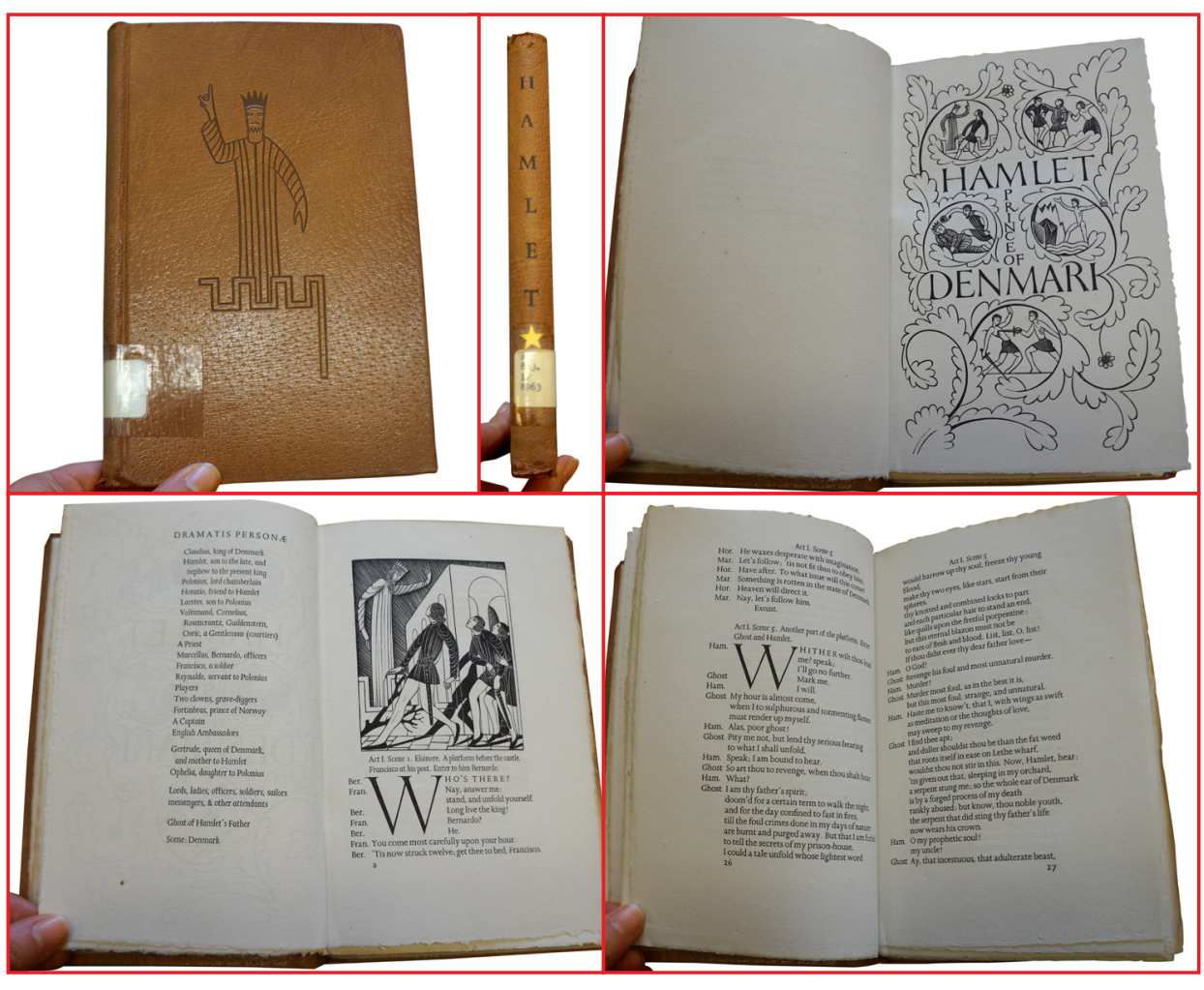

17 Segundo definição de Farias (2004: 2) letreiramento é: "processo manual para a obtenção de letras únicas, a partir de desenhos".
Esta edição de Lisístrata (figura 44), de Aristófanes, é ilustrada pelo renomado artista espanhol Pablo Picasso. O texto foi composto em Caslon em corpo e entrelinha 14/20 relativamente grandes como tamanhos de texto, mas a escolha do tamanho provavelmente deve-se à proporção com o tamanho do volume, de $30 \mathrm{~cm}$ de altura. $O$ papel utilizado é levemente texturizado de marca Rives. A composição apresenta elementos refinados, como uso de versaletes para evidenciar o nome dos personagens, e tanto as ilustrações quanto os textos laterais (título corrente e o texto da ação dos personagens) foram impressos na mesma cor de tinta, um tom marrom avermelhado. A capa dura foi impressa com ilustrações e o título em uma etiqueta colada sobre a capa.

Figura 44. Lisistrata, de Aristófanes (a.C. 446-a.C. 386) publicada publicada pela The Limited Editions Club em 1934. Livro do Acervo da Cleveland Public Library. Fotos da autora.

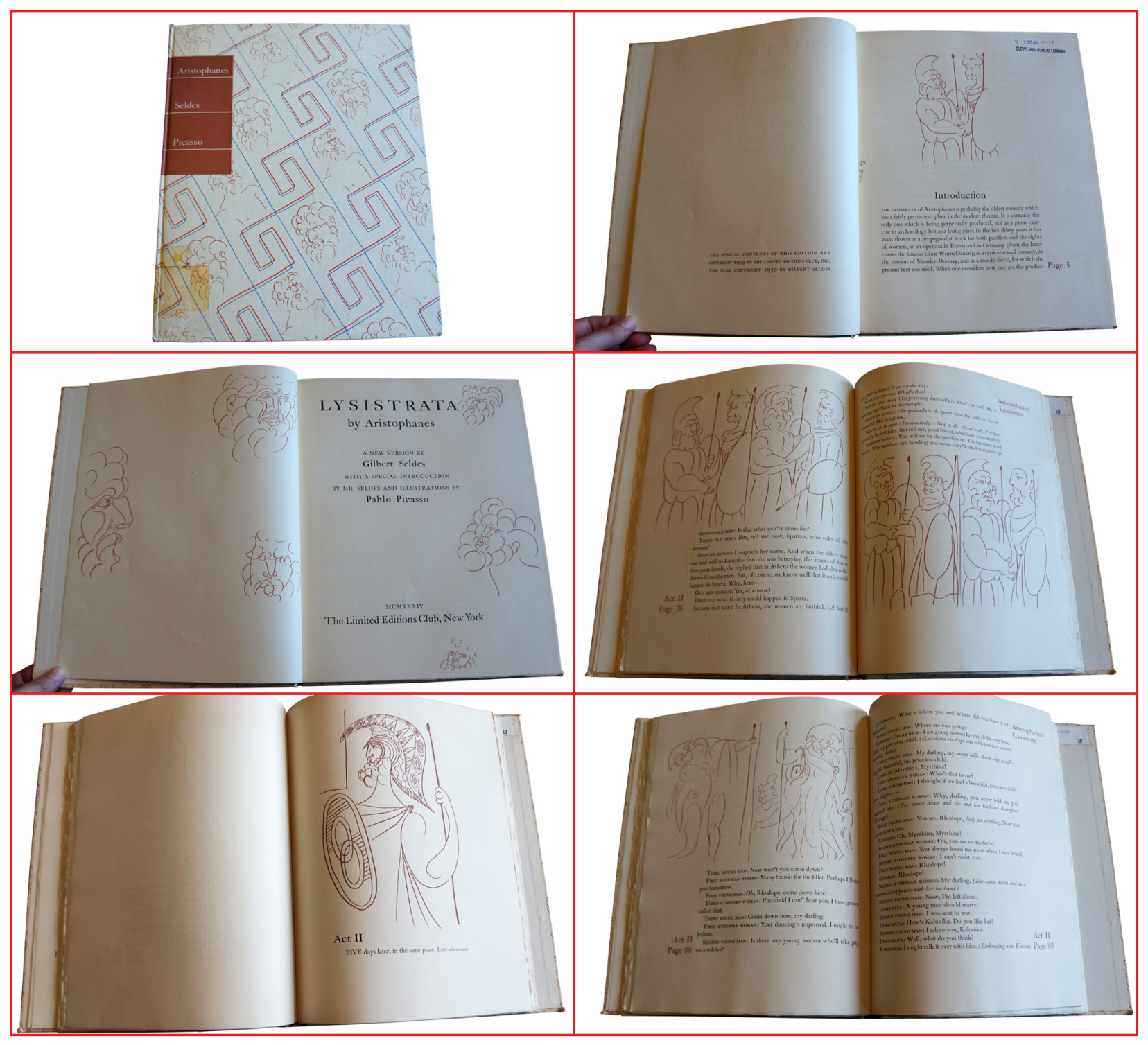


A Christmas Carol in Prose; Being a ghost story of Christmas (figura 45), de Charles Dickens, foi publicado pela The Limited editions Club em 1934 e teve o design e a impressão feitos por Daniel Berkeley Updike e ilustrado por Gordon Ross. As ilustrações coloridas que aparecem no meio do texto foram feitas em forma de elipse, deixando a página arejada ao redor da ilustração. É possível perceber a marca da impressão nas páginas com ilustração. O texto foi composto em tipo oldstyle, bem leve e com espaço generoso entre as linhas. O título do livro na página de rosto foi composto em um tipo gótico (blackletter) que se repete nas aberturas de capítulo, em que há pequenas vinhetas ilustradas em preto e branco na parte superior. Foram usadas iniciais caligráficas (script) em contorno, leves e elegantes. As margens também são generosas e o papel é de alta gramatura (aproximadamente 120 ou $\left.150 \mathrm{~g} / \mathrm{m}^{2}\right)$.

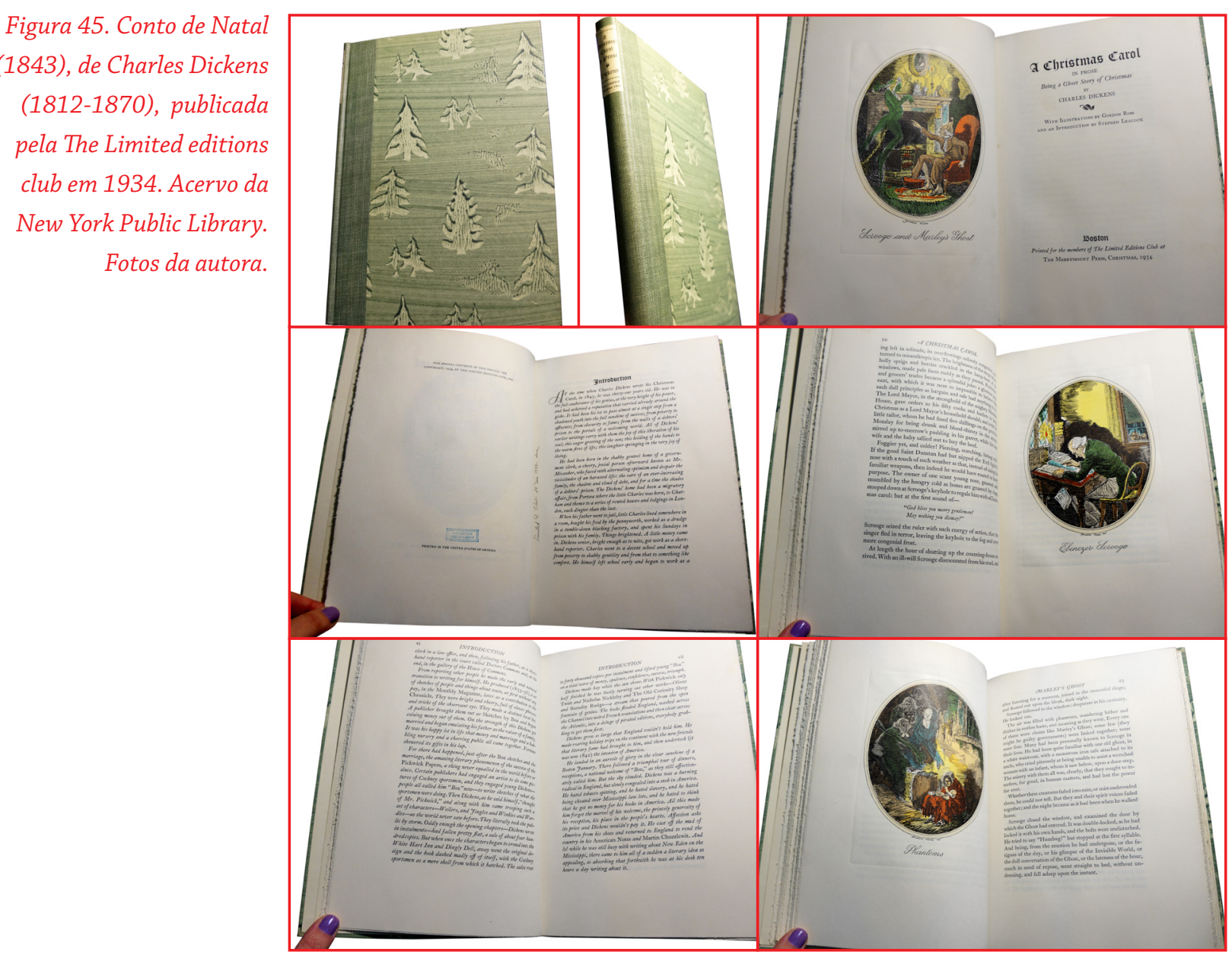

Pride and Prejudice (figura 46), de Jane Austen, foi também projetado por Daniel Berkeley Updike, com ilustrações de Ellen Sewell. O volume tem as dimensões de $15 \times 24 \mathrm{~cm}$ e o tipo usado apresenta contraste de eixo vertical, sendo talvez da classe transicional, delicado e composto em corpo 11 e entrelinha 13 de pontos. Esta escolha pode, de certa forma, aludir à época e ao local em que o romance foi escrito ${ }^{18}$. Para o título, Updike escolheu um tipo display romano em contorno (outlined). Os títulos correntes foram compostos em itálico espacejados centralizados na página, o que remete ao estilo do impressor inglês Baskerville. Os fólios se encontram na mesma linha, porém alinhados à esquerda e à direita, o que deixou as margens inferiores livres de qualquer elemento. Figura 46. Orgulho e As seções do texto foram separadas com um pequeno elemento decora- preconceito (1813), de tivo, uma linha decorada centralizada e delicada, seguida por texto com uma capitular simples e a primeira palavra composta em versalete. As ilustrações, todas em preto e branco, são leves e com muitos meios-tons, o que parece combinar com o texto.

Jane Austen (1775-1817),

publicada pela The Limited Editions Club em 1940 Libra da New York Public

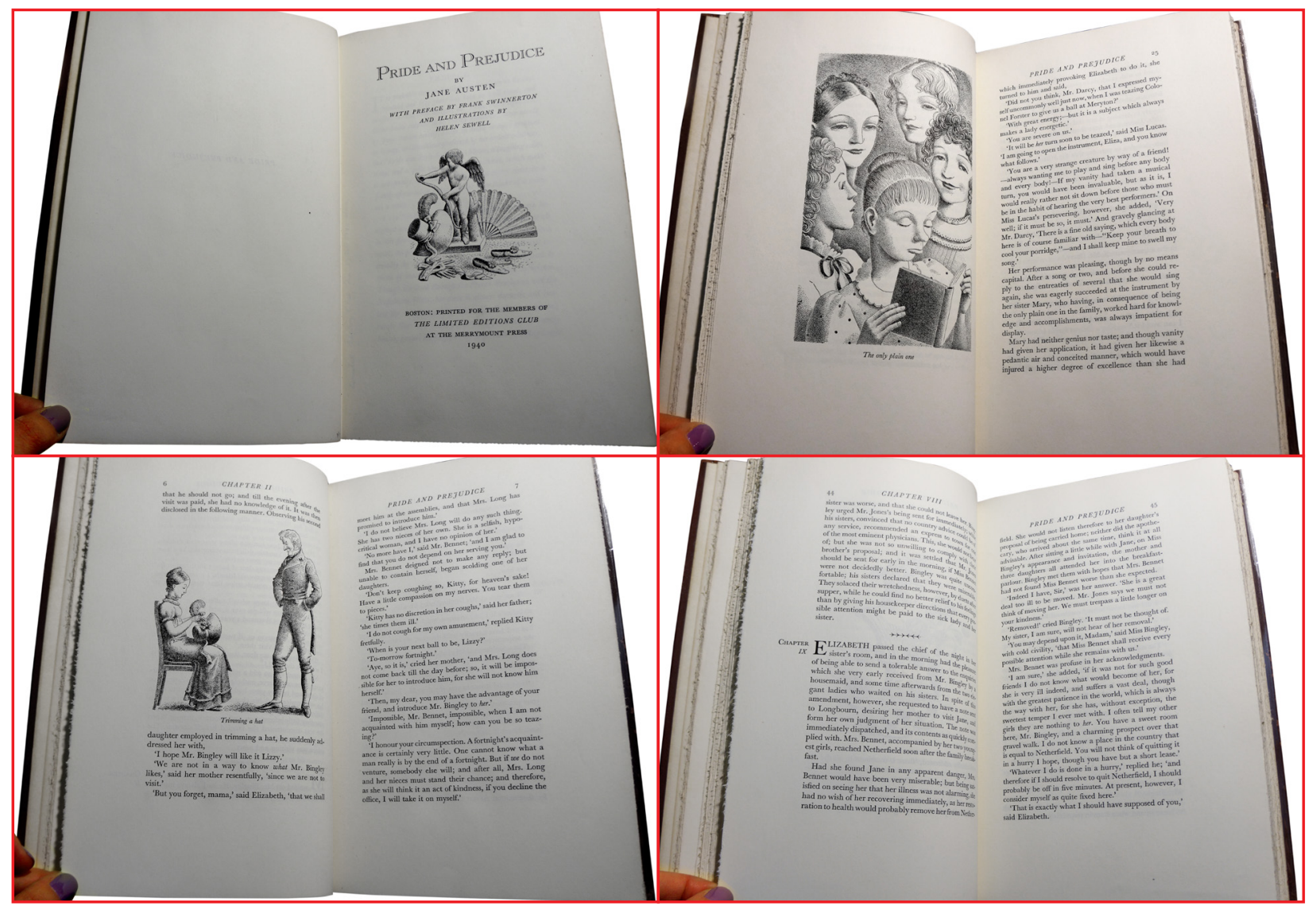

18 Tipos transicionais, como o de Baskerville e Bell, são originários da Inglaterra, local onde se passa a trama. 
Alusão, interpretação e saturação

Apresentamos na seção anterior diversos exemplos de livros visíveis, assim como algumas ideias de alguns de seus designers. Livros "visíveis" na época, ou ilustrados ou com ornamentos, não se restringiam aos designers e tipógrafos da "fina impressão", ao menos nos Estados Unidos, como se pode observar em algumas edições de editoras comerciais como Dodd and Mead, porém optou-se aqui por apresentar exemplos da "fina impressão". Os praticantes dessa "abordagem" parecem ter formado um grande clube, já que muitos se conheciam e defendiam a prática da impressão de qualidade, que ia além do cuidado com os processos, mas com a virtude de se produzir obras duráveis, como eram os primeiros livros impressos, já que muitos livros comerciais rapidamente pereciam pela baixa qualidade dos materiais. Segundo Benton (2005: 47), a partir de descrição de Paul Johnston, os livros "feitos para durar" diferem dos comuns pelo uso de materiais e procedimentos utilizados, como papéis produzidos a partir de fibras de tecido, em uma encadernação em que capa e miolo realmente são unidos pela costura e não apenas colados.

Todos os livros apresentados acima mantêm essa preocupação com a qualidade dos materiais e processos, além de serem objetos tanto para ser lidos como vistos. Esses livros, porém, obviamente eram objetos produzidos para uma elite. Os designers apresentados acima eram alguns dos mais bem pagos e mais conhecidos do período.

Megan Benton (2005) percebe nesse período da fina impressão nos Estados Unidos que duas abordagens ganham espaço, a do design alusivo e interpretativo, além do fenômeno dos designers "de renome", em suas palavras ("Brand Name Designers"), designers de muita fama e que ganhavam status "autoral", no sentido de que o designer torna-se um criador da obra, ganha tanta importância quanto o próprio autor do texto, o que se contrapõe ao ideal do designer invisível e subserviente ao texto. Sobre o design alusivo, Benton (2005: 92-93) explica que:

Este termo de arte se referia à composição tipográfica de um livro que se baseia no estilo do local e período em que o texto foi originalmente tos, convenções de leiautes e estilos de ilustração, comuns nessa época e nesse local. A tipografia alusiva também buscava ser fiel à gênese do texto através de decisões que envolvem a escolha do papel, cor da tinta formato, encadernação e até mesmo seus métodos de produção.
Benton (2000: 94) pondera que, na verdade, a abordagem alusiva existe desde os incunábulos, que procuravam imitar os livros manuscritos. A autora cita como outros exemplos o estilo neomedieval de Morris, entre outros, porém observa que o designer que mais se destacou nessa abordagem foi Bruce Rogers:

O mais célebre praticante da tipografia alusiva foi Bruce Rogers, que descreveu a técnica como "de certa forma como uma montagem de um palco para uma peça. Um estilo contemporâneo para um texto antigo poderia ser comparado a encenar Hamlet com um figurino moderno. No entanto, novo e eficaz a seu próprio modo, você sente que isso é estranho e to, novo e eficaz a seu próprio modo, você sente que isso é estranho a pensar sobre a composição e sobre o designer, em vez do texto". Aqui, Rogers invoca o dogma do invisível dos leitores modernos não familiarizados, nesse caso, com a produção de livros ingleses do início do século XVII. Rogers apontou em outro lugar que ele projetou livros para que seus autores se sentissem confortáveis e satisfeitos com a apresentação dos seus textos; quando um autor viveu em uma época anterior ou em um lugar exótico, o design pode visualmente aludir àquela alteridade, levando o leitor a esta aura. A tipografia alusiva buscou ser invisível para os leitores da época do autor, não para o público contemporâneo. (BENTON, 2005: 93)

Daniel Berkeley Updike (in PETERSON, 2002: 42), outro grande tipógrafo e designer americano, também conhecido por suas práticas "alusivas", explica no ensaio The Essentials of a Well-Made Book, de 1940, que a "invenção" da tipografia alusiva tem sido atribuída a ele, porém que esta é uma prática muito antiga, uma vez que certos tipos de letras eram associados a certos tipos de texto, como góticos a textos sagrados e jurídicos e romanos à literatura e a outros textos "profanos". Updike cita como exemplo dessa apropriação e alusão ao trabalho de Pickering e Wittingham, no século XIX, e destaca, como exemplo de sua época entre os grandes praticantes da tipografia alusiva, o trabalho de Bruce Rogers e algumas edições da Nonesuch Press.

Benton (2000: 99) acrescenta que a produção desses livros alusivos trouxe repertório de estudo da história da impressão, tanto para impressores quanto para bibliófilos:

A tipografia alusiva apresentou detalhado conhecimento histórico das tradições europeias de impressão, tanto que institui a especialização acadêmica do impressor para transmitir esse conhecimento para seus clientes. Frederic Warde descreve tipografia alusiva como um "jogo gracioso" que ofereceu a um crescente número de entusiastas da impressão um "desa- 
fio sutil" de sua aprendizagem e gosto. Era claramente pedante em algum grau, tacitamente ensinando os clientes a reconhecer eminentes estilos tipográficos tradicionais, não apenas para que pudessem apreciar as hatipograficos tradicionais, não apenas para que pudessem apreciar as ha-
bilidades dos designers, mas de usá-las. Como a comunidade da fina impressão do pós-guerra tornou-se a mais informada sobre características históricas do ofício, tipografia alusiva levou muitos ao reconhecimento de certas características. Por conseguinte, esta comunidade sucumbiu às vezes a uma espécie de terminologia visual tornada possível pela crescente moda por estudos bibliógráficos. Estabeleceu-se, assim, certa troca de conhecimento entre os bibliófilos que agora, historicamente informados, conhecimento entre os bibliofilos que agora, historicamente in
podiam distinguir e definir um livro comum de um livro fino.

Ainda segundo a autora (BENTON, 2000: 99), a tipografia alusiva também foi alvo de críticas, uma vez que, voltando-se ao passado, era difícil desenvolver um estilo propriamente contemporâneo, isto é, do início do século XX. Benton lembra também que a tipografia alusiva era acusada por alguns como uma "epidemia de roubo" e que a tipografia, também conhecida por "period typography", podia ser "tediosa como um móvel antigo".

Sobre a tipografia interpretativa, Benton (2000: 102-103) explica: "Se o designer alusivo funcionava como um designer cenográfico, na interpretação tipográfica o designer torna-se o centro da performance, a estrela do show".

Como exemplo dessa abordagem interpretativa, Benton cita o design de The Strange Case of Dr. Jekyll and Mr. Hide, produzido por William A. Dwiggins, cujo exemplo já foi por nós apresentado:

Quando Bill Dwiggins projetou e ilustrou a edição de Robert Louis Stevenson de O Estranho Caso do Dr. Jekyll e do Sr. Hide para a Random House, por exemplo, sua inconstante visão traçou uma linha interpretatise, por exemplo, sua inconstante visão traçou uma linha interpretati-
va. Desde o início, ele pretendia criar contrastes na forma do livro que ecoassem o tema dos opostos ligados do texto. Em agosto de 1927, ele explicou a Elmer Adler, que supervisionou a produção do livro, que imaginou para o revestimento da capa dura um tecido preto liso que seria envolto por uma caixa impressa em cores vivas - "um livro muito sóbrio dentro de uma caixa alegre".

Benton (2000: 102-103) explica que as ideias de Dwiggins migravam para uma linguagem mais popular e que Adler havia se recusado a produzir um livro que tinha a intenção de ser "fino", inspirado em "thrillers baratos que enchiam bancas do final do século XIX". O resultado final, como se pode observar pelas imagens do volume apresentado acima, diferem de suas ideias iniciais.
Segundo Benton, "o design interpretativo convidava os impressores a expressar suas personalidades artísticas" e que, nesse caso, a personalidade do designer torna o livro visível:

Personalidade tornou-se o ingrediente especial e altamente visível que elevou o design do livro de comum a especial, qualidade esta ainda mais importante do que o uso de materiais caros e produção meticulosa. Mesmo portante do que o uso de materiais caros e produção meticulosa. Mesmo
Stanley Morison admitiu que a fina impressão necessitava de algo a mais. (...) Um livro belo vai além de 'algo para ser lido'. (Benton, 2000: 103)

A autora (idem, 2000: 103) conclui que a personalidade e a visão artística do designer de certa forma "ofuscavam" o livro, o que para ela

parcialmente explica a sagacidade do mercado de livros finos, cujos textos já estavam disponíveis em outros formatos; muitos livros finos dos anos 1920 eram publicados apenas para oferecer a gráfica interpretação de Rockwell Kent e Bruce Rogers de alguns textos clássicos.

Nesse trecho e em outros tópicos, Benton explica que a maioria dos livros finos eram reimpressões de textos clássicos, de livros que poderiam ser consumidos de outra forma, como em edições mais baratas, por exemplo.

Ela explica também que a escolha da tipografia tem um papel fundamental na abordagem do design interpretativo:

A tipografia é a principal ferramenta expressiva para o designer. Cada tipo de letra oferece uma mistura única de associações históricas e culturais, bem como as características visuais de cor ou qualidade de traço (firme, bold, vigoroso, delicado, frágil e assim por diante). Designers habilidosos desenvolveram sensibilidades aguçadas relativas a estas qualidades tipográficas. (idem, 2000: 105)

É importante esclarecer aqui que a maioria dos livros da "fina impressão", segundo Benton (2000: 27), eram reimpressões de clássicos por uma estratégia comercial: "Reimprimir clássicos era um rumo editorial seguro, especialmente para os editores finos, com relativamente pouco interesse em ou poucos insights especiais em problemas editoriais". Esses livros, na época, não eram produzidos essencialmente para a leitura, já que muitas vezes o leitor podia possuir outras versões da mesma obra e assim eram feitos para ser colecionados e admirados. Nesse sentido, ela explica:

Legibilidade não era em geral uma questão importante, porque não era uma fonte primária de valor dos livros finos. As críticas dentro do mun- 
do bibliográfico tendiam a ser suaves ou na surdina e poucos outsiders tinham a oportunidade de observar e portanto avaliar a legibilidade dos livros finos. Ocasionalmente, porém, um virulento ressentimento era expressado, quando as ambições formais e materiais eram alcançadas às custas totais do texto. Mesmo se alguém não pretendesse primariamente ler o texto finamente impresso, deveria pelo menos poder fazer, se desejasse, protestavam os críticos. (idem, 2000: 148)

Outra questão importante discutida por Benton (2000: 245) sobre os livros "finos" era a de que alguns editores "ordinários descobriram o apelo lucrativo de edições limitadas e assinadas". No início, até o The Limited Editions Club, responsável por publicar centenas de livros finos produzidos por alguns dos mais importantes designes e impressores, também foi criticado por anunciar sua empreitada em busca de assinantes, como se os livros fossem uma espécie de investimento lucrativo para a posteridade (idem, 2000: 226-227). Importantes nomes da cena editorial criticaram o clube, mas eles acabaram depois sendo contratados para produzir esses livros.

É possível perceber, após esse breve panorama sobre a visibilidade do livro de literatura ao longo da história da impressão, que hoje as abordagens são diferentes e umas são mais visíveis, seja pela tipografia, seja pelos materiais utilizados ou pelas ilustrações.

É importante ressaltar que os livros apresentados, desde os antigos até os publicados pelas prensas particulares ou por designers da "fina impressão", têm tiragens limitadas e custo elevado. No século XIX, como já exposto, surgiram livros mais baratos, porém ainda ornamentados e destinados a um público maior. No início do século XX ainda existiam livros populares ilustrados, mas aparentemente, com a explosão de edições simples e de bolso, as obras simples dominaram o mercado. Assim, livros "visíveis" são exceção. Porém não se pode comprovar se os livros de ficção após a Segunda Guerra deixaram de ser ilustrados ou com design arrojado, porém há exemplos que apontam novas tendências, especialmente quanto ao uso da tipografia após a década de 1960, assunto que será abordado adiante.

\section{A TIPOGRAFIA DÁ O TOM}

Como vimos no capítulo anterior, a "visibilidade" de um livro de literatura pode estar relacionada a diversos recursos materiais, ilustrações e ornamentos tipográficos, mas a tipografia, o próprio desenho dos caracteres, pode alterar completamente o leiaute de uma página. Parece pertinente, assim, apresentar um panorama de diversas abordagens de autores e designers sobre a escolha da tipografia e como ela pode promover sentido e sensações ao leitor de um texto.

Diante da suposta transparência do texto, isto é, da página impressa, experimentos feitos especialmente por poetas e artistas que, no final do século XIX e início do século XX, conseguiram demonstraram que a palavra escrita, antes de representar uma unidade sonora da linguagem verbal, é um signo visual, ou seja, "visível".

Os poetas que trabalham com uma abordagem visual do texto produzem "poesia visual", assim definida por Menezes (1998: 14):

Por 'poesia visual' pode-se entender toda espécie de poesia ou texto que utilize elementos gráficos para se somar às palavras, em qualquer época da história e em qualquer lugar; já "poesia concreta" é um estilo de poesia visual que nasce num dado período histórico com características bem definidas.

O poeta francês Stéphane Mallarmé, em seu Un coup de dés ${ }^{1}$, percebeu as propriedades visuais do texto e de como sua configuração na página era capaz de produzir outros níveis de significação. Depois das experiências visuais de Mallarmé, o italiano Filippo Tommaso Marinetti lançou as bases do futurismo, movimento artístico que viu nas tecnologias do mundo moderno o grande fim estético de sua época. Marinetti percebeu nas máquinas a beleza que antes só era compreendida através do trabalho do artista, do homem. Seu poema Zang tumb tumb configura visualmente um jogo de palavras em movimento, causado por sua disposição em sentidos, pesos e estilos de tipos diferentes. O trabalho de Ardengo Soffici, outro integrante do movimento futurista, apresen- 
ta mudanças de estilo e tamanho de tipos, considerado por Richard Hollis como um "sussurro na página" (HOLLIS, 2000: 37), que indica que esses recursos visuais de composição do texto poderiam expressar e orientar a ideia de entonação, som e ruído. Por mais que não seja o objetivo desta tese tratar da visualidade tipográfica na poesia, não se pode ignorar essas manifestações e o impacto que elas podem ter tido na percepção da materialidade das letras, isto é, de suas formas.

Para Carter, Day e Meggs (2002: 74), a "mensagem tipográfica é verbal, visual e vocal. Enquanto a tipografia é lida e interpretada verbalmente, ela pode ser vista e interpretada visualmente, ouvida e interpretada pela audição". Ainda para esses autores (Idem, 2002: 77), os signos tipográficos operam tanto nas dimensões sintática quanto semântica:

A linguagem, em qualquer de suas muitas formas, é um sistema independente de signos interativos que comunicam ideias. Apenas como elocução e diç̧ão intensificam e esclarecem o significado de nossas palavras faladas. Signos tipográficos podem ser manipulados por um designer, para encontrar uma comunicacão tipográfica mais lúcida e expressiva. (..) Signos operam em duas dinnsões: sintática e semântica. Quando a mente está preocupada com a forma de um signo, ela é envolvida pela sintaxe tipográfica. Quando ela associa um significado particular a um signo, está operando a dimensão semântica.

O ponto de vista de Carter, Day e Meggs (2002) de que a tipografia opera também em uma dimensão semântica é discutida por outros autores como Swann (1991), Haslam (2007) e Farias (2001), que propõem que os recursos tipográficos podem carregar significados.

Os aspectos formais dos tipos (ou fontes) podem carregar ideias ( $\mathrm{Fa}-$ rias, 2001; Haslam, 2007; Lee, 2004), assim como o leiaute e demais recursos tipográficos (Swann: 1991).

Existem hoje milhares de famílias de tipos digitais para texto ${ }^{2}$ e, apesar de muitas vezes serem um pouco semelhantes, é possível observar diversas diferenças em suas formas, como observa Cláudio Rocha (2003: 46)

2 Tipos para texto são menos "expressivos" e elaborados do que aqueles para outras finalidades, como tipos display para uso em títulos, em publicidade etc.
As variações de estilo podem ser muito sutis. Devem, obviamente, carregar os sinais minir leitura. Portanto, conhecer suas diferencas e nuances permite escolher a letra mais adequada ao texto que será "vestido" por essa fonte.

A partir de Claudio Rocha (2003), reconhece-se então a necessidade de se conhecer em profundidade as partes que formam as letras, de modo a se saber diferenciar os estilos das fontes. É possível identificar as diferenças formais entre famílias tipográficas, ou seja, as particularidades de seus desenhos a partir de suas partes, como terminais, tipos de serifa, caudas, aberturas, entre outros atributos como variação e eixo de contraste, largura ${ }^{3}$, e espessura ${ }^{4}$, e proporção entre hastes ascendentes, descendentes e altura de $\mathrm{x}$. Nas figuras abaixo, a partir de Rocha (2003) e Farias (2004), são apresentados elementos anatômico da tipografia (figura 47)

Figura 47. Anatomia tipográfica (baseada em Rocha, 2003: 42-43). 2000) de Robert Slimbach Univers (1957) de Adrian Frutiger.

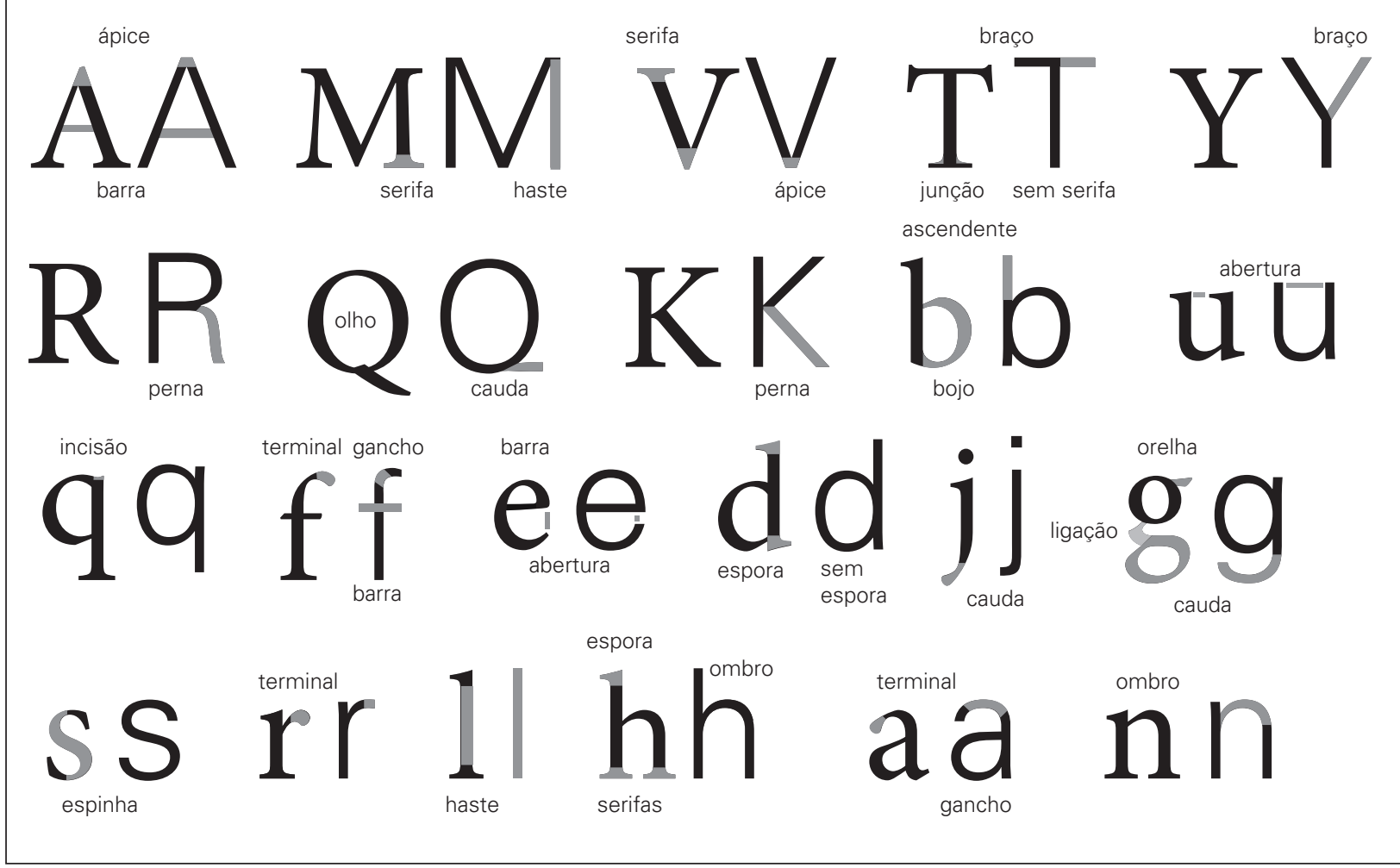

Condensado, expandido, regular etc.

4 Há tipos mais espessos e outros menos, mesmo em estilo regular. 
Figura 48. Tipos de serifas, eixo de contraste e tipos de terminais (baseado em Farias, 2004) Desenvolvida pela autora.

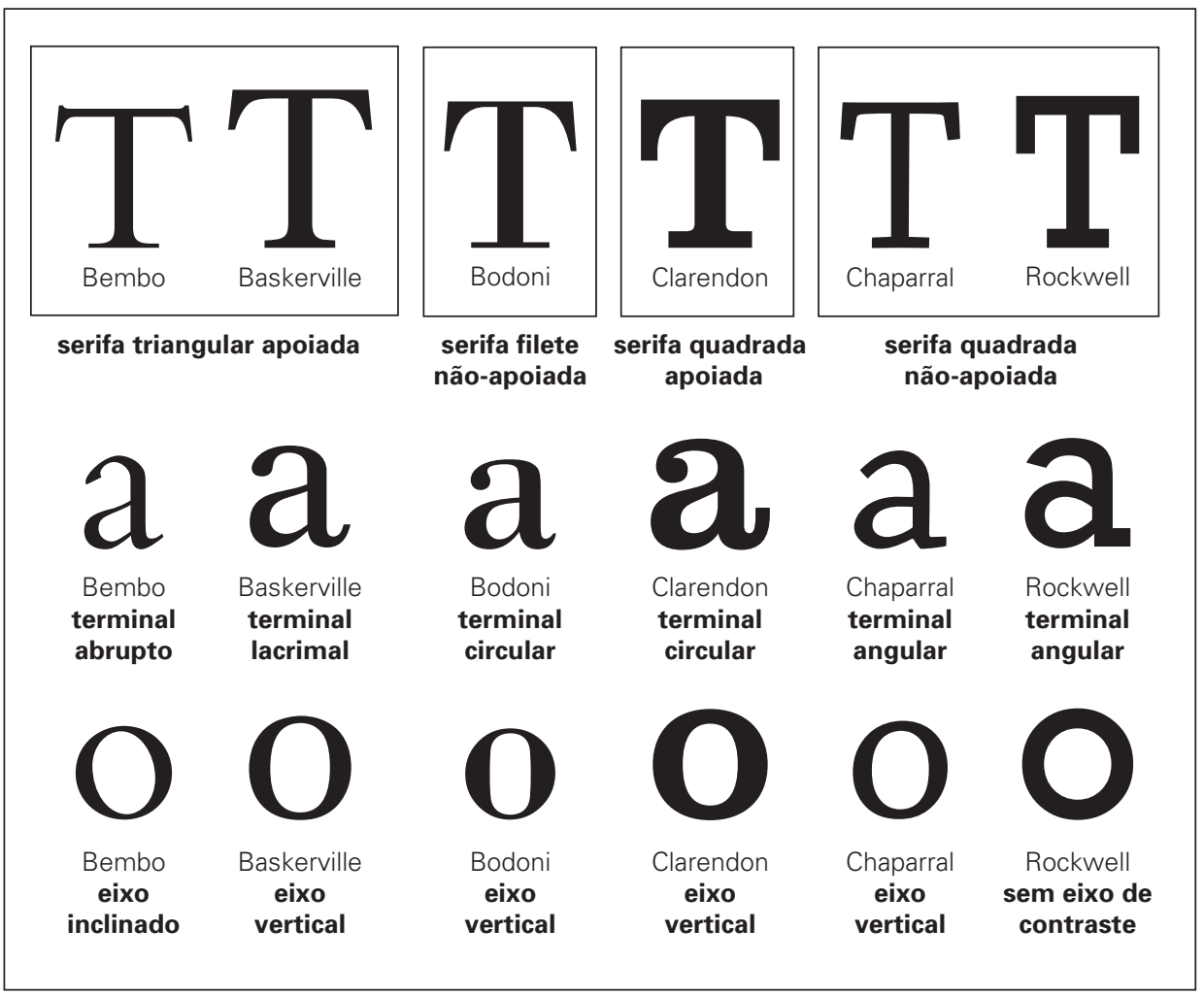

A altura-x, além é claro das serifas e do contraste, é um dos elementos que mais variam entre as fontes. Fontes de mesmo corpo, ou seja altura total dos caracteres, podem ter proporções diferentes relativas a altura-x que, segundo definição de Bringhurst, é:

"A distância entre a linha de base e a linha mediana de um alfabeto, que corresponde à altura aproximada das letras minúsculas sem extensores - a, c, e, m, n, o, r, s, u, v, w, x, z - e do torso das letras b, d, h, k, p, q y. A relaça $a, d a, r, s, u, v, w, x, z-e$ do torso das letras $b, d, h, k, p, q$, portante de toda fonte latina bicameral, enquanto a relaça a da altu importante de toda fonte latina bicameral, enquanto a relaçáo da altura-x com o comprimento do extensor é uma propriedade crucial de qualquer caixa-baixa latina ou grega." (BRINGHURST, 2005: 353)

Quando se muda uma fonte, sem alterar o corpo, muitas vezes o rendimento das páginas muda, ou seja, a quantidade de texto. Essa questão é relacionada à altura-x ou à condensação dos tipos (tipos mais estreitos). Outra questão importante é a de que tipos com maior altura-x nescessitam de mais espaço interlinear do que aqueles com altura- $\mathrm{x}$ menor.

Além dos elementos anatômicos apresentados acima, há outras variações de acabamento e estrutura que podem ser identificadas a partir de Cardinali (2015: 252-255), apresentadas nas figuras a seguir:

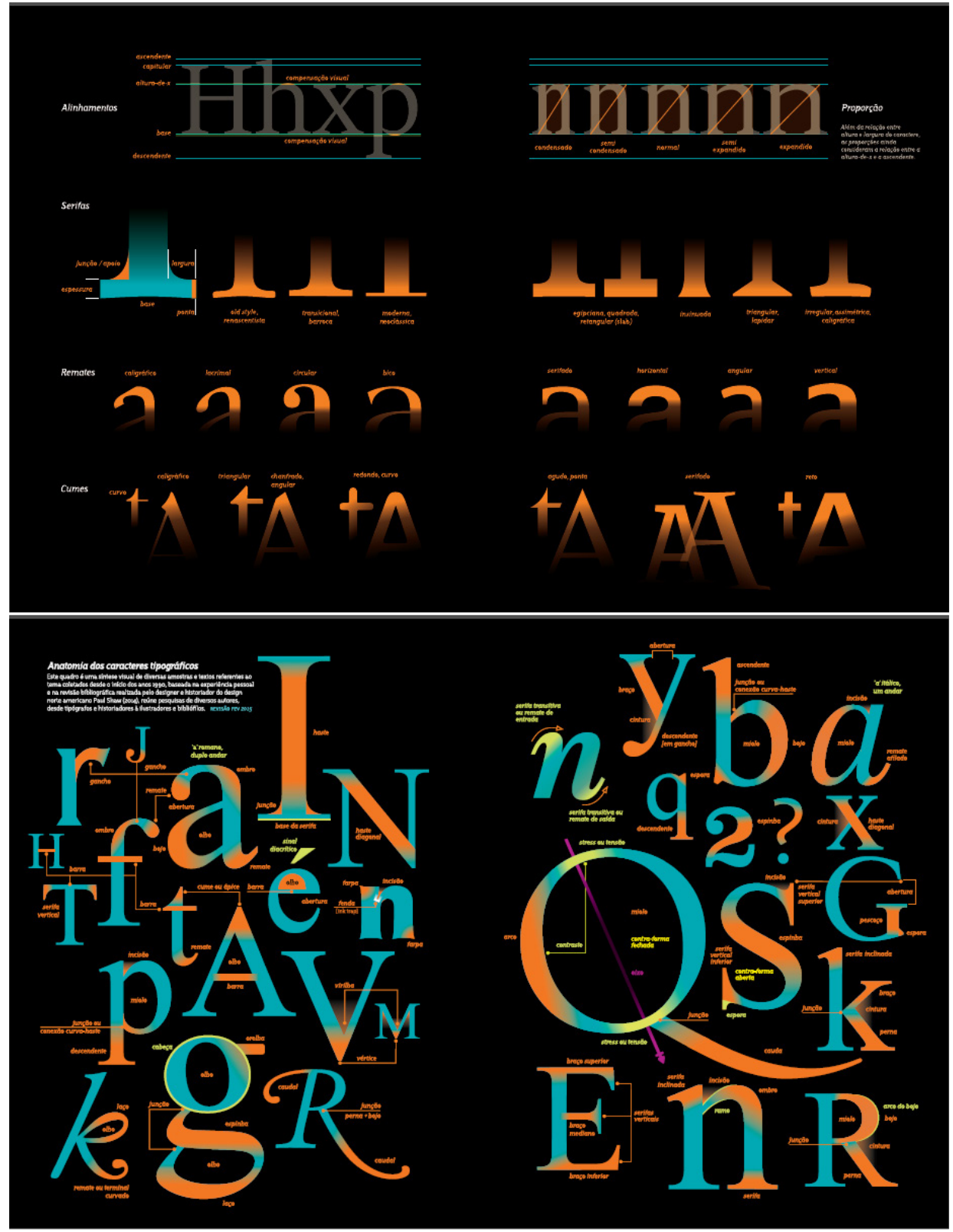

A partir da figura, Cardinali apresenta remates (ou terminais) serifados e cumes (ou ápices) arredondados, que por raramente serem encontrados em fontes clássicas nos levam a inferir que podem ser acabamentos de fontes mais contemporâneas.

Marshall Lee (2004: 117) explica que faces tipográficas para uso em texto apresentam tanta variação formal quanto aquelas usadas em títulos (display). Muitas vezes, porém, a diferença não é notada, pois costuma-se observar os tipos em pequenos tamanhos, mas "enquanto os leitores podem não perceber conscientemente as distintas caracte- 
rísticas de um tipo para texto, eles podem ser afetados por eles". Dessa maneira, os tipos "devem ser escolhidos a partir de sua harmonia com o texto". (idem, 2004: 117)

Uma das diferenças mais perceptíveis em faces tipográficas são seus níveis de força $a^{5}$ e delicadeza ${ }^{6}$. Alguns tipos são definitivamente fortes $\mathrm{e}$ robustos, alguns são claramente leves e delicados, alguns estão no meio termo. Embora aqui, como em outras classificações de caráter, podem existir diferenças de opinião, é razoavelmente seguro dizer que quase todo mundo consideraria as fontes Caledônia, Times Roman e Monticello relativamente fortes; Granjon, Weiss, e Bodoni book relativamente delicadas. Mas em todos os casos, a sensação transmitida pelo tipo depende em parte da forma como é usado. (LEE, 2004: 117)

Marshall Lee (2004: 117) acredita que a escolha da tipografia de um livro, a seleção de determinada família tipográfica, pode apresentar certas características formais capazes de conotar personalidades distintas:

Tipos ${ }^{7}$, assim como os rostos de pessoas, possuem características distintas que indicam aspectos do caráter, além de apenas força e delicadeza. Alguns atributos são bastante pronunciados, alguns são mais sutis e sujeitos à interpretação pessoal. (LEE, 2004: 117)

Lee (2004: 118) apresenta em seguida uma lista de tipos de uso relativamente comum para composição de textos (em design editorial, especialmente livros) com suas respectivas características. Para ilustrar, foi desenvolvida uma tabela com amostras dos tipos apresentados por ele.

- Baskerville: clássica e elegante (classical and elegant)

- Janson ${ }^{9}$ : arredondada e acolhedora (round and warm)

\section{Strenght. \\ 6 Delicacy.}

7 Typefaces.

8 Segundo Peter Dawson (2013: 33), o tipo Baskerville, da classe transicional, criado por John Baskerville em 1757, "apresenta contraste moderado entre traços finos e grossos,

a letra $\mathrm{Q}$ maiúscula letra $\mathrm{R}$ míscula com perna alongada e retilínea (long straight leg on upper case R); e eixo vertical". O autor acrescenta também que o design tipográfico de John Baskerville procurara "aprimorar os desenhos de tipos de seu contemporâneo William Caslon" (DAWSON, 2013:33)

Descrição de Janson, adaptada e traduzida do site myfonts.com.

versão digital é uma recriaçáo fiel de uma das fontes holandesas do século XVII cortadas por Nicolas Kis. As matrizes originais faziam parte do acervo de Stempel, foram adaptadas (com novo italico) para as máquinas de conposiçao a quente da Mengentlaler Linotype por Chauncey Griffith e, em versão posterior para fotocomposição, teve nova adaptação
- Granjon ${ }^{10}$ : arredondada, acolhedora e graciosa (round, warm, and graceful)

- Caledonia ${ }^{11}$ : limpa, firme, do ambiente corporativo (clean, firm, business-like)

- Times Roman ${ }^{12}$ : rígida, fria e formal (stiff, cold, formal)

- Electra ${ }^{13}$ : leve, descolada e eficiente (light, cool, efficient)

Fairfield ${ }^{14}$ : indistinta (fuzzy)

- Bodoni: dramática (dramatic) ${ }^{15}$

- Waverly: arredondada e descolada (round and cool)

Sabe-se que muitas vezes certas características tipográficas em textos de leitura contínua podem parecer sutis, porém na mancha de texto esses tipos aplicados criam "texturas" diferentes. O próprio autor

com retorno dos itálicos originais. Designers: Miklós Tótfalusi Kis - Versão digital: 1985 Publisher: Linotype

10 Peter Dawson (2013: 78) descreve a fonte da classe Old Style a partir de suas características: "Delicada, 'serifas similares a incisores, alto contraste de fios, ascendente limitada com declive para baixo; pequeno olho no caractere minúsculo 'e'; pequeno bojo no caractere minúsculo 'a' e eixo vertical". O tipo foi criado por George W. Jones para a fundidora Linotype que "teve como fonte de inspiraçáa o tipo Garamond impresso no livro Historia Ecclesiastica do parisiense Jean Poupy em 1592". (DAWSON, 2013: 78)

11 Descrição de Caledonia, adaptada e traduzida da distribuidora myfonts.com: William A. Dwiggins desenvolveu o tipo Caledonia para a Linotype em 1939. Inicialmente, o designer tinha a intenção de misturar os elementos de Scotch Roman e Bulmer. Disponível em: http://www.myfonts.com/fonts/adobe/new-caledonia/; acesso em maio de 2014

$12 \mathrm{O}$ tipo da classe transicional Times New Roman possui as seguintes características, de acordo com Peter Dawson (2013: 111): "grande altura x, descendentes curtos, largura dos caracteres relativamente estreita se comparada a outros tipos serifados". O tipo original foi criado para o jornal inglês The Times por Stanley Morison e Victor Lardent em 1931, mas teve, desde seu lançamento, diversas variaçōes.

13 Descrição de Electra adaptada e traduzida da distribuidora myfonts.com Projetada em 1935 por William Addison Dwiggins, Electra tem sido um tipo padrão ("standard") de livro desde o seu lançamento, devido à sua uniformidade de design e alta legibilidade. Disponível em: http://www.myfonts.com/fonts/adobe/electra/; acesso em 20.03.2014

14 Descrição de Fairfield adaptada e traduzida da distribuidora myfonts.com: Fairfield é um tipo para texto que pode ser usado em livros e em textos curtos, criado para a empresa Linotype entre 1940 e 1949 por Rudolph Ruzicka. Descricão adaptada do site da distribuidora Myfonts. Disponível em. http.//www myfonts.com/fonts/adobe/fairfield/.

15 Peter Dawson (2013: 41) descreve a Bodoni, criada por Giambattista Bodoni em 1790, como um tipo da classe moderna, didone, que apresenta "alto contraste entre traços finos e grossos, serifas filete não apoiadas, cauda da letra Q centralizada na linha de base e eixo vertical". $O$ autor explica que o extensivo uso da fonte em periódicos sobre moda se dá pelos aspectos formais (serifas finas, variação de contraste) que "refletem elegância,
refinamento e estilo". (DAWSON, 2013: 41) 


\begin{tabular}{|c|c|}
\hline $\begin{array}{l}\text { ITC New Baskerville, } \\
\text { italic, bold } \\
\text { aAbBcCdDeEfFgG- } \\
\text { hHiIJJlLmMnNoOp- } \\
\text { PqQrRsStT } \\
\text { uUwWxXyYzZ } \\
\text { 1234567890 }\end{array}$ & $\begin{array}{l}\text { Janson text, italic, bold } \\
\text { aAbBcCdDeEfFgG- } \\
\text { hHiIJlLmMnNoOp- } \\
\text { PqQrRsStT } \\
\text { uUwWxXyYzZ } \\
1234567890\end{array}$ \\
\hline $\begin{array}{l}\text { Granjon, italic, bold } \\
\text { aAbBcCdDeEfFgG- } \\
\text { hHiIjJlLmMnNoOp- } \\
\text { PqQrRsStT } \\
\text { uUwWxXyYzZ } 1234567890\end{array}$ & $\begin{array}{l}\text { New Caledonia Lt Std, } \\
\text { italic, bold } \\
\text { aAbBcCdDeEfFgG- } \\
\text { hHiIjJlLmMnNoOp- } \\
\text { PqQrRsStT } \\
\text { uUwWxXyYzZ } 1234567890\end{array}$ \\
\hline $\begin{array}{l}\text { Times Roman, italic, bold } \\
\text { aAbBcCdDeEfFgG- } \\
\text { hHiIjJlLmMnNoOp- } \\
\text { PqQrRsStT } \\
\text { uUwWxXyYzZ } \\
\text { 1234567890 }\end{array}$ & $\begin{array}{l}\text { Electra LT Std, cursive, } \\
\text { bold } \\
\text { aAbBcCdDeEfFgG- } \\
\text { hHiIjJlLmMnNoOp- } \\
\text { PqQrRsStT } \\
\text { uUwWxXyYzZ } 1234567890\end{array}$ \\
\hline $\begin{array}{l}\text { Fairfield LH, italic, bold } \\
\text { aAbBcCdDeEfFgG- } \\
\text { hHiljJlLmMnNoOp- } \\
\text { PqQrRsStT } \\
\text { uUwWxXyYzZ } \\
1234567890\end{array}$ & $\begin{array}{l}\text { Bodoni MT, italic, bold } \\
\text { aAbBcCdDeEfFgG- } \\
\text { hHiIjJILmMnNoOp- } \\
\text { PqQrRsStT } \\
\text { uUwW XXy YzZ } \\
1234567890\end{array}$ \\
\hline
\end{tabular}

explica que as faces são muito diferentes, porém, como quase sempre são vistas em corpo muito pequeno, alguns detalhes podem passar despercebidos.

Quando se amplia as letras é possível verificar grandes diferenças formais entre os caracteres, especialmente entre terminais, aberturas dos caracteres, eixo de contraste, proporção (altura x e largura), e serifas, como se pode observar na tabela a seguir (figura 51):

Lee (2004: 118) adverte: "Na escolha tipográfica, é melhor considerar essas características que seguir regras históricas ou convencionais. É o caráter do tipo, não sua história, que afeta o leitor". Nesse sentido,

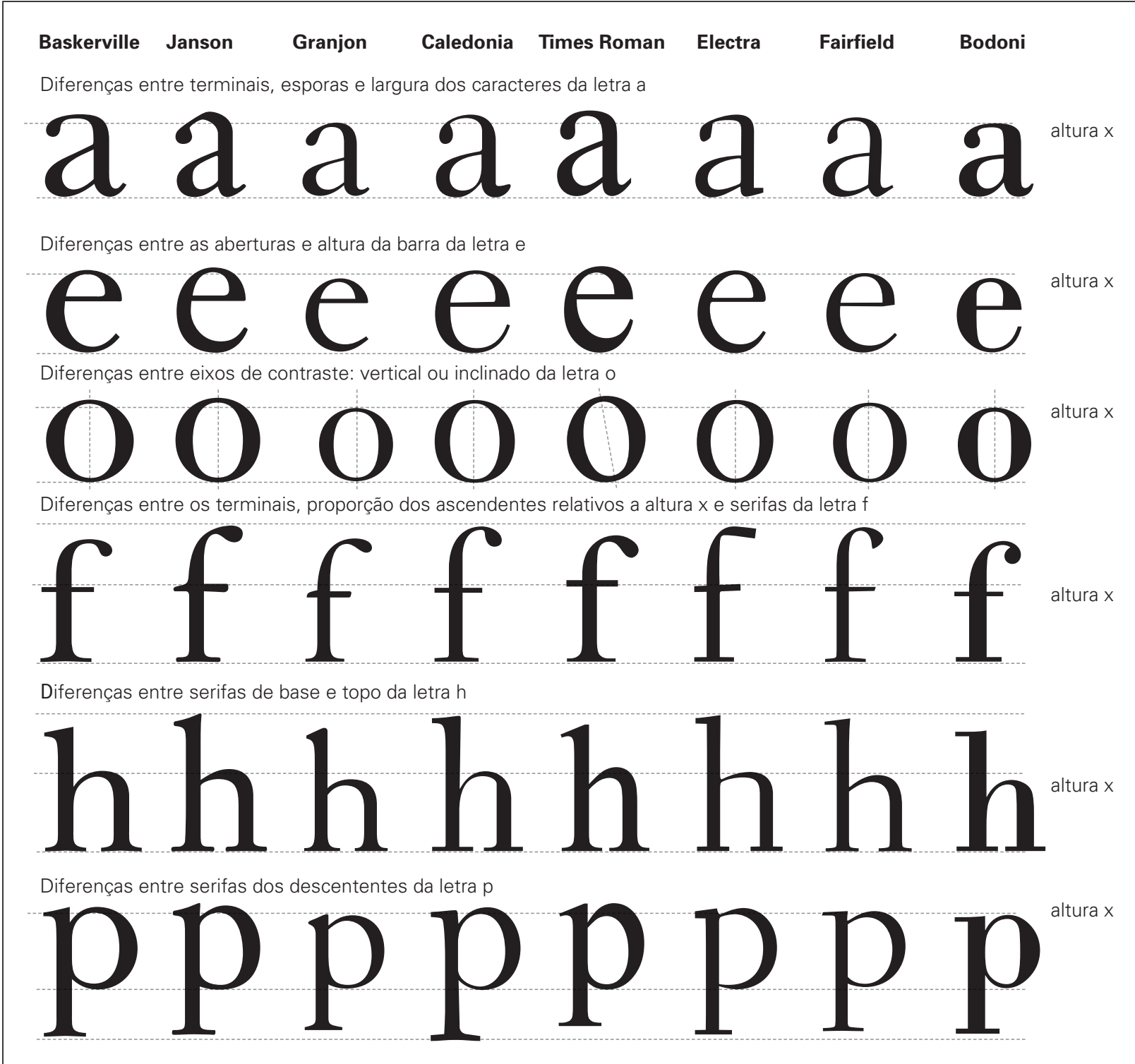

o autor acredita que a escolha do tipo deva ser relacionada a seus atri- Figura 51.

butos formais e não a questões 'alusivas' como uma escolha histórica, por exemplo.

diferenças entre os tipos

Priscila Farias (2001) aponta linhas teóricas que verificam níveis de (2004). Desenvolvida apresenta um artigo publicado em 1995 por Gérard Mermoz, na revista Emigre, sobre o debate contemporâneo da legibilidade em que se pode "levar em conta a contribuição de funções estéticas, expressivas e referenciais da comunicação se quisermos dar conta da complexidade da comunicação tipo(gráfica)" (MERMOZ apud FARIAS, 2001: 71) Farias acrescenta que Mermoz acredita que a ideia de que a tipogra- 
fia apresenta apenas um nível denotativo deveria ser reavaliada, uma vez que, por apresentar ao menos dois níveis denotativos - o primeiro refere-se à transposição de elementos sonoros à forma gráfica e o segundo aos "possíveis significados e interpretação do texto" (MERMOZ apud FARIAS, 2001: 71)

Farias (2001: 71-72) apresenta em seguida a abordagem da relação entre forma tipográfica e conteúdo do texto entendidas pelos termos "congenialidade", por Spencer, ou "conotação", por (Blanchard e Swann).

Ao procurar estabelecer relações entre forma e conteúdo, Spencer (1969) apresenta estudos realizados nas primeiras décadas do século XX que apontam a adequação ou congenialidade entre o conteúdo do texto e a forma dos tipos de modo a categorizar famílias tipográficas de acordo com "valores da atmosfera" (SPENCER, 1969: 238).

Segundo Spencer (1969: 29), em 1933, os pesquisadores Poffenberger e Fanken relacionaram 29 faces tipográficas a cinco qualidades:

- Cheapness (baixo preço, qualidade inferior);

- Dignity (dignidade);

- Economy (economia);

- Luxury (luxo);

- Strenght (força);

Spencer apresenta também pesquisa de Ovink que realizou uma série de testes envolvendo 70 temas a 30 tipos de texto tipos display. Segundo Spencer (1969: 29), “Ovink propôs avaliações sobre a adequação de 13 tipos para livro a oito assuntos literários e 17 tipos display para oito temas de publicidade".

A partir dessa investigação, Ovink concluiu que as faces tipográficas, em termos de "valores de atmosfera" (atmosphere-value), podem ser agrupadas a partir de três qualidades:

1- Luxo e refinamento (luxury - refinement);

2- Economia e precisão (economy - precision)

3- Força (strength). (SPENCER, 1969: 29)

Spencer (1969: 29-30) adverte, no entanto, que a congenialidade tipográfica pode apresentar certa instabilidade temporal (estilos de época) e apresenta o exemplo de que tipos sem serifa foram utilizados no século XX para "expressar a noção de modernidade" e que no século anterior estavam associados a uma "antiguidade grosseira"
Ovink (1938: 127) explica que "Chama-se de valor atmosférico de uma face tipográfica as propriedades e sentimentos que ela provoca no leitor". Ele explica que o leitor tem uma percepção sobre as propriedades visuais do tipo que vai além de qualquer "julgamento de beleza ou legibilidade. A natureza e vivacidade dessa impressão é expressa pelo valor atmostérico da face tipográfica".

Alem de "valor atmosférico" (atmosphere-value), Ovink usa o termo "feeling-tone" que em português traduziríamos literalmente por "sensação tonal", porém que se refere à percepção de uma composiçao tipográfica "de transmitir uma mensagem e ao mesmo tempo criar certo 'estado de espírito' ou 'sensação'”. (OVINK, 1938: 127)

Ovink (1938: 128) assinala que os tipógrafos franceses estiveram entre os pioneiros "na adaptação da tipografia ao caráter do texto", citando como exemplo o trabalho do editor Edouard Pelletan. Porém, sabe-se que o que Ovink talvez chame aqui de valor de atmosfera, ao menos nesse contexto sobre o trabalho do Pelletan, já foi explorado no capítulo anterior pelo termo 'tipografia alusiva', usado por outros autores. Mas valor de atmosfera, conforme os experimentos feitos por Ovink, diferem da alusão, pois o autor testa as sensações dos leitores ao ver certos tipos fora de um contexto específico, ou seja, fora de um livro ou de uma peça publicitária. Além de desenvolver experimentos sobre as sensações provocadas pela forma da tipografia, Ovink (1938: 181) também estuda a influência das margens, entrelinhas, cor e qualidades do papel, ou seja, seus experimentos também exploraram as sensações que podem ser promovidadas pelo uso dos materiais e elementos de leiaute.

Farias (2001: 72) cita pesquisa semelhante, realizada por R. Linkens:

pesquisador francês Gérard Blanchard cita um experimento efetuado pelo semiologista belga R. Linkens, no qual este testou a convergência dos "significados tradicionais" normalmente atribuídos a certas fontes. Linkens dividiu as fontes em cinco grupos - Garaldes, Réales, Didones, Mécanes e Lineales - e buscou verificar a validade de atributos tais como 'elegância', 'equilíbrio', 'dignidade', precisão, 'legibilidade', etc., habitualmente relacionados a eles. Segundo Blanchard, Linkens demonstrou que mesmo leitores pouco familiarizados com convenções tipográficas são capazes de atribuir 'significados verbais' distintos e convergentes para fontes de grupos diferentes. (FARIAS, 2001: 72) 
Farias (2001: 72) apresenta graficamente o experimento, conforme figura abaixo:

\section{Garaldes (Caslon): bela, delicada, elegante, aristocrática}

Reales (Baskerville): equilibrada, clássica, limpa, de qualidade

Didones (Bodoni): digna, austera, uniforme, lógica

\section{Mécanes (Clárendon): mecânica, industrial, estáve}

Lineáles (Univers): Legível, sóbria, precisa, moderna

Os experimentos de Linkens mencionados por Farias (2001: 72) sobre níveis semânticos que a tipografia pode apresentar se baseia em uma generalização a partir da classificação tipográfica (o sistema de classificação aparentemente utilizado e o criado por Maximilien Vox em 1954 que, segundo Silva \& Farias (2005), elaborou seu sistema observando, por um lado, personagens e eventos importantes da história da tipografia, e por outro os aspectos formais das letras para encontrar os adjetivos correspondentes.

O teste de Linkens apresentado por Farias, por mais que seja generalista se comparado ao de Lee (referido acima), é interessante à medida que verifica conotações relativas também ao período histórico e contextual, quando afirma que as Lineales (por exemplo) são legíveis, sóbrias e precisas ou Mecânicas (clarendon), industriais e estáveis. São características menos subjetivas do que as apresentadas por Lee.

É importante notar que, a partir do experimento de Linkens, relacionando os atributos às classes, pode ser importante conhecer com profundidade os sistemas de classificação para analisar as famílias tipográficas e seus respectivos atributos.

Há, hoje, diversos sistemas que podem ser usados para classificar tipos com características semelhantes, porém muitas vezes certos sistemas não contemplam todas as diferenças formais de todos os tipos hoje existentes.

Silva e Farias (2005) desenvolveram um panorama apresentando e comparando classificações tradicionais como as de Thibaudeau (1921) Vox (1954), Novarese (1956), Giò Fuga (1990), Vox-AtypI (1962), BS 2961 (British Standards 2961:1967) e DIN 16518, assim como a indi- cação de outras propostas como as das fabricantes de tipos como Monotype, Linotype, Bitstream, Microsoft e Adobe, e algumas desenvolvidas por autores influentes como Jan Tschichold, Walter Tracy, Phil Baines, Erik Spiekermann e Robert Bringhurst, as quais podem:

ser consideradas variantes de algum sistema, outras (em especial aquelas utilizadas por alguns fabricantes ou distribuidores) parecem ser propostas totalmente independentes. Entre as variantes do BS, é comum encontrar classificações onde as duas primeiras classes de letras serifadas (humanistas e garaldinas) são agrupadas em uma única classe (old style, ou 'estilo antigo'), e o termo modern ('moderno') é usado para caracterizar as fontes chamadas de 'didônicas' no BS. (SILVA e FARIAS, 2005: 76)

Uma das últimas classificações apresentadas pelos autores foi criada a partir de pesquisa desenvolvida no Central Lettering Record, por meio de um projeto iniciado em meados de 1990 por pesquisadores do Central Saint Martins College of Art \& Design, em Londres.

O projeto tem como objetivo catalogar todo tipo de manifestação de design de letras, não se limitando à tipografia (enquanto estudo de tipos para impressão), mas incluindo também letras pintadas, desenhadas, esculpidas, gravadas, etc. Como parte desse projeto, Catherine Dixon deculpidas, gravadas, etc. Como parte desse projeto, Catherine Dixon desenvolveu uma classificação de tipos or

Ao comparar os sistemas apresentados no artigo, percebe-se, que o sistema apresentado por Dixon é um dos mais completos, enquanto o Vox AtypI e British Standards é um dos mais conhecidos. No entanto, Silva e Farias advertem

Ao analisarmos as classificações de tipos tradicionais, percebemos que elas possuem diversas limitações e problemas. Uma vez que são elaboradas a posteriori, estas classificacões correm um alto risco de tornarem-se datadas e parciais, especialmente em tempos onde o experimentalismo e novidade são valorizados. $O$ descompasso entre norma e uso corrente da nomenclatura, somado à incerteza sobre a correta interpretação de certos termos, é outro fator gerador de problemas, especialmente para o ensino do design. Se é verdade que as classificações de tipos necessitam de atualização urgente, o primeiro passo para isso deve ser a compreensão dos sistemas existentes, e das tentativas de torná-los mais compreensíveis coerentes. Novas propostas, ou qualquer tipo de modificação consistente nas classificações existentes somente pode partir de um conjunto de conhecimentos bem fundamentados a respeito dos aspectos históricos, técnicos e estéticos que envolvem a tipografia. (SILVA e FARIAS, 2005) 
Mesmo que seja problemático o sistema de classificação, pois há muitas famílias com variações de estilo que as desafiem, pode ser importante para uma análise de projeto gráfico assumir um dos sistemas de classificação para que a análise tipográfica de um projeto gráfico seja feita. Em nossa tese de doutoramento, optou-se por usar o sistema de Dixon a partir da tabela abaixo de autoria de Silva e Farias (2005: 13), embora em alguns trechos da tese em vez do termo didônicas, que se refere aos tipos modernos de serifas finas e contraste acentuado, tenhamos empregado o termo moderno, pois foi o utilizado pela maioria dos autores citados neste trabalho.

Além dos sistemas observados por Silva e Farias (2005) há outros mais complexos, como o de Sutton e Bartram (1999: 16-17), cuja classificação observa não apenas a anatomia e o momento histórico, mas também diferenças regionais, e de autores como Stephen Coles (2012: 12-21), que

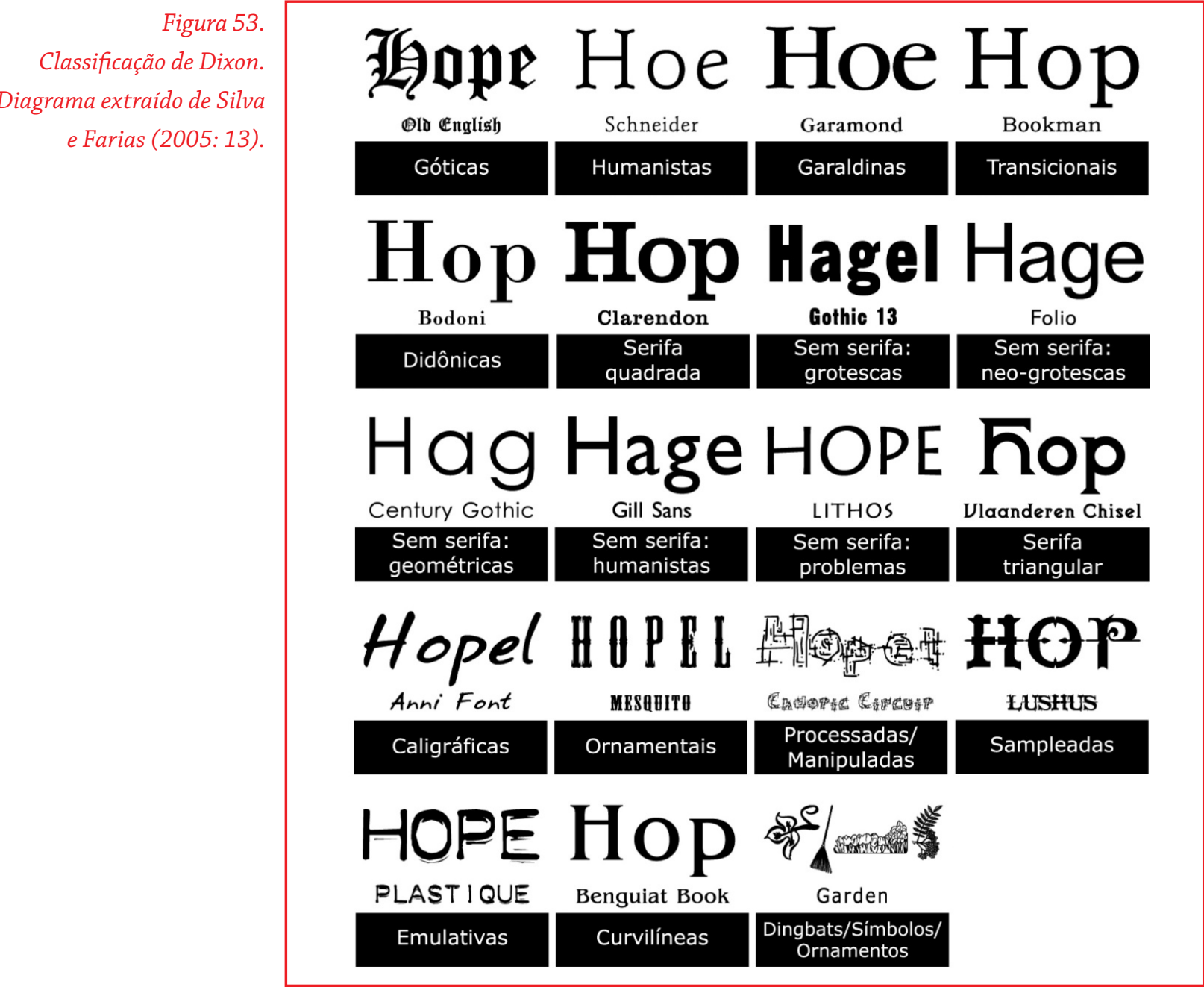

apresenta e analisa fontes digitais atuais e para tanto desenvolve um sistema de maior abrangência, que leve em conta aspectos anatômicos característicos da tipografia digital, na qual o desenho da letra se afasta cada vez mais da caligrafia e de processos de criação manuais.

Philip Meggs (1992: 120) utiliza o termo ressonância tipográfica para se referir aos niveis semânticos que a tipografia pode alcançar:

Ressonância tipográfica é gerada pela estilística cultural e pelas propriedades conotativas que as fontes possuem, além de suas funções como signos do alfabeto. Uma fonte ganha essas qualidades de ressonância por meio da tradição histórica, de associações relacionadas a seu uso comum e de suas propriedades ópticas.

Cal Swann (1991) defende a ideia de que o design tipográfico pode apresentar níveis conotativos (semânticos), de acordo com o conteúdo e seu contexto.

A linguagem escrita e a tipografia têm níveis paralelos de conteúdo, forma e contexto. O conteúdo (verbal - nesse caso escrito) ${ }^{16}$ é a ortografia, a sintaxe e a estrutura semântica das palavras, cuja forma é tipográfica (visual). Existem as pistas prosódicas de reforço ou entonação, uma vez que a língua falada é geralmente acompanhada de expressões faciais, movimentos dos olhos e gestos similares a sinais. O estilo das letras, o tamanho, o peso e a distribuição espacial são os equivalentes visuais para as pistas prosódicas e paralinguísticas. (1991: 53)

Swann (1991: 54) apresenta três exemplos de como o design tipográfico, pode, nesse caso particular, ter diferentes significados (conotações) a partir da composição (Figura 54): a primeira imagem se apresenta como um tímido sussurro (a palavra " $m e$ " [eu]) posicionada no canto da página em corpo pequeno e peso regular, enquanto a segunda, um grito (tipo em bold inclinado; a terceira, mais expressiva ou informal por meio de uso de um tipo cursivo).

Pelos exemplos apresentados, pode-se inferir que a tipografia é capaz de sugerir entonação e intenção, além de apontar, de certa forma, para a personalidade do "falante".

Outros exemplos de níveis semânticos da tipografia apresentados pelo autor relacionam-se a contextos históricos e culturais.

Swann explica que o alfabeto ocidental evoluiu a partir dos fenícios, por meio das civilizações grega e romana. O surgimento das capitais 
Figura 54. Adaptado e traduzido a partir de Swann (1991: 54). Tipos utilizados com base no original: Univers light, Impact e Brush Script. Digitalizada pela autora.

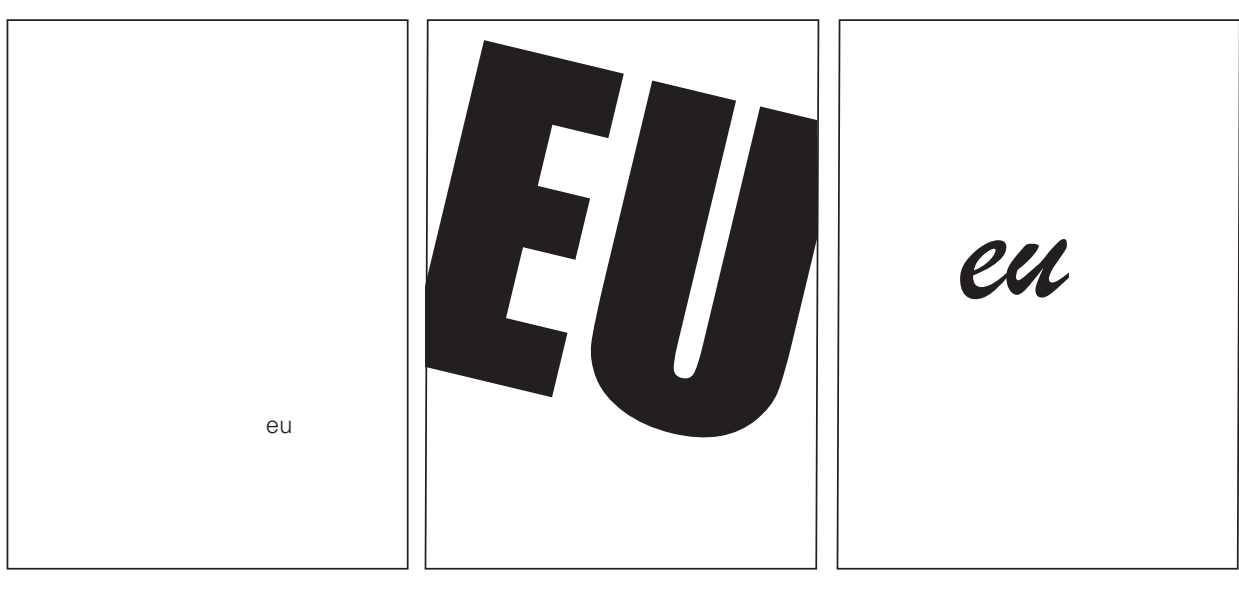

romanas 2.000 anos atrás proporcionou proporções básicas "para o que consideramos ser esteticamente agradável", da mesma forma que as minúsculas manuscritas do século $\mathrm{X}$ também inspiraram o modelo de nossas minúsculas atuais; no entanto, "o número de variações no desenho do alfabeto romano desde a invenção da imprensa é impressionante considerando-se suas limitações estruturais". (Swann, 1991: 55)

O pesquisador chama a atenção para o fato de que leitores podem, em alguns casos, associar a forma de alguns tipos às suas origens históricas e geográficas. Alguns tipos podem conotar a nação, o estilo particular de um país, como o exemplo apresentado de desenhos de letras que remetem à Irlanda, pois um dos mais conhecidos livros manuscritos apresenta um desenho específico que segue como estilo tipográfico do país. O autor (Swann, 1991: 55) apresenta outros exemplos, como um tipo transicional que lembra a Baskerville para representar os ingleses, um tipo sem serifa grotesco para representar os americanos, tipos de letras "quebradas" ou góticas para representar os alemães, além de um tipo da classe moderna (Bodoni) para representar os italianos.

Para argumentar que tipos podem ser associados a uma nação em particular, Swann cita Emil Ruder, que verifica que vários centros europeus, ao se separarem, começaram a imprimir suas línguas nacionais utilizando famílias tipográficas produzidas na região:

O desenvolvimento de fontes nacionais está intimamente ligado às diferenças entre as línguas daquele país. Garamond está intimamente associada com a língua francesa, Caslon com a língua inglesa e Bodoni com o italiano. Se um deles é usado para uma língua estrangeira, pode perder seu efeito. (RUDER, 1996: 44)
Em relação ao design editorial, Ruder chama atenção para diferenças na textura de um bloco de texto composto com o mesmo tipo, porém em línguas diferentes. Ele explica que apenas alguns designs de tipos podem ser utilizados em ampla variedade de línguas, como Meridien e Univers, ambos desenhados por Adrian Frutiger. Sabe-se que Ruder, professor da Escola de Design de Basileia, na Suiça, foi um dos mentores do "estilo internacional", que clamava por designs objetivos, neutros, atemporais e especialmente "internacionais" que pudessem ser compreendidos em amplo contexto, rompendo barreiras nacionalistas da linguagem visual.

Para defender sua hipótese, Ruder (1996: 42) apresenta testes com o mesmo texto traduzido em línguas diferentes e compostos com o mesmo tipo e a mesma mancha. Os tipos usados seguem na língua em que foram desenvolvidos e em alemão: garamond - francês e alemão; caslon - inglês e alemão; bodoni - italiano e alemão.

Os textos em alemão se apresentam claramente diferentes devido a especificidades da língua, como acentos, letras específicas e especialmente em relação aos substantivos que sempre se iniciam com letras maiúsculas, o que difere de outras línguas e que altera substancialmente a textura de uma página pelo excesso de maiúsculas no bloco de texto.

Ruder exemplifica o uso da tipografia Meridien (1996:44), criada por Adrian Frutiger, que, por possuir caracteres em caixa alta com altura menor que a dos ascendentes, comporta-se melhor em textos de outras línguas, especialmente a alemã.

Importante notar que o livro de Ruder, uma obra trilíngue (inglês, alemão e francês), é composto em Univers (também de Adrian Frutiger), fonte que ele acredita que se comporta bem em outros idiomas.

Apesar de Ruder acreditar que certos tipos como Garamond e Bodoni não funcionem em línguas diferentes das quais foram criadas (francês para a Garamond e italiano para a Bodoni), estas são fontes extensivamente empregadas em diversas línguas (em especial a Garamond) e talvez já tenham se tornado familiares em diversas culturas, fato que Ruder não leva em conta no seu texto. 
Em português, temos sinais que não são utilizados em muitas outras línguas, como a cedilha (ç). Laura Benseñor Lotufo ${ }^{17}$ (2010) pesquisou os impressos no Brasil Colônia e verificou que um dos primeiros textos impressos no Brasil (1747), "Relação da Entrada que Fez o Excelentissimo e Reverendissimo D. F. Antonio do Desterro Malheyro...", produzido sem autorização do governo português, já que "durante os séculos XVI, XVII, e XVIII, qualquer atividade impressora em terras brasileiras era proibida" (MELO, COIMBRA: 2011: 24) isto é, impresso de forma ilegal por António Isidoro da Fonseca, apresenta a adaptação pouco usual da cedilha (ç) compondo-a com um ponto de interrogação invertido abaixo da letra $C$ e do til ( ) composto por uma letra J maiúscula em cima da letra $\mathrm{O}$

Além da referência geográfica que as famílias tipográficas podem apresentar, os tipos podem ter a capacidade de persuadir. Swann (1991: 58) assinala que é comumente aceito que conotações emotivas das formas das letras são aplicáveis especialmente a projetos que pretendem persuadir, desta maneira opondo-se às que pretendem unicamente informar (design de informação): nesta última abordagem "espera-se que seja apresentada com o uso de famílias tipográficas neutras com o máximo de clareza". (SWANN, 1991: 58). Swann, no entanto, cita o exemplo de que mesmo tipos menos legíveis, como os góticos ou old english, foram recomendados na década de 1970 pela $\mathrm{HMSO}^{18}$ para o uso em documentos oficiais 'solenes'. Esse estilo tipográfico, old english ${ }^{19}$, segundo o autor, é acompanhado de uma forte conotação de antiguidade, talvez por ter sido muito utilizado em documentos oficiais e jurídicos "é o estilo tipográfico frequentemente utilizado por antiquários". (SWANN, 1991: 58)

A conotação de antiguidade apresentada por Swann também pode ser encontrada em faces tipográficas baseadas em desenhos cursivos dos séculos XVIII e XIX e comumente utilizadas em firmas tradicionais, especialmente de advocacia. (SWANN, 1991: 59)

Outro aspecto a ser considerado é relativo à composição, à estrutura visual da mensagem tipográfica. Swann (1991: 59) explica que, em pro-

17 http://www2.uol.com.br/historiaviva/noticias/a_primeira_fonte_tipografica_ brasileira_imprimir.html

18 Setor de Informação Pública Inglês

19 Estilo gótico sa (texto contínuo), o leitor costuma preferir textos com pouca interferência de leiaute, porém em outros tipos de mensagem, como pôsteres, há maior liberdade visual para atrair a sensibilidade estética do leitor.

Swann afirma que existem certas convenções, especialmente em tamanhos de tipos usados para a leitura de textos contínuos, mas que vez ou outra é possível fugir dos padrões e, dessa maneira, "inevitavelmente, podem afetar a interpretação semântica, da mesma maneira que sotaques regionais ou tons solenes afetam a linguagem oral". (SWANN, 1991: 61-66)

Hugh Williamson (1985: 104) explica, em Methods of Book Design, que, na seleção do tipo,

aspectos estéticos da impressão têm algum efeito; o material impresso parece mais legivel e a leitura parece se tornar mais precisa e rápida quando o material é impresso em um tipo esteticamente agradável para o leitor, mesmo sem este perceber.

Williamson assinala que:

O caráter, origem, ou "atmosfera" de uma série (tipográfica ${ }^{20}$ pode exercer uma influência sutil na seleção. É bastante óbvio que as letras possam ter a aparência delicada ou robusta; há qualidades menos óbvias em seus detalhes, que podem ser percebidas, mas que dificilmente podem ser descritas sem recurso a uma vaga extravagância da linguagem. Até certo ponto as características de uma série podem ser derivadas a parti da sua origem; para um texto que trate de um período ou um país, o design de um tipo produzido naquele lugar pode ser uma escolha particularmente adequada. No entanto, preferências 'alusivas' deste tipo devem levar em conta considerações práticas. (WILLIAMSOM, 1985: 104)

Ao tratar dos usos da tipografia em livros, Andrew Haslam (2007) indica diversas abordagens e muitas delas podem se relacionar ao contexto e também à atmosfera no livro, uma vez que existem diversos tipos e muitos deles conotam coisas distintas. Haslam afirma que:

Quando se escolhe um tipo de letra para determinado livro, muitas questões influenciam a decisão do designer, incluindo o conteúdo, sua origem o período em que foi escrito, seus antecedentes históricos, seu público leitor, a possibilidade de sua publicação em outras línguas, as questões práticas de legibilidade, a variedade de pesos, versaletes ou frações disponíveis na fonte, além dos custos de produção estimados. (HASLAM, 2007: 92)

20 Parênteses nosso 
Já que há variações de abordagens e necessidades manifestadas pelo próprio texto ou contexto de publicação, Haslam assinala que "é difícil fornecer uma orientação definitiva sobre a questão da escolha dos tipos", mas é importante observar soluções dadas de acordo com projetos da mesma categoria. (HASLAM, 2007: 92)

$\mathrm{O}$ autor apresenta algumas abordagens que podem ser utilizadas pelos designers na escolha dos tipos de um livro, como a de escolher uma fonte produzida no mesmo local em que o autor nasceu (HASLAM, 2007: 92), ou a uma tipografia alusiva a que ele usa como termo "pilhagem de tipos históricos" (HASLAM, 2007: 93), ou mesmo a ideologia "do internacionalismo", em que se trabalha a partir dos preceitos do Estilo Suíço que consiste em sempre usar uma fonte neutra, como Univers ou Helvetica (HASLAM, 2007: 94). O autor apresenta outras abordagens práticas e funcionais e uma lista de perguntas (HASLAM, 2007: 96) que o designer deve sempre fazer ao editor e explica a importância de o designer criar seu próprio briefing e descobrir qual abordagem ou metodologia é a mais apropriada para desenvolver determinado livro.

As abordagens na escolha da tipografia em livros apresentadas por Haslam indicam que podem existir diversos fatores na escolha de fontes de texto para livros que não necessariamente são usadas apenas por conta de sua legibibidade, mas por poderem de diversas maneiras se relacionar com o conteúdo de determinado texto, seja por razões históricas, geográficas, contextuais ou temáticas. Sabe-se, porém, que muitos livros, de acordo com a editora que os publica, mantêm um padrão editorial que não necessariamente remete ao contexto específico daquela obra.

Em Typefaces for Books, Sutton e Bartram (1999) apresentam uma coletânea de tipos em tamanhos diversos, como um catálogo para mostrar como certos tipos se comportam em um bloco de texto. Sobre a escolha dos tipos, eles acreditam que a tipografia dá o "tom", mas, assim como Warde: "Tipos para textos devem ser transparentes, permitindo que o leitor ouça a voz do autor sem distorções ou interferências." (SUTTON e BARTRAM, 1999: 7)
Sutton e Bartram (1999: 7) acreditam que a tipografia pode transmitir o tom da voz do autor, que pode ser um sussurro ou um canto, no entanto, o designer deve ter a consciência de que a tipografia deve ser clara. Apesar de a afirmação dos autores parecer contraditória, o que se infere dessa passagem é que há tipos claros o suficiente, mas que apresentam certos atributos formais ligeiramente expressivos que podem dar diferentes "tons" ao texto.

Hochuli e Kinross (2007: 46) também se questionam sobre a escolha da tipografia, "qual tipografia para cada livro? Um tipo contemporâneo para literatura? Caslon para Dr. Johnson? Walbaum para Goethe? para Homero, Dante, Henry James?". Os autores explicam a seguir que:

Cada tipografia interpreta o texto, mas a tipografia sozinha não faz nada. Os tipos manifestam-se meramente como formas de letras. O tamanho do tipo, a largura da linha, a entrelinha, a profundidade da coluna, a posição da área do texto na página, a tinta, o uso da cor e a qualidade do papel, materiais de encadernação; a presença física do livro, sua rigidez ou flexibilidade: todos esses elementos contribuem para dar sua impressão. (HOCHULI e KINROSS, 2007: 46)

Os autores (idem, 2007: 46) complementam a importância de como o papel influencia a aparência da tipografia, assim como Beatrice Warde (in BEAUJON, 1933: 8-9) no capítulo anterior também ponderou que "tipos modernos ou neoclássicos funcionam melhor em papéis lisos" e que tipos oldstyle mesmo impressos em offset "funcionam melhor em papéis macios e off-white", ou seja, em papéis não alcalinos, papéis com tons amarelados.

Ademais, Hochuli e Kinross (2007: 46) afirmam que:

há apenas uma regra: que o tipógrafo do livro seja um leitor sensível do manuscrito. (E de qualquer maneira, ele ou ela deve ser um leitor habitual!) Desse modo, a partir das fontes disponíveis, o tipógrafo vai escolher o que é apropriado para o trabalho e vai escolher todos os outros elementos constituintes do livro, para criar a "atmosfera" pretendida.

Danilo Pegorara Ferreira (2007) fez um levantamento sobre o uso de fontes em livros de ficção, especialmente best sellers, lançados entre 2006 e 2007 no Brasil (totalizando 32 volumes de editoras diferentes) e verificou a incidência das fontes nessas publicações: 9 livros foram compostos em Garamond, 8 em Minion, 3 em Sabon, 3 em Times, 2 
em Bembo, 1 em Deepdene, 1 em Electra, 1 em Helvetica, 1 em Joanna, 1 em Baskerville, 1 em Palatino e 1 em Schneidler. (FERREIRA, 2007: 71)

A partir de entrevistas com os designers de alguns desses livros, Ferreira percebe que o uso de determinadas fontes é atríbuido ao aproveitamento desses tipos ou a uma questão de identidade da editora e não a uma escolha baseada em critérios estéticos específicos.

Conclui-se, portanto, que, em determinados casos, o rendimento é um fator determinante na escolha. Não é a livre "escolha do designer" para este ou aquele livro, mas sim uma escolha que satisfaça as necessidades de orçamento da editora, sem, no entanto, comprometer as necessidades do texto. (FERREIRA, 2007: 68)

Middendorp (2012: 20), a partir de Hans Peter Willberg, apresenta uma classificação de modos de leitura e como deve ser o tratamento tipográfico relativo a esses modos: leitura imersiva, leitura seletiva, leitura consultiva, tipografia ativa, tipografia cenográfica e tipografia informativa.

A leitura imersiva pode também ser chamada de leitura linear: o texto é lido de forma concentrada do início ao fim em cada seção subsequente, página ou capítulo. Exemplos típicos são romances, ensaios e artigos de revista longos. (MIDDENDORP, 2012: 20)

O autor (MIDDENDORP, 2012: 20) explica que, nesse caso, o design não deve distrair o leitor e "um tipo amigável que não chama atenção para si é um pré-requisito”. Além disso, alerta para a importância da largura da linha e da entrelinha, pois se "o olho encontra dificuldade em encontrar o início da próxima linha, essa é uma falha do design”. É nessa categoria que, segundo o autor, se encontra a leitura de livros literários e, nesse caso, a partir do que expôs a simplicidade é requerida.

A leitura seletiva (MIDDENDORP, 2012: 20) refere-se a revistas, jornais e alguns livros ilustrados: "O objetivo do leitor é obter informação de modo rápido e eficiente". Para que isso aconteça, o autor explica que é necessária uma "clara divisão do texto e uma clara hierarquia".

A leitura consultiva, segundo Middendorp (2012: 20), relaciona-se à leitura de dicionários e de materiais de referência em que uma clara "navegação é essencial".
Sobre a tipografia ativa, Middendorp (2012: 21) explica que a estratégia "é chamar a atenção do leitor e estimulá-lo a ler". Ainda sobre este tópico, Middendorp acrescenta que "O principal objetivo da tipografia ativa é o olhar; a leitura acontece em uma segunda instância". Essa tipografia "ativa" é encontrada no design editorial especialmente em revistas (títulos, boxes etc.) e em capas de livros. Além do design editorial é usada na publicidade e em embalagens. Nesses casos, o autor explica que:

Legibilidade não é a principal preocupação aqui, nesse caso o espectador precisa, para ser seduzido, de todos os meios visuais disponíveis. Quase não existem regras ou receitas e os designers podem ser capazes de reivindicar muita liberdade. Dessa maneira, espera-se deles mais habilidade. A tipografia ativa é feita muitas vezes em equipes, nas quais os designers colaboram com escritores, editores e/ou especialistas em marketing. (MIDDENDORP, 2012: 21)

Outra modalidade apresentada é a da tipografia cenográfica:

qualquer trabalho de tipografia existe para dar a um texto a forma para abordar seu público. Mas nós nos reservamos o termo "encenação tipográfica" para aqueles casos em que a tipografia alcança seus objetivos, como em meios teatrais, truques visuais e efeitos especiais. É longe do mundo dos livros que as encenações mais impressionantes acontecem: na publicidade, em sequências de títulos de filmes (vinhetas), letras em espaços públicos, etc. (MIDDENDORP, 2012: 21)

Middendorp acrescenta que nessa modalidade não há "regras nem restrições. O céu é o limite". A última modalidade apresentada pelo autor (2012: 21), a partir de Wilberg, é da tipografia informativa, que se relaciona a sistemas de sinalização e orientação em que o designer lida com uma série de restrições e regras.

Após apresentar essas modalidades de leitura, Middendorp (2012: 22) retorna ao campo dos livros de literatura e aqui defende a invisibilidade

Há pouca utilidade em se criar uma forma surpreendente em livros de literatura. Em um romance ou ensaio - sem contar os estranhos romances ilustrados -, é a linguagem (verbal) ${ }^{21}$ que precisa fazer todo o trabalho. $\mathrm{O}$ texto é um fluxo de ideias com uma estrutura linear para ler do começo ao fim. Com meras letras, palavras e frases, um mundo completamente diferente é conjurado. O leitor é convidado a mergulhar fundo no texto -

21 Parênteses nosso. 
é por isso que esse tipo de leitura é chamada de imersiva. Ela geralmente funciona melhor quando o tipo e o leiaute não chamam a atenção para si e se aproximam do ideal da tipografia 'invisível'. (...) O livro literário é apenas um dos muitos meios de comunicação nos quais a tipografia desempenha um papel central. Como ele tem uma tradição tão rica e de desempenha um papel central. Como ele tem uma tradição tão rica e de
grande prestígio, há muito tempo, já foi estabelecida a discussão sobre tipografia e leiaute de textos. Os critérios para compor um texto literário linearmente, no entanto, não se aplicam necessariamente a outras formas de leitura.

Apesar de Middendorp (2012: 23) acreditar que a melhor maneira de trabalhar com o texto literário é de forma invisível, como exposto acima, ele ainda apresenta uma abordagem diferente, em livros de literatura, a qual chama de "tipografia narrativa", em que apresenta o trabalho da designer francesa Fannette Mellier, que trabalha a tipografia do texto literário de forma expressiva. Além do exemplo apresentado por Middendorp, observaremos nos próximos capítulos outros exemplos de tipografia narrativa ou até mesmo de tipografia cenográfica em livros de literatura.

A classificação dos modos de leitura de Wilberg apresentadas por Middendorp é acompanhada por abordagens distintas de acordo com a sua especificidade.

Baines e Haslam (2005: 124) também apresentam tipos de abordagens ou categorias relativas ao design tipográfico e explicam que em um trabalho podem ser combinadas mais de uma delas. As abordagens apresentadas são documentação, que se sefere ao trabalho mais simples como o de uma carta ou uma lista; analítico, relativo a projetos mais complexos como diagramas e mapas; conceitual, associado especialmente ao design para publicidade já que:

Faz o uso de trocadilhos, paradoxos, clichês e do pastiche; desenvolve símiles visuais, metáforas e alegorias; e combina duas ideias anteriormente não relacionadas para lançar luz sobre uma terceira. Com o uso de uma abordagem reducionista e geralmente simplista, designs conceituais apelam ao intelecto e dependem do designer e do público compartilharem a sutileza de um jogo de palavras.

A última abordagem apresentada pelos autores é a expressiva:

Uma abordagem expressiva é aquela que apela para as emoções do receptor. Como a música, ela apela primariamente a nosso coração: ela se empenha através da cor, da elaboração de marcas e do simbolismo para a "reposição" emocional do receptor. A clareza absoluta nem sempre é a intenção aqui: a abordagem do design é impressionista, poética e lírica, convidando o leitor a refletir sobre o conteúdo.

Baines e Haslam acreditam que, para a composição de um simples livro, algumas dessas abordagens são restritivas. Eles não afirmam qual dessas abordagens devem ser evitadas no design do livro, mas inferese que seja a expressiva. Baines e Haslam (2005: 125) explicam que, desde a origem da impressão, "o modo que lemos fundamentalmente não mudou" e que:

A estrutura da tipografia, como o design e a manufatura do tipo, fundamentalmente lida com temas de espaço vertical e horizontal, constantemente explorando a minúcia das relações de proporção dentro da forma da letra e do leiaute. Na impressão, o leitor é apresentado à informação que está fixada no tempo e na aparência, como determinado pelos editores e designers. Ainda que a presunção seja em geral de que a impressão é, por definição, linear e sequencial, a realidade é muitas vezes bem diferente. Uma vez que um livro é produzido, por exemplo, não há controle sobre como ele é lido ou acessado: isso se torna uma relação privada le sobre como ele é lido ou acessado: isso se torna uma relação privada
entre o leitor e o autor. De nenhuma maneira os livros são feitos para ser sequenciais ou lineares; trabalhos de referência, por exemplo, são elaborados para ser acessados de diversas maneiras, enquanto muitos artistas e escritores modernos lutaram para subverter as noções aceitas de um livro linear.

Sobre a escolha da tipografia, os autores (2005: 125) explicam que tipos podem ser escolhidos por motivos históricos, por exemplo, "enquanto um romance que se passa na Itália Renascentista ou no século XVIII na Inglaterra pode se beneficiar pelo uso de Bembo, ou Baskerville, respectivamente". Eles explicam, porém, que essa não é a principal questão ou o argumento crucial para a escolha:

O que importa é que o texto seja passível de leitura e atraente para seu público desejado hoje. Um conhecimento abrangente de história - da arquitetura e social, bem como da tipográfica - é um auxílio útil no processo de design, mas isso não deve se tornar uma camisa de força. Tipos de texto (em geral considerados como os de menos de 14 pontos) devem em geral ser 'auto-ofuscados': a ideia é ler as palavras, em vez de notar o tipo. Para uso em displays, porém - seja para panfletos, pôsteres, logos ou sites -, os designers podem escolher algo que chame mais a atenção e podem dar significado adicional por meio do emprego de um tipo com fortes poderes associativos 
Baines e Haslam (2005: 125-126) acrescentam ainda a necessidade que o designer tem de conhecer as especificidades de cada trabalho, ler o texto e basear sua escolha nas necessidades de cada obra, como se é um romance, se o texto inclui notas, números, subtítulos, intertítulos etc.

Outra questão levantada pelos autores, que já foi anteriormente abordada, relaciona-se com a escolha do papel e da adequação de certos estilos tipográficos a certos tipos de papel e impressão:

Nada supera o teste de opções no início do processo e os computadores atualmente permitem que os primeiros leiautes já simulem o design finalizado. Há uma relação entre os designs de tipos e os papéis nos quais eles foram originalmente impressos. Os tipos dos séculos XV a XVII (por exemplo Bembo, Caslon, Ehrhardt, Garamond, Janson), impressos em papéis razoavelmente ásperos, são muito diferentes em seus detalhes em comparação com aqueles do fim do século XVIII e do início do XIX (como Baskerville, Bodoni, Didot, Walbaum), que eram impressos em papeis de superfície mais lisa. Esses tipos mais antigos, pelo menos como eram originalmente usados, tinham certa robustez que pode parecer muito inadequada nos papéis finos atuais. Analogamente, a delicadeza de muitos tipos modernos não reproduzem bem em papéis de textura muito grossa. Analogamente, impressoras profissionais de 600 dpi são úteis na produção de materiais com aspecto inacabado de um design em uma variedade de tipos de papel, sua resolução pode resultar que, em certos tamanhos de texto, algumas das sutilezas do design de tipos acabem ofuscados ou, talvez pior, cruelmente imitados. (BAINES e HASLAM, 2005: 127-129)

Os autores (idem, 2005: 130) concluem essa passagem notando que, em romances ou em livros que contêm basicamente texto, o papel é geralmente offwhite. $\mathrm{O}$ uso desse papel, que diminui o contraste e a luminosidade, é útil também aos leitores que sofrem de dislexia. Por outro lado, livros ilustrados são melhor impressos em papéis revestidos e nem todo tipo de letra se adequa bem a eles: "Tipos com contraste abrupto entre (traços) ${ }^{22}$ grossos e os finos podem dar um efeito um tanto ofuscante, que pode se mostrar cansativo para o olho".

Para Williamson (1985: 104), a escolha da tipografia também deve levar em conta aspectos estéticos e sobre a questão "atmosférica", também acredita que pode influenciar a escolha, mas que considerações práticas devem ser levadas em conta:

22 Parênteses nosso.
Na seleção do tipo para o texto, o aspecto estético da impressão tem certo efeito prático; impresso significa necessariamente mais legível leitura parece ser mais precisa e rápida, quando o material está composto em um tipo no qual o leitor, talvez sem perceber, encontre prazer estético. (...) O caráter, a origem ou a 'atmosfera' de uma série pode exercer uma influência sutil sobre a seleção. Sejam as letras delicadas ou robustas na aparência pode ser óbvio o suficiente; há características menos óbvias de detalhe, que podem ser percebidas, mas dificilmente descritas sem o recursos a uma extravagância de linguagem. Num sentido limitado, o caráter de uma série pode ser derivado de sua origem; para um texto relativo a um período ou a um país, um design de tipo desse lugar ou dessa época pode ser uma escolha particularmente adequada. Uma escolha alusiva como essa deve, porém, ser ponderada ante considerações práticas.

Algumas fontes são mais legíveis do que outras e para o uso em textos Jury (2004:32) explica quais as características fundamentais que elas devem ter. As letras, para o autor, devem ser abertas e ovais, com serifas apoiadas moderadas e obviamente devem ter um pouco de contraste, mas não um contraste excessivo como no caso de Bodoni. Outra ponto importante é a proeminência das hastes ascendentes e descendentes, pois "ajudam a definir a forma das letras". Em resumo, para Jury,

A face do texto deve ter todas as quatro características, mas certamente é possível para um tipo ter apenas três das quatro e ainda ser satisfatório para muitos aspectos da composição do texto. A escolha específica dependerá de uma série de fatores, como o quão eficientemente o tipo preenche a página, o total necesário de 'cor' do texto e aquelas características que se adequam melhor à questão subjetiva. (JURY, 2004: 32)

\section{Retórica tipográfica}

Em The Rethoric of Neutrality, Robin Kinross investiga a tipografia em exemplos de design de informação, como em quadros de horários de estações ferroviárias, e apresenta exemplos de mudanças tipográficas relativas à época em que foram criadas.

Kinross explica que, para encontrar a retórica, ele costuma isolar um elemento de composição: a tipografia utilizada, explicando que o estilo das letras não é o aspecto mais importante em tipografia, porém "a escolha da face tipográfica sempre comunica ou indica ideias e crenças que informam o processo de design". (KINROSS, 1989: 135) 
A partir de sua investigação, o autor conclui o artigo afirmando que "nada é livre de retórica, que manifestações visuais emergem de circunstâncias históricas particulares, que vácuos ideológicos não existem" (KINROSS, 1989: 143)

Barnard (2005: 17), a partir de Kinross, afirma que o texto pode apresentar uma “(...) demonstração de como o design gráfico pode aparentar realizar apenas uma função, mas pode acabar apresentando outra função também".

Victor Margolin explica a importância do artigo de Kinross, pois o texto "levanta muitas perguntas sobre a crença dos designers modernistas de que a comunicação é um processo objetivo". (MARGOLIN, 1989: 20)

Mesmo que os exemplos de Kinross refiram-se ao design de informação (tabelas com horários de trens), os argumentos que apresenta demonstram que, mesmo aparentemente neutro, o design reflete ideais que podem ser políticos e culturais, e não somente formais. Esse estudo trata a tipografia como linguagem, portadora de um discurso que não pode ser negligenciado. Por mais que o designer possa querer não manifestar uma ideologia e um conceito por trás de um projeto, mesmo acreditando que o uso de tipos sem serifa como Univers ou Helvetica sejam necessariamente "neutros", eles remetem a um momento particular, o que Kinross explica como a "ideologia sem ideologia", ou seja, uma retórica sobre a neutralidade.

Brisolara (2009b) explica, a partir de apontamentos de Schriver (1997), que:

A legibilidade de um documento é, certamente, questão recorrente e necessária na elaboração de projetos tipográficos. Schriver (1997: 283) adverte, porém, que legibilidade não é suficiente, a escolha por uma determinada tipografia deve atentar para sua adequação retórica, ou seja, para "a relação entre a tipografia, a proposta do documento, seu gênero, a situação e as necessidades, desejos e propósitos da audiência". Tal adequação é o que irá influenciar o modo com que o leitor percebe, organiza e lembra o conteúdo. (BRISOLARA, 2009b: 74)

Brisolara afirma que o tratamento tipográfico pode ser usado para identificar o tipo de documento em que se trabalha e também aproxima a ideia de adequação tipográfica a documentos específicos, a tipos ou categorias de escrita propostas por Mandel (2006): escrita pública ou monumental; escrita cultural ou livresca; escrita privada ou usual; escrita informativa (jornalística); escrita informática (gerencial) e escrita publicitária (BRISOLARA, 2009b: 75).

Brisolara (2009b) apresenta também ideias do pesquisador Arroyo (2005), que articula a retórica com a tipografia:

A respeito destas competências, Arroyo (2005) argumenta que a tipografia opera, ao mesmo tempo, a retórica verbal e a retórica visual, um vez que as letras são signos tanto linguísticos (e aí se utilizam de artificios discursivos, como as figuras de 'retórica', quanto visuais, exercendo várias 'funcões' Nesse sentido, propõe um paralelo ente as funções retóicas da linguagem (língua) e as funcões, também retóricas, da tipografia. (BRISOLARA, 2009: 113)

Brisolara apresenta também a pesquisa de Ehses (1998 apud Brisolara 2009b: 114), que associa formas tipográficas a figuras de retórica como metáfora, personificação, sinédoque, metonímia, antítese, amplificação, elipse e aliteração.

\section{Materialidade}

Em Letter and Image, Massin (1970) mostra a importância da materialidade da tipografia, isto é, as qualidades estéticas dos desenhos, composições tipográficas e suas implicações históricas, a partir de um amplo panorama de tipografia explicitamente visual (contrárias à tipografia neutra e pouco expressiva), desde os primeiros poemas figurativos (poemas ropálicos gregos do século IV a.C.), capitulares decorativas da Idade Média, renascentistas e neoclássicas, retratos tipográficos do século XVIII, poemas visuais do final do século XIX e início do século XX e inclusive sinalização urbana e peças publicitárias até a segunda metade do século XX.

Massin afirma que a imagem é a linguagem universal da humanidade e lembra que elas já existiam nas cavernas pré-históricas e que milhares de anos as separaram da escrita, isto é, da "projeção abstrata do pensamento" (MASSIN, 1970: 7). Ele explica a importância da letra para a comunicação impressa, que muitas vezes passa despercebida ao olhar de "leitores apressados e impacientes" (MASSIN, 1970: 19). A letra é perceptível, mas muitas vezes é apenas a representação "invisível" e "silenciosa" da fala. No entanto, a partir dos exemplos apresentados pelo autor, a letra, isto é, sua configuração visual, deve ser percebida, 
uma vez que experimentos gráficos a evidenciem, como os que podem ser vistos há muito tempo nos manuscritos medievais anteriormente ao desejo de Marinetti e poetas visuais desejavam quanto "à liberdade das letras". (MASSIN, 1970: 19)

A letra é simbólica e, nesse sentido é compreendida como uma entidade, que pode ser vista isolada de seu contexto, isto é, do texto ou da palavra a que se refere: "Lançada em perspectiva, fazendo jogo de luz e sombra, habilmente distorcida, chama a atenção para os seus próprios valores estéticos". (MASSIN, 1970: 20)

A partir do exposto acima, verifica-se que muitos autores concordam que a escolha do tipo pode ser usada para conotar uma certa atmosfera em relação a determinado texto, porém outros acreditam que essa escolha deve ser feita por questões práticas. De toda forma, em linhas gerais a forma das letras, sua materialidade e os significados que essas formas podem dar são incontestáveis. Há inúmeras fontes (tipos) disponíveis para composição de textos, como já foi exposto, e cada uma delas apresenta particularidades tanto históricas quanto visuais que, de forma explícita ou implícita, podem contribuir na construção de significado ou criar certa "atmosfera". O leitor, por mais que se saiba que muitas vezes nem perceba diferenças de desenho dos tipos, pode, pela composição, ter experiências diversas.

Para apresentar essas diferenças e esses valores diversos, temos como exemplo a criação nos anos 1940 de uma proposta da Associação dos Artistas Gráficos Americanos (AIGA) ${ }^{23}$ para que quatro designers criassem projetos para o mesmo texto, ou seja, que cada um deles interpretasse-o. Os resultados, especialmente relativos à mancha de texto, são muito diferentes.

\section{ESTUdO DE CASO: 4 PROPOSTAS PARA A AIGA}

Para comprovar que alterações na escolha dos tipos alteram a percepção da página impressa de um livro, utilizaremos como exemplo um panfleto de número $67^{24}$, publicado em 1940 pela Associação dos De-

23 American Institute of Graphic Arts.

24 Thoreau's "Cape Cod": A problem in Book Design as solved by Rudolph Ruzicka, Helen Gentry, D. B. Updike, William A. Kittredge. A Keepsake of The American of Graphic Arts

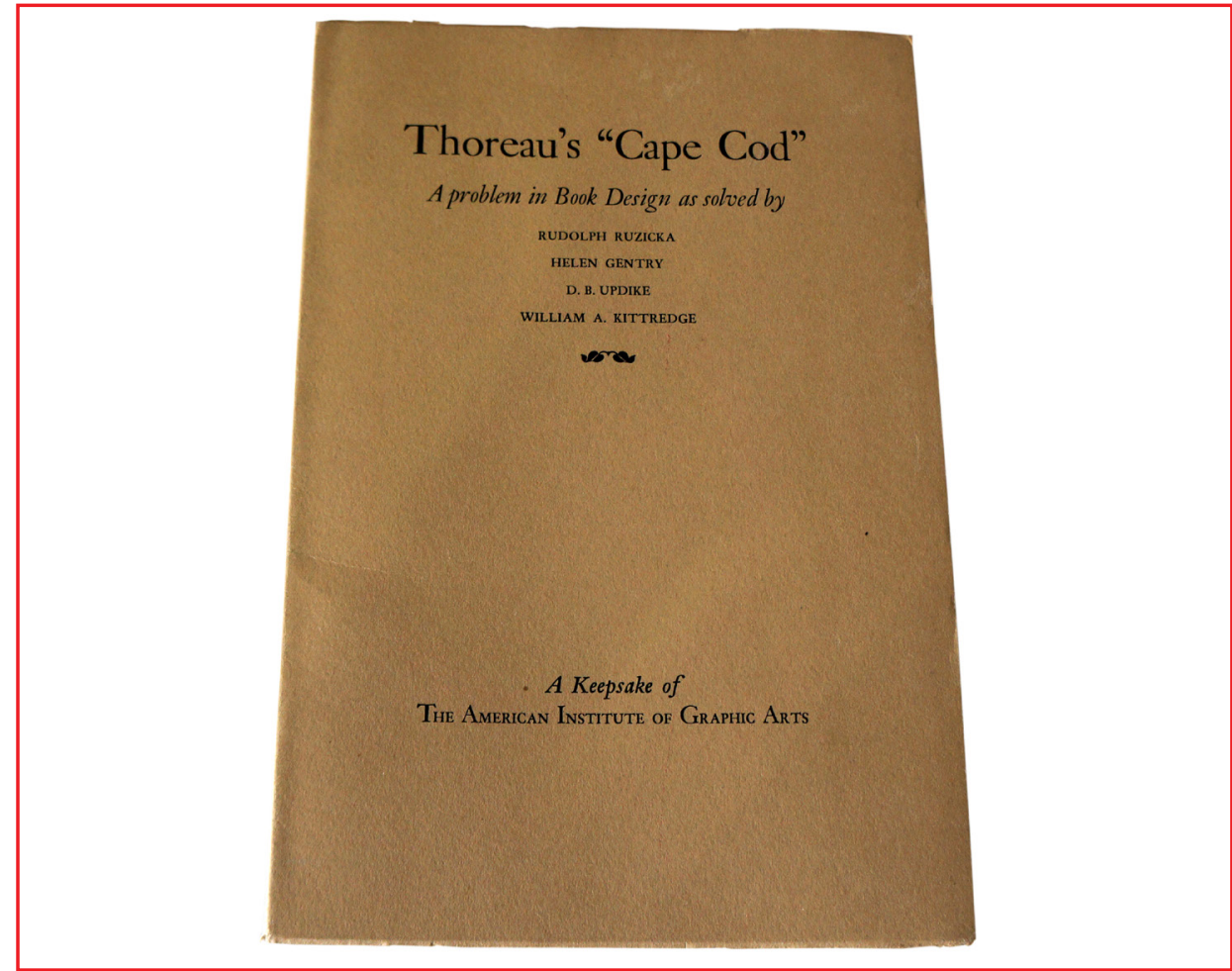

Capa do Folheto da AIGA

Acervo da autora

Foto da autora.

signers Gráficos Americanos, a AIGA (American Institute of Graphic Arts), que propôs a quatro designers que apresentassem cada um uma solução diferente de design para um mesmo texto. O escolhido foi um relato de viagem de Henry David Thoreau intitulado Cape Cod, que trata da jornada do autor no Estado de Massachusetts. Cada designer apresentou uma página de rosto, uma abertura de capítulo e uma página de texto. Os designers convidados foram Rudolph Ruzicka, Helen Gentry, Daniel Berkeley Updike e William A. Kittredge.

$\mathrm{Na}$ introdução do folheto se lê:

A Associação Americana de Artes Gráficas apresenta este panfleto No 67 como recordação para mostrar a solução de um problema idêntico em de sign de livros por quatro designers reconhecidos. Cada designer preparou uma página de rosto, uma abertura de capítulo e página de texto típico para uma nova edição de Cape Cod, escrita por Henry D. Thoreau, publicado pela primeira vez em 1865 . Os designers foram instruídos a usar o mesmo texto, limitando-se apenas en papel disponíveis ${ }^{25}$. Espera-se que a comparação das soluções deste problema, trabalhada de forma totalmente independente pelos quatro designers, seja de grande interesse aos membros (dessa associação) ${ }^{26} .{ }^{27}$

25 Os papéis utilizados foram fornecidos pela Strathmore Paper Company.

26 Parênteses nosso.

27 The American Institute of Graphic Arts presents this pamphlet as Keepsake No. 67 to 
O primeiro exemplo foi produzido por Rudolph Ruzicka (figura 56), que apresenta sua estratégia no texto abaixo:

Embora a página de rosto e a de texto do presente projeto estejam longe de um livro acabado, elas foram concebidas como as de uma obra completa. A ṕrina de abertura de capitulo indica o tratamento das nove restantes: as ilustrações decorativas variarão em tamanho e forma, e a posição do cabeçalho e o recuo da primeira linha serão alterados de acordo com elas. A cor também mudará de forma a corresponder à atmosfera menos sombria dos capítulos subsequentes, porém a cor será alterada de acordo com as nuances de uma escala apropriada ao tom acizentado do papel ${ }^{28}$

A capitular, pela descrição do projeto, é alinhada à imagem, e, pelo que parece pela descrição do recuo, a primeira linha vai variar de acordo com a posição da ilustração. A ilustração (xilogravura) é monocromática e representa um mar violento, com céu pesado, cujas linhas diagonais saindo de dentro das nuvens possam representar uma tempestade, que é também sugerida pela posição dos pássaros no canto esquerdo que pode representar sua fuga dessa tempestade. Outro elemento dessa imagem é um mastro de uma embarcação que parece cair no mar no canto inferior direito.

Em relação ao leiaute das páginas de texto, os numerais que aparecem no meio do texto são do tipo oldstyle (ou desalinhados). $\mathrm{O}$ formato é de 15,5 x $23 \mathrm{~cm}$ e foram utilizadas as seguintes medidas para as margens: superior $2,8 \mathrm{~cm}$, inferior $4,5 \mathrm{~cm}$, interna $1,8 \mathrm{~cm}$, externa 3,2 cm (aprox.). Largura da mancha 25 paicas, ou 10, $5 \mathrm{~cm}$, altura da mancha $37^{1 / 2}$ paicas ou $15,7 \mathrm{~cm}$. Os elementos textuais da página de rosto foram compostos centralizados e o mesmo lettering da página de rosto foi usado na inicial de abertura do capítulo. O texto composto em Fairfield, projetado pelo próprio designer, foi composto em corpo 12/14 justificado com recuo de 12 pontos, que dá uma média de $63 \mathrm{ca}-$ racteres por linha e 31 linhas de texto. Os títulos correntes foram com-

show the solution of an identical problem in book design by four well-known designers. Each designer has prepared a title-page, opening chapter, and typical text page for a new edition of Cape Cod by Henry D. Thoreau, first published in 1865 . The designers were instructed to use the same text, being limited in their schemes only by available stock sizes of paper. It is hoped that the comparison of the solutions of this single problem, worked out entirely independently by the four designers, will prove of interest to the mencer

28 O papel que Ruzicka escolheu foi strathmore book, white wove substance 80 (papel de extrema qualidade e com marca dágua). postos em maiúsculas de corpo 12 pt espacejadas e o fólio foi recuado da mancha de texto em $1 \mathrm{~cm}$. A mancha gráfica do texto é arejada, devido à propria leveza dos caracteres Fairfield, que apresentam pouco contraste entre traços grossos e finos e relativamente baixa "altura x".

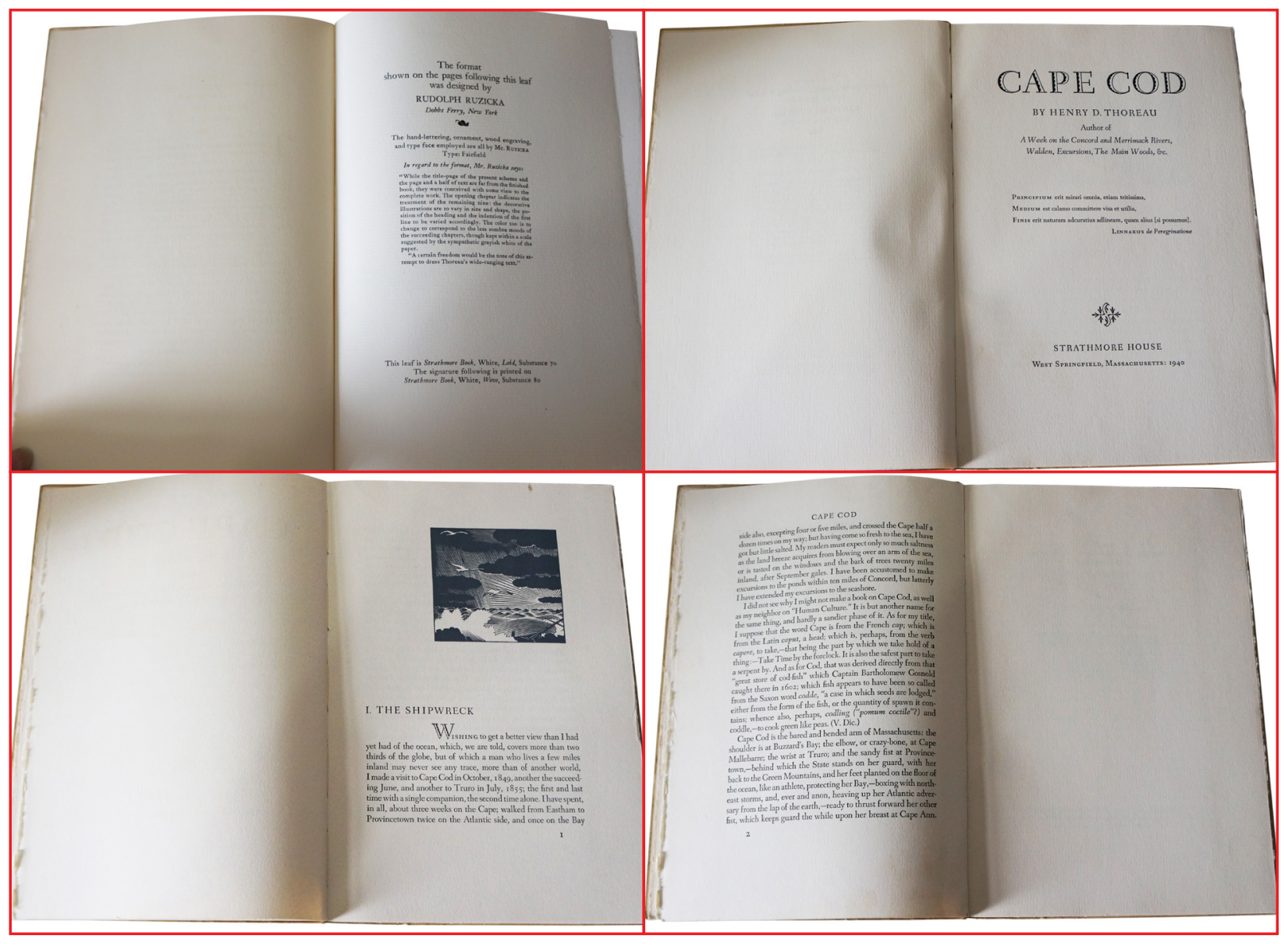

O segundo projeto é de autoria de Helen Gentry, da Gentry Press Figura 56. Proposta de (Figura 57). A designer explica que o problema inicial era o de tentar design de Rudolph Ruzicka projetar uma edição popular que pudesse atrair leitores não familia- para Cape Cod. rizados com esta obra de Thoreau. Ela explica que procurou trabalhar Fotos da autora. com um conceito formal vigoroso e a ilustração apresenta "não o homem e a natureza, mas o homem e o mar". Sobre a tipografia, explica que escolheu Bembo por não ser nem "seca" nem "barulhenta".

Na página de rosto, o título foi composto em bembo corpo aproximado 125 pt., em caixa alta e baixa na cor azul (um tom mais claro que o cyan e talvez com um pouco de preto na mistura, sendo um tom claro, porém sóbrio). A palavra Cape foi alinhada à esquerda na man- 
cha e Cod à direita. Talvez fosse necessário o ajuste de espaço (kerning) entre as letras minúsculas "a" e "p" da palavra "Cape", já que há certa irregularidade de espaços entre as letras. A tipografia, de classe garalde (Bembo), em tamanho display, ou seja, para título, apresenta muitas irregularidades de desenho. Na página de abertura há uma ilustração de Maxwell Simpson representando três homens descansando em um deque com o mar ao fundo. O formato utilizado foi o de 15,5 x $23 \mathrm{~cm}$ e as margens apresentam as seguintes dimensões: superior $3 \mathrm{~cm}$, inferior 4, $3 \mathrm{~cm}$, externa $3,5 \mathrm{~cm}$, interna 2,3 cm. A largura da mancha apresenta $9,7 \mathrm{~cm}$ ou 23 paicas, com altura de $16 \mathrm{~cm}$ ou 38 paicas. $O$ fólio foi alinhado à esquerda com uma entrelinha de distância entre a mancha e título corrente centralizado na parte superior junto ao fólio. O texto foi composto em Bembo com corpo e entrelinha de 11/13 pontos e a mancha apresenta 35 linhas de texto, com rendimento médio de 58 caracteres por linha. O papel escolhido foi Strathmore Book, Ivory, Wove, Substance 70

A terceira proposta foi projetada por Daniel Berkeley Updike (figura 58), na The Merrymount Press, em Boston.

Updike explica sua proposta: "Minha intenção era a de projetar um volume de preço razoável ${ }^{29,}$ portátil, que pudesse ser lido tão facilmente que o leitor não percebesse conscientemente seu design." Nessa frase, Updike aparentemente procurou desenvolver seu projeto com base na ideologia da invisibilidade, em que o leitor não deve prestar atenção ao seu design. Para os nossos referenciais contemporâneos, porém, o livro apresenta níveis "visíveis", como ilustração de abertura, ainda que a página de texto seja simples. Updike optou por trabalhar com um formato menor que os demais designers, tendo a seguinte medida: $12,7 \times 19,4 \mathrm{~cm}$.

Na página de rosto, Updike cria uma moldura geométrica ao redor de um mapa, com o texto integrado ao leiaute. $O$ texto em latim que se apresenta na página de rosto é posicionado dentro de uma bandeirola, como fazendo parte da ilustração. O título (corpo 36 pontos) foi composto em caixa alta e baixa em tipo Bulmer itálico. Para o nome do autor foi utilizado corpo de 12 pontos em caixa alta e, para a informação editorial, corpo de 9 pontos em itálico. Essas informações foram compostas em um blo-

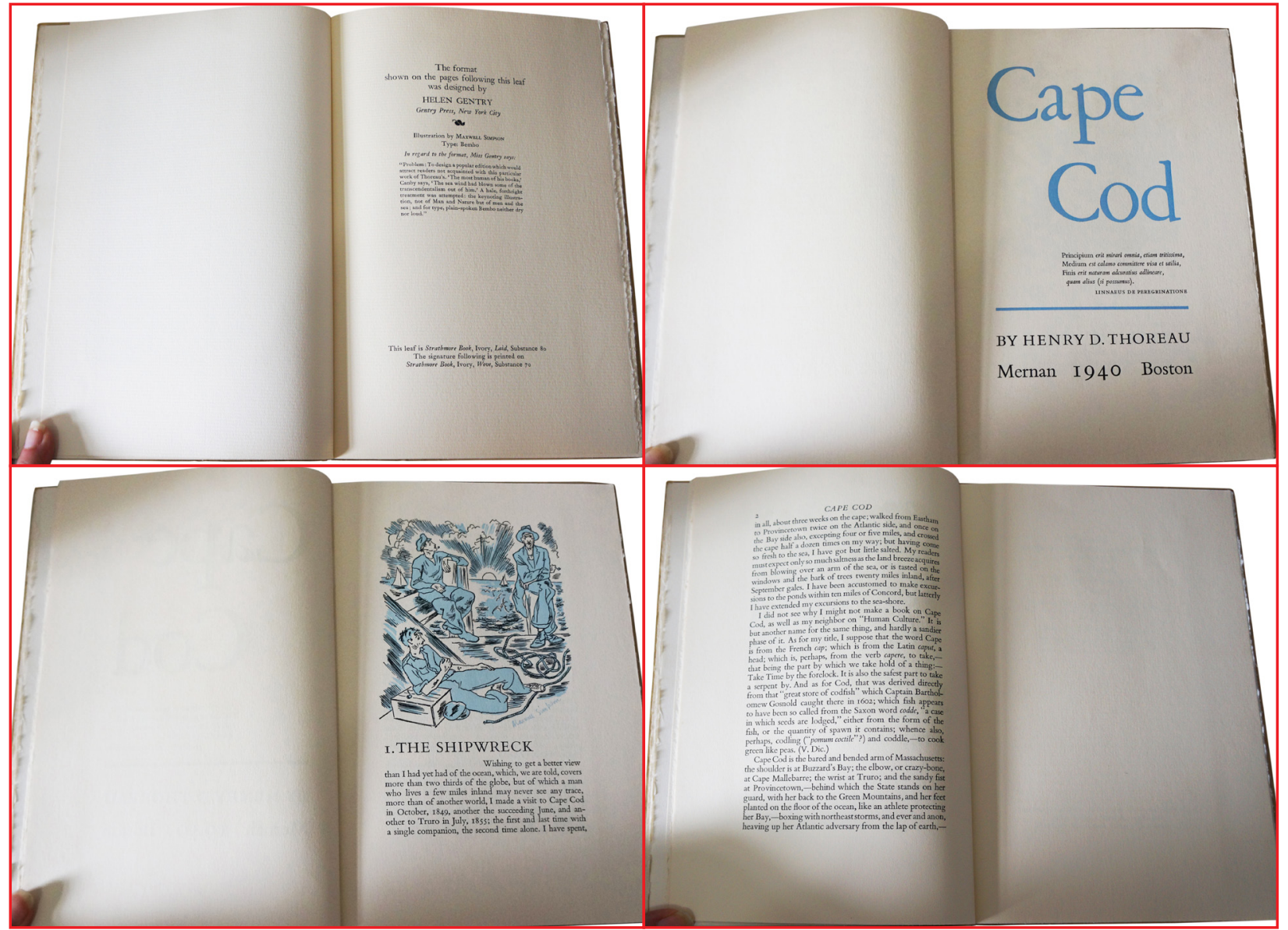

co de 4, $2 \mathrm{~cm} \times 1,4 \mathrm{~cm}$. O título do livro e o bloco com o nome do autor Figura 57. Proposta de apresentam quase as mesmas dimensões, já que o bloco do título tem design de Helen Gentry $4,0 \mathrm{~cm}$ e a mesma altura. As informações da cidade, data de publicação para Cape Cod. e a oficina tipográfica foram compostas em itálico, caixa alta e baixa em Fotos da autora. corpo de 16 pontos alinhado aos demais elementos textuais (blocado)

Para as páginas de texto foi utilizado o tipo Bulmer, composto em corpo 10 e entrelinha de 14 pontos com um rendimento médio de 55 caracteres por linha. A largura da mancha tem $8 \mathrm{~cm}$, ou 19 paicas, e altura da mancha 13, $1 \mathrm{~cm}$, ou 31 paicas. Como o tipo Bulmer é mais escuro (mais denso e contrastado que os tipos usados nas duas propostas anteriores), o designer provavelmente utilizou uma entrelinha maior para compensar a tonalidade da mancha gráfica. O fólio foi posicionado na parte superior esquerda alinhada à mancha e o título corrente em caixa alta em itálico em corpo 11 pt. O rendimento da mancha de texto é de 27 linhas e a dimensão das margens é: superior 2,2 $\mathrm{cm}$, inferior $4 \mathrm{~cm}$, lateral externa $2,6 \mathrm{~cm}$, interna $2 \mathrm{~cm}$ 


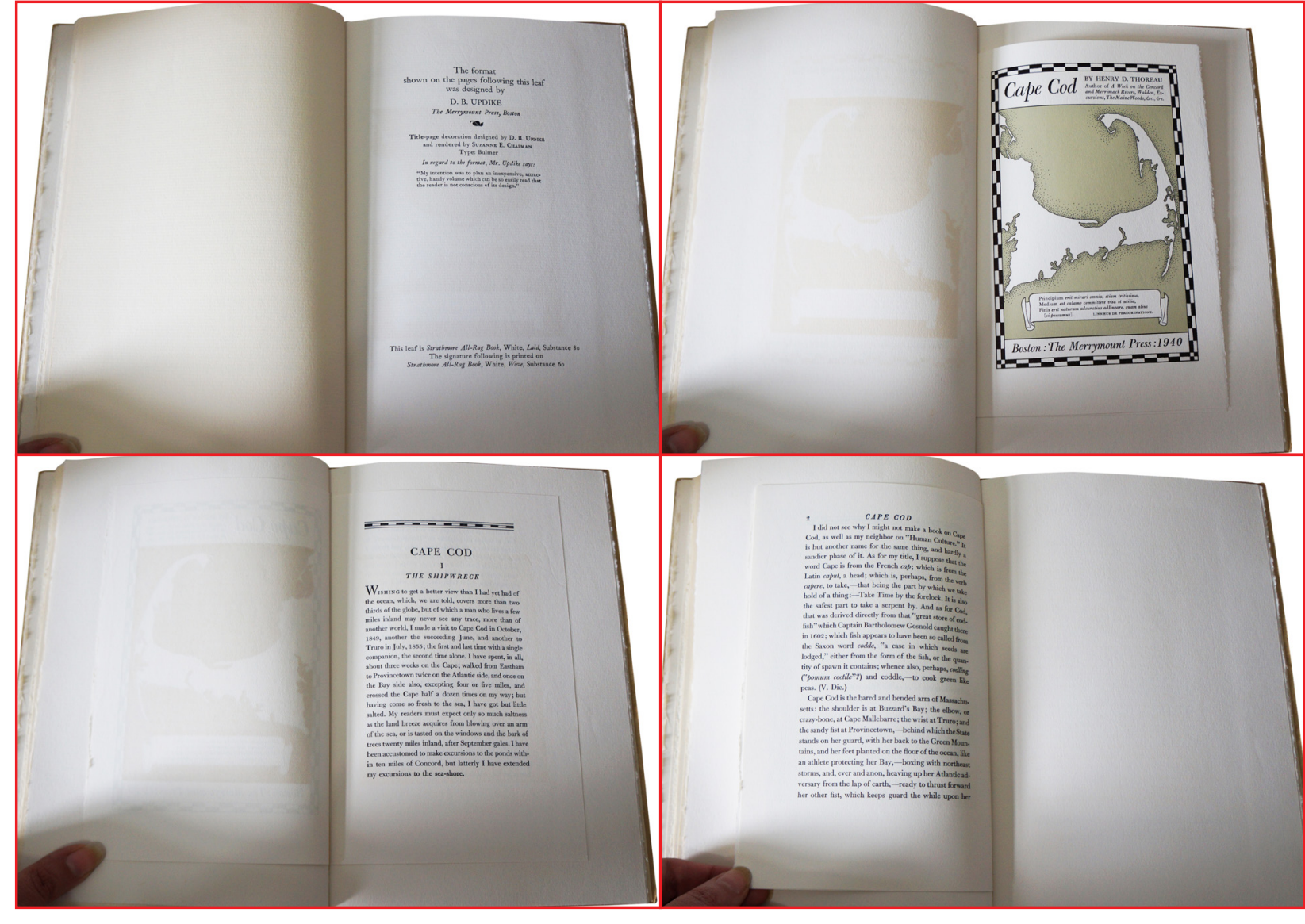

Figura 58. Proposta de A abertura de capítulo não apresenta ilustração, apenas uma linha design de Daniel Berkeley decorativa na parte superior com o título do livro em uma linha, o núUpdike para Cape Cod. mero do capítulo em outra e o título na linha subsequente. A página de Fotos da autora abertura apresenta mais texto do que as demais, já que há apenas um elemento decorativo. A primeira linha do texto abre com uma capitular com a primeira palavra em versalete.

A última proposta deste panfleto é de William A. Kittredge, da Lakeside Press, uma divisão de livros especiais da editora R.R Donnelley \& Sons Company, em Chicago (figura 59). Kittredge explica que:

Ao conceber este volume de "Cape Cod" de Henry D. Thoreau, tentei imaginar um livro impresso em tipo claro impresso em preto sobre um reluzente papel branco, com realces de tonalidade na posição e ilustraç̃̃es de abertura de capítulo para enfatizar ainda mais o agradável contraste do abertura de capitulo para enfatizar ainda mais o agradável contraste do
preto e do branco. Esta história, que trata de uma viagem autobiográfica de Thoreau, é repleta de ar e luminosidade e alusões à natureza. Neste projeto, presume-se interpretar e sugerir este 'estado de espírito' ao leitor por meio da ilustração, tipografia, gravura, papel e tinta. Se o livro é convencional na forma, é porque o designer quis interpretar com maior clareza os pensamentos do escritor sem se distrair com 'truques tipográficos'.
Neste projeto, para a página de rosto o título da obra foi composto em caixa alta em Scotch Roman espacejado, seguido na linha de baixo pelo nome do autor composto na fonte Ultra Bodoni, também espacejada e ocupando toda largura da mancha, seguido pelas informações editoriais com uma larga entrelinha, e logo abaixo uma ilustração com o mapa da península Cape Cod, com o texto em latim centralizado a ela com uma distância de uma entrelinha. O local, casa editorial e data encontram-se centralizados na parte inferior, com o nome da empresa que forneceu o papel em Bodoni ultra itálico em caixa alta espacejado, com a mesma largura do nome do autor. A data de publicação foi composta na linha de baixo em Scotch Roman itálico.

As páginas de texto foram projetadas de acordo com as seguintes características: o texto foi composto em Scotch Roman em corpo 12 e entrelinha de 16 pontos, e a mancha teve rendimento de 26 linhas (medindo 15,2 ou 36 paicas) e 9,7 de largura (ou 23 paicas). As margens apresentam as seguintes medidas: superior $2,9 \mathrm{~cm}$, inferior $5 \mathrm{~cm}$ lateral externa $3,5 \mathrm{~cm}$, lateral interna $2,2 \mathrm{~cm}$.

Figura 59. Proposta

de design de William A.

Kittredge para Cape Cod. Fotos da autora

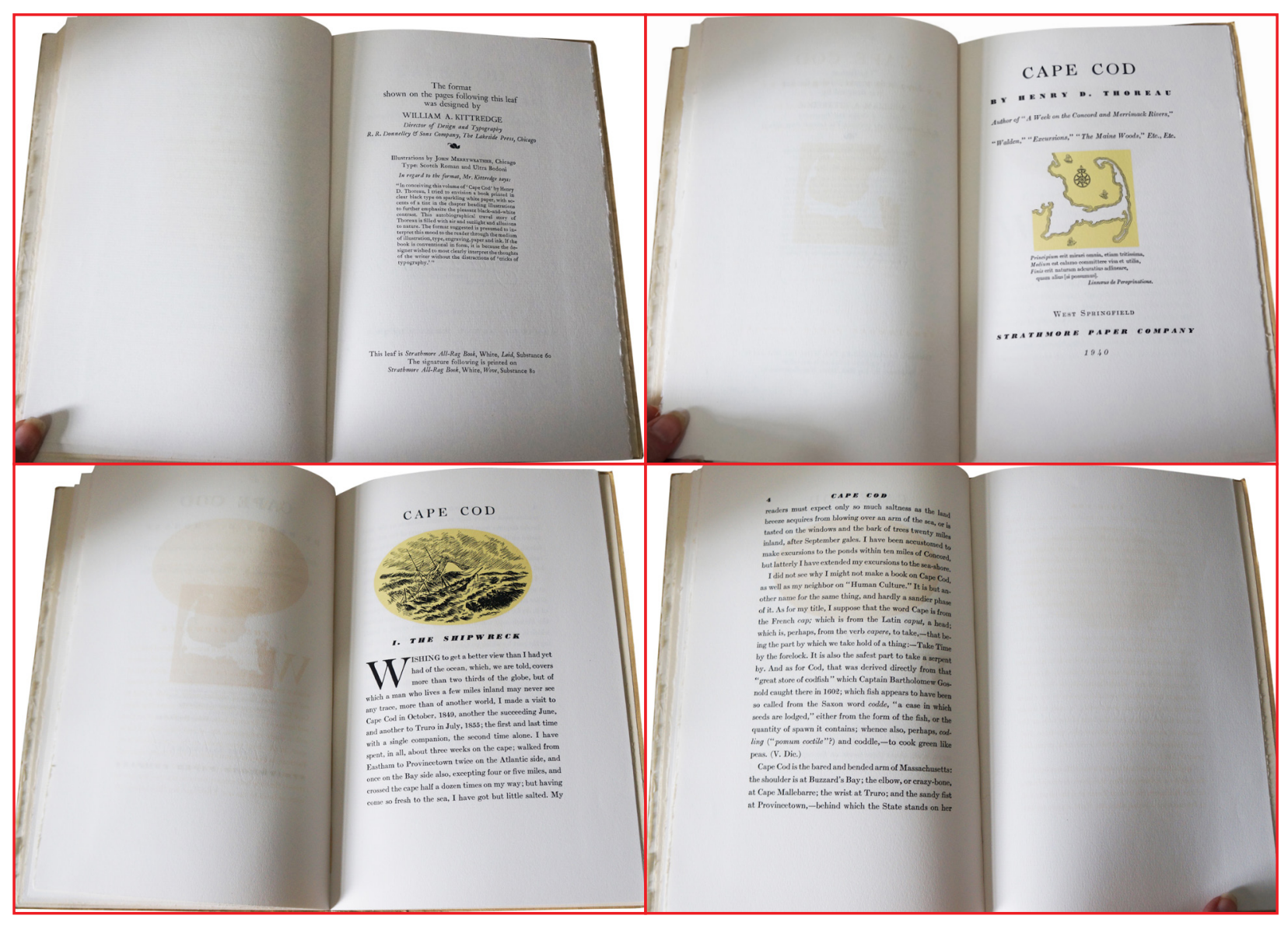


As entrelinhas e margens generosas provavelmente foram escolhidas para equilibrar a densidade do peso do tipo, que também apresenta contraste acentuado entre traços finos e grossos, por ser de classe moderna. O papel usado foi o Strathmore All-Rag Book, White, Wove, Substance 80.

Cape Cod, de Henry David Thoreau, descreve uma região praiana no Estado de Massaschusetts, na costa leste dos Estados Unidos. O capítulo inicial, "Shipwreck", apresentado no projeto das quarto versões, apresenta o local, a etimologia do nome do local (em que o capitão Bartholomew Gosnold encontrou bacalhau na região em 1602) e o desastroso acidente com uma embarcação, que teve como consequência inúmeras mortes.

As ilustrações das aberturas de capítulo de Ruzicka e Kittredge representam um mar violento, um ambiente de certa forma inóspito, que pode sugerir que algo sombrio como um acidente possa ter ocorrido.

Já Updike opta por um mapa, palavra citada no texto, uma vez que o autor o estuda para explorar o local, mas a ilustração talvez represente ainda uma ideia geral de descobrimento, de exploração e aventura. Helen Gentry opta por uma página de rosto lisa, apenas tipográfica.

É possível perceber nesse panfleto como cada solução é uma interpretação do designer sobre o texto. Ruzicka e Gentry escolheram tipos para a composição do corpo do texto mais leves e Updike e Kittredge, tipos mais pesados, mais contrastados e expressivos, talvez para conotar certa tensão e peso. Apesar de Kittredge e Updike terem escolhido tipos mais pesados, eles compensaram usando entrelinha maior para facilitar a legibilidade ${ }^{30}$.

Esses exemplos criados para o folheto da AIGA mostram a preocupação dessa associação em promover o design editorial na época e, ao selecionarem quatro reconhecidos designers para criarem quatro projetos gráficos diferentes de páginas de um livro em prosa, de certa forma, apontam que pode existir diversas possibilidades de leiaute para o mesmo texto e dessa forma, pode-se inferir, há uma crítica à padronização, já que cada projeto apresenta características diferentes.

30 Bringhurst (2006: 45) assinala que tipos mais pesados requerem mais entrelinha: "Fontes como a Bauer Bodoni, com cor forte e eixo vertical rígido, precisam de muito mais entrelinha do que fontes como a Bembo, em que a cor é clara e o eixo se baseia na escrita manual".

Os designers podem ter escolhido a tipografia e os demais elementos gráficos de forma a criar uma atmosfera para o texto. Ou como no caso de Daniel Berkeley Updike que em seu texto sobre o conceito criativo explicou que preferia um modelo compacto, funcional e que não atrapalharia a leitura, mas a fonte que ele escolheu é bastante densa se comparada às demais, o que, por consequência gerou uma página mais pesada, que poderia ou não remeter a densidade do texto, especialmente sobre o início do texto que trata de um naufrágio. Mesmo que as páginas de texto sejam parecidas e não tenham muita ornamentação, se comparadas às páginas de abertura ou às de rosto, a escolha da tipografia, a composição da mancha das quatro edições têm densidades e pesos diferentes, e porque não dizer, apresentam tonalidades diferentes. Assim, mesmo escolhas aparentemente "sutis", podem ter algum impacto, especialmente quando quatro edições são comparadas. De qualquer forma, não se pode saber qual era a intenção do designer na escolha da tipografia, mas se o conteúdo é o mesmo sua "entonação" visual é diferente, assim como diferentes atores ou diretores teatrais dão diferentes interpretações ao mesmo texto.

Vimos neste capítulo como a tipografia, especialmente para livros, é mais do que uma simples representação padronizada da linguagem. Há muitos tipos (fontes) e diversas abordagens que podem ser utilizadas para trabalhar com eles. Conhecer em profundidade aspectos anatômicos e práticos da tipografia parece ser fundamental para o desenvolvimento de bons projetos, além de propiciar um olhar mais aguçado sobre o texto literário, em aspectos anteriormente pouco "visíveis". 


\section{ABORDAGENS CONTEMPORÂNEAS "VISÍVEIS"}

No segundo capítulo, apresentamos um panorama sobre os livros de ficção "visíveis" desde o início da impressão até o movimento das prensas particulares, passando também pelas edições limitadas dos anos 1920 e 1930, em que foi notada a importância da "visibilidade" do livro impresso. Neste capítulo, trataremos de propostas contemporâneas do design do livro "visível".

Apresentamos, no capítulo anterior, um repertório teórico e crítico sobre a "visibilidade" da tipografia, um dos elementos mais importantes do design do livro, podendo inclusive ter um caráter expressivo e narrativo, como acontece em A cantora careca, de Ionesco, projetada pelo designer francês Massin, nos anos 1960.

Com exceção de A cantora careca, a maioria dos exemplos que serão apresentados neste capítulo foi produzida nas primeiras duas décadas do século XXI. Esses livros parecem retomar algumas das ideias já apresentadas, como a alusão e, especialmente, a de trabalhar o design do livro como uma interpretação gráfica do texto.

Os materiais utilizados e a forma como eram produzidas as obras são atualmente completamente diferentes. Os livros até agora apresentados eram impressos em tipografia (seja manualmente, seja em composição a quente em máquinas como linotipo e monotipo). Trataremos, aqui, de livros produzidos em escala industrial, impressos em offset e compostos digitalmente ${ }^{1}$ e não feitos de forma artesanal e limitada. Com os processos tecnológicos de hoje, o designer tem o completo domínio do processo e da criação. $\mathrm{Na}$ época em que os livros eram compostos com tipos de metal ou mesmo em fotocomposição, o designer não tinha total liberdade sobre a forma, pois dependia de outros profissionais, como os compositores, impressores e arte-finalistas. Adrian Wilson (1993: 68) apresenta uma lista dos materiais com os 
quais o designer trabalhava nos anos 1960 e nela réguas, tipômetros, papel quadriculado e canetas faziam parte de um processo no qual o leiaute era feito à mão. Hoje, com o computador, o processo é bastante diferente e o leiaute visto na tela pelo designer é muito próximo ao que será impresso. Essa revolução digital pode ser um dos fatores que impulsionaram ou inspiraram a produção de livros de literatura mais "visíveis", como os encontrados ao longo desta pesquisa. A indústria gráfica também mudou consideravelmente e hoje temos à disposição, de acordo com levantamento de Liu (2014), diversos acabamentos e processos gráficos. Infere-se, portanto, que novos recursos gráficos podem ter impulsionado os designers a aproveitar esses recursos.

Outra questão que deve ser considerada, a partir de Poynor (2003: 128-147), é que, a partir dos anos 1980, surgiram livros literários produzidos pelos próprios designers, e, em alguns desses volumes, percebe-se a relação entre o texto e o projeto gráfico como uma integração do pensamento do autor-designer. Alguns dos autores citados por Poynor são Warren Lehrer, Johanna Drucker, Graham Rawle e Mark Z. Danielewski, surgidos durante ou após o período considerado por alguns como Pós-Moderno². Poynor apresenta esses exemplos a partir do conceito do "designer como autor", cujas ideias podem ter sido reflexo de uma abertura dos processos criativos do designer a partir do conceito de "morte do autor", de Roland Barthes (POYNOR, 2003 118). É importante mencionar neste contexto também o impacto que teve a publicação do livro The Telephone Book (1989) de Avita Ronnel cujo designer Richard Eckersley, segundo Eskilson (2007: 357), traba-

2 Alguns dos autores /designers mencionados por Poynor como Drucker de Lehrer produziram na época livros em pequenas tiragens, mas outros como Danielewski e Rawle publicaram livros em grandes tiragens por editoras comerciais e dessa forma possawe influenciado o segmento.

3 Barthes (2004: 59) acredita que a crítica literária procurava entender a obra apenas do ponto de vista do autor, como se a obra não se dissociasse de seu criador. Ele considera que um texto não apresenta um unico sentido, que seria a "mensagem" do Autor-Deus, mas é um espaço de dimensões múltiplas: "o texto é um tecido de citações, oriundas dos mil focos da cultura." (BARTHES, 2004: 62) Para a crítica literária, havia o ideal de que, se fosse decifrado o autor, o texto seria explicado. Dessa forma, havia uma imposição de que o significado estava no autor e que o leitor precisava desvendar. Barthes assinala que, na crítica clássica, só havia uma figura na literatura, que era o autor, mas, segundo ele, a figura que realmente deveria ser estudada é o leitor: "o nascimento do leitor deve pagar-se com a morte do autor". (BARTHES, 2004: 64) lhou o design das páginas como uma interpretação gráfica do texto, como uma interpretação gráfica dos conceitos teóricos pós-modernos presentes no volume. Dessa maneira, pode-se inferir que essa abordagem, a de se interpretar visualmente o conteúdo textual de um livro, pode ser uma das muitas estratégias vinculadas ao design pós-moderno. ${ }^{4}$ Não é possível avaliar em que medida essas ideias tiveram impacto na produção literária atual e no design de livros, no entanto, o que se pode observar é que muitos dos exemplares analisados nessa seção apresentam uma clara relação entre texto e projeto gráfico, que pode ou não ser reflexo dessa atitude pós-moderna mencionada anteriormente, mas que talvez, de forma indireta, o trabalho dessses designers possa ter aberto caminho para uma visão mais aberta e mais interpretativa do design.

Outra questão que talvez possa ser um indício de uma tendência para que os livros tornem-se mais visíveis é a "suposta ameaça" do livro digital. Em um contexto de predominância de livros "simples", "padronizados", "descartáveis" ou "virtuais", é perceptível a crescente e recente abordagem de editoras comerciais por livros de qualidade, visual e materialmente mais experimentais. Editoras como a brasileira Cosac Naify, a britânica Visual Editions, a argentina Libros del Zorro Rojo e a mexicana Almadía, por exemplo, tratam alguns de seus livros de literatura como objetos integrados, com capa e miolo que apresentam relações formais, as páginas de texto de diversos livros apresentam tratamento particular e não padronizado, como o da maioria das editoras contemporâneas que produzem seus livros a partir de modelos pré-determinados. Além desse sentido de objeto único e integrado, evidenciam uma função estética, semântica e sensorial do objeto.

A visibilidade pode ocorrer por meio de distintas abordagens. Há livros em que existe uma interpretação tipográfica e livros nos quais as ilustrações são os elementos visuais em destaque, além de livros em que o uso dos materiais e a produção gráfica são os elementos que os tornam "visíveis". Nesse sentido, a visibilidade pode ser classificada conforme o destaque a um ou outro elemento:

4 Pode-se inferir como estratégia pois não é uma prática isolada, em 1978 alunos da Cranbrook Academy of Art produziram o design de uma edição de um periódico como uma interpretação gráicca do texto, como será debatido mais adiante 
- Tipografia (composição);

Acabamentos e materiais (produção gráfica);

Ilustração.

Há edições, no entanto, como Decameron, de Boccacio (2013), e Primeiro amor, de Samuel Beckett (2004), publicados pela editora Cosac Naify, em que tanto materiais, acabamentos, tipografia e ilustrações se integram, criando uma experiência única de leitura.

Neste capítulo, apresentaremos brevemente exemplos. Alguns dos livros foram mais explorados do que outros e isto se deve ao nível de importância. A Cantora careca ${ }^{5}$, por exemplo, foi uma obra privilegiada, por ser uma das precursoras na interpretação tipográfica do livro em prosa ${ }^{6}$. Além disso, no caso de outros livros havia mais material disponível para a análise. Foram realizadas entrevistas com designers da Visual Editions e da Cosac Naify, o que enriqueceu a análise aqui empreendida. Uma análise mais detalhada, porém, foi buscada em relação à edição de Bartleby, o escrivão, publicada em 2005, que será abordada em outro capítulo.

\footnotetext{
5 A cantora careca não foi a primeira "interpretação" tipográfica em prosa, pois experimentos como os de Kurt Schiwitters e Theo Van Doesburg já apontam um caminho Porém, experimentos expressivos em textos em prosa também não são novid 2004: 41). surgiram apenas no século XX. Massin (1970: 226) apresenta do autor francês Restif de la Bretonne (1734-1806) que pessoalmente compôs Monsier Nicolas usando diferentes corpos tipográficos no meque livro com variç̃es e ênfases no "que ele considerava ser

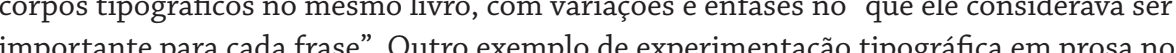
século XVIU é o de Laurence Sterne em A vida e as opiniões do cavalheiro Tristram Shandy (1759-1767), cuja importância foi apresentada por Camargo (2006: 103-104).

6 A interpretação tipográfica ou o uso da tipografia como recurso visual é muito antiga, pois desde a Grécia Antiga já se produziam poemas visuais. Os primeiros versos cuja configuração das palavras e pictorica (MASSIN, 1970: 158) surgiram na Grecia Antiga. Um importante poeta deste gênero foi Simmias de Rhodes, que viveu durande o reino de Ptolomeu I e escreveu os poemas visuais que representam asas, ovo e machado. Os poemas visuais ficaram muito conhecidos no final do século XIX e inicio do século XX a partir do trabalho de poetas como Mallarmé ou Apollinaire ou mesmo os futuristas. Como já observado, não sera abordada nesta tese a poesia visual, mas não se pode ignorar que ela pode ter influenciado de certa forma alguns designers, especialmente Massin (1970), que se dedicou a pesquisa de diversas manifestaçôes em que a tipografia aparece como element expressivo ao longo da história do design, da arte e da literatura.
}

\section{A Visibilidade do livro a partir \\ DA INTERPRETAÇÃO TIPOGRÁFICA}

Nesta seção, apresentaremos a visibilidade do design do livro literário a partir de uma abordagem que aponte certa interpretação tipográfica do texto pelo designer. A visibilidade do texto, da tipografia, claramente já foi muito explorada na poesia e em vanguardas artísticas do início do século XX, porém, talvez um dos exemplos mais explícitos de uma interpretação tipográfica de um texto em prosa tenha vindo de Massin. O designer francês desenvolveu, na década de 1960, interpretações tipográficas de textos teatrais que comprovam a possibilidade de se utilizar a tipografia de forma expressiva em prosa, não apenas em poesia, como o próprio designer já havia demonstrado em sua coletânea de textos visuais de 1970, Letter and Image. Neste trabalho, Massin apresenta a importância da materialidade da tipografia, isto é, as qualidades estéticas dos desenhos, composições tipográficas e suas implicações históricas, a partir de um amplo panorama de tipografia explicitamente visual (contrárias à tipografia neutra e pouco expressiva), desde os primeiros poemas figurativos (poemas ropálicos gregos do século IV a.C.), capitulares decorativas da Idade Média, renascentistas e neoclássicas, retratos tipográficos do século XVIII, poemas visuais do final do século XIX e início do século XX e inclusive sinalização urbana e peças publicitárias até a segunda metade do século $\mathrm{XX}$.

\section{A cantora careca}

Segundo Laetitia Wolf (2007: 7), Massin produziu uma série de interpretações de obras dramáticas e musicais que desafiam "radicalmente a estrutura linear de livros, rompe com as convenções de leiaute e cria um novo meio de expressão", ao introduzir uma nova abordagem experimental que altera as relações de escrita e leitura de um texto.

A primeira dessas interpretações foi o de A cantora careca, que pretendia introduzir noções temporais e espaciais do teatro para a página impressa. (WOLF, 2007: 78)

Wolf (2007: 78) adverte que, apesar de o termo "tipografia expressiva"7 ser amplamente associado ao trabalho de Massin, ele já tinha

\footnotetext{
7 Expressive typography.
} 
Figura 60. La Cantatrice chauve (The Bold Sopran A cantora careca), de 1950, de Eugène Ionesco (1909-1994). Adaptaçâo tipográfica de Massin (1925-), em 1964, para a ditora Gallimard. Image (WOLF, 2007)
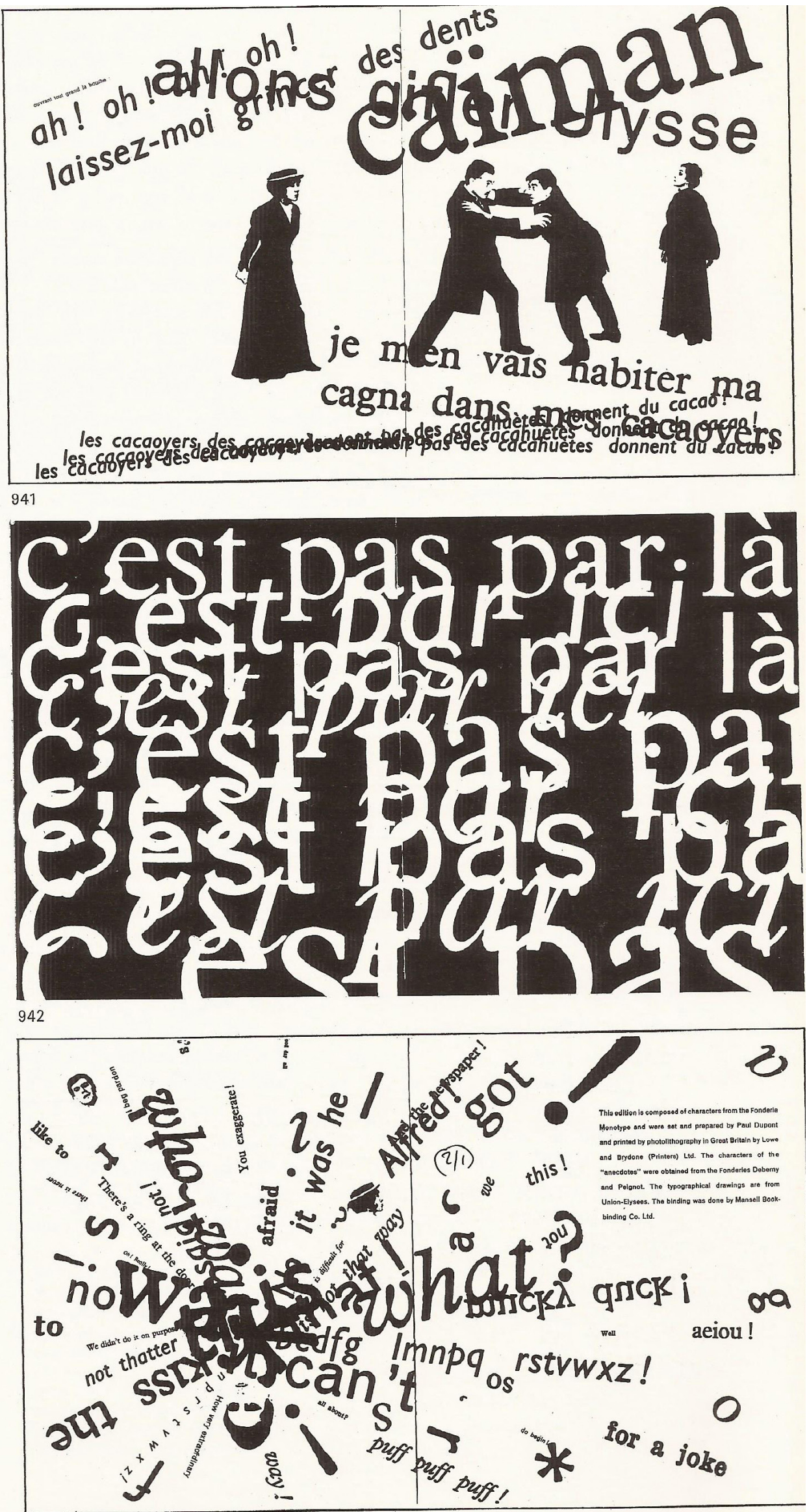

sido antes popularizado, como argumenta o tipógrafo Paul Shaw, pelo trabalho de Herbert Lubalin. Este utilizava a tipografia expressiva não como um meio mecânico de inserir palavras na página, mas como um recurso criativo.

É importante notar também que muitos dos textos dramáticos usados para suas "interpretações tipográficas" desafiavam a linguagem e talvez pudessem, dessa forma, ser compostos de modo expressivo: "Talvez a tipografia expressiva de Massin não tivesse prosperado se não se tornasse uma espécie de eco gráfico ao questionamento dos dramaturgos do período". (WOLF, 2007: 84)

As obras A cantora careca e Délire à deux, de Ionesco, e Conversation sinfonietta, de Jean Tardieu, "interpretadas por Massin" são textos do gênero da "teatro do absurdo", que questionavam problemas da comunicação, "ou da não comunicação", com a "autodestruição da linguagem". Dessa maneira, a partir desse tipo de texto, "a tipografia expressiva encontrou o terreno perfeito para testar seu papel”. (WOLF, 2007: 87)

Em suas transposições teatrais tipográficas, Massin fornece uma traducão gráfica do silêncio na conversação, a explosão e repeticão obsessiva de palavras e a onipresença de silêncio nas situacõos mais cômicas. Estes experimentos de tipografia expressiva, iniciados em meados da década de 1960, deixaram uma profunda marca sobre o mundo do livro - publicação e arte gráfica, não só através da escala de explorações mantida ao longo de livros inteiros, mas também através da ressonância cultural trazida a partir da tradução para o inglês da obra A cantora careca. (WOLF, 2007: 87)

Ainda de acordo com a autora (WOLF, 2007: 92):

A tipografia expressiva de Massin joga com o tempo, o som e o ritmo na página. A noção de tempo liga-se à experiência do leitor com o livro como um objeto que "se desenrola" a partir da ideia sequencial inspirada pelo cinema. A relação com o teatro se dá a partir da estrutura física do livro, que se conecta à narrativa da peça. $O$ desafio de trazer a vida a página por meios tipográficos é aprimorado por meio de fotografias ( $A$ cantora careca) bolhas e manchas (Délire à deux), que evocam o movimento dos atores no palco. Massin traz expressão visual para a linguagem oral através das relações dinâmicas entre variações tipográficas (famílias tipográficas, pesos e tamanho), letras entrelaçadas, linhas sobrepostas, o uso de fontes diferentes para traduzir de cada personagem entonação, velocidade, volume e dicção. (WOLF, 2007: 92) 
Meggs (1998) assinala a importância da tipografia expressiva de Massin, uma vez que, "durante os anos 1960 as comunidades de design e literatura ficaram surpresas e encantadas com a tipografia experimental de Rober Massin". Meggs explica também que seu trabalho possui afinidades com a tipografia dos futuristas e dadaístas, porém sua abordagem de junção da narrativa literária e das formas visuais em uma unidade coerente é capaz de expressar de forma única os significados da obra. (Meggs, 1998: 443).

A interpretação tipográfica de A cantora careca, do dramaturgo romeno Eugène Ionesco ${ }^{8}$, realizada por Massin e fotografada por Henry Cohen, segundo Wolf (2007: 99), foi criada a partir da encenação da peça por direção de Nicolas Bataille. Ainda de acordo com Wolf (2007: 101), Massin assistiu à montagem por vinte vezes e procurou representar graficamente aos leitores a experiência da encenação. Massin também gravou a peça em fita para procurar traduzir não só o texto da peça, mas as inflexões, as entonações e os silêncios dos atores. Esta edição foi publicada pela primeira vez pela editora francesa Gallimard em 1964 e teve como base o texto da "anti-peça" (anti-play), publicado anteriormente pela mesma editora em 1950. Esta adaptação teve edições traduzidas para o inglês nos Estados Unidos, em 1965 (The Bald Soprano, Nova York, Grove Press), e no Reino Unido, em 1966 (The Bald Prima Donna, Londres, Calvers and Boyars).

Segundo Wolf (2007: 99), La Cantatrice chauve foi criada por Ionesco após sua experiência cômica de tentar aprender inglês. Os diálogos são sucessões de expressões idiomáticas, provérbios, máximas e outras frases que tornam o todo sem sentido, em um ambiente de uma casa burguesa no qual seis personagens jogam com as variações linguísticas. Não há uma estrutura definida como no teatro clássico, "mas uma série de esboços fragmentados". A cantora careca, título da peça, não existe e, portanto, nunca aparece em cena. No entanto, apesar de não

8 Segundo Wolf (2007: 101): "Eugène Ionesco, pai do Teatro do Absurdo, nasceu na Romênia em 1909, de pai romeno e mãe francesa. Em 1938, ele se estabeleceu permanentemente em Paris, onde recebeu uma bolsa estatal para estudar poesia francesa. Foi relativamente tarde em sua carreira que lonesco escreveu A cantora careca (1949), que estilhaça clichês e lugares-comuns, tornando-os uma caricatura desenfreada, uma caricatura absurda (Ionesco preferia o termo 'derrisão' [zombaria, sarcasmo] a redução da linguagem a palavras desconectadas. Ionesco rejeitava a lógica do desenvolvimento da trama e do personagem, substituindo isso por uma farsa que ressalt a existência sem sentido da modernidade humana, em uma sociedade governada pelo caso e pela convenção". aparecer, como afirma Wolf, a cantora careca é mencionada pelo bombeiro em sua última aparição em cena: "Speaking of that - The Bold Soprano?" (IONESCO, 1965) $)^{10}$

O texto inicia com o casal, Sr. e Sra. Smith conversando em sua residência. Em seguida, aparece a empregada chamada para abrir a porta para a visita do casal Sr. e Sra. Martin. Enquanto espera pelos anfitriões, o casal Martin conversa como se fossem duas pessoas desconhecidas, mas acreditam já terem se visto antes. Nesse diálogo absurdo, uma série de eventos os leva a crer que são casados. Finalmente, o casal Smith se junta a eles e diz que não estão felizes com o atraso. Subitamente, toca a campainha e a Sra. Smith vai abrir a porta e não vê ninguém. Ocorre a mesma coisa novamente. Os casais discutem o mistério e chegam a um impasse sobre se há alguém atrás da porta sempre que se toca a campainha. Na quarta vez que a campainha toca, a Sra. Smith abre a porta novamente e, para sua surpresa, há um bombeiro esperando. O bombeiro entra na casa, é questionado sobre a sua presença e diz que tinha de averiguar se havia algum incêndio na casa. Todos afirmam que não. Os personagens passam a contar histórias sem sentido e chega o momento em que o bombeiro deixa o palco. Quando o bombeiro deixa a cena, as falas dos personagens tornam-se cada vez mais absurdas e, na interpretação de Massin, cada vez mais abstratas e gráficas.

Cada personagem é identificado por uma fonte diferente, embora os casais sejam apresentados por variações de uma mesma família: homem em romana e mulher em itálica. (WOLF, 2007: 101)

- Sr. Smith - Plantin

- Sra. Smith - Plantin italic

- Sr. Martin - Monotype Grotesque 215

- Sra. Martin - Gill Sans italic (adaptada para fazer par com a Monotype Grotesque 215, pois esta não possuía itálico.

- Marie, a empregada (maid) - Cheltenham bold roman (Massin via nessa personagem um tom mais masculino e optou por representá-la pela fonte romana em bold, diferentemente das outras mulheres, representadas em itálico (WOLF, 2007: 101)

- Bombeiro - Monotype Clarendon

9 “Por falar nisso, onde está a cantora careca?"

10 Esta edição norte-americana de A cantora careca não apresenta numeração de páginas. Provavelmente a edição francesa também não. 
Figura 62: Edição de A cantora careca com anotações de Massin para a interpretação tipográfica. (WOLF, 2007)
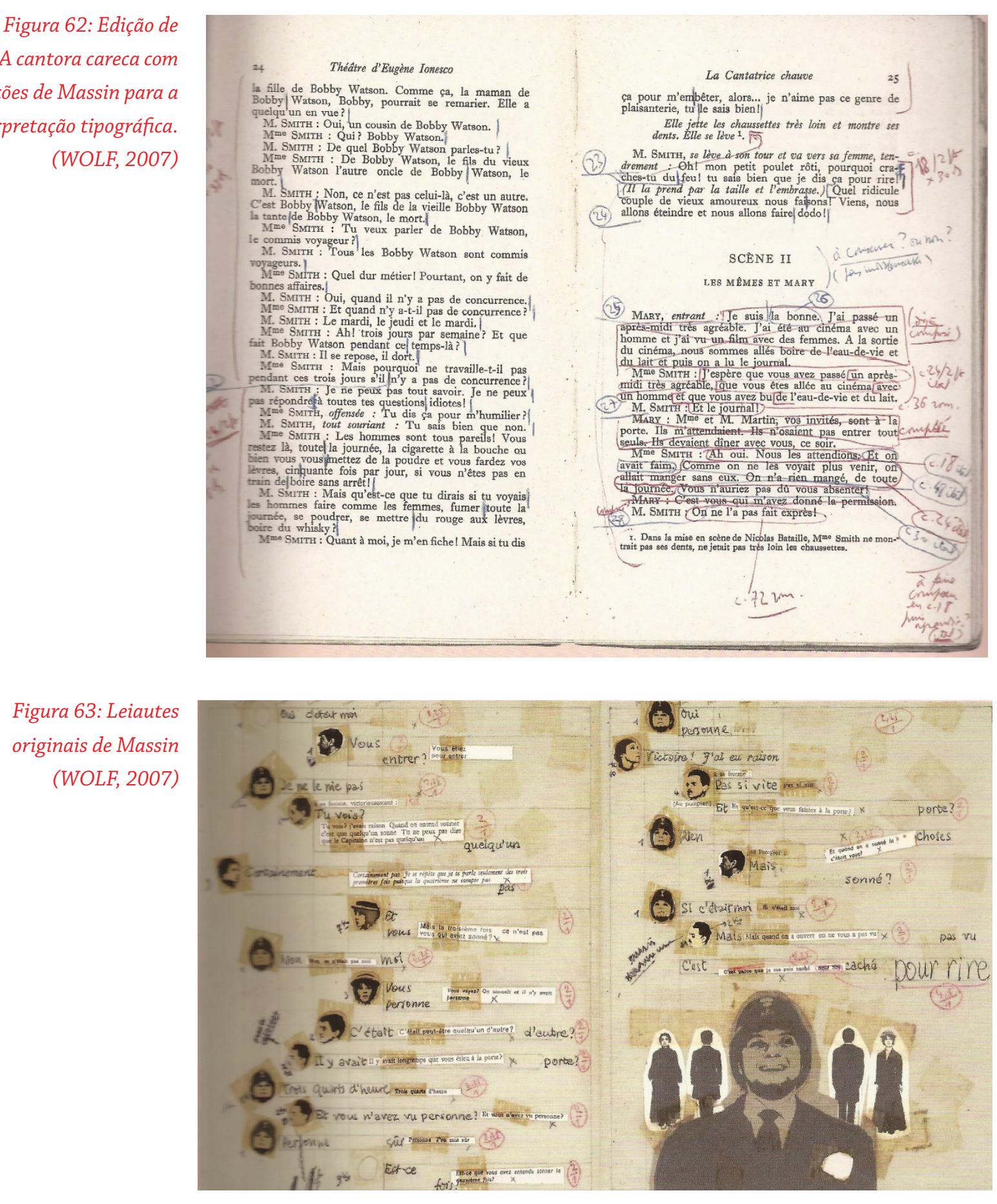

A diferença entre os tipos - entre as personalidades das fontes que representam os seis personagens - é mostrada na tabela (figura 61):

Este exemplo mostra a integração entre texto e projeto gráfico e, mesmo que o leiaute pareça radical, não é difícil de ler. É interessante notar como o designer optou por escolher fontes que expressassem o "caráter" dos personagens. As imagens também reforçam o projeto e criam uma ambientação e um contexto para o texto verbal.

Como já se observou anteriormente, este trabalho teve grande impacto por seu experimentalismo. Em entrevista, o designer e escritor Warren Lehrer ${ }^{11}$, que produziu livros com abordagem semelhante ${ }^{12}$, relatou que, para ele, Massin foi uma grande referência.

\section{Smith - Plantin}

aAbBcCdDeEfFgGhHilijlLmMnNoOpPaQrRsStTuUwWxXyYzZ 1234567890

Mne. Smith - Plantin italic

aAbBcCdDeEfFgGhHiJjflLmMnNoOpPqQrRsStTuUwWxxXyzZ 1234567890

\section{Martin - Monotype Grotesque 215}

aAbBcCdDeEfFgGhHiljJlLmMnNoOpPqQrRsStTuUwWxXyYzZ 1234567890

Mne. Martin - Gill Sans italic

aAbBcCdDeEffgGhHilijlLmMnNoOpPqQrRsStTuUwWx XyYzZ 1234567890

Marie, a empregada - Cheltenham bold roman

aAbBcCdDeEfFgGhHiljJILmMnNoOpPqQrRsStTuUwWxXyYzZ 1234567890

Bombeiro - Monotype Clarendon
aAbBcCdDeEfFgGhHiIjJILmMnNoOpPqQrRsStTuUwWxXyYzZ 1234567890
Figura 61. Tabela com as fontes usadas para cada personagem. Desenvolvida pela autora. 

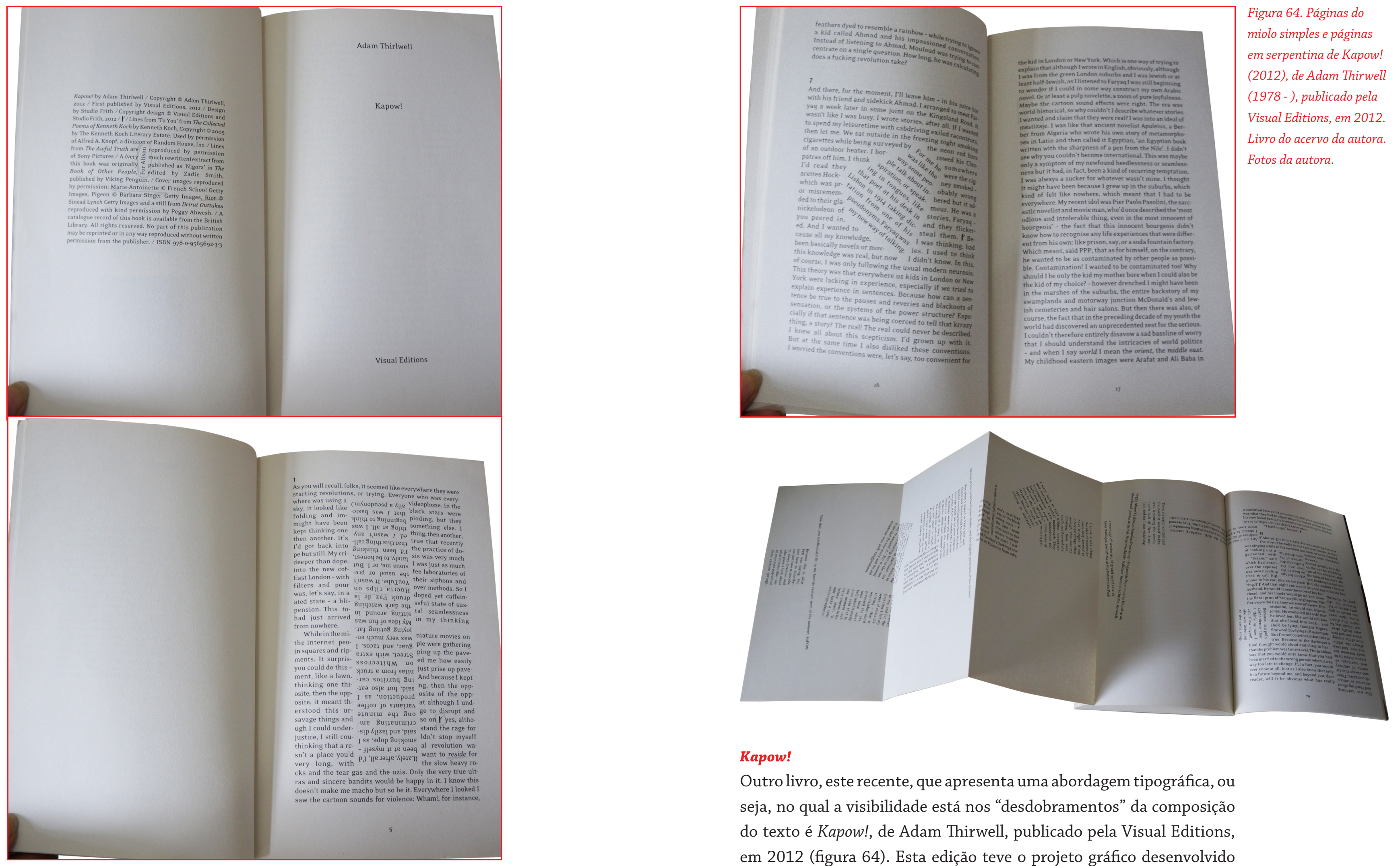

Kapow!

Outro livro, este recente, que apresenta uma abordagem tipográfica, ou seja, no qual a visibilidade está nos "desdobramentos" da composição do texto é Kapow!, de Adam Thirwell, publicado pela Visual Editions, em 2012 (figura 64). Esta edição teve o projeto gráfico desenvolvido pelo estúdio de design britânico Studio Frith. O volume apresenta, porém, recursos de produção gráfica em que páginas dobram e desdo- 
bram e há em uma parte do livro uma sequência de páginas em formato de "acordeão" ou "serpentina".

Em Kapow!, Adam Thirwell conta a história de um escritor, constantemente sob efeito de maconha e cafeína ${ }^{13}$, que busca escrever, a partir do relato de um taxista libanês chamado Faryaq, a história de seu irmão Moloud, salvo por outro taxista chamado Rustam, durante os manifestos de 2011 na Praça Tahir, no Cairo, Egito, na chamada "Primavera Árabe". O narrador se questiona sobre seu próprio conhecimento sobre o mundo árabe, a partir de notícias que ele lia em jornais, e sobre se poderia escrever sobre isso estando em outro continente.

Em um ponto de sua narrativa digressiva, ele questiona a própria forma que deveria ter seu texto:

Eu acho que, em vez disso, isso teve apenas algo a ver com esta nova mania por conexões, minha ideia de integridade que significava que você tinha que levar cada pensamento o mais longe possível, até todos os tristes becos sem saída. E para apresentar este novo modo de pensar eu comecei a imaginar novas formas, como sentenças desentranhadas, e múltiplas variações de alta velocidade na direção. Eu imaginei páginas em formato de sanfona de histórias, figuras coladas. E por que não? Não é que eu quisesse tornar as palavras visuais, como os antigos futuristas. Eu não acreditava como aquelas marionetes que fazer as coisa para seu olhar pudesse aumentar o poder expressivo das palavras. Mas estava imaginando uma história que era formada por tantas digressões evasões que, a fim de torná-la legível, ela precisaria ser dividida em cad direção. De modo que se fosse escrita como um bloco contínuo seria mesma, mas também diferente. Não era porque meu ideal fosse algum tipo de simultaneidade. Era mais como os russos que eu adorava, como Maiakovski e El Lissitzky - esta ideia de tentar fazer as coisas o mais rápido possível. Eu queria tornar a leitura uma experiência que envelhecesse você. (THIRWELL, 2012: 18-19)

No trecho acima o autor explica seu conceito formal e de escrita da obra que está produzindo, um conto sobre uma revolução árabe a partir do relato do taxista. O narrador pensa que a forma é a das "concertina stories", estórias que se dobram e desdobram. Ele explica que sua ideia não é a de tornar as palavras visuais (visíveis) e expressivas, mas elaborar uma história com múltiplas digressões e evasões.

13 Do trecho: "so I was let's say in a doped yet caffeinated state' a blissful state of suspension". (THIRWELL, 2012: 5)
A narrativa apresenta múltiplas interferências textuais dentro do bloco de texto principal e digressões "marginais", que se apresentam como blocos que "invadem" o texto principal. É possível ler a mancha principal sem ler os textos marginais (ou textos ruídos), espécies de notas deslocadas espacialmente. Há um texto contínuo, apesar da mistura entre o conto e a experiencia de ouvir o taxista narrando a história e a própria reflexão do narrador sobre a forma que o conto deveria ter, ou as reflexões sobre modos de escrever.

O próprio conceito gráfico é, de certa forma, justificado no próprio texto:

Digamos que eu apenas nutria esta ideia de escrever algo que continuasse se desdobrando sobre si, uma história que absorvesse quantas outras fosse possível. Então eu comecei ali, com Faryaq, na congelante cidade de Londres, dizendo para mim sobre algo acontecendo em outra parte, no lugar da revolução. Ele queria me contar a história de seu irmão te, no lugar da revolução. Ele queria me contar a história de seu irmão
Moloud, que foi um de seus heróis da revolução. Com seu companheiro chamado Ahmad e seu novo amigo Rustam, eles iriam reformar o mun do. Mas enquanto Faryaq estava contando uma história - a de Rustam e Mouloud e a trajetória deles, ou seja, o que for através da floresta da revolução, eu continuava vendo outra história com Faryaq que eu não estava relatando para mim. Eu pensava em Ahmad, o companheiro, como o verdadeiro herói desta outra história - que era uma história de amor, e sua heroína era Nigora, a mulher de Rustam. Dentro da história de Faryaq havia outra, que ele não podia ver. (THIRWELL, 2012: 19)

Antes da conclusão, o autor escreve em uma das notas "e esta é a última das minhas histórias sanfonadas"14 (THIRWELL, 2012: 76), que precede cinco páginas dobradas em sanfona com diversas notas espalhadas.

Sobre o projeto gráfico do livro, Steven Pole $(2012)^{15}$, em crítica para o jornal The Guardian, argumenta que, apesar desses truques gráficos refletirem os príncipios do texto, "as estórias dentro das estórias" poderiam ser, em vez da forma em que se apresentam, "inseridas entre travessões, parênteses ou notas de rodapé". Pole acredita que:

Tais jogos com o leiaute teriam uma justificação temática maior como em House of Leaves de Mark Z. Danielewski, mas mesmo nele não seriam absolutamente novas. Logo, em Kapow! a descrição do narrador de sua fiç̧ão como "um novo tipo de estória" (representando não menos do que

14 Do original "and this was the last of my concertina stories".

15 Disponível em http://www.theguardian.com/books/2012/may/25/kapow-adamthirlwell-review; acesso em maio de 2015 
"uma nova forma de pensar") parece um tanto otimista. De qualquer forma, o narrador confessa que o ponto principal é cansar e entediar o leitor: "Eu queria tornar a leitura uma experiência que te envelheceria". Nisso, ele se sai admiravelmente bem.

Ao final de sua resenha crítica, Steven Pole afirma que, apesar do visual da obra, do leiaute do livro ser "datado", é o texto, a escrita em si, que é interessante.

Nicholas Royle (2012) ${ }^{16,}$ em texto para o jornal Independent, argumenta que:

As estórias de Nigora, Ahmad e Rustam se desenrolam contra o pano de ça Tahrir. Para refletir a natureza da revolução e da multiplicidade de histórias, o livro parece uma represália tipográfica. Digressões, apartes factuais e observações entre parênteses deslizam através da página ou aparecem de cabeça para baixo, mesmo correndo em páginas extras que se desdobram do corpo principal do livro.

Para Royle (2012), embora o projeto gráfico não seja convencional, a narrativa é convencional:

Enquanto a impressão inicial é de um arrojado experimento formal do romance polifônico, uma vez que torna-se evidente que a maior parte das inserções funcionariam como notas de rodapé, também se torna claro que este é um romance surpreendentemente convencional - se romance. Não há nada errado em ser convencional, mas é uma arapuca parcecer ousado quando na verdade não se é ${ }^{17}$.

Ambos os críticos de certa forma concordam com o fato de que não há motivos tão evidentes para que o leiaute fosse dessa maneira. Ou seja, para eles, a obra não "justifica" tanto a escolha do projeto gráfico. No texto, porém, o autor defende em algumas de suas digressões que esta é a forma ideal.

16 Disponível em: http://www.independent.co.uk/arts-entertainment/books/reviews/ kapow-by-adam-thirlwell-7734226.html; acesso em maio de 2015.

17 While the initial impression is of a bold formal experiment with the polyphonic novel, once it becomes evident that for the most part the inserts work as unanchored footnotes, it also becomes clear that this is a surprisingly conventional novel - if novel it is. There's nothing wrong with it being conventional, but it is tricked out to look tricksy, while the rick is that it's not.
A leitura é interrompida por essas "digressões", o que pode ser um pouco cansativo. Por outro lado, o texto em si convida a isso. Sabe-se que muitas vezes notas de rodapé podem não ser lidas e são pouco convidativas à leitura, mas essas digressões, do modo curioso em que se apresentam, podem convidar o leitor a lê-las, a interromper um pouco a leitura e a retomá-la, o que pode ser exaustivo, mas interessante ao mesmo tempo.

Além disso, a leitura torna-se também a experiência de abrir as páginas, dobrar e desdobrar, ler além da mancha do texto principal, tocar um papel de uma gramatura um pouco maior do que a maioria dos livros encadernados em brochura e ver, ou admirar, a materialidade da página impressa.

Fragmentos compostos com a mesma fonte, mesmo corpo e mesma entrelinha invadem o texto, às vezes em formas regulares como círculos e quadrados e às vezes irregulares. Esses fragmentos por vezes estão ocultos nas páginas em "sanfona" que se desdobram. O papel, branco alcalino, tem uma gramatura maior que a normal em livros, provavelmente mais do que $100 \mathrm{~g} / \mathrm{m}^{2}$ e esse recurso, da alta gramatura, deve ter sido utilizado para que não se veja nada através do papel. A encadernação do livro é em brochura com capa flexível. Na capa, foi utilizado como elemento principal a imagem de Maria Antonieta (personagem recorrente nas digressões sobre revoluções do narrador) com o título e um ponto de exclamação gigante "cortando" a imagem. Na contracapa há a imagem de um pé quebrando algo, como uma sugestão de revolta, contestação, revolução.

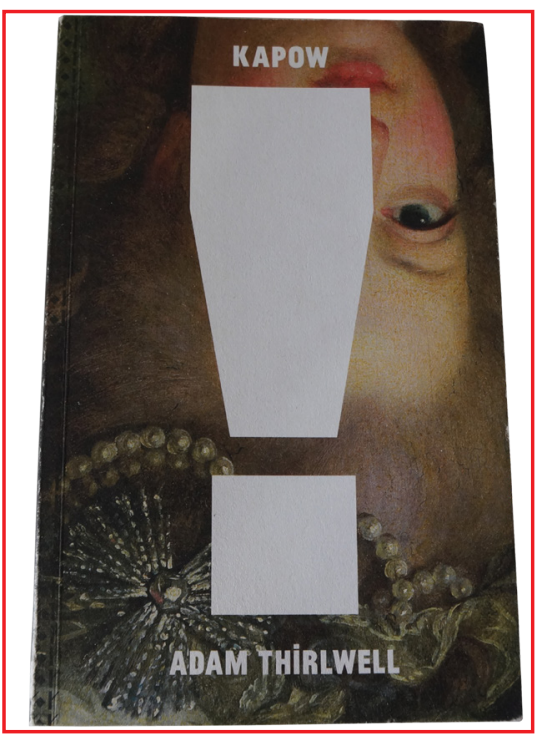

Figura 65. Capa de Kapow! (2012), de Adam Thirwell (1978 - ), publicado pela Visual Editions, em 2012. Livro do acervo da autora. Fotos da autora. 


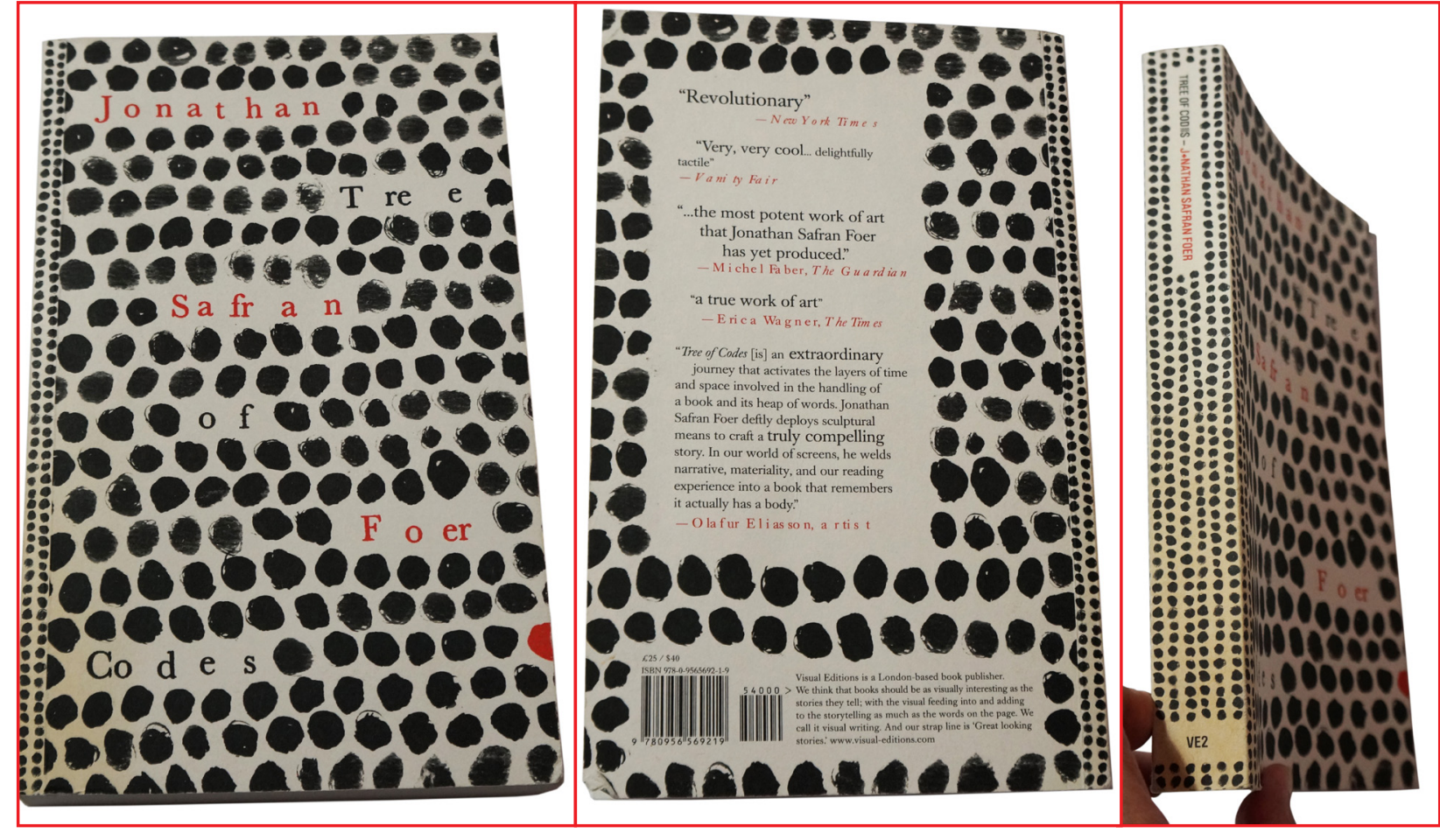

Figura 66. Capa, contra A VISIBILIDADE DO LIVRO A PARTIR DA PRODUÇÃO GRÁFICA capa e lombada de Tree of

Codes (2010), de Jonathan Nesta seção, serão apresentados exemplos produzidos nas últimas Safran Foer (1977-), duas décadas em que o design do livro o torna visível, especialmente publicado em 2010, pela Visual Editions. Livro do

acervo da autora.

Fotos da autora. pelo uso de recursos materiais (tipos de papel e outros substratos) e de acabamentos gráficos (faca especial, uso de cor especial, encadernação etc.). Os exemplos apresentados foram produzidos pelas editoras Visual Editions (Inglaterra) e Cosac Naify (Brasil).

Tree of Codes

O livro Tree of Codes, de Jonathan Safran Foer, publicado pela editora inglesa Visual Editions (figuras 66 e 67), em 2010, foi "escrito" a partir de recortes no texto original de Bruno Schulz intitulado The Street of Crocodiles. O livro foi projetado pelo Sara De Bondt Studio e a composição da capa apresenta uma textura de círculos irregulares e elementos textuais: nome do autor e nome da obra foram compostos com a mesma fonte e o mesmo corpo, variando apenas a cor: vermelho para o autor e preto para o título. Há irregularidades no espacejamento ${ }^{18}$ entre

8 Segundo definição de Faria e Pericão (2008: 306): "espacejamento: espaços entre linhas, letras ou palavras; espaceamento, espacejação".

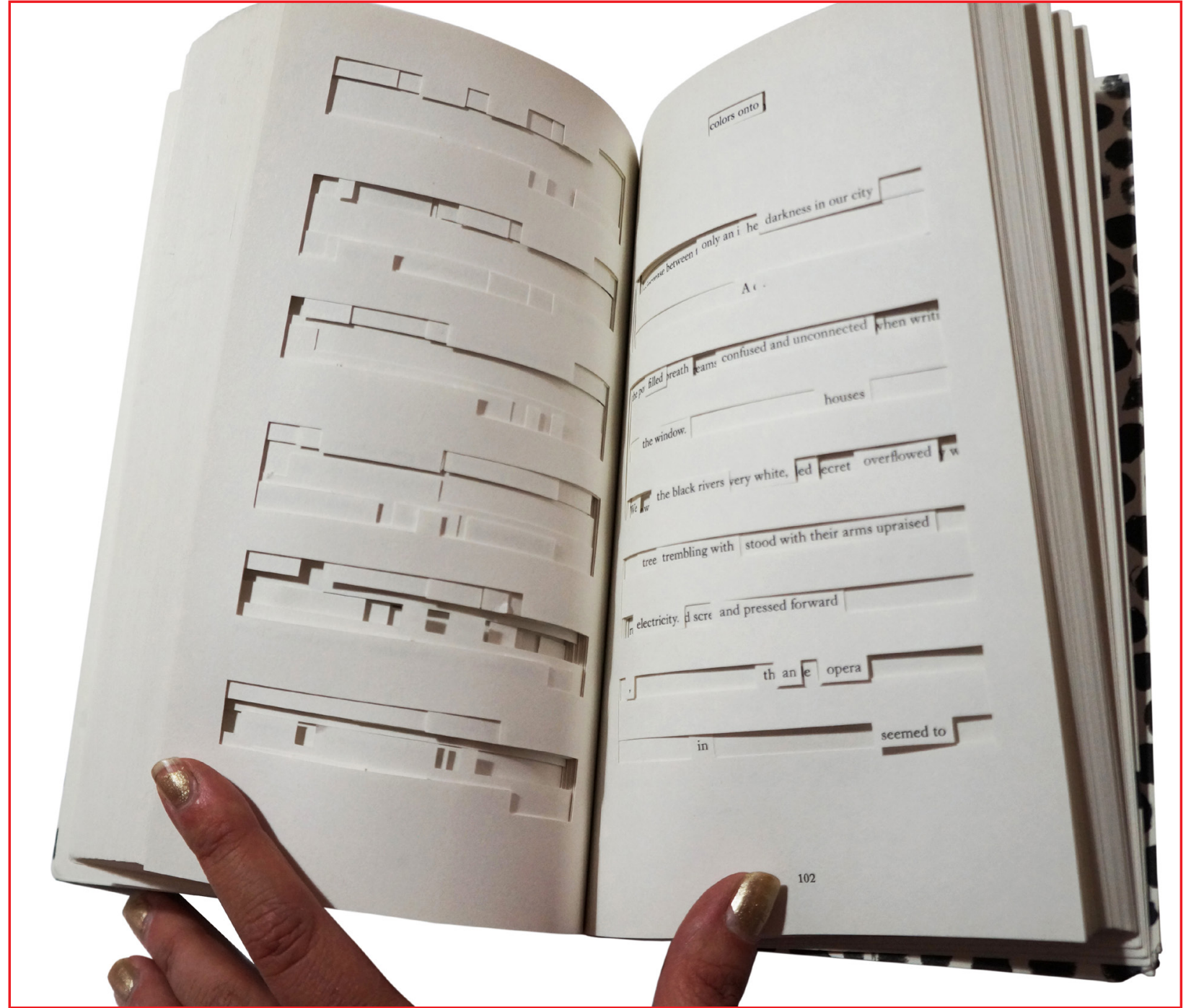

as letras e algumas letras parecem não estar na mesma linha de base. Figura 67. Imagem do Vendo de perto a capa, simula-se uma impressão "defeituosa", como miolo recortado de Tree of erro de impressão ou para manter um aspecto mais fluido como o das Codes (2010), de Jonathan bolinhas, possivelmente desenhadas com nanquin. A separação das le- publicado em 2010, pela tras pode se relacionar com a separação das palavras do próprio texto. Visual Editions. Livro do O título da obra deriva do título do original The Street of Crocodiles que acervo da autora. pode ser observado pela marcação em bold: The Street of Crocodiles. Fotos da autora. $\mathrm{Na}$ capa, o uso de espaços irregulares entre as letras pode sugerir a ausência das letras que formavam o título original como apresentado em nosso exemplo acima (figura 66).

O miolo do livro é todo recortado, todas as páginas apresentam recorte com faca especial e o texto é impresso em só uma face do pape ${ }^{19}$

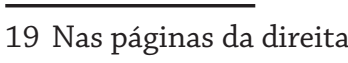


É possível ler o texto e em certas partes há algum sentido textual, mas talvez a principal intenção tenha sido a de explorar a materialidade do suporte, em vez de se buscar livro para leitura convencional.

Em entrevista realizada via Skype em setembro de 2014, Anna Gerber, uma das diretoras da Visual Editions, explica que este livro, apesar de sua forma radical, vendeu mais de 30 mil exemplares. Segundo Gerber, a intenção aqui não é a de produzir livros de artista, mas de produzir obras que estimulem experiências de leitura:

Então Tree of codes foi nosso best-seller e foram vendidas 30 mil cópias, o que era muito considerando-se que éramos uma editora completamente desconhecida, num momento em que o livro também era muito extrefeito antes, portanto estávamos muito orgulhosos, porque isso significa que ele realmente alcançou grandes públicos. Essa tem sido nossa ambição em toda a trajetória, não estávamos muito interessados em ser uma editora limitada ou de livros de artista, estávamos realmente interessados em alcançar o público em geral.

Segundo Michael Faber ${ }^{20}$ (2010), em comentário para o jornal The Guardian:

Forma e conteúdo estão aqui em diálogo íntimo. Este objet d'art, composto substancialmente de espaços vazios, é um item conceitual essencial. Se as massas não podem se relacionar com ele, os intelectuais podem ver toda a razão para concordar com o julgamento da "Vanity Fair" de que é "muito, muito cool".

Safran Foer (2011) explica no posfácio que:

Durante anos quis criar um livro elaborado por cortes através do apagamento, um livro cujo significado fosse exumado de outro livro. Eu havia pensado em vincular a técnica com o dicionário, a enciclopédia, o catálogo telefônico, vários trabalhos de ficção e não fiç̧ão e com meus próprios romances. Mas nenhuma dessas opcões teria sido minimamente bemsucedida para o processo. O livro teria sido um exercício. Eu estava em busca de um texto cujo apagamento fosse de alguma maneira uma continuação de sua criação. (...) The Street of Crocodiles é geralmente minha resposta à questão impossível de responder: Qual seu livro favorito? E ainda assim me levou um ano para reconhecê-lo como o texto que estava procurando. Por quê? Porque eu adorava muito o livro para admitir mudá-lo, ainda mais apagá-lo? Porque os ecos históricos eram demasiado poderosos? (FOER, 2011: 138)

20 Disponivel em: http://www.theguardian.com/books/2010/dec/18/tree-codes-safranfoer-review; acesso em outubro de 2015 .
Ele explica que trabalhar com esse livro foi extremamente difícil, pois a obra era muito bem escrita e certas sentenças eram difíceis de desmembrar, ou, em suas palavras, "unbreakdownable".

Este não é de maneira alguma um livro como The Streets of Crocodiles. uma modesta resposta àquele grande livro. É uma história por direito próprio, mas não exatamente um trabalho de ficção. É, além disso, ouproprio, mas não exatamente um trabalho de ficção. É, além disso, ou-
tro bilhete deixado nas rachaduras da parede. (...) É derivado desse livro tro bilhete deixado nas rachaduras da parede. (...) É derivado desse livro maior imaginado, este último livro cujas palavras jamais foram escritas, faladas ou pensadas é desentranhado. The Book of Live é o Templo em que nossas vidas lutam por entrar, mas em vez disso apenas evocam. The de desentranhamento mais próximo que qualquer outro livro de que eu tenha conhecimento. (FOER, 2011: 139)

Em entrevista, Heather Wagner (2010) ${ }^{21}$ da Vanity Fair pergunta a Foer como ele teve a ideia de cortar as palavras de um romance já existente e ele explica:

Algumas questões: uma coisa é o livro The Street of Crocodiles, de Bruno Schulz, este é um livro que sempre amei. Algumas coisas você ama apaixonadamente, outras você ama ativamente. Nesse caso, eu senti a compulsão de fazer algo a partir disso. Então comecei a pensar sobre o que os livros parecem, o que eles parecerão, como o formato do livro está mudando muito rapidamente. Se não pensarmos muito, [a mudança] não será para melhor. Há uma alternativa aos e-books. E eu adoro a questão será para melhor. Há uma alternativa aos e-books. E eu adoro a questão
física dos livros. Eu adoro quebrar a lombada, cheirar as páginas, levá-lo ao banheiro...

Tanto Tree of Codes como Kapow!, publicados pela mesma editora, não só apresentam um projeto gráfico original e "visível", mas refletem o próprio interesse dos autores de pensar em livros com formatos e estrutras diferentes, que por sua vez exigem uma "escrita" diversa, não linear. Dessa forma, estrapola-se não apenas o objeto, mas a forma da escrita, e reflete-se a importância de um diálogo entre a forma material do livro e seu próprio texto.

1 Disponivel em: http://www.vanityfair.com/culture/2010/11/jonathan-safran-foertalks-tree-of-codes-and-paper-art; acesso em outubro de 2015. 


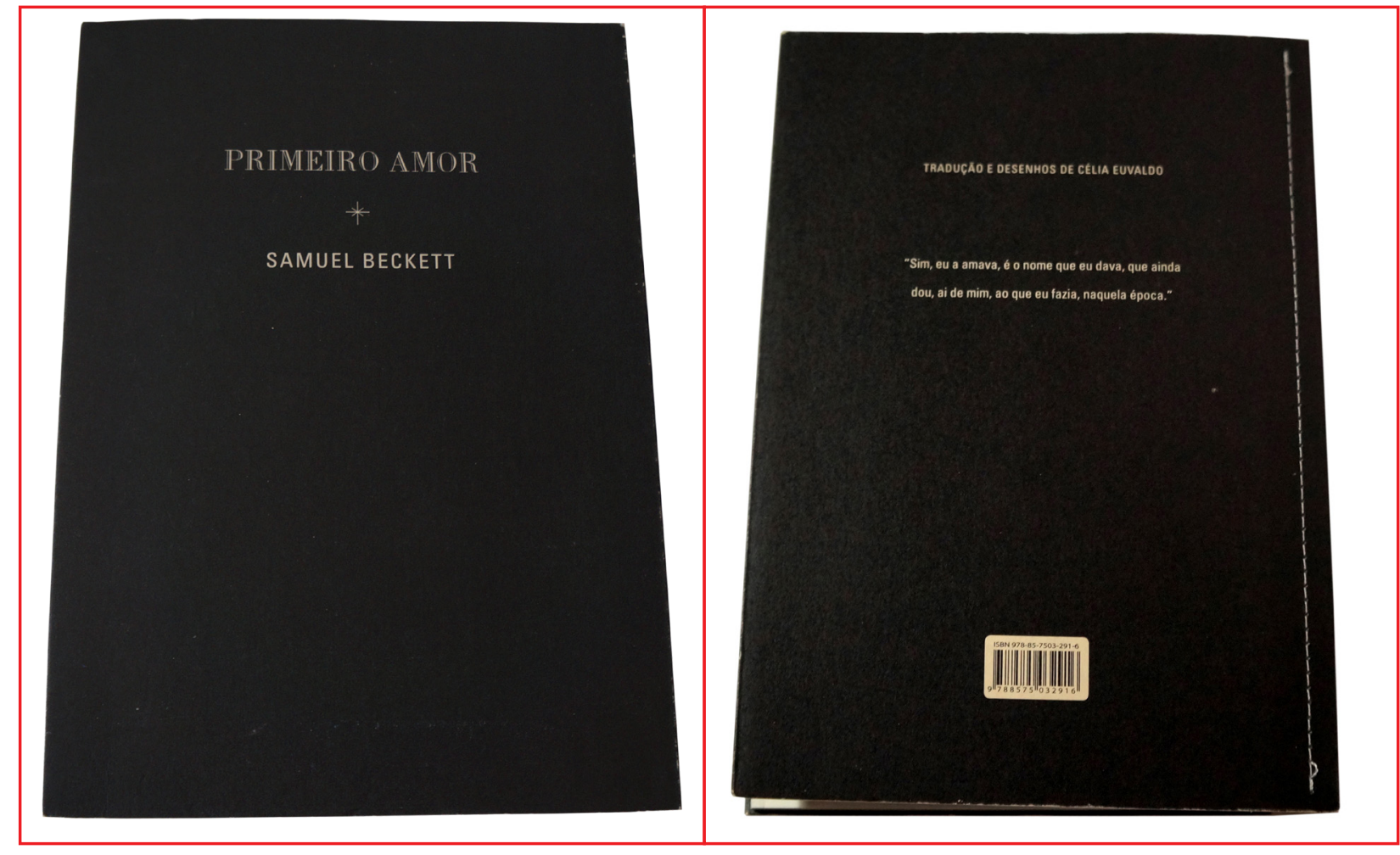

Figura 68. Capa e contra Primeiro amor

capa de Primeiro amor Primeiro amor, de Samuel Beckett (figuras 68 e 69), foi publicado em (First Love, de 1973), de 2004, inaugurando a "Coleção Particular" de novelas curtas clássicas Samuel Beckett (1906-

1989), publicado pela

Elitora Cosac Naifyem e abjeto que se muda, sem saber, para a casa de uma prostituta que se 2004. Livro do acervo da apaixona por ele.

autora. Fotos da autora. Esta edição de Samuel Beckett, por ser uma das primeiras edições de textos literários cujo projeto é mais experimental, pode, de certa forma, ser considerado o primeiro passo da editora de uma longa trajetória de experimentação em projetos gráficos em livros de literatura.

Em entrevista, a designer ${ }^{22}$ Elaine Ramos afirmou que esta edição partiu de uma das editoras da Cosac Naify, Célia Euvaldo, que na época havia traduzido a novela de Samuel Beckett e trabalhado em ilustrações inspiradas pelo texto. Elaine Ramos propôs então à colega que desenvolvessem uma edição ilustrada e especial do texto:

Essa foi a primeira vez que fizemos uma novela sozinha (já que textos curtos normalmente se apresentam em uma coletânea) ${ }^{23}$ em uma edição

22 Entrevista realizada em 2013.

23 Parênteses nosso. pequena mas ilustrada, edição especial porém financeiramente simples, já que não é um livro luxuoso, mas possui o pensamento de um livro único" (RAMOS, 2013).

O volume de 16 × $23 \mathrm{~cm}$ apresenta a mancha de texto apertada na lateral esquerda, com margens de aproximadamente 5 milímetros. $\mathrm{O}$ texto foi composto em um tipo pesado, condensado e sem serifa (Univers), de corpo 10 e entrelinha de 14 pontos, aproximadamente, que,

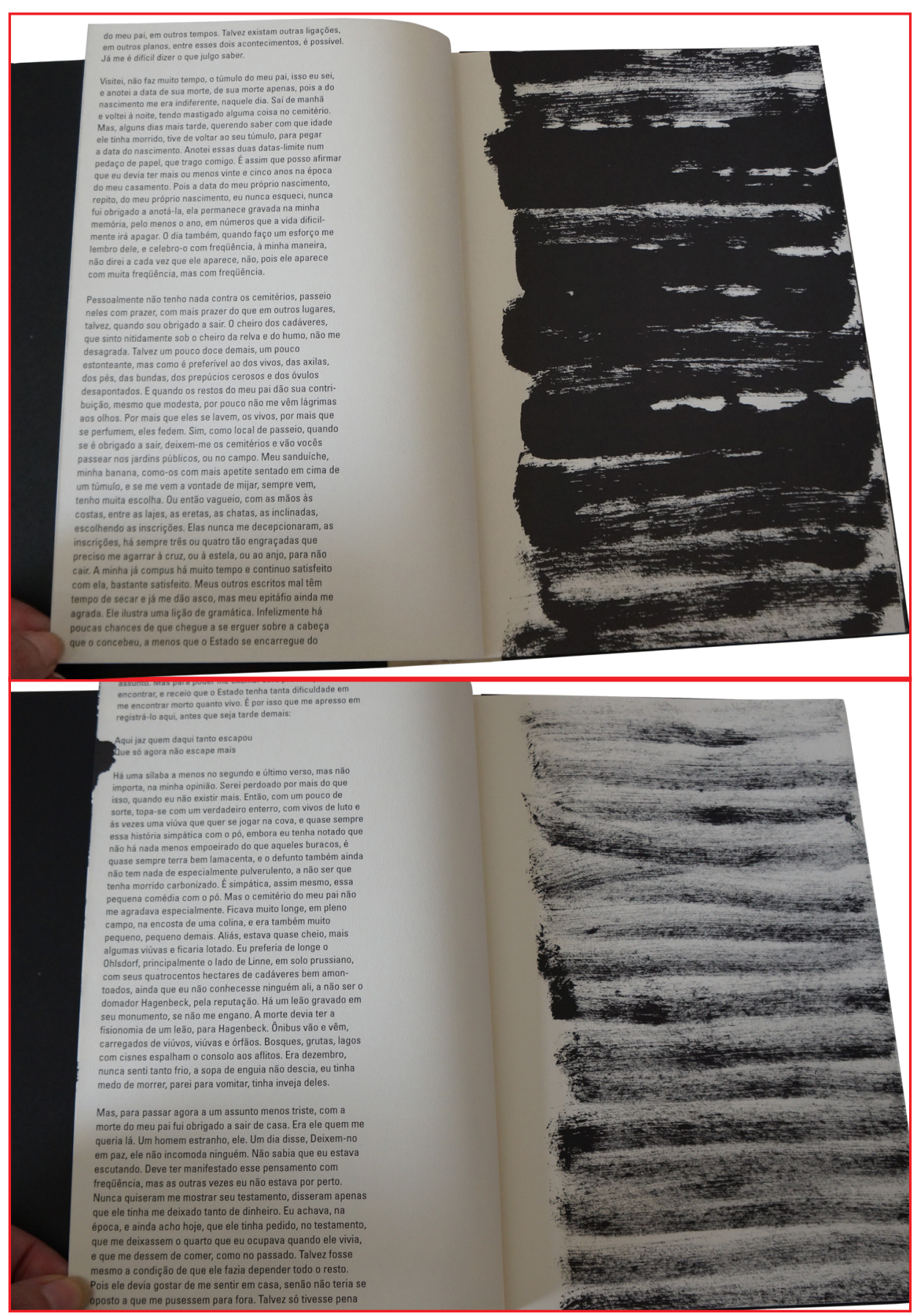

Figura 69. Páginas do miolo de Primeiro amor (First Love, de 1973), de Samuel Beckett (19061989), publicado pela Editora Cosac Naify em 2004. Livro do acervo da autora. Fotos da autora. 
de certa forma, foge dos padrões convencionais do design de livros de literatura. Mas pode-se inferir que elementos do projeto como a mancha apertada, por ser um pouco "desagradável", dialoguem com o personagem abjeto de Beckett. Por se tratar de um texto curto, a designer, talvez, tenha deixado de colocar a numeração das páginas (fólios) propositalmente. A encadernação é francesa, as páginas são dobradas e não há impressão na parte interna. O papel usado foi o Chamois fine dunas, de $67 \mathrm{~g} / \mathrm{m}^{2}$. De acordo com Elaine Ramos, o projeto foi difícil de ser aprovado para publicação, mas, depois de longas discussões, o diretor editorial à época, Augusto Massi, resolveu aprová-lo e como resultado teve boas vendas e recepção positiva. Massi foi então um dos responsáveis, segundo Ramos, pela abertura da editora para desenvolver esse tipo de projeto. Após esse sucesso, os editores da Cosac Naify pensaram que "era possível fazer edições desse tipo... a Cosac poderia fazer esporadicamente edições desse tipo, novelas curtas com projeto especial". (RAMOS, 2013)

Segundo a análise de Marc Bogo (2014: 66):

Pensando-se eideticamente na forma assumida pela mancha de texto, alinhado à esquerda, percebe-se certa fluidez que emula as pinceladas horizontais presentes na semiose pictórica. O resultado, assim, é de uma natural irregularidade e um certo desalinho. As linhas de texto nascem sempre da margem esquerda da página, emolduradas pela porção visível da segunda capa negra e por vislumbres das imagens pictóricas que ficaram para trás, porém das quais se vê apenas um fragmento dee ao esquema de dob ao esquema de dobras das páginas. Os tipos, por serem condensados, acarretam uma cromaticidade de menor brilho (escura). Pelo desenho dos caracteres, da família Univers, ser de eixo racionalista (vertical), as linhas verticais ascendentes e descendentes dos tipos se destacam e, ainda pela proximidade entre caracteres decorrente da escolha do tipo condensado, criam um ritmo na página similar ao das caligrafias góticas. O efeito de sentido é de irregularidades, de pequenas marcações desalinhadas que seguem, porém, uma fluidez e um ritmo contínuos.

Dessa maneira, a partir de nossa análise e da de Marc Bogo, percebe-se que o projeto não é apenas "vísível", os elementos do projeto contribuem decisivamente para a construção de sentido e de uma experiência diferente de leitura. Neste livro, tanto a produção gráfica (encadernação e materiais) quanto ilustrações e tipografia parecem criar um objeto coerente.

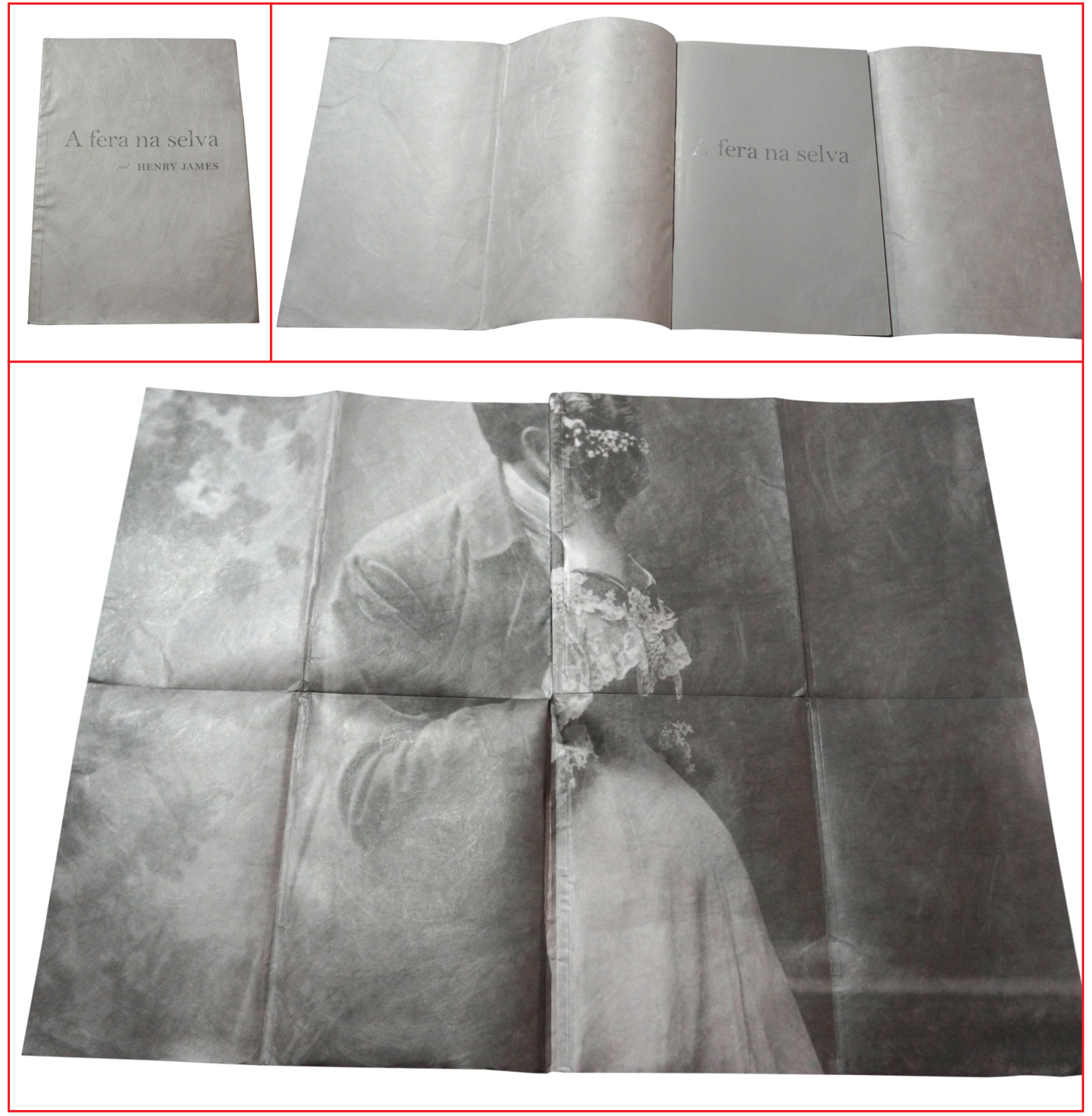

A fera na selva

Este volume de A fera na selva, de Heny James, assim como Primeiro Figura 70. Capa de A fera amor, apresentado anteriormente, faz parte da "Coleção Particular", na selva, de Henry James. da Cosac Naify (figura 70 e 71). O projeto gráfico, de Luciana Facchini, Livro do acervo da autora. impressiona pelo uso de seus materiais. A capa forma uma sobrecapa Fotos da autora. que, quando aberta (desdobrada), é uma lâmina que parece um pôster. A capa foi impressa em tyvek ${ }^{24}$, um material que lembra papel, mas não

24 Tyvek Dupont $68 \mathrm{mg}$ 


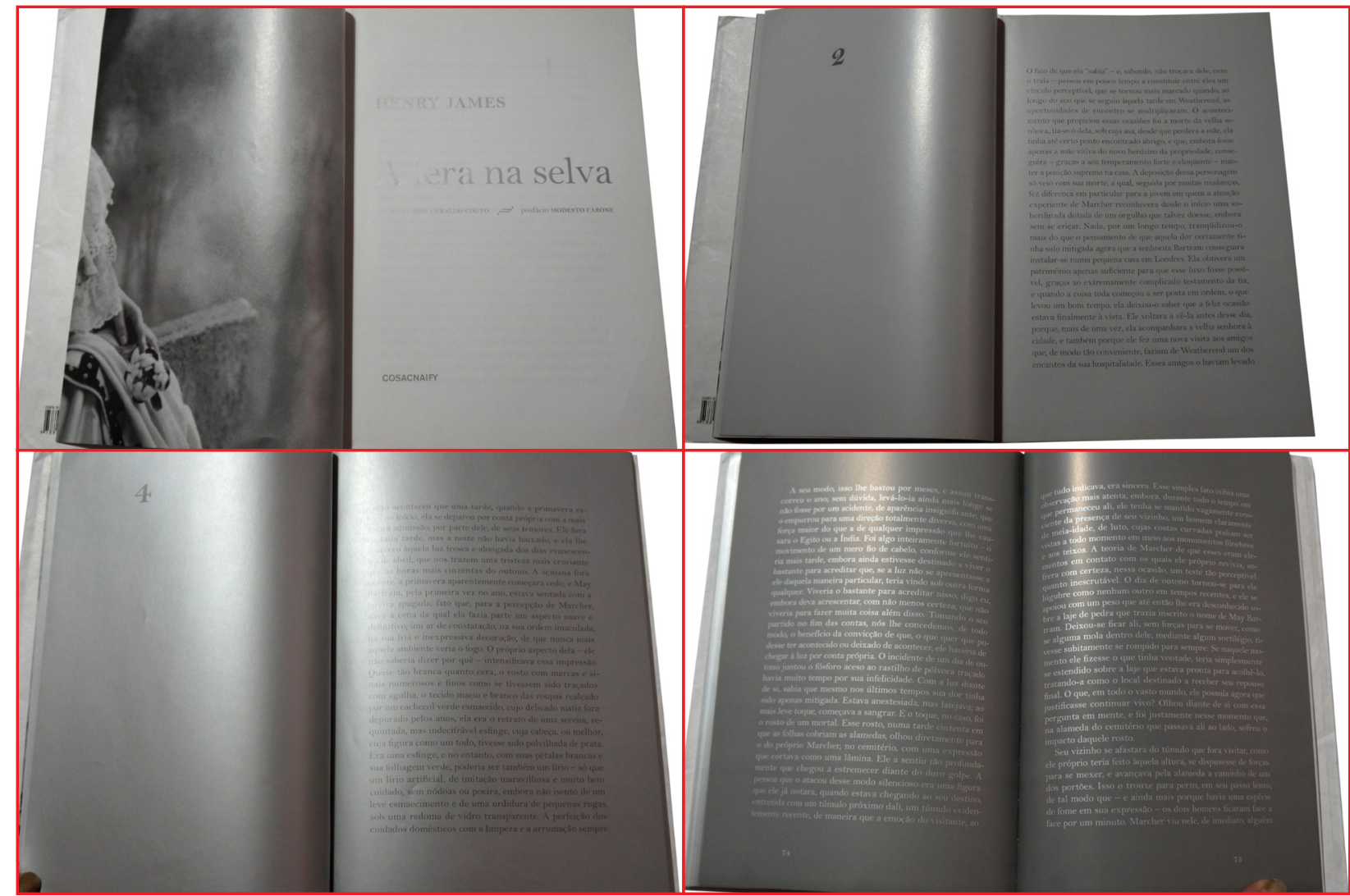

Figura 71. Folha de rosto, rasga, fibroso e com certo brilho. Os elementos gráficos (tipográficos) página de abertura e da capa aparentemente são simples: o título encontra-se centralizado páginas de texto de A fera e o nome do autor, em caixa alta e alinhado à direita. Antes do nome do na selva, de Henry James. Livro do acervo da autora.
Fotos da autora fonte Bell MT, um tipo de classe tansicional inglês do século XVIII. A impressão é em pantone prateado e a fibra do material é brilhante também, e chama atenção ao toque, pois tem uma leve textura.

Marc Bogo (2014: 85) acredita que a escolha desse material cria uma conexão sensorial com o leitor:

O leitor é seduzido tatilmente ao tocar a capa do livro, pelo contato físico e por isso começamos a análise pela dimensão matérica. O papel escolhido para a capa trata-se do Tyvek Dupont $68 \mathrm{~g} / \mathrm{m}^{2}$, um papel importado de toque suave e com uma textura que lembra a trama de um tecido. Assim, ao tomar o livro em suas mãos, o leitor é envolvido corporeamente, pois á conv o lo a entir a suvidade da capa a sentir as sutilezas de sentido é convidado a sentir a suavidade da capa, a sentir as sutilezas de sentido do livro. Porém, essa suavidade trata-se de uma falsa fragilidade - o pape é na verdade muito resistente, não rasga e nem molha, e por isso é usado pelo sistema de correios americano Fedex. Essa grande durabilidade nos remete ao tema principal do livro: a passagem do tempo.
No miolo, há uma progressão de cor e de gramatura dos papéis. A impressão é em pantone prateado e prejudica um pouco a leitura, pois emite luz. No entanto, como o texto é curto, de certa forma não atrapalha tanto, ainda que talvez devesse haver mais contraste para uma leitura mais fluida. A tipografia usada faz referência ao local onde se passa a trama, a Inglaterra, e a fonte é inglesa. O volume de dimensões $16 \times 23 \mathrm{~cm}$ apresenta margens quase simétricas, porém generosas: inferior $7 \frac{1}{2}$, superior, $7 \frac{1}{2}$, interna $4 \frac{1}{2}$, externa 5 paicas. A largura da mancha também parece proporcional à largura do volume (26 paicas de largura e 39 de altura). O texto foi composto em corpo 12 com entrelinha de 16 pontos e o fólio foi recuado da mancha em $4 \frac{1}{2}$ paicas. O uso da entrelinha generosa, nesse caso, compensa 0 brilho do papel, tornando o texto um pouco mais legível. Ainda sobre o miolo, nota-se que a composição é simples, já que é o material e a impressão que chamam atenção. As aberturas de capítulo também são simples, com o número do capítulo iniciando na página esquerda, alinhado ao topo da mancha, porém em corpo maior.

$\mathrm{O}$ texto trata de dois amigos, um homem e uma mulher. O homem possui um segredo, em que acha que algo de terrível lhe acontecerá: "algo estaria à espreita dele, por trás de uma curva no desenrolar dos meses e dos anos, como uma fera na selva" (JAMES, 2007: 25). A progressão de tonalidade e espessura do papel pode remeter à progressão temporal, ao mesmo tempo o uso do pantone reflete luz, um elemento especial da trama, segundo o posfácio da edição, de Modesto Carone (in JAMES 2007: 85):

Insistindo na tecla, é sabido que muitos ficcionistas empenham apenas atividade mimética na construção da trama. James, ao contrário, aplicase mais a metáforas e símbolos encadeados para compor uma história tensa de supressões e ressonâncias internas. Veja-se o lapso de tempo entre março e maio é coberto pelo mês de abril, o que leva o leitor a esperar a irradiaça o plena da primavera e as promessas que ela traz. Mas o escritor corre em sentido contrário para sublinhar o temperamento do herói, incapaz de atrelar o próprio destino ao cenário e ao vigor da estação. Longe disso, a novela é dominada em larga escala pelo outono e pela luz que ele espalha. 
A partir do exposto acima, percebe-se que há uma clara intenção de alusão e interpretação gráfica dos elementos textuais no projeto, a começar pela tipografia, e prosseguindo com a eleição dos materiais empregados. No próprio colofon da edição ${ }^{25}$ há uma explicação sobre a origem da tipografia, para que talvez o leitor perceba que o uso remete ao local em que se passa a trama.

\section{AbordagenS Do LivRo ILUSTRADO}

Nesta seção serão apresentados livros de literatura, produzidos nesta década, cuja visibilidade é construída especialmente por meio da ilustração. A visibilidade não se restringe obviamente à ilustração, em muitos casos também os materiais valorizam a produção do volume. Os exemplos escolhidos foram publicados pelas editoras Libros del Zorro Rojo (Argentina e Espanha), Sexto Piso (México e Espanha), Almadía (México) e Cosac Naify (Brasil).

Os livros abaixo foram publicadas pela Libros del Zorro Rojo, que tem sedes na Argentina e na Espanha. A editora é especializada na publicação de livros de literatura ilustrados adultos e infantis, e aqui nesta tese são apresentados apenas alguns dos 200 títulos de seu catálogo ${ }^{26}$. No site da editora há um pequeno texto explicativo que apresenta sua estratégia, de "valorizar o livro ilustrado como espaço de experiências estéticas e literárias”:

Desde sua fundação, em 2004, em Barcelona, Libros del Zorro Rojo se consolidou como editora de referência na edição de obras ilustradas. A maior parte de seu catálogo é formada por projetos próprios, muitos deles publicados em coedição com reconhecidas casas editoriais da Europa e da América. Na construção de seu catálogo subjaz a firme intenção de valorizar o livro ilustrado como espaço de experiências estéticas e literárias capazes de desenvolver a sensibilidade cultural e social dos leitores. ${ }^{27}$

25 No colofon aparece: Fonte: Bell MT (fonte inglesa neoclássica gravada em Londres por Richard Austin).

26 Incluindo livros adultos e infantis.

27 Disponível em: http://librosdelzorrorojo.blogspot.com.br/; acesso em dezembro de 2015.

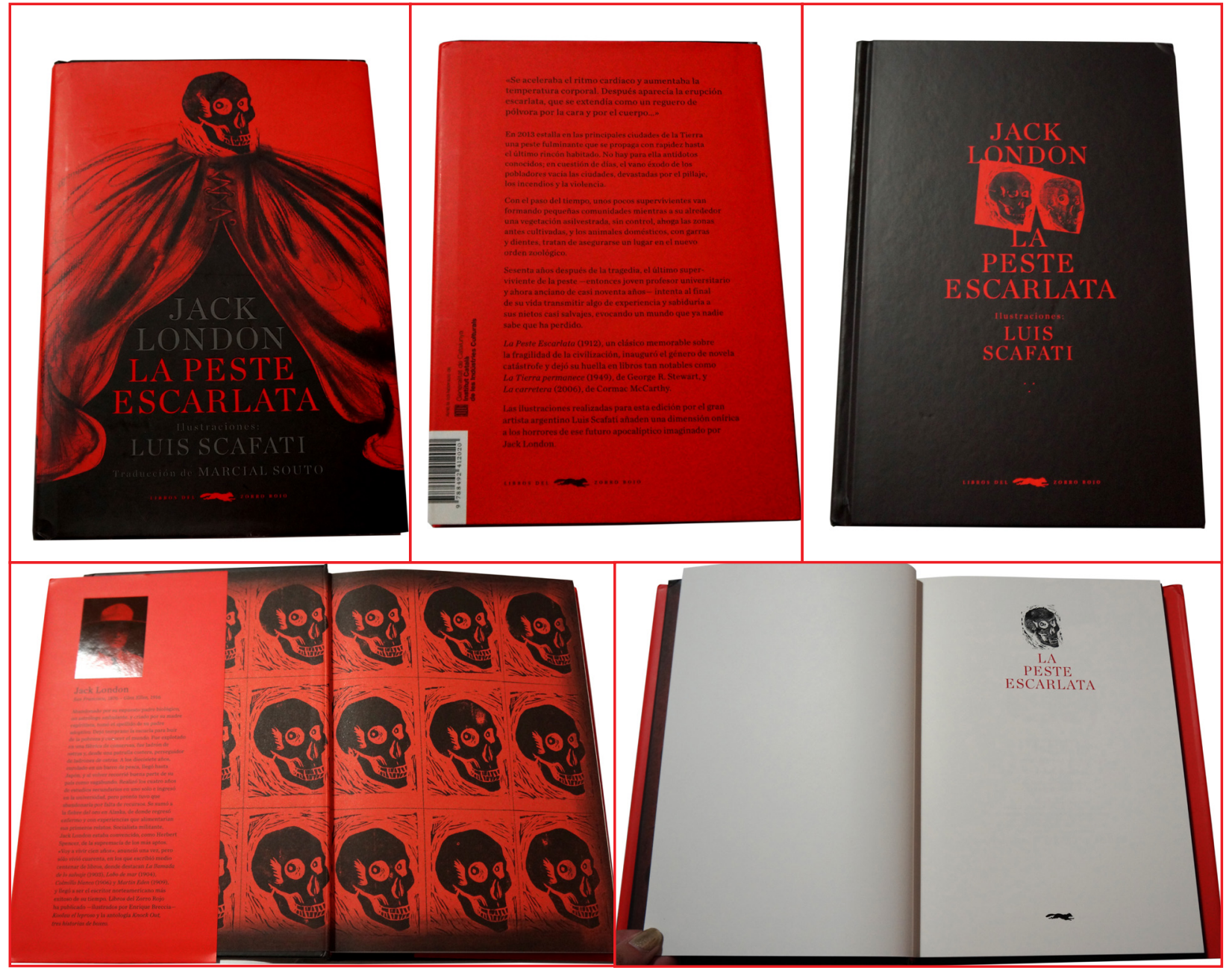

Neste texto explicativo, entende-se a missão da editora como a de Figura 72. Sobrecapa, publicar não apenas livros, mas objetos que também possuem uma capa, orelha, folha de função estética. A editora é pequena, porém é comercial e seus livros, guarda e falsa folha de publicados em espanhol, são comercializados na Espanha e na Amé- rosto de La peste escarlata é- (1912), de Jack London rica Latina. Também conquistou algumas honrarias, como o Premio (1876-1916), publicada Nacional a la Mejor Labor Editorial na Espanha, em 2011, e o prêmio pela Libros del Zorro Rojo de melhor editora europeia na Feira do Livro de Bolonha ${ }^{28}$ em 2015 em 2012. Livro do acervo da autora. Fotos da autora.

La peste escarlata

Esta é uma edição em capa dura com sobrecapa com ilustrações do argentino Luis Scafati (1947) (figuras 72 e 73). Na sobrecapa observa-se ilustração de uma caveira com um manto envolvendo o título e demais

28 A feira Internacional do Livro de Bolonha é a principal feira no segmento de livros infantis e juvenis. 


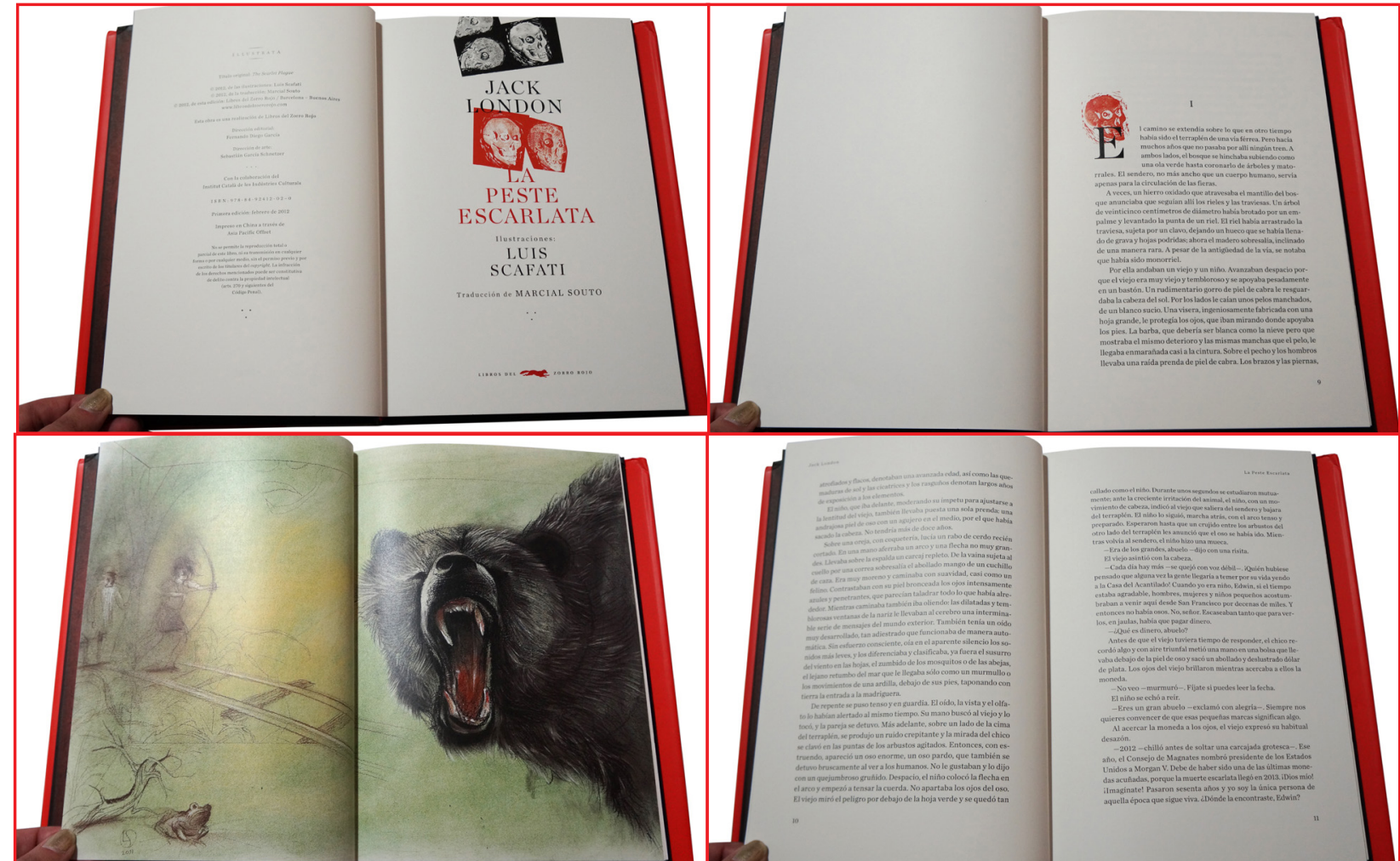

Figura 73. Folha de rosto, elementos textuais. O manto parece ter sido ilustrado com lápis ou página de abertura de pastel e o crânio da caveira parece ser feito a partir de uma xilogravura capítulo, página dupla (ou desenho chapado em um papel texturizado). O nome do autor e o ilustrada e página dupla de
texto de La peste escarlata (1912), de Jack London em cores diferentes: vermelho para o título, que se integra às cores da (1876-1916), publicada ilustração, e cinza para o nome do autor e demais elementos textuais pela Libros del Zorro Rojo (nome do ilustrador e tradutor). O logo da editora foi impresso em verem 2012. Livro do acervo melho. Na composição, a ilustração parece acolher os elementos tex-

da autora. tuais em extrema integração formal. A capa dura é revestida de papel Fotos da autora. couché fosco. O fundo é preto e todos os elementos, tanto texto quanto ilustrações, foram impressos em vermelho. A composição dos elementos é centralizada. Acima há o nome do autor, abaixo duas caveiras em preto sobre retângulos irregulares vermelhos e abaixo da ilustração o título da obra e o nome do ilustrador. A fonte utilizada tanto para a sobrecapa quanto para a capa é de eixo vertical rígido, serifas apoiadas e pertencente à classe transicional. Na folha de guarda há uma textura com a repetição da mesma caveira usada na capa impressa em preto sobre fundo vermelho. Na falsa folha de rosto no topo há outra caveira (crânio), porém o desenho é diferente do da capa e das folhas de guarda. Abaixo da ilustração tem-se o título da obra centralizado. Há um grande espaço em branco no centro da folha e no rodapé se localiza o símbolo da editora impresso em preto. Já na folha de rosto temos outra composição com múltiplos desenhos de crânios dentro de formas irregulares. No canto superior dois crânios vazados em boxes irregulares pretos, seguindo pelo nome do autor, que se sobrepõe à ilustração seguinte de mais dois crânios vazados em boxes impressos em vermelho, com o título da obra encostando nesses boxes. Em tamanho menor estão as outras informações textuais, impressas em preto.

A abertura do capítulo foi planejada para começar sempre na página ímpar, com o texto inicial recuado da mancha em $5 \mathrm{~cm}$. Na abertura, o texto começa com uma capitular e embaixo desta há a imagem do crânio da caveira, que funciona como uma espécie de carimbo. Os capítulos não têm título, são apenas numerados e, acima do bloco de texto, os números foram compostos em algarismos romanos.

O texto foi composto em corpo e entrelinha de 11/15 pontos e a fonte utilizada também é de classe transicional, mantendo então uma relação formal entre a tipografia da capa e do miolo. A mancha tem $26 \frac{1}{2}$ paicas de largura por $42 \frac{1}{2}$ de altura. O volume apresenta margens generosas, porém quase simétricas, de dimensões: inferior 7 , paicas, superior $6 \frac{1}{2}$ paicas, interna $6 \frac{1}{2}$ e externa $5 \frac{1}{2}$. Os títulos correntes foram compostos em corpo menor (8 pt) deslocados da mancha e localizados à esquerda e à direita e estão posicionados após $3 \frac{1}{2}$ paicas do início da folha. Os fólios estão alinhados à esquerda e à direita da mancha e foram compostos no mesmo corpo de texto.

A trama se passa em San Francisco, nos Estados Unidos, em 2073 e conta a estória da trajetória de um velho e seus netos na região, agora inabitada, após a ocorrência de uma praga (epidemia) que dizimou a humanidade. No texto, o velho explica a seus netos como era o passado, lembrando-se, por exemplo, de quando viu o primeiro avião sendo construído e quando viu o último sendo destruído. Ele procura ensinar coisas que os garotos nunca viram e, nesse sentido, o texto, em vez de completamente catastrófico, carrega um ar de esperança. Mesmo assim, também trata da sobrevivência dos personagens em um ambiente inóspito. Diante disso, o projeto gráfico parece coerente com esse universo, as ilustrações do meio do texto são coloridas e a questão da morte está sempre presente. 


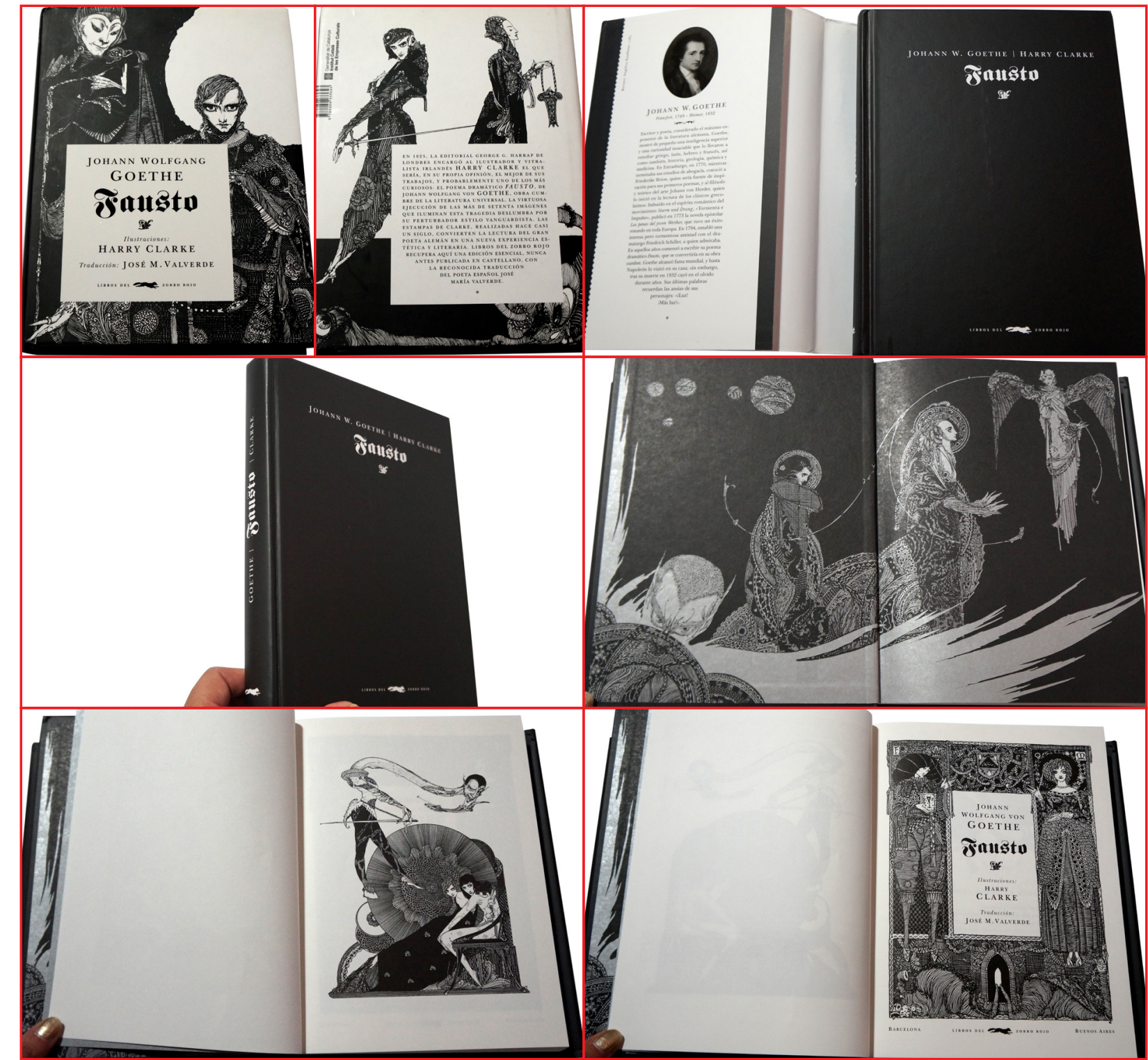

Figura 74. Capa, Fausto sobrecapa, folha de guarda, falsa folha de rosto e folh de rosto de Fausto (1831) de Goethe (1749-1832) publicado pela editora espanhola e argentin Libros del Zorro Rojo em 2012. Livro ilustrado po Harry Clarke. Acervo da autora. Foto da autora.

A nota sobre a edição esclarece que:

A Libros del Zorro Rojo apresenta o primeiro livro da tragédia, que narra o pacto diabólico entre Mefistófeles e Fausto, a luta deste junto a Margarita pelo destino de suas almas, e recupera as belíssimas imagens realizadas por Harry Clarke para a primeira edição inglesa da obra, publicada em 1925 pela editora George G. Harrap, de Londres. As mais de setenta imagens que iluminam esta edição foram reproduzidas cuidadosamente a partir de um antigo exemplar de coleção, numerado e assinado pelo virtuoso artista irlandês.

O livro, de formato 18 x 24,5 cm (figuras 74 e 75), apresenta uma sobrecapa ilustrada em preto e branco. O título e demais elementos

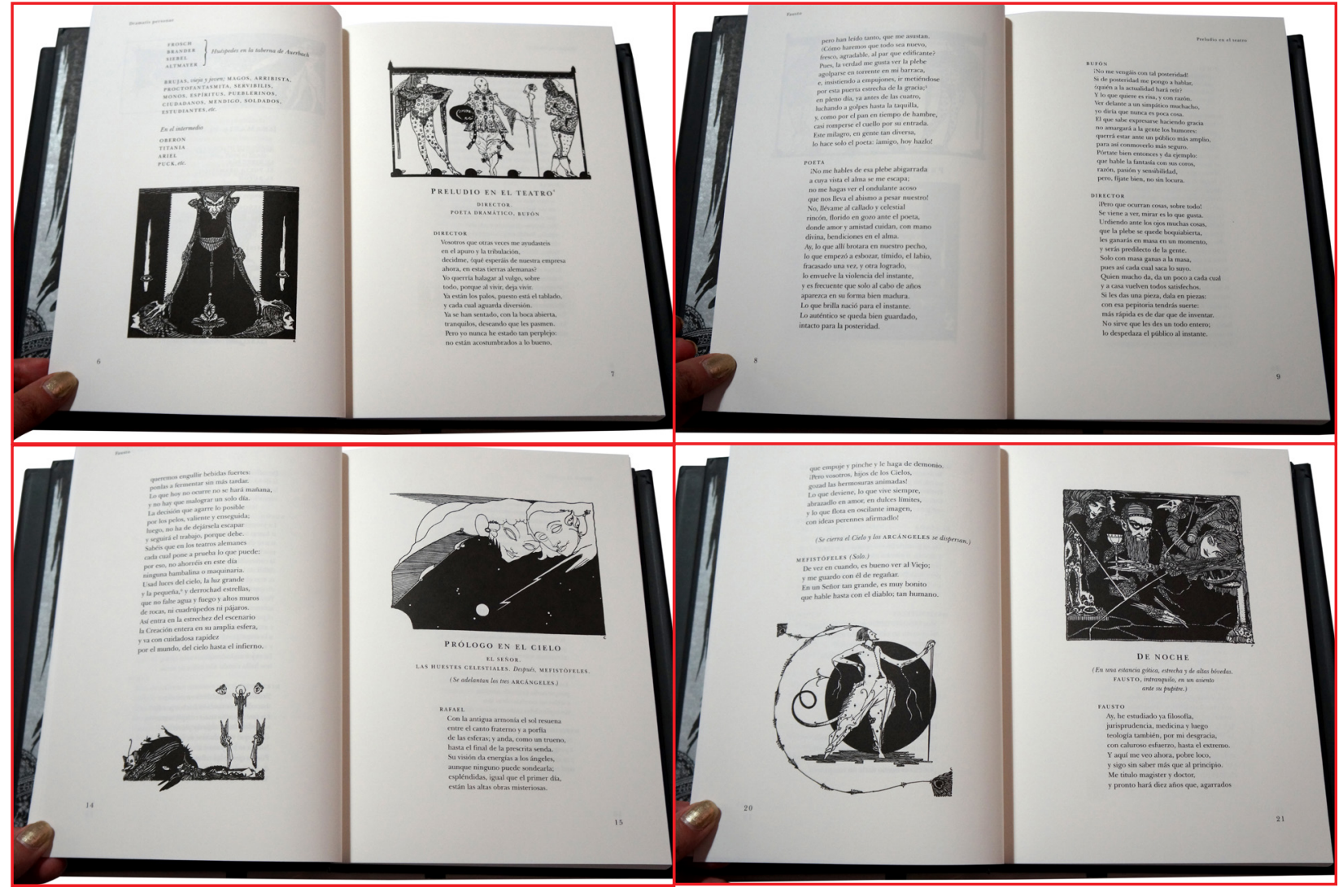

textuais foram acondicionados em um box de cor branca com acaba- Figura 75. Páginas de mento de verniz localizado, enquanto o resto da capa tem acabamento abertura das cenas e de laminação fosca O mesmo tratamento foi utilizado na lombada. O páginas de texto de título foi composto em tipos góticos (blackletter), talvez para remeter Fausto (1831), de Goethe à origem e à época do autor ${ }^{29}$, e os demais elementos textuais compos- pela editora espanhola tos em um tipo de classe transicional. A capa dura do livro apresenta eargentina Libros del apenas os elementos textuais sem ilustração. As folhas de guarda são Zorro Rojo em 2012. Livro ilustradas e utilizou-se um papel especial de tom prateado com a ilus- ilustrado por Harry Clarke. tração impressa em preto. Na contracapa e nas orelhas, o bloco de tex- Acervo da autora. to é composto em formato fundo de lâmpada ${ }^{30}$.

29 Tipos góticos, originários da idade média, eram comumente usados na Alemanha até DS infere-se a importânci dese estilo para o país e ascolha dessa tipografia pars este livo foi provalmente inspirada por esse costume.

30 Fundo de lâmpada, segundo Frederico Porta (1958), consiste em: “Composição em forma de triàngulo, na qual cada linha, centrada na medida, se faz sempre um pouco mais curta que a anterior, ate a ultima, constituida por apenas uma palavra ou silaba. $\hat{E}$ disposição que se costumava dar, em muitos livros, à parte final dos capitulos. 2. Vinheta ou gravura, terminada geralmente em ponta, que se põe em fins de capículo, o mesmo que (PORTA, 
A página que antecede a folha de rosto, a falsa folha de rosto, não apresenta elementos textuais, mas sim uma ilustração.

$\mathrm{Na}$ folha de rosto, a ilustração encontra-se dentro de uma moldura. Para os elementos textuais foi utilizada a mesma tipografia usada na capa e sobrecapa e estes foram encaixados em um retângulo branco. As informaç̃̃es editoriais localizam-se abaixo da ilustração/moldura.

Há uma nota introdutória com uma ilustração cujo texto foi com posto em um tipo transicional em corpo 10 ou 11 com entrelinha de 15 pontos. O primeiro recuo do texto mede $7 \frac{1}{2}$ paicas e o título se encontra centralizado na mancha em corpo 12. Margens generosas são utilizadas tanto nas páginas da introdução quanto nas do texto principal que, por se tratar de um poema dramático, foi composto alinhado à esquerda, porém recuado do nome do personagem composto em caixa alta corpo 10. A fonte, o corpo do texto e a entrelinha são os mesmos da introdução. A mancha do texto da introdução mede $21 \frac{1}{2}$ paicas e as margens medem: inferior $10^{1 / 2}$ paicas, superior $7 \frac{1}{2}$, interna $10^{1 / 2}$ e externa 9. A mancha do texto do poema mede 17 paicas e as margens: inferior 9 , superior $8 \frac{1}{2}$, interna $12^{1 / 2}$ e externa $11^{1 / 2}$. Pelo uso das margens, as páginas tornam-se bastante arejadas, porém as margens quase simétricas parecem uma moldura. A margem interna costuma, segundo a tradição, ser a menor e a inferior a maior de todas. Há no livro ilustrações que aparecem antes das cenas da peça que ocupam um pouco menos que um terço da página e ilustrações de página inteira em determinadas passagens do texto. A cor e os traços e a caracterização dos personagens das ilustrações dão um toque sombrio ao texto, que trata de um homem que vende sua alma ao diabo em troca de plenos poderes e sabedoria.

El príncipe feliz y otros cuentos

Esta edição de contos de Oscar Wilde (figuras 76 e 77), segundo a nota da edição, é uma nova versão de uma edição publicada em 1888 pelo editor David Nutt, de Londres, ilustrada originalmente por Walter Crane (1845-1915) e George Percy Jacomb-Hood (1857-1929). O volume é uma coletânea de contos do autor. A nota da edição explica que hoje restam poucos exemplares do original, que consistia em uma série limitada de setenta e cinco livros assinados pelo autor e pelo editor. Esta edição publicada agora pela Libros del Zorro Rojo conta com o texto traduzido e as ilustrações originais da primeira edição. Dessa maneira as ilustrações, como foram criadas naquele contexto específico, refletem o estilo da época.

O primeiro conto, que dá título ao volume, conta a estória de uma bela estátua chamada "Príncipe Feliz" e de uma andorinha que está de passagem pela cidade. A estátua é venerada por todos, por acreditarem que seria possível a felicidade retratada pela obra. Um dia a andorinha dorme aos pés da estátua e gotas de água caem sobre ela. A andorinha pensa que são gotas de chuva, mas na verdade são lágrimas do príncipe. Estátua e andorinha iniciam um diálogo e o "príncipe feliz" diz ter realmente sido feliz em seu castelo da despreocupação, porém naquele momento sofria vendo a tristeza e miséria por toda parte. Ele pede que a andorinha leve partes nobres de seu corpo, como as pedras preciosas de seus olhos e o ouro que o recobre, para famílias carentes. A andorinha resolve não abandonar a estátua e morre de frio. No final do conto, a estátua já não é mais bela e as autoridades resolvem fundir Fotos da autora.

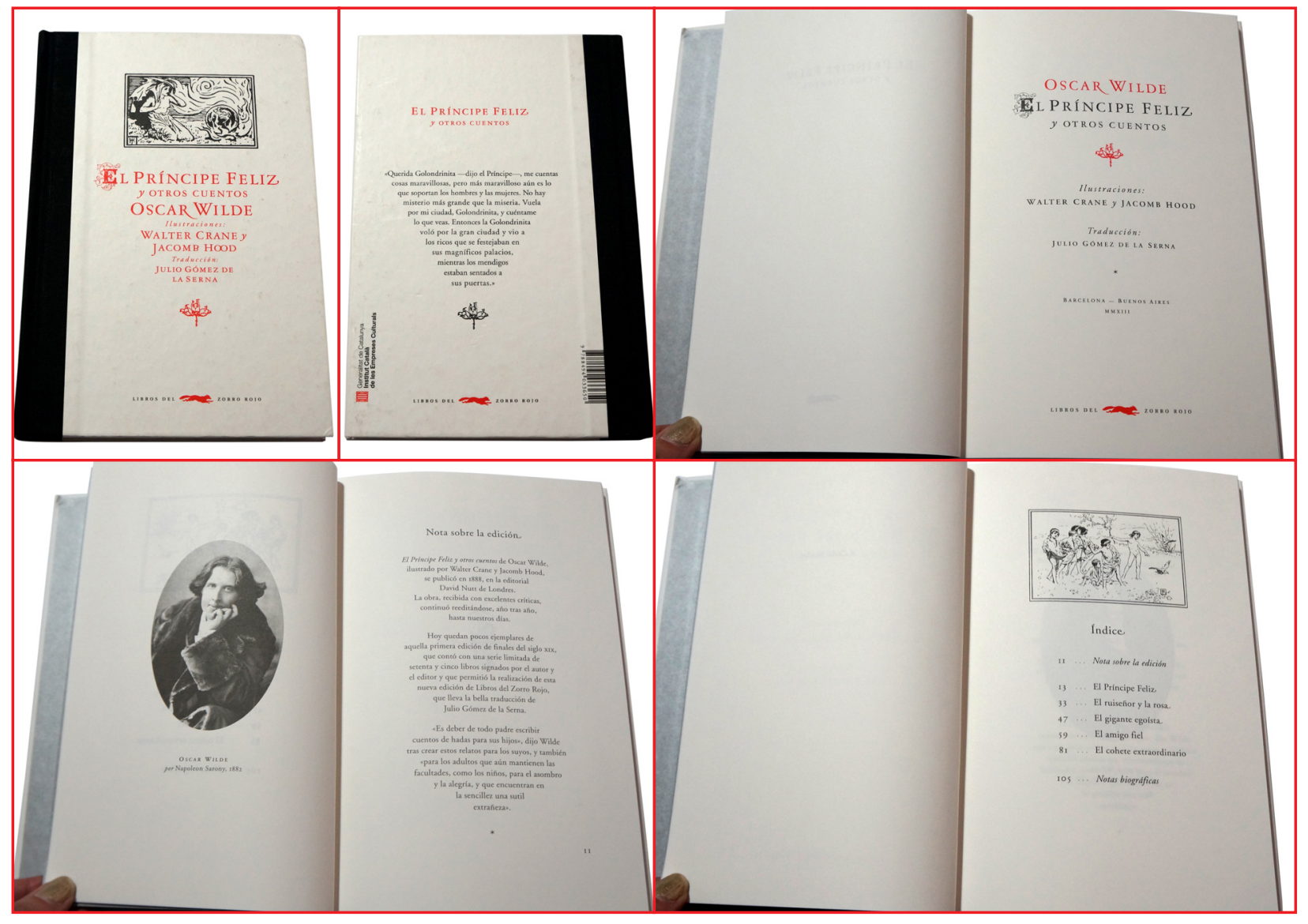




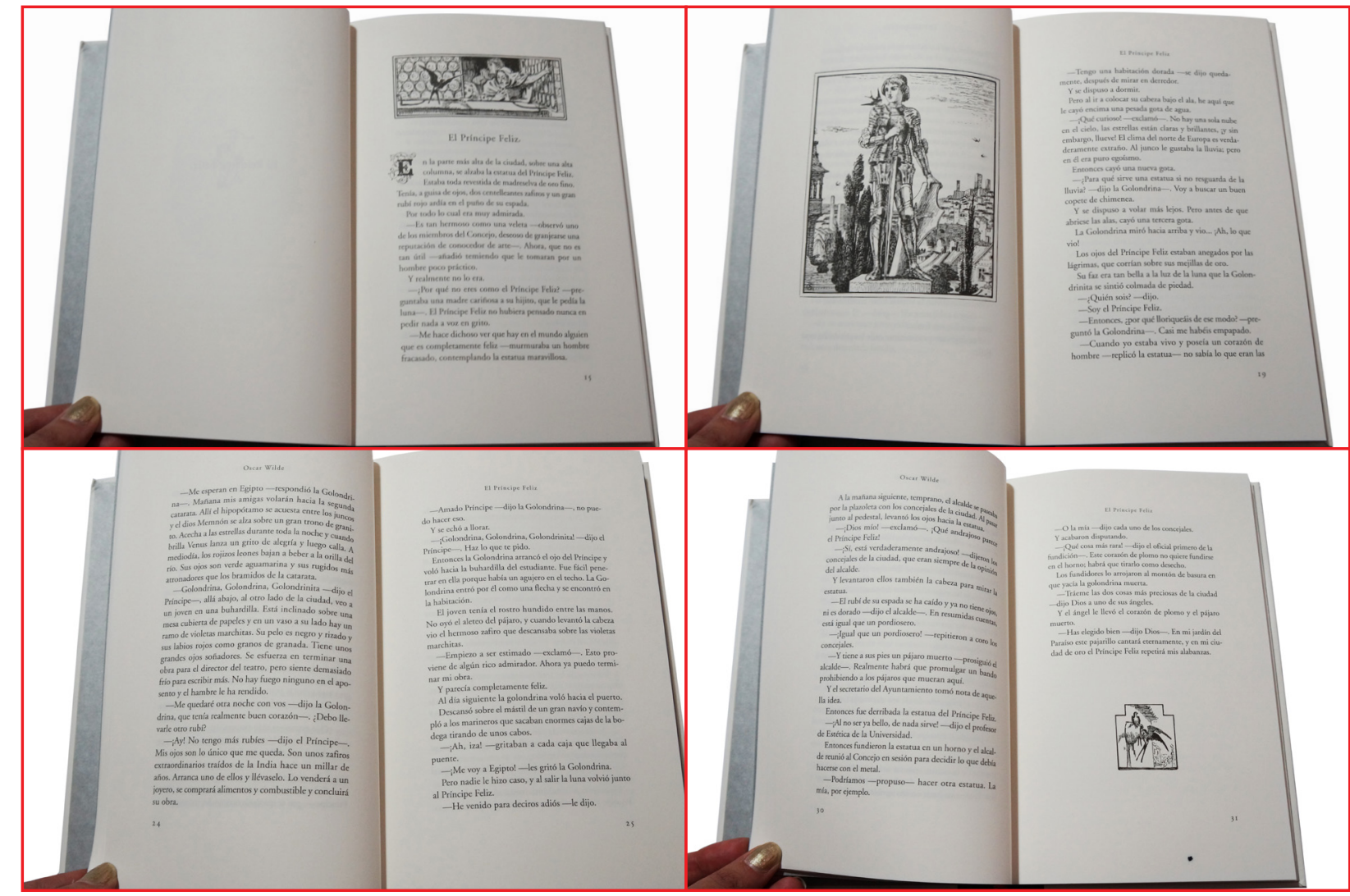

Figura 77. Página de o metal, porém o coração de chumbo não se derrete e acaba jogado abertura e páginas de texto fora ao lado do pássaro morto. Um anjo, com a missão de levar ao céu ilustradas de El príncipe as duas coisas mais preciosas da cidade, elege o coração de chumbo e a

(1888), de Oscar Wilde andorinha morta, logo, tanto o príncipe quanto a andorinha acabam (1854-1900), publicado no paraíso.

em 2013 pela Libros del Este livro de capa dura, de dimensões 14 x $21 \mathrm{~cm}$, tem a lombada Zorro Rojo. Livro do acervo revestida com tecido e apresenta os elementos textuais impressos na da autora. Fotos da autora. espinha em hot melt dourado. O resto da capa é revestido em papel branco com laminação fosca. Na capa foram usadas duas cores: preto e vermelho. A ilustração foi impressa em preto e se encontra dentro de uma moldura retangular e os elementos textuais, título, autor, nome do ilustrador e tradutor, foram compostos centralizados e impressos na cor vermelha. A composição textual forma uma escadinha (ou fundo de lâmpada) e, como a entrelinha é pequena, todos os textos ficam muito próximos, criando uma unidade visual. A primeira letra do título da obra é uma capitular decorada e embaixo da composição há um florão (uma pequena vinheta) remetendo a composições clássicas. A folha de guarda é de papel especial prateado sem impressão. Na falsa folha de rosto só o título foi impresso, na mesma fonte porém sem a capitular decorada. A folha de rosto apresenta os elementos textuais dispostos centralizados mas separados, sem formar a escadinha. É interessante notar que a letra $\mathrm{R}$ do título possui uma cauda que desce além da linha de base. Além dessa alteração (ou manipulação na forma das letras), a letra $S$ foi usada de forma invertida. O papel utilizado no livro é offwhite, ou seja, não alcalino, o que auxilia a legibilidade. Nas aberturas de capítulo, há uma ilustração em preto emoldurada em uma forma retangular que tem a mesma largura da mancha de texto. Na contracapa, o texto foi também composto em "fundo de lâmpada".

No miolo, o título de cada conto é disposto centralizado na mancha, que mede $201 / 2$ paicas de largura e $33^{1 / 1} 2$ de altura. O tipo utilizado é de classe garalde, composto em corpo 10 ou 11, com entrelinha de 15 pontos. Os textos começam com uma capitular decorada no mesmo estilo da usada na capa. As margens medem: inferior $8 \frac{1}{2}$ paicas, superior $7 \frac{1}{2}$, interna $5 \frac{1}{2}$, externa 5 paicas. Os títulos correntes apresentam-se em corpo menor de aproximadamente 8 pontos, centralizados na página, com uma distância de $1 \frac{1}{2}$ paica da mancha de texto e os fólios encontram-se alinhados à esquerda e à direita da mancha na parte inferior. Ao final de cada capítulo, encontram-se pequenas ilustrações que funcionam como vinhetas. Todas as ilustrações foram impressas na mesma cor do texto (preto) e parecem gravura em metal, uma das formas nas quais se podia imprimir ilustrações na época em que o texto foi escrito. As páginas são bastante arejadas e o texto bem legível, especialmente por conta da entrelinha generosa utilizada no volume. 


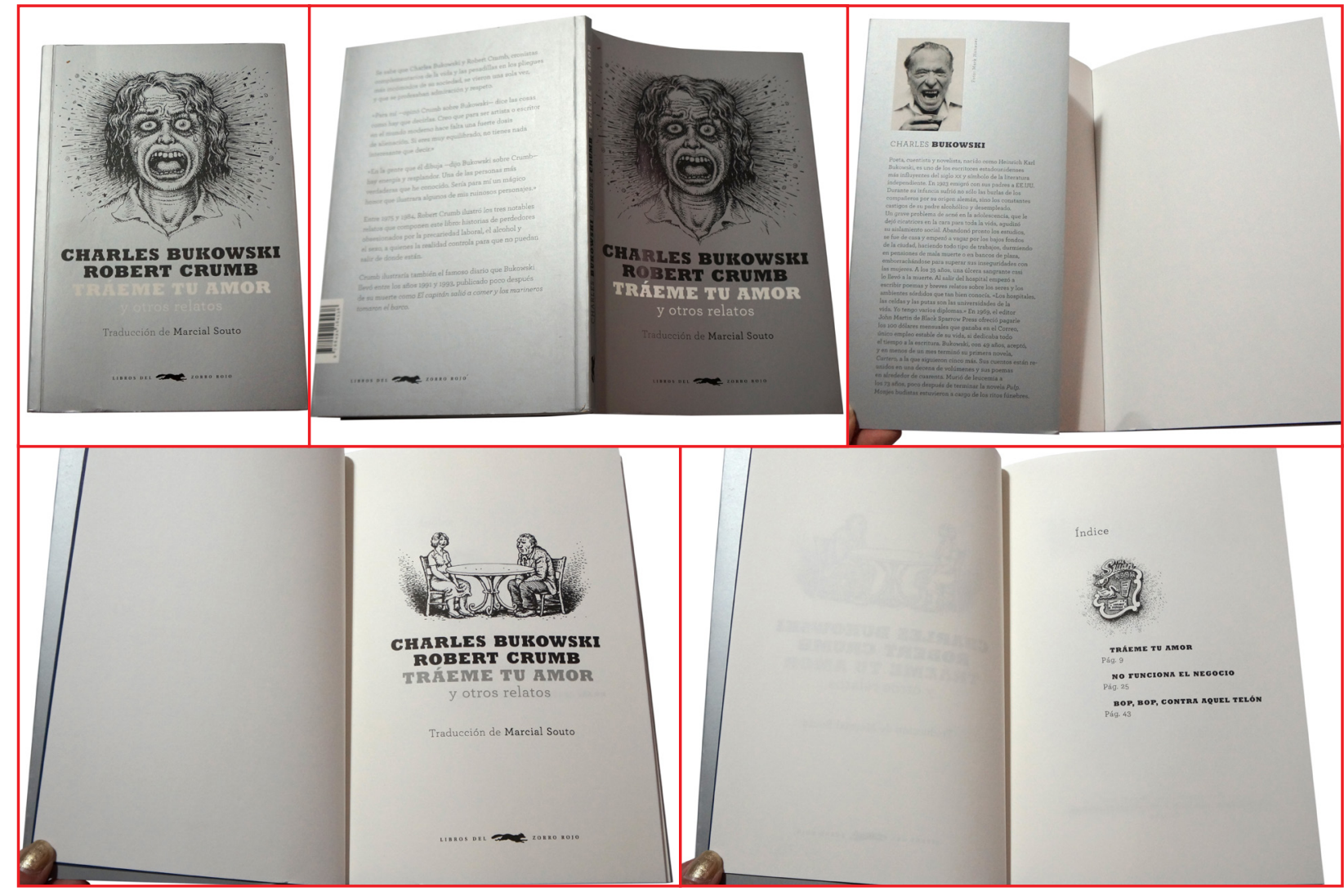

Figura 78. Capa e folhas de Tráeme tu amor y otros relatos

rosto de Tráeme tu amor Esta edição de Tráeme tuamoryotros relatos (figuras 78 e 79), de Bukowski, y otros relatos, de Charles é uma coletânea de três textos do autor ilustradas por Robert Crumb. O ilustrado por Robert primeiro texto, "Tráeme tu amor" (Bring me your love) foi originalmenrumb (1943 - ), publicado te publicado em 1983 pela Black Sparrow Press (Califórnia). O segundo, em 2014 pela Libros del "No funciona el negocio", foi publicado pela mesma editora, porém em Zorro Rojo. Livro do acervo 1984, e o terceiro, “Bop, Bop, contra aquel télon”, foi publicado em 1975 da autora. Fotos da autora. na revista californiana Arcade. Todos os textos apresentam linguagem coloquial e personagens envolvidos com drogas, álcool e prostituição. Em "Tráeme tu amor", texto que dá nome à coletânea, temos a estória de uma mulher internada em um sanatório que, ao receber a visita de seu marido, acusa-o de traí-la com prostitutas. O texto e as ilustrações, ambos informais e contemporâneos, combinam com a escolha da tipografia da capa e do miolo, de classe slab serif, ou serifa quadrada, que por ter pouco contraste e serifas retas é mais moderna do que as outras fontes utilizadas na maioria dos livros analisados ao longo desta tese.

Esta edição, de dimensões 14,5 x 21,5 cm, é uma versão brochura. O papel da capa é cartão e foi utilizada uma cor especial (pantone me-

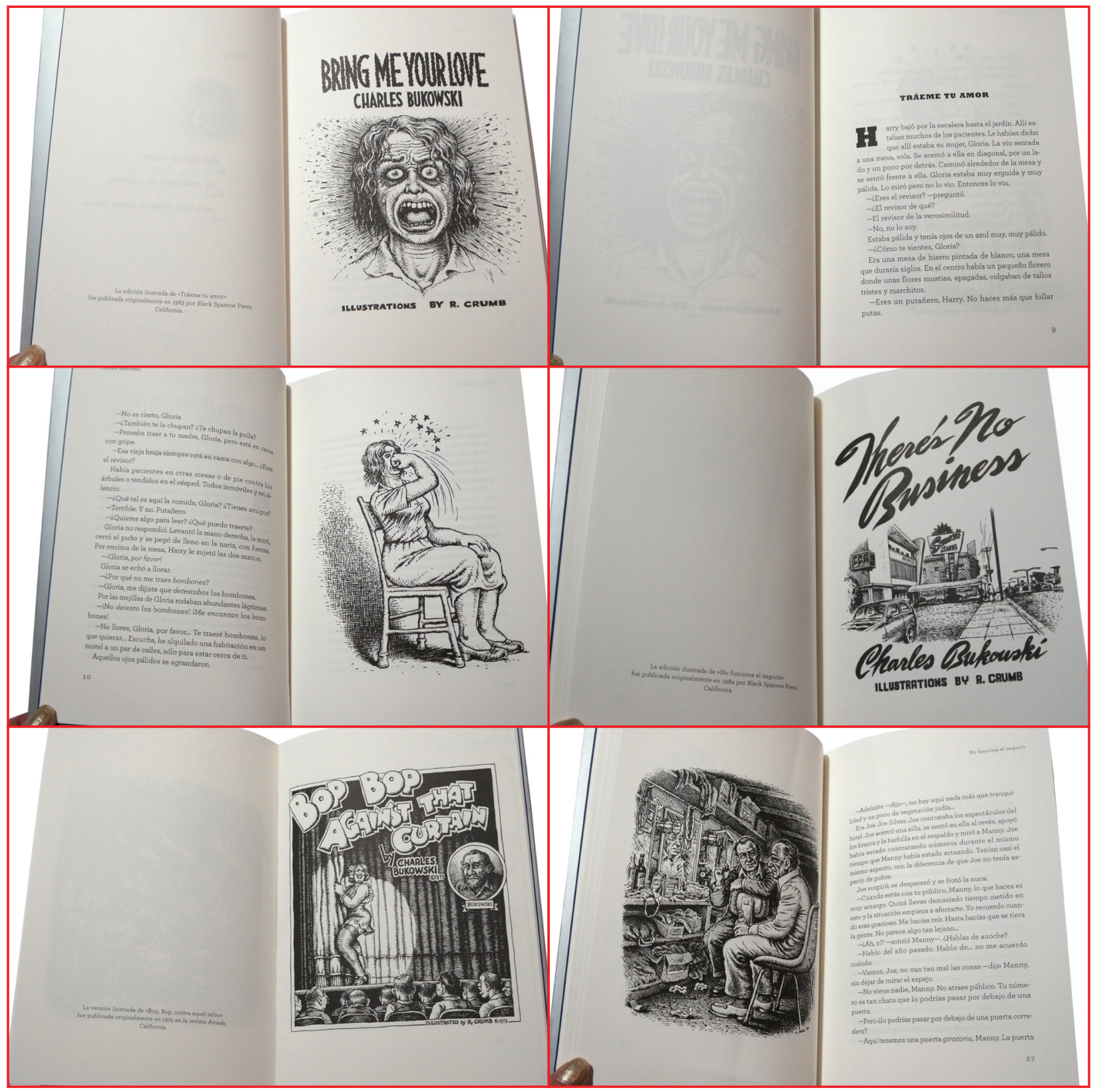

tálico) para o preenchimento do fundo e o texto e a ilustração foram Figura 79. Páginas de impressos na cor preta. Para os elementos textuais dispostos centrali- abertura e de texto de zados foi utilizada uma fonte de serifa quadrada. Para o título e nome Tráeme tu amor y otros relatos, de Charles do autor foi utilizado o estilo bold, enquanto o estilo light foi utilizado Bukowski(1920-1994), para os demais elementos textuais. A capa apresenta orelha com infor- ilustrado por Robert mações sobre o autor e o ilustrador (que na capa tem o mesmo peso Crumb (1943-), publicado que o nome do autor do texto). O papel da folha de guarda é provavel- em 2014 pela Libros del mente color plus azul escuro. A falsa folha de rosto apresenta o nome Zorro Rojo. Livro do acervo do autor, do ilustrador e o título numa só linha no topo da página, da autora. Fotos da autora. 
deixando o meio da página livre de elementos gráficos. No pé há o logo da editora (somente o símbolo, uma raposa). Na página de rosto os elementos textuais da capa apresentam-se da mesma maneira e há uma ilustração acima, de um casal sentado junto a uma mesa vazia.

As páginas de abertura de cada conto apresentam uma ilustração na página ímpar. Nesse caso, os títulos dos contos são desenhados (letreiFigura 80. Capa, contra ramento) e têm um estilo gráfico coerente com o estilo da ilustração capa, lombada e página e foram feitos pelo próprio ilustrador. Na primeira página do texto a de rosto de Una ocasión mancha é deslocada para baixo com 19 paicas de medida entre o topo para una pequeña mancha é deslocada para baixo com 19 paicas de medida entre topo desesperación, de Franz e a mancha de texto. O título apresenta-se centralizado em um tipo Kafka (1883-1924), de serifa quadrada em bold. O texto se inicia com uma capitular desilustrado por Nicolaus ta mesma fonte em bold. A fonte do texto apresenta serifa quadrada Heidelbach e publicado e pouco contraste em peso light, é leve e dá um tom moderno à pápela Libros del Zorro Rojo gina. O corpo e a entrelinha são de aproximadamente 11/15 pontos. em 2011. Livro do A mancha mede 23 paicas de largura por 32,5 de altura. As margens Fotos da autora. utilizadas medem: inferior 7, 5, superior 10, 5, interna 6 externa 5 .

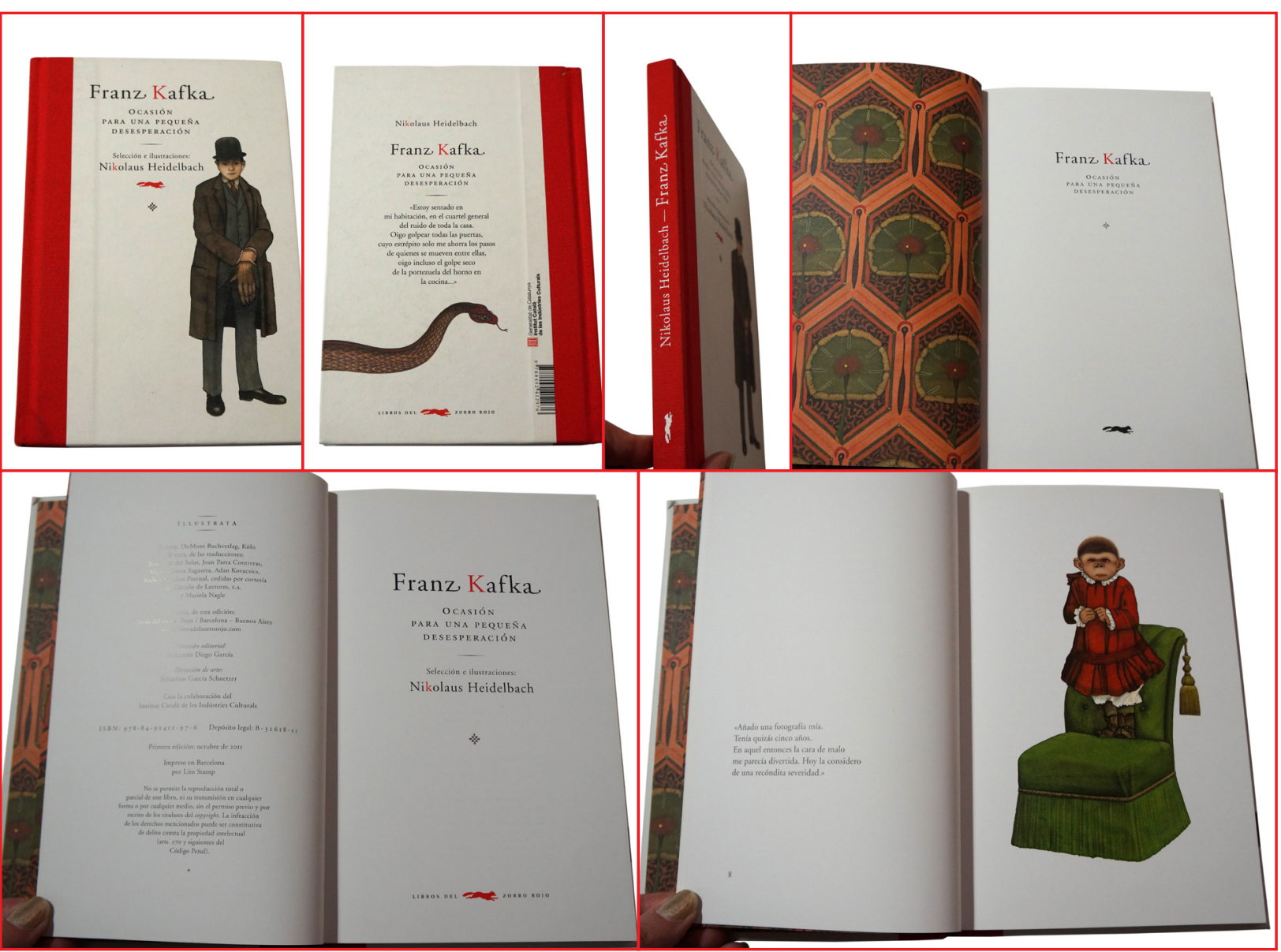

Novamente, o uso das margens foge da tradição em que a inferior é maior que a superior e a externa maior que a interna. O papel usado no miolo é offwhite (não alcalino).

\section{Una ocasión para una pequeña desesperación}

O livro traz uma coletânea de textos curtos de Franz Kafka, escolhidos e ilustrados pelo ilustrador alemão Nikolaus Heidelbach (1955-) (figuras 80 e 81). Esta é uma edição adaptada da original alemã de 2009 publicada pela DuMont Buchverlag, Köln e foi traduzida para o espanhol ${ }^{31}$. As ilustrações, provavelmente inspiradas pelo imaginário kafkaniano, são sólidas e coloridas. Dessa maneira, provavelmente, foram utilizados guache ou pastel, pois esses materiais tornam as ilustrações opacas.

Este é um volume de capa dura e suas folhas de guarda são ilustracasión para una pequeña desesperación, de Franz Kafka (1883-1924), ilustrado por Nicolaus Heidelbach e publicado pela Libros del Zorro Rojo m 2011. Livro do

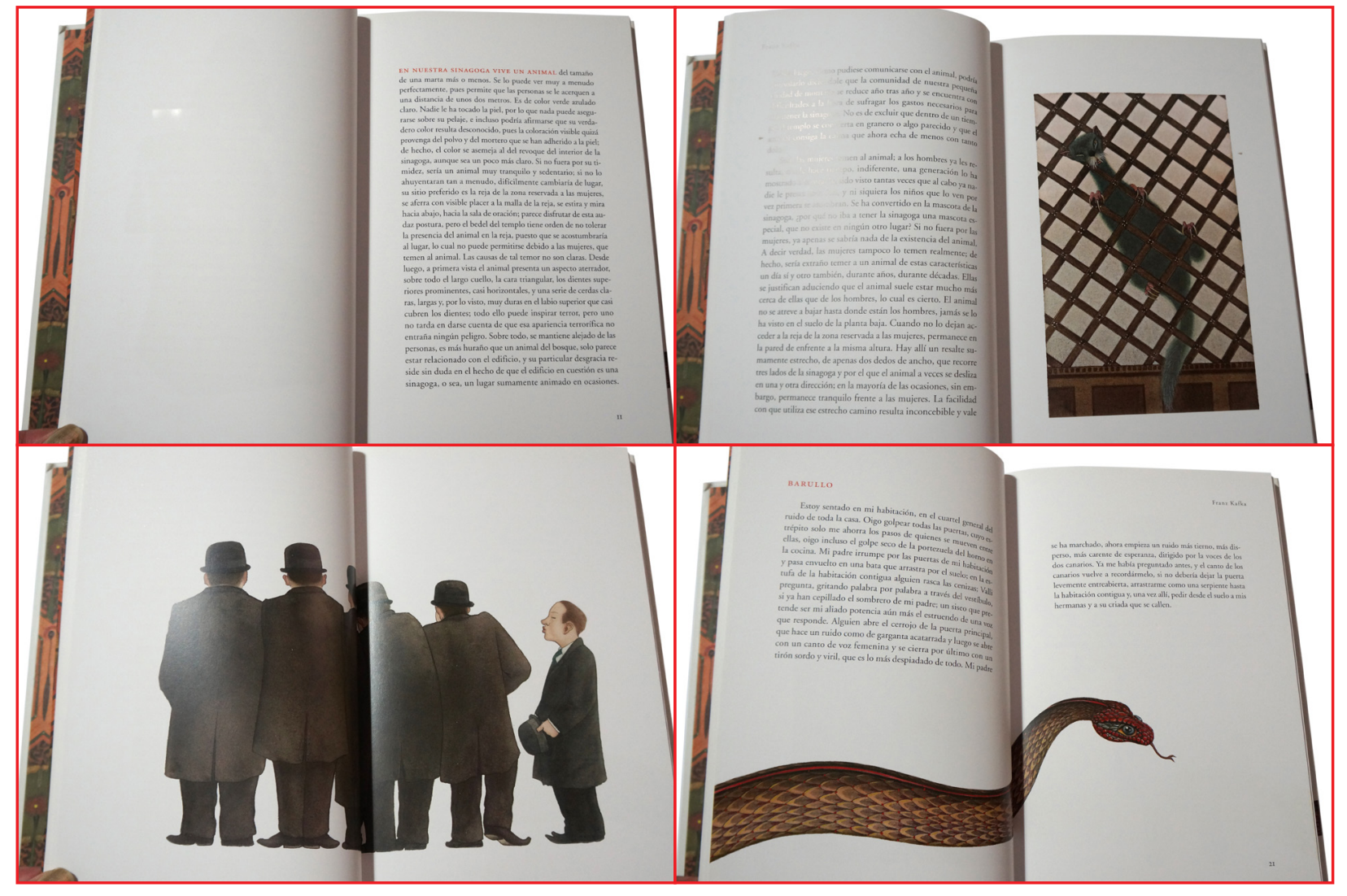

1 As traduções foram feitas por Juan José del Solar, Joan Parra Contreras, Miguel Sáenz Sagazeta, Adan Novacsis e Andrés Sanchez Pascual que em nota foram cedidas por cortesia do Círculo de Lectores, S. A. y Mariela Nagle. 
internas. Na capa, no título parece que houve uma intervenção no desenho da fonte, com a adição de uma cauda na letra a (como se um pedaço da cauda de letra $z$ fosse adicionada).

O papel do miolo é couché fosco (papel revestido), de gramatura aproximada $120 \mathrm{~g} / \mathrm{m}^{2}$. Este papel deve ter sido escolhido para que as ilustrações coloridas "vibrassem" e fossem mais bem impressas que em papel sem revestimento, porém esse tipo de papel reflete um pouco de luz e não é tão adequado à leitura contínua. No entanto, os textos são curtos, são contos e dessa maneira é possível fazer pausas. A composição das páginas apresenta título corrente só do lado esquerdo, fólio alinhado à esquerda e à direita da mancha e a mancha tem 22 paicas de largura e 35 paicas de altura. O corpo do texto, composto em fonte de classe garalde, é de 10 pontos e a entrelinha, de 14 pontos. A largura da mancha possui 22 paicas de largura por 35 de altura e as margens têm as seguintes dimensões: Inferior 8 , superior 61/2, interna 6 e externa 5 paicas.

\section{A metamorfose}

Esta edição publicada em $2009^{32}$ Ilustrada pelo argentino Luis Scafati, esta edição de bolso, de dimensões 13 x $23 \mathrm{~cm}$ com encadernação brochura, apresenta orelhas na capa (figuras 82 e 83). O miolo do livro foi todo impresso em preto, logo as ilustrações apresentam variações tonais do preto. A capa foi impressa nas cores pantone prata e preto e apresenta a ilustração de um sujeito segurando as mãos, com um x ao centro ocultando o corpo do homem, que tem um olho escuro e outro claro, como se estivesse se transformando. Ainda na capa, o nome do autor foi composto em um tipo caligráfico, o título e demais elementos textuais em um tipo sem serifa.

Nas páginas de abertura dos capítulos, foram utilizadas capitulares decoradas e o texto se inicia abaixo da mancha (141/2 paicas). Esse recurso, segundo Faria e Pericão (2008: 484), pode ser chamado de margem de título ${ }^{33}$. A mancha de texto apresenta $21^{1 / 2}$ paicas de largura por $40^{1 / 2}$ paicas de altura. $\mathrm{O}$ volume é bem estreito, mas mesmo assim mantém margens satisfatórias, que medem: inferior $6 \frac{1}{2}$, superior $6 \frac{1}{2}$, interna 5 e externa 3 paicas. As páginas possuem títulos correntes centralizados em

\section{Reimpressa em 2012.}

33 Segundo as autoras (2008: 484), margem de título é a "distância compreendida desde a margem exterior até ao início do título (a segunda linha vertical)".

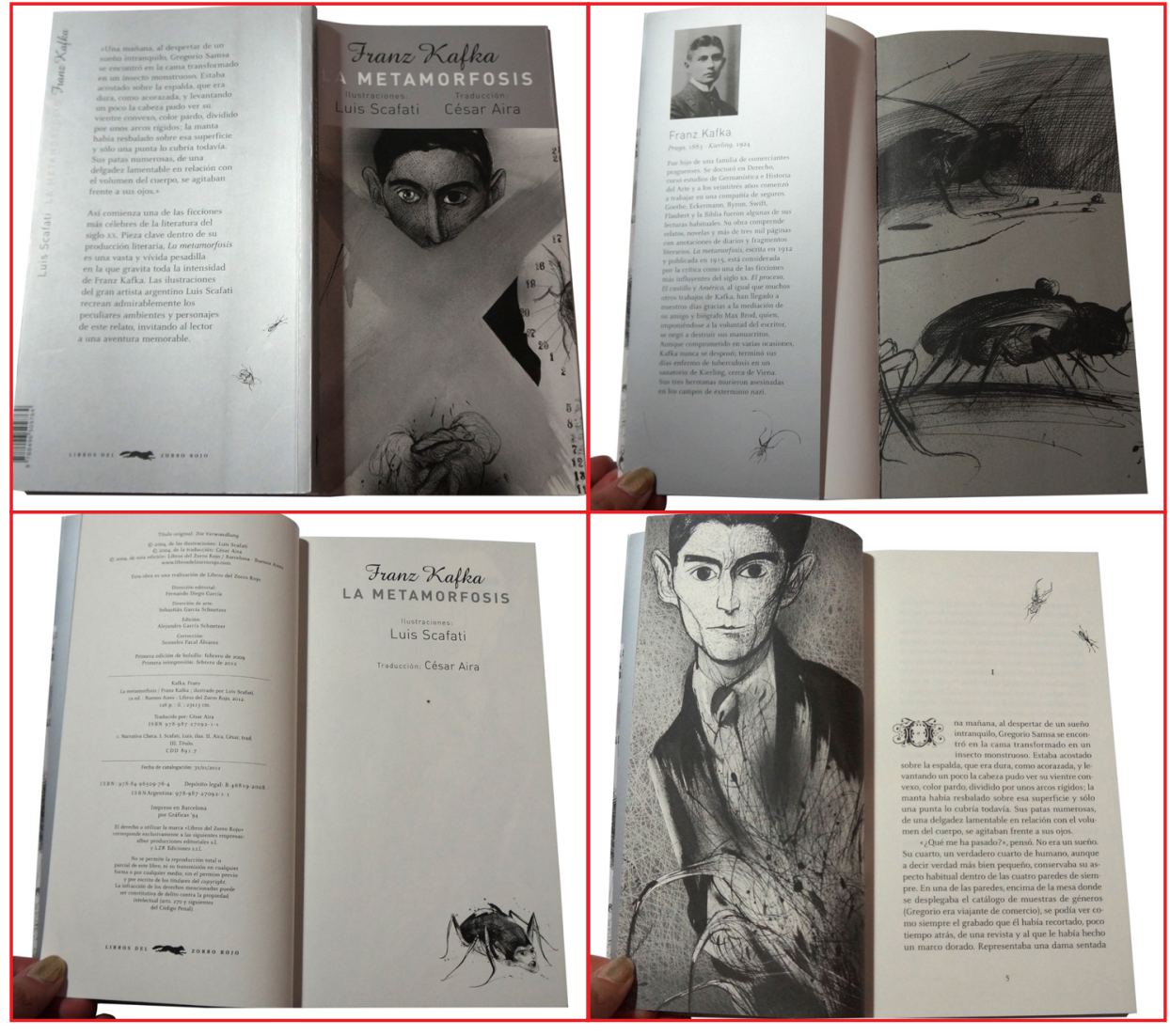

Figura 82. Capas e folha A metamorfose (1915) de Franz Kafka (18831924), publicada em 2009 pela Libros del Zorro Rojo. Livro do acervo da autora. Fotos da autora.

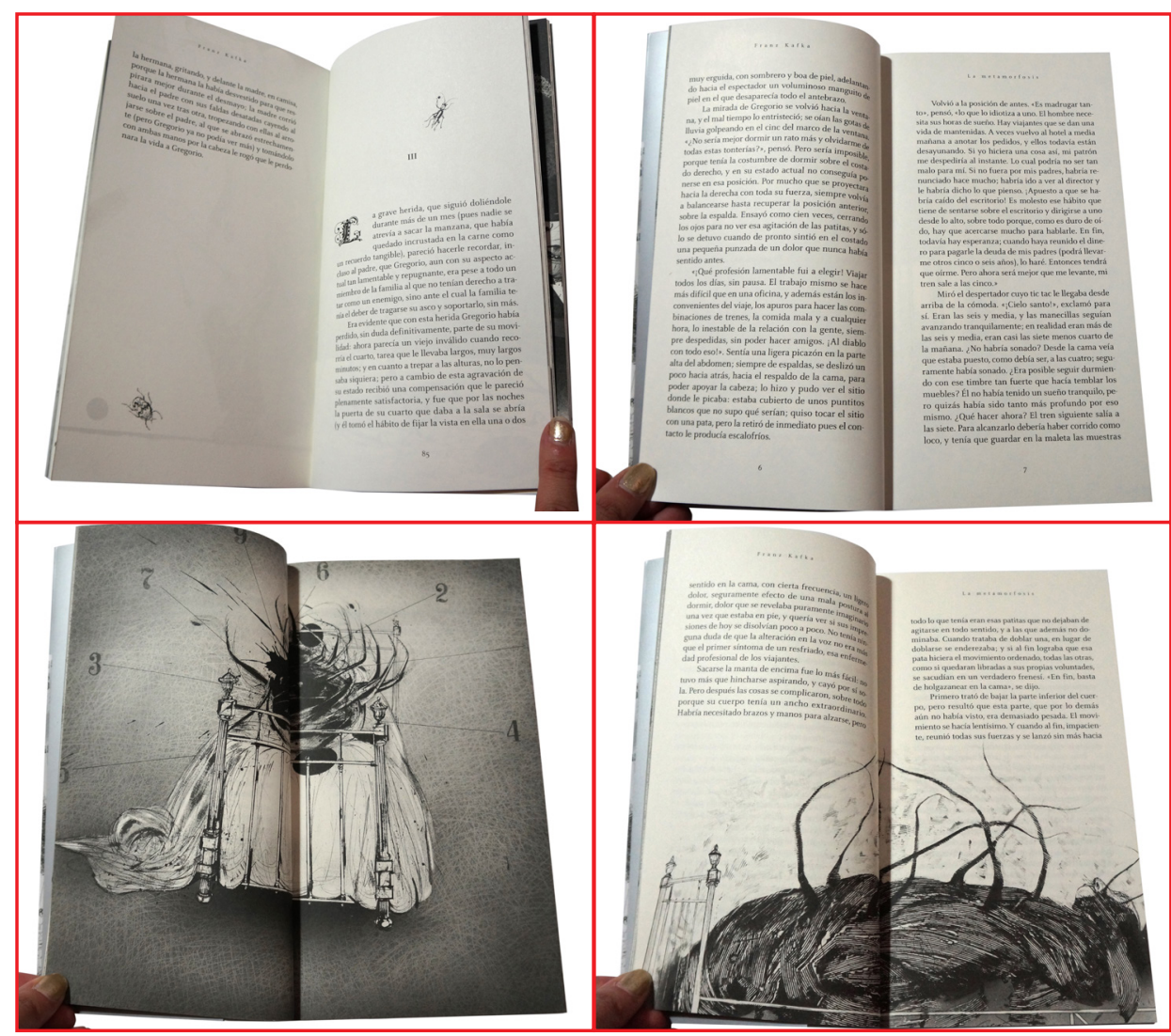

Figura 83. Páginas internas de A metamorfose (1915), de Franz Kafka (1883-1924), publicada em 2009 pela Libros del Zorro Rojo. Livro do acervo da autora. Fotos da autora. 
corpo menor caixa alta e baixa, porém espacejados (tracking). O texto foi composto com um tipo serifado mais contemporâneo, com corpo 11 entrelinha de 15 pontos, que não pode ser classificado pelo sistema Dixon ou British Standards, mas pode ser classificado, a partir de Coles (2012: 16), como "Contemporary serif" ou serifa contemporânea, que apresenta simplificação nos detalhes e menos contraste. O uso de um tipo mais contemporâneo em vez de um tipo clássico parece combinar com o estilo expressivo das ilustrações. Aparentemente, as ilustrações foram feitas com técnica mista (nanquim, bico de pena, lápis...) e o uso desses materiais dá certa dramaticidade ao desenho e cria uma atmosfera densa e surreal que acompanha e complementa, de certa forma, o texto.

Los culpables

De dimensões 19,5 x $26 \mathrm{~cm}$, o livro apresenta sobrecapa impressa na cor laranja, com as informações textuais em branco (figuras 84 e 85). O texto foi desenhado e as letras parecem acompanhar o desenho, que, na verdade, é vazado (recorte com faca especial). A ilustração se assemelha às partes de um animal. Quando se tira a sobrecapa, o animal inteiro, uma iguana, aparece. A ilustração é em baixo relevo, sem impressão na capa dura revestida por tecido verde claro. Na lombada e na contracapa da capa dura há informações textuais impressas em branco ${ }^{34}$, já que na parte frontal temos apenas o relevo da ilustração.

A falsa folha de rosto apresenta o nome do autor e o título da obra com o mesmo estilo de desenho de letra da capa, porém em cores e com sobreposições do texto em transparência criando um efeito tridimensional. A folha de rosto apresenta fundo colorido amarelo, com o texto composto da mesma maneira que na falsa folha de rosto, porém com outras tonalidades. Após a folha de rosto, apresenta-se uma dupla de páginas com fundo laranja com pequenas ilustrações simples (siluetas de objetos e animais) em amarelo chapado.

O sumário ocupa duas páginas (duplas) e o título dos capítulos apresenta o mesmo estilo do desenho de letra dos demais elementos sobrepostos em transparência ao número da página.

As aberturas de capítulo foram todas criadas em uma dupla de páginas, preenchidas por uma ilustração. O título do capítulo, por ser de-

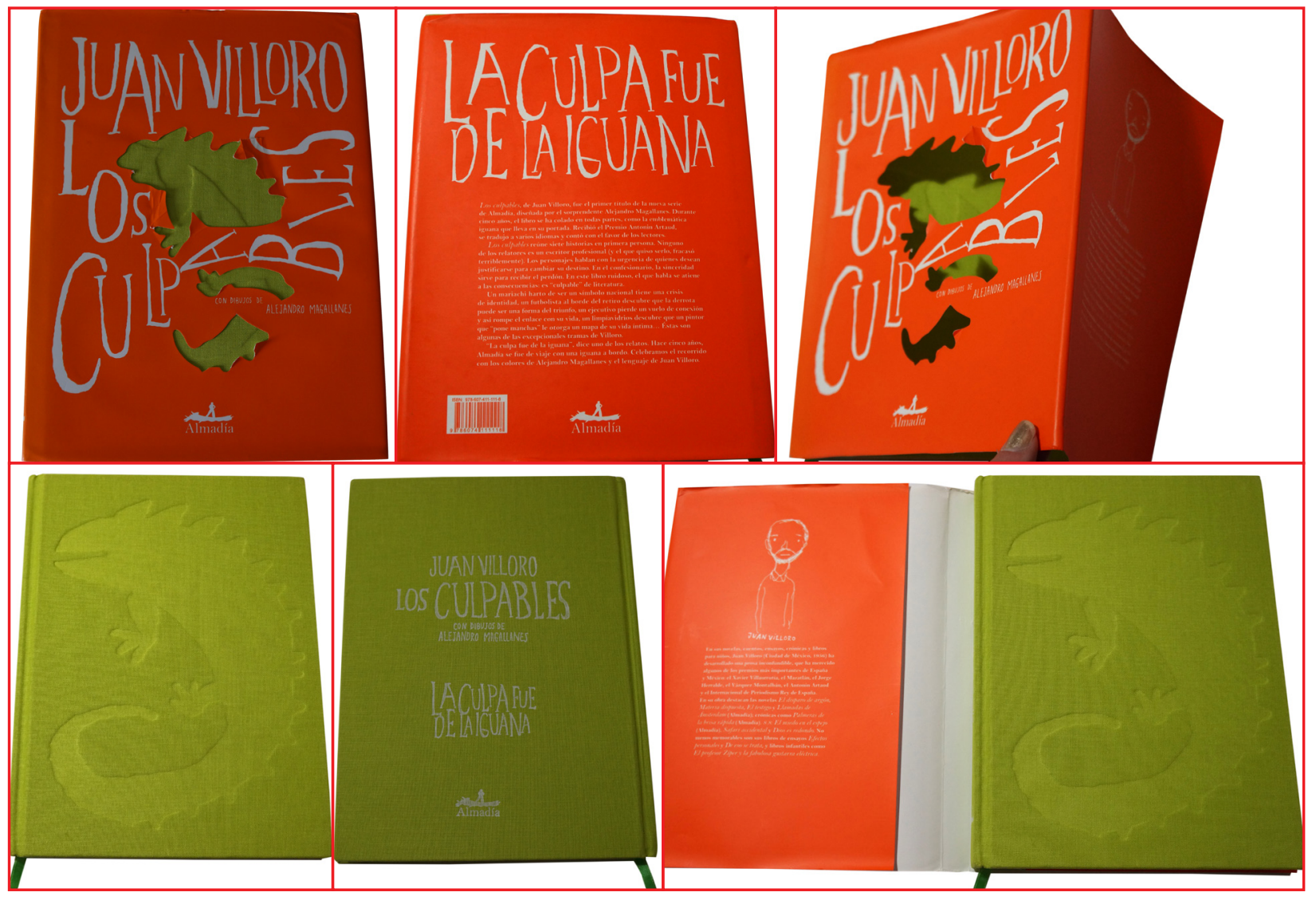

senhado (lettering), tem o mesmo estilo de traço da ilustração e dessa forma há uma integração formal entre as informações textuais e imagem, já que o próprio texto é tratado como imagem. Em cada capítulo há uma cor correspondente e uma alternância entre páginas brancas e coloridas em todo o livro. Quando a cor do fundo é clara o texto é impresso em preto e quando a cor do fundo é escura o texto é impresso em branco. O texto foi composto na fonte Bell MT, em corpo $12 \mathrm{pt}$ e entrelinha $18 \mathrm{pt}$. A mancha mede $30^{1 / 2}$ paicas de largura por $36 \mathrm{de}$ altura e as margens: inferior 8 , superior $14 \frac{1}{2}$ interna $6 \frac{1}{2}$ externa 6 paicas. $\mathrm{O}$ fólio localiza-se na margem inferior centralizado à mancha. No início do texto a primeira frase foi composta em corpo maior, tendo uso similar ao de uma capitular. O corpo desse texto de abertura é de 16 pontos em caixa alta e baixa.

O livro traz uma série de contos que tem o México como cenário. O texto que dá o título ao livro, Los Culpables, é narrado por um alcóolatra que é pressionado pelo irmão a escrever um roteiro, no qual usasse sua experiência e seus conhecimentos da região da fronteira

\section{Figura 84. Capae} sobrecapa de Los Culpables (2007), de Juan Villoro (1956-), edição comemorativa Almadía em 2013 com projeto gráfico e ilustrações de Alejandro Magallanes. Livro do acervo da autora. Fotos da autora. publicada pela editora 


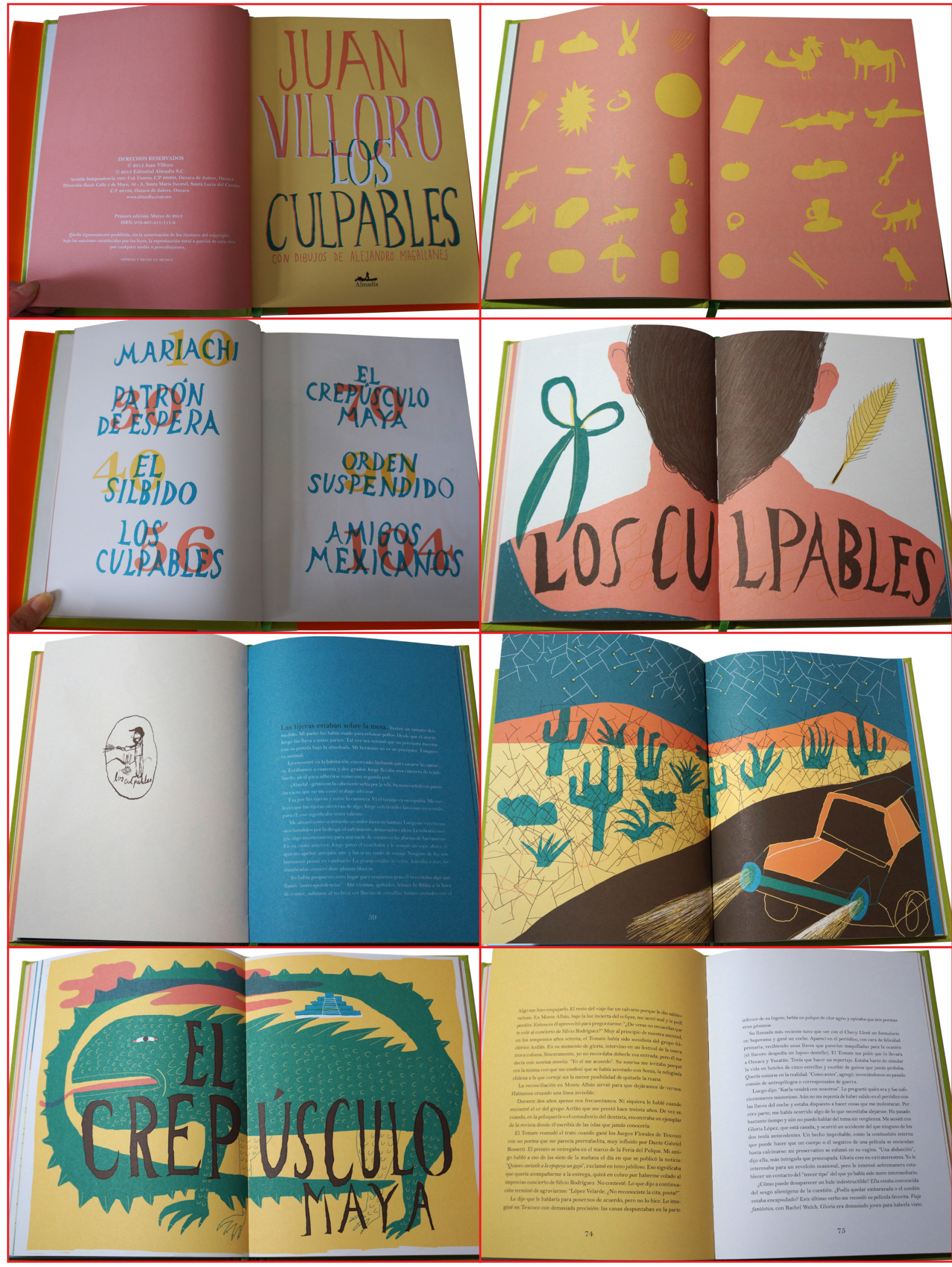

Figura 85. Folha de rosto, sumário, páginas de abertura de capitulos e páginas de texto de Los Culpables (2007). Livro do acervo da autora. Fotos da autora. entre México e Estados Unidos. Em uma experiência que lhe marcou, o narrador transportou dois imigrantes que havia encontrado ao acaso em uma rodovia até o outro lado da fronteira. O narrador também se envolve com a ex-companheira de seu irmão e a culpa por essa relação acaba funcionando como combustível para a criação de um roteiro cinematográfico. Há uma ironia sobre a visão de fora do México em relação à violência e as condições em geral naquele país.

O conto El Crepúsculo Maya, por sua vez, narra a relação de dois amigos que viajam acompanhados de uma mulher, Karla. O narrador e o amigo, conhecido apenas pelo apelido Tomate, têm uma relação ao mesmo tempo de companheirismo e rivalidade. Tomate queria começar uma relação com Karla, mas quem consegue é o narrador. Os amigos compram no percurso uma iguana, que se torna uma espécie de animal de estimação do grupo. Karla diz que se interessou pelo narrador pela forma como ele a olhou em Oaxaca, mas ele na verdade estava olhando para ela de maneira diferente porque naquele momento estava sendo mordido pela iguana. Por isso a "culpa foi da iguana". No fim do conto, quando a iguana se une a outros animais da sua espécie, o casal recém formado acaba sofrendo um acidente de carro e logo se separa. A iguana parece, então, na trama, o insólito elemento de união. O projeto da capa relaciona-se ao conto "El Crepúsculo Maya" em que aparece uma iguana, e não a Los Culpables, conto que dá título à obra.

Todas as ilustrações do volume, incluindo as das páginas de abertura de capítulo, parecem se relacionar com o texto, pois seu estilo informal e o colorido podem ser lidos como um estilo de imagens e cores que remetem ao ambiente em que se passa a maioria dos contos.

\section{Frankenstein}

Este exemplar publicado pela Sexto Piso (Espanha e México) pertence a uma coleção de livros ilustrados ${ }^{35}$ (figuras 86 e 87). A editora tem em seu catálogo uma grande coleção de livros de literatura ilustrados. Esta versão do clássico de terror de Mary Shelley foi ilustrada por Lynd Ward (1905-1985) em 1934, conforme explicado na contracapa: 
Frankenstein inspirou diversas versões em obras literárias, plásticas e audiovisuais. Nesta ocasião, a série de gravuras em madeira que um dos pais da novela gráfica (graphic novel), Lynd Ward, dedicou ao monstro pais da novela grafica (graphic novel), Lynd Ward, dedicou ao monstro
em 1934 plasma a ambivalência própria do texto de Shelley, graças a seu domínio da técnica e à combinação de elementos do expressionismo alemão e da art déco. Vista por Ward, a criatura é ao mesmo tempo patética e terrível e suas perspectivas e claros/escuros pouco usuais são o complemento perfeito para esta obra-prima.
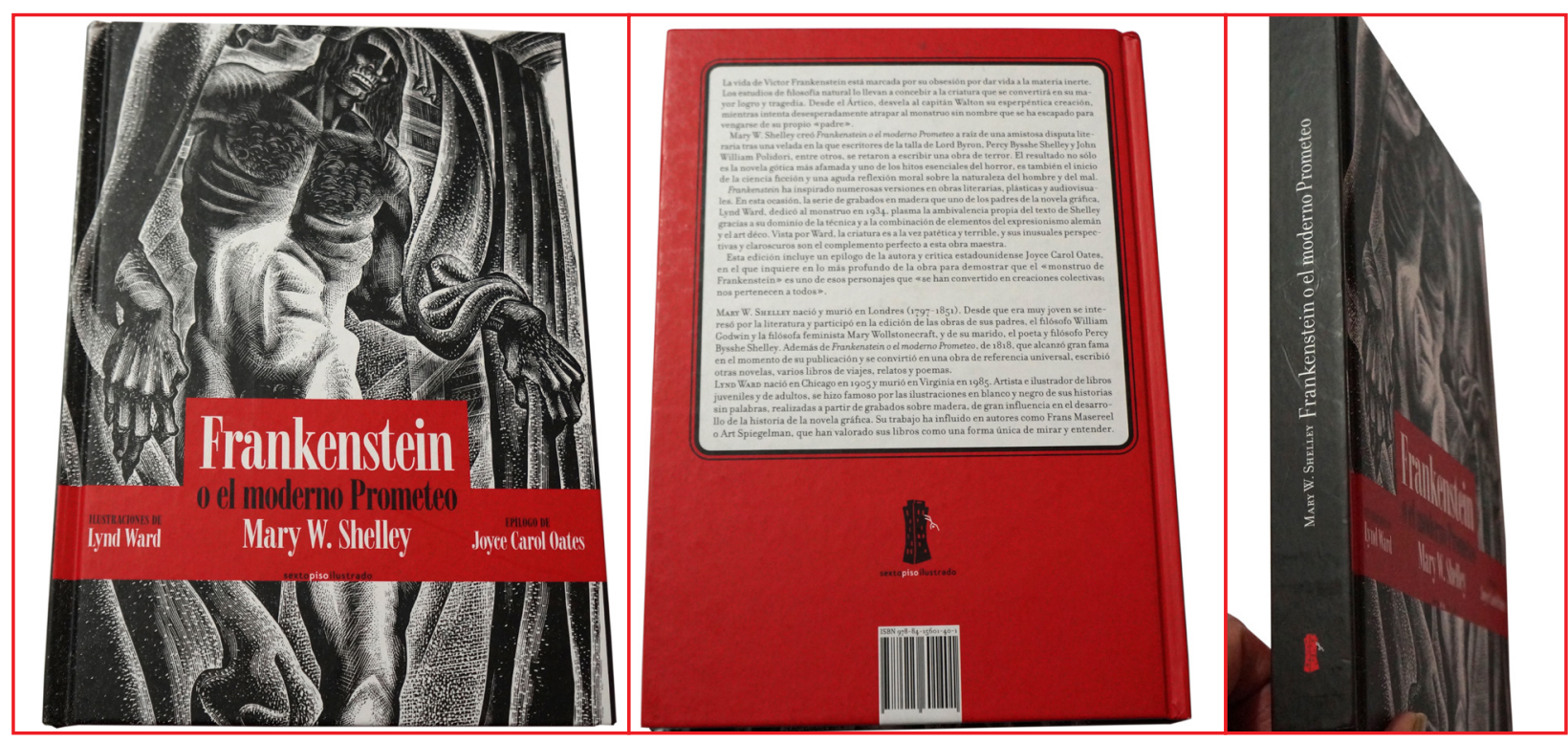

Figura 86. Capa e contra capa de Frankenstein: o el moderno Prometeo (1818),

O projeto gráfico do volume foi produzido pelo Estúdio Joaquín de Mary W. Shelley (1797Gallego. A superfície da capa é coberta por uma ilustração em preto e branco de um monstro saindo por trás de uma cortina ou de uma 1851) publicado pela Sexto porta. O títúlo e demais elementos textuais foram acondicionados em Piso em 2013. Livro do um box vermelho composto de um retângulo maior e um menor sobreacervo da autora. Fotos da autora. postos. O título e o nome da autora encontram-se centralizados nesse box e demais elementos textuais, como nome da ilustradora e o autor do epílogo, alinhados à esquerda e à direita desse box. A fonte usada na capa é de classe moderna condensada (serifas filetes e sem junção entre as hastes), que dá um "tom" dramático e clássico. Tipos modernos foram extensivamente usados no século XIX, época em que também se passa a trama, dessa maneira, há aí certa alusão histórica.

O miolo, de dimensões $23,5 \times 16,5 \mathrm{~cm}$, foi composto com um tipo de classe moderna porém não é condensado. É um tipo com propriedades semelhantes, porém não é o mesmo, mas mantém uma coerência por ser da mesma classe. A mancha foi composta com o tipo em corpo e

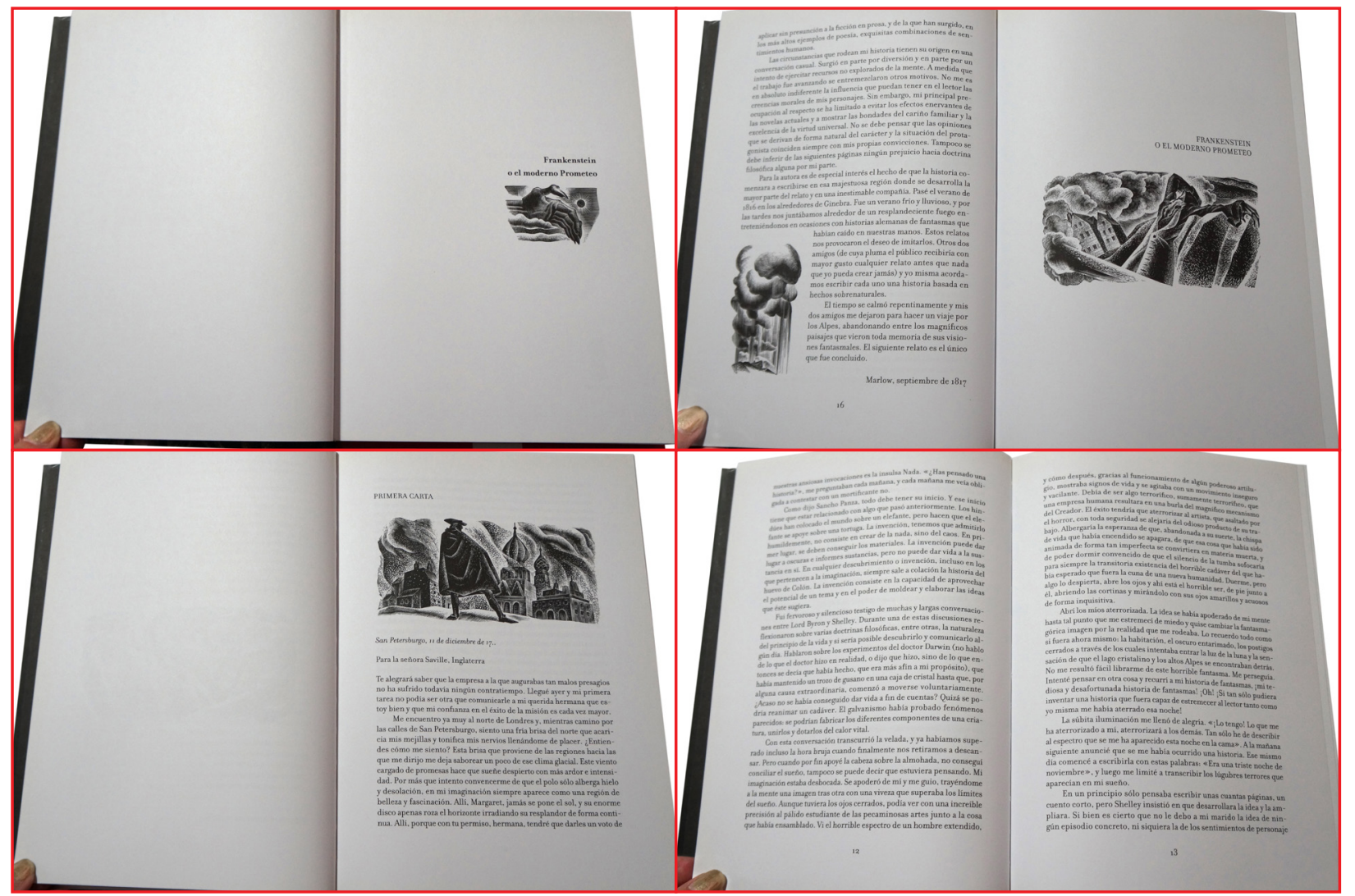

entrelinha de 12/14 pontos, mas como o tipo tem a altura $\mathrm{x}$ menor Figura 87. Página de rosto (pequena), a entrelinha parece maior. O fólio localiza-se centralizado e páginas internas de

na margem inferior. A mancha de texto é mais larga que o costume Frankenstein: ol moderno devido à largura do volume: $28 \frac{1}{2}$ paicas ou $12 \mathrm{~cm}$. As margens são Prometeo (1818), de Mary são W. Shelley (1797-1851) proporcionais ao tamanho do livro e a mancha e apresentam as se- publicado pela Sexto Piso guintes dimensões: inferior 71/2, superior 4, interna 41/2 e externa 6 pai- em 2013. Livro do acervo cas. O papel é branco alcalino, porém um pouco mais espesso do que da autora. Fotos da autora. o utilizado em edições comuns ( $120 \mathrm{~g} / \mathrm{m}^{2}$ aproximadamente). O uso de um papel mais espesso e opaco pode ter sido escolhido devido ao tom escuro das ilustrações ${ }^{36}$. As ilustrações de Ward, em xilogravura, são bem pesadas, com uma área escura maior do que clara, que condiz com a atmosfera da trama sobre o monstro criado em laboratório pelo cientista Victor Frankenstein.

6 Se o papel fosse mais fino, provavelmente as ilustrações seriam vistas no verso da folha. 
Decameron

Decameron, de Giovanni Boccaccio (figuras 88 e 89), é um clássico que, segundo Maurício Santana Dias (in BOCCACCIO: 2013: 11), marca a prosa de ficção no Ocidente:

Quando Giovanni Boccaccio começou a escrever Decameron, a Europa tinha acabado de ser devastada pela peste negra de 1348. O quadro geMé o que domina a introdução de sua obra-prima, escrita entre 1349 e 1351 (ou 53) e considerada o marco inaugural da prosa de ficção no Ocidente. Assim, o grande livro das "dez jornadas" ou "cem novelas"

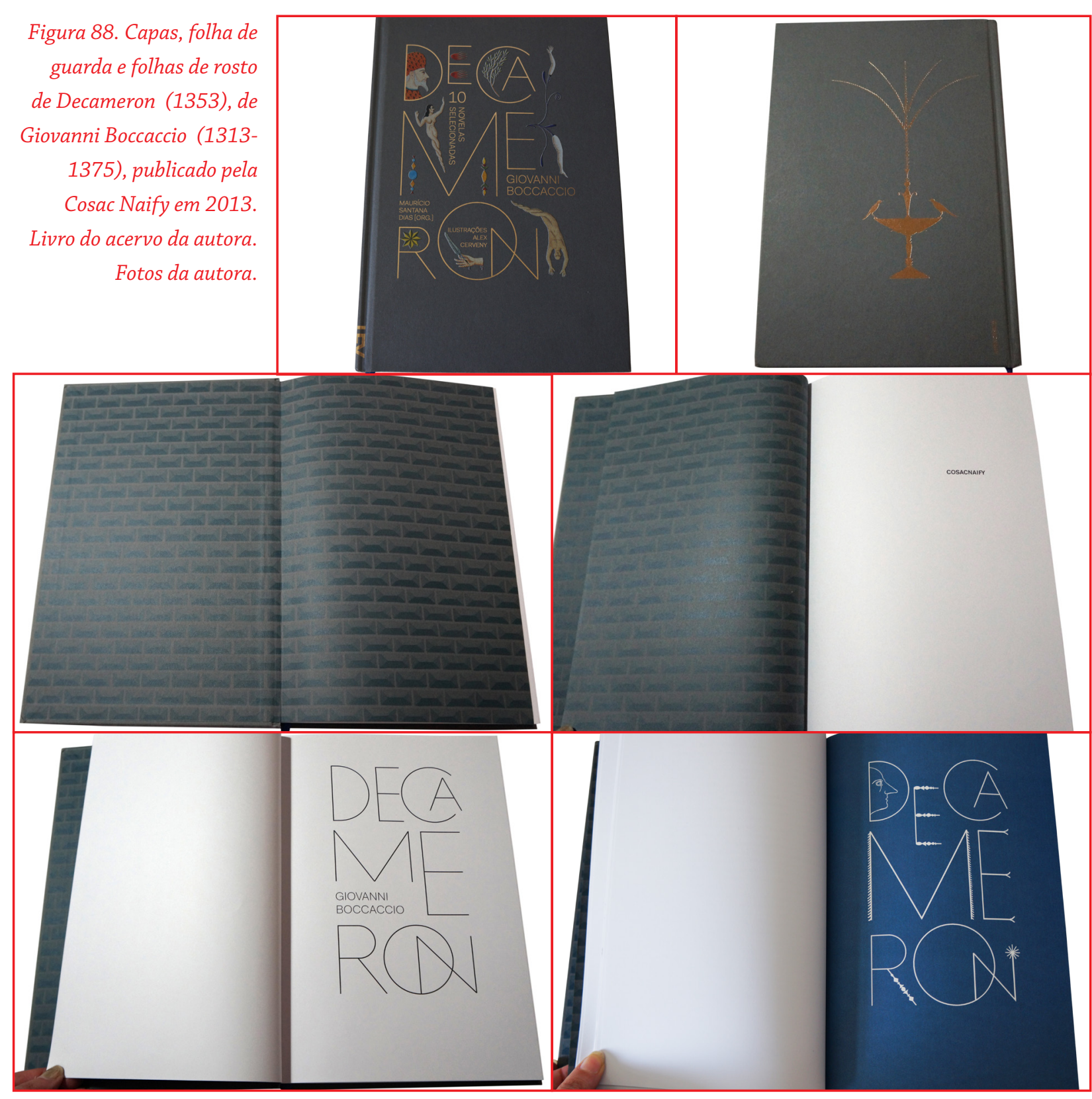

nasce de um duplo impulso: fazer o luto dos mortos - durante a peste, Boccaccio perdeu o pai, a madrasta e muitos amigos - e celebrar a vida que prossegue e se regenera.

Figura 88. Páginas de abertura e páginas

Este volume traz dez novelas selecionadas das cem escritas pelo autor. internas de Decameron O texto é um conjunto de pequenas histórias (contos) narradas pelos (1353), de Giovanni personagens (sete jovens damas e três cavalheiros) apresentados na in- Boccaccio (1313-1375), trodução do texto que se reúnem todas as tardes para contar histórias: publicado pela Cosac Naify

as personagens que acervo da autora. vão constituir a "moldura" romanesca dentro da qual cem novelas serão Fotos da autora.

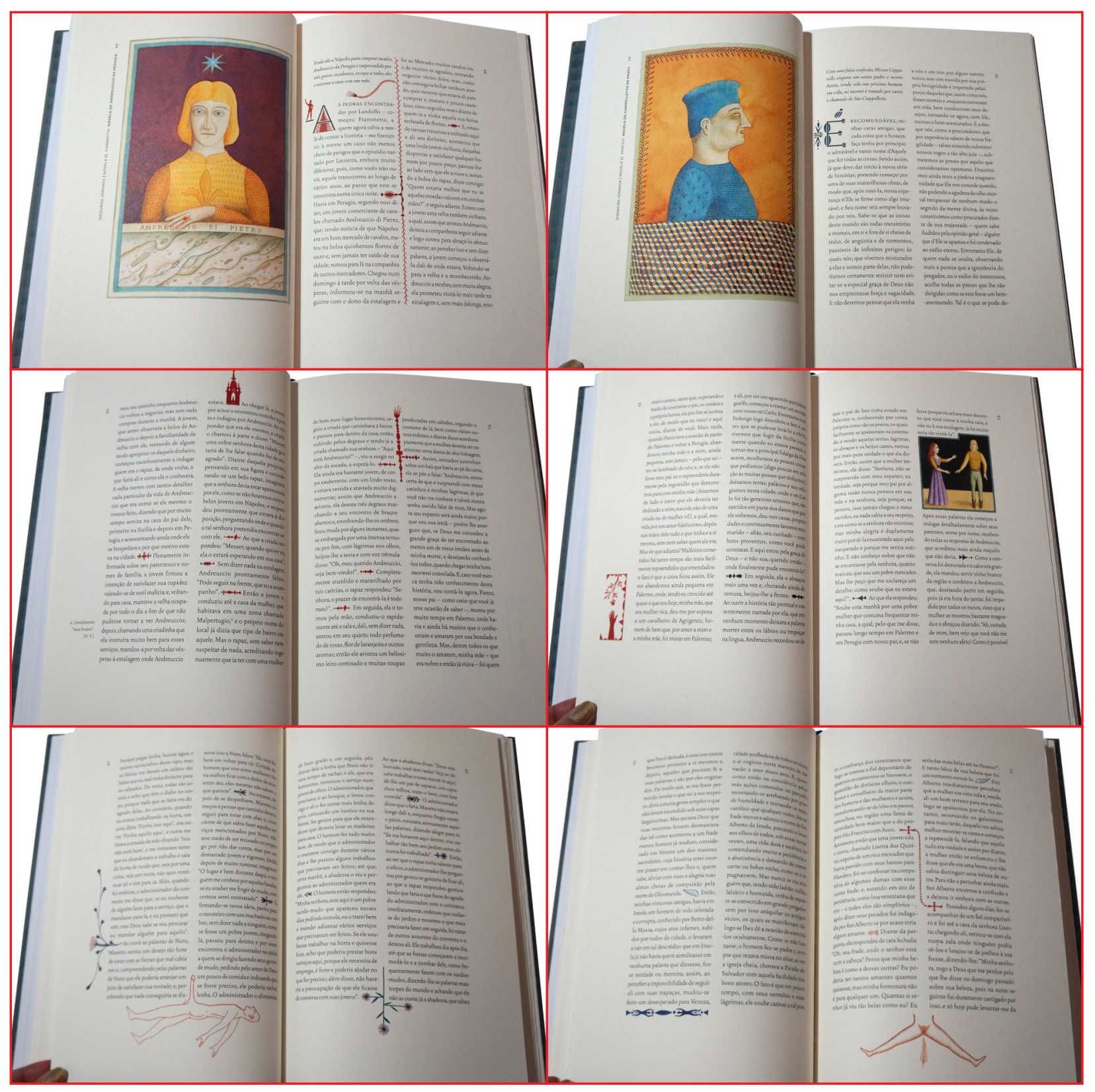


narradas. Sete jovens damas e três cavalheiros se encontram por acaso na igreja de Santa Maria Novella, a mesma que hoje se avista quando se sa da estação ferroviária de Florença. As mulheres estavam ali em busca de abrigo e proteção divina, até que uma delas propõe às amigas uma fuga de Florença para as colinas próximas, ainda preservadas da peste. Todas concordam com a ideia, mas como um grupo de jovens mulheres se deslocaria até lá sem a companhia de cavalheiros que as defendessem em caso de algum ataque? É então que aparecem os três jovens nobres, que pronde algum ataque? Ee enta que aparecen os tres jovens nobr, que tamente aceitam o convite. Os dez, então, acompanhados de sete criados, partem para uma villa senhoril afastada da cidade e ali poderão, em alguma medida, reconstituir o modo de vida que levavam até o caos instaurado pela doença. Em meio ao inferno sombrio de Florença tomada pela peste, abre-se então uma clareira, o locus amoenus que tornará possível o esquecimento da morte por alguns dias. (DIAS in BOCCACCIO: 2013: 14)

$\mathrm{Na}$ capa mesclam-se letras e imagens componto o título em três linhas e as informações textuais estão alinhadas a algum elemento desta composição. O volume tem capa dura e as informações textuais foram impressas usando hot stamp dourado. As folhas de guarda são ilustradas (textura que lembra tijolos). $\mathrm{Na}$ falsa folha de rosto há o título da editora e na folha de rosto há uma composição semelhante com a da capa porém sem as ilustrações.

Na página de introdução foi utilizado um papel alcalino (branco) tipo offset, com o texto composto em um tipo sem serifa neogrotesco chamado Fakt, criado por Thomas Thiemich em 2010 e distribuído pela Fontshop.

Após a introdução e demais elementos textuais impressos em papel alcalino, o papel do texto principal, das dez novelas selecionadas de Bocaccio, é offwhite de gramatura aproximada 120 ou $150 \mathrm{~g} / \mathrm{m}^{2}$, que faz alusão à tonalidade e à textura do papel da época. $\mathrm{O}$ texto é composto em duas colunas em corpo 11 ou 12 com entrelinha de 16 pontos na tipografia Vendetta, que é uma fonte serifada com eixo humanista criada em 1999 por John Downer e distribuída pela Emigre. A mancha possui 41 paicas de altura e cada coluna 131/2 paicas com duas paicas de distância entre cada coluna (gutter). Assim como nos antigos manuscritos, todo o texto foi composto e depois foi "iluminado", ilustrado por Alex Ceverny. O texto apresenta espaços em branco para marcações que foram usadas pelo ilustrador, foram deixados espaços em branco para ilustrações, marcações de parágrafo e etc. e em cada página o ilustrador apresenta ornamentos diferentes. Algumas das novelas são bem eróti- cas e esse elemento é trabalhado pelo ilustrador em algumas vinhetas. Nas capitulares foi usada a fonte sem serifa fact, porém o ilustrador, posteriormente, fez contornos e ornamentou essas letras. É uma versão contemporânea, que faz alusão aos processos de produção de um original da época. O texto é bastante legível e as margens generosas, como eram os livros da época: margem inferior $131 \frac{1}{2}$ paicas, superior 8 $1 / 2$, interna $4 \frac{1}{2}$ externa 9 . Nas páginas de texto, o fólio foi rotacionado a 90 graus (nas páginas de abertura os títulos correntes também foram rotacionados como os fólios), alinhado à parte superior da mancha, com distância de 2 paicas. Todas as páginas apresentam ilustrações ou vinhetas ou floreios em cores, além da ornamentação da capitular.

As novelas escolhidas são divertidas e apresentam elementos do acaso, da fortuna, do erotismo e da engenhosidade humana. Em cada novela o ilustrador trabalha o tema e em alguns casos também usa o traço com humor, como na novela de Masetto da Lamporecchio, em que genitais masculinas invadem o espaço entre colunas e recuos de texto. Na novela de Frei Alberto da Imola, o ilustrador aplica genitais masculinas no meio do texto e femininas na margem.

Como se pode perceber, os livros apresentados neste capítulo não são apenas "visíveis". São livros em que o projeto gráfico estabelece uma relação, ou melhor, uma série de relações, com o texto literário.

No próximo capítulo serão apresentadas questões teóricas para análise de livros de literatura para depois, no capítulo subsequente, realizar uma análise mais aprofundada de edições de Bartleby, o escrivão, de Herman Melville. 


\section{PERSPECTIVAS TEÓRICAS PARA A ANÁLISE DE PROJETOS GRÁFICOS DE LIVROS DE LITERATURA}

No próximo capítulo serão analisadas quatro edições de Bartleby, o escrivão, de Herman Melville. Duas delas apresentam projetos gráficos complexos, que estabelecem relações semânticas com o texto literário e, assim, tornou-se necessário discutir algumas perspectivas teóricas para a análise do texto literário, do projeto gráfico e de suas interações.

Diversos autores da área da bibliografia e da literatura destacam a importância do projeto gráfico para a construção de significados de um texto.

Gérard Genette (2009) classifica o projeto gráfico de um livro como paratexto. Segundo Genette, paratextos são textos que acompanham um texto principal e podem, ou não, estar no mesmo volume. Genette distingue dois tipos de paratexto: o peritexto e o epitexto. O primeiro está no próprio volume, como notas, prefácio etc. $\mathrm{O}$ epitexto abrange informações externas ao volume, como entrevistas, correspondências etc.

Grande parte dos paratextos são de natureza verbal, como títulos, prefácios, resenhas, mas há paratextos não verbais que correspondem à estrutura física do volume (materiais, acabamento e tipografia):

(...) quase todos os paratextos considerados serão de ordem textual ou, pelo menos, verbal: títulos, prefácios, entrevistas, assim como enunciados, possuindo tamanhos bastante diversos, mas compartilhando o estatuto linguístico do texto. No mais das vezes, portanto, o paratexto é um texto: se ainda não é o texto em si, pelo menos já é texto. Mas deve-se pelo menos ter em mente o valor paratextual que outros tipos de manifestações podem conter: icônicas (as ilustrações), materiais (tudo o que envolve, por exemplo, as escolhas tipográficas, por vezes muito significativas, na com- 
posição de um livro) $)^{1}$, ou apenas factuais. Chamo de factual o paratexto que consiste não numa mensagem explícita (verbal ou não), mas num fato cuja própria existência, se é conhecida do público, acrescenta algum comentário ao texto e tem peso em sua recepção. (GENETTE, 2009: 14)

Genette amplia a noção de paratexto. incluindo os elementos materiais do livro como formato, capa, página de rosto e composição, que correspondem ao que ele denomina peritexto, isto é, textos complementares (verbais ou não) dentro do corpo físico do livro.

Denomino peritexto editorial toda zona do peritexto que se encontra sob a responsabilidade direta e principal (mas não exclusiva) do editor ou talvez, de maneira mais abstrata, porém com maior exatidão, da edição, isto é, do fato de um livro ser editado, e eventualmente reeditado, e proposto ao público sob uma ou várias apresentações diferentes. A palavra zona indica que o traço característico desse aspecto do paratexto é essencialmente espacial e material; trata-se do peritexto mais exterior: a capa, a página de rosto e seus anexos; e da realização material do livro cuja execução depende do impressor, mas cuja decisão é tomada pelo editor, em eventual conjunto com o autor: escolha do formato, do papel, da composição tipográfica, etc. (GENETTE, 2009: 21)

Genette não aprofunda a discussão sobre o projeto gráfico como paratexto para não invadir o campo de outras disciplinas ${ }^{2}$, mas abre caminho para que seja explorado por outros pesquisadores.

D.F. McKenzie, em Bibliografía y sociología de los textos, reunião de uma série de palestras proferidas em 1985, aponta que a configuração gráfica de certos textos produz diferentes significados de acordo com seu contexto, assim, a análise textual pode ser atrelada à análise de elementos gráficos e tipográficos. Para comprovar essas diferenças o autor compara duas frases de William Congreve: a publicada na versão original (1710) e em um contexto de citação feito por outros autores (1946) e compostas de forma diferentes. Após a comparação ele verifica que a composição tipográfica tem uma função expressiva:

Tenho agora que voltar a considerar o caso particular dos textos impressos. Ao fazê-lo, a questão em concreto que desejo colocar é se as formas materiais dos livros, os elementos verbais dos signos tipográficos, a disposição do próprio espaço, têm uma função expressiva ao transmitir 1 Grifo nosso.

2 Genette usa o termo bibliotecnia, porém, nesse contexto, poder-se-ia usar o termo design editorial. significado e se seu estudo constitui propriamente uma incumbência bibliográfica. (MCKENZIE, 2005: 34)

Nessa passagem, McKenzie legitima a pesquisa da configuração visual e material do texto aos estudos da bibliografia. Ao dizer que os elementos gráficos apresentam uma "função expressiva", confere pertinência aos estudos relativos à relação entre o texto e sua configuração material.

Permitam que diga, de entrada, que meu único propósito ao recorrer a um exemplo tomado desse artigo é demonstrar que em alguns casos possível fazer leituras cheias de significado a partir dos signos tipográficos tanto como dos verbais, pois estas têm a ver com decisões editoriais relativas a como se deve reproduzir um texto, assim como uma leitura de tais signos bibliográficos pode repercutir gravemente em nosso juízo sobre a obra de um autor. (...) Meu raciocínio, portanto, gira em torno da defesa do significado autoral, sobre a base do qual este, em alguma medida, é recuperável, apesar de reconhecer que, para o bem ou para o mal, os leitores inevitavelmente constituem seus próprios significados. Em outras palavras, todas as leituras são características de suas circunstâncias temporais podendo, ao menos parcialmente, ser reconstruídas a partir das formas materiais do texto, constituindo essas diferenças de leituras uma história muito reveladora. Nenhuma história do livro pode ignorar questões como o que pensaram que estavam fazendo os escritores ao compor textos, os impressores e livreiros ao projetá-los e publicá-los ou os leitores ao criar sentido a partir deles. (MCKENZIE, 2005: 36)

McKenzie verifica a importância da configuração visual de um texto referente a determinado contexto cultural, porém pode-se tomar como ponto de partida a importância do leiaute de um livro como reflexo de diferentes formas pelas quais um leitor pode ler um texto, já que cada edição pode apresentar configurações visuais diferentes.

Se os menores detalhes de tipografia e composição, os signos materiais que constituem um texto, criam significado da maneira que venho tentando sugerir, é preciso deduzir que toda história do livro - sujeitos como estão os livros a mudanças tipográficas e materiais - também tem que ser uma história dos erros de leitura. Não é tão estranho quanto possa parecer. Cada sociedade reescreve seu passado, cada leitor reescreve seus textos e, se estes gozam de uma fortuna prolongada, até certo ponto cada impressor os redesenha. (MCKENZIE, 2005: 42)

Assim como em McKenzie, verifica-se uma preocupação com os elementos gráficos de um livro como elementos significativos em Jerome McGann. Em Black Riders: The Visible Language of Modernism, McGann 
(1993) se interessa pelas condições materiais em que o livro é produzido, apresentando exemplos da relação entre escritores como William Morris, Yeats e Pound entre outros, com a produção e impressão de seus textos, como indicações de preocupação formal e estética e explica a importância do "renascimento do livro" e da formação das "prensas particulares" para o desenvolvimento da literatura modernista do final do século XIX e início do século XX.

Em The Textual Condition, McGann (1991) aborda a importância da investigação do texto pensando em suas condições materiais e históricas. Além de introduzir caminhos, apresenta um panorama sobre a questão

McGann (1991: 12) explica a importância do estudo da textualidade fundamentado pela paleografia, bibliografia e sociologia dos textos, porém percebe que ultimamente os textos têm sido mais estudados sob o ponto de vista da hermenêutica. Propõe, por isso, mudar o foco para o estudo das variações das estruturas materiais do texto, tendo como objeto de investigação "a forma física dos livros e manuscritos (papel, tinta, tipografia, leiaute) ou seus preços, publicidade e mecanismos de distribuição".

O autor comenta que um estudo dessa natureza também é proposto por Gérard Genette em Paratextos editoriais ${ }^{3}$, mas que este estudo falha por não considerar, ou não aprofundar, a pesquisa sobre a materialidade do texto:

A distinção, texto/paratexto pode ser útil para certos fins descritivos, mas para uma investigação mais profunda sobre a natureza da textualidade não é forte o suficiente. Nos últimos seis anos, tenho explorado uma abordagem diferente, chamando a atenção para o texto como uma rede atada dos códigos linguísticos e bibliográficos. (...) Trata-se, por um lado, de uma distinção que autoriza um estudo mais abrangente da textualidade uma distinção que autoriza um estudo mais abrangente da textualida-
de. A distinção texto/paratexto, como formulada em Paratextos editoriais, não vai, pela própria afirmação de Genette, explorar assuntos como tinta, tipo de letra, papel e vários outros fenômenos cruciais para a compreensão da textualidade. Eles caem fora das suas preocupações, porque tais características textuais não são linguísticas. Mas é claro que todos os textos, como todas as outras coisas humanas, são fenomenos encam tos, como todas as outras colos hanas, sao fenomo e o corpo do texto não é exclusivamente linguístico. Ao estudar os textos através de uma distinção entre códigos linguísticos e bibliográficos, ganhamos ao mesmo tempo uma visão mais global e uniforme sobre os textos e processos de produção textual. (MCGANN, 1991: 13-14)

3 Título original Seuils.
Bonnie Mak credita aos autores mencionados acima a importância de se pensar as diversas edições e os atributos gráficos de um texto para legitimar pesquisas no âmbito das relações entre o texto de um livro e suas configurações materiais, isto é, seus projetos gráficos.

Bibliógrafos e editores textuais, como D.F. McKenzie e Jerome McGann, percebem, no livro impresso, uma prova material do passado e incentivam a pesquisa de 'códigos bibliográficos' de determinadas edições e a investigação de histórias sociais ou 'sociologias' de textos impressos em que se identifica as particulares circunstâncias de sua produção, circulação e recepção. Além disso, a noção complementar de uma 'cultura de impressão' introduz e define uma comunidade que pode ser estudada po seus hábitos de leitura e escrita. O 'livro impresso' e a 'cultura da impressão' foram, assim, circunscritos como entidades aprovadas para investigação acadêmica. Esse reconhecimento disciplinar habilita historiadores e estudiosos literários para entender o livro impresso como um objeto para a exploração do uso e recepção de um texto, e também para justificar o exame de leitores específicos e suas atividades. (MAK, 2011: 6)

Bonnie Mak investiga diversas edições, desde manuscritas a eletrônicas, de um tratado escrito no início do século XV por Buonaccorso de Montemagno, chamado Controversia de nobilitate. O autor verifica em suas diferentes edições diferentes códigos gráficos que podem alterar a leitura do texto. Ele observa que, em algumas edições francesas, o texto foi composto de forma, com elementos gráficos ou códigos, que sugeririam a leitura do texto como se fosse a de um romance. Ou seja, comprova dessa maneira que a página impressa, em suas diferentes abordagens trabalhadas por designers (ou impressores) e suas relações com os leitores promovem diversas maneiras de ler um texto.

Todos esses estudos apontam caminhos para a análise do texto do ponto de vista da materialidade, ou seja, do design. De modo inverso, a análise do projeto gráfico de um livro também pode se beneficiar da análise do texto. Uma vez que nosso objeto de estudo é o livro de ficção, torna-se necessário discutir algumas perspectivas teóricas para a análise do texto literário e seu projeto gráfico.

Jonathan Culler (1999) apresenta uma breve síntese da teoria literária e aponta que o texto literário pode ser analisado de maneiras diferentes, de acordo com a abordagem teórica, como, por exemplo, a estruturalista, pós-estruturalista, marxista, pós-colonialista, de estudos de gênero etc. Culler investiga a problemática definição do que é 
literatura e apresenta uma revisão bibliográfica para o estudo do sentido do texto literário.

Ao apresentar as variáveis interpretativas decorrentes da perspectiva teórica que se utiliza para analisar e interpretar uma obra, de certa maneira o autor percebe que os significados da obra variam de acordo com diversos parâmetros externos à obra:

O sentido de uma obra não é o que o autor tinha em mente em algum momento, tampouco é simplesmente uma propriedade do texto ou a experiência de um leitor. O sentido é uma noção inescapável porque não é algo simples ou simplesmente determinado. É simultaneamente uma experiência de um sujeito e uma propriedade de um texto. É tanto aquilo que compreendemos como o que, no texto, tentamos compreender. Discussões sobre sentido são sempre possíveis e, sendo assim, o sentido é impreciso, está sempre a ser decidido, sujeito a decisões que nunca são irrevogáveis. Se devemos adotar algum princípio ou fórmula geral, poderíamos dizer que o sentido é determinado pelo contexto, já que o contexto inclui regras de linguagem, a situação do autor e do leitor e qualquer outra coisa que poderia ser concebivelmente relevante, que a ampliação do contexto poderia conseguir alterar o que consideramos como sentido de um texto. O sentido está preso ao contexto, mas o contexto é limitado. (CULLER, 1999: 69-70)

Uma importante abordagem teórica, a estética da recepção, propõe que o leitor é o responsável pela interpretação a partir de seu horizonte de expectativas, ou seja, a partir de um repertório e conhecimento prévio que pode fazê-lo compreender e interpretar um texto diferentemente de outros leitores:

A ideia de competência literária focaliza a atenção no conhecimento implícito que os leitores (e escritores) trazem para seus encontros com os textos: que espécies de procedimentos os leitores seguem ao responder às obras da maneira que respondem? Que tipo de pressupostos devem ser apropriados para explicar suas reações e interpretações? Pensar nos leitores e na maneira como eles entendem a literatura levou ao que é chamado de "estética da recepção", que afirma que o sentido do texto e da experiência do leitor (uma experiência que inclui hesitações, conjecturas e autocorreções). Se uma obra literária é concebida como uma sucessão de ações sobre o entendimento de um leitor, então uma interpretação da obra pode ser uma história desse encontro, com seus altos e baixos: diversas convenções e expectativas são postas em jogo, ligações são postuladas, e expectativas derrotadas ou confirmadas. Interpretar uma obra é contar uma história de leitura. (CULLER, 1999: 66)
A partir da estética da recepção, que investiga então a experiência do leitor de um texto e na construção de sentido que ele faz em relação a seu horizonte de expectativas, ou seja, a um conhecimento ou repertório prévio, talvez fosse possível, em pesquisa posterior, investigar a recepção do leitor ao projeto gráfico de um livro.

Para Culler, "O foco nas variações históricas e sociais dos modos de ler enfatiza que interpretar é uma prática social. Os leitores interpretam informalmente quando conversam com amigos sobre livros ou filmes; interpretam para si mesmos à medida que leem" (CULLER, 1999: 67), ou seja, há um modo mais informal que se pode usar para interpretar um texto literário. Para uma análise formal dos textos, o autor explica que:

Para qualquer elemento de uma obra, você pode perguntar o que ele faz, como ele se relaciona com outros elementos, mas a interpretação pode, em última análise, envolver jogar o jogo do "sobre": então sobre o que é essa obra realmente? Essa questão não é inspirada pela obscuridade de um texto; é ainda mais apropriada para textos simples do que para o perversamente complexos. Nesse jogo, a resposta deve satisfazer certas condições: não pode ser óbvia, por exemplo; deve ser especulativa. Dizer que "Hamlet é sobre o colapso da ordem no mundo elisabetano", ou "Hamlet é sobre o medo que o homem tem da sexualidade feminina". Ou "Hamlet é sobre a não confiabilidade dos signos" valem como possíveis respostas. O que é comumente visto como "escolas" de crítica literária ou "abordagens" teóricas da literatura são, do ponto de vista da hermenêutica, disposições de dar tipos específicos de respostas às questões de sobre o que, em última instância, uma obra é: "a luta de classes" (marxismo), "a possibilidade de unificação da experiência" (new criticism), "conflito edipiano" (psicanálise), "a contenção de energias subversivas" (novo historicismo), "a assimetria das relações de gênero" (feminismo), "a natureza autodesconstrutivista do texto" (desconstrução), "a oclusão do imperialismo" (teoria pós-colonial), a matriz heterossexual" (gay and lesbian studies). (CULLER, 1999: 67)

Percebe-se, nesse contexto, que a interpretação da obra pode se basear no "jogo do sobre", a partir de uma série de perguntas que podem ser levantadas e respondidas sobre a obra a partir de uma determinada perspectiva teórica, não só do campo da teoria literária como de outras ciências humanas, como a psicologia ou a sociologia. Para se desenvolver uma análise da relação que a obra literária pode ter em relação a projeto gráfico, talvez o caminho apropriado seja o inverso: a partir de elementos do projeto gráfico buscar entender citações ou mensagens 
do próprio texto. Como ponto de partida para a análise de um projeto de livro, pode-se talvez formular perguntas do campo do design editorial, tentando respondê-las com base no texto literário.

Como observado nos capítulos anteriores, muitos livros apresentam elementos gráficos que chamam a atenção para seu design e que provavelmente incitam experiências de leitura diferentes da do livro simples ao qual o leitor comum está acostumado. Elementos gráficos como ilustração e tipografia podem apresentar relações implícitas ou explícitas com o conteúdo verbal e estas relações podem ser importantes na construção de sentido.

Mas como identificar essas relações, como analisar um projeto gráfico de um livro? Não há bibliografia específica que trate de procurar estabelecer associações entre o projeto gráfico e texto literário, talvez por conta de que muitos livros se apresentam de forma realmente simples e uma análise formal possa ser suficiente, mas no caso de um livro com um projeto mais complexo talvez outros métodos possam ser utilizados, uma vez que, supostamente, o projeto gráfico não é apenas utilitário, mas colabora na construção de sentido.

Autores como Roland Barthes (1990) e Martine Joly (1996) estudaram a relação entre texto e imagem, especialmente nos campos da publicidade e da fotografia, mas não trouxeram muitas contribuições para este estudo.

A formação de significado em projetos de design gráfico tem sido explorada por autores como Barnard (2005), Meggs (1992) e Hall (2008). Muitos dos conceitos utilizados para a análise do design gráfico, e nesse caso o design de livros, são emprestados de outras áreas, especialmente teoria literária, linguística e semiótica.

Segundo Barnard, há nas linguagens (verbal e visual) dois níveis de significado: denotação e conotação. $\mathrm{O}$ autor nota que os significados são relativos, diferenciam-se de acordo com o receptor e com a cultura em que se inserem, porém a denotação é menos "culturalmente específica" que a conotação. Conhecer as especificidades de cada nível, de acordo com Barnard, é fundamental para a análise do design gráfico. (BARNARD, 2005: 35)

Segundo Samira Chalhub (1987: 9), a conotação é popularmente chamada de linguagem figurada. A linguagem denotativa tem, para
Chalhub, relação direta, sem intermediação ou figuração. Nessa perspectiva, infere-se que a denotação é objetiva e a conotação, subjetiva. Brandão (1989: 7) explica que a conotação é "forma aberta a duas ou mais interpretações, o sentido figurado parece que projeta nas razões de sua estrutura a polivalência que caracteriza seu efeito no receptor".

Sobre o sentido figurado, ou conotação, Roberto de Oliveira Brandão explica, em seu livro As figuras de linguagem, que ele pode ser percebido em:

Forma aberta a duas ou mais interpretações, o sentido figurado parece que projeta nas razões de sua estrutura a polivalência que caracteriza seu efeito no receptor. Daí o profundo compromisso que mantém não só com a literatura, mas praticamente com todos os campos de interesse do homem teratura, mas praticamente com todos os campos de interesse do homem,
arte, cinema, mitologia, cultura, psicanálise, etc. (BRANDÃO, 1989: 7).

Meggs (1992: 14), ao trabalhar os níveis semânticos das mensagens dentro do campo do design gráfico, define os dois níveis de significado, denotação e conotação:

Denotação é o significado direto de uma palavra, sinal, ou imagem. Conotação, um segundo nível de significado, é transmitido ou sugerido para além da denotação. As palavras político e estadista denotam uma pessoa eleita ou nomeada que está ativamente envolvida em assuntos governamentais. No entanto, a conotação de cada palavra é muito diferente. Político conota uma pessoa interessada em ganho pessoal, que promove interesses estreitos, enquanto estadista conota um indivíduo que está preocupado com os interesses de longo prazo de todos os cidadãos. (MEGGS, 1992: 14)

A partir de Barthes, Barnard (2005: 36) explica que:

Conotação é poderoso tipo de significado: todo projeto gráfico depende dele para ser eficaz e o design gráfico (em geral) ${ }^{4}$ é eficaz pelo modo pelo qual a conotação funciona. Conotação faz com que indivíduo seja entendido como membro de um determinado grupo social, uma vez que valores e crenças de uma cultura podem interagir com textos, imagens e leiautes do design gráfico. Dessa maneira (a conotação) ${ }^{5}$ pode ser pensada como a interface entre o indivíduo e sua cultura: onde os valores e crenças de uma cultura geram significado.

Barnard (2005: 36) explica que os significados denotativos e conotativos podem ser identificados a partir de perguntas sobre o objeto.

4 Parênteses nosso.

5 Parênteses nosso. 
Para entender o nível denotativo de uma imagem, a pergunta que se deve fazer é "que imagem é essa?", para entender o nível denotativo da tipografia, as perguntas podem ser: "Qual é a fonte? Qual o tamanho de corpo usado aqui? Isso é uma serifa?". A denotação é "o sentido literal de uma peça de design gráfico" e o sentido denotativo pode ser correto ou incorreto, isto é, é um nível de significado em que não há muita margem para interpretação. Segundo Baker, "A construção ou entendimento de significados denotativos requer um nível básico de conhecimento cultural, mas ainda é um conhecimento específico de acordo com a cultura (contexto) ${ }^{6}$ (Baker, 1985, apud BARNARD: 36). Ou seja, mesmo os significados denotativos, literais, dependem da inserção cultural do objeto e da recepção de um integrante dessa cultura específica, sendo que fora de contexto o objeto pode não ser entendido, reconhecível.

Barnard usa a mesma estratégia de identificar o sentido através de uma pergunta para o nível conotativo da mensagem. As perguntas que podem ser feitas no campo do design são: "qual sensação essa imagem te passa?", "Em que essa família tipográfica te faz pensar?". Os significados conotativos são "associações que a peça de design gráfico pode levar a um membro de uma cultura específica: o modo pelo qual a imagem cria sensações não pode ser (entendido na esfera do) correto ou incorreto" (BARNARD, 2005: 36). Ou seja, a interpretação dos níveis de significação conotativos é aberta, o significado é diferente de acordo com o indivíduo que o interpreta. Barnard explica ainda que os significados conotativos dependem do contexto, se a mensagem lida com significados estranhos ao receptor não funciona. Barnard (2005: 36) cita como exemplo o famoso estudo e análise de Roland Barthes sobre o anúncio da marca de massas Panzani, porém explica que Barthes, nesse exemplo, tem mais interesse no texto do que nas imagens propriamente, mas o conceito de "conotação, porém, pode ser usado para analisar e explicar famílias tipográficas, bem como imagens".

Estudos como esses podem ser importantes para analisar o projeto gráfico do livro em níveis denotativos ou conotativos, e em especial no nível conotativo, que por ser mais aberto pode promover diferentes interpretações do projeto gráfico.

6 Parênteses nosso.
É comum observar, tanto nas linguagens verbais (CULLER, 1999) como nas visuais (HALL, 2008), em especial quando nos referimos aos níveis conotativos, modos de trabalhar o texto em sentido figurado, por construções conhecidas por figuras de linguagem. É importante para o estudo do campo do design editorial, especialmente hoje em que alguns projetos gráficos de livros de literatura são formalmente e conceitualmente mais complexos, procurar conhecer essas figuras e identificá-las, especialmente em projetos de capas de livros (onde muitas vezes é possível identificar o uso desses recursos).

Segundo Culler (1999: 73),

A teoria literária tem se preocupado muito com a retórica e os teóricos discutem a natureza e a função das figuras retóricas. Uma figura retórica é geralmente definida como uma alteração ou desvio do uso "comum", por exemplo, "Meu amor é uma rosa vermelha, vermelha" usa rosa para se referir não à flor, mas a algo belo e precioso (essa é a figura da metáfora). Ou "The secret sits" torna o segredo um agente do ato de sen$\operatorname{tar}$ (personificação). Antigamente, os retóricos tentavam distinguir os "tropos" específicos que "mudam" ou alteram o sentido de uma palavra (como na metáfora) das "figuras" mais misturadas de dissimulação que ordenam as palavras para obter efeitos especiais. Algumas dessas figuras ordenam as palavras para obter efeitos especiais. Algumas dessas figuras
são: aliteracão (a repetição de uma consoante); apóstrofe (dirigir-se a algo que não é um ouvinte regular, como em "aquieta-te teu coração!) e assonância (a repetição de um som vocálico).

Percebe-se em literatura o amplo uso de figuras de linguagem. Figuras de linguagem são comuns também na comunicação visual e no design gráfico. Barnard (2005) explica que o uso de figuras é também indicativo da "construção e reprodução das crenças e valores de determinados grupos culturais" (2005: 50-51).

Hall amplia o uso de figuras na linguagem visual e soma outros exemplos. O autor apresenta diferenças entre sentido literal e não literal e é nesse último tipo de sentido que geralmente se observa as figuras e outros procedimentos que conferem significado, apresentados por Hall como mentira, impossibilidade, descrição e representação. $\mathrm{O}$ autor explica que:

Há várias maneiras de dizer o que você quer realmente. Símiles estranhas e metáforas bizarras, metonímias inteligentes e ironias genuínas, pequenas mentiras e impossibilidades verdadeiras. Descrições incomuns e representações curiosas são todas do interesse daqueles que estudam semiótica, porque nos permitem dizer o que queremos de uma manei- 
ra não literal. Estas formas não literais de significação nos permitem tornar fumiliar o que não é nvice-versa. (..) literal seja muito útil (por exemplo, a medicina seria muito difícil sem ela), a comunicação não-literal é geralmente mais interessante e não menos importante. É por isso que as agências de propaganda, os poetas, os humoristas, os cineastas e os pintores geralmente a usam. Afinal de contas, a verdade sobre o mundo geralmente é mais sedutora e temos de nos esforçar um pouco para entendê-la. É a comunicação não-literal que fará com que nos esforcemos mais quando se trata de decifrar os vários significados que o ser humano cria. (HALL, 2008: 33-34).

Barnard explica que é muito comum observar metáforas visuais, especialmente no campo da publicidade, como em anúncios de perfume, cigarros, alimentos e bebidas. O autor explica que isso se dá pois é necessário usar uma coisa para substituir outra, ou para comunicar outra, como em anúncios de perfume com mulheres e homens belos, ao se tentar "comunicar cheiro usando algo diferente de cheiro", ou quando se usa, para representar uma experiência, uma imagem de uma bela paisagem em anúncios de cigarro. (BARNARD, 2005: 52). No entanto, metáforas e outras figuras de linguagem podem ser encontradas em projetos gráficos de livros de literatura como veremos no próximo capítulo.

Um livro, especialmente ilustrado, apresenta relações mais evidentes de texto com a imagem, do que um livro de texto simples. No campo da ilustração, diversas pesquisas foram conduzidas para aproximar as relações entre a linguagem da ilustração e o texto, como Sophie Van der Linden (2011) e Maria Nikolajeva e Carole Scott (2011). Nikolajeva e Scott questionam estudos sobre a ilustração de livros infantis de outros autores sobre o tema e criam categorias de relação entre os elementos textuais e visuais, porém apenas em livros infantis, cujo propósito é um pouco diverso de livros de literatura ilustrados para o público adulto, como os apresentados ao longo desta tese de doutorado.

Sophie Van der Linden (2011: 120-121) identifica significados específicos em partes do projeto como páginas duplas, formatos, guardas, páginas de rosto etc. Apesar de se dedicar ao livro ilustrado infantojuvenil, as categorias relacionais apresentadas abaixo podem ser úteis para nossa investigação: redundância, colaboração e disjunção. Na redundância, a linguagem visual não acrescenta nada de novo à verbal; na relação de colaboração, há complemantaridade entre as duas linguagens:
Articulados, textos e imagens constroem um discurso único. Numa relação de colaboração, o sentido não está nem na imagem nem no texto: ele emerge da relação entre os dois. Quanto mais as respectivas mensagen parecem distantes uma da outra, mais importante será o trabalho do leitor para fazer emergir a significação. Esse distanciamento pode inclusive assumir uma nuance irônica. (LINDEN, 2011: 121)

Sobre a relação da disjunção a autora explica que "Texto e imagem não entram em estrita contradição, mas não se detecta nenhum ponto de convergência”. (LINDEN, 2011: 121)

As relações de redundância, colaboração e disjunção, como apresentadas por Linden, referem-se ao uso da ilustração em relação ao texto em um livro ilustrado. Se avaliarmos essas relações em design de livros, poderíamos talvez pensar, além da relação que se estabelece entre texto e projeto gráfico, as relações do objeto como um todo (capa e miolo), uma vez que muitos livros apresentam capas com pouca ou nenhuma relação com a parte interior do livro.

De acordo com levantamento obtido a partir de exemplos de várias editoras apresentados no capítulo anterior, percebem-se algumas abordagens de projeto que podem ter relações com a obra textual. As conexões estabelecidas de miolo com o texto podem ser:

1. Tipográficas e leiaute. As relações tipográficas e de leiaute com o texto podem ser sutis ou evidentes;

2. Materiais (papéis, acabamentos, etc.);

3. Ilustradas (quando o volume apresenta ilustrações - exemplo:

livros de prosa literária adulta ilustrados).

É importante verificar se há no volume alguma relação entre as partes do livro: capa e miolo, uma vez que muitas editoras privilegiam a expressividade na capa e apresentam projetos de miolo padronizados. As abordagens de projeto gráfico apresentadas acima como materiais, tipográficas e ilustradas podem ser justificadas a partir de pesquisas anteriores, que embasam investigações, de certa forma, semânticas.

Pela abordagem material, tomemos Munari (2002) como exemplo em que o designer apresenta experimentos abordando as "possibilidades de comunicação visual do material editorial". Ele explica que, quando se fala em livros, fala-se mais sobre seu conteúdo (literário, filosófico, histórico etc.) do que de sua forma e dos elementos que o constituem: encadernação, cor de impressão, tipografia etc., ou seja, "por todos os 
elementos com que se visualiza o livro como objeto". (2002: 210) Ao experimentar o livro que ele denomina "invisível", Munari propõe excluir o texto e verificar propriedades físicas que podem comunicar (significar) alguma coisa sem depender do texto. (2002: 211)

Munari decompõe os elementos constituintes do livro e busca, a partir da análise, pesquisar materiais (tipos de papéis e outras fibras - suporte) como o que cada papel - pode comunicar através de sua superfície, textura: "se um papel é transparente comunica transparência, se é áspero comunica aspereza" (MUNARI, 2002: 213) e assinala que o papel "por si comunica sua qualidade, e isso já é uma razão para ser usado como comunicante".

O designer explica que formatos de páginas e a alteração de tamanhos influem no ritmo, ou seja, "na informação rítmica" do livro. (MUNARI, 2002: 213). Após mostrar esses experimentos formais, o autor apresenta o livro infantil Na noite escura (formato 1:16, todo em papel negro) que apresenta experiências de texturas e matérias. $\mathrm{O}$ autor explica: "esse livro que foi recusado por diversos editores porque 'não tinha texto’ teve várias edições”. (MUNARI, 2002: 219).

Por mais que os experimentos de Munari, especialmente dos livros invisíveis, investiguem as propriedades "comunicativas" dos materiais, desacompanhados de um "texto", eles mostram que, se usados de forma consistente, materiais e acabamentos gráficos podem comunicar ideias. Como um dos precursores desse tipo de experimentação, Munari pode servir de base para entender as potencialidades semânticas dos materiais em relação a seu contexto verbal.

Em sua dissertação de mestrado, Eunice Liu apresenta diversos recursos materiais que podem ser usados em projetos gráficos, especialmente livros. Liu explica que:

Projetos editoriais podem explorar o uso de materiais, textura, transparência, cor, tipo e temperatura de toque de superfícies, dentre outros, seja no miolo, guarda, capa, sobrecapa, luva e outras partes do livro, conforme projeto, em coerência com conteúdo e propósito. Materiais diferentes requerem cuidado de colagem, costura e fixação. (LIU, 2013: 113)

Para a abordagem do livro ilustrado, mesmo que os livros estudados nesta pesquisa de doutoramento sejam de literatura adulta, pode-se utilizar como base para compreensão os próprios conceitos de relação explorados por Linden (2011) anteriormente.
Em um projeto de livro, de acordo com sua condição paratextual (Genette), verifica-se a importância da análise de projeto em relação ao próprio texto da obra literária (ou obra de não ficção também, por exemplo), Como existem poucos modelos propostos de análise de projetos editoriais, adaptações são necessárias.

Villas-Boas (2009: 4) apresenta um modelo de análise gráfica baseado em análises desenvolvidas em sala de aula cuja ênfase versa especialmente sobre os "elementos técnico-formais" e "elementos estético-formais":

As duas grandes categorias, que abarcam o primeiro nível de subcategorias e, em consequência, aquelas de segundo nível, podem ser resumidas desta forma: Elementos técnico-formais (ou, simplesmente, elementos técnicos) - Como comentado anteriormente, são aqueles elementos que o observador comum não vê. Ou seja, aqueles que ele tende a não identificar objetivamente, pois se referem à organização geral dos elementos estético-formais na superfície do projeto, mas não a estes elementos em si mesmos. Tal organização, quando realizada a partir de uma metodologia mais sistematizada e quando regida por uma cultura projetual mais complexa - ingredientes que tendemos a associar à prática profissional, própria de designers gráficos -, é definida por dois tipos diferentes de condicionantes: 1) pela posição assumida frente a determinados princípios projetuais determinados historicamente e com pretensões consensuais entre os agentes do campo, e 2) por dispositivos de ordem técnica, em geral obtidos via educação formal.

Villas-Boas explica que as duas categorias que propõem elementos técnico-formais e elementos estético-formais não devem ser entendidas de forma isolada, assim como a forma e conteúdo, uma vez que:

O próprio leiaute como um todo é o "conteúdo" também, porque ele não consiste na soma dos elementos estético-formais, mas na relação entre eles, condicionada pelos elementos técnico-formais. Ou seja: na perspectiva disciplinar do design, não há - mesmo a fórceps - como dividir um leiaute em termos de forma e conteúdo. (VILLAS-BOAS, 2009)

O modelo teórico de Villas-Boas apresentado na tabela abaixo pode servir como base para a análise gráfica de livros pois abrange todos os elementos formais que um volume pode ter:

O projeto gráfico de um livro é muitas vezes pensado a partir da tipografia, como se esta fosse o elemento mais importante, pois é a partir dela que a leitura é possível. No campo da tipografia, alguns autores trabalham com modelos de projeto e de análise a partir de dois termos: micro e macro tipografia. 
Figura 89: Tabela baseada em Villas-Boas, 2009: 10 Desenvolvida pela autora

\begin{tabular}{|c|c|c|c|}
\hline \multirow[t]{5}{*}{ Leiaute } & \multirow{5}{*}{$\begin{array}{l}\text { Elementos } \\
\text { técnico-formais } \\
\text { Elementos } \\
\text { estético-formais }\end{array}$} & \begin{tabular}{|l} 
Princípios \\
projetuais
\end{tabular} & $\begin{array}{l}\text { Unidade } \\
\text { Harmonia } \\
\text { Síntese } \\
\text { Balanceamento } \\
\text { Movimento } \\
\text { Hierarquia } \\
\end{array}$ \\
\hline & & \begin{tabular}{|l|} 
Dispositivos \\
de composição
\end{tabular} & $\begin{array}{l}\text { Mancha gráfica } \\
\text { Estrutura } \\
\text { Centramento } \\
\text { Eixo } \\
\end{array}$ \\
\hline & & $\begin{array}{l}\text { Componentes } \\
\text { textuais }\end{array}$ & $\begin{array}{l}\text { Antetítulos } \\
\text { Títulos } \\
\text { Subtítulos } \\
\text { Massas de texto } \\
\text { Capitulares } \\
\text { Legendas } \\
\text { Olhos } \\
\text { Unidades recorrentes } \\
\text { (etc.) } \\
\end{array}$ \\
\hline & & \begin{tabular}{|l|} 
Componentes \\
não textuais
\end{tabular} & \\
\hline & & $\begin{array}{l}\text { Componentes } \\
\text { mistos }\end{array}$ & $\begin{array}{l}\text { Gráficos } \\
\text { Tabelas ilustradas } \\
\text { Infográficos } \\
\text { (etc.) }\end{array}$ \\
\hline
\end{tabular}

Hochuli e Kinross (2007: 32) definem os termos:

O designer de livro preocupa-se com as seguintes questões específicas: formato, extensão, tipografia (estes três, em parte, determinam uns aos outros); materiais (papéis, materiais de encadernação); reprodução; impressão; acabamento. Aqui lidamos principalmente com a tipografia e, dentro desta categoria, nos assuntos que fazem parte do que pode se chamar macrotipografia. Microtipografia ou tipografia de detalhe lida com os seguintes itens: forma das letras, espaços entre letras e palavras, espaços entre linhas e coluna.

A macrotipografia - é também chamada de leiaute - refere-se ao projeto, isto é, definir o formato da página e do tamanho das colunas de texto, a distribuição das ilustrações, a organização dos títulos e legendas, e de todos os outros elementos tipográficos.

Nesse sentido, tudo que se relaciona aos detalhes tipográficos, como a forma das letras e seus espaços, encontra-se no domínio da microtipografia e o projeto gráfico como um todo no domínio da macrotipografia.
Willi Kunz (2002: 97) trabalha com os conceitos de micro e macro estética ainda no campo do design tipográfico, isto é, no design com tipos. Embora ele não trate especificamente do design do livro como Hochuli, trata do design em que a tipografia é o principal elemento. Kunz explica que "o design tipográfico inevitavelmente expressa emoções subjetivas e comunicativas que afetam a percepção".

Kunz (2002: 97) afirma que: "O Design tipográfico é percebido em duas escalas estéticas: macro (explícita e óbvia) e micro (sutil, sofisticada, talvez apenas perceptível subconscientemente)." Kunz explica que a macroestética é mais evidente, porém é na microestética que se "revela as sensibilidades e inteligência criativa do designer".

Kunz (2002: 98) define e explica esses dois níveis também em relação à percepção do leitor e na sua importância. Primeiro define o nível macroestético:

No nível macroestético, os primeiros componentes visuais de um projeto são reconhecidos primeiro: tamanho e proporção espacial, forma composição e cor dos elementos principais; a estrutura como um todo; $\mathrm{e}$ o contraste entre os elementos fundamentais e o espaço que os circunda. A macroestética captura a atenção inicial do leitor e o leva, então, a um nível mais complexo, o microestético. (KUNZ, 2002: 98)

\section{Depois define o nível microestético:}

A microestética engloba forma, tamanho, peso e relação de elementos secundários: características tipográficas; forma e contraforma das letras; espaços entre letras, palavras e outros elementos gráficos. Embora a macroestética possa, inicialmente, parecer mais importante, a microestética desempenha um papel mais significativo na qualidade expressão de uma composição visual. Um projeto que não funciona no nivel microestético muitas vezes falha como um meio de comunicação eficaz. (KUNZ, 2002: 98)

A partir de Kunz verifica-se que a macroestética relaciona-se com a composição como um todo e a microestética com detalhes tipográficos como a forma das letras, e assim, há um paralelo entre as categorias de Kunz e Hochuli e Kinross apresentados acima.

Gerard Unger (2007: 85) percebe também a importância desses dois domínios não apenas em relação ao design e à composição, mas diante do fato de que a leitura depende tanto do leiaute como um todo (macrotipografia) quanto dos detalhes tipográficos (microtipografia): 
Como vimos, a nossa convenção de leitura consiste não só de tipos, mas do texto como um todo, ou seja, o sistema completo de nossos hábitos de leitura: de ler linha por linha da esquerda para a direita, lendo uma coluna ou página de cima para baixo, e para diante. Vai além do que a simplesmente a estrutura geral de uma página de um livro ou jornal: ele também inclui, por exemplo, a maneira em que novos parágrafos são indicados, como são destacadas partes de um texto, como sumários, índices e outras listas podem ser mais bem compostas, ou como são compostas notas de rodapé. A facilidade de leitura, na medida em que consideramos a leitura de um texto em particular irritante ou fácil, depende tanto da microtipografia como da macrotipografia. (UNGER, 2007: 85)

Hartmut Stöckl (2005) propõe o estudo da sintaxe tipográfica criando uma metodologia de análise que abrange quatro domínios, ampliando os então mencionados acima: microtypography (microtipografia), mezotypography (mesotipografia), macrotypography (macrotipografia) e, por fim, paratypography (paratipografia).

Stöckl apresenta em seu texto a importância de se estudar a tipografia no campo da linguística, que por muito tempo se concentrou apenas no sistema fonético grafema-fonema. $\mathrm{O}$ autor apresenta recentes pesquisas que verificam a importância do estudo da tipografia para entender as "funções cruciais da tipografia e do design com tipos (do original design de texto - text design)". Essa reflexão mostra que o estudo dos tipos relaciona-se com o significado textual. (Stöckl, 2005 204-205)

Para estabelecer uma gramática da tipografia, Stöckl apresenta o funcionamento dos termos: semântica, sintaxe e pragmática adaptadas ao campo. (Stöckl, 2005: 209):

\section{SEMÂNTICA}

A semântica da tipografia reside na sua riqueza de significados conotativos derivados de seus detalhes gráficos e de suas qualidades pictóricas. (Stöckl, 2005: 209)

\section{SINTAXE}

O nível sintático da tipografia compreende todos os arranjos e combinações de elementos tipográficos no espaço de uma página ou a estrutura de um documento. (Stöckl, 2005: 209)

\section{PRAGMÁTICA}

A pragmática da tipografia está incorporada no uso de certos elementos tipograficos para alcançar determinado objetivo. Semelhante à lingua, há ampla variedade de formas para o comunicador (ou designer), que precisa conhecer regras estilísticas e decoro pragmático. (Stöckl, 2005: 209)

Para Stöckl, o sistema tipográfico pode ser dividido em quatro do mínios:

Microtipografia: fontes e letras individuais;

- Mesotipografia: configuração dos signos tipográficos em linhas ou blocos de texto (alinhamento da mancha de texto, entrelinhas);

- Macrotipografia: a estrutura gráfica no documento (Mancha de texto, hierarquias textuais, indentação e parágrafo);

- Paratipografia: suporte, superfície, materiais e instrumentos (tecnologia - acréscimo produção gráfica).

Cada domínio de trabalho tipográfico compreende um conjunto de propriedades ou elementos identificados na tabela a seguir (Figura 90), extraída de Brisolara ${ }^{7}, 2009 b$.

Como se pode observar nessa tabela, os elementos dos domínios mesotipografia e macrotipografia trabalham um em continuação ao outro. Stöckl divide, por exemplo, o trabalho com entrelinhas e largura da mancha em mesotipografia e apresenta recuos e marcação de parágrafo e capitulares em macrotipografia. Quando analisamos um projeto gráfico de um livro, por exemplo, poderíamos dividir a análise em três domínios, e não em quatro como propõe Stöckl.

1 - Microtipografia: o desenho e a estrutura de uma família tipográfica;

2 - Macrotipografia: estrutura gráfica e mancha do texto;

3 - Paratipografia: suporte e superfície.

A junção que propomos entre Mesotipografia e Macrotipografia se dá especialmente em relação à metodologia de trabalho de um designer. Quando se cria um projeto gráfico, pensa-se essencialmente em todos os elementos de trabalho de forma conectada: marcação de parágrafos e indentação e hierarquias textuais estão intimamente relacionadas à largura da mancha gráfica.

Com base nos modelos apresentados e nos conceitos apreendidos dos domínios da macro e da microtipografia, para a análise e compreensão do projeto gráfico de um livro, foi criado um modelo que será utilizado no próximo capítulo em que se abrange os itens sintáticos da

7 Brisolara traduziu e adaptou a tabela original de Stöckl em sua dissertação de mestrado (BRISOLARA, 2009b), que será utilizada aqui. 


\begin{tabular}{|c|c|c|}
\hline Domínios da tipografia & Blocos de construção tipográfica & Propriedades tipográficas \\
\hline \multirow{4}{*}{$\begin{array}{l}\text { Microtipografia } \\
\text { Design de fontes e signos } \\
\text { gráficos individuais }\end{array}$} & Tipo & Garamond, Helvetica, etc. \\
\hline & Tamanho do tipo & Pontos (tamanho) \\
\hline & Estilo do tipo & $\begin{array}{l}\text { Traçado, estilo, modo } \\
\text { (características) }\end{array}$ \\
\hline & Cor do tipo & Positivo $\mathrm{x}$ negativo ou colorido, etc. \\
\hline \multirow{7}{*}{$\begin{array}{l}\text { Mesotipografia } \\
\text { Configuração dos signos } \\
\text { gráficos em linhas e } \\
\text { blocos de texto }\end{array}$} & Ajuste da letra & Padrão, espaçado, reduzido, etc. \\
\hline & Espaçamento entre palavras & Estreito, largo, etc. \\
\hline & Espaçamento entre linhas & Espaço dupo, espaço simples \\
\hline & $\begin{array}{l}\text { Mancha (tipo)gráfica quantidade } \\
\text { de impressão na página }\end{array}$ & Caracteres por página \\
\hline & Alinhamento dos tipos (composição) & $\begin{array}{l}\text { Alinhamento à esquerda, à direita, } \\
\text { centralizado, justificado }\end{array}$ \\
\hline & Posição/direção das linhas & $\begin{array}{l}\text { Horizontal, vertical, diagonal, } \\
\text { circular, etc. }\end{array}$ \\
\hline & Mistura de fontes & $\begin{array}{l}\text { Escrita à mão (caligráfica) + } \\
\text { body type (c/ ou sem serifa }\end{array}$ \\
\hline \multirow{5}{*}{$\begin{array}{l}\text { Macrotipografia } \\
\text { Estrutura gráfica do docu- } \\
\text { mento }\end{array}$} & Recuos e parágrafos & $\begin{array}{l}\text { Tamanho dos blocos de texto, } \\
\text { distância entre blocos }\end{array}$ \\
\hline & Capitulares & Ornamentada/colorida \\
\hline & Ènfase tipográfica & Sublinhado, itálico, bold, etc. \\
\hline & $\begin{array}{l}\text { Dispositivos de organização da infor- } \\
\text { mação }\end{array}$ & $\begin{array}{l}\text { Titulação hierárquica, numeração, } \\
\text { tabelas, diagramas, índices, notas } \\
\text { de rodapé, etc. }\end{array}$ \\
\hline & $\begin{array}{l}\text { Agrupamento de texto e gráficos } \\
\text { (imagens) }\end{array}$ & $\begin{array}{l}\text { Relação imagem-legenda, letras } \\
\text { figuraticas. 'tipopictorialidade' }\end{array}$ \\
\hline \multirow{2}{*}{$\begin{array}{l}\text { Paratipografia } \\
\text { Materiais, instrumentos } \\
\text { e técnicas de produção } \\
\text { tipográfica }\end{array}$} & $\begin{array}{l}\text { Qualidade material do meio } \\
\text { (qualidade do papel) }\end{array}$ & Espessura, formato, superfície, etc. \\
\hline & $\begin{array}{l}\text { Práticas e produção de signos } \\
\text { tipográficos }\end{array}$ & Grafar, escrever, compor, moldar \\
\hline
\end{tabular}

pografia como o leiaute como um todo, incluindo os acabamentos e materiais do livro, e também foi acrescentado um novo item que corresponde ao "jogo do sobre" de Culler em que se procura verificar a partir dos elementos gráficos relações de colaboração (LINDEN, 2011) com o texto literário.

Figura 90: Tabela composição para depois verificar se esses elementos estabelecem alDominios da tipografia, guma relação de sentido em relação ao texto verbal. Obviamente, esta

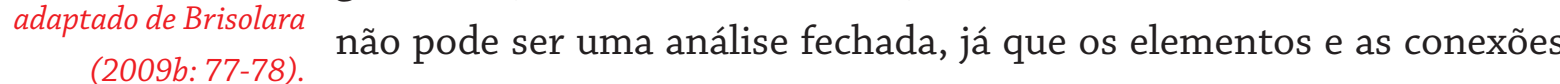
Redesenhado pela autora. simbólicas, tanto gráficas quanto textuais, são subjetivas.

Utilizaremos, no próximo capítulo, um modelo de análise inspirado em Stöckl, Hochuli e Villas-Boas, no qual se procurou contemplar os domínios da micro e da macrotipografia, pensando na macroti- 


\section{BARTLEBY, O ESCRIVÃO: ENTRE A INVISIBILIDADE E A VISIBILIDADE}

Neste capítulo analisaremos a visibilidade em algumas de edições do conto Bartleby, o escrivão: uma história de Wall Street, de Herman Melville (1819-1881), publicado anonimamente na revista Putnam's Monthly, em 1853.

A edição de Bartleby, o escrivão, da editora Cosac Naify, foi o exemplo que, de certa maneira, nos levou a procurar estudar com mais profundidade a relação entre texto e projeto gráfico nos livros de literatura, além de perceber e buscar investigar a questão da visibilidade, uma vez que esta edição de Bartleby foge das convenções formais de um livro comercial tradicional.

Bartleby, o escrivão, é um conto ${ }^{1}$ de Herman Melville, disponível em diversas edições e línguas. A fim de abordarmos as relações entre texto e projeto gráfico, serão analisadas quatro edições, das editoras Assírio Alvim, Rocco, Cosac Naify e Indulgence Press. As duas primeiras edições são comuns, de capa flexível (brochura), e as duas últimas apresentam design gráfico mais "visível".

Antes de apresentar a análise do projeto gráfico dessas edições, faremos um breve comentário sobre o texto para que se possa obter pistas de como o projeto gráfico pode colaborar ou não na produção de significados.

\section{O CONTO "BARTLEBY, O ESCRIVÃO"}

Bartleby, o escrivão: uma história de Wall Street, de Herman Melville, é um conto cujo narrador é um rico advogado de Wall Street, proprietário de um escritório que trabalha com hipotecas (financiamentos imobiliários) e títulos, que introduz brevemente a rotina de seu escritório, de seus dois funcionários não muito eficientes, Nippers e Turkey, e 
narra a chegada do novo funcionário, Bartleby, uma das mais fascinantes figuras que havia conhecido. Bartleby é, portanto, o elemento que desestabiliza a trama.

No decorrer da narrativa, o enigmático e monossilábico funcionário passa a recusar os pedidos do patrão, chegando a morar clandestinamente no escritório. Mesmo após um pedido para que se retirasse do local, Bartleby se nega a deixar aquele ambiente. $\mathrm{O}$ narrador sofre e se aborrece com as constantes recusas do funcionário, demorando um longo período até decidir tomar a iniciativa de chamar a polícia e expulsar o agora ex-funcionário, que acaba detido e morre de fome na prisão por se recusar a comer.

Bartleby é, como se sabe, um texto de gênero narrativo, entendido por Calligaris (2005) como uma novela curta, enquanto Perrone-Moises (2005) o considera um conto. O enredo de Bartleby é linear, progredindo da apresentação ao desenlace (desfecho).

Utilizando a classificação feita a partir de Norman Friedman quanto à tipologia do foco narrativo abordada por Abdala Junior (1995) e Ligia Chiappini Moraes Leite (1985), verifica-se que o narrador de Bartleby, o advogado que observa e conta a dinâmica de seu escritório e de sua relação com o personagem principal, pode ser classificado como "eu" como testemunha.

Abdala Junior (1995: 28-29) explica que esta categoria de narrador:

É um foco de primeira pessoa, onde o narrador é uma personagem de menor relevo e que relata fatos ocorridos com a personagem central ou personagens centrais. Este foco é mais limitado que o anterior [onisciência neutra]: o narrador só consegue narrar o que viu ou pesquisou, não conseguindo penetrar na consciência das personagens. (1995: 28-29)

A escolha desse ponto de vista (ou foco narrativo) contribui para o retrato de Bartleby como personagem extremamente misterioso e que desafia, desestabiliza o narrador. Como o personagem é funcionário do narrador, cria-se também uma relação assimétrica entre os dois, ampliando o estranhamento.

A escolha desse tipo de narrador, portanto, não é casual. Em uma história que pretende destacar o mistério da opção radical do protagonista, somente um narrador que não tivesse a capacidade de penetrar na mente de Bartleby poderia manter esse mistério insolúvel, deixando possíveis interpretações a cargo dos leitores.
Em Bartleby, o desenvolvimento da ação é apresentado pelo personagem dono do escritório. Há uma progressão de eventos, de "recusas" do personagem à ação. Quando o patrão pede a Bartleby para trabalhar, ele não trabalha, quando pede a Bartleby que saia do escritório, ele recusa-se a sair e, quando pede que se alimente, ele também não se alimenta. Há uma intensificação das recusas. Como afirma PerroneMoisés (2005), o bordão do personagem ("Preferiria não o fazer") antes da inação não é negativa, mas sim evasiva. Mesmo que a frase que precede a ação do personagem seja evasiva, sua resposta é negativa, pois ele não faz nada do que se pede.

Em Bartleby, o conflito se dá pela expectativa do personagem narrador, que espera uma ação positiva de seu funcionário, seguida pela ruptura da expectativa quando há a negação. A tensão (conflito) narrativa surge após a apresentação da história e a sucessão é crescente, o personagem se nega primeiramente a fazer coisas simples e, chegando ao fim, nega-se a comer e o resultado (desenlace) disso é sua morte.

Bartleby é complexo (personagem redondo) ${ }^{2}$, por se comportar de modo não previsível, sem explicação aparente, o que é reforçado por não se saber exatamente o que ele pensa.

Bartleby é o protagonista e, em certo sentido, poderíamos considerar o advogado seu oponente. Não como vilão, mas sim como alguém que demanda ou ordena ações contrárias às vontades do personagem, que "não quer fazer nada" do que lhe é solicitado.

A ação se passa em Nova York, precisamente no escritório do advogado em Wall Street, e há ainda um breve momento na prisão, na qual Bartleby morre por recusar-se a se alimentar. Há uma relação entre o espaço físico (escritório) e o espaço psicológico do personagem, que ali se instala e não quer sair.

2 Podem existir em uma narrativa personagens planas (simples) e redondas (complexas) e segundo (ABDALA JUNIOR, 1995: 42) “A personagem redonda, pela sua caracterização complexa, deve figurar entre as personagens centrais da narrativa. Ela é imprevisível e sua predicações vêm aos poucos. Por ela apresentar complexidade psicológica, a personagem redonda pede focalizações internas, seja dela própria ou de outras personagens que a observam". 
Segundo Leyla Perrone-Moisés ${ }^{3}$, a negação de Bartleby a partir do "Preferia não fazer" 4 é extremamente perturbadora:

Bartleby, como se sabe, é a personagem de um conto de Melville, um modesto escriturário que perturba seu patrão, o escritório, a ordem social e talvez até mesmo a ordem do universo pela resposta que costuma dar a qualquer ordem recebida: "Preferiria não o fazer".

A crítica aponta que Bartleby é um dos personagens mais famosos da ficção moderna, cuja chave se encontra especificamente pela frase evasiva:

Tudo está na resposta "preferiria não o fazer"s, que não é negativa nem afirmativa, mas evasiva. Bartleby não é o contestatário de um poder, mas um resistente passivo que põe em xeque qualquer poder. Sua resposta não permite qualquer contradição ou ilação. Ele é o mais humilde dos indivíduos, mas sua possibilidade de dizer que "preferiria não" the confere uma dignidade e uma soberania invencíveis. ${ }^{6}$

Perrone-Moisés debate a importância desta narrativa de ficção a partir de comentários e citações de críticos e filósofos como Gilles Deleuze e Jaques Derrida sobre a recusa do personagem Bartleby:

Os estudos sobre Bartleby já eram numerosíssimos no âmbito anglo-saxão, mas foi o posfácio ao conto escrito por Gilles Deleuze em 1989, intitulado "Bartleby ou a fórmula", que colocou em circulação filosófica internacional a personagem de Melville e sua frase. Deleuze observa: "A fórmula arrasadora elimina tão impiedosamente o preferivel quanto qualquer não preferido. Ela abole o termo a que se refere, e que ela recusa, mas também o outro termo que ela parecia preservar, e que se torna impossível". Depois de çaram sobre Bartleby como Giorgio Agamben ("Bartleby o della contingenza") e Jacques Derri-
da (em cursos e trechos de livros). Inicialmente interessado em Bartleby pelo tema do "segredo", o último Derrida enfatizava, no escriturário, o tema da "resistência ética". Outros estudiosos assinalaram a afinidade da atitude de Bartleby com a própria "desconstrução" derridiana, pelo fato de esta evitar o dualismo do sim ou não. ${ }^{7}$

3 Disponivel em: http://www1.folha.uol.com.br/fsp/mais/fs1302200512.htm; acesso em abril de 2014.

4 A expressão "I would prefer not to" pode ser traduzida de várias maneiras; na edição da Cosac Naify foi vertida como "Acho melhor não".

5 A tradução da expressão que a autora usou provavelmente não é a mesma da tradução da Cosac Naify.

6 Disponivel em: http://www1.folha.uol.com.br/fsp/mais/fs1302200512.htm; acesso em 1.05.2014.

7 Disponível em: http://www1.folha.uol.com.br/fsp/mais/fs1302200512.htm; acesso em 2014.
A partir dessa breve análise e especialmente a partir dos comentários de Perrone-Moisés, percebe-se a importância desse texto no campo da teoria literária e entende-se que o conceito chave da trama é o da recusa, da negação de tudo e até da vida do personagem principal e do mistério que envolve essas ações.

\section{ANÁLISES DE QUATRO EDIÇõES DE "BARTLEBY, O ESCRIVÃo"}

No capítulo anterior foram apresentadas propostas de diversos autores para a análise de projeto que podem auxiliar a identificar as relações que podem existir entre texto e projeto gráfico no livro de literatura. Dessa maneira, foram realizadas quatro análises baseadas nos modelos apresentado acima de quatro diferentes edições do mesmo texto. O modelo é uma versão simplificada das propostas de Stöckl e Villas-Boas e neste se faz a descrição técnica procurando contemplar tanto os domínios da macro e micro tipografia, além de materiais e acabamentos gráficos, e estabelecer uma relação entre esses elementos e o texto de Bartleby. Já que se trata do mesmo texto, é possível fazer uma análise comparativa. Os volumes das editoras Assírio Alvim e Rocco apresentam poucas informações sobre o projeto (não há, por exemplo, colofão no volume nem informações sobre o designer do projeto) e dessa forma foram realizadas análises compactas. Já as edições da Indulgence Press e da Cosac Naify apresentam mais informações no volume, que tornaram possível uma análise mais completa, além do fato de que os designers dos projetos concederam entrevistas.

A análise do volume editado pela Cosac Naify é mais extensa, devido a este ter sido o objeto de base para a presente investigação. Além da apresentação e análise da presente edição, introduzimos, para uma contextualização, a editora através de entrevista realizada em outubro de 2013 com a diretora de arte e responsável por esta edição, Elaine Ramos. 
Edição de Bartleby, da Editora Assírio e Alvim (1988)

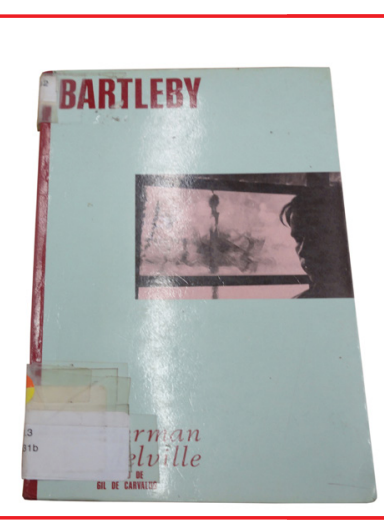

Figura 91. Capa e páginas de Bartleby da editora

Assirio Alvim

Livro do acervo da

biblioteca do Centro

Cultural São Paulo.

Fotos da autora
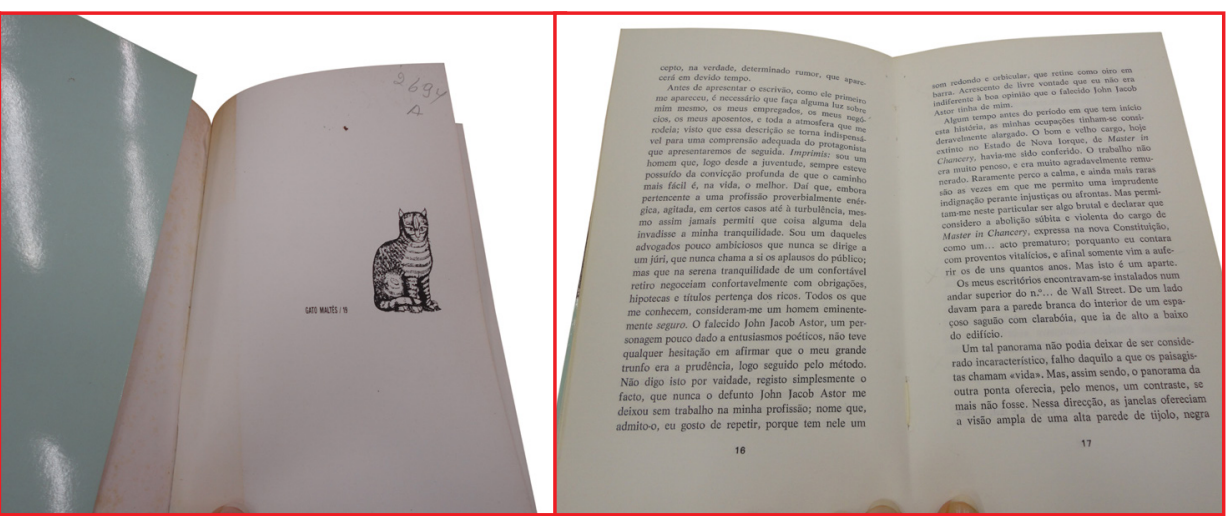

\section{Descrição técnica}

Impressão: offset

Formato: $115 \times 186 \mathrm{~mm}$

O volume apresenta lombada de

$7 \mathrm{~mm}$ e duas orelhas de $90 \mathrm{~mm} \mathrm{de}$

largura cada.

Encadernação e acabamento:

brochur

Papel da Capa: cartão (aprox. 300

$\mathrm{mg} / \mathrm{m} 2$ ) com laminação brilhante.

\section{Capa Microtipografia:}

- título: sem serifa grotesta,

condensada, composta em caixa

alta em corpo de $15 \mathrm{~mm}$ caixa alta;

cor: vinho.

- nome do tradutor: sem serifa

grotesca, condensada, composta em

caixa alta em corpo de $3 \mathrm{~mm}$ caixa

alta; cor: vinho.

-nome do autor: tipo itálico com

corpo de $4 \mathrm{~mm}$ (altura x); cor:

vinho.

\section{Macrotipografia}

Todos os elementos textuais se

encontram localizados do lado

esquerdo enquanto a foto se

encontra alinhada do lado direito,

o que pode dar um certo equilíbrio

à capa, sendo que a disposição do

elementos não tende a pesar para

apenas um lado. $O$ quadro com a

foto (elemento ilustrativo) tem a

dimensão de 77 x $51 \mathrm{~mm}$.

\begin{tabular}{|c|c|}
\hline $\begin{array}{l}\text { Imagem da capa: } \\
\text { Fotografia monocromática posicio- } \\
\text { nada em quadro de dimensão de } 77 \\
\text { x } 51 \mathrm{~mm} \text {. } \\
\text { Figura humana em primeiro plano e } \\
\text { janela em segundo plano. }\end{array}$ & $\begin{array}{l}\text { As imagens das capas desta coleção } \\
\text { mudam a cada volume. A escolha da foto } \\
\text { provavelmente mantém alguma relação } \\
\text { de complementaridade semântica com o } \\
\text { texto. No caso da presente edição, temos } \\
\text { a imagem de um rosto na sombra de olhos } \\
\text { fechados com um fundo pouco nítido que } \\
\text { lembra uma janela cuja paisagem não é } \\
\text { possível identificar devido ao desfoque } \\
\text { ou ao uso de algum filtro fotográfico que } \\
\text { pode ter sido utilizado com o intuito } \\
\text { de distorcer a imagem. Pode denotar } \\
\text { melancolia e passividade. } \\
\text { Talvez essa imagem represente ou } \\
\text { remeta, metaforicamente, ao personagem } \\
\text { Bartleby, imóvel diante da opacidade } \\
\text { do mundo (janela). A visão é lúgubre } \\
\text { e desfocada e as pálpebras cerradas do } \\
\text { homem podem ser interpretadas como a } \\
\text { recusa do olhar. }\end{array}$ \\
\hline $\begin{array}{l}\text { Papel do miolo: Offset branco } \\
\text { (aprox. } 80 \text { ou } 90 \mathrm{mg} / \mathrm{m} 2 \text { ). } \\
\text { Papel sem revestimento alcalino. } \\
\text { Papel comumente utilizado em } \\
\text { publicações. }\end{array}$ & \\
\hline $\begin{array}{l}\text { Microtipofrafia do miolo: face } \\
\text { tipográfica do texto: eixo inclinado } \\
\text { e terminais em gota }(2 \mathrm{~mm} \text { altura x }) \\
\text { peso regular; cor: preto. } \\
\text { Face tipográfica da numeração de } \\
\text { página: grotesca sem serifa de peso } \\
\text { semibold. } \\
\text { Face tipográfica comumente } \\
\text { utilizada na composição de textos } \\
\text { em livros. } \\
\text { Paratipografia } \\
\text { Mancha gráfica: } 81 \times 138 \mathrm{~mm} \text {. } \\
\text { Margens: superior } 19 \mathrm{~mm} \text {; inferior } \\
30 \mathrm{~mm} \text {; lateral externa } 16 \mathrm{~mm} \text {; } \\
\text { lateral interna } 16 \mathrm{~mm} .\end{array}$ & $\begin{array}{l}\text { Para uma análise mais precisa seria } \\
\text { necessário saber exatamente qual é a } \\
\text { família, para saber se pode existir alguma } \\
\text { referência histórica ou regional. Como não } \\
\text { há colofão, foi feita uma breve descrição } \\
\text { formal do tipo. }\end{array}$ \\
\hline
\end{tabular}


Edição de Bartleby, o escriturário, da Editora Rocco (1986)

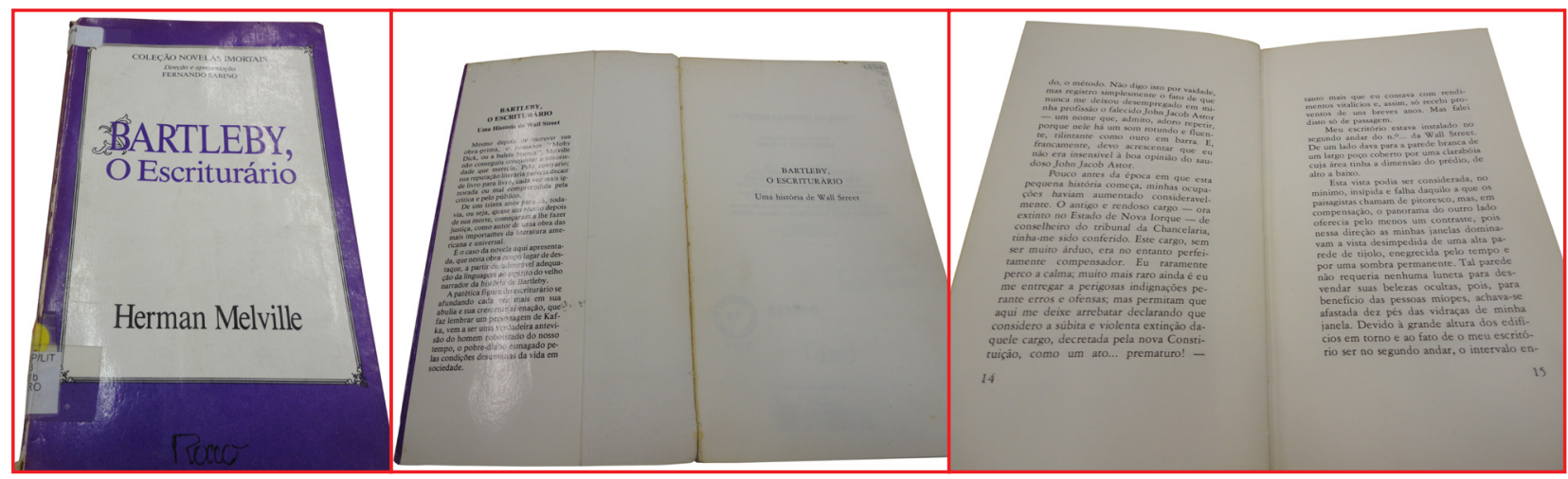

Figura 92. Descrição técnica

Capa e páginas de Bartleby

da editor

Rocco. Livro do acervo da biblioteca do Centro

Cultural São Paulo.

Fotos da autora.

\section{Impressão: offset}

Formato: $120 \times 200 \mathrm{~mm}$ (fechado) $O$ vol

apresenta lombada de $8 \mathrm{~mm}$ e duas orelhas

de $74 \mathrm{~mm}$ de largura cada.

Encadernação e acabamento: brochura. Capa colada ao miolo.

Papel da capa: cartão (aprox. 300 mg/m2) com laminação brilhante.

\section{Capa:}

\section{Microtipografia:}

título: romana serifada - serifa triangular

terminais lacrimais, eixo reto nas letras

maiúsculas e inclinado nas minúsculas (caixa

alta em BARTLEBY - $15 \mathrm{~mm}$ - e alta e baixa

em $O$ Escriturário - $7 \mathrm{~mm}$ alt. $X$-; condensa-

da. Cor: roxa.

O título se encontra mal espacejado. Enten-

demos que tenha sido feito dessa maneira

para justificar o título e o subtítulo.

A capa possui margens em roxo com quadro

branco no centro com uma fina moldura

preta ornamentada. Todos os elementos

textuais se encontram centralizados dentro

desse quadro branco.

Ha relação com a identidade

coleção (padrão editorial). Este

volume, por ser parte integrante de

uma coleção, possui elementos grá-

ficos comuns aos outros livros da

Papel do miolo: offset branco (aprox. 80 ou

série "Coleção Novelas Imortais".

$90 \mathrm{mg} / \mathrm{m} 2)$

Papel sem revestimento alcalino. Não há.

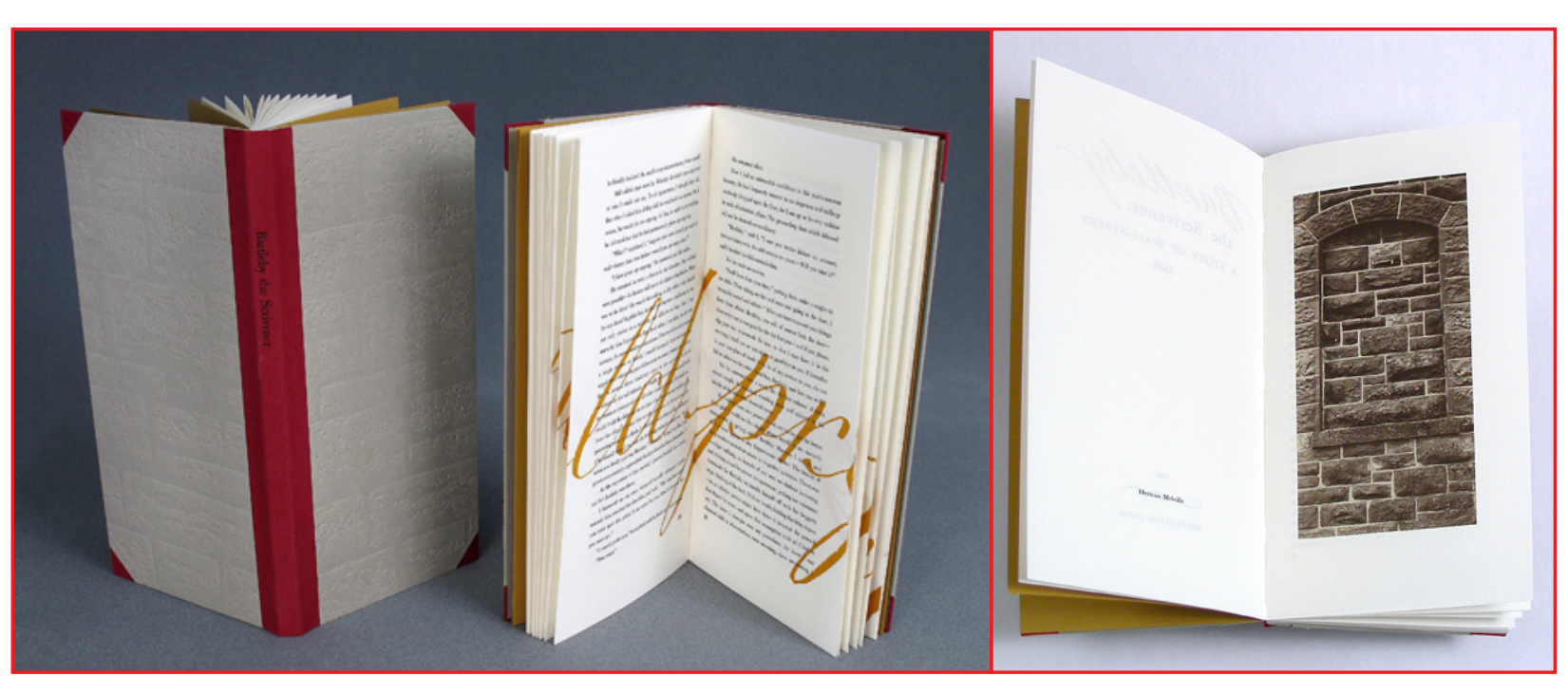

Descrição técnica

Impressão: Letterpress ${ }^{1}$

Tamanho: Formato fechado:

$152,4 \mathrm{~mm} \times 304,8 \mathrm{~mm}(12 \times 6$

polegadas).

Encere

Encadernação e acabamento:

Capa dura com lombada quadrada.

Encadernação costurada.

Páginas de guarda sem impressão

em papel artesanal produzido por MacGregor \& Vinzani.

8 Disponivel em: http://www.indulgencepress.com/Books/Bartleby.html; acesso em

fevereiro de 2014

\section{Relação entre texto e projeto}

Denota documento legal, utiliza como

referência formatos utilizados em

documentos de textos legais.

Relaciona-se à atividade do escritório

de advocacia.

Aimpressão com tipos de metal

impressão usado na época em que o texto

foi escrito

Denota sobriedade do documento por aca-

bamento e materiais de qualidade.

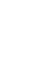

Tipografia do miolo: face tipográfica texto: eixo levemente inclinado e terminais lacrimais abruptos ( $2 \mathrm{~mm}$ altura $\mathrm{x}$ ) peso regular. Cor: preto.

Aparentemente é um tipo da classe Garalde. Face tipográfica da numeração de página: aparentemente a mesma da mancha gráfica. Mancha gráfica: 76 x $126 \mathrm{~mm}$.

Margens: superior $37 \mathrm{~mm}$; inferior $39 \mathrm{~mm}$;

lateral externa $18 \mathrm{~mm}$; lateral interna $22 \mathrm{~mm}$.

Edição de Bartleby the Escriviner, pela editora Indulgenge Press (1995)

Formato de proporção 1 x 2 .

Para uma análise mais precisa, teríamos de saber exatamente qual é a família, para saber se pode existir alguma referência historica ou regional. Como não há colofão fizemos uma breve descrição formal do tipo.
Figura 93: Capa e páginas de Bartleby, da Indulgence Press. Imagens do site da casa publicadora. 


\begin{tabular}{|c|c|}
\hline $\begin{array}{l}\text { Papel da capa: revestimento da } \\
\text { capa dura em papel Arches } \mathrm{MBM}^{2} \\
\text { com textura produzida a partir de } \\
\text { moldes }^{3} \text {. } \\
\text { A textura do papel lembra uma } \\
\text { parede de tijolos }\end{array}$ & $\begin{array}{l}\text { Há relação com o personagem Bartleby que } \\
\text { costuma ficar olhando para a parede. } \\
\text { Remete a parede de tijolos à vista. }\end{array}$ \\
\hline $\begin{array}{l}\text { Tipografia da capa: não há texto } \\
\text { na capa, só na lombada. } \\
\text { Ausência de texto. }\end{array}$ & $\begin{array}{l}\text { O designer fez uma citação direta a uma } \\
\text { pasta de documentos legais. } \\
\text { Relaciona-se a atividades de um } \\
\text { escritório de advocacia. }\end{array}$ \\
\hline $\begin{array}{l}\text { Imagem da capa: textura da pare- } \\
\text { de de tijolos em alto relevo. }\end{array}$ & $\begin{array}{l}\text { Há relação com o personagem Bartleby que } \\
\text { costuma ficar olhando para a parede. } \\
\text { Pode denotar melancolia e passividade. }\end{array}$ \\
\hline $\begin{array}{l}\text { Papel do miolo: Arches MBM } \\
\text { mould made (papel que tem um } \\
\text { aspecto artesanal). }\end{array}$ & $\begin{array}{l}\text { Relaciona-se, por ter uma aparência } \\
\text { artesanal, ao tipo de papel usado no } \\
\text { século XIX. }\end{array}$ \\
\hline $\begin{array}{l}\text { Microtipografia do miolo: } \\
\text { a) Bulmer para o texto } \\
\text { (tipo moderno); } \\
\text { b) Lettering que sobrepõe o texto } \\
\text { com a frase da negação de Bartle- } \\
\text { by (caligrafia na cor amarela que } \\
\text { sobrepõe o texto). }\end{array}$ & $\begin{array}{l}\text { a) relação da tipografia com o ambiente } \\
\text { austero; } \\
\text { b) O lettering em amarelo que sobrepõe o } \\
\text { texto traz o bordão do protagonista "I would } \\
\text { prefer not to". Que começa legível e depois } \\
\text { vai se tornando cada vez mais presente e se } \\
\text { torna abstrata devido à escala. Apresenta } \\
\text { relação direta com o texto e com a } \\
\text { progressão da trama. }\end{array}$ \\
\hline
\end{tabular}

Este Bartleby é uma edição especial e limitada com tiragem de apenas 100 exemplares nos moldes das Prensas Particulares, já que o processo de produção foi artesanal. ${ }^{9}$

Em entrevista realizada em fevereiro de 2013, Wilber H. "Chip" Schilling explica que entende Bartleby como a história de um advogado. Logo, deve ter sido devido a esse fator que ele criou o formato do livro, baseando-se na forma de documentos legais (legal ledger). Como a história se passa em Wall Street e Bartleby olha fixamente o muro, Schilling criou uma textura para o papel que reveste a capa dura em alto relevo, representando um muro de tijolos à vista.

Schilling explica também que não colocou o nome do autor na página de rosto (na capa não há impressão do título, apenas na lombada), uma vez que o original havia sido publicado de forma anônima em uma revista.
A fonte utilizada para a composição do texto (impressa em tipografia em metal - letterpress) foi a Bulmer ${ }^{10}$, criada em 1928 por Morris Fuller Benton, tipógrafo americano. Segundo Schilling, trata-se de um tipo transicional que ele achou adequado para remeter à época. A família Bulmer, no entanto, pode ser considerada da classe moderna por possuir serifas de tipo filete, eixo de contraste vertical e grande variação de espessura entre traços grossos e finos, como se pode perceber no gráfico abaixo (figura 94):

\section{Bulmer Regular}

aAbBcCdDeEfFgGhHiljJLmMnNoOpPqQrRsStTuUwWxXyYzZ 1234567890

Bulmer italic

aAbBcCdDeEfFgGhHiIjflLmMnNoOpPqQrRsStTuUwWxXyYzZ 1234567890

\section{Bulmer Bold}

aAbBcCdDeEfFgGhHiIjJlLmMnNoOpPqQrRsStTuUwWxXyYzZ 1234567890

\section{Bulmer Regular os tipos apresentam alto contraste entre traços finos e grossos. aAoOpPqQfFtT}

Ao longo do livro, há a interferência de um lettering caligráfico Figura 94: Amostra dos desenhado por Suzanne Moore que se sobrepõe ao texto. Wilber H. tipos usados na edição "Chip" Schilling explica que "chega uma parte da história em que daIndulgence Press. você começa a imaginar quem é o Bartleby que se recusa a fazer todas Desenvolvido pela autora. aquelas coisas e começa a se tornar, cada vez mais, um personagem abstrato. Dessa maneira suas respostas (I would prefer not to, na caligrafia de Suzanne Moore $)^{11}$ começam a ficar maiores e se expandem ao longo das páginas.

10 A Bulmer foi desenvolvida primeiramente em 1792 pelo tipógrafo William Martin. Disponivel em: http://www-myfonts.com/fonts/mti/bulmer-mt/; acesso em 21.04.2014. Disponivel em: http://www myfonts.com/fonts/adobe/bulmer/; acesso em 21.04.2014 11 Parênteses nosso. 
Há então duas vozes tipográficas: a do advogado impressa em Bulmer e a de Bartleby, caligráfica, e esta última acompanha a progressão abstrata do personagem. À medida que Bartleby se torna abstrato, a caligrafia também sofre o mesmo processo (já que, ampliada, ela funciona mais como textura que como texto).

Schilling, em entrevista realizada em fevereiro de 2013, acredita também que a narrativa é ambígua e:

Chega um ponto em que você se pergunta se o personagem realmente existiu ou se é fruto da imaginação do advogado. No fim da história Bartleby é preso porque ele se recusa a sair do prédio e na prisão se recusa a comer e morre.

O designer homenageia no colofão do livro um amigo que, segundo ele, cometeu suicídio, um evento obviamente muito triste, mas que em suas palavras representa em última instância o "acho melhor não" ("I would prefer not to") do personagem principal.

Muitos dos elementos utilizados por Schilling citam graficamente, remetem às atividades legais e à época: o formato do livro em formato de documentos legais, a parede de tijolos (tanto a parede que Bartleby olha fixamente quanto Wall Street, referenciando a localidade geográfica em que se passa a trama), a frase-chave do livro, "I would prefer not to", em letra cursiva, que alude ao ofício de escrivão, uma vez que o escrivão da época trabalhava copiava textos à mão.

Wilber H. "Chip" Schilling explica que, quando passou a projetar livros, pensou em imprimir Bartleby devido às muitas metáforas e significados escondidos no texto. É importante também observar que a versão utilizada pelo designer é a que foi impressa anonimamente em 1853 na revista Putnam's Monthly (Vol. II No. XI, A Magazine of Literature, Science \& Art). O designer explica em entrevista que havia diferenças sutis no original publicado pela revista e no posterior já assinado por Melville publicado em livro
Edição de Bartleby, o escrivão: uma história de Wall Street,

da Editora Cosac Naify (2005)

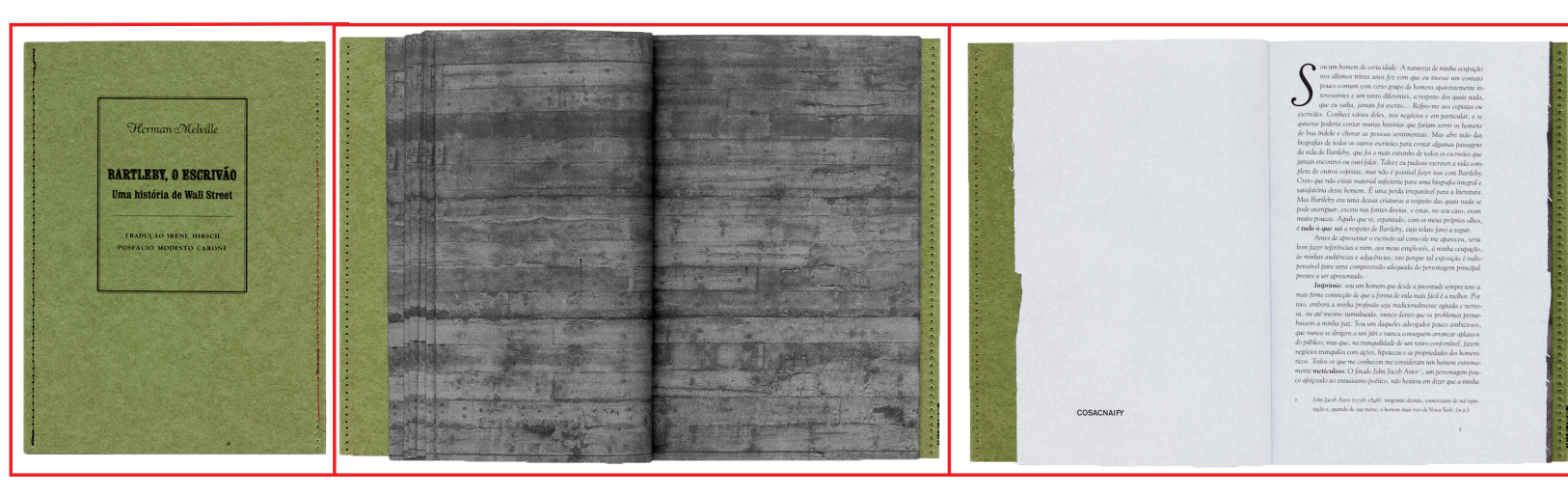

\begin{tabular}{|c|c|}
\hline Descrição técnica & Relação entre texto e projeto \\
\hline $\begin{array}{l}\text { Impressão: offset } \\
\text { 167mm x 230mm (fechado) } \\
\text { 338mm x 230mm (aberto). }\end{array}$ & $\begin{array}{l}\text { Formato apresentado em outros } \\
\text { exemplares da editora. }\end{array}$ \\
\hline $\begin{array}{l}\text { Encadernação e acabamento: costura } \\
\text { plana lateral na lombada unindo miolo } \\
\text { e capa. Costura lateral plana do lado } \\
\text { oposto da lombada, formando um lacre. } \\
\text { Encadernação francesa sem refile dos } \\
\text { cadernos no canto lateral (fore edge). } \\
\text { A capa é costurada de ambos os lados } \\
\text { e é necessário puxar a linha do lado } \\
\text { direito para abrir. O miolo do livro não } \\
\text { é refilado, sendo assim, é necessária a } \\
\text { abertura de página a página do livro } \\
\text { com a espátula que o acompanha. }\end{array}$ & $\begin{array}{l}\text { O personagem Bartleby se nega a } \\
\text { fazer tudo, até comer, o que causa } \\
\text { perplexidade no narrador, seu patrão. } \\
\text { Os lacres que dificultam a abertura do } \\
\text { livro podem sugerir as dificuldades } \\
\text { para entender o personagem. }\end{array}$ \\
\hline $\begin{array}{l}\text { Papel da capa: } \\
\text { VEDPRESS GT 0,4 - (papel isolante elé- } \\
\text { trico de aproximadamente } 400 \mathrm{mg} / \mathrm{m}^{2} \text { ). } \\
\text { O papel lembra o material utilizado na } \\
\text { confecção de fichários de arquivos. }\end{array}$ & $\begin{array}{l}\text { Relaciona-se diretamente ao material } \\
\text { (arquivo) do escritório, ambiente em } \\
\text { que se passa a trama. }\end{array}$ \\
\hline $\begin{array}{l}\text { Microtipografia da capa: } \\
\text { Clarendon BT Bold Condensed, } \\
\text { Clarendon BT Condensed, } \\
\text { Goudy Extra Bold, } \\
\text { OPTIGoudy Cursive. } \\
\text { Macrotipografia da capa: } \\
\text { Alinhamento centralizado; } \\
\text { Textos centralizados no meio da página } \\
\text { e com duas famílias tipográficas em } \\
\text { quatro pesos e variações diferentes. } \\
\text { Há em volta dos textos (mensagem } \\
\text { linguística da capa) um quadro que os } \\
\text { envolve, como se fosse um rótulo. }\end{array}$ & $\begin{array}{l}\text { O projeto gráfico de Elaine Ramos } \\
\text { para o clássico pode lembrar à } \\
\text { primeira vista modelo de tratamento } \\
\text { tipográfico do século XIX, já que } \\
\text { há uma mistura de tipos e alguns } \\
\text { deles como Clarendon são tipos do } \\
\text { século XIX. } \\
\text { Relação aos elementos textuais da } \\
\text { capa, os mesmos também poderiam } \\
\text { remeter à "etiqueta", que igualmente } \\
\text { poderia remeter a esse meio: } \\
\text { "etiquetas em fichários". }\end{array}$ \\
\hline
\end{tabular}

igura 95: Capa e miolo e Bartleby, o escrivão publicado pela Cosac Naify em 2005. Imagens fornecidas pela editora. Fotógrafo Nino Andrés. 


\begin{tabular}{|c|c|}
\hline $\begin{array}{l}\text { Papel do miolo: paperfect } 56 \mathrm{~g} / \mathrm{m}^{2} . \\
\text { Papel de baixa gramatura de fácil } \\
\text { dobragem, do lado externo é impressa } \\
\text { a imagem (fotografia) de um muro } \\
\text { de concreto do lado interno o texto. }\end{array}$ & $\begin{array}{l}\text { O muro pode ser entendido } \\
\text { como uma barreira. } \\
\text { No conto, Bartleby olha fixamente } \\
\text { para um muro. }\end{array}$ \\
\hline $\begin{array}{l}\text { Tipografia do miolo: } \\
\text { Microtipografia: goudy old style } \\
\text { itálica corpo } 10 \text { pontos. } \\
\text { Uso no texto principal - narrativa - } \\
\text { itálico e no posfácio romana regular. } \\
\text { Macrotipografia: } \\
\text { Alinhamento: Justificado; } \\
\text { Mancha gráfica } 100 \text { x } 191 \mathrm{~mm} ; \\
\text { Largura do papel do miolo } 160 \mathrm{~mm} \text {; } \\
\text { Margens: superior } 12 \mathrm{~mm} \text {, inferior } 27 \\
\text { mm, lateral interior (pós-encadernação) } \\
16 \mathrm{~mm} \text {, anterior } 25 \mathrm{~mm} \text { ), lateral } \\
\text { exterior } 37 \mathrm{~mm} \text {. }\end{array}$ & $\begin{array}{l}\text { Uso de fonte itálica na narrativa } \\
\text { remete a escrita cursiva, caligráfica. } \\
\text { O personagem Bartleby era um } \\
\text { escrivão - relação da forma da letra } \\
\text { com o ofício do personagem que } \\
\text { copiava os processos jurídicos. }\end{array}$ \\
\hline
\end{tabular}

A designer desse projeto, Elaine Ramos, explica em entrevista que o conceito desse trabalho era o de evidenciar a partir da forma do livro o bordão "Prefiro não fazer" do personagem principal. A designer entende o próprio projeto como a metáfora da negação. Desta forma, o projeto possui figuras de linguagem como as apresentadas no capítulo anterior, o que prova que este tipo de recurso linguístico pode ser usado em projetos de livros de texto literário (projeto como um todo miolo e capa) e não apenas em capas ou em peças publicitárias.

Ao descrevermos os elementos constitutivos do projeto, verificamos que, em linhas gerais, a maior parte deles estabelece uma relação efetiva com o texto.

Segundo Contardo Calligaris $(2005)^{12}$,

"Bartleby, o escrivão", de Herman Melville (o autor de "Moby Dick"), está se tornando um pequeno best-seller. O fato é que a editora, Cosac Naify, criou um maravilhoso livro-objeto, que reproduz materialmente o espírito do próprio Bartleby: fechado e costurado, resistente.

Na capa do livro a composição dos elementos textuais remete à composições tipográficas do século XIX em que se costumava misturar diversas fontes num mesmo bloco de texto. $O$ papel utilizado na capa lembra o papelão comumente utilizado na confecção de fichários de arquivos, o que pode remeter ao cotidiano do escritório. Ainda com relação aos elementos textuais da capa, por estarem encaixados em uma moldura poderiam remeter à "etiqueta", um elemento que também pertence a esse universo do escritório.

A capa é costurada de ambos os lados e é necessário puxar a linha do lado direito para abrir o volume. Quando abrimos o livro, mais uma surpresa: o miolo não é refilado, sendo assim necessária a abertura de página por página, com a espátula que o acompanha. As páginas que não contêm texto, que são a frente das páginas impressas com o texto que se encontra no verso, possuem uma textura acinzentada, similar à de um muro, em um diálogo com as dificuldades de comunicação presentes e com o ambiente árido do escritório em que se passa a trama.

É importante lembrar que, há algumas décadas, os livros não eram refilados, como observa Nogueira (2009: 57-58) em trecho dedicado ao trabalho de Ênio Silveira, que, em 1952, havia se tornado editor na Editora Civilização Brasileira e que, de certa forma, introduziu o refile nas páginas, lembrando que antigamente os livros não eram refilados:

Segundo o próprio Ênio, ele teria introduzido no Brasil a brochura aparada, algo que os editores mais tradicionais lamentavam. Até meados do século passado, a maioria dos livros não eram refilados, sendo que 0 leitor devia abri-los com uma espátula. (NOGUEIRA, 2009: 57-58)

Marc Bogo (2014: 150), em sua dissertação de mestrado sobre a Coleção Particular da Editora Cosac Naify, aponta que esses processos como o de abrir as páginas são interessantes, pois também trazem referências e dados históricos sobre a própria história do livro. Porém ele identifica que esse ato de abrir as páginas também cria significados novos:

O leitor de Bartleby constrói o objeto final com suas próprias mãos e dedos sensiveis, executando e ao mesmo tempo sentindo o que é costurar o livro, abrir as páginas dos cadernos, folhear a obra da direita para esquerda e tatear sentindo a página. Assim, gestos que estavam inicialmente dessemantizados para muitos leitores em potencial, como o mero virar de páginas, são ressemantizados. A repetição automatizada do gesto da leitura dá lugar, por meio do projeto gráfico elaborado pela equipe da editora Cosac Naify, a gestos carregados de sentido em um livro que marca sua diferença em relação à grande maioria dos volumes disponibilizados no mercado editorial nacional. (BOGO, 2014: 84) 
O projeto gráfico possui elementos, como a do livro lacrado e com as páginas cerradas, de uma metáfora que remete à clausura e ao enigmático personagem. O livro cria uma atmosfera gráfica que emula à do enredo, conforme verifica-se na explicação de Ramos (2013b). A designer aponta neste trecho o dado mencionado acima de que antes os livros não eram refilados e necessitavam ser abertos, como na época em que se passa a trama.

Com um texto extremamente sugestivo em mãos, procurei aprofundar o diálogo entre forma e conteúdo, incluindo o suporte como linguagem. O livro, portanto, materializa a negação representada pela personagem é costurado tanto do lado da lombada quanto do lado oposto, obrigando o leitor a puxar a linha que mantém a capa vedada aos curiosos, para deparar-se surpreendentemente, com um novo obstáculo: uma parede uniforme repetida em todas as páginas, sem nada escrito. Para acessar o texto é necessário insistir e, como à época de Bartleby, abrir (com o marcador que vem encartado) todas as páginas rasgando na dobra ${ }^{13}$ (RAMOS, 2013b in DERDYK, 2013: 98)

Esse exemplar da Cosac Naify faz parte de uma coleção, mas a relação de semelhança entre os outros títulos se dá pela investigação do projeto gráfico e sua relação com o texto, ou seja, os elementos que tornam identificáveis os livros são os conceitos de interpretação de texto, materialidade, investimento e investigação da produção gráfica como elemento significativo, claro no caso de Bartleby pela escolha dos materiais e propriedade de livro-objeto. A questão da coleção ao qual Bartleby pertence foi estudada por Marc Bogo (2014), que acredita que se trata de uma coleção que de certa forma difere do conceito de coleção comercial em que todos os títulos apresentam projetos gráficos semelhantes.

A escolha da família tipográfica Goudy OldStyle pode apresentar de certa forma referência à localização geográfica: a história se passa nos Estados Unidos, o autor também é norte-americano, e a família Goudy foi desenvolvida no país pelo tipógrafo de mesma nacionalidade, Frederic Goudy, que segundo Paulo Heitingler ${ }^{14}$ foi um dos principais tipógrafos do país.

\section{Grifo nosso.}

4 Disponivel em: http://www.tipografos.net/designers/goudy.html; acesso e 21.04.2014
A família tipográfica desenhada por Goudy em $1915^{15}$ é inspirada no desenho das capitais cortadas por Peter Schoeffer, o jovem, filho de Peter Schoeffer, que foi aprendiz de Gutenberg, segundo a distribuidora MyFonts. Mesmo tendo sido criado no início do século XX, o tipo remete aos tipos cortados no século XV. A família é apresentada no gráfico abaixo:

\section{Goudy Old Style}

aAbBcCdDeEfFgGhHiljJlLmMnNoOpPqQrRsStTuUwWxXyYzZ 1234567890

Goudy Old St

aAbBcCdDeEfFoGhHiljlLmMnNoOpPaQrRsStTuUwWx Xy YzZ 1234567890

Goudy Old Style Bold

aAbBcCdDeEfFgGhHiljJlLmMnNoOpPqQrRsStTuUwWxXyYzZ 1234567890

Goudy Old Style

\section{aAoOpPqQfFtT \\ Terminal Serfía triangular com Exixo de \\ $\begin{array}{lll}\text { base irregular (ñão } & \text { contraste } \\ \text { é reta) e com junção } & \text { inclinad } & \end{array}$}

oudy Old Style italic utilizada no texto principal de Bartleby.

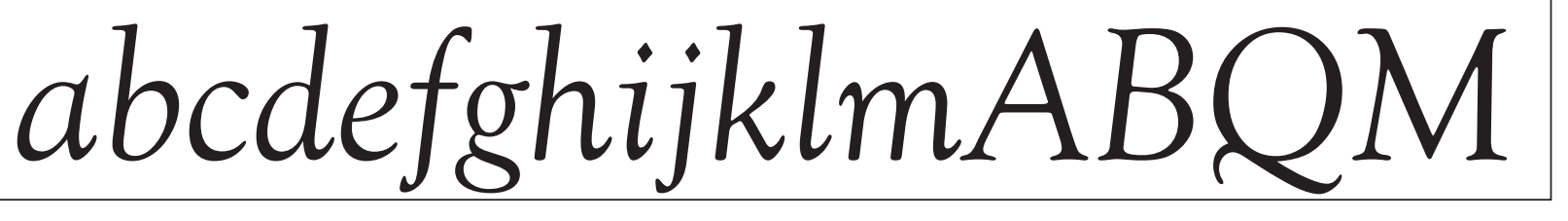

O texto de Bartleby é composto todo em itálico, como uma referên- Figura 96: Amostra dos cia à escrita cursiva, aludindo dessa maneira ao ofício do escrivão. É tipos usados na ediç̃õo mportante notar que a composição de textos em tipos itálicos (toda a mancha e não apenas ênfases no meio do texto) remete à criação dos pela primeiros itálicos tipográficos, cujos desenhos são inspirados na escrita cursiva criados por Francesco Griffo para Aldo Manuzio em Veneza na primeira década do século XVI com o intuito de serem utilizados para composição de livros portáteis ${ }^{16}$.

15 Disponível em: http://www.myfonts.com/fonts/bitstream/goudy-old-style/; acesso em 21.04.2014.

16 Essa questão foi abordada no primeiro capítulo desta tese. 
A designer da edição, Elaine Ramos, explica em entrevista realizada em outubro de 2013 que a escolha do itálico se dá para representar o cursivo, porém ela acredita que o itálico desta fonte em especial não é muito inclinada. Quando questionada se os leitores haviam notado a diferença de todo texto em itálico, já que, na maioria das vezes, os livros são impressos com tipos romanos regulares, ela diz que provavelmente perceberam, mas que achava que os leitores iriam reclamar, o que não aconteceu, talvez também pelo fato de o texto ser curto, não chega a cansar os leitores. Ramos complementa que o condensamento do texto em itálico auxiliava em outro processo do livro, que precisava ficar curto, pois tem uma produção complicada em que era necessário intercalar manualmente as páginas dos cadernos.

Elaine Ramos é, também, responsável pela criação de grande parte dos projetos gráficos de livros da editora e explica em entrevista que a Cosac Naify possuía no momento da entrevista uma equipe de design interna ${ }^{17}$. Ramos explica que o processo é diferente em grandes editoras, nas quais se trabalha com um miolo padrão e o investimento em design é na capa. Já na Cosac Naify "cada designer é responsável pelo livro como um todo e tem uma conversa muito próxima com o editorial e com a produção gráfica".

Ramos explica que os designers leem os textos para criar os projetos (ou o livro inteiro, mas obrigatoriamente ao menos uma parte do texto). O editor de texto produz um briefing sobre o projeto mas, mesmo assim, o designer precisa ler o texto para entender o contexto e alinhar o projeto ao tema do livro. Além de uma proposta de maior integração do projeto com o texto, há também o pensamento de livro como um objeto único, no qual capa e miolo apresentam-se como um objeto coerente:

Mesmo que seja uma brochura básica, sempre o miolo vai ter uma relação com a capa, sempre o papel foi pensado para aquela quantidade de texto, sempre há uma integração do livro, acho que esse é o principal diferencial da Cosac, que não é a capa e o livro padrão, o livro é sempre pensado como único. (RAMOS, 2013)

7 Em outubro de 2013 a equipe contava com seis designers internos. Em 30 de novembro de 2015, um dos donos da editora, Charles Cosac, anunciou seu fechamento.
No mercado editorial alguns projetos de livros são pensados de maneira integrada, como nos livros de arquitetura, design, artes etc., porém essa é uma abordagem rara em editoras comerciais que publicam obras literárias ${ }^{18}$. Ramos explica que, pelo fato de que a Cosac Naify antes de ampliar a linha editorial para literatura e outros assuntos era uma editora com foco no mercado de arte, isso pode ter influenciado a estratégia adotada para a produção dos livros de literatura:

A Cosac começou como uma editora de arte e no mercado de arte os livros são pensados inteiramente. Em livros de arte, é muito raro que alguém tenha feito a capa e outra pessoa, o miolo. Acho que a Cosac trouxe essa ideia da relação do livro de arte para o miolo, para o livro de literatura. E isso que deu essa característica tão única. (RAMOS, 2013.)

Elaine Ramos explica em entrevista como surgiu a ideia da metáfora da negação, presente nas páginas não refiladas (lacradas) e a capa costurada de Bartleby, o escrivão. O tipo de encadernação de costura plana unindo as páginas do livro ao miolo já tinha sido utilizado em outra obra publicada pela editora: a novela Primeiro amor, de Samuel Beckett.

No caso de Bartleby, o livro é lacrado e, quando se abre a capa, todas as páginas apresentam a da imagem da parede fotografada por Nelson Kon. O texto de Bartleby está nas páginas internas, já que o livro não é refilado. Existem, dessa maneira, duas dificuldades para se chegar ao texto: abrir a capa que está lacrada pela costura plana na lateral direita, além da costura da encadernação na lateral esquerda. A segunda dificuldade é abrir cada página. Esse recurso estrutural e gráfico do relaciona-se ao texto, o que Ramos explica como a "metáfora da negação".

Quanto à falta de refile do canto direito, como mencionado acima, antigamente os livros não eram refilados, as páginas do miolo eram dobradas e encadernadas (costuradas pela lateral), mas não eram refiladas, o que exigia que o leitor abrisse as páginas uma a uma. Porém Ramos explica que esse processo existia, mas que não há citação histórica a esse procedimento, a principal ideia desse recurso era a da negação, do "acho melhor não" do personagem Bartleby, e a capa lacrada também colabora para evidenciar essa ideia.

18 Pequenos selos e artistas ou autores independentes podem trabalhar dessa maneira, mas em editoras comerciais é mais difícil. 
Segundo Liu (2013), há cinco tipos de miolo (que podem ser verificados em livros e em outros produtos editoriais): aberto, envelope, desdobrável, sanfona e assimétrico. O miolo de Bartleby, a partir de Liu, é o do tipo envelope, cuja definição é:

Envelope: as páginas de um volume podem ser duplas, refiladas e abertas somente na parte superior e inferior do miolo. (...) É possível ter continuidade perfeita de um texto ou imagem, entre uma página dobrada e outra. O rasgo manual das páginas pode gerar uma aresta com rebarbas. (LIU, 2013: 105)

É importante mostrar que, quando se abre o livro com a espátula, a aresta dele fica com rebarba e estas podem, segundo Liu, também ser usadas como um recurso gráfico:

Rebarbas em arestas de livros ou volumes atribuem aspecto artesanal ao livro. As folhas dobradas para a montagem dos cadernos são abertas manualmente, em vez de serem refiladas. Papéis mais macios e fibrosos originam rebarbas com mais textura. (LIU, 2013: 107)

Bartleby é um livro especial, com uma abordagem pouco usual, mas que vendeu mais de 12.000 exemplares $^{19}$, considerado uma quantidade alta para a estrutura da editora. $O$ valor de capa dessa ediçãa ${ }^{20}$, em abril de 2014, era de $R \$ 44,00$, relativamente alto, considerando-se o tamanho do texto. Ramos explica que o alto valor das edições, não apenas de Bartleby, é fruto do alto custo de produção, pois os livros apresentam leiaute exclusivo e materiais e processos de impressão e acabamento especiais, que não fazem parte de um sistema de produção massificado utilizado por grandes editoras: "As tiragens são muito pequenas, isso faz com que o valor unitário seja muito alto. Isso faz com que a Cosac tenha uma estrutura grande, uma estrutura cara." (RAMOS, 2013)

A encadernação de Bartleby, como mencionado anteriormente, é baseada na encadernação do primeiro livro da coleção particular, Primeiro amor, de Samuel Beckett. Ramos explica que descobriu que era possível trabalhar com esse tipo de costura na lateral ao observar que nas gráficas

19 Dado obtido em abril de 2014. Provavelmente mais cópias foram vendidas até o término da redação desta tese de doutorado. Hoje todas as edições do livro encontram-se esgotadas e provavelmente não serão reimpressos devido ao fechamento da editora em novembro de 2015. 20 Disponivel em: http://editora.cosacnaify.com.br/ObraSinopse/10900/Bartleby,-oescriv\%C3\%A3o---Uma-hist\%C3\%B3ria-de-Wall-Street.aspx; acesso em 18.04.2014.

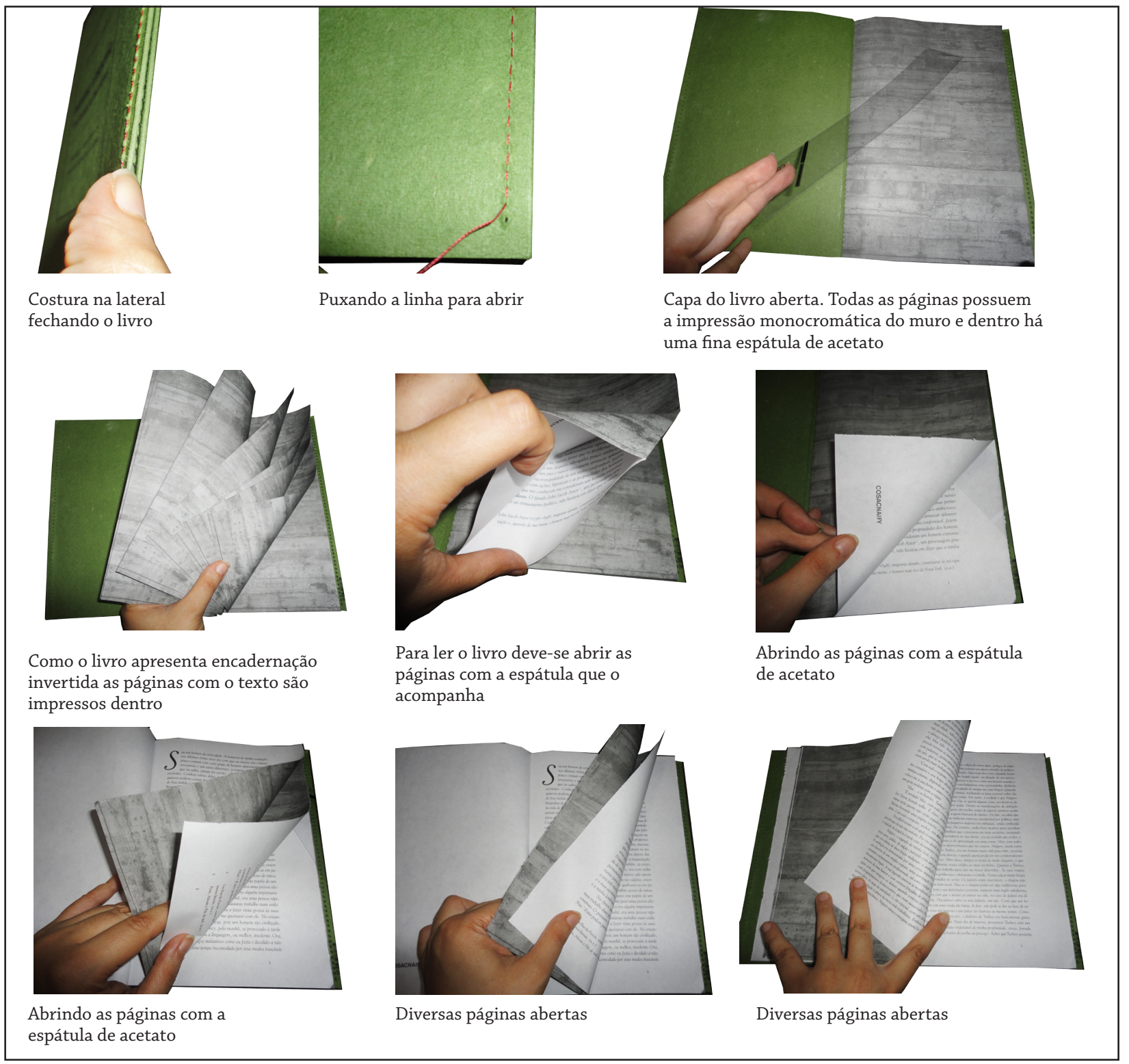

as capas de Bíblia de couro são costuradas com esse tipo de máquina que Figura 97: Manuseio do não é a de encadernação tradicional, é uma máquina de costura plana volume. Abertura das Singer. Segundo Ramos, essa edição de Bartleby não é muito difícil de páginas. Passo a passo. Desenvolvido pela autord. Para realizar este trabalho a escolha dos materiais era fundamental, o papel devia ser fino o suficiente para esse tipo de costura e para o manuseio de abrir as páginas com a espátula, porém não poderia ser fino demais, transparente demais, porque assim poderia prejudicar consideravelmente a leitura. O material da capa, o papel que lembra pasta arquivo, já era conhecido pela designer antes da produção deste volume, quando ela ainda era aluna de graduação da FAU-USP, pois em uma ocasião verificou 
que esse tipo de papel tinha sido usado na capa de uma publicação dos estudantes chamada Caramelo. Ramos explica em entrevista (RAMOS, 2013) que usou esse papel "porque o objetivo era lembrar uma pasta de documentos antigos, o mundo burocrático de documentos".

O papel usado na capa a princípio era um isolante elétrico, mas foi mudando de acordo com as reimpressões, uma vez que o papel de capa da primeira edição acumulava umidade e embolorava o livro. Ramos explica que o primeiro papel utilizado tinha uma textura interessante, era gelado ao toque, porém a umidade atrapalhava demais, deixando engruvinhado o miolo. A leitura de Bartleby é, de certa forma, performática, o leitor tem que abrir as páginas do livro para conseguir ler o texto e, dessa maneira, vivencia a 'negação' de Bartleby... o leitor ao ver o livro lacrado poderia pensar "acho melhor não abrir".

Além do lacre da costura, em algumas edições o livro era fechado também com uma embalagem plástica e sobre ela era aplicado um adesivo com a seguinte frase: "apesar de $\mathrm{xxxx}$ exemplares vendidos, acho melhor não comprar". A última sentença da frase "acho melhor não comprar" foi composta em tipo bold para chamar a atenção e mais uma vez reforça a ideia da negação, mas ao mesmo tempo estimula o leitor, pois apesar de ter sido sucesso de vendas, como apontado pelo adesivo, a recusa é incentivada. Trata-se obviamente de uma ironia e este recurso retórico talvez tenha força de instigar a compra da obra.

Uma vez totalmente aberto, a força da negação do lacre do projeto é minada, dessa maneira a experiência é perecível. Elaine Ramos, em entrevista, explica que:

O livro em essência é um objeto perene e Bartleby vai nessa contramão (...) A partir do momento que você lê, você o destrói, o projeto se refere à negação do personagem, mas também é a negação do sentido do livro, porque o sentido do livro é perpetuar e dessa maneira, também nega a própria essência do livro que é a de perpetuação.

Ainda sobre esta edição de Bartleby, foi realizada entre janeiro e maio de 2014 uma pesquisa informal com vinte e dois leitores (ANEXO) e a maioria deles não se incomodou com a composição do texto em itálico e muitos deles conseguiram estabelecer um paralelo entre o texto e o projeto gráfico e acharam a experiência de leitura interessante, o que demonstra o interesse de um público leitor por livros "visíveis" e esti- mulantes se comparados às edições comuns. A pesquisa, então, de certa forma, apresenta uma tendência, ou então uma abertura do público a experimentos desta natureza nos dias de hoje.

As quatro edições discutidas apresentam características e propósitos diversos e esses propósitos podem também ser considerados em relação às próprias estratégias editoriais das casas publicadoras. As duas primeiras edições de Bartleby são edições comerciais tradicionais e uma delas faz parte de uma coleção e tem seu projeto padronizado. O penúltimo exemplo foi criado no modelo das "prensas particulares", produzido com materiais nobres e com processos artesanais e edição limitada. Já Bartleby da Cosac Naify é de uma editora que tem feito seu "nome", criado sua identidade justamente a partir de projetos especiais, de uma concepção do livro como objeto único. Ainda assim é uma editora comercial e suas tiragens não são limitadas.

Os dois primeiros exemplos apresentam sutis relações entre o texto e o projeto, sendo ambos os projetos mais utilitários. Já os dois últimos apresentam evidentes relações de projeto gráfico com o texto, a visibilidade do volume se dá especialmente na colaboração, para utilizar o termo proposto por Linden (2011) para a criação de sentido junto ao texto verbal.

É possível verificar, com base nos exemplos e na literatura teórica apresentada neste capítulo, que a visibilidade do livro de literatura pode ser uma abordagem de design que contribui efetivamente na construção de sentido, complementa o texto literário e pode enriquecer a leitura. A edição de Bartleby da Cosac Naify é um exemplo bem sucedido da integração entre texto e projeto, e não é apenas interessante do ponto de vista do design, mas como um produto cultural, já que mostrou que projetos como esse tem seu valor e são apreciados pelo público, uma vez que a edição recebeu críticas positivas e retorno comercial. 


\section{SER VISÍVEL OU INVISÍVEL, EIS A QUESTÃO}

Como vimos nos capítulos anteriores, é possível distinguir duas abordagens ao design do livro de literatura: uma, mais visível e outra, invisível. Neste capítulo propomos um contraponto entre essas duas abordagens, verificando novas tendências para os dias de hoje, críticas à baixa qualidade de alguns livros e à padronização, além de investigar a suposta ameaça do livro digital.

Segundo Richard Hendel (2013: 7):

Existem duas abordagens filosóficas ao design de livros: há os que acreditam que o design deva ser neutro e atemporal e outros que ele deva refletir o conteúdo de uma forma mais óbvia (usando tipografia ou elementos de design relevantes relativos ao tema do livro).

A abordagem que deve "refletir o conteúdo" corresponde ao que denominamos visível, pois os elementos gráficos e a tipografia são utilizados com a intenção de criar novos significados ou trazer certa atmosfera, como em Bartleby, o escrivão, da Cosac Naify, apresentado no capítulo anterior.

Hendel (2013: 7) explica que os designers que almejam um design neutro e atemporal "costumam chamá-lo de 'taça de cristal' a partir do ensaio homônimo de Warde". Hendel observa que:

Warde não estava sozinha em sua postura que defende que o projeto para livros deve ser diferente de outros tipos de design gráfico. De forma diferente que a de outros designers gráficos, aqueles que projetam livros precisam estar cientes das convenções de como as pessoas leem.

Hendel defende a postura de Warde, que almejava livros bem feitos e úteis, convencionais e 'transparentes', mas mostra também a posição de outros designers como Will Powers, que praticam uma abordagem mais visual e procuram trabalhar com uma grande variedade de faces tipográficas. (HENDEL, 2013: 7)

Mesmo apresentando essa abordagem mais visível, Hendel (2013 
127) explica que o design dos livros de ficção projetados por ele mesmo foi criado para que as obras se enquadrassem dentro de padrões, de templates:

Grande parte da ficção que eu projetei foi destinada para caber em um projeto modelo. Projetar as especificações de um modelo ${ }^{1}$ para um livro de ficção é parecido com projetar para um jornal, exceto que geralmente há menos problemas para se prever. A principal consideração é encontrar uma fonte neutra, como a Minion, que oferece uma gama completa de pesos, compõe razoavelmente bem e sem muito ajuste, e tem uma versão para títulos ${ }^{2}$ que aparenta ter sido feita para esse propósito (em vez de parecer uma versão apenas "aumentada" do desenho do tipo de texto)

Hendel apresenta uma série de entrevistas com designers de livros de diversos segmentos e, no que se refere aos livros literários, entrevistou Virginia Tan, diretora de design da Knopf, e Anne Winslow, diretora da arte da Algoquin.

Hendel (2013: 127-128) cita o depoimento de Virginia Tan, que explica suas estratégias para escolher tipografias para livros:

A escolha de uma fonte de texto se baseia tanto na legibilidade e no fator "sabor" -eu gosto de tipografias historicamente relevantes, bem como de capturar a sensação da trama, especialmente na fição. Se a história é masculina ou feminina, noir, romântica, de aventura, cômica ou trági ca; ambientalista etc., qualquer desses fatores poderia influenciar minha escolha tipográfica. Mesmo dentro do texto em que poderia utilizar fontes mistas em extratos; um itálico para passagens descritas no texto Roman composto em tamanho pequeno e condensado para um artigo de jornal. Esses são estímulos visuais para o leitor que, espero, chamam a atenção do olho e da mente para a história. Eu, pessoalmente, sou uma leitora lenta porque inconscientemente, enquanto leio, exibo uma história como um filme em minha cabeça. Eu quero dar isso aos leitores nos livros em que trabalho.

Como se pode perceber, Virginia Tan procura trabalhar com uma tipografia de certa forma alusiva e que sua escolha, a partir do que foi observado no capítulo "A tipografia dá o tom", relaciona-se a uma busca por um valor de atmosfera, por conotações que estilos de fontes podem trazer.

1 Template.

2 Display.
Em depoimento a Hendel (2013: 129), Virginia Tan explica que, no entanto, nem todas as editoras trabalham como ela e que muitas usam modelos padronizados, nos quais não há uma escolha tipográfica específica para cada tipo de texto:

Algumas editoras como a Knopf projetam cada livro. No entanto, em outras casas publicadoras, como a Faber, onde mais de 200 títulos são tratados por uma pequena equipe de design (até o momento não há nenhuma equipe interna de design para o projeto do miolo), eles têm um modelo padrão, modelos relativamente simples e geralmente usam a mesma fonte para toda obra de ficção. No design do modelo original para Faber feito por Gerry Cinamon, o tipo usado era Palatino. Como o plano editorial mudou, um novo formato e novos tipos foram necessários, e em vez de Palatino foram usados Minion, Sabon e Ehrhardt. Possivelmente, por conta de sua onipresença, a Palatino parece ser a menos popular entre designers.

Ainda a partir de Hendel (2013), temos o depoimento da diretora de arte Anne Winslow, da Algoquin, que tem um ponto de vista um pouco diferente de Tan: "Eu não quero que o estilo da fonte, o tamanho ou a composição distraia o leitor da leitura" (HENDEL 2013: 130). Ou seja, Winslow mostra-se uma profissional a favor do design "invisivel", ao contrário de Tan.

Winslow (in HENDEL, 2013: 130) explica que antes havia uma correlação maior entre o design, os temas e o público, porém sua posição é mais funcional, pois muitos dos livros que ela projeta acabam também virando versões digitais: "Na versão EPUB, digital, o leitor pode mudar a fonte, logo, mais do que o desenho de uma fonte, o que mais importa é o conjunto de negritos, itálicos, versaletes, e não de fontes individuais".

Jan Middendorp (2012: 16) acredita que em alguns casos é necessário trabalhar com a tipografia invisível. Para ele, a tipografia deve ser invisível justamente nos livros de literatura.

Ruari McLean (1992: 9), assim como Middendorp, acredita no papel funcionalista do design de livros e também defende a abordagem "invisível":

Como tipógrafo, você é um funcionário do autor - colega, se preferir -, mas seu trabalho é ajudar o autor a atingir seu público. Você não está criando obras de arte próprias; você está transmitindo, com muita habilidade, graça e eficiência, como é necessário, as palavras de outra pessoa. 
A invisibilidade, no entanto, pode ser um conceito relativo, uma vez que, por mais que não se queira chamar a atenção do leitor para o projeto gráfico, pequenos detalhes tipográficos podem ser percebidos, mesmo que de forma inconsciente, como já discutido.

A invisibilidade do design do livro de literatura no contexto trabalhado pelos autores acima é de que a tipografia do livro seja simples e não chame atenção, mas, em relação ao uso de ornamentos e ilustrações não fica claro se são favoráveis ou contra. Middendorp (2012), Hendel (2006) e Lee (2004) também não abordam o uso de ilustrações no leiaute do livro de literatura, talvez porque por muitos anos a quase totalidade dos livros desse segmento deixou de ser ilustrada e, normalmente, tem a forma simples de hoje, com exceção de livros ilustrados contemporâneos como os apresentados nesta tese.

\section{A INVISIBILIDADE SOB SUSPEITA}

Há, porém, os que avaliam a abordagem invisível como conservadora e próxima de uma postura linguística ultrapassada, como observa Flávio Cauduro (1998) em Desconstrução e tipografia digital. Cauduro associa a visão funcionalista da tipografia como "auxiliar" da linguagem a uma visão logocêntrica da linguística de Saussure, da escrita como "auxiliar" na representação da linguagem falada:

Esse logocentrismo ainda sobrevive em muitos modelos de comunicação social, em que qualquer prática significante é colocada em termos de um simples processo de troca de mensagens, que são vistas como não problemáticas, como simples meios materiais neutros e transparentes para "transporte" de informações mentais, para intercâmbio de significados "padrões". Em decorrência disso, muitos estudos sobre a comunicação escrita tendem a ser simples exercícios verbais sobre "análise de conteúdo", com muito pouca atenção sendo prestada aos papéis desempenhados tanto pelas qualidades materiais dos textos quanto pelas subjetivi dades dos leitores (e dos investigadores, inclusive) envolvidos na produção (e reprodução) de sentidos e significados. (CAUDURO, 1998: 85)

Cauduro alude, aqui, a uma visão da comunicação verbal composta por três elementos: um falante (ou escritor), um ouvinte (ou leitor) e aquilo que é falado (ou escrito), muitas vezes denominado "mensagem". Nesse modelo, ao "receptor" cabe apenas "descodificar" a "men- sagem" "codificada" pelo "emissor". O leitor tem, assim, um papel passivo nessa equação. Ao longo do século passado, várias linhas teóricas, tanto da linguística quanto da comunicação e da literatura, procuraram discutir esse esquema, valorizando, entre outros, o papel do leitor na construção dos significados. É esse esquema que Cauduro classifica como logocêntrico.

Para ele, esse posicionamento da linguística, que ele acredita estar associado a uma ideologia funcionalista do design de livros, está intimamente relacionado ao design "neutro" de livros sérios, como se pode observar na passagem a seguir:

Não é de se admirar, portanto, que a escrita linear interrompida, não -ilustrada, monotonamente 'cinza', tenha se tornado a norma e o idea tipográfico dos chamados livros 'sérios', numa tentativa fútil de impressores e editores de torná-la uma representação neutra e tão fiel quanto possível à 'fala original' e aos significados pretendidos por seus autores. (CAUDURO, 1998: 87)

Nesse trecho, Cauduro apresenta uma crítica aos livros "sérios" e simples e rechaça a ideia de representação neutra, que em outras palavras poderia ser considerada "invisível". Além disso, quando a tipografia é considerada apenas "utilitária" e "auxiliar" da linguagem, desempenha um papel subalterno. Cauduro observa que, a partir dessa posição, justifica-se o pensamento de tratar a tipografia como um ofício técnico e pouco intelectualizado. (CAUDURO, 1998: 93)

O autor, em seguida, critica a posição de Warde sobre a invisibilidade da tipografia associada à produção dos livros "sérios" e igualmente a posição logocêntrica, que parece estimular e reforçar a ideia de que a escrita é sempre contínua e linear, pois, para ele, "essa forma retórica também cria a ilusão que o texto poderá ser consumido linearmente, de uma só vez, ininterruptamente e com um mínimo de esforço; e sempre com o mesmo resultado". (CAUDURO, 1998: 96).

Sabe-se que, durante o período chamado pós-moderno, entre as décadas de 1970 e 1990, o princípio da "invisibilidade" foi altamente questionado, talvez não em relação ao seu contexto original, quando Warde o utilizou pela primeira vez em 1930, mas como uma reação contra a tradição. Contra a premissa da invisibilidade, um projeto desenvolvido em 1978 na Cranbrook Academy of Art pode ilustrar a visibilidade como 
oposição à invisibilidade, quando regras editoriais são deliberadamente negligenciadas. Esse projeto é apenas um exemplo de projetos editoriais que exploram a materialidade da tipografia. Apesar de não ser um livro de ficção, mas o projeto para o periódico científico Visible Language sobre estudos das linguagens verbais e visuais pode ser considerado um exemplo eficaz como crítica ao princípio da invisibilidade.

O projeto gráfico da edição intitulada French Currents of the Letter, de 1978, para o periódico Visible Language, produzido pelo Departamento de Design da escola de artes e arquitetura norte-americana Cranbrook Academy of Art, foi coordenado por Katherine McCoy, teve consultoria do arquiteto Daniel Liebeskind ${ }^{3}$, e foi desenvolvido pelos alunos Richard Kerr, Alice Hetch, Jane Kosstrin e Herbert Thompson Esta edição apresenta oito artigos com temas pós-estruturalistas de diversos autores.

Em minha dissertação de mestrado (Camargo, 2011), desenvolvi um levantamento da importância deste projeto e verifiquei que para ele os alunos tiveram minicursos ${ }^{4}$ sobre a teoria linguística francesa e que "O projeto reflete a leitura e a interpretação do conjunto dos textos desses autores" ${ }^{\prime \prime}$. (149-151)

A introdução à edição $0^{6}$, escrita por George H. Bauer, apresenta ideias sobre a visualidade presentes nos artigos. O projeto gráfico da edição, por sua vez, parece refletir especialmente a ideia contida neste texto introdutório que trata da visualidade oposta à transparência, uma vez que a "Transparência do texto dá lugar à opacidade. Palavras não vistas, letras invisíveis, agora surgem magicamente diante de seus olhos como objetos plásticos. A linguagem é novamente visível".

Quando se fala que se passa da transparência e da invisibilidade à

\footnotetext{
3 Diretor do departamento de arquitetura da Cranbrook Academy of Art.

4 Ou debates com Daniel Liebeskind.

5 Autores dos artigos da edição do periódico em questão.

6 Texto completo da introdução no original: This is not the place to inscribe the story of the re-emergence of letters, words, and books as objects to be seen; nor would it be appropriate to bundle tidily the delirium of readings you see before you. Transparency of the text gives way to opacity. Words unseen, letters invisible, now magically appear before your eyes as plastic object games. Language is once again visible. The tradition is long, but marginal - at the edge. Here as gathered unscientifically and purposefully obsessiona. French Currents of the Letter.
}

opacidade e à visibilidade do texto, pode-se inferir que exista certa referência aos pressupostos da invisibilidade e transparência da tipografia prescritos por Warde em 1930

O projeto gráfico desta edição acaba por tornar visível o texto, ao romper com uma série de paradigmas do design editorial, o que acaba chamando a atenção para a própria configuração do texto.

A tipografia é "invisível" quando não há nenhuma interferência, quando o leitor identifica no projeto padrões aos quais já está acostumado, como entrelinhas regulares, pequenos recuos marcando os parágrafos, espaços regulares entre palavras e entre letras e notas de rodapé discretas. A visibilidade neste projeto se dá especialmente pelas relações espaciais horizontais e verticais do texto, notadamente nas entrelinhas, entre palavras e entre letras.

Ao romper com alguns desses padrões, os designers exigiram do leitor atenção ao projeto gráfico. Os oito artigos da edição foram compostos de maneira diferente, mas seguindo uma progressão de interferências. $O$ primeiro artigo é quase comum, seguindo algumas regras tipográficas de espaços (entrelinhas, espaço entre palavras etc.), porém aos poucos essas normas são desafiadas e obviamente o resultado é uma performance de leitura fragmentada e difícil. Rick Poynor (2003: 53) explica o processo de progressão do leiaute dos artigos:

Â medida que o leitor vê os oito ensaios, convenções de padrão de livros são progressivamente minadas. As colunas de texto se expandem preenchem as margens internas; espaços, entrelinhas aumentam, espaços entre palavras inflam até que o texto exploda em partículas. Notas de rodapé, normalmente confinadas a um papel subsidiário, deslizam até o corpo do texto. A intenção era evidenciar a fisicalidade da palavra impressa e estabelecer novas conexões não lineares entre as palavras, abrindo possibilidades de modos de ler alternativos.

No decorrer de minha dissertação (CAMARGO, 2011: 59), a proposta apresenta quebras hierárquicas, "tais como: variações no texto corrido e nas notas de rodapé, e é um exemplo radical que 'ilustra' ideias inspiradas por conceitos pós-estruturalistas".

Quando um trabalho apresenta soluções originais e quebras de paradigmas ele é suscetível a críticas, o que de fato ocorreu quando foi publicado. Segundo Heller (2007: 277), "o trabalho chocou quase todo mundo, atraindo a fúria e a zombaria de designers ainda comprometidos com o 


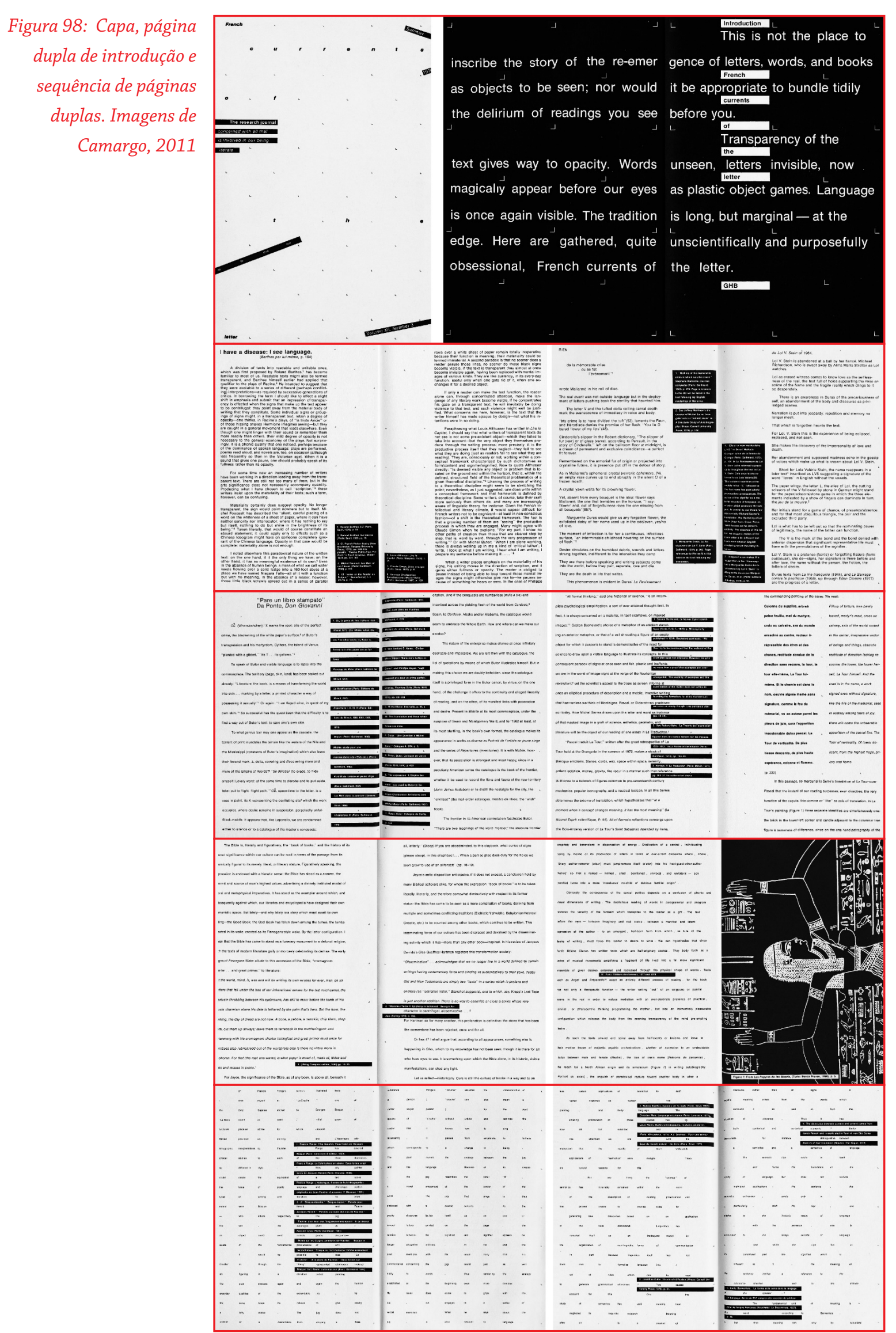

cânone modernista de simplicidade, legibilidade e solução de problemas". Na avaliação de Ellen Lupton (1996: 7), esse projeto, que quebrou alguns padrões de espaço e ordenação dos elementos na página - espaços entre palavras, entrelinhas, notas de rodapé no corpo do texto -, rejeitou a ideologia estabelecida da "solução de problemas" e a objetividade e clareza do design gráfico moderno.

Apesar das críticas apresentadas por Heller e Lupton, Lorraine Wild (1990) acredita que a maioria dos críticos não percebeu a relação óbvia entre o leiaute do projeto desta edição e seu conteúdo:

O design da edição ataca a 'transparência' visual do texto por trás do design de livros tradicional, da mesma maneira que os autores atacaram as noções de 'transparência' do significado por trás da linguagem. (WILD, 1990: 33)

O exemplo acima traz uma representação clara da visibilidade como crítica à invisibilidade e, mesmo sendo bastante radical, ajuda-nos a entender a crítica de alguns profissionais contra o design editorial simples, neutro e invisível.

Um trabalho anterior bastante radical, mas produzido em outro contexto e com outros propósitos, é a interpretação de $A$ cantora careca por nós apresentada no capítulo anterior. No caso de French Currents of the Letter, apenas apresentamos esse exemplo como postura crítica à "invisibilidade", pois ele "ilustra" uma estratégia "visível" pela quebra de paradigmas do design editorial e como expressão gráfica das ideias dos artigos do periódico.

McVarish (2010) explica que muitas das premissas de Warde foram retomadas e criticadas por teóricos do design nos anos 1990. Ela pondera, porém, que muitos não levaram em conta o contexto do período em que Warde promoveu tais ideias.

Deve-se, sem dúvida, levar em consideração que estamos em um período muito distante daquele em que a "invisibilidade" como princípio foi concebido. Hoje somos rodeados de imagens e talvez a linguagem das revistas, cada vez mais visual, cada vez mais gráfica, como a Wired, entre outras, possa influenciar o design de livros também, uma vez que o leitor acostumado a um design "visível" em outros produtos editoriais não estranhe tanto um livro como Kapow!, discutido anteriormente.

Poynor (2003: 143-144) apresenta argumento semelhante ao trata de livros de literatura não convencionais, como o romance House of Lea- 
ves, de Mark Z. Danielewski, publicado em 2000 pela Pantheon Books, no qual a tipografia é tratada de forma expressiva. Poynor sustenta:

Ninguém que tenha conseguido transpor as estruturas fraturadas de Ray Gun ou mesmo os leiautes com alta voltagem elétrica da [revista] Wired inicial deveria ter qualquer dificuldade em lidar com os provocadores caminhos e sentidos figurados de House of Leaves. Entre esses caminhos há fontes alternadas, notas de rodapé que proliferam insanamente, passagens com palavras riscadas e letras que faltam, tipos que se leem no sentido inverso, texto apresentado de cabeça para baixo e em formatos estranhos e páginas que trazem uma única sentença.

Ou seja, mesmo livros experimentais como House of Leaves ou Kapow! podem não parecer tão radicais hoje, já que outras mídias continuam explorando as possibilidades expressivas da superfície visual. Esse tipo de tratamento, infere-se, funciona se há necessidade, se o texto pede, e não se trata aqui de defender que, aleatoriamente, todos os livros de fiç̧ão devam a partir de agora ser extremamente radicais. Kapow!, por exemplo, tinha um argumento, um conceito por trás do texto, que justificava seu projeto gráfico.

\section{A INVISIBILIDADE COMO DESCASO}

Ao retomarmos a ideia de invisibilidade, percebe-se que alguns autores acreditam que este conceito vai além da página simples, legível e que não chama a atenção. A invisibilidade, além de conotar o livro "funcional" cujo projeto parece ser feito para auxiliar a leitura, também, a partir de Megan L Benton (2000: viii), pode conotar seu estado de "culturalmente invisível", no sentido de que talvez, hoje, tenha perdido cada vez mais seu valor e sua forma seja negligenciada:

O desdém pelo livro impresso hoje invariavelmente começa pelo divórcio da natureza e do interesse de um livro de seu texto, pelas diversas funções formais da necessidade de seu conteúdo. O livro impresso é frequentemente retratado como um fardo para o seu texto, uma barreira intrusa entre texto e leitor que serve aos interesses de escritores e editores privilegiados. (BENTON, 2000: viii)

Se a forma é muito simples, leitores e inclusive editores poderiam pensar que a forma da página é algo banal e que não há nenhum critério por trás, já que hoje pode-se compor um livro utilizando softwa- res não apropriados para este fim, disponíveis a qualquer um. Melot (2012: 99) diz que antes apenas os profissionais eram "sensíveis a diferenças estéticas" tipográficas, mas que hoje todos são "escribas", todos podem ter acesso à composição tipográfica por meio de um computador pessoal:

Somente os profissionais eram sensíveis a essas diferenças estéticas. Hoje, a banalização das práticas tipográficas graças aos computadores pessoais torna o escriba muito mais consciente da dimensão estética que se deve levar em conta. Como no manuscrito, o computador convida o leitor a se comportar como um escriba e as duas funções acabam por se confundir. (MELOT, 2012: 99)
citor a se comportar como um

Essa banalização mencionada por Melot pode ser um fenômeno interessante na medida em que mais pessoas se tornam conscientes das diferenças estéticas tipográficas. Essa própria difusão e popularidade, porém, talvez possam ser prejudiciais ao profissional que realmente conhece com profundidade as diferenças entre os tipos e leva em conta as regras básicas de legibilidade, entre outras questões. Se qualquer um pode fazer, o editor pode se ver tentado a não valorizar o trabalho da forma como deveria, como observa Hendel:

Algumas editoras não têm qualquer conhecimento do design de livro. Preocupam-se apenas em colocar o máximo possível de letras numa página. A falta de estilo ou de elegância de seus livros é tamanha que só posso presumir que nenhum designer sequer chegou perto dos livros que publicam. (HENDEL, 2006: 3)

Além do descaso com o projeto por parte das editoras, Hendel (2006: 2-3) acredita que a "invisibilidade" é uma estratégia para o anonimato do profissional:

Os designers nem sempre são responsáveis pela degradação do que poderia ter começado como uma peça tipográfica concebida com cuidado. Por isso, numerosos designers de livros, além de defenderem o design "invisível", também querem ser invisíveis - ou, pelo menos, preferem permanecer anônimos. Quando veem um livro acabado que segue vagamente as especificações originais estabelecidas, sabem do valor do anonimato do design. (HENDEL, 2006: 2-3)

Como se pode observar, a ideia de "invisibilidade" pode conotar diversos significados, além do ideal da página simples que não interfere 
na leitura. Essas outras conotações são potencialmente problemáticas, pois refletem o descaso com o design e do livro como objeto.

$\mathrm{Na}$ época em que os livros de bolso, com leiaute simples e uso de materiais e acabamentos mais baratos, ganharam fama, Chappel e Bringhurst (1990: 270) afirmam que eles eram produtos feitos para ter vida curta. Os autores dizem que a encadernação feita com cola (páginas coladas a uma capa), que foi em parte a "receita de sucesso da Penguin Books", de livros de qualidade de texto, porém baratos, pode ser justificada "caso os livros sejam entendidos como descartáveis". Essa ideia é apresentada pelos autores no contexto da Segunda Guerra em que soldados, ao viajar por regiões inóspitas, poderiam ter a opção de descartá-los. Esses exemplos apresentados não se relacionam ao texto, mas à qualidade dos materiais do livro que o tornam barato.

Faz sentido o livro ser descartável apenas quando existem outras reimpressões de qualidade e duradouras. Muitas editoras, no entanto, podem ter encontrado vantagens em produzir livros mais baratos:

Havia uma pressão em alguns setores para reduzir livros a este formato, não só no caso de reimpressões populares, mas também no caso de primeiras edições. Quando o único formato em que um livro existe é uma forma perecível, então a essência da forma, o que faz um livro ser um livro, foi traída. (...) Há milhares de livros em bibliotecas que apenas existem em versão brochura. Alguns deles apresentam capa dura, mas suas páginas vem vez de costurad é livre de ácido, suas páginas podem sobreviver por séculos, mas se sobreviverem serão perdidas em caixas de arquivo. Sua encadernação não pode durar não há nada a costurar, logo não podem ser efetivamente encadernados. (CHAPPEL e BRINGHURST, 1990: 270)

Dessa maneira, os autores acima preocupam-se com a permanência dos livros produzidos de acordo com as condições que hoje são atuais muitos livros, por não serem encadernados "à moda antiga" podem facilmente se decompor.

Frederic B. Adams Jr. (1968: 6), no prefácio de Homage to the Book afirma que: "Neste apogeu da embalagem descartável e o recipiente não retornável, estamos gratos pelo livro descartável, a brochura. Tal livro não sente nenhum insulto se for jogado fora". Nesta passagem irônica, o autor evidencia a importância da qualidade e condena este tipo de livro que, assim como as embalagens descartáveis, para ele não tem valor.
Hoje, muitos livros são colados em vez de costurados e, quando costurados, não têm a mesma durabilidade que outro encadernado há 500 anos. Dessa maneira, pode ser que suas páginas se soltem com mais facilidade. Por outro lado, muitos dos livros de hoje ganham uma versão digital, o que permite que o texto seja preservado em um arquivo que dificilmente não será corrompido como um livro físico. ${ }^{7}$ Em nossa pesquisa de campo nas bibliotecas, impressionava a qualidade e a preservação dos livros antigos, sendo que alguns pareciam inclusive novos, com folhas intactas. Hoje, obviamente, os livros são muito mais frágeis. Porém, apesar da preocupação de Chappel e Bringhurst de que livros de baixa qualidade perecerão e o mesmo ocorrerá com seu conteúdo, é ainda mais preocupante a falta de cuidado com o leiaute, pois este interfere na leitura, seja de um livro recém-saído de uma gráfica, seja de outro com as páginas um pouco mais surradas. Sobre a baixa qualidade da composição, Spiekermann afirma (2011: 77):

A maneira como os livros são lidos não se alterou muito nos últimos 500 anos, portanto o aspecto dos livros não teve que mudar também. Apenas a economia mudou, o que significa que os editores de hoje insistem em colocar cada vez mais texto na página e nem sempre estão preparados para pagar por uma boa composição, exceto aqueles que realmente se preocupam com o design interno de um livro e não apenas com a capa. Cada real gasto a mais na manufatura de um livro acrescenta sete ou oito reais no seu preço de venda. ${ }^{8}$

Nessa passagem, Spiekermann critica o descaso com o projeto do miolo em que, por questões econômicas, o projeto interno é, muitas vezes, negligenciado tendo em vista a economia em aspectos como a quantidade de papel utilizada e os custos de impressão.

Já Wilson explica que, no final da década de 1960, havia uma maior preocupação com o design da capa e que o projeto de miolo era também de certa forma prejudicado, o que mostra que a falta de cuidado com o miolo dos livros não é recente na indústria editorial:

Livros para o mercado em geral, vendidos em livrarias ou através de clubes do livro, precisam ser tão atrativos em formato quanto são no conteúdo, ou mesmo mais. Muito frequentemente, no passado, muito

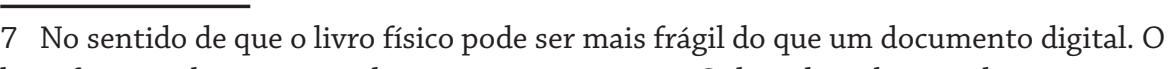
livro físico pode ser vítima de intempéries e pragas. O digital também pode ser corrompido, mas isso depende do número de cópias feitas e do nível de segurança dos provedores que armazenam as cópias digitais.

8 O texto original é em inglês e a unidade monetária é o dólar americano e os dados na moeda real brasileira foram traduzidos e adaptados pelo tradutor do volume. 
esforço era desprendido na sobrecapa e quase nenhum nas páginas [internas], mas hoje se veem muitos exemplos de cuidado e gosto nos livros comercialmente produzidos dentro de orçamentos restritos. Este o maior desafio do designer. (WILSON, 1993: 111)

Depois do trecho acima, porém, Wilson afirma que, após algum tempo, os livros passaram a ter um maior cuidado. Nesse contexto, o autor apresenta ao longo de seu texto exemplos bem feitos. No entanto, apesar de sua afirmação de uma tendência de melhora, ainda existem livros muito mal projetados.

John Kane (2012: 117) explica que hoje temos uma variedade muito maior de tamanho de papel para o miolo, mas a indústria editorial impõe restrições e, dessa maneira, as margens, que deviam ser proporcionais e funcionais são muitas vezes reduzidas por razões obviamente econômicas:

A impressão de livros permite uma liberdade maior na escolha do tamanho da página, mas restrições visando à economia de papel geralmente impõem margens muito mais estreitas e linhas muito mais longas do que aquelas toleradas pelos antigos padrões (veja em qualquer livro-texto).

Bartram (1999: 9) também aborda questões sobre o mercado livreiro e as diferenças de custo para se produzir um volume de qualidade.

Infelizmente, em geral os custos são maiores para produzir bons livros que ruins. Uma boa impressão e um bom papel são geralmente mais caros do que os maus. Um bom design vai custar um pouco mais do que nenhum design. Uma edição cuidadosa é dispendiosa se são necessárias fotografia e ilustrações, a qualidade precisa ser paga. A boa produção de livros é trabalhosa e cara. Um livro é como um iceberg, lá está ele flutuando calmamente na livraria, mas oitenta por cento do esforço para dar forma a ele é invisível.

O autor explica também que muitos livros não são pensados em termos de ergonomia e de facilidade para serem manuseados e lidos, mas pelo impacto que seu formato tem na livraria, isto é, o apelo visual que editoras usam para que seja vendido mais caro:

Livrarias preferem editores que lançam seus romances duas ou três vezes maiores que seu formato normal, independentemente do quão in(para refeições, de forma a criar um aparente 'value for money', um valor para seu dinheiro. (BARTRAM, 1999: 9-10)
O autor (idem, 1999: 9-10) afirma que muitas questões acabam sendo orientadas para aspectos de mercado e que se perdeu de certa forma a "inocência no mundo da edição". Segundo ele, hoje muitos editoras são "grandes negócios". Nesse sentido, deve-se pensar nos grandes conglomerados editoriais que foram se formando ao longo das últimas décadas, tendo hoje imensos grupos como, por exemplo, a Penguin Random House ${ }^{9}$, que domina atualmente uma grande fatia do mercado livreiro de ficção internacional.

Bartram (1999: 11) lamenta que muitos editores ainda não percebem a diferença entre um bom projeto de livro de texto:

Infelizmente, muitos editores de hoje, bons editores que publicam livros de valor, são incapazes de ver a diferença entre um livro de texto bem composto e legível de um texto mal composto, porém ainda legível. Eles aprenderam apenas a metade do seu negócio. Desconforto e até mesmo às vezes a ilegibilidade afastam o prazer.

Jason Epstein (2002), que trabalhou por mais de cinquenta anos como editor em casas como a Random House e a Doubleday, acredita que a indústria anda desgastada e não mais possui as virtudes de outrora:

O ramo da edição de livros desviou-se de sua verdadeira natureza, assumindo, coagido pelas desfavoráveis condições de mercado e pelos equívocos dos administradores distanciados, a postura de um negócio convencional. Essa situação levou a muitas dificuldades, pois publicar livros não é um negócio convencional. Assemelha-se mais a uma vocação ou a um esporte amador, em que o objetivo principal é a atividade em si em vez do seu retorno financeiro. Para os donos de editoras e editores dispostos a trabalhar pelo prazer da tarefa, a edição de livros na minh época foi muito recompensadora. Para os investidores de olho nos retornos convencionais, um desapontamento. (EPSTEIN, 2002: 21)

Nesse sentido, ele aponta certa dissonância entre empresas que almejam o lucro e o negócio do livro, que não é lucrativo como outros e é importante como produtor de bens não apenas de consumo, mas culturais.

Chappel e Bringhurst (1999: 295) também questionam o papel de grandes editoras hoje, quando a produção, a composição de um texto pode estar nas mãos de qualquer um:

9 Sabe-se, por exemplo, que a Penguin comprou parte das ações da editora brasileir Companhia das Letras. Disponível em: http://colunas.revistaepoca.globo.com/ menteaberta/2011/12/05/editora-penguin-compra-45-da-cia-das-letras/; acesso em outubro de 2015. 
A liberdade para publicar é também agora, em muitos países, quase absoluta. Ainda assim, no mundo falante do inglês, a impressão, a publicação e o marketing de livros estão em grande medida nas mãos de blicação e o marketing de livros estão em grande medida nas mãos de
algumas poucas companhias gigantes. Estranhamente, essas não são empresas para as quais os livros e as publicações como tais são os interesses primordiais. As companhias mais importantes no setor editoria pertencem a outras companhias e, consequentemente, gerenciadas po pessoas cuja profissão não é publicar, mas gerenciar. Os objetivos de livros, aproveitar os muitos prazeres da vida literária e fazer um pouco de dinheiro nesse processo. Os objetivos de um gerente, via de regra, são o máximo de penetração de mercado, com o máximo de lucro. Esses objetivos não são necessariamente diametralmente opostos, mas diferentes o suficiente para que, nessa interação, a cara da publicação tenha mudado. (idem, 1999: 295)

Os autores (ibid: 295) ainda acrescentam que, tradicionalmente, o papel de um editor era o de promover o conhecimento, de tornar um conteúdo público:

Publicar tradicionalmente tem significado - e para a maioria dos editores ainda significa - tornar público, no simples entendimento de que o que é abertamente sabido e avaliado tem sua vida própria e sua própria chance de futuro. Isso é tudo que a cultura imortal pode fornecer. Publicar não é pregar, nem mesmo dar publicidade, ainda que essas coisas possam estar envolvidas. Mas quando o espírito público não está presente, publicar torna-se outro empreendimento e precisa de outro nome.

A partir do exposto acima, o livro é, antes de tudo, um produto cultural e, como observou Epstein, há certa contradição no momento em que grandes editoras visam o lucro de um produto que difere essencialmente de outros bens de consumo.

Há séculos o livro é um objeto de valor, e, dependendo dos materiais utilizados, possui ainda mais valor. Uma brochura simples de bolso é obviamente mais barata que uma edição em capa dura. Alguns livros podem ser mais do que objetos para serem lidos, podem ser objetos de desejo, como os "preciosos" e "finos" livros produzidos pelas prensas particulares entre o final do século XIX e início do XX, que apontaram o caminho para uma preocupação com a qualidade material, com seu acabamento. Livros como aqueles não eram feitos apenas para leitura, eram livros para ser colecionados e admirados, infelizmente, porém, por uma pequena elite que podia arcar com os altos preços, como foi apontado por Benton (2000) no segundo capítulo desta tese.

Pode-se também inferir que é sua qualidade material que revela como o leitor "cuidará" do livro. Como vimos a partir dos argumentos de Chappel e Bringhurst, a essência da brochura era a do descarte, a de um livro barato e leve que seria facilmente descartado por militares durante a guerra. Hoje esse formato é ainda utilizado, mas será que os leitores simplesmente descartam esses livros após lê-los? Certamente alguns desses livros deterioram-se facilmente. No Brasil, há algumas décadas, muitos livros de literatura eram lançados como brindes de jornal, porém seu papel era frágil e quebradiço. Hoje, mesmo obras baratas não utilizam esse tipo de papel. Mesmo os papéis mais baratos não são feitos a partir da fibra de madeira, mas a partir de um processo químico que quebra a fibra da celulose e torna o material mais duradouro.

A brochura, a edição de bolso, além de muitas vezes ser produzida com materiais e processos inferiores, pode também ter um design de má qualidade que prejudica, especialmente, a fluência da leitura ou leiturabilidade (readability). Como já mencionado, os fatores que influenciam na leiturabilidade são a escolha do tipo, o corpo do tipo, as entrelinhas, a largura da coluna, as margens e a tonalidade do papel. A questão da leiturabilidade também confere valor à obra, já que livros que não atingem critérios mínimos de conforto visual podem ser abandonados pelo leitor. Mesmo livros de boa qualidade material, costurados e com papel de boa qualidade podem ter um projeto gráfico de miolo ruim ${ }^{10}$.

\section{Padronização}

No mercado atual, a maioria dos livros é simples, é invisível, porém há projetos bons e ruins. A invisibilidade pode estar relacionada também à padronização, pois mesmo editoras que produzem livros de qualidade trabalham com projetos padronizados. Livros bem feitos do ponto de vista apenas utilitário da leitura são de grande valor, porém talvez não estabeleça uma relação afetiva com o leitor, como é a de um bibliófilo e sua coleção de livros raros e especiais.

10 Nesse contexto, em relação ao leiaute das páginas, da mancha de texto. 
Mesmo hoje, com uma grande variedade de materiais, processos, acabamentos e tipografias disponíveis, muitas editoras acabam usando as mesmas fontes, o que pode ser comprovado pelo estudo de Ferreira (2007), apresentado anteriormente, além, é claro, de o mesmo estilo de composição e o mesmo tipo de papel.

Algumas vezes o design da capa de um livro é criado a partir de um briefing sobre o texto e o projeto de miolo muitas vezes é criado a partir de um template isto é, seguindo um modelo. Caso seja um template, nem sempre atende às especificidades de um texto particular e é utilizado muitas vezes, especialmente porque já foi testado e se ganha tempo no sistema de produção, como vemos, por exemplo, nos padrões da Companhia das Letras, que apresentam manchas gráficas e escolhas tipográficas e de papéis (tonalidade e gramatura) adequadas para a leitura contínua.

Há na Companhia das Letras uma pequena equipe interna de designers responsável pela gestão das capas, que geralmente contrata capistas externos, e outra equipe responsável pela diagramação do miolo. Essa separação é recorrente em outras editoras. Designers capistas, como Barbara de Wilde e David Drumond, que trabalham criando para grandes casas, projetam apenas a capa, enquanto o miolo é produzido por outras equipes. Um capista, em geral, recebe um briefing do editor. ${ }^{11}$

No entanto, edições padronizadas são algumas vezes necessárias, pois barateiam os processos e viabilizam trabalhos de editoras que não teriam condições de arcar com projetos customizados, como é o caso da Perspectiva.

Ex-editor da Perspectiva, Plínio Martins Filho (1997: 53) explica a necessidade de se trabalhar de maneira padronizada em uma casa pequena, com uma equipe enxuta:

Alguém pode pensar como uma editora, com tão poucas pessoas, pode funcionar, publicando uma média de 30 títulos novos por ano. A resposta a esta indagacão está, a meu ver, concretiza só pela escolha de textos a serem publicados; é preciso que tenha a sustentá-la um projeto cultural, elemento que norteia a Perspectiva desde o seu nascimento. A Perspectiva, além de um projeto cultural,

1 Dados obtidos a partir de entrevistas com os designers Alceu Nunes, Barbara de Wilde e David Drumond. possui também um projeto gráfico moderno, idealizado de forma que apenas duas ou três pessoas executem todo o processo de edição.

No caso de uma editora como esta, o projeto gráfico tem de ser mais simples e foi criado de forma que outras pessoas facilmente pudessem diagramar e dar continuidade à produção:

O que estamos tentando mostrar é que uma editora nesses moldes possui maiores probabilidades de êxito, caso tenha, além de um projeto cultural, também um projeto gráfico bem definido e eficiente. Nesse sentido, salientamos a vantagem de se editar coleções, porque cada coleção já tem o seu projeto gráfico determinado. Assim, quando um texto chega à producão, já passou por um exame, que indica a coleção em que deve ser editado. No caso, portanto, vemos que, ao adaptar o texto a uma determinad coleção com o seu projeto gráfico específico, ou melhor, fixo, o processo de edição caminha mais rápido, uma vez que, em regra geral, não é necessário contar com o serviço de um diagramador, de um capista etc. Se fosse uma edição normal, comum, fora de coleção, a Perspectiva precisaria, no momento, de pelo menos cinco vezes mais profissionais do que possui. Em resumo, com um projeto gráfico já planejado, o tempo gasto no processo de edição é reduzido quase para a metade, o que, de certo modo, barateia também o custo da produção. (MARTINS FILHO, 1997: 53-54)

\section{A VISIBILIDADE COMO TENDÊNCIA E A “AMEAÇA DigitaL"}

A editora Companhia das Letras é reconhecida pela qualidade tanto dos textos que publica quanto pelo design de seus livros, porém eles, em sua maioria, apresentam projeto gráfico de miolo padronizados. Designer da editora, Fabiana Roncoroni explica em entrevista ${ }^{12}$, que a Companhia das Letras tem quatro projetos diferentes de miolo e o selo editorial Objetiva, dois projetos. Roncoroni diz que os projetos da Companhia foram criados em 2000, pelo designer Raul Loureiro. A diagramação, segundo a profissional, é muitas vezes terceirizada. Ultimamente, porém, ela afirma que a editora tem trabalhado com livros com projeto diferente dos padronizados, pois há uma expectativa do mercado por projetos diferenciados:

Há algum tempo o mercado exige produtos diferenciados, isso aconteceu, por exemplo, no relançamento de grandes autores como Jorge Amado, Drummond, entre outros. Apesar do considerável impacto financeiro, grupo Companhia valoriza o diferencial gráfico, sempre que possível. ${ }^{13}$

12 Depoimento de Fabiana Roncoroni em entrevista realizada via e-mail em dezembro de 2015 .

13 Depoimento da designer em entrevista. 
Dessa afirmação destacamos que o desenvolvimento de um projeto gráfico diferente dos já testados e utilizados com frequência obviamente gera um custo adicional, porém ultimamente o mercado tem exigido "produtos diferenciados". Há nessa afirmação uma sugestão de mudança de paradigma do projeto simples e padronizado para outro, mais trabalhado, que reflete talvez, pelo menos no mercado brasileiro, a importância do design, da materialidade e visibilidade do objeto.

A partir do exposto nos capítulos anteriores, é possível observar que nas últimas décadas uma abordagem mais visível ao livro de literatura vem sendo utilizada pelas editoras Cosac Naify, Almadía, Libros del Zorro Rojo, Visual Editions, entre outras. Talvez o trabalho dessas editoras venha influenciando as demais. Outra casa brasileira que tem trabalhado ultimamente com projetos gráficos "visíveis" é a editora especializada em literatura de ficção científica Aleph, que tem publicado algumas edições especiais, com projeto de capa e miolo que refletem uma preocupação "visível". Pedro Inoue ${ }^{14}$, um dos designers que trabalha para a Aleph, nos falou sobre o sucesso e a importância da materialidade e do design de algumas edições publicadas pela editora.

Inoue afirma que grande parte do sucesso da Aleph se dá por ser uma editora de nicho, cujo público é interessado e entende do assunto. Como exemplo, ele explica o caso de uma capa para o livro do Jurassic Park que teve, em uma mídia social, a divulgação de uma prévia da imagem da capa e que logo em seguida gerou o telefonema de um leitor, que conhecia com profundidade os esqueletos dos dinossauros e apontou um erro no desenho. Nesse contexto, Inoue exclama:

E é uma loucura como eles (leitores) ${ }^{15}$ participam, comentam, falam, conhecem as sutilezas, enxergam tudo. Eles olham o acabamento, (...) compram uma versão fechada de colecionador e outra pra deixar um pouco na estante.

Inoue complementa que procurou em alguns de seus projetos estabelecer uma relação entre o conteúdo e o projeto como, por exemplo, o da edição de 2001, uma odisseia no espaço, em que o livro é todo preto e remete ao monolito presente na trama. Esse é apenas um dos exemplos citados pelo designer em que o público imediatamente percebeu

14 Em entrevista realizada em de janeiro de 2016

15 Parênteses nosso. a associação. "Acho que hoje em dia, com a rede, contexto é a palavra mais importante, não se é necessariamente bonito ou feio. Não estamos está atrás do que é bom ou ruim, mas do que se trata, de onde vem isso", comenta ainda o designer.

A partir desse depoimento, verifica-se que a abordagem da editora, diante de um mercado muito específico, é a de atender a um público que também espera livros "bem trabalhados", feitos com cuidado, e aprecia também o livro cujo projeto crie associações com o texto. Nessa entrevista, constatou-se a preocupação do designer em criar projetos que tenham alguma referência com o conteúdo, onde os elementos gráficos apresentem essa relação. É interessante notar, no entanto, como o público dessa editora em especial espera projetos como esse. No entanto, mais adiante na entrevista, Inoue lamenta que falte hoje experimentação no mercado editorial:

Eu acho que temos um grande problema: tudo é mercado. Enfim, de novo vamos olhar o contexto, porque você precisa de um design bom, porque design bom vende mais, uma coisa mais bonita vende mais. E de repente o bom design ficou acessível, as pessoas podem comprar um template na internet e ter um website super cool, super hipster, portanto hoje em dia está muito mais bonito, de certa maneira, as pessoas estão olhando para o Pinterest ${ }^{16}$, olhando para o que está sendo feito lá fora com uma fluidez muito maior em termos de níveis de estética. Antigamente, quando eu ia viajar, entrava numa livraria e ficava quatro horas, olhando revistas livros, hoje em dia, quando viajo, metade das coisas já vi online... você já viu, as pessoas já falaram nos blogs, de uma certa maneira tudo está mais horizontal em níveis de criação e acho que isso aguça o olhar das pessoas, dessa forma você pode arriscar mais. Quando eu mostrei para o editor da Aleph a capa do Neuromancer, da caixa que é aquela coisa meio louca, ele ficou com medo no começo, achava que não ia passar pelo comercial. Mas os agentes e a editora do William Gibson $^{17}$ adoraram quiseram usar a ilustração. De repente, uma editora pequena que lança livros aqui no Brasil vira referência internacional, justamente porque são poucas pessoas apostando nisso. Se você tem um nicho e sabe do que está falando, se você está investindo nisso, não só o dinheiro, mas a força criativa de um conjunto de pessoas pode gerar retorno.

16 Rede social de compartilhamento de imagens e referências.

17 Autor de Neuromancer, o livro de que Inoue fez o projeto que foi elogiado por seus agentes. 


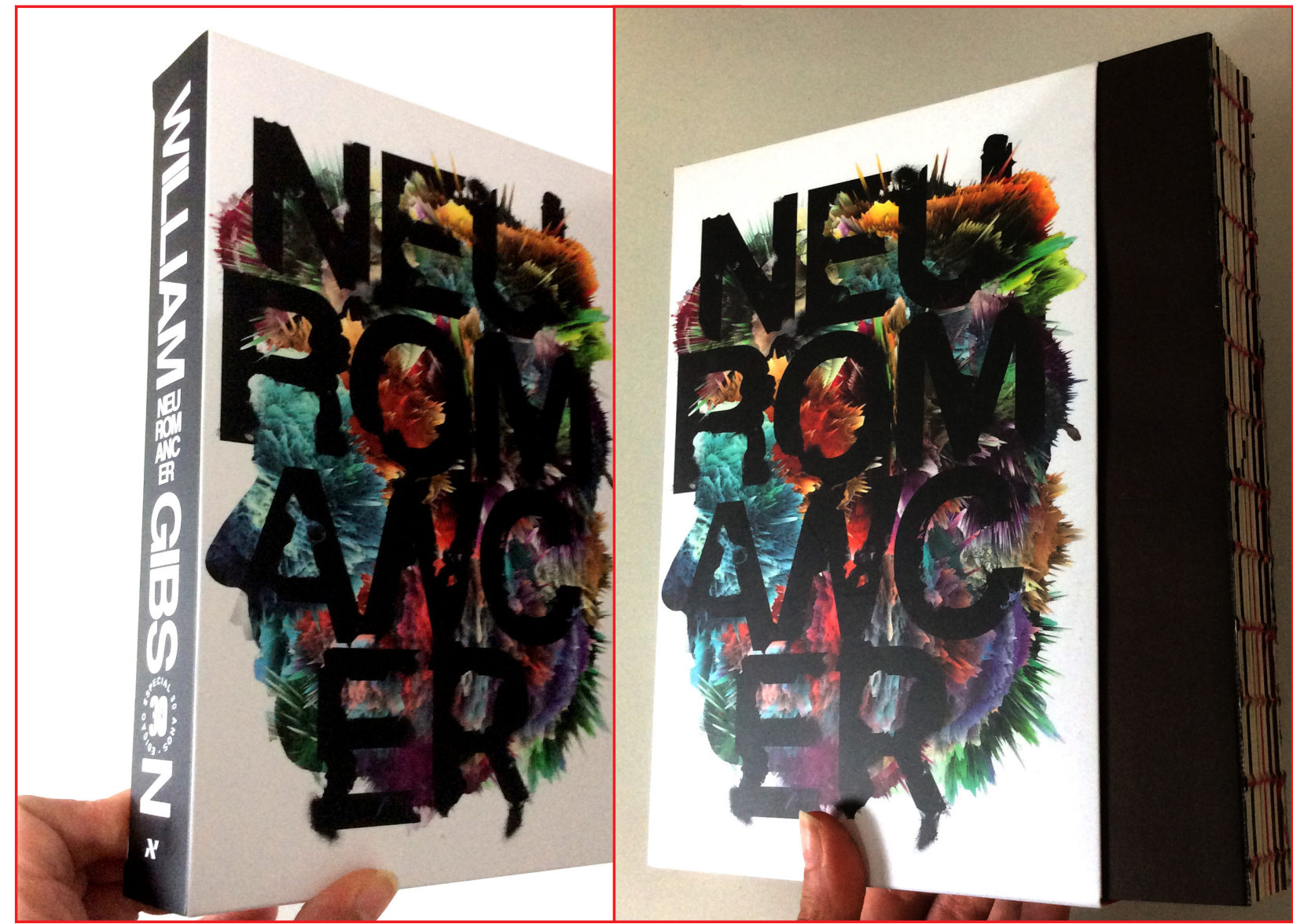

Figura 99. Capa box de O trabalho das editoras Cosac Naify, Libros del Zorro Rojo, Almadía, Neuromancer, de William Sexto Piso e Visual Editions traz uma alternativa ao livro comum, seja Gibson, publicada pela brochura ou capa dura. São livros que inovam ou no leiaute ou na prode Pedro Inoue O volume dução gráfica, são visíveis e, como visto anteriormente, os elementos tem como outro elemento gráficos mantêm relação com o próprio conteúdo textual. A Chronicle visivel a lombada aparente. Books apresenta estratégia semelhante, segundo a qual designers traLivro do acervo da autora. balham desde a capa até o miolo, buscando a integração entre ambos.

Fotos da autora Além desses exemplos de designers que pensam o projeto do livro a partir do texto, na década de 1980, designers como Warren Lehrer e Johanna Drucker passaram e escrever seus próprios textos, tendo assim liberdade de trabalhá-los de forma visual e integrada.

O designer Adrian Wilson (1923-1988), também proprietário da The Press Tuscany Valley, nos anos 1960, tinha uma visão parecida com a de algumas das editoras mencionadas acima, de que cada livro deve ser único e ter personalidade:
Tenho a tese de que para cada designer cada livro tem uma personalidade e uma forma particulares. O designer de livro engenhoso buscará até que encontre a personalidade e a forma que darão a ele a expressão mais completa. Em seus próprios termos, dentro dos limites do plano da editora e do orçamento. Idealmente, o designer terá precisão sobre os estilos das

qual o papel pode potencializar esses elementos. (WILSON, 1993: 67)

Sobre a abordagem do livro "visível", é interessante notar que alguns dos volumes apresentados nesta tese, aparentemente, possuem coerência visual entre capa e miolo - há elementos da capa (seja tipografia ou alguma vinheta) no miolo ou vice-versa; o livro parece ter sido concebido como um todo e não como duas partes separadas, como comumente se apresentam os livros de literatura. Como já exposto acima essa não é, claro, uma separação física, é uma separação formal e estrutural em que a capa tem aparência diversa do miolo, justamente por ser comum no meio editorial se pensar em dois projetos distintos, o de capa e o de miolo, cada um deles desempenhando uma função diversa. Além dessa questão, muitas vezes capa e miolo são desenvolvidos por designers diferentes.

Isso ocorre talvez pelo fato de que muitas editoras ainda considerem o projeto gráfico do miolo apenas a partir do ponto de vista utilitário e não estético, como apontado anteriormente. Ou seja, pensa-se no aproveitamento da mancha de texto, composta com uma fonte já testada e para que não seja preciso adquirir fontes novas para cada projeto de miolo. Sendo o miolo simples e de rápida execução, provavelmente sobrará verba do projeto para investimento nas capas, cuja função já foi a de proteger o livro e hoje parece ser sobretudo a de marketing:

A capa do livro evoluiu de um simples objeto utilitário para um meio de comunicação altamente visual e conceitualizado. Enquanto as primeiras capas de livros datam da década de 1820, até o final desse século as capas haviam sido usadas apenas como embalagem de protecão e tendiam a ser não picA mportância na década de 1890, com o reconhecimento de que poderiam ser uma forma de atrair a atenção de compradores. (...) Ao final da primeira década do século XX, a capa do livro começou a criar raízes como uma ferramenta promocional e seu design passou a receber mais importância. Em meados do século XX, nos Estados Unidos, as capas que apresentavam ilustracões prosaicas e "letterings" simples aprimoraram-se a partir de referêncherenintegração entre texto e imagem. (DREW, STERNBERGER, 2005: 20) 
Não só as capas evoluíram graficamente, para fisgar a atenção dos leitores, como hoje podem-se observar capas com materiais diversos, que atraem também outros sentidos, a exemplo do livro The Wild Things, de David Eggers, publicado pela McSweeneys em 2009 e que apresenta capa revestida com pelúcia (figura 100). Esse livro, apesar de ter uma capa extremamente sensorial, tem o projeto de miolo muito simples.

Alan Bartram (1932-2013), um dos mais destacados designers britânicos do século XX, questiona:

Se o design da capa ou do miolo se relacionam? Ideal e teoricamente eles deveriam; na prática, raramente isso acontece. Em meus exemplos, apenas três se corr apenas tres se conrespondem, apenas un deles - sigificativamente, um livro sobre arquitetura - faz isso com qualquer rigor. Nos livros de arte ou nos catálogos de mostras, o designer do livro é geralmente res-

Figura 100. Capa de The Wild Things, de David Eggers, publicado pela McSweeneys em 2009. Livro do acervo da autora. Foto da autora

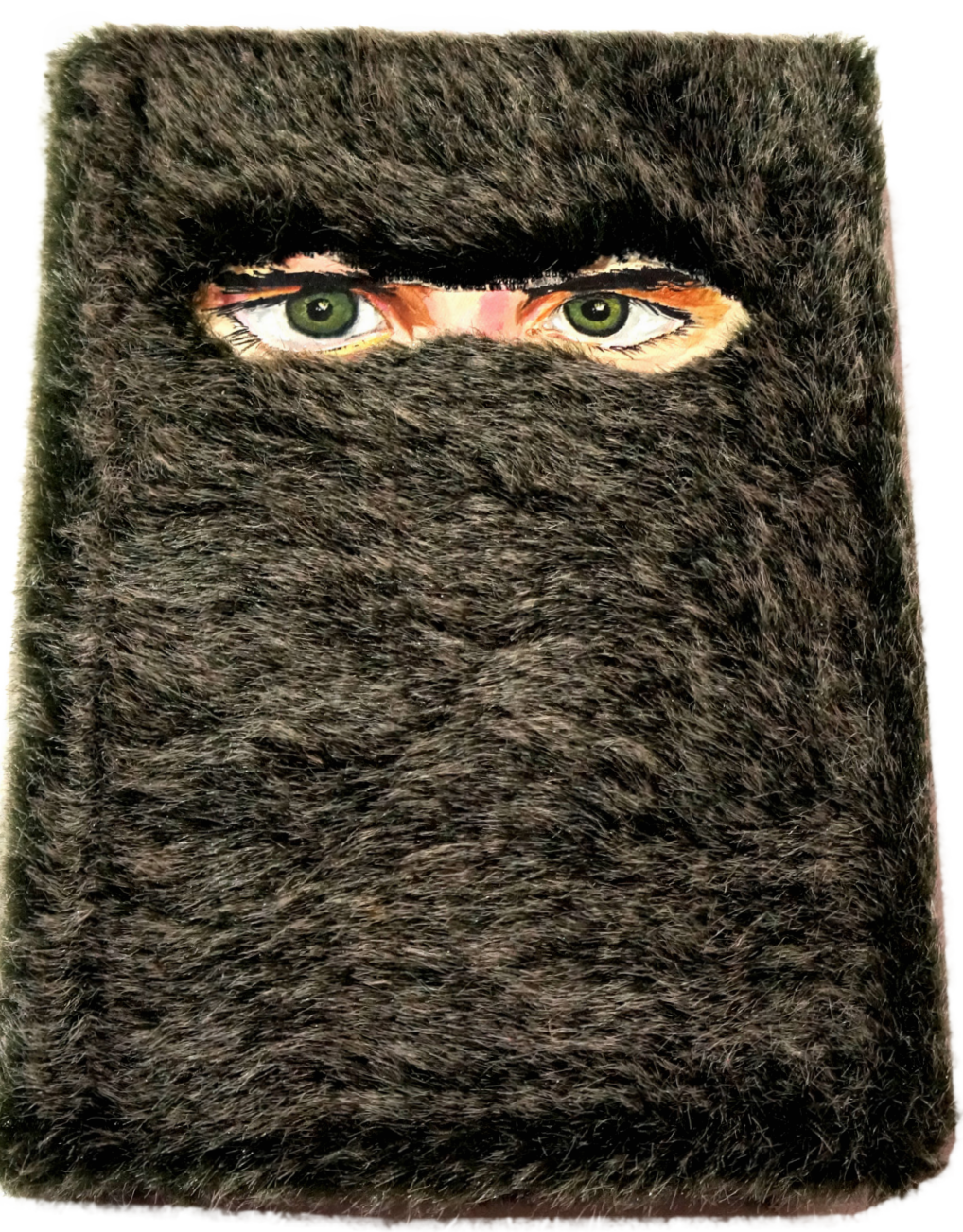

ponsável pela totalidade, quando pelo menos alguma consistência pode ser atingida pela escolha do tipo. Mas para a maioria dos livros sempre foi raro que o mesmo designer trabalhasse na capa e no miolo. O divórcio entre os dois, ainda que possa ser de se lamentar, simplesmente reflete a necessidade de se considerar os preconceitos dos vendedores. Compreensivelmente, eles preferem ver não apenas algo que foi trabalhado antes, mas também uma imagem mais vigorosa derivada do design do miolo. É preciso um editor de coragem para ir contra a corrente. (BARTRAM, 1999: 153)

Sobre essa afirmação de Bartram de que idealmente capa e miolo devessem ter coerência, observou-se nos livros que apresentamos ao longo do capítulo sobre o design dos livros contemporâneos exemplos de livros em que há uma integração entre os dois, a obra é pensada como um objeto único, sem divisão entre suas partes.

A questão sobre a capa é que muitas vezes ela é pensada como uma ferramenta publicitária, como uma embalagem que vai vender um produto.

Outra questão que deve ser abordada quanto ao fenômeno desses livros "visíveis" publicados recentemente é a relação que se pode estabelecer entre esses novos livros impressos que chamam a atenção pela forma e materiais utilizados e os livros digitais em que "quase não há leiaute", já que se torna possível para o leitor, a partir de dispositivos como e-readers e tablets, configurar o leiaute, adequá-lo a critérios e escolhas específicas de cada um.

Há pouco mais de uma década, alguns autores como Roger Chartier e Jean Lebrun passaram a especular e investigar a suposta crise do suporte livro impresso, com o advento do livro eletrônico, que os autores citados acreditam ser "a realização da proposta iluminista", de difusão e infinita liberdade de expressão. Esses mesmos autores percebem, no entanto, que muito dificilmente o objeto livro deixará de existir, principalmente por suas qualidades físicas, pela função de coleção e pela proximidade com o leitor, como Jean Lebrun afirma em entrevista a Roger Chartier (1998: 16): "O texto eletrônico torna possível uma relação muito mais distanciada, não corporal.”.

No entanto, a resposta a estas questões, a partir de Michel Melot, pode estar na própria forma do livro, substancialmente diferente da versão eletrônica. Melot (2012: 23-24) explica que, por muito tempo, a "história do livro se confundiu com aquela dos conteúdos do livro, com a história das ideias, da literatura e dos gêneros literários, a his- 
tória, sobretudo dos autores", mas um livro não é um texto, um livro pode "suportar" ou "portar" um texto, mas também é um objeto que pode apresentar todas as qualidades de um objeto de design ou de uma obra de arte. Melot parece cético quanto ao fim do códice, cuja forma, conforme ele explora ao longo de seu ensaio, foi responsável por substanciais alterações na forma de se escrever e pensar.

Quais são, nesse sentido, as virtudes que protegem o livro e o distin guem da tela, enquanto esta, por um movimento paradoxal, ressuscita o deslizar do texto nos moldes do rolo antigo? Por que este texto composto em um software tão maleável quanto a argila, solúvel no tempo, continua sendo fixado no mesmo clichê que o imprimirá sobre o papel, tornando-o tão duradouro quanto possa ser o seu suporte? O livro, apresentando-se sob a forma que o conhecemos há mais de dois mil anos, ou seja, sob a forma do códice, com suas páginas imbricadas e encadernadas, triunfou sobre as formas antigas do rolo, da tabuinha, ou da estela, as quais o precederam por muitos milênios, sem que possamos afirmar com exatidão nem quando, nem como isso aconteceu. Parece correto dizer que as respostas a estas questões devem ser buscadas na forma do livro e não em seu conteúdo, uma vez que o conteúdo, na medida em que se apresenta independente da forma, passa de um suporte a outro, acredita-se, sem mudar sua natureza. (MELOT, 2012: 25)

Melot lembra que hoje os textos podem ser lidos tanto na tela quanto em papel e aponta que o suporte não altera o sentido:

Os mesmos textos antes encontrados apenas nos livros, agora podem ser lidos na tela, sem que o sentido, imagina-se, tenha se alterado. Um poema de Baudelaire não perderá seu valor literário ao ser lido no papel vergé, ou em uma fotocópia ruim ou na tela do computador. As imagen desconfiança nas reproduções, porém quando se trata de imagens digitalizadas, poder-se-ia recomendar, no momento de seu registro e de sua comunicação, que fossem respeitados os mesmos padrões de "reprodução"? Se os conteúdos migraram com uma série de vantagens para os servidores eletrônicos, somente o estudo da forma do livro e de suas propriedades singulares pode explicar seu sucesso duradouro. No mais, supõe-se que as razões que conduziriam à vitória do códice sobre seus ancestrais, a tábua e o rolo, têm alguma coisa a ver com estas singularidades, graças às quais ele se mantém em condição de igualdade com as telas do computador e da televisão. (MELOT, 2012: 25)

O autor (ibid: 34-35) defende o livro como um objeto autônomo, um objeto que tem razão de existir por sua forma física e talvez seja essa forma, tão consolidada, que poderá perpetuar o objeto em detrimento do eletrônico.

A vantagem do livro impresso sobre o livro digital parece ser, a partir de Melot, essa forma fixa e imutável, que se consolida sem alterações:

Pela tela do computador os textos podem fugir: a tela é um livro que apresenta suas fugas. Longe de estabilizar textos definitivos, a tela tudo faz para permitir o deslizamento dos conteúdos. Assim a escrita encontra outros caminhos que o livro, de certo modo, lhe havia interditado. (MELOT, 2012: 36)

Charlotte Rivers diz que por um tempo acreditou que os novos suportes, como tablets, Ipads e mesmo aplicativos para celulares, poderiam criar uma significativa crise no livro impresso. No entanto, a autora afirma que aconteceu o contrário: "A venda dos livros continua a crescer ano a ano e seu formato se tornou um antídoto necessário a um mundo cada vez mais impulsionado pela tecnologia”. (RIVERS, 2009: 8). Ou seja, é justamente a forma material do livro que poderá mantê-lo vivo, diante das "ameaças" digitais.

Assim como Rivers, Caroline Roberts considera exagerada a ideia da morte do livro impresso frente ao eletrônico: "Perversamente, parece que quanto mais a sociedade da tela avança, mais livros impressos são produzidos". (FAWCET-TANG, 2007: 11). Neste caso, é preciso ressaltar, porém, que os argumentos das autoras tratam do livro genericamente e não em seus diferentes tipos.

Alice Twemlow acredita que com a ameaça do livro digital os livros impressos venham a ser cada vez mais "ousados" ou mais especiais:

Talvez isto seja assim porque, confrontados com a ameaça da redundância numa cultura cada vez mais rendida ao digital, os designers de livros estejam a reinventar e a reposicionar-se num esforço de validar a sua prática. não se trata apenas de gestos ousados - o poder dominador ou humorístico da capa do livro ou a narrativa sedutora que atrai a atenção de um leitor para um volume - trata-se também dos pormenores. O posicionamento das notas de rodapé ou do número de páginas, o tratamento da informação dos direitos do autor, as cronologias, bibliografias e índices - todos esses elementos de um livro, quando tratados tanto com dignidade como com imaginação podem transformar um livro de uma ferramenta utilitária num objecto apreciado e duradouro. (IWEMLOW, 2007: 104) 
Em Fully Booked: Ink on Paper, Robert Klanten, Matthias Hübner e Andrew Losowsky apresentam uma ampla coletânea de recentes projetos gráficos de livros impressos cujo design reflete novas ideias e conceitos. Os textos críticos dessa coletânea sugerem a forma de manifestos críticos a favor do livro impresso, enaltecendo as riquezas do impresso quando comparadas aos livros digitais. Nesse texto-manifesto, os autores explicam:

Pretendemos mostrar como a impressão evoluiu em reação à expansão contínua do seu irmão digital. Há agora uma grande variedade de tecnologias de impressão - offset e digital, centenas de tipos de papel e opções de encadernação, tecidos e superfícies macias. A imaginação de designers e editores pode se tornar não apenas uma ilustração da narrativa, mas um elemento vital da própria narrativa. (KLANTEN, HÜBNER, LOSOWSKY, 2013: 3)

Mathieu Lommen (2012: 12), na introdução de The book of books em que justifica a importância da publicação de um panorama de mais de quinhentos anos do livro impresso, argumenta que:

Muitos designers e leitores, contudo, ainda sentem-se tão fortemente ligados ao livro impresso: por suas qualidades táteis, pelas variedades de papel e seus efeitos sobre as ilustrações e pelas várias maneiras de finalizar um livro. $O$ futuro do livro impresso repousa em suas qualidades como objeto físico.

A partir de Lommen, é possível inferir que outros designers podem ter se dado conta de que o trunfo do livro impresso é o da visibilidade e não é de se espantar que os exemplos contemporâneos apresentados nesta tese foram todos produzidos quando já existiam livros digitais Talvez não seja coincidência que abordagens mais visíveis tenham ganhado mais força, diante do impulso gerado pela ameaça virtual.

Além desses depoimentos, que datam de pelo menos três anos antes da redação desta tese, no início de janeiro de 2016 Adrian Shaughnessy ${ }^{18}$ escreve ao Design Observer que é justamente a ameaça do livro eletrônico que tem impulsionado a ideia do livro como objeto material e, por isso, provavelmente o impresso se perpetuará: "Eu argumento que as publicações eletrônicas falham em estabelecer uma alternativa source=dlvr.it\&utm_medium=twitter; acesso em: janeiro de 2016. emocionalmente satisfatória ao livro impresso e têm realçado seu status material". Shaughnessy apresenta também dados sobre o mercado na Inglaterra, segundo os quais nas primeiras 36 semanas de 2015 a venda de livros impressos aumentou $4,6 \%$, se comparados ao mesmo período do ano anterior.

Ademais, ultimamente a relação entre texto e projeto gráfico tem sido defendida por alguns autores que acreditam que o design deve refletir o conteúdo.

Para Ned Drew e Paul Sternberger, é importante entender o objeto livro como resultado de uma aproximação das palavras do autor com as ideias do designer:

O livro como um objeto é confortavelmente substancial em seu conteúdo e em sua presença material. Em um momento com muita dispersão da informação em sua forma virtual, é especialmente importante examinar o livro como um objeto distinto, que reflete o casamento da visão das palavras do autor e do designer.(DREW, STERNBERGER, 2005: 8)

Haluch (2013: 29) defende, em seu guia editorial, a importância de os designers conhecerem com profundidade o texto do livro, para que o projeto se adeque a ele, e exemplifica especialmente a importância desse processo em livros de literatura:

Dependendo do livro, é essencial lê-lo todo - no caso de um romance, por exemplo. Em outros casos - livros técnicos, instrumentais etc. - com o sumário, a introdução e o primeiro capítulo já temos noção do que se trata aquele livro. (HALUCH, 2013: 29)

O processo de leitura do texto pelo designer é fundamental, uma vez que: "Quanto mais nos acostumarmos a ler os originais e percebermos neles as diferenças de estilo de cada autor, poderemos projetar buscando um design que faça sentido com aquele texto." (HALUCH, 2013: 33) A autora ressalta que é importante não se restringir a um "único estilo", pois é preciso procurar entender o texto para utilizar elementos gráficos que reforcem seu sentido (HALUCH, 2013: 33). Aparentemente, a autora faz uma crítica ao design de livros padronizados pelo termo "único estilo".

Sabe-se que, na maioria das vezes, a editora prevê frequentemente prazos muito curtos para a execução do livro, o que nem sempre permite ao designer realizar uma leitura atenta do original e nem mesmo uma reflexão sobre o texto que possibilite algum tipo de pesquisa e 
interpretação do conteúdo, mas que esta pode ser uma atitude que ajude o processo criativo. Essa relação entre texto e projeto gráfico, em que o projeto reflete uma interpretação do texto pelo designer, ou seja, através de uma atenta leitura e pesquisa, foi explorado anteriormente nesta tese, em especial no capítulo dedicado à análise de Bartleby, o escrivão.

Muitos dos exemplos de livros visíveis apresentados nesta tese foram publicados pela Cosac Naify, que recentemente anunciou o encerramento de suas atividades. A notícia foi divulgada no dia 30 de novembro de 2015 pelo seu fundador, Charles Cosac. Com um catálogo de aproximadamente 1.600 títulos, a editora era referência pela qualidade do design de seus livros tanto na edição de livros de arte, design, arquitetura, literatura, infantojuvenis, teóricos etc.

Em entrevista a Antônio Gonçalves Filho para o jornal O Estado de S. Paulo ${ }^{19}$, Charles Cosac explica que o fechamento não está diretamente relacionado à crise econômica que atinge o Brasil neste momento e nega que esteja em processo de falência, apesar de a empresa estar deficitária.

Já em entrevista para a reportagem da GloboNews para o Jornal das $10^{20}$, o empresário cita vários fatores que influenciaram sua decisão, especialmente a alta do dólar e a crise econômica.

Em outra matéria ${ }^{21}$ que trata do fechamento da editora, o colunista do jornal Folha de S. Paulo Maurício Meirelles entrevista a editora Florência Ferrari, segundo a qual o mercado editorial brasileiro está em crise desde 2014, com a interrupção de várias compras do governo federal. Além disso, a alta do dólar prejudicou a editora, que costumava imprimir seus livros fora do país, com materiais e processos caros. Ela afirma que "teríamos que tirar a capa dura, empobrecer os projetos".

19 Disponível em: http://cultura.estadao.com.br/noticias/literatura,referencia-nomercado-por-livros-de-arte-de-luxo--cosac-naify-fecha-as-portas,10000003450; acesso em dezembro de 2015

20 http://g1.globo.com/globo-news/jornal-das-dez/videos/v/dono-da-cosac-naify-explicaos-motivos-para-o-fechamento-da-editora/4650283/; acesso em dezembro de 2015.

21 http://www1.folha.uol.com.br/ilustrada/2015/12/1713513-cosac-naify-quer-passarvros-adiante-para-outras-editoras.shtml?utm_source=hootsuite; acesso em dezembro de 2015.
O jornalista Daigo Oliva, também do jornal Folha de S. Paulo, entrevista $^{22}$ a diretora de arte Elaine Ramos e a questiona sobre o impacto do fechamento da editora para o mercado editorial brasileiro:

\section{o que significa o fim da Cosac Naify para o mercado editorial?}

O fim da editora abre uma clareira no mercado. É uma série de perfis de livros que não tem ninguém, além da Cosac, publicando aqui. Livros de arquitetura, história da arte, de fotografia, de teoria da fotografia, design... Isso é bastante trágico. Agora, eu acho também que é uma experiência que abriu caminhos. Hoje existem muitas editoras novas que têm um cuidado com o design, um cuidado que não existia há dez anos. Isso tem a ver com a Cosac.

\section{Comecei a entrevista te perguntando sobre o que significa o fe-} chamento da Cosac para o mercado. E para você, pessoalmente?

Uma sacudida gigante, que pode ser boa. Eu estava há muito tempo ali. Agora, para a minha área, que é o design editorial, é trágico. Porque, embora existam editoras novas fazendo coisas mais legais do que há dez anos, a Cosac ainda era uma referência muito forte. Não só publicando livros de design, como no design dos livros. Espero que seja algo positivo, uma sacudida numa certa altura da vida. Considero missão cumprida, fiz o que eu pude, aproveitei o quanto pude, fiz coisas legais, tenho orgulho do que fiz. Tenho essa leveza.

A afirmação de Elaine Ramos, de que a editora abriu caminhos para projetos mais "visíveis", pode ser, ao menos no Brasil, uma realidade. A Cosac Naify pode realmente ter influenciado inúmeras editoras a trabalhar com abordagens mais visíveis e também ter mudado a expectativa do leitor por um projeto gráfico mais elaborado, como afirmou acima Fabiana Roncoroni, da Companhia da Letras, de que ultimamente o mercado espera projetos mais "especiais".

Por outro lado, o fechamento da editora aponta que livros especiais têm um custo e, em épocas de crise, como a que o Brasil passa no momento da redação final desta tese ${ }^{23}$, alguns projetos tornam-se inviáveis. Um livro "visível" é obviamente mais dispendioso, pois pode haver tanto um maior investimento em design quanto em materiais e acabamentos, além de custos com ilustração etc.

22 http://entretempos.blogfolha.uol.com.br/2015/12/01/a-cosac-foi-muito-maldministrada-afirma-diretora-de-arte-elaine-ramos/; acesso em dezembro de 2015.

23 Durante o ano de 2015 e no início de 2016 
Mesmo assim, há um movimento, não apenas das editoras que abordamos nesta tese, mas, no Brasil e fora dele, em busca de livros que chamem atenção também por sua materialidade, como é o caso da recente editora Carambaia, que, segundo a reportagem do jornal O Globo, publica clássicos em tiragens limitadas, com projeto gráfico especial:

Há cerca de um ano, [o editor Fabiano] Curi chamou a também jornalista e pesquisadora Graziella Beting para ajudá-lo na tarefa de escolher o que gostaria de publicar em edições trabalhadas, com tiragem de mil exemplares, numerados e para venda apenas no site da empresa. ${ }^{24}$

Outro fenômeno que não se pode ignorar em relação ao livro "visível" é o crescimento das editoras independentes, tanto no Brasi como no exterior. No Brasil, na última década feiras de livros de publicações independentes têm crescido e, em sua maioria, os projetos gráficos dos livros chamam atenção para sua "visibilidade". Como exemplos temos, na cidade de São Paulo, a Feira Plana, a Feira Miolo, entre outras.

No exterior, temos a NY Art Book Fair e a La Art Book fair, ambas organizadas pela Printed Matter Inc. ${ }^{25}$, organização sem fins lucrativos que distribui esse tipo de publicação ${ }^{26}$. Outro importante evento, este principalmente dedicado à exibição e comercialização de livros, é a Codex, realizada nos Estados Unidos ${ }^{27}$, no México e na Austrália e organizada pela Codex Foundation ${ }^{28}$, por nós visitada em fevereiro de 2013, que contava tanto com estandes de livros de artista quanto de pequenas casas publicadoras dedicadas a produzir livros clássicos feitos nos moldes das prensas particulares do final do século XIX e início do XX, com tipos móveis de metal e papéis artesanais, como, por exemplo, o trabalho do designer Wilber H. "Chip" Schilling (Indulgenge Press) e sua edição especial de Bartleby, o escrivão já comentada.

24 Disponível em: http://oglobo.globo.com/cultura/livros/obras-fora-de-catalogo-ou-nuncapublicadas-no-brasil-ganham-edicoes-de-mil-exemplares-15951214; acesso em outubro de 2015. 25 http://printedmatter.org/; acesso em julho de 2015.

26 Fizemos uma visita técnica à loja-sede da organização em julho de 2013.

27 A edição de 2013 da feira sediada em Richmond, Califórnia, foi visitada nos dias 10, 11, 12 e 13 de fevereiro.

28 http://www.codexfoundation.org/; acesso em fevereiro de 2015
A partir de visita técnica à Feira do Livro de Guadalajara em dezembro de 2013, percebemos ainda um papel significativo da produção independente de livros na América Latina.

Em novembro de 2005, foi publicado no mesmo evento um manifesto de publicação independente com apoio da Unesco e assinado por 70 casas editoriais espalhadas pelos continentes americano, africano e europeu. No manifesto, os autores assinalam a importância dessa união na medida em que:

O papel dos editores independentes, como atores essenciais da difusão de ideias, da construção do indivíduo e do cidadão - verdadeiros transmissores de imaginação - se encontra hoje gravemente ameaçado no in indo iro. Os editores independentes padecem imensamente os efeitos da globalização econômica, que favorece a concentração financeira desse setor, dominado hoje por grandes grupos editoriais. A lógica puramente financeira empurra o mundo editorial rumo a uma mercantilização, incompatível com a criação e a difusão de bens culturais. Em todas as partes a bibliodiversidade corre perigo. ${ }^{29}$

É perceptível a importância desses designers e editores independentes especialmente porque, talvez, sem a pressão comercial, experimentos gráficos possam ser mais livres e interessantes do ponto de vista estético e conceitual.

Na Colômbia, é possível verificar o crescimento de editoras independentes que procuram trabalhar a união de projeto gráfico e texto como Destiempo, Tragaluz, La silueta, Luna Libros, Laguna Libros, La Madriguera del Conejo, La Valija de Fuego, Babel, R+N, El Peregrino e Editorial Robot.

Da cena independente relativa ao trabalho experimental gráfico destacam-se Laguna Libros ${ }^{30}$, Rey Naranjo $(\mathrm{R}+\mathrm{N})$, que, além de editora, é também estúdio de design gráfico e no site explica sua filosofia:

Estamos convencidos de que a época atual é a mais emocionante para estar vinculado ao mundo editorial. Desde os tempos de Gutenberg não se presenciava tanta emoção vinculada ao livro. Somos especialistas em conceber e produzir conteúdos de grande impacto cultural e, como editores, esperamos compartilhar nossa paixão por livros. ${ }^{31}$

29 Disponivel em: http://www.editoresindependientes.com/informacion/declaracion-delos-editores-independientes-del-mundo-latino.pdf; acesso em 18.12.2013.

30 http://lagunalibros.com/laguna-original/?lang=en; acesso em dezembro de 2013.

31 Disponivel em: http://www.reynaranjo.net/; acesso em dezembro de 2013. 
Outro ponto em relação aos independentes e que talvez futuramente possa causar algum impacto na indústria editorial são as publicações pelo sistema print on demand, como se pode observar a partir de Lyons (2011: 204-205):

Publicações pelo sistema de print on demand (POD), "impressão baseada na procura", mudaram o modelo tradicional de venda de livros. Em 2007, na unidade central da Biblioteca Pública de Nova York, foi instalada a primeira Espresso Machine, que não servia café, mas brochuras feitas por encomenda, impressas a partir de um arquivo de computador encadernadas em uma única operação (...) Os editores estão se adaptando a um novo ambiente econômico em que dispositivos portáteis para leitura de livros, como o Kindle, da Amazon, e o iPad, da Apple, se tor nam progressivamente mais fáceis de usar e ganham espaço à custa de alguns segmentos do mercado de livros impressos. Também graças à internet, o mercado de livros usados é hoje global e facilmente acessível, o ternet, o mercado de livros usados é hoje global e facil
que também compromete a venda de livros novos.

A partir do que foi exposto neste capítulo, pode-se inferir, mesmo com as críticas e a defesa ao livro sóbrio e invisível, que existe uma tendência cada vez maior a explorar visualmente o design de livros de literatura (além de obras de outros segmentos). Esse fenômeno provavelmente não extinguirá os livros simples, pois cada um deles tem seu público e suas virtudes.

No entanto, independentemente de sua abordagem, se visíveis ou invisíveis, livros devem ser bem feitos. Como bem observou Eric Gill, o livro é um objeto feito para ser lido e a qualidade da leitura, como já abordado, depende de inúmeros fatores. O designer é uma figura indispensável no processo de produção da obra e, como assinala Adrian Wilson no seu clássico The Design of Books, publicado em 1967:

O design de livros é necessário por uma razão: levar ao comprador um livro da melhor qualidade possível pelo preço que ele pode e está disposto a pagar. Isso exige o uso discriminado de um vasto maquinário industrial que o homem criou, a complexa rede da manufatura do livro moderno. É o desafio do designer de livro elaborar, a partir dessa estrutura, um produto de precisão e beleza. Ele precisa, é claro, ter a cooperação do autor, da editora, do editor, do gerente de produção e dos trabalhadores manuais. Mas é o conhecimento e a imaginacão que ele leva aos leiautes e sua constante insistência em altos padrões que influenciarão o sucesso do livro como um veículo de comunicação. (WILSON, 1993: 7)

\section{CONSIDERAÇÕES FINAIS}

O ideal do livro invisível, como se pode observar no primeiro capítulo, vai além do livro simples; pressupõe a obra bem elaborada, feita para "ser lida", nas palavras de Eric Gill, mas pode ser entendido também como um princípio estético de clareza e limpeza. Beatrice Warde escreveu seu famoso ensaio de 1930, The Crystal Goblet, or Why Printing Should be Invisible, justamente numa época em que muitos livros "finos" e ilustrados eram produzidos, especialmente nos Estados Unidos, e designers que assumiam essa abordagem, como Bruce Rogers, eram amigos da autora. Havia uma grande troca entre designers e tipógrafos por meio de clubes, associações e periódicos. Dessa forma, um texto "radical" como o de Warde é um tanto estranho naquele contexto, mas talvez a ideia não tenha sido a de criticar os livros belos e "visíveis" dos grandes designers do período, mas sim a de promover doutrinas eficientes para a produção de livros a partir da mecanização, já que Warde trabalhava para a Monotype Corporation, uma das maiores empresas de máquinas de composição e distribuição de faces tipográficas do período. Não se pode aqui também esquecer-se do fato de que Warde promovia a venda de tipos (tipografia) para esta empresa, então talvez esses ideais de simplicidade e clareza pudessem fazer parte do pacote de um ideal de livros bem feitos produzidos tanto com o maquinário quanto com as fontes da Monotype.

Por outro lado, livros simples são sem dúvida mais baratos e fáceis de produzir, e isto em qualquer época, e como claro exemplo da abordagem simples ou invisível do design como elemento que influencia questões econômicas do negócio editorial temos como exemplo o já mencionado caso dos livros simples e portáteis de Aldo Manuzio. A questão que talvez deva ser pensada é a de que talvez a simplicidade do design do livro, isto é, ao leiaute simples de suas páginas, como elemento favorável à industrialização, pois por serem mais econômicas poderiam impulsionar a indústria e como consequência aumentar a oferta e a demanda. Sabe-se que, nas décadas de 1930 e 1940, Stanley Morison, grande amigo de Warde, era favorável à padronização dos livros, o que aponta ainda um caminho para a simplificação e a economia dos processos de composição 
e design. Tanto Morison como Warde, no entanto, defendiam livros bem feitos, bem compostos. Como exemplo da simplicidade a favor da difusão e viabilização de edições observou-se no capítulo anterior o exemplo da editora Perspectiva, que sem um projeto editorial "simples" e padronizado talvez não pudesse existir. No entanto, o problema surge quando editoras, ao perceberem que o processo é simples demais, acabam por negligenciar o design do miolo do livro por questões econômicas, como se pode observar a partir dos textos de autores como Erik Spiekermann, Richard Hendel, entre outros.

Sobre a abordagem do livro visível, nos exemplos de edições de diversas épocas de clássicos da literatura como Decameron e Dom Quixote que eram ilustradas e ornamentadas, infere-se que a "visibilidade", nesse contexto, esteja relacionada a um estilo de época ou do impressor e não a uma estratégia ou uma reflexão entre a relação entre texto e design. De qualquer forma, percebe-se a partir desses exemplos que em muitos casos a ornamentação era desejada e aí percebe-se a importância da função estética da página impressa. Em alguns momentos a página impressa ganhava mais ou menos ornamentação e este é um indício de que o público leitor de literatura poderia não se contentar apenas com a página simples e limpa mas esperar algum adorno, algum ornamento, algum indício de que alguém fez mais do que apenas compor palavras em uma página.

A partir de Megan Benton, infere-se que a visibilidade ganha uma função semântica nos livros "finos e limitados" ou produzidos pelas "prensas particulares", quando designers trabalham o projeto gráfico ou a tipografia "alusivos", ou quando criam uma interpretação gráfica do texto. Como se pode também notar pelos exemplos apresentados, os livros eram mais visíveis em relação ao design de suas páginas (do miolo) e as capas eram mais simples, embora produzidas com materiais nobres, talvez porque não deviam ter a função de venda (marketing) que as capas de hoje têm. Percebe-se então, a partir dos exemplos deste período, que surge uma preocupação por parte dos designers não apenas de trabalhar a configuração visual da página impressa mas de procurar interpretar e refletir o conteúdo textual, estratégia que depois é retomada de forma mais enfática nas primeiras décadas do século XXI por designers e editoras contemporâneas.
Há também, como se pode observar no terceiro capítulo, divergências quanto ao uso e à escolha da tipografia. Alguns designers defendem que ela tem "valores atmosféricos" e que seu uso em determinados contextos e em relação a um certo tipo de texto pode transmitir significados, enquanto outros defendem a tipografia simples e funcional. De qualquer maneira, comprovou-se que a forma das letras pode sugerir "entonações" diferentes e, a partir do estudo de caso do folheto da AIGA, verificou-se o quão diferentes podem ser os leiautes de um mesmo texto com o uso de fontes distintas. Por mais que a maior variação dos leiautes destes exemplos esteja nas páginas de rosto e nas abertura de capítulos, a escolha de tipos (tipografias) diferentes para compor a mancha de texto pode ser identificada como escolha ao menos minimamente expressiva pois os tipos utilizados, a saber, Bembo, que é mais leve, utilizada por Helen Gentry e Bulmer que é mais pesada escolhida por Daniel Berkeley Updike, podem sutilmente sugerir ou conotar o "tom" do texto. Se a estratégia fosse a mesma e se o texto sugerisse a mesma ideia a todos os designers talvez todos escolhessem tipos de mesma classe, o que não foi o caso.

Como se observou no quarto capítulo, pelo menos a partir dos exemplos encontrados, pode-se inferir que há nos dias de hoje uma certa tendência à visualidade. Os livros analisados apresentam coerência formal entre capa, miolo e demais elementos e, em certa medida, mantêm uma relação com o texto ou com elementos como local em que nasceu o autor ou em que foi publicada a obra, entre outros. Dessa forma, esses livros diferem dos livros padrão tanto por ter o design do miolo bem trabalhado e uma integração desses elementos. Em alguns desses livros, como se pode observar, o designer que fez a capa é o mesmo que fez o miolo e dessa maneira todos esses elementos estão integrados. Esses livros não têm apenas um resultado visível, mas refletem uma nova maneira de se pensar no sistema de produção em que o designer é responsável pelo projeto inteiro. Um fato curioso sobre alguns desses livros, especialmente os publicados pelas editoras Cosac Naify, Libros del Zorro Rojo e Sexto Piso, é que assim como nas décadas de 1920 e 1930 impressores americanos e europeus interessavam-se por imprimir textos clássicos, estas editoras contemporâneas também criaram novas versões para estes textos clássicos, que hoje, por serem 
de domínio público são isentos de direitos autorais, o que pode reduzir o custo total da obra para talvez investir mais em produção gráfica ou ilustração. Ou talvez, pelo fato de estes livros serem conhecidos pelo grande público, podem fazer com que leitores já familiarizados com o conteúdo destas obras sejam estimulados a comprar os exemplares mais pelo projeto gráfico do que pelo conteúdo, da mesma forma como o leitor se relacionava com esse tipo de obra na década de 1930, como abordado por Benton no segundo capítulo desta tese.

No quinto capítulo, foram apresentados modelos e abordagens que podem ser utilizadas para a análise de projeto gráfico de livros e essas referências serviram como base para o modelo de análise das quatro edições de Bartleby realizadas no capítulo seguinte.

No sexto capítulo, a partir das análises das edições de Bartleby verificou-se uma clara estratégia da abordagem visível como evidência da relação que o projeto gráfico de um livro pode ter em relação ao seu texto, especialmente a edição de Bartleby publicada pela Indulgence Press e a publicada pela Cosac Naify. Essas edições apresentam um comprometimento do design como complementar ao texto, criando novas experiências de leitura e interpretações tanto do conto quanto do design.

A partir das edições comentadas no quarto capítulo e no sexto capítulo (estudo de caso de Bartleby), pode-se comprovar a hipótese de que os livros "visíveis" apresentam funções tanto estéticas quanto semânticas. A visibilidade não é apenas uma ornamentação vazia ou uma "perfumaria", pelo menos nos exemplos apresentados, pois os elementos "visíveis" de uma forma ou de outra remetem ou aludem a elementos presentes no texto. Nesses exemplos, a visibilidade tem uma função semântica, pois o projeto instiga o leitor a interpretá-lo, pois produz associações e novos significados. Em alguns casos, como se pode observar a partir de A fera na selva, de Henry James, publicado pela Cosac Naify, a leitura fica um pouco comprometida pelo projeto. Nos casos de Kapow! e Tree of Codes, o design também não favorece a leitura linear e contínua, mas desafia o leitor a novas maneiras de ler. Nestes últimos dois exemplos pode-se também notar como apresentado no capítulo correspondente uma possível influência de experimentos de design editorial pós-moderno, em especial aqueles em que o escritor participa do processo que resulta em uma integração entre texto e projeto gráfico.

É importante notar aqui que mesmo livros simples, se bem compostos, também apresentam funções estéticas, são agradáveis ao olhar, e se pensarmos nos pressupostos de Warde em relação ao livro invisível, o livro simples trata-se do livro bem feito, bem composto, de um livro tido como "ideal" e, dessa maneira, talvez não seja inteiramente invisível, pois torna o torna o texto visível ao olhar, e por ser bem feito apresenta funções estéticas, mas nesse caso não se procura estabelecer entre o projeto gráfico e o texto literário relações e interações como as vistas em Bartleby, por exemplo.

No sétimo capítulo, estabelecemos um contraponto entre autores que defendiam a invisibilidade ou a visibilidade. Para Flávio Cauduro, por exemplo, a invibilidade se relaciona a ideais ultrapassados da linguística e do design. A invisibilidade pode ser um fator positivo quando seus ideais se aproximam aos de Warde ou de Morison, que é o caso de uma obra simples, porém bem feita. A simplicidade ou a padronização pode ser necessária, como se observa a partir do exemplo da editora Perspectiva, já que, que por diminuir custos, permite que edições relevantes do ponto de vista cultural sejam produzidas e circulem. Por outro lado, pelo que se verificou, muitas vezes as editoras negligenciam o projeto do miolo, talvez por pensarem que a simplicidade seja sinônimo de economia. Livros "invisíveis" e padronizados devem ser bem feitos e, como exemplo da padronização e qualidade dos livros simples, temos as edições da brasileira Companhia das Letras. No entanto, mesmo trabalhando a partir de modelos pré-estabelecidos, Fabiana Roncoroni, designer da editora, explicou em entrevista que há certa expectativa por parte do mercado em relação a edições especiais, que apresentem projetos gráficos específicos. A editora é muito conhecida também pela qualidade gráfica de suas capas, para as quais sempre são convidados alguns dos mais importantes designers do país para projetá-las.

Designer da editora especializada em livros de fição científica Aleph, Pedro Inoue argumentou em entrevista que certos leitores, como o público-alvo da editora, esperam que o projeto dos livros seja especial, pois há de certa forma uma relação afetiva do leitor com o objeto. Além 
disso, por conhecerem o assunto, percebem a relação entre o design e o conteúdo, quando veem o projeto gráfico de certos livros, como o caso de 2001, uma odisseia no espaço.

Outra questão apresentada, que pode ou não ter relação com essa tendência da visibilidade, é a suposta ameaça do livro digital, pois já que o leitor tem controle sobre o leiaute das páginas pode aumentar ou trocar a fonte e mudar a tonalidade da superfície da plataforma. Nesse caso, o leitor acaba se tornando o "designer" daquele texto, o que pode justificar que livros impressos sejam cada vez mais visuais, mais interessantes do ponto de vista do design, a fim de criar uma relação afetiva com o leitor e levá-lo a privilegiar o impresso ao digital. Sobre este tópico avaliamos que há ainda muito a investigar e debater para se chegar a alguma conclusão, porém não deve ser mero acaso que justamente com a chegada dos livros eletrônicos houve um aumento na preocupação com o design do livro impresso de literatura.

Em todo caso, a partir de nossa investigação, infere-se que há diferentes níveis, tanto relativos à visibilidade quanto à invisibilidade. Existem livros em que aspectos visíveis, como a escolha da tipografia, são sutis, e também outros, como A cantora careca, de Massin, nos quais a visibilidade é bastante evidente.

A partir do panorama aqui apresentado, esperamos que sejam realizadas outras pesquisas sobre estas duas abordagens, que são conceitos-chave para a pesquisa e a produção em design editorial.

Não se buscou aqui valorizar nem desvalorizar um ou outro caminho, pois ambos são importantes: a abordagem invisível, se o livro é bem feito, é útil do ponto de vista econômico, ao gerar livros mais baratos e tradicionais, voltados para um público desejoso de um livro de literatura simples e de leitura fluida. A abordagem visível, por sua parte, pelo que se observou tem se tornado uma tendência, possui seu pú blico, ou algumas das editoras apresentadas não prosperariam. Essas editoras desenvolveram projetos que trouxeram interessantes relações entre texto e design, o que valoriza a profissão e cria novas oportunidades no campo criativo.

Pelo fato de os livros visíveis serem mais dispendiosos, porém, em momentos de crise como o que o nosso país vem atravessando casas importantes, como a Cosac Naify, fecharam suas portas. Trata-se, é cla- ro, de grande perda pois, de certa maneira, a abordagem visível dessa editora em livros de literatura talvez fosse pioneira no Brasil e mesmo em outras partes, com livros especiais como Bartleby, em que a materialidade, o conceito e a visibilidade criam uma interessante relação do objeto com seu conteúdo, um exemplo extremo não encontrado nesse nível em nenhum outro lugar. Apesar de outros livros apresentarem relações entre texto e projeto gráfico, Bartleby, a partir da análise realizada, parece o exemplo mais bem sucedido da integração desses elementos: Bartleby é o personagem que se nega a fazer tudo, tem uma personalidade impenetrável e o livro emula essa impenetrabilidade com seu lacre, as páginas fechadas com uma textura de muro impressa e o texto composto em itálico, como abordado no sexto capítulo.

Deseja-se, por fim, que os conceitos introduzidos e discutidos ao longo desta tese ampliem o vocabulário técnico e formal do design do livro e estimulem novas pesquisas sobre o tema e esperamos que este trabalho estimule designers a produzir livros bem feitos, tanto "visíveis" como "invisíveis". 


\section{BIBLIOGRAFIA CONSULTADA}

ABDALA JUNIOR, Benjamin. Introdução à Análise da Narrativa. São Paulo: Scipione, 2005.

ADAMS JR, Frederic B. Homage to the Book. New York, West Virginia Pulp and Paper Company: Westvaco Building, 1968.

AGNER, Dwight (org). The Books of WAD: A Bibliography of the Books Designed by W.A. Dwiggins. San Francisco: Alan Wofsy Fine Arts, 1977.

ARAÚJO, Emanuel. A construção do livro. Rio de Janeiro: Editora Nova Fronteira, 2000 (4 tiragem)

ARMSTRONG, Helen (org.) Graphic Design Theory: Readings from The Field. New York: Princeton Architectural Press, 2009

Teoria do Design Gráfico. Tradução de Cláudio Marcondes. São Paulo: Cosac Naify, 2015

BAINES, Phil. HASLAM, Andrew. Type \& Typography. New York: WatsonGuptill Publications, 2005

BARKER, Nicolas. Stanley Morison. Cambridge: Harvard University Press, 1972

BARNARD, Malcolm. Graphic Design as Communication. New York: Routledge, 2005.

BARTHES, Roland. 0 rumor da língua. Tradução Mário Laranjeira. 2.ed. São Paulo, Martins Fontes, 2004

o Óbvio e o Obtuso: Ensaios críticos III. Tradução Léa Novas. Rio de Janeiro, Nova Fronteira: 1990.

BARTRAM, Alan. Five hundred years of book design. New Haven, Yale University Press: 2001.

Oak Knoll Press, 1999.

Making Books: Design in British Publishing Since 1945

Bauhaus, modernism and the illustrated book. New

Haven: Yale University Press, 2004

BEAUJON, Paul (Beatrice Warde). On the choice of type faces. London,

Monotype recorder, volume XXXII: 1933. P. 5-11 
(Beatrice Warde) On Decorative printing in America. The Fleuron: A journal of Typography n. 6. Cambridge, At the University Press AND New York, Doubleday Doran \& CO. 1928. (p. 69-93)

(Beatrice Warde) Epitaph upon "period" printing. In The fleuron A journal of typography, n 7.1932

BENTON, Megan L. Beauty and the Book: Fine editions and cultural distinction in America. New Haven \& London: Yale University Press, 2000 BECKETT, Samuel. Primeiro Amor. Tradução de Célia Euvaldo. São Paulo: Cosac Naify, $2^{a}$ reimpressão, 2007

BLUMENTHAL, Joseph. The Printed Book in America. Hanover: University Press of New England, 1989.

Typographic Years: A printer's journey through a half century 1925-1975. New York: Frederic C. Beil, 1982.

\section{Art of the Printed Book 1455-1955: Masterpieces of}

typography through five centuries from the collections of the Pierpont Morgan Library New York. New York: The Pierpont Morgan Library and Boston, David R. Godine, 1973

BOCCACCIO, Giovanni. Decameron. Tradução, introdução e notas de Maurício Santana Dias. São Paulo: Cosac Naify, 2013

BONDT, Sara de. Beatrice Warde: Manners and type. Eye no. 84 vol. 21 2012. Disponível em: http://www.eyemagazine.com/feature/article/beatricewarde-manners-and-type. Acesso em setembro de 2015.

BRANDÃO, Roberto de Oliveira. As figuras de Linguagem. São Paulo: Ática, 1989

BRINGHURST, Robert. Elementos do Estilo Tipográfico. São Paulo: Cosac Naify, 2005

BRISOLARA, Daniela Velleda. Proposição de um modelo analítico da tipografia com abordagem semiótica. InfoDesign Revista Brasileira de Design da Informação 6 - 2. 2009a Disponível em: http://www.infodesign.org. br/conteudo/artigos/396/ing/ID_v6_n2_2009_30_41_Brisolara_et_al.pdf

\section{BRISOLARA, Daniela Velleda. Design (tipo)gráfico e Semiótica:}

proposição de um modelo analítico e semiótico da tipografia produzida por não-experts. Dissertação de mestrado Departamento de Design.

Universidade Federal do Paraná. 2009b Disponível em: http://dspace.c3sl.ufpr. br/dspace/bitstream/handle/1884/18180/BRISOLARA,\%20DANIELA\%20 VELLEDA.pdf?sequence $=1$

BOGO, Marc Barreto. A Coleção Particular da Cosac Naify: explorações sensíveis do gosto do livro. Dissertação de Mestrado. Pontifícia

Universidade Católica de São Paulo, 2014.
BUCKLEY, Paul. Penguin 75: Designers/Authors/Commentary (the good, the bad..). New York, Penguin Group (USA): 2010.

BUKOWSKY, Charles. CRUMB, Robert. Tráeme tu amor y otros relatos.

Tradución de Marcial Souto. Barcelona e Buenos Aires: Libros del Zorro Rojo, 2014

CALLIGARIS, Contardo. Bartleby. 2005. Disponível em: http://www1.folha. uol.com.br/fsp/ilustrad/fq1108200520.htm acesso em 10.05.2014

CAMARA JR., J. Mattoso. Dicionário de linguística e gramática: referente à língua portuguesa. 16 ed. Petrópolis: Vozes, 1992.

CAMARGO, Iara Pierro de. o Departamento de Design Gráfico da Cranbrook Academy of Art (1971-1995) : novos caminhos para o design [online]. São Paulo : Faculdade de Arquitetura e Urbanismo, Universidade de São Paulo, 2011. Dissertação de Mestrado em Design e Arquitetura. [acesso 2014-04-11]. Disponível em: <http://www.teses.usp.br/teses/ disponiveis/16/16134/tde-26012012-155305/>.

CAMARGO, Luís Hellmeister de. Encurtando o caminho entre texto e ilustração: homenagem a Angela Lago. Tese de doutorado. Campinas. Universidade Estadual de Campinas. Instituto de Estudos da Linguagem: 2006

CARDINALI, Luciano. A Tipografia Customizada como elemento identitário em Sistemas de Identidade Visual: Um estudo sobre o desenvolvimento de fontes digitais personalizadas. Dissertação de Mestrado apresentada a Faculdade de Arquitetura e Urbanismo da Universidade de São Paulo. 2015. Disponível em: http://www.teses.usp.br/ teses/disponiveis/16/16134/tde-26082015-103125/pt-br.php

CARDOSO, Rafael. Uma introdução à história do design. São Paulo: Edgard Blucher, 3 edição: 2008.

CARTER, Rob. DAY, Ben. MEGGS, Philip. Typographic Design: Form and Communication. Third edition. Hoboken, New Jersey: John Wiley \& Sons, 2002.

CAUDURO, Flávio Vinicíus. Desconstrução e tipografia Digital. 1998. Disponivel em: http://www.esdi.ueri.br/arcos/arcos-01/01-06.artigo flavio(76a101).pdf Acesso em 19.03.2014

CHAPPELL, Warren. BRINGHURST, Robert. A Short History of the Printed Word. Vancouver: Hartley \& Marks Publishers Inc, 1999

CHARTIER, Roger. A aventura do Livro: do Leitor ao Navegador. Conversações com Jean Lebrun. São Paulo: Editora Unesp, 1998.

CHALHUB, Samira. Funções da Linguagem. São Paulo: Ática, 1987.

CLAIR, Kate. BUSIC-SNYDER, Cynthia. Manual de Tipografia: a história, a técnica e a arte. Tradução de Joaquim da Fonseca. Porto Alegre: Bookman, 2009. 
CLELAND. T. M. Harsh Words in HART, James D. (Intro) About Books: A Gathering of Essays. Berkeley, The Book Arts Club of the University of California: 1941

COBDEN-SANDERSON, Thomas James. The Whole Duty of Typography. In MCLEAN, Ruari (org). Typographers on Type. New York and London: W.W. Norton \& Company, 1995.

CONKWRIGHT, P.J. University Press book Design. In WILSON, Thomas J. Graphic Forms: The Arts as related to the Book. Cambridge: Harvard University Press, 1949 (p.15-22)

COLES, Stephen. The Anatomy of Type: A graphic guide to 100 typefaces. New York: Harpers Collins, 2012.

CULLER, Jonathan. Teoria literária: uma introdução. Tradução de Sandra G. T. Vasconcelos. São Paulo: Becca, 1999

DAWSON, Peter. The field guide to typography: Typefaces in the urban landscape. London: Thames \& Hudson, 2013

DE VINNE, Theodore Low. The practice of Typography: Modern Methods of Book Composition; A treatise on type-setting by hand and by Machine and on the proper arrangement and imposition of pages. New York: The Century Co., De VInne Press, 1904. Disponível em: https://archive. org/stream/practicetypogra11vinngoog\#page/n125/mode/2up. Acesso em Agosto de 2015

DWIGGINS, W. A. Trade Book Design. In WILSON, Thomas J. Graphic Forms: The Arts as related to the Book. Cambridge: Harvard University Press, 1949 (p.23-27)

DWIGGINS, William Addison. Extracts from An Investigation into the Physical Properties of Books as They Are at Present Published. Boston, The Society of Calligraphers, 1919. Disponível em: https://archive.org/details/ extractsfrominve00socirich. Acesso em março de 2015.

DOUBLEDAY, Richard B. Ressurgimento do Design Clássico. In JONG, Cees W. De...(et all). Jan Tschichold: Mestre da Tipografia: Vida e Obra. São Paulo: Editora da Universidade de São Paulo, 2013.

DREW, Ned. STERNBERGER, Paul. By Its Cover: Modern American Book Cover Design. New York: Princeton Architectural Press, 2005

DRUCKER, Johanna. The Visible World: Experimental Typography and modern art, 1909-1923. Chicago, The University of Chicago Press: 1994 DRUCKER, Johanna, MCVARISH, Emily. Graphic Design History: A critical guide. New Jersey, Pearson Prentice Hall: 2009.

EAGLETON, Terry. Teoria da Literatura: Uma Introdução. Tradução de Waltensir Dutra. São Paulo: Martins Fontes, 2001.
EPSTEIN, Jason. O Negócio do Livro. Tradução de Zaida Maldonado. Rio de Janeiro e São Paulo: Editora Record, 2002.

ESKILSON, Stephen F. Graphic Design a New History. London: Laurence King, 2007

FABER, Michael. Tree of Codes by Jonathan Safran Foer Review. The Guardian, dezembro de 2010. Disponivel em: http://www.theguardian.com/ books/2010/dec/18/tree-codes-safran-foer-review

FARIA, Maria Isabel. PERICÃO, Maria da Graça. Dicionário do Livro: da Escrita ao Livro Eletrônico. São Paulo: Edusp, 2008.

FARIAS, Priscila Lena 2004. 'Notas para uma normatização da nomenclatura tipográfica'. Anais do P\&D Design $2004-6^{\circ}$ Congresso Brasileiro de Pesquisa e Desenvolvimento em Design (versão em CD-Rom sem numeração de página). FAAP: São Paulo.

FARIAS, Priscila. Tipografia Digital: 0 impacto das novas tecnologias. 3 ed. Rio de Janeiro: 2AB, 2001.

FEBVRE, Lucien; MARTIN, Henry-Jean 0 aparecimento do Livro. São Paulo: Unesp, 1992

FERREIRA, Danilo Pegorara. Análise de fontes utilizadas no mercado editorial Brasileiro entre 2006 e 2007. Trabalho de Conclusão de Curso do Centro Universitário Senac: 2007

FOER, Jonathan Safran. Tree of Codes. London: Visual Editions, Second Edition, 2011

GENETTE, Gérard. Paratextos Editoriais. São Paulo: Atelier Editorial, 2009 GILL, Eric. An Essay on Typography. Jaffrey, New Hampshire: David R. Godine Publisher Inc., 1988.

GODFREY, Jason. BiblioGráfico: 100 livros clássicos sobre design gráfico São Paulo: Cosac Naify, 2009.

GRABHORN, Edwin. The Fine Art of Printing. in HART, James D. (Intro) About Books: A Gathering of Essays. Berkeley, The Book Arts Club of the University of California: 1941 (p. 65-78)

GRUENDLER, Shelley. Beatrice Warde. 2011. Disponivel em: http:// elarcadearciniegas.blogspot.com.br/2011/10/beatrice-warde-by-shelleygruendler.html

GRUSZYNSKY, Ana Cláudia. Design Gráfico: Do Invisivel ao Ilegível. Segunda Edição. São Paulo: Rosari, 2008.

HALL, Sean. Isto significa isso. Isso significa aquilo: Guia de Semiótica para Iniciantes. Tradução Andréa Mariz. São Paulo: Rosari, 2008. 
HASLAM, Andrew. 0 livro e o Designer II: Como criar e produzir livros. Tradução Juliana A. Saad e Sérgio Rossi Filho. São Paulo: Rosari, 2007. HALUCH, Aline. Guia Prático de design editorial: criando livros completos. Teresópolis: 2AB, 2013.

HAWTHORN, Jeremy. A Concise Glossary of Contemporary Literary Theory. London: Edward Arnold, 1992.

HELLER, Steven. Linguagens do Design: Compreendendo o Design Gráfico. Tradução Juliana Saad. São Paulo: Ediç̧ões Rosari, 2007.

HELLER, STEVEN. Digital Publishing Worrying you? Read This.... Print, julho, 2012. Disponível em: http://www.printmag.com/graphic-design/digitalpublishing-worrying-you-read-this/

HENDEL, Richard. O Design do Livro. Tradução Geraldo Gerson de Souza e Lúcio Manfredi. São Paulo: Atelier Editorial, 2006.

University of Iowa Press, 2013

Aspects of Contemporary Book Design. Iowa City:

HOCHULI, Jost. KINROSS, Robin. Designing Books: practice and Theory London: Hyphen Press, 2007.

HOCHULI, Jost. $O$ Detalhe na Tipografia. Tradução Karina Jannini. São Paulo: WMF Martins Fontes, 2013.

HOLLIS, Richard. Design gráfico: uma história concisa. Tradução Carlos Daut. São Paulo: Martins Fontes, 2000.

IONESCO, Eugéne. The Bald Soprano. New York: Grove Press, 1965.

JAKOBSON, Roman. Linguística e Comunicação. Tradução de Izidoro Blikstein e José Paulo Paes. 12 ed. São Paulo: Cultrix, 1985.

JAMES, Henry. A Fera na Selva. Tradução de José Geraldo Couto. São Paulo: Cosac Naify, 2007.

JANSEN, Frans A.The Eighteenth century. In LOMMEN, Mathieu et all. The book of books: $\mathbf{5 0 0}$ years of graphic innovation. London: Thames \& Hudson, 2012. P. 172-175

JOLY, Martine. Introdução à análise da imagem. Campinas: Papirus, 1996. JOSEPHY, Robert. The Planning or the Illustrated Book. In The Dolphin: A Journal of the making of Books. New York: The Limited Editions Club, 1935, Vol. 2 .

LOPEZ, Fábio. Tutorial. 2014. Disponível em: http://issuu.com/fabiolopez/ docs/tutorial_flopez acesso em 06.04.2014

JURY, David. About Face: Reviving the rules of typography. Rotovision, 2004
JURY, David. O que é tipografia. Tradução Armanda Rodrigues. Barcelona: Editorial Gustavo Gili, 2007.

KAFKA, Franz. Ocasión para una pequeña desesperación. Selección e ilustraciones de Nikolaus Heildelbach. Barcelona e Buenos Aires: Libros del Zorro Rojo, 2011.

KANE, John. Manual dos Tipos. Tradução Rogério Bettoni. Barcelona: Editorial Gustavo Gili, 2012.

KEPES, Giorgy. Function in Modern Design. In WILSON, Thomas J. Graphic Forms: The Arts as related to the Book. Cambridge: Harvard University Press, 1949 (p.3-14)

KENNETT, Bruce. The Private Press Activities of William Addison Dwiggins. Fine Press Book Association, 2012. Disponível em: http://www. fpba.com/parenthesis/select-articles/p21_private_press_activities_of_ dwiggins.html

KINROSS, Robin. Modern Typography. London: Hyphen Press, 2004.

KINROSS, Robin. The Rhetoric of Neutrality. In MARGOLIN, Victor. Design Discourse: History, Theory, Criticism. Chicago, The University of Chicago Press: 1989

KLANTEN, Robert. HÜBNER, Matthias. LOSOWSKY, Andrew. Fully Booked: Ink on Paper: Design \& Concepts for New Publications. Berlin, Gestalten: 2013

KUNZ, Willi. Typography: Macro + Micro Aesthetics. Zurich, Verlag Niggli: 2002 (Third printing)

LEE, Marshal. Bookmaking: Editing, Design, Production. Third Edition New York, W.W. Norton \& Company: 2004

LEEUWEN, Theo Van. Tipographic Meaning. London: SAGE Publications, 2005.

LEITE, Ligia Chiappini Moraes. O Foco Narrativo (Ou a polêmica em torno da ilusão). Série Princípios, São Paulo: Ática, 1985.

LEWIS, John. The 20th Century Book: Its illustration and design. New York: Van Reinhold Company Inc., 1967.

LINDEN, Sophie van der. Para ler o livro ilustrado. Tradução Dorothéende Bruchard. São Paulo, Cosac Naify: 2011.

LIU, Eunice. Design gráfico: processo como forma. 2013. Dissertação

(Mestrado em Design e Arquitetura) - Faculdade de Arquitetura e Urbanismo, Universidade de São Paulo, São Paulo, 2013. Disponível em: <http://www. teses.usp.br/teses/disponiveis/16/16134/tde-14102013-154730/>. Acesso em: 2014-04-25. 
LOTUFO, Laura Benseñor.Isidora: um resgate tipográfico desenvolvimento de uma familia de fontes tipográficas digitais para a composição de textos. Faculdade de Arquitetura e Urbanismo da Universidade de São Paulo, trabalho final de graduação: 2010.

LYONS, Martyn. Livro: uma história viva. Tradução Luís Carlos Borges. São Paulo: Editora Senac, 2011

LOMMEN, Mathieu et all. The book of books: $\mathbf{5 0 0}$ years of graphic innovation. London: Thames \& Hudson, 2012.

LUPTON, Ellen. Pensar com tipos. Tradução André Stolarski. Sao Paulo : Cosac Naify, 2006.

LUPTON, Ellen. MILLER, J. Abott. Design writing research. London: Phaidon Press, 2006

The Academy of Deconstruction. EYE Magazine, EYE3/1991. Design writing research. London, Phaidon Press, 2006.

LUPTON, Ellen, MAKELA, Laurie Haycock. Underground Matriarchy. EYE, No 14, 1994 in BIERUT, Michael et all. Looking Closer 2: Critical writings on graphic design. New York: Allworth Press, 1997.

MAK, Bonnie. How the Page Matters. Toronto: University of Toronto Press, 2011

MANGUEL, Alberto. Uma História da Leitura. Tradução Pedro Maria Soares. São Paulo: Companhia das Letras, 1996.

MARGOLIN, Victor. Design Discourse: History, Theory, Criticism. Chicago: The University of Chicago Press, 1989

MARTIN, Douglas. Book Design: A practical introduction. New York: Van Nostrand Reinhold, 1989.

MARTINS FILHO, Plínio (org). A Arte Invisível ou a Arte do Livro. São Paulo: Ateliê Editorial, 2003.

MARTINS FILHO, Plínio (org). FERREIRA, Jarusa Pires. GUINSBURG, Jacó. BOCCHINI, Maria Otília. Livros, Editoras e Projetos. Cotia: Ateliê Editorial, 1997.

MASSIN, Robert. Letter and Image. Tradução do francês para Inglês de Caroline Hillier e Vivienne Menkes. London: Studio Vista, 1970.

McGANN, Jerome J. The Textual Condition. New Jersey: Princeton University Press. 1991.

Black Riders: The Visible Language of Modernism. New Jersey: Princeton University Press, 1993.

McKenzie. D.F. Bibliografia y Sociología de los Textos. Prólogo del Roger Chartier. Traducción de Fernando Bouza. Madrid: Ediciones Akal, 2005.
MCLEAN, Ruari. Modern Book Design: From William Morris to the present day. London: Faber \& Faber, 1958

. Victorian Book Design \& Colour Printing. Second edition,

enlarged and revised. London: Faber \& Faber, 1972.

Publisher, 1975

Jan Tschichold: Typographer. Boston: David R. Godine

The Thames and Hudson Manual of Typography. London nd New York: Thames and Hudson, 1992 (reprinted with corrections).

. (org). Typographers on Type. New York and London: W.W. Norton \& Company, 1995.

MCVARISH, Emily. Reconsidering: "The Crystal Goblet": The Underpinnings of Typographic Convention. Design and Culture, Volume 2. Number 3.

November 2010. Disponivel em: http://www.designstudiesforum.org/journalarticles/reconsidering-\%E2\%80\%9Cthe-crystal-goblet\%E2\%80\%9D-theunderpinnings-of-typographic-convention/ Acesso em 25.08.2014.

MENESES, Philadelpho. Roteiro de Leitura: Poesia Concreta e Visual. São Paulo: Ática, 1998.

MEGGS, Philip. PURVIS, Alston. W. Meggs' history of graphic design. 4

Ed. Hoboken, New Jersey: John Wiley \& Sons, 2006.

MEGGS, Philip B. História do Design Gráfico. São Paulo: Cosac Naify, 2013. MEGGS, Philip. B. Type and Image. New York: John Wiley \& Sons, 1992.

MELO, Chico Homem de. (Org.). O design gráfico brasileiro: anos 60. 1a. ed. São Paulo: Cosac Naify, 2006.

MELO, Chico Homem de. COIMBRA, Elaine Ramos (Orgs). Linha do tempo do design gráfico no Brasil. São Paulo: Cosac Naify, 2011.

MELOT, MICHEL. Livro,. São Paulo: Ateliê Editorial, 2012.

MELVILLE, Herman. Bartleby, o escrivão. Tradução Irene Hirsh. São Paulo: Cosac Naify, 2005.

MENEZES, Philadelpho. Roteiro de Leitura: Poesia Concreta e Visual. São Paulo: Ática, 1998.

MESQUITA, Samira Hadid de. O Enredo. Série Princípios. São Paulo, Ática: 1987

MEYNELL, Francis. A Printer considers a Book. In Monotype Recorder volume XXXII número 3: 1933

MORGAN, John. WELTON. Peter. See what I mean?: An introduction to visual communication. - 2nd ed. New York: Routledge, 1992 
MIDDENDORP, Jan. Shaping Text. Amsterdam: Bis Publishers, 2012.

MORISON, Stanley. On Decoration in Printing. In The Monotype Recorder, London, Vol XXII: 1923. P. 3-7

\section{On Type Faces: Examples of the use of type for printing} of Books. London, The Medici Society e The Fleuron. 1923 Limited, 1927

A review of recent typography. London: The Fleuron Company, 1936

First Principles of Typography. New York: The Macmillan Inc., 1960

Four centuries of Fine Printing. New York: Barnes \& Noble

MORISON, Stanley. DAY. Kenneth. The Typographic Book: 1450-1935. Chicago, The University of Chicago Press: 1963

MORRIS, William. Aims in founding the Kelmscott Press. In MCLEAN, Ruari (org). Typographers on Type. New York and London, W.W. Norton \& Company: 1995

.A Note By William Morris on His Aims in Founding The Kelmscott Press. Hammersmith, Kelmscott House: 1895

MUNARI, Bruno. Das coisas nascem as coisas. Traduçao José Manuel de Vasconcelos. São Paulo: Martins Fontes, 2002.

NICOLAJEVA, Maria. SCOTT, Carole. Livro ilustrado: palavras e imagens. Tradução Cid Knipel. São Paulo: Cosac Naify, 2011.

NOGUEIRA, Julio Cesar Giacomelli.Letra e Imagem: A tipografia nas capas de livros desenhadas por Eugênio Hirsch. Campinas, SP: [s.n.], 2009. Orientador: Profa. Dra ${ }^{a}$. Anna Paula Silva Gouveia.

OVINK, G. W. Legibibility, Atmosphere-Value and Forms of Printing Types. Leiden: A. W. Sijthoff's Uitgeversma Atschappij N.V, 1938

PAIVA, Ana Paula Mathias de. A aventura do Livro Experimental. São Paulo: Edusp, 2010

PELTA, Raquel. Diseñar Hoy: Temas contemporâneos de diseño gráfico. Barcelona: Paidós, 2004

PERRONE-MOISÉS, Leyla. O mal de Bartleby. 2005. Disponível em: http:// www1.folha.uol.com.br/fsp/mais/fs1302200512.htm acesso em 1.05.2014 PETERSON, William S. The Well-Made Book: Essays \& Lectures by Danie Berkeley Updike. New York: Mark Batty Publisher, 2002.

POLE, Steven. Kapow! By Adam Thirwell review. The Guardian, maio de 2012. Disponível em http://www.theguardian.com/books/2012/may/25/ kapow-adam-thirlwell-review Acesso em maio de 2015

POYNOR, Rick. No more rules: Graphic Design and Post modernism. London: Laurence King Plublishing, 2003.

PORTA, Frederico. Dicionário de Artes Gráficas. Porto Alegre: Editora Globo, 1958.

RAFAELI, Ari. Book Typography. New Castle: Oak Knoll Press: 2005

RAMOS, Elaine. 2013a. Entrevista a Iara Pierro de Camago realizada em outubro de 2013 na Editora Cosac Naify, São Paulo.

RAMOS, Elaine. Livro em Processo. In DERDYK, Edith. Entre ser um e ser mil: o objeto livro e suas poéticas. São Paulo, Editora Senac: 2013b. P.95110

RIVERS, Charlotte. Book-Art: Innovation in Book Design. Switzerland: Rotovision, 2009.

ROCHA, Cláudio. Projeto Tipográfico: Análise e produção de fontes digitais. São Paulo: Rosari, 2003. 2 edição.

ROGERS, Bruce. Paragraphs on Printing. New York: Dover Publications Inc., 1979.

ROLLINS, Carl Purington. Gilding the Lily. In the Designing of Books There's no Sin Like Complacency. In: MIERS, Earl Schenck. ELLIS, Richard (org). Bookmaking and Kindred Amenities. New Brunswick: Rutgers University Press, 1942

ROLLINS, Carl Purington. Evaluation. In WILSON, Thomas J. Graphic Forms: The Arts as related to the Book. Cambridge: Harvard University Press, 1949 (p.28-32)

ROYLE, Nicholas. Kapow! By Adam Thirwell. The Independent, maio de 2012. Disponivel em: http://www.independent.co.uk/arts-entertainment/ books/reviews/kapow-by-adam-thirlwell-7734226.html. Acesso em maio de 2015.

RUDER, Emil. Typography: a manual of design. Verlag: Niggli AG Suíça 6 edição, 1996 (1967)

SILVA, Fabio Luiz Carneiro Mourilhe \& FARIAS, Priscila Lena. Um panorama das classificações tipográficas. Estudos em Design, 2005 v. 11, n. 2, p. 67-81. SAMARA, Timothy. Grid: Construção e desconstrução. Tradução: Denise Bottmann. São Paulo: Cosac Naify, 2007.

SANDFORD, Christopher. The Aesthetics of the Illustrated Book. In The Dolphin: A Journal of the making of Books. New York: The Limited Editions Club, 1935, Vol. 2.

SHAUGHNESSY, Adrian. Books. Still not dead. Design Observer, 
04.01.2016. Disponível em: http://designobserver.com/feature/books-stillnot-dead/39123/?utm_source=dlvr.it\&utm_medium=twitter. Acesso em 04.01 .2016

SHELLEY, Mary. W. Frankenstein o el moderno Prometeo. Traducción Rafael Torres. Madrid: Sexto Piso España, 2013.

SOARES, Angélica. Gêneros Literários. Série Princípios. São Paulo: Ática, 1993. SOUZA, Pedro Luiz Pereira de. Notas para uma história do design. Rio de Janeiro: 2AB, $20013^{\mathrm{a}}$ edição.

SPENCER, Herbert. Pioneers of Modern Typography. MIT Press, 2004. SPENCER, Herbert. The visible word. London: Lund Humphries, 1969. SPIEKERMANN, Erik. A linguagem Invisível da tipografia. Tradução Luciano Cardinali. São Paulo: Blucher, 2011

STEINBERG, S. H. Five Hundred Years of Printing. Third Edition revised by James Moran. Middlesex, New York, Ontario and Auckland: Penguin Books, 1979

STÖCKL, Hartmut. Typography: body and dress of a text - a signing mode between language and image. Visual Communication 2005 4: 204 Disponível em: http://vcj.sagepub.com/content/4/2/204. Acesso em maio de 2014

SUTTON, James. BARTRAM, Alan. Typefaces for books. New York: New Amsterdam books, 1999.

SWANN, Cal. Language and Typography. London: Lund Humphries Publishers: 1991

THIRWELL, Adam. Kapow! London: Visual Editions, 2012,

THORP, Joseph. Printing for Business: A manual of Printing Practice in non-technical idiom. London, John Hogg: 1919. disponível em: https:// archive.org/stream/printingforbusin00thor\#page/48/mode/2up. Acesso em setembro de 2015

TSCHICHOLD, Jan. A Forma do Livro. Tradução José Laurênio de Melo Cotia: Ateliê Editorial, 2007

TWEMLOW, Alice. Para que serve o design gráfico? Barcelona, Editorial Gustavo Gili: 2007

UNGER, Gerard. While You're Reading. New York: Mark Batty Publisher, 2007.

UPDIKE, Daniel Berkeley. Printing Types: Their History, Forms and Use. A Study in Survivals. Volume 1. Second Edition. New York, Dover Publications: 1980
WAGNER, Heather. Jonathan Safran Foer Talks Tree of Codes and Conceptual Art. 2010 Disponivel em: http://www.vanityfair.com/ culture/2010/11/jonathan-safran-foer-talks-tree-of-codes-and-paper-art acesso em outubro de 2015

WARDE, Beatrice. The Crystal Goblet: Sixteen Essays on Typography. Cleveland: World Publishing Company, 1956.

VILLAS-BOAS, André. Sobre Análise gráfica, ou Algumas estratégias didáticas para a difusão de um design crítico. Rio de Janeiro, ARCOS DESIGN 5 - Dezembro de 2009 Disponível em: http://www.esdi.uerj.br/arcos/ arcos-04-2/04-2.arcos-design-04-2-completo.pdf Acesso em 20.05.2014

VILLAS-BOAS, André. 0 que é [e o que nunca foi] design gráfico. $6^{a}$ edição Rio de Janeiro, 2AB: 2007.

VILLORO, Juan. Los Culpables. Oaxaca de Juárez: Editorial Almadía, 2013.

WILD, Lorraine. Transgression and Delight: Graphic Design at Cranbrook. In: ALDERSEY-WILLIAMS, Hugh et al. Cranbrook Design: The New Discourse. New York, Rizzoli International Publications, Inc.;1990. p.30-36.

WILDE, Oscar. El príncipe feliz y otros cuentos. Ilustrado por Jacomb Hood y Walter Crane. Traducido por Julio Gómez de la Serna. Buenos Aires: Libros del Zorro Rojo, 2013.

\section{WILLIAMSON, Hugh. Methods of Book Design: The practice of an}

ndustrial Craft. 3 edição 2 reimpressão. New Haven and London: Yale University Press, 1985.

WILSON, Adrian. The design of books. San Francisco: Chronicle Books, 1993.

WOLF, Laetitia. Massin. London: Phaidon Press, 2007.

ZILBERMAN, Regina. Fim dos Livro, Fim dos Leitores?. São Paulo: SENAC, 2001. 


\section{ANEXO}

Pesquisa Realizada com leitores

(A PARTIR DA EDIÇÃo de BARTLEBY DA COSAC NAIFY)

Foi realizado entre janeiro e maio de 2014 um teste de leitura com vinte e dois voluntários (perfil dos leitores na tabela abaixo) que se dispuseram a comprar a edição Bartleby, o escrivão da editora Cosac Naify. A pesquisa se deu a partir de questões abertas (pesquisa qualitativa) com o objetivo de avaliar como o leitor entendeu a experiência de um livro não tradicional. A pesquisa foi realizada de modo informal, com voluntários que se dispuseram a comprar o livro, e não foi baseada em grupos ou classes sociais, com o intuito apenas de procurar entender

\begin{tabular}{|l|l|l|l|}
\hline \multicolumn{4}{|l|}{ Perfil dos Leitores } \\
\hline Nome & Idade & Profissão & Escolaridade \\
\hline Iberê & 32 & Jornalista & Superior completo \\
\hline Alice & 54 anos & Funcionária Pública & $2^{\circ}$ grau \\
\hline Ana & 27 anos & Arquiteta e Urbanista / Prof. educação superior & Mestrado \\
\hline Leilane & 32 anos & Estilista e Professora Universitária & Doutorado Incompleto \\
\hline Marcele & 27 anos & Fisioterapeuta & Especialização strictu senso \\
\hline Vanessa & 34 anos & Professora & Mestrado \\
\hline Alexandre & 40 anos & Designer gráfico e professor & Ṕs-graduação \\
\hline Erica & 30 anos & Jornalista & Pós-graduação \\
\hline Lúcia & 30 anos & Animadora cultural & Superior completo \\
\hline Marcio & 42 anos & Professor univresitário e Produtor Audiovisual & Mestrado em Artes \\
\hline Tarcisio & 31 anos & professor & Doutorando \\
\hline Amaranto & 31 anos & Cientista da Computação & \\
\hline Mariana & 32 anos & Redatora publicitária & Superior completo \\
\hline Rodrigo & 31 anos & Administrador. & Superior completo \\
\hline Andreia & 28 anos & Designer gráfico & Superior completo \\
\hline Edison & 30 anos & Engenheiro Elétrico & Superior completo \\
\hline André & 30 anos & Jornalista & Superior completo \\
\hline Cleber & 22 anos & Designer Gráfico & Superior completo \\
\hline Angela & 30 anos & Jornalista & Superior completo \\
\hline Michaela & 25 anos & Editora & Ensino Superior (cursando). \\
\hline Natália & 31 anos & Jornalista e cientista social & Pós-graduação \\
\hline Camila & 30 anos & Jornalista & Superior completo \\
\hline
\end{tabular}


um pouco a recepção do projeto pelos leitores. A pesquisa pode não ter valor científico nem se pretende a comprovar que os leitores compreenderam o projeto do modo como foi concebido, mas entender a aceitação por parte de um grupo de leitores heterogêneo de um projeto gráfico não convencional.

A leitura do texto e do projeto é subjetiva, mas os testes apontam que muitos leitores tiveram experiências semelhantes. Alguns ficaram incomodados em abrir as páginas e a capa, mas entenderam a relação dessa ação "incômoda" com a própria narrativa.

Entre esses leitores nenhum havia lido esse texto anteriormente em outra edição e apenas dois dos vinte e dois já tinham conhecimento anterior sobre a edição.

Dezessete leitores gostaram do fato de a capa ser lacrada e entenderam o mistério, como por exemplo Marcele: "ela aguçou e muito a minha curiosidade e aumentou minhas expectativas com relação à estória. Fiquei imaginando o que encontraria lá dentro".

Cinco leitores ou ficaram confusos ou com medo de rasgar a capa, ou intimidados em abri-la, como Natália: "A ideia da capa lacrada é interessante, mas confesso que eu teria lido o livro antes se ela já estivesse aberta, porque por um par de vezes eu posterguei a leitura por não ter um objeto à mão que me ajudasse a descosturar a capa".

O texto principal desse volume, como visto anteriormente, foi composto em itálico, um recurso gráfico pouco habitual em livros de texto corrido contemporâneos (apesar de ter sido mais comum no passado. Leia-se Imprensa Aldina). Doze leitores notaram a escolha do itálico para a composição do texto principal e, desses, seis atribuíram a escolha à conexão da forma do tipo com a narrativa, como no depoimento de Andréia: "Remete à letra cursiva do escrivão que criou um elemento visual forte com a narrativa, totalmente legível". Dos que notaram o tipo em itálico apenas duas leitoras acharam que atrapalhou um pouco a leitura (Ana e Érica) e mesmo assim entenderam a relação da escolha com o tema da obra.

Sobre os materiais e tipografia da capa, os leitores entenderam que remete a:

Iberê: "Lembram-me escritórios antigos, balancetes, relatórios, processos". Alice: "A um livro preferido e bem guardado, um mimo"

Ana: "Para mim são o ambiente do escrivão daquele tempo".
Leilane: "Às capas de processos judiciais".

Marcele: "O material da capa me deu uma ideia de pasta para documentos de escritório, antigas".

Vanessa: "remetem aos materiais de escritórios, coisas relacionadas vida e ao dia a dia dos escrivães".

Alexandre: "A capa tem um cheiro característico, um pouco incômodo talvez, que remete ao cenário em que se passa boa parte da história. Lembrei de uma pasta de documentos, cartório antigo, arquivo morto com muitos papéis guardados, cheiro de mofo, etc.".

Érica: "A um diário ou um livro de registros".

Lúcia: "É como se fosse uma espécie de diário, de caderno autobiográfico do personagem/narrador? Um livro de registros pessoais que está sendo escrito pelo narrador?

Márcio: "À reciclagem"

Tarcísio: "Não sei explicar".

Amaranto: "Antigo, vintage".

Mariana: "Também achei a capa sisuda, com uma textura grossa, acredito que também remeta bem ao ambiente sisudo e "sem vida" em que se encontravam." ${ }^{1}$

Rodrigo: "O material da capa, a meu ver, remete a um papel utilizado em pastas e dossiês de processos públicos - judiciários ou não. Em relação à tipografia da capa, pareceu-me um carimbo com diferentes fontes, o que também pode estabelecer uma conexão com a burocracia pública".

Andreia: "Ao trabalho do escrivão, a um documento de advocacia, a formalidade."

Edison: "Um processo"

André: "Sem maiores elucubrações, a um caderno de anotações."

Cleber: "Não consegui notar nenhuma relação do material da capa com a história. A tipografia parece se relacionar com o ofício de Bartleby. Não sei...Talvez a um caderno de cartório? Ou a um diário."

Michaela: "A um pensamento hermético, discorrido na fala, de alguém que revela sua experiência. Remeteu-me a um manuscrito, uma espécie de diário de alguém no qual se registra memórias.

Camila: "O material da capa me pareceu papel reciclado. A tipografia, achei bem básica, como a de um livro antigo, da época em que se passa a narrativa."

Muitos dos leitores, como pode ser observado acima, associaram os materiais e a tipografia da capa à rotina do escritório, a pastas de arquivo antigas. Interessante notar, com base nesse resultado, o depoimento de Alexandre, que notou não só a aparência dos materiais como seu cheiro, que coincidentemente, associou ao "ambiente" da trama. Segundo entrevista com Elaine Ramos, designer do projeto, o material

Mariana uniu sua resposta à da pergunta "Acha que o projeto do livro mantém alguma relação com o texto? Qual poderia ser essa relação?" 
da capa, era um isolante elétrico que "pegava muita umidade", por isso talvez tenha esse cheiro forte de mofo. Interessante que o material, dessa vez ao acaso, propiciou essa experiência olfativa.

\section{Vejamos como responderam à seguinte pergunta: "Acha que o pro- jeto do livro mantém alguma relação com o texto? Qual poderia ser essa relação?"}

Iberê: "Sim, ele é como imagino capas dos documentos dos quais os escrivães faziam as cópias".

Alice: "Acho que é a relação do segredo que o narrador faz sobre o escrivão, o livro também está fechado como um segredo".

Ana: "Penso que sim. Acho que o livro todo tem um ar bastante "retrô", apesar de essa não ser a palavra exata, que no momento me foge. $\mathrm{O}$ material da capa, a escrita... tudo parece reforçar o ambiente do escrivão e da história".

Leilane: "Além da que descrevi acima², tem a coisa do muro para o qual o Bartleby olha. Ele remete aos muros da prisão onde padecerá no futuro $\mathrm{e}$ às paredes que o enclausuram em Wall Street enquanto ele trabalha e vive ou vive para trabalhar. $O$ próprio nome da rua já soa irônico nesse caso. Lembra-me do panóptico. É como se todos os humanos que trabalham de forma remunerada (como nós) estivessem presos fisicamente pelas paredes e psicologicamente pela condição de dependência. E para ter acesso à história somos obrigados a "fitar" a parede, querendo ou não, pois elas estão entre uma página e outra."

Marcela: "As páginas serem uma parede cinza transmitem uma ideia depressiva e quando se é falado que o personagem passa boa parte do tempo olhando para aquela parede, pode-se ter a nítida sensação de estar preso, incapaz de enfrentar o que se tem diante de si, da tristeza por estar diante de uma barreira que não o deixa com nenhum caminho a seguir."

Vanessa": "Achei interessante sim, mas no meio do livro achei um pouco chato... Reclamei "Putz, mais uma pra abrir". Mas gostei. Acho que para um livro grande não funcionaria, mas para um conto a ideia e boa. Não sei se consegui associar as páginas estarem fechadas ao tema do livro, ao conteúdo... Hum, talvez por contas dos muros... De Wall Street e a

\footnotetext{
2 Resposta de Leilane na questão que se refere como complemento a questão apresentada O que você achou do projeto do livro como um todo?

Lindo e às vezes meio maçante como a dinâmica daquele escritório no qual a história se desenrola. Acho que a beleza e o sucesso do projeto gráfico estão em não ser literal, mas em passar de certa forma o sentimento que os ambientes, a ́́poca es costumes emanam ao longo da história. Uma ajuda na tradução do l'air du temps.

3 Vanessa mesclou a pergunta com a anterior "O que você achou do projeto gráfico como um todo".
}

cada página havia um pouco desse muro, e na história também, o muro da falta de comunicação entre Bartleby e o dono do escritório, o muro representando a falta de compreensão do que acontecia com Bartleby e as muitas suposições do dono do escritório. As páginas fechadas podem representar os muros que atravessamos junto ao narrador." Alexandre: "Várias: mistério, desconhecido, clausura, falta de perspectiva, etc. A ligação com o tema e com o personagem principal é grande." Erica: "Sim. Existe um paralelo entre a dualidade do desejo/dificuldade de se entender Bartleby e o mesmo sentimento em relação ao livro."

Lúcia: "A relação é bem grande. As barreiras para começar a leitura se parecem com as barreiras da personagem e suas ações insólitas. Para o leitor, não é apenas pegar o livro e começar a leitura, é preciso "vence barreiras", "derrubar muros", o que tem muito a ver com o enredo. É como se a estética cheia de absurdos, que envolve o enredo, perpassasse também o design, criando impedimentos para o início da leitura."

Márcio: "Acho que sim! O muro instalado entre a comunicação do Advogado e Bartebly."

Tarcísio: "Sim. As páginas grudadas representam "barreiras"."

Amaranto: "O conceito do projeto parece se opor ao do personagem principal , que acha que o caminho mais fácil é o melhor caminho."

Mariana: "Achei que o fato de abrir as páginas mostra a personalidade do cara, super fechada. Também remete à burocracia do trabalho que os personagens desempenhavam. Também achei a capa sisuda, com uma textura grossa, acredito que também remeta bem ao ambiente sisudo e "sem vida" em que se encontravam.

Rodrigo: "Sim. O projeto do livro exige que o leitor se relacione de maneira mais ativa com o objeto material, seja deslacrando a capa, seja abrindo suas páginas. Em outras palavras, o projeto é conquistado e apropriado aos poucos pelo leitor. $O$ texto também apresenta uma relação ativa entre o narrador e a personagem Bartleby, uma vez que o primeiro tenta insistentemente investir no segundo, descobrindo aos poucos algumas de suas características, ainda que quase nunca consiga desenvolver um relacionamento pleno.

Andreia: "A tipografia que imita a letra cursiva do escrivão, o uso de uma cor apenas, o traço simples e formal da capa que poderiam facilmente serem reproduzidos a mão."

Edison": "Por um lado, acho que a forma de abrir o livro e suas páginas talvez tenha contribuído para experimentar a sensação de descoberta do personagem Bartleby. Por outro lado, enquanto eu abria o livro achava todo o processo desnecessário."

André: "Sim. Tentar entender Bartleby requer ao menos que paredes cinzentas sejam demolidas, o que exige esforço e paciência."

Cléber: "Interpretei o projeto como uma representação do "Acho melho não". É como se, o tempo todo, o livro dissesse ao leitor que talvez "seja melhor não ler"." 
Angela: "Sim. Pensei que o barulho de rasgar as páginas lembra o de uma repartição e que há um paralelo entre a dificuldade de acessar as páginas e a personalidade fechada de Bartleby; como se ambas fizessem referêne a personalidade."

cia a um enigma."
Michaela: "Repito o que já havia dito: a ideia da falta de praticidade do livro já implica numa predisposição requerida do leitor para desvendá -lo. A capa é lacrada da mesma maneira que o texto é "lacrado", exigindo muito mais de quem está em posse do produto, o livro. As páginas que simulam uma falta de texto - e que só o revelam quando se "abre" a página, rasgando-a para encontrá-lo na parte interior - são, na minha opinião, uma ideia genial. Uma sutileza que conversa completamente com o conteúdo do livro."

Natália: "Sim, há uma relação. A narrativa é envolvida por um mistério e incerteza. A experiência de abrir as páginas me remetia à sensação do protagonista de não saber bem o que ele encontraria ou descobriria sobre Bartleby a cada dia que passava".

Camila: "Sim. O livro não tem capítulos. É como se fosse um conto, que começa e termina, numa tacada só. $\mathrm{O}$ fato das páginas terem que ser abertas faz, de certa forma, essa função...de parada pra refletir um pouco sobre o que acabamos de ler. Acho interessante também porque os personagens são escrivães/copistas, e o fato do livro ser mais fechado, com um papel mais diferenciado, como se fosse o de um cartório, vai bem com o tema."

Percebe-se, a partir das respostas acima, que todos os vinte e dois leitores perceberam algum tipo de relação entre o projeto gráfico do livro e a narrativa. São citadas como vínculo principal do texto com a narrativa as páginas lacradas. Em outra questão, perguntou-se aos mesmos leitores o que eles acharam das páginas fechadas.

Quanto à pergunta: Como você poderia resumir toda sua expe-

\section{riência de leitura?}

Iberê: "Gostei do texto mas, tirando a capa, os elementos do projeto gráfico que fugiram do padrão não me agradaram. A costura da capa soltou pequenos fios pretos que se espalharam pela casa. Não gostei de rasgar pequenos fios pretos que se espalharam pela casa. Não gostei de rasgar
as folhas porque fazia barulho, atrasava a leitura e eu percebia que havia sido gasto mais papel do que o necessário. Além disso, tinha que manter o marcador de página comigo o tempo todo para ajudar a rasgar. A gramatura das folhas também era muito baixa, tornando as páginas moles (dava a impressão de que estavam úmidas) e suscetíveis ao vazamento de tinta de uma página para outra - o que acontece com o livro todo, por conta do desenho da parede que permeia todas as páginas. A baixa gramatura do papel também me pareceu incompatível com o tamanho do livro, já que, quanto maior o papel, maior vai ser a relação área / espessura e mais as páginas vão parecer moles. A margem menor no centro da página causou um desequilíbrio que me desagradou, especialmente por dar a sensação de que a página foi impressa do jeito errado, desalinhada, e de que falta margem de descanso para os olhos no lado de dentro sobra do lado de fora. A tipografia, para quem enxerga mal como eu, tornou a leitura mais cansativa. Por fim, o cheiro da tinta é um pouco forte. Parece que ainda está fresca".

Alice: "Divertida, muito interessante e diferente, penso até em presentear alguém especial".

Ana: "Foi uma experiência intensa. O livro é curto, o que faz com que se mergulhe nele de uma vez. Gostei da experiência sensorial/manual e também da estória em si, Melville é um gênio. Fiquei feliz que este conto tenha recebido um projeto gráfico todo especial e pensado pra ele.

Leilane: "O livro é curto e interessante então li em três dias. Nessa conta coloquei a abertura do livro. Até o cheiro de tinta forte (que acho que não é proposital) é estimulante. Tudo no livro te leva a pensar onde a história te levará enquanto está lendo.

Li sessenta por cento do livro no terceiro dia. Fiquei encantada com o projeto gráfico e ele desviou minha atenção da leitura, mas isso não uma crítica. Entendo como parte do processo de leitura desse exemplar. Marcele: "O primeiro contato com o livro aguçou minha curiosidade e minha imaginação: queria saber e especulei mentalmente do que trataria tudo aquilo. Ter que cortar as páginas só intensificou o processo. Como o texto trás uma certa angústia por não se estar claro o que se passa, por não se conhecer o que há de errado, agradeci pela iniciativa de já ter deixado todas as páginas abertas, porque isso me deixaria ainda mais tensa."

Vanessa: "foi bom, imagina ler um livro sobre Bartleby num campo no meio do nada..rs na Alemanha. Li na paz... Sem pressa de rasgar as páginas."

Alexandre: "A experiência foi fantástica. O livro é curto mas intenso e as características físicas e visuais do livro contribuem para criar uma imersão total no texto. Gostei bastante."

Érica: "O projeto gráfico é excelente e percebe-se que os detalhes foram muito bem pensados. A compreensão desses detalhes não aconteceu durante a leitura e sim posteriormente, o que cria uma experiência pós-leitura interessante, cheia de momentos "a-ha". O projeto gráfico foi um complemento sóbrio-lúdico para essa leitura cheia de aspectos ambíguos, misteriosos e vagos."

Lúcia: "Apesar de não me preocupar muito com o design do livro na hor da compra, achei a experiência bem interessante. Mas levantei uma questão: lacrar todo o livro, para que forma e conteúdo estejam ainda mais ligados não é algo que tira o livro do seu tempo (século)? O que quero dizer é que essa preocupação na associação entre forma e conteúdo me parece bastante contemporânea, e o livro foi escrito no século do me parece bastante contemporânea, e o livro foi escrito no século
XIX. Não tenho fundamentos teóricos nem conheço a história do design, mas foi algo que me ocorreu quando acabei de ler o livro: não é querer adicionar, à obra, um valor que ela não tem? Ou que não foi pensada para ter? Essas perguntas não são um juízo de valor sobre o trabalho, mas um 
questionamento mesmo, para o qual não tenho resposta."

Márcio: "Foi uma leitura diferente de um livro normal, já a partir de descosturar a capa. Tudo interagindo com o texto, a capa, as páginas e o marcador. Melhorou no entendimento do texto."

Tarcísio: "A leitura foi boa, e o projeto gráfico realmente enriqueceu complementa a leitura... Mas o livro é mais do que sua leitura. É um objeto com memória, para ser guardado com cuidado para ser consultado depois. E nesse aspecto, meu livro deixou uma impressão um pouco ruim pois as páginas ficaram mal cortadas... Eu teria mais gosto de guardá-lo caso as páginas estivessem inteiras..."

Amaranto: "O trabalho requerido para que se pudesse evoluir com a história deu um certo senso de evolução que foi interessante.

Mariana: Achei bem interessante!"

Rodrigo: "Em relação ao projeto gráfico, tive uma experiência interessante, talvez por ter ela sido uma novidade para mim. Em relação ao conteúdo, tive uma sensação de angústia por não saber mais informações sobre o escrivão Bartleby, o que me parece ter sido justamente a intenção do autor da obra, que utiliza um narrador não-onisciente para discorrer a trama." Andréia: "Estimulante, uma experiência tátil e manual que ampliou as possibilidades de um texto curto, porém cheio de sensações e questões sobre os anseios do homem, e estas, muito bem refletidas no projeto gráfico" Edison: "Acho que o projeto foi válido, enriquece a leitura, porém não gostei do livro, a história não me chamou a atenção."

André: "Instigante no começo (a curiosidade originada pelo projeto gráfico me despertou a começar a ler a obra) e enfastiante em outros momentos."

Cleber: "Foi, no mínimo, inusitada. No primeiro momento, me impressionou o fato de eu ter que "destruir" o livro para poder lê-lo. Cheguei a duvidar sobre o que eu deveria fazer exatamente. Essa dúvida me levou a prestar bastante atenção cada vez que eu precisasse abrir uma página para me assegurar de que estava destruindo a coisa certa." Angela: "Adorei."

Michaela: "Intrigante e bonita."

Natália: "Foi inusitada e interessante. Gostaria de ter a oportunidade de poder interagir com projetos gráficos inteligentes mais frequentemente - como foi o caso-, desde que não comprometam a fluidez da leitura."

Camila: "no início, inquieta e um pouco irritada, porque é muito diferente de tudo que já tinha experimentado. Gosto de ler livros deitada, de forma que abrir página por página foi bastante trabalhoso. Depois me acostume e peguei gosto pela experiência. Queria abrir as páginas logo para saber o que ia acontecer e que fim levaria Bartleby. Mesmo assim, achei melhor abrir página por página. Gostei do texto, do posfácio e do livro como um todo. A tipografia era agradável e facilitou a leitura. Foi uma boa experiência. Compraria um livro desse, numa próxima oportunidade."

É possível verificar que 21 leitores gostaram de alguma forma da experiência, com exceção do leitor Iberê, que achou o projeto pouco prático e a leitura difícil por conta do itálico.

Há ressalvas dos leitores quanto ao fato de que as páginas vieram

cerradas, o que pode ser verificado na pergunta: "A experiência de

abrir as páginas foi interessante? Há, para você, alguma cone-

\section{xão entre este ato e o conteúdo?"}

Sobre a pergunta acima, como muitas vezes a resposta é semelhante quanto a relação do projeto com a narrativa, optou-se por apresentar o resultado de forma resumida abaixo:

Leitores que não expressaram sensação de incômodo nas respostas: Alice, Ana, Leilane, Alexandre (gostou pela conexão e, curioso pela narrativa, abriu todas as páginas de uma vez), Márcio (gostou também de que veio anexo o marcador transparente que servia para abrir as páginas); Amaranto (gostou pois abrir as páginas deu um certo sentido de evolução); Mariana (gostou pois viu relação com o personagem), Rodrigo (gostou pela relação com a narrativa); Edison (gostou pela relação com a narrativa); André (gostou pela relação com a narrativa) Cleber (gostou pela relação com a narrativa); Ângela (gostou pela relação com a narrativa); Michaela (gostou pela relação com a narrativa);

Leitores que se sentiram incomodados de alguma maneira com a necessidade de ter que abrir as páginas: Iberê, Marcela (achou estressante) Vanessa (achou chato, mas gostou pela relação com a narrativa); Érica (ficou irritada, porém depois associou esta frustração à de Bartleby); Lúcia (achou interessante e estressante, associou esse recurso a "vencer barreiras"); Tarcísio (não gostou pois "rasgou" a página de maneira errada e danificou o objeto); Andréia (viu como um teste de paciência), Natália (no começo gostou e depois ficou irritada pela interrupção da leitura), Camila (se irritou no começo mas depois conseguiu entender a relação)

É possível entender com base nas respostas dos leitores que todos entenderam algum tipo de relação entre o texto e a narrativa, mesmo que alguns tenham se incomodado com o projeto. Os leitores tiveram opiniões e leituras diversas que enriqueceram nossa pesquisa, pois apontam para caminhos passíveis ainda de serem explorados. Os leitores entenderam a relação entre o "lacre" do livro com a personalidade "fechada" do personagem, porém, apenas metade percebeu alguma relação da tipografia que compõe o texto do volume com a narrativa. Os 
que entenderam observaram a ideia da cursividade. Há, porém, outros detalhes mais sutis de relação, que podem ser observados em um nível mais especializado (por designers, editores) na análise gráfica acima, que a tipografia Goudy foi criada por um tipógrafo americano, assim como o autor do livro (dado que provavelmente leitores em geral não perceberiam).

Outro aspecto importante é o fato de que os leitores, de modo geral, gostaram de interagir com o objeto e entenderam a experiência enriquecedora propiciada pelo projeto. 